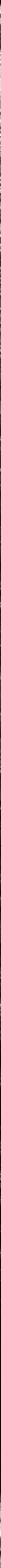



4<smiles>c1ccccccccc1</smiles>

$$
\text { 2. 2. en - }
$$



THE ANTIQUARY'S BOOKS GENERAL EDITOR: J. CHARLES COX, LL.D., F.S.A.

THE MEDIÆVAL HOSPITALS OF ENGLAND 

Digitized by the Internet Archive in 2007 with funding from Microsoft Corporation 


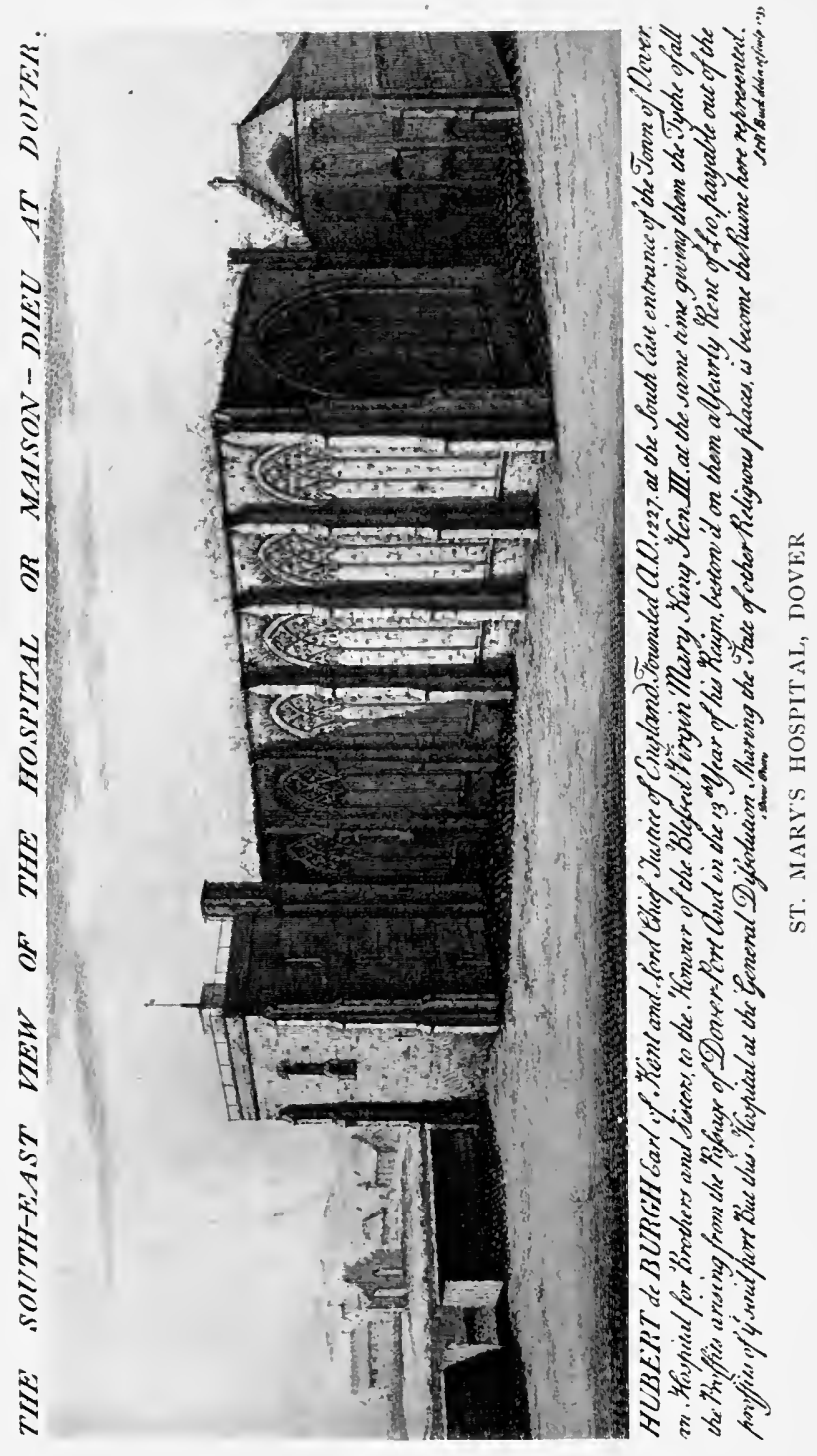




\title{
THE
}

\section{MEDIÆVVL HOSPITALS OF ENGLAND}

\author{
BY \\ ROTHA MARY CLAY
}

WITH A PREFACE BY

THE LORD BISHOP OF BRISTOL

WITH 78 ILLUSTRATIONS

METHUEN \& CO.

36 ESSEX STREET W.C

LONDON 


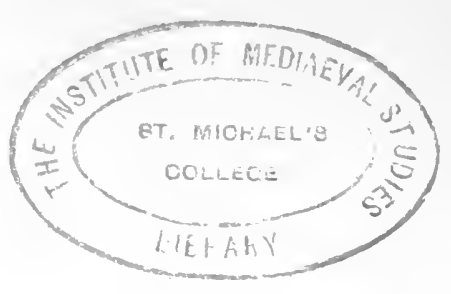

DEC 119945
13008

First Published in 1009 
DEDICATED TO

FRANCES ARNOLD-FORSTER

WITH GRATEFUL AFFECTION 



\section{PREFACE}

WHEN the able author of this book asked me to write a Preface to a work on Hospitals, I replied that I must first see the sheets in proof. This was not due to any doubt of the ability of the writer, it was due to some doubt as to the adequacy of the material at her disposal. This doubt has been much more than removed. The mass of the material collected is remarkable. Still more remarkable is the evidence of the very large part played by Hospitals-in the widest senses of the word-in the social life of the people of this land in the earlier Middle Ages. For the fuller understanding of the social life of our ancestors, this book contributes information of the most luminous character. It will serve also as an example and pattern for young and earnest students of real history, the history of ordinary human beings rather than of generals and of kings. And it must be added that, although the division into numerous headings leads to frequent repetitions of the names and characters of institutions of the nature of Hospitals, it has the great advantage of reducing to order a mass of material which might under less careful treatment have had a chaotic appearance. As a book of 
viii

PREFACE

reference for readers and writers, this treatise on the Mediæval Hospitals of England ought to hold a distinguished place.

G. F. BRISTOL

July, 1909. 


\section{CONTENTS}

Preface by THE Lord Bishop of Bristol vii INTRODUCTION . $. \quad . \quad . \quad . \quad$ xvii

$$
\text { PART I }
$$

CHAPTER I

Hospitals For WAYFARERS AND THE Sick . . . I

CHAPTER II

Homes for the Feeble and Destitute • • . 15

CHAPTER III

HOMES FOR THE INSANE .

CHAPTER IV

The Lazar-House

\section{CHAPTER IV}

CHAPTER V

The Leper in England .

CHAPTER $V$

CHAPTER VI

Founders AND Benefactors

CHAPTER VII

Hospital Inmates

CHAPTER VIII

Hospital Dwellings

CHAPTER IX

The Constitution 


\section{x MEDI EVAL HOSPITALS OF ENGLAND}

CHAPTER X

The Household and its Members

CHAPTER XI

CARe of the Soul

CHAPTER XII

Care of THE Body

CHAPTER XIII

Hospital Funds .

CHAPTER XIV

Relations with Church and State

CHAPTER XV

Decline of the Hospitals

212

CHAPTER XVI

The Dissolution of Religious Houses and its Effect UPON Hospitals

- 226

Hospital Patron-Saints

\section{PART II}

APPENDIX A

Office at the Seclusion of a Leper

273

APPENDIX B

Tabulated List of Foundations

- 278

BIBLIOGRAPHY

- 339

General Index

- 343 


\section{LIST OF ILLUSTRATIONS IN THE TEXT}

* Asterisk denotes that buildings remain in much the same condition as shown.

The seals are copied mainly from impressions in the British Museum.

1. St. John's Hospital, Oxford

J. Charles Wall PAGE

[After M. Paris, B.M. Roy. ${ }_{4}$ C. vii. f. 221.]

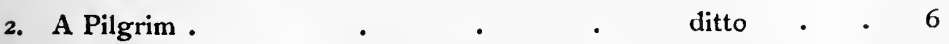

[B.M. 17 C. xxxviii. f. 39, xiv. cent.]

3. Domus Conversorum, London . . ditto . 20

[Idem.] Home for Jews, founded 1232. Site occupied by Rolls Chapel, Chancery Lane.

4. ${ }^{*}$ Poor Priests' Hospital, Canterbury $\quad$. B. C. Boulter $\quad{ }_{23}$ [From Ancient Cities Series.]

5. "The Bede-House, Stamford

- J. Charles Wall . 29

6. Seal of the Lazar-House, Mile End . ditto . 47

7. The Leper and the Physician $\quad . \quad$ d ditto $\quad . \quad 59$

[Trin. Coll. Camb. O.I. 20, by permission of the Librarian.]

Represents, perhaps, the examination of a suspected person.

8. Elias, a Leper-monk . Pans in Canterbury Cathedral;
[Notes on Painted Glass

ditto . $\quad 64$

from window in the Trinity Chapel, partly new, partly fragments of old glass.]

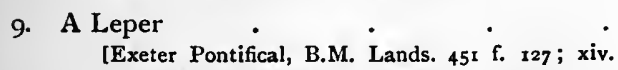
cent. MS., marginal sketch possibly xv. cent.]

10. "The Memorial of Matilda the Queen" .

[After Matthew Paris, Hist. Major, Corp. Chr. Coll. Camb., MS. xvi, xxvi, by permission of the Librarian.]

Memoriale Matildis regine scilicet hospitale Sancti Egidii quod est Londonia.

11. *Tomb of Rahere in St. Bartholomew's, Smithfield .

ditto . $\quad 76$ 


\section{xii MEDI EVAL HOSPITALS OF ENGLAND}

12. Memorial Brass of John Barstaple

[By kind permission of Mr. J. W. Arrowsmith.]

13. *St. Bartholomew's Hospital, Bristol .

[By kind permission of the Proprietor of the Western Daily Press.]

14. Seal of St. Bartholomew's, London

- J. Charles Wall . 93

15. Seal of Knightsbridge Hospital .

Depicts Blessed Virgin and Child with St. Leonard. Inscribed: Sigillum: ospici sci: lenarde (?): kynght brigge.

16. Seal of St. Alexis, Exeter

17. Seal of St. John's, Exeter

18. Seal of St. John's, Stafford

19. Plan of St. Mary's, Chichester

S. J. Loxton . $\quad 89$

[Dollman's Domestic Architecture.]

20. Plan of St. Nicholas', Salisbury . ditto . . 103

Drawn by Mr. J. Arthur Reeve, architect. By kind permission of Canon Wordsworth.

21. Sherburn Hospital, near Durham.

$\begin{array}{llll}\text { ditto } & \cdot & \cdot & 107 \\ \text { ditto } & . & . & 107 \\ \text { ditto } & . & . & 108 \\ \text { ditto } & . & . & 112\end{array}$

[Hutchinson's Durham, 1787.]

The gateway and chapel remain.

22. Plan of St. Mary Magdalene's, Winchester. J. Charles Wall . 119 [After Scbnebbelie.]

23. ${ }^{*}$ Chapel of Abbot Beere's Almshouse, Glastonbury

24. Seal of the leper-women of Westminster

25. *Ancient Hospital Altar at Glastonbury . [By kind permission of Mr. George Gregory, Bath, from Rev. C. L. Marson's Glastonbury.]

In the chapel of the almshouse founded or refounded by Abbot Beere.

26. A Leper with clapper and dish

[After a Miniature in the Bibl. de l'Arsenal, Paris, MS. 5060 ; xiii. cent. ; from La Vie Privée d'Autrefois, "L'Hygiène," A. Franklin, r8go.]

27. Document and Seal of Holy Innocents', Lincoln [B.M. Harl. cb. 44 A. 29.]

28. Alms-box, Harbledown Hospital .

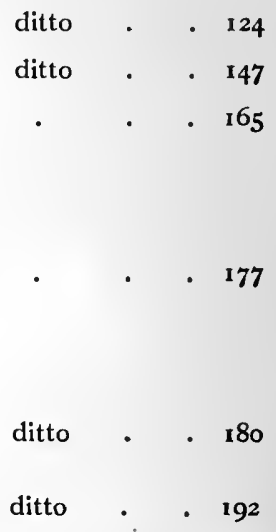

Erasmus dropped a coin into it on his visit to Harbledown. 


\section{LIST OF ILLUSTRATIONS IN THE TEXT xiii}

29. *Bell-turret of St. Mary Magdalene's, Glas[From Ancient Cities Series.]

30. Seal of St. Anthony's, London [Gent. Mag. ${ }^{78} 8_{4}$ ii.]

31. *Gateway of St. John's, Canterbury [From Ancient Cities Series.]

32. Seal of St. Mary Magdalene's, Bristol

33. Seal of St. Mark's, Bristol

34. Seal of St. Clement's, Hoddesdon

35. Seal of St. Katherine's, Bristol .

36. A Pilgrim's Sign

[Collectanea Antiqua.]

Canterbury souvenir found at York.

37. Seal of St. Bartholomew's, Rochester

- E. H. New • • 198

- J. Charles Wall - 208

B. C. Boulter $\quad$ 24I

- J. Charles Wall $\quad 2^{2}$

ditto . 254

ditto . 256

ditto . 260

. $\quad 265$

ditto $\cdot 27^{1}$ 


\section{LIST OF PLATES}

*Maison Dieu, Dover .

Frontispiece

[Buck's engraving, r735.]

S.E. view of St. Mary's Hospital. The restored buildings form part of the Town Hall; the chapel on the N.E. is used as a police-court.

I. Refreshment for Wayfarers

["The Pilgrim." B.M. Tib. A. vii. f. go, xv. cent.]

II. *Pilgrims' Hospital, Canterbury

[Drawn by J. Raymond, engraved by Cook.]

N. view of St. Thomas', Eastbridge. The windows are those of the chapel, rebuilt circa $1_{3} 6_{3}$.

III. *St. John's, Canterbury

[Idem.] The chapel exists, but altered. The hall contains charters, almsbox, account.books, etc.

IV. ${ }^{*}$ Cloister of St. Giles', Norwich

[Photograph, London and Co. Photo Press.]

V. ${ }^{*}$ Harbledown Hospita]

[Drawn by Nelson, I766, engraved by Cook.]

Church remains, dwellings rebuilt; hall contains ancient utensils, etc.

VI. (a) St. Bartholomew's, Gloucester

[From Lysons' Antiquities.]

S.E. view. Hospital rebuilt temp. Henry III.

(b) *St. Mary's, Chichester

[S. H. Grimm, B.M. Add. Burrell.]

VII. *God's House, Southampton.

[Woodward and Wilks, Hampshire.]

St. Julian's Chapel and God's House Gate.

VIII. *Hospital of St. Cross

[From Guide, J. Wilkes, r780.]

The southern wing has disappeared.

IX. The Death of Richard Whittington

[Life of John Carpenter, by T. Brewer, p. 26; original in Mercers' Hall.]

X. ${ }^{*}$ Hall of St. Cross, Winchester.

[Woodward.] 
XI. *St. Mary Magdalene's, Glastonbury .

(a) View from the West. [Drawn by E. H. New.]

(b) Ground-plan. [Drawn by J. Charles Wall.]

XII. St. Giles-in-the-Fields, London

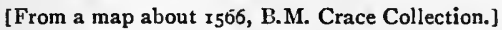

(a) Plan of the Leper Hospital. (b) Church of St. Giles.

XIII. *Ford's Hospital, Coventry .

[Photograph by Frith.]

XIV. The Savoy Hospital, London .

[G.V. ${ }_{7736}$, Vetusta Monumenta.]

XV. ${ }^{*}$ Hospital of St. Nicholas, Salisbury .

[Original drawings by J. Buckler, B.M. K. xliii.]

(a) S.E. view; the present chapel is shown, and to the right a former chapel, now a kitchen.

(b) W. view; the weathering of the original porch is seen.

XVI. (a) The Warden's House, Sherburn

[Original drawing by Grimm, B.M.]

This residence was destroyed in 1833 .

(b) *Gateway, Kepier

[Surtees' Durbam.]

This fine gateway (1333-45) has a groined ceiling with beautiful bosses.

XVII. *The Almshouse, Ewelme . . . . . ${ }^{\mathbf{r}^{\mathbf{r}}}$

[Photograph by Taunt.]

"The Pratie Hospitale of poore Men" with its "very fair Welle" was visited by Leland.

XVIII. * *St. Mary's, Chichester

[Photograph by Valentine.]

XIX. St. Bartholomew's, Sandwich

[Drawn by G. Maxwell, engraved in W. Boys' Collections, 1787.]

(a) Chapel. (b) Gateway.

XX. The Beggars' Dole

[Gentleman's Magazine, 1793, from stained glass.]

Food distributed to the hungry ; one cripple uses a "stool" or support.

XXI. St. Mary Magdalene's, Winchester .

[J. Schnebbelie, 1788, Vetusta Monumenta.]

(a) Master's House and Chapel. (b) Chapel from West.

A Norman doorway from this destroyed chapel was removed to St. Peter's Street.

XXII. *St. Bartholomew's, Oxford

[Drawn by Hollis, Gent. Mag., I 833, i.]

The chapel and buildings remain at Bartlemas Farm, Cowley Road. 


\section{xvi MEDI $Æ V A L$ HOSPITALS OF ENGLAND}

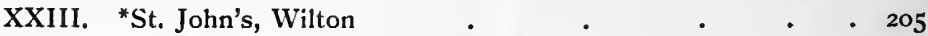

[Original drawings by J. Buckler, B.M.]

(a) S.E. view. (b) N. view.

The "Priory" is still picturesque and ivy-clad. The walls are of flints, with large quoins; the original buttresses and windows remain. The chapel $(a)$ is in use.

XXIV. *St. Leonard's, York (ambulatory) . $\quad$ • • . 227

$\mathrm{XXV}$. *St. Leonard's, York (chapel) . . . . ${ }^{2} 3^{2}$

XXVI. *The Almshouse, Abingdon. . . . . $\quad 235$

[Photograph by Taunt.]

Now called Christ's Hospital.

XXVII. St. Mary's, Newcastle

(After lithograph, J. Storey, 1844 ; reproduced by permission of the Society of Antiquaries, Newcastle-upon-Tyne, from Transactions, 1892.1

XXVIII. (a) St. Petronilla's, Bury St. Edmunds _. . . 256

(b) *Lepers' Chapel, Dunwich . . . . $25^{6}$

XXIX. The Hospitality of St. Julian ․ . . 259

[By Cristofano Allori, Palazzo Pitti, Florence, photograph by Brogi.]

XXX. (a) Spital-on-the-Street . $\quad$ • $\quad$ • $\quad . \quad 264$ [S. H. Grimm, B.M.]

(b) *St. Edmund's, Gateshead . . . . $\quad 264$

[Idem.] The chapel was built circa 1247 , and restored 1837 ; now Holy Trinity Church, High Street. 


\section{INTRODUCTION}

\section{"And to relief of lazars and weak age, Of indigent faint souls, past corporal toil, A hundred almshouses, right well supplied."}

(Shakespeare : Henry V., i. I.)

W HILE we are justly proud of our institutions for the amelioration of the lot of the infirm and destitute, we are apt to forget that they are not the outcome of any modern philanthropic movement, but are rather England's inheritance for above a thousand years.

Much has been written of the regular monastic houses. These are situated, as it were, upon the high-roads of ecclesiastical history; but comparatively little attention has been paid to the existence and development of the foundations known as "Hospitals." Although it is with some trepidation that we tread the less-frequented by-paths of history, an attempt will be made in this volume to illustrate the place of the hospital in pre-Reformation times, and by this means to secure a fuller recognition of the widespread activity of the Church of England in former days. Hospitals played an important part in the social life of the Middle Ages, and from the study of them much may be learnt of the habits of a distant past.

At the outset it will be well to make clear what the hospital was, and what it was not. It was an ecclesiastical, 
not a medical, institution. It was for care rather than cure : for the relief of the body, when possible, but preeminently for the refreshment of the soul. By manifold religious observances, the staff sought to elevate and discipline character. They endeavoured, as the body decayed, to strengthen the soul and prepare it for the future life. Faith and love were more predominant features in hospital - life than were skill and science.

It will surprise many to learn that-apart from actual monasteries and friaries-there existed upwards of $75^{\circ}$ such charitable institutions in Mediæval England. ${ }^{1}$ To appreciate the relative magnitude of this number, it must be remembered that the total population was smaller than that of London at the present day. The fact proves that clergy and laity were battling bravely with social problems. There existed a sense of responsibility, causing real charitable effort, although mediæval methods may appear mistaken in the light of modern scientific and economic principles.

The study of these ancient charities calls attention to the following points. The first is the extent of leprosy in England. There are, indeed, conflicting opinions concerning the prevalence of the disease, but it is certain that the figure mentioned above includes over 200 hospitals occupied at one time by lepers. Secondly, a number of the early foundations were in the main houses of hospitality for strangers; and this testifies to the widespread practice of pilgrimage. There were also general hospitals in which temporary and permanent relief was

1 Nearly 800 are set down in the appended list, but some are uncertain. 
given to needy persons of all sorts and conditions. Some were very small institutions, mere cottage-hospitals. It is often impossible to ascertain the character of an ancient charity. As long ago as 1594, it was reported concerning St. Edmund's, Gateshead : "the poor ... are and have been indifferently of both kindes as men and women; but whether sicke or wholl, lepers or way fairinge, so they be poore, needie, and indigente, is note respected." On the other hand, in the case of large towns, hospitals were often differentiated. Situated in the main street, perhaps, was an infirmary-almshouse for the sick and helpless; near a frequented gate stood a hostel for passing pilgrims and others; outside the walls there would be at least one leper-hospital.

It is not possible to be precise in chronology, or even to give approximate dates. In Chantry Surveys there is often a memorandum that no foundation can be shown, this being lost in obscurity, and the house founded "before time of memory." Probably the earliest authentic fact relating to charitable houses other than monasteries is that concerning the Saxon hospital at York, for although, in the words of Canon Raine, "its beginning is enveloped in an atmosphere of historical romance," the munificence of Athelstan enables us to date its origin about the year 937 .

The year I 547 serves as a useful limit to our period, and may well for the purposes of this book denote the close of the Middle Ages in England. Its selection in no way implies a lack of continuity in the Church with which every hospital was intimately associated,-yet it marks 
a time of transition. Charity was crippled for a time by the confiscations of endowments designed for the relief of the destitute, until a new generation of philanthropists arose and endeavoured to replace them. Thomas Fuller truly says, "the reformed Religion in England hath been the Mother of many brave Foundations." To support this he instances certain famous hospitals, as that at Warwick, built by the Earl of Leicester (1571); Croydon, by Archbishop Whitgift (I596); Guildford, by Archbishop Abbot (before 1617 ), and Sutton's Charterhouse (1611). There is, indeed, no fundamental difference between the earlier and later almshouses of the sixteenth century. The author of $A$ History of English Philanthropy gives two reasons for using the period of the dissolution of monasteries as a starting-point. "It was then," he says, "that modern problems began to formulate themselves with great precision; and charity was then ceasing to be under the immediate direction and tutelage of the Church." For the same reasons, the year I547 is here used to conclude the earlier philanthropic era.

A tabulated list of hospitals will be found in Appendix B. Additions and corrections are earnestly invited by the author, as local and particular knowledge is required to make it accurate and exhaustive. From this list are excluded such infirmaries as formed an integral part of a monastic house; but in cases where some abbey maintained a separate institution outside its gates (with distinct constitution, separate dedication-name, and sometimes a separate seal), the foundation is set down as a hospital. The institutions known as Colleges have no 
place unless, indeed, they maintained bedemen. The "House of Converts" does, however, rightly belong to our subject, for it was an almshouse and industrial home. "Hospitals" of the Orders of the Temple and St. John of Jerusalem are excluded, because they differ in character, although the work they carried on was partly the same. Moreover, as they formed part of great societies, famous in and beyond Europe, they have their own historians. Houses of the Knights of St. Lazarus must, however, consistency notwithstanding, find a place, because any account of relief provided for lepers would be incomplete if that comparatively small Order were passed over. "Hospital" was a wide-embracing term, and the occasional application of the word to religious foundations of one kind or another has not always been accounted a reason for their inclusion.

The history of many houses is obscure, limited in some cases to a single reference. The great scholars Bishop Tanner and Sir William Dugdale reaped harvests, which are garnered in their Monasticons; yet even a humble student may now glean after them by means of the invaluable printed Calendars of the Public Record Office. The labours of the Historical Mánuscripts Commission are likewise fruitful. Wills are useful as showing the period up to which these institutions had popular support. Although Appendix B was mainly compiled before the issue of the Victoria County History, certain shires have received several additions from that great work, the forthcoming volumes of which will doubtless supplement the present list. Episcopal archives throw light upon 


\section{xxii MEDI EVAL HOSPITALS OF ENGLAND}

hospital-life, as upon every department of ecclesiastical history; fresh information and confirmatory evidence about which will be forthcoming when, by means of the Canterbury and York Society and other Record Societies, more Registers become accessible. It is much to be desired that local Archæological Societies should take up and develop the history of particular houses. It is difficult to ascertain which ancient charities still continue, but an attempt has been made to record approximately in the appended table such endowments as now exist.

Grateful thanks are due to those who have assisted the writer in her task. And first, to the Lord Bishop of Bristol, whose kind offer to contribute the Preface to this volume is only the latest proof of the ever-helpful interest he has taken in the whole work. Mention must also be made of $\mathrm{Mr}$. R. C. Fowler, of the Public Record Office, who, after personally examining the List of Foundations, gave hints for its improvement. The Rev. C. S. Taylor, F.S.A. and the Rev. Canon Wordsworth have given invaluable assistance, particularly by the translation of the Office found in Appendix A. In various ways help has been rendered by Miss Arnold-Forster, Professor G. H. Leonard, Mr. W. F. Rawnsley, and by friends and correspondents too numerous to mention. Lastly, it remains for the writer to acknowledge her indebtedness to the Rev. Dr. Cox, General Editor of the Series, without whose kindly encouragement she would never have ventured to go beyond a private study of the subject in hand. 


\section{đIje Sputtell houts.}

đ. Uopland.

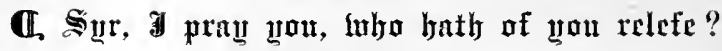

II. Jarter.

(II. J Forsath then tlyat be at surbe muachefe That for theur lunuñ tan io no labaur And baue an fremess to to them sarour As old̀ people sele and impotent

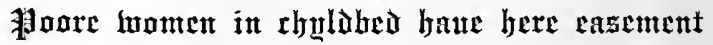

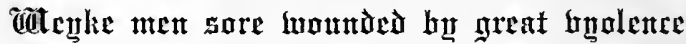
And sore men caten inith porkes and pestulyme And bonest folke fallen in great pourerte

Bhy mischaunce or atber infyrmyte

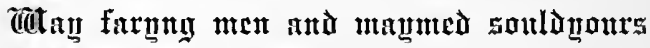
9fone theur reluef in this poore bous of ours And all ather inhich lme same gonò and playne

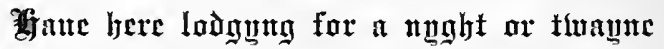

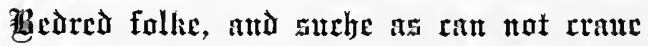
$\mathfrak{3} \mathfrak{a}$ these plares monst reluef they baue And uf they bap Initlin our place to İye

Than are then hurued luell and hanestly

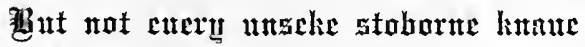

Ffor that Ine shold atucr ntaty batr.

1 From The hye way to the Spyttell hous (circa 1536), in which Robert Copland speaks with the Porter of a London hospital, probably St. Bartholomew's. 


\title{
MEDIEVAL HOSPITALS OF ENGLAND
}

\author{
P A R T O N E
}

\section{CHAPTER I}

HOSPITALS FOR WAYFARERS AND THE SICK

"Founded for the maintenance of poor pilgrims and other infirm persons resorting thither to remain until they are healed of their infirmities."

"For the poor, for persons going to Rome, for others coming to Canterbury and nceding shelter, and for lying-in women." (St. Thomas', Canterbury.)

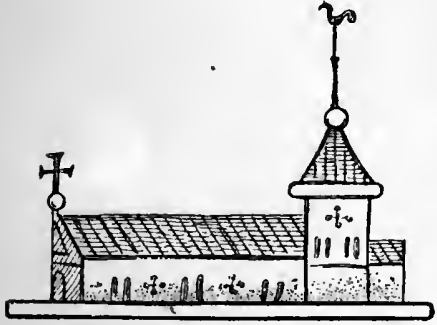

I. ST. JOHN'S HOSPITAL, OXFORD

$7 \mathrm{HE}$ earliest charitable 1 institutions of England were houses of hospitality. In sketching the development of these guesthouses we must bear in mind that the hospital (derived from hospes, a host or guest) was a wayside shelter for all comers.

$$
\text { FIRST PERIOD (circa 925-1170) }
$$

Travellers were exposed to peril by the rudeness of the times, but in those early days hospitality was regarded as a solemn obligation. To receive any stranger was a 
duty: to welcome the passing pilgrim was a sacred privilege. Although the private entertainment of guests was widely practised, some public institutions were required. Tradition tells of at least two "hospitals" or hospices founded in the tenth century (925-940). Both were in Yorkshire, ${ }^{1}$ one being in the distant country parts, the other in the populous town. At Flixton in Holderness was a house of refuge "to preserve travellers from being devoured by the wolves and other voracious forest beasts." 2 The city of York, on the other hand, was so great a place of thoroughfare that it was impossible to entertain all who came. Athelstan, recognizing that the Canons of the Minster were men of holy life, active in helping the needy who flocked to them, assisted them in their hospitality by the foundation of St. Peter's hospital.

Two other early houses of charity are ascribed to the Saxon bishops Oswald and Wulstan of Worcester. In the eleventh century at least we emerge from tradition, for it seems clear that St. Wulstan founded that hospital near his cathedral city which afterwards bore his name. It will be remembered that bishops were especially bound by their vows at consecration to be given to hospitality. In pre-Norman days, the solemn question was in substance what is asked to-day: "Wilt thou shew mercy and kindness, for the name of the Lord, to the poor, the stranger, and all in want?" (pauperibus et peregrinis omnibusque indigentibus). To this the elected bishop re-

1 There were probably other Saxon hospitals. Leland notes the tradition that St. Giles', Beverley, and St. Nicholas', Pontefract, were founded "afore the Conquest."

2 Dugdale, charter temp. Henry VI. 
plied, "I will." This formula occurs in the Exeter Pontifical, compiled about nine hundred years ago, and is repeated in Osmund's Sarum Use.

There were, of course, pilgrims among those who sojourned in early hostels. Englishmen have always loved travel. Not only did our Saxon forefathers journey to Rome (receiving shelter by the way in hospitals of English foundation), but they constantly visited their national shrines. Probably a fresh impetus was given to pilgrimage by the coming of the Normans. Monastic life was strengthened, and this was a guarantee of hospitality. "Guests are to be received as if they were Christ Himself," said the rule of St. Benedict. In the century after the Conquest, as in those which preceded it, the chief works of mercy were done in the monastery. There was the hospitium within the abbey-gate, as at St. Mary's, York; and the "Strangers' Hall" at Winchester. Then followed the shelter outside the walls, as at Battle, referred to (circa 1076) as "the house of the pilgrims which is called the hospital." During the twelfth century more independent foundations became common. All sorts and conditions of men were lodged-wayfarers, invalids, and even lepers.

About the year 1148, St. Bartholomew's, Smithfield, was the resort of sick pilgrims, of whom "many and innumerable were schewid tokynnys of myracles." The patients who flocked to the famous shrine and hospital were "langwissyng men greuyd with uariant sorys"; one sought "remedie of his akynge hede," another suffered from "bleriednes of yen" (eyes), and yet another from "ryngyng of his erys." Victims of the falling sickness 


\section{MEDI EVAL HOSPITALS OF ENGLAND}

(epilepsy), paralysis, dropsy, fevers, insanity, found relief; deaf and dumb were healed; a child born blind received sight from "the heuenly leche."

Theobald, Archbishop of Canterbury, about I I4I, invited help for "the hospital house of Dover, which two brethren, Osbern and Godwin, are diligently building for the reception of the poor and strangers." This hospital of St. Bartholomew (Buckland) was also used for lepers. The need of further provision for travellers was felt, and a benefactor made extensive grants on condition that a house was provided for the reception of needy people disembarking from ships: before I 63 reference is made to the hospitium for strangers. It was doubtless frequented by voyagers returning from the Crusades; but before long an event occurred which brought multitudes to Dover, and then the old hospital proving insufficient, became chiefly the resort of lepers, and a new Maison Dieu was built near the quay. (See Frontispiece.)

\section{SECOND PERIOD (circa I I 70-I 270)}

The year ıा 7o marks an epoch, ushering in the great pilgrimage within and towards England. When the shrine of St. Thomas of Canterbury became the goal of pious wayfarers it was necessary to find accommodation for them. The hospitals of Canterbury and Southwark bearing the martyr's name were among the earliest. Within a few years such houses (often called Domus Dei) were founded in most of the southern ports and along the Pilgrims' Way, as at Dover, Ospringe, and Maidstone. At Strood "the poor, weak, infirm and impotent, as well neighbouring inhabitants as travellers from distant 


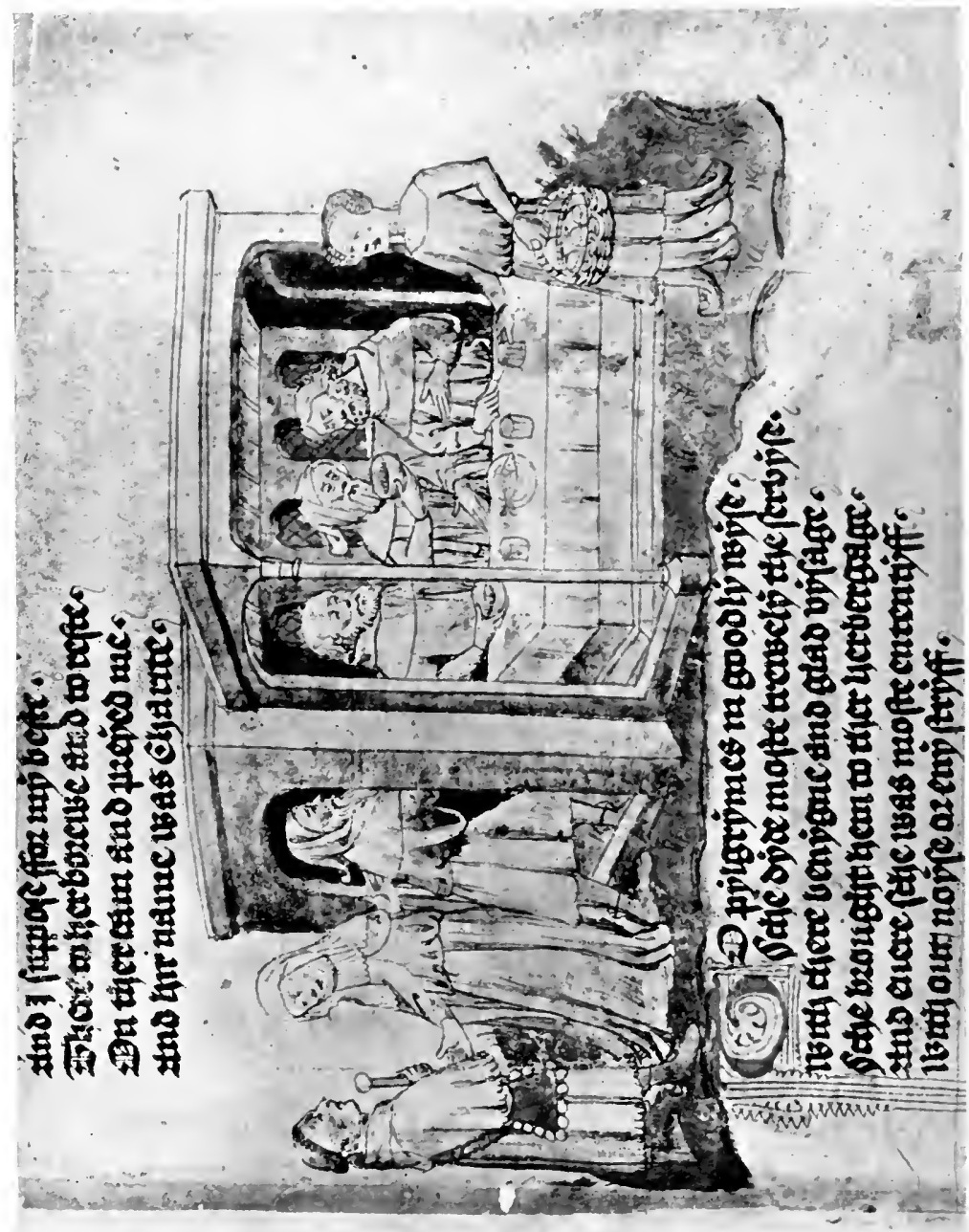


places," were cared for " until they die or depart healed." Norfolk, like Kent, was studded with houses of charity, especially near the highway to Walsingham. Thirteen pilgrims were lodged at Bec, near Billingford. At Thetford there was a hospital near the passage of the river. Among other early hostels we may enumerate those of Newcastle, Hexham, Ripon, Stamford, Aynho, London (St. Mary's), Bridgwater, and Ledbury.

The hospital was a guest-house and infirmary in one. That on the outskirts of Oxford was called in a charter (circa 1194) Herebergeria Hospitalis S. Joh. Bapt.; in I 233 this was refounded (Fig. I) "that therein infirm people and strangers might receive remedy of their health and necessity." The inmates of St. Nicholas', Salisbury, are described as passengers (transeuntes) and as sick and infirm (egroti et infirmi). The same two-fold work of charity was carried on at Chichester, as shown by St. Mary's statutes :-

"If anyone in infirm health and destitute of friends should seek admission for a term, until he shall recover, let him be gladly received and assigned a bed. . . . In regard to the poor people who are received late at night, and go forth early in the morning, let the warden take care that their feet are washed, and, as far as possible, their necessities attended to."

There is a MS. in the British Museum entitled The Pilgrim. It is an allegorical poem in the manner of the "Pilgrim's Progress," and sets forth the adventures of the traveller. The illustration (P1. I) and description were probably taken from experience of earthly pilgrimage. "Charity" is seen welcoming strangers, 


\section{MEDI $Æ V A L$ HOSPITALS OF ENGLAND}

at which work she was always busy in mediæval England :-

\section{"And I suppose for my beste}

There to herborewe and to reste

On ther cam and preyed me

And her name was Charite

To pylgrymes in goodly wyse

Sche dyde moste trewely the seruyse

With chere benygne and glad uysage

She brought hem to ther herbergage." 1

Among shrines which the pious Englishman visited may be mentioned Bury St. Edmunds, Westminster, Durham, Beverley, St. Albans, Waltham. ${ }^{2}$

\section{THIRD PERIOD (I 27O-I470)}

(a) Pilgrimage and Vagrancy.-The greatest century of pilgrimage was past, but vagrancy was an ever-

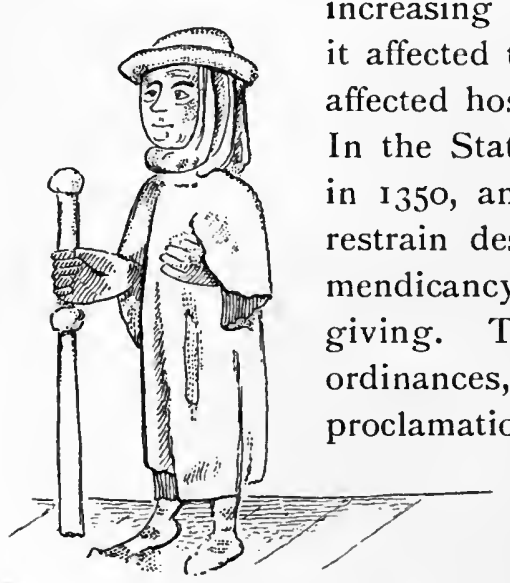

2. A PILGRIM increasing problem, and inasmuch as it affected the social life of England, it affected hospitals, directly or indirectly. In the Statute of Labourers, drawn up 1350, an attempt had been made to resultory wandering, idleness, mendicancy and indiscriminate almsgiving. This was followed by many ordinances, local and general. By a proclamation in I359 the municipal authorities of London declared that such unworthy beggars "do waste divers alms, which would otherwise be given to many poor folks, such as lepers, blind, halt,

1 Cott. Tib. A., vii. f. 90.

${ }^{2}$ See also J. C. Wall, Shrines of British Saints in this Series. 
and persons oppressed with old age and divers other maladies." In 1369 they issued a precept "for mendicants, vagrants and pilgrims to leave the city." The Statute of Westminster (1383) ordered inquiry concerning vagabonds "wandering from place to place, running in the country more abundantly than they were wont in times past." The Act of 1388 declared that those who "go in pilgrimage as beggars" when fit for employment, should be dealt with according to the previous Statute. It will be observed that these measures were framed from an economic standpoint, not to check pilgrimage as such.

Although pilgrimage was declining, there were still many pilgrims. Some of these were professional palmers, and hirelings fulfilling vows by proxy; for there are numerous bequests in the fourteenth century to persons undertaking journeys on the testator's behalf to Canterbury, Walsingham, and Bury St. Edmunds, as well as to St. James of Compostella, Rome, or the Holy Land. The special "Jubilee" at Canterbury in 1420 was attended by 100,000 persons, and in 1434 thousands set sail for Compostella.

(b) Provision for temporary relief.-Existing houses of hospitality were kept up, but a growing tendency to discriminate amongst applicants may be noticed. In many cases more beds were reserved for chronic invalids than for casual comers. St. Thomas' hospital, Canterbury, carried on its old work, but the renewed statutes of Archbishop Stratford (1342) direct "that poor pilgrims in good health shall be entertained only for one night . . . that greater regard shall be had for the sick than for the well pilgrims." With some diplomacy it describes itself, in a petition to the Pope, as designed "for persons going 
to Rome (Romipete), for others coming to Canterbury and needing shelter,"1 etc.

The chief building period was over, as far as this particular kind of temporary provision is concerned, but one or two new foundations must be mentioned. St. John's, Winchester, was built about I275 "for the relief of sick and lame soldiers, poor pilgrims, and necessitous wayfaring men, to have diet and lodging thereto fit and convenient for one night or longer, as their abilities to travel gave leave." In 1393, the Bishop of Ely offered an indulgence to persons contributing to the sustentation of a hospital at Brentford, which consisted of a chapel, newly constructed, "with two houses built there, furnished with beds and other necessaries for the entertainment of poor travellers." The old hospital at Brackley was reconstituted for the same purpose (1425). It was, however, suppressed sixty years later, because hospitality was being neglected.

One special form of temporary relief came to the front about this time. The assistance of women in childbirth was named in the Petition and Statute of 1414 as part of the recognized aim and scope of hospital charity. The heading to this chapter alludes to the work undertaken at St. Thomas', Canterbury, in 1363 . The foundation deed of Holy Trinity, Salisbury, sets forth that "lying-in women are cared for until they are delivered, recovered and churched." The Spital near Blyth was newly constructed in 1446 for the lodging of strangers and distressed women.

It is recorded that the two London infirmaries of St. Mary without Bishopsgate and St. Bartholomew under-

${ }^{1}$ Cal. Pap. Letters, 4, p. $3^{6 .}$ 


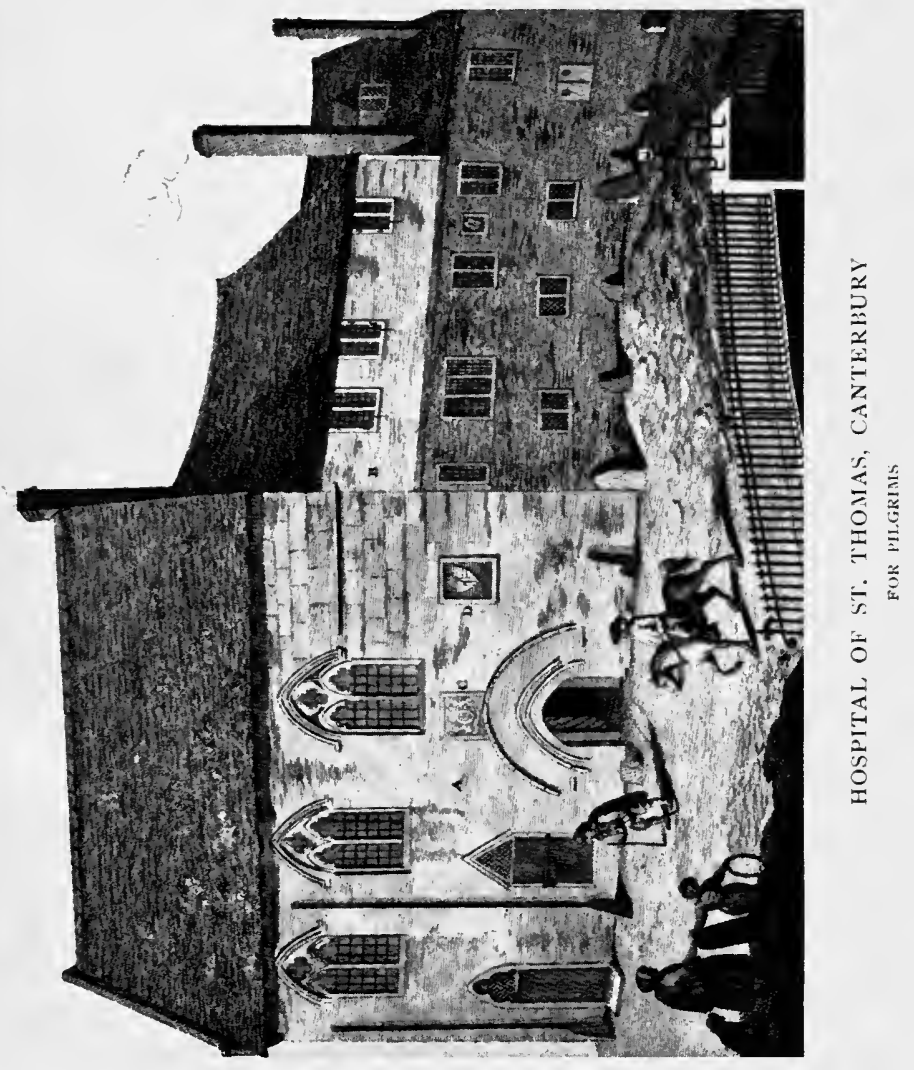



took this work; in both institutions the touching provision was made that if the mother died, her child should be brought up there until the age of seven. ${ }^{1}$ In the year 1437 privileges were granted to the latter hospital "in consideration of their great charges in receiving the poor, feeble and infirm, keeping women in childbirth until their purification, and sometimes feeding their infants until weaned." William Gregory, a citizen of London, describing in his commonplace book various foundations, says of "Bartholomewe ys Spetylle" :-

" Hyt ys a place of grete comforte to pore men as for hyr loggyng, and yn specyalle unto yong wymmen that have mysse done that ben whythe chylde. There they ben delyueryde, and unto the tyme of puryfycacyon they have mete and drynke of the placys coste, and fulle honestely gydyd and kepte."

General hospitals for the sick were thus in process of development. St. Bartholomew's was steadily fulfilling its founder's vow to provide a place for the "recreacion of poure men." After three and a half centuries of usefulness, a roll of 1464 records with approbation "works done within the hospital in relief of poor pilgrims, soldiers, sailors and others of all nations."

\section{FOURTH PERIOD (circa I470-I 547)}

(a) It is evident that pilgrimage was no longer an important factor in the social life of the country. The daily resort to shrines had practically ceased, but the special anniversaries were kept. Such pious travellers as there were, lodged chiefly in inns. At Glastonbury a Pilgrims' Inn was built by Abbot John, about the year 1475, to accommodate those visiting the holy places of

${ }^{1}$ Close Rolls I 344, I 353 . 
St. Joseph of Arimathæa and St. Dunstan. A later abbot, Richard Beere, writing to Archbishop Warham to defend the genuineness of St. Dunstan's relics, stated that people had come from far and near to visit the new shrine, especially upon St. Dunstan's Day (1508). ${ }^{1}$ Although the regular stream of pilgrims to Canterbury was no longer seen day by day, the great " Jubilee " celebrations

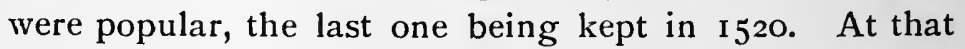
time the needs of visitors were met by special provision, a post being set up in the main street with "letters expressing the ordering of uitell and lodyng for pylgrymes." Probably the bailiffs and citizens made all arrangements for bed and board as they had done in 1420 .

Vagrancy still constituted an increasingly grave problem. By "An Acte agaynst vacabounds and beggers," in I 495 (re-enacted I503), previous legislation was amended and "every vagabound heremyte or pilgryme," partially exempt hitherto, was henceforth compelled to fare like wandering soldier, shipman or university clerk. In a letter from Henry VIII to the Mayor of Grimsby it is observed that the relief of the impotent is much diminished by the importunate begging of the sturdy and idle, and it is required that measures be taken "that the weedes over growe not the corne." 2 The Statutes became increasingly stern, and able-bodied beggars were scourged with the lash from town to town by the Act of $1530-1$. But " the greatest severities hitherto enacted were mild in comparison with the severe provisions of the enactment" of the first year of Edward VI (I547). If the young king's father had literally chastised beggars with whips, his own counsellors desired that they should be chastised with scor-

${ }^{1}$ Chron. and Mem. 63, p. 434 .

${ }^{2}$ Hist. MSS. 1 th R. (8) 249. 
pions. They might be reduced to the condition of slaves : their owners might put a ring round their necks or limbs, and force them to work by beating and chains, whilst a runaway could be branded on the face with a hot iron. ${ }^{1}$ This brutal law was repealed two years later.

(b) Where towns were few and far between, the need of shelter for strangers was especially felt. Extensive works of hospitality were done by religious houses, particularly in the northern counties. That fresh provision, although on a small scale, was still made for shelter, indicates its necessity. When an almshouse was built at Northallerton (1476), accommodation was made not only for thirteen pensioners, but for two destitute and distressed travellers, who should stay a night and no longer. A hostel solely for temporary shelter was founded at Durham (1493). One Cuthbert Billingham directed the provision of eight beds in a " massendeue or spittel," where " all poore trauellyng people ther herbery or logyng asking for the loue of Gode shall be herbered and logide." In Westmorland, a little hospital, with two beds for passers-by, was built by John Brunskill at Brough-under-Stainmoor (1506): it was situated on the pass into Yorkshire.

At seaports and in places of thoroughfare, shelter was still provided for travellers. God's House, Southampton, expended $£ 28$ annually upon "daily hospitality to wayfarers and strangers from beyond the sea," and similar charity was provided at Dover. Leland describes St. Thomas', Canterbury, as "An Hospital within the Town on the Kinges Bridge for poore Pylgrems and way faring men." At Sandwich there was a "Harbinge" attached to St. John's almshouse. Provision was made for lodgers,

1 C. J. Ribton-Turner, Vagrants and Vagrancy, 1887. 
and the buildings included "the chambre of harber for strange wemen, the gentilmen chambre and the long harbur chamber" (1489). The town authorities ordered "that no persons do harbour beggars, who are to resort to St. John's Hospital " (1524).

The existing provision for temporary relief was in fact wholly inadequate. In the metropolis, for example, there was a crying need. It was stated by Henry VII in 1509 that :-

"there be fewe or noon such commune Hospitalls within this our Reame, and that for lack of them, infinite nombre of pouer nedie people miserably dailly die, no man putting hande of helpe or remedie."

The king, recognizing the need, planned to convert the old Savoy Palace into a magnificent institution (PI. XIV) in which " to lodge nightly one hundred poor folks." If this charity corresponded with the recent Statute, it would relieve those vagrants who alone were exempt, namely, women in travail and persons in extreme sickness. The king contemplated building institutions similar to the Savoy in York and Coventry, but the design was not carried out.

The problems arising from true poverty and false mendicancy were, of course, intimately connected with hospital life. A graphic picture of the difficulties which beset administrators of charity about the year ${ }^{5} 56$ is given by Robert Copland in The hye way to the Spyttell hous. The author states that one wintry day, he took refuge from the snow-storm in the porch of a hospital, probably St. Bartholomew's. Here he got deep into conversation with the porter of the house. While they talked, there gathered at the gate people of very poor estate,-lame, blind, bare- 
foot-and Copland, who does not despise the honest poor, only those who live in need and idleness, inquires whether they admit all who ask for lodging. The porter at first answers, "Forsooth, yes," and Copland goes on to protest against indiscriminate hospitality :-

"Me thynk that therin ye do no ryght

Nor all suche places of hospytalyte

To confort people of suche iniquyte.

But syr I pray you, of your goodnes and fauour

Tell me which ye leaue, and which ye do socour."

The porter replies that the house is no supporter of sham beggars. There are some who counterfeit leprosy, and others who put soap in their mouth to make it foam, and fall down as if they had "Saynt Cornelys euyll." He goes on to describe those who hang about by day and sleep at night at St. Bartholomew's church door -drunkards, spendthrifts, swearers and blasphemers, those who wear soldiers' clothing, but are vagabonds, and men who pretend to have been shipwrecked. Many of these live by open beggary, with bag, dish and staff :-

"And euer haunteth among such ryf raf

One tyme to this spyttell, another to that."

The porter intimates that an effort is made to discriminate among those daily harboured, but he confesses that they are obliged to receive many unsatisfactory men, and disreputable women so numerous that they are weary of them ; but they refuse stubborn knaves who are not ill, for they would have over many. Indeed, the aim of the hospital is to relieve those who cannot work and are friendless - the sick, aged, bedridden, diseased, wayfaring men, maimed soldiers, and honest folk fallen into poverty. (See p. xxiv.) 


\section{I4 MEDI EVAL HOSPITALS OF ENGLAND}

It is clear, however, that during the sixteenth century there was much genuine distress besides unthrifty beggary and sham sickness. From various economic causes there was a considerable increase of destitution. Legislation entirely failed to solve the problem of an ever-shifting population. The Statute of I530-I had recognized the value of charitable foundations by its clause :- " provided also, that it be lawful to all masters and governors of hospitals, to lodge and harbour any person or persons of charity and alms." Although hospitals had been abused, the neglect of the sick and homeless which their reduction involved was a far worse evil. One writer after another breaks out into descriptions of the increased poverty and pain. Brinklow, in The Lamentacyon of a Christian agaynst the Cytye of London (1545), bewails the condition of the poor :-

"London, beyng one of the flowers of the worlde, as touchinge worldlye riches, hath so manye, yea innumerable of poore people forced to go from dore to dore, and to syt openly in the stretes a beggynge, and many . . . lye in their howses in most greuous paynes, and dye for lacke of ayde of the riche. I thinke in my judgement, under heaven is not so lytle prouision made for the pore as in London, of so riche a Cytie." 1

Again, referring to the old order and the new, $A$ Supplication of the Poore Commons (1546) speaks of poor impotent creatures as " now in more penurye then euer they were." Once they had scraps, now they have nothing. "Then had they hospitals, and almeshouses to be lodged in, but nowe they lye and storue in the stretes. Then was their number great, but nowe much greater."

1 Early Eng. Text Soc. Extra Series 22, p. 9o. 



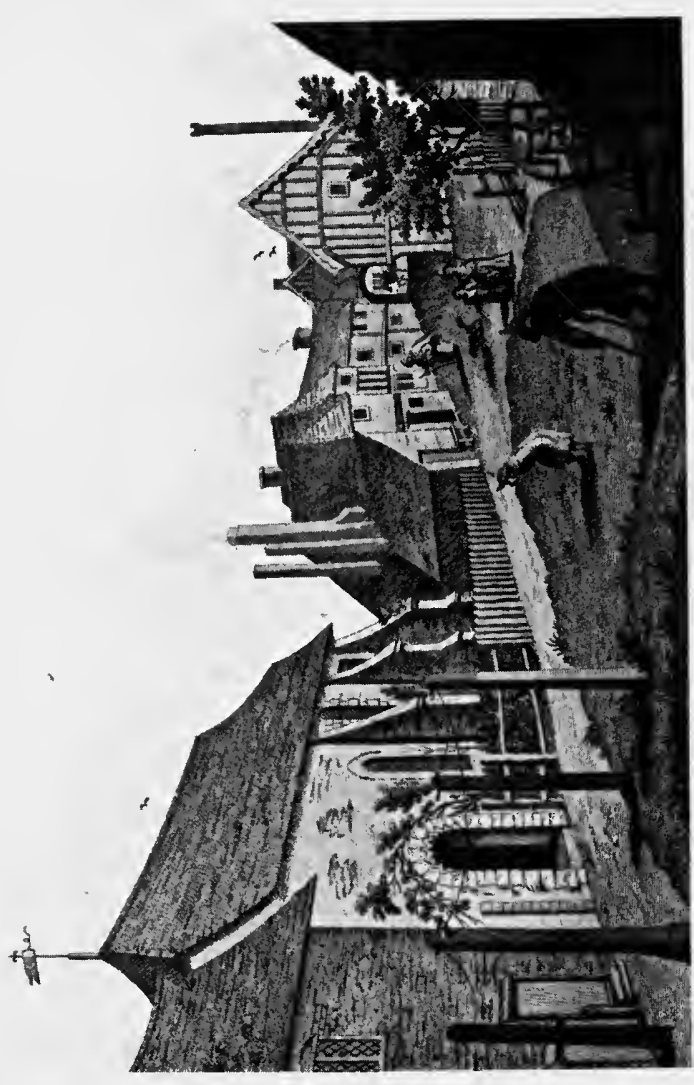

告 


\section{CHAPTER II}

\section{HOMES FOR THE FEEBLE AND DESTITUTE}

"Hospitals in cities, boroughs and divers other places . . to sustain blind men and women. . . and people who have lost their goods and are fallen into great misfortune." 1

7 majority of hospitals were for the support of

1 infirm and aged people. Such a home was called indiscriminately " hospital," "Maison Dieu," "almshouse" or "bedehouse." It was, as in the case of Kingston-upon-Hull, "God's House . . . to provide a habitation for thirteen poor men and women broken by age, misfortune or toil, who cannot gain their own livelihood." It occupied the place now filled by almshouses, union workhouses, and homes for chronic invalids or incurables.

\section{(I) ALMSHOUSES IN CITIES}

One of the most ancient hospitals for permanent relief was St. John's, Canterbury, founded about 1084, and still existing as an almshouse. (P1. III.) Eadmer tells us that it was intended for men suffering from various infirmities and for women in ill health. The inmates are described as a hundred poor, who by reason of age and disease cannot earn their bread; and again, as a hundred brothers and sisters blind, lame, deaf and sick. It is

1 Rolls of Parl. 2 Hen. V, Vol. IV, p. 19 b Petitions, No. III. 
characteristic that the earliest foundation of this type should be found in the chief cathedral city of England: every such town had a hospital in connection with the See. The prince-bishops of Durham, for example, provided houses of charity around the city and at their manors. Ralph Flambard built St. Giles', Kepier ; Philip of Poitiers founded St. James' near Northallerton; Robert de Stichill, St. Mary's, Greatham ; and Nicholas of Farnham, St. Edmund's, Gateshead. The most famous episcopal hospital remaining is that of St. Cross, near Winchester. (P1. VIII.)

Other charities were associated with cathedral clergy. There was a hospital for the poor in the precincts of St. Paul's Cathedral. Before the year I 190, one of the canons gave his house for the purpose, and the Dean endowed it with certain tithes. St. Nicholas', Salisbury, founded by the Bishop, was afterwards committed to the Dean and Chapter. The existing almshouses in Chichester and Hereford were likewise associated with those cathedrals.

\section{(2) ALMSHOUSES IN BOROUGHS}

The municipal control of charity is an ancient custom. Before burgesses were called to Parliament, townsmen of Exeter, Northampton, Nottingham and Wallingford were trustees of the hospitals of St. John in those places. The leper-houses of Lynn and Southampton were also early instances of municipal administration. In the reign of Edward I the hospitals in Scarborough were declared to have been "founded by burgesses of the town of old." During the fourteenth century, if not before, the "keepers" of Beverley, the "jurats" of Hythe, 
and the commonalties of Bedford, Gloucester, Huntingdon, Pevensey, Sandwich, Wilton, etc., controlled almshouses in those towns. ${ }^{1}$ Old deeds of the Winchester corporation refer to Devenish's hospital as "oure hous of Synt John." Freemen had an advantage, if not a monopoly, when seeking entrance into houses under municipal supervision. The "Customals" of Rye and Winchelsea show that men and women "who have been in good love and fame all their time, and haye neither goods nor chattels whereof to live" were received without payment into the hospitals of the town. Bubwith's almshouse, Wells, was to receive men so poor that they could not live except by begging, and so decrepit that they were unable to beg from door to door. Reduced burgesses were assigned "the more honourable places and beds." At St. Ursula's, Chester, candidates were preferred who had been one of "the twenty-four," or the widows of aldermen and common council-men.

In some towns charities were not directly connected with the municipality but with local trustees. St. Katherine's, Rochester, was under the governance and correction of the parish priest, the city bailiff and the founder's heirs. Davy of Croydon put his almshouse under the vicar and other townsmen, answerable ultimately to the Mercers' Company, and provided that his pensioners should be "householderers or trewe laborers" from within four miles, preference being given to residents of long standing, if of good character and destitute.

I St. John's, Bedford, was intended only for townsmen; all such applying to the master for relief were to be received, but "all poore folkes dwellyng without the same town to be expulsed and put out," Chantry Cert. (ed. J. E. Brown). 
(3) GILD ALMSHOUSES

The gilds were an important factor in the economy of towns, and their works of piety sometimes included hospital maintenance. St. Cross, Colchester, having been practically disendowed-the advowson was granted to the commonalty in aid of the repair of the town walls-was revived in 1407 as an almshouse under the auspices of St. Helen's gild. Barstaple of Bristol founded his almshouse for twenty-four poor, (granting the advowson to the mayor and commonalty,) and also a fraternity for himself, his wife and others who wished to join. The institutions were incorporated separately. Each community was ruled by a warden, possessed a common seal, and had power to make ordinances. ${ }^{1}$ In other cases a private individual attached his charity to an existing association to secure continuity of rule. Hosyer's almshouse in Ludlow, e.g., "appertained" to the Palmers' gild. These religious societies often began in connection with some trade. At Winchester, financial assistance was given to St. John's by "the fraternity of St. John, in the hospital there by providence of the Tailors of Winton first ordained."

The craft-gilds and city companies supported disabled members in places like the Maison Dieu of the Shoemakers at York, called also the Bedehouse of the Cordyners. There are countless references in wills to the poor of the Drapers' or Fullers' Halls, etc. Although such institutions were really almshouses, they are not (with certain exceptions) included in the appended list, and their history must be sought in connection with the trades.

1 Pat. 9 Hen. IV, Pt. i. m. 8. 
In ports, special provision was made for seafaring men. Leland remarks that St. Bartholomew's, Sandwich, was "fyrst ordened for Maryners desesid and hurt." The Fraternity of the Blessed Trinity at Kingston-upon-Hull maintained "an house of alms of poor mariners," and a similar institution was incorporated with Trinity House, Newcastle-upon-Tyne. A society of merchants at Bristol provided for poor seamen within the old hospital of St. Bartholomew (1445). Upon arrival in port, masters and mariners alike contributed to the charity because "the wheche prest and pore peple may nott be founden ne susteyned withoute grete coste." This fraternity was in fact a benefit-club, for members became eligible for admission after paying their dues for seven years. The community was especially bound to pray for seamen in time of peril.

\section{(4) PRivate almshouses}

In villages, the lord of the manor or squire provided a charity for his retainers, tenants or neighbours. This was done at Arundel, Donnington near Newbury, Heytesbury, Ewelme, Thame, etc. A man who had risen to prosperity occasionally remembered his birthplace in this way, as Chichele did at Higham Ferrers.

Although most hospitals were of a general character, some were designed for particular classes of persons, such as homeless Jews, poor clergy, decayed gentle-people, women and children.

(5) HOMES FOR JEWS

The chief "hospital" for Jewish converts was in London. The inmates were not ailing in health, but they needed succour because they were unable to earn a 
living, and were cut off from their own families as apostates. Converts were often sent to monasteries for maintenance. The names of almost five hundred, together with the particular houses that received them, are recorded in one roll of 39 Henry III. ${ }^{1}$

Special provision for the maintenance of converted Jews was made in 1232, when Henry III founded the House

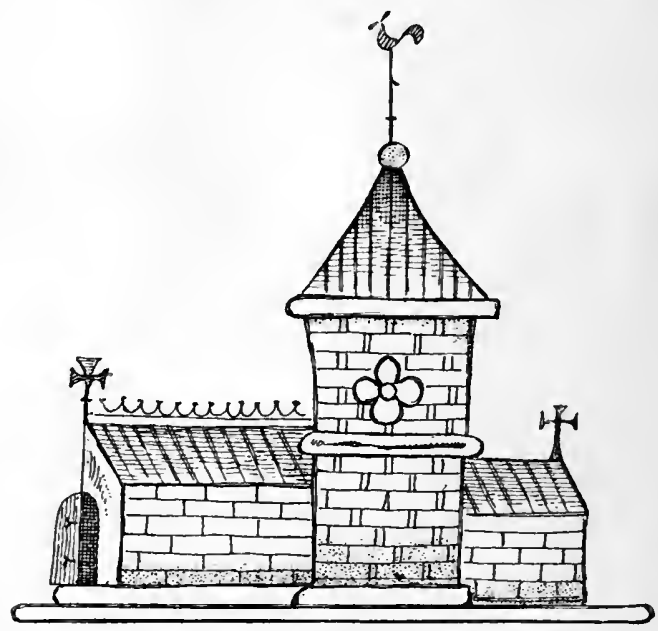

3. HOUSE OF CONVERTS, LONDON

of Converts, Hospital of St. Mary or "Converts' Inn," near the Old Temple. Within twenty years Matthew Paris described its purpose, also making a drawing (Fig. 3) in the margin :-

"To this house converted Jews retired, leaving their Jewish blindness, and had a home and a safe refuge for their whole lives, living under an honourable rule, with sufficient sustenance without servile work or the profits of usury. So it hap-

1 Tovey, Anglia Judaica, 227. 
pened that in a short time a large number were collected there. And now, being baptized and instructed in the Christian law, they live a praiseworthy life under a rector specially deputed to govern them."1

The year of this chronicler's death (1256), upwards of I60 convert brothers received tunics from the king's almoner. Probably about half were inmates, and half unattached pensioners. The number may have been increased from interested motives on account of the persecution of Jews which followed the supposed "horrible crime lately perpetrated in the city of Lincoln, of a Christian boy crucified." In January I256, pardon was granted to John the convert, who was a Jew of Lincoln when the so-called "little St. Hugh" was put to death.

The Domus Conversorum was rebuilt by Edward I, who bestowed much attention upon it. By his ordinance, the pensioners were taught handicrafts and trained to support themselves. He ordered that school should be kept and that suitable converts might be educated as clerks or chaplains. St. Mary's was an industrial home or training institution for persecuted Jewish Christians, who were safe only under royal protection. Another roll of the same year shows that a special effort was made at that time to evangelize the Jews. Orders had recently been given to repress notorious blasphemers, and those who after baptism had been "perverted to Jewish wickedness." Edward also directed that strenuous efforts should be made by the Friar Preachers for their conversion. Finally he set himself to improve the endowments of the institution :-

"He therefore, in order that those who have already turned

1 Chron, and Mem. 44, iii. 262. 
from their blindness to the light of the Church may be strengthened in the firmness of their faith, and those who still persist in their error may more willingly and readily turn to the grace of the faith, has taken measures, under divine guidance, to provide healthfully for their maintenance."1

The House of Converts was then supporting ninetyseven persons. Of these fifty-one remained in 1308 . After the great expulsion in 1290 , the numbers were quickly reduced. In $\mathrm{I}_{327}$, there were twenty-eight. In I344, the institution supported eight converts and seven admitted for other causes. After that date the pensioners dwindled to two. During the fifteenth century, a few foreign Jews were received from time to time, the household varying between eight and three. The hospital was empty in the days of Edward VI, and remained so until 1578 ; its subsequent history is related by Adler.

The Domus Conversorum in Oxford was likewise founded by Henry III. There, says Wood, "all Jews and infidells that were converted to the Christian faith were ordained to have sufficient maintenance. By which meanes it was soe brought about that noe small number of these converts had their abode in this place and were baptized and instructed." The building (figured in Skelton's Oxonia Antiqua) subsequently became a Hall for scholars.

According to Leland and Stow there were homes, or, at least, schools, for Jews in London and Bristol before Henry III turned his attention to this work. Stow, referring to the original foundation of St. Thomas' hospital, Southwark (I213), says that it was a house of alms for converts and poor children. Leland, quoting from a manuscript of the Kalendars' Gild in Bristol, states that

1 Pat. 8 Edw. I, m. 17. 
in the time of Henry II there were "Scholes ordeyned in Brightstow by them for the Conversion of the Jewes." The information (which he gleaned from the Little Red $B o o k$ ) originated in the bishop's inquisition made in ${ }^{1} 318$, which found that Robert Fitz-Harding and the Kalendars "established the schools of Bristol for teaching Jews and other little ones under the government of the same gild and the protection of the mayor." It should be noticed that scola also refers to a Jewish synagogue, but the term Schola Judacorum is applied by Matthew Paris to the House of Converts in London.

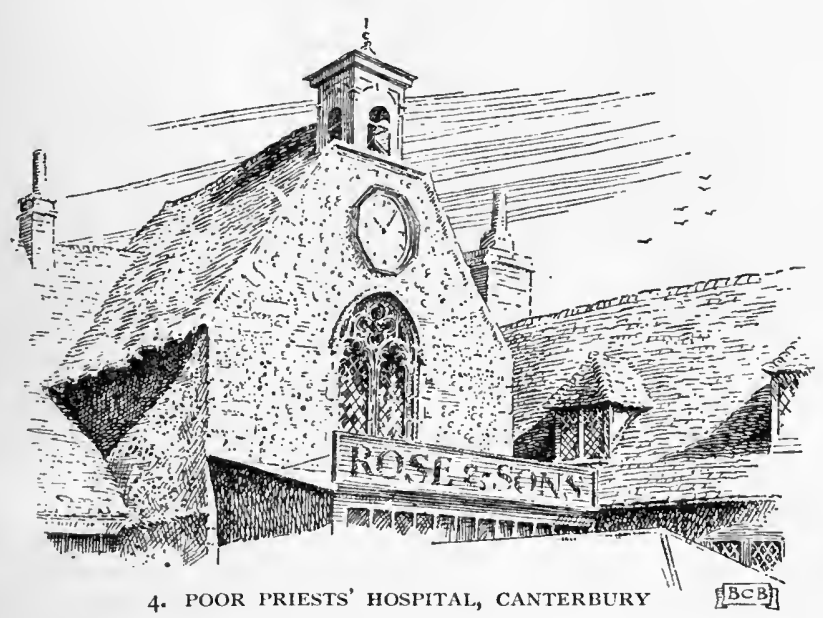

(6) HOMES FOR POOR CLERGY AND FOR LAY GENTLEFOLK

Diocesan clergy-homes were provided during the thirteenth century in most ecclesiastical centres. At Canterbury, the Archdeacon built (before 1225) the Poor Priests' hospital (Fig. 4). St. Richard of Chichester began 


\section{MEDI EVAL HOSPITALS OF ENGLAND}

a similar charity at Windeham in his diocese. Walter de Merton designed a small institution at Basingstoke for "ministers of the altar whose strength is failing," and incurables of Merton College. There were three beds for chaplains at St. Wulstan's, Worcester, and the Stratford gild intended to initiate a hospital for the diocesan clergy. To St. Giles', Lincoln, were admitted "needy ministers and servants and canons not able to work."

Similar retreats arose in the following century. The Bishop of Exeter built near his palace at Clist Gabriel a home for twelve blind, infirm, ancient or disabled priests, deacons and sub-deacons. The Dean of York maintained six infirm chaplains in St. Mary's, Bootham. Clergyhomes were usually founded by ecclesiastics; but in $\mathbf{1} 329$, a London layman, Elsyng by name, touched by the sufferings of the clergy in that time of scarcity, began his almshouse, ordaining that among the hundred pensioners, blind, paralytic and disabled priests should be specially cared for. The need is evident from a deed concerning St. Giles', Norwich (1340). The house had been founded for the poor " and principally to minister the necessaries of life to priests of the diocese of Norwich, who, broken down with age, or destitute of bodily strength, or labouring under continual disease, cannot celebrate divine service"; but the number of such priests and infirm persons "flocking to the hospital hath so grown and daily groweth" that assistance was urgently required. Although the priesthood was temporarily diminished by the pestilence of 1349 , clerks acting as chantry priests were again numerous during the fifteenth century. These unbeneficed clergy, it was said, "when depressed by the weight of old age, or labouring under weak health ... 


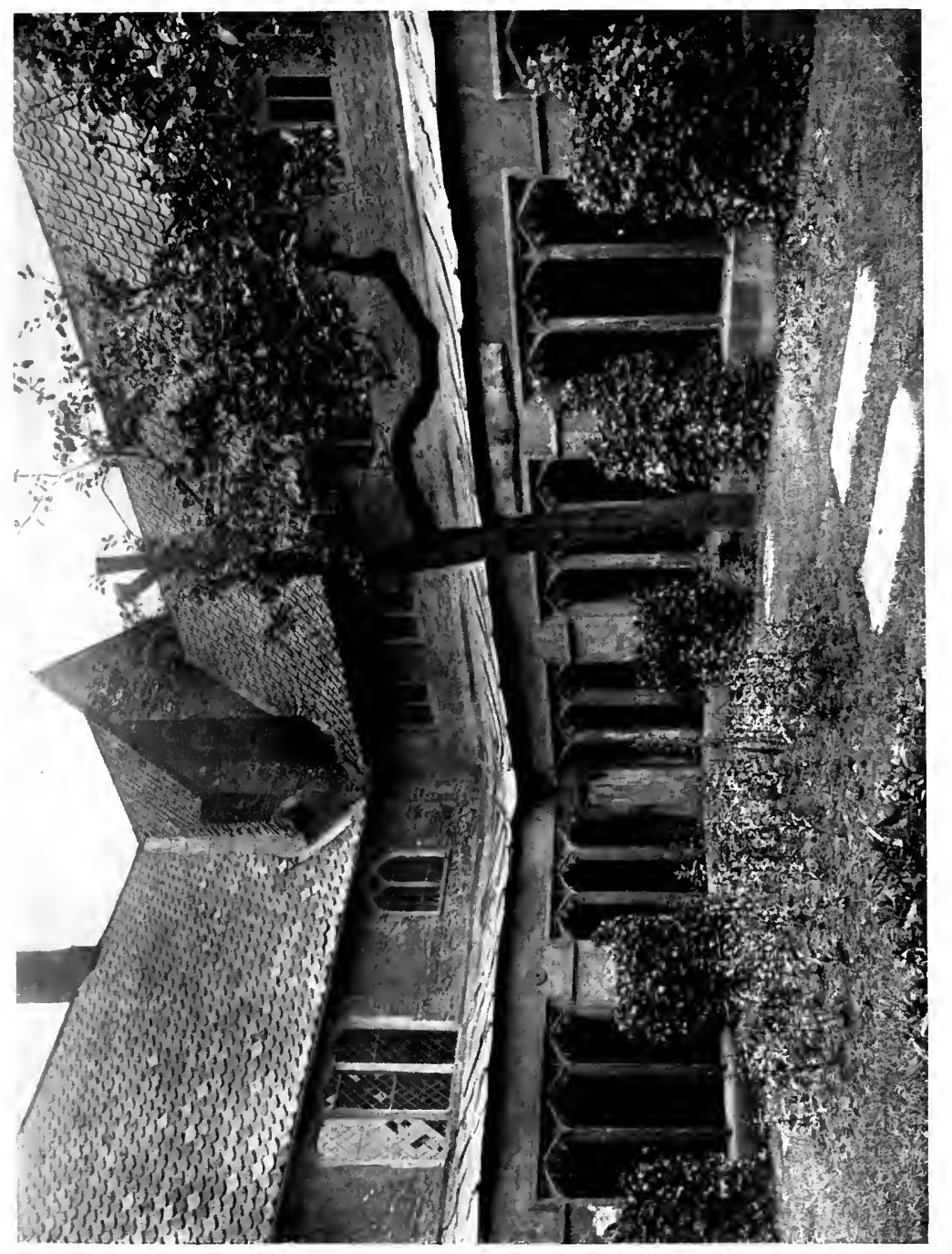

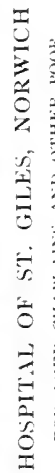



are by necessity compelled to wander about, begging miserably for food and raiment . . . to the displeasure of Him whose ministers they are." To put an end to this scandal, "the fraternity of St. Charity and St. John Evangelist" was founded in London (1442), and this clerical almshouse was commonly called "The Papey." Gregory, who was mayor in 1451 , describes it in his notebook :-

"Pappy Chyrche in the Walle be twyne Algate and Beuysse Markes. And hyt ys a grete fraternyte of prestys and of othyr seqular men. And there ben founde of almys certayne prestys, both blynde and lame, that be empotent."

Persons of gentle birth who had suffered reverses of fortune often retreated into convents, or were received into hospitals with a semi-official position. During the fifteenth century one or two institutions' arose to benefit those decayed gentlefolk who, as one has said, are of all people "most sensible of want." Staindrop College maintained a staff of priests and clerks, and certain gentlemen (certi pauperes generosi) and yeomen (pauperes valecti) who had been in the Earl of Westmorland's service. The "New Almshouse of Noble Poverty" (Nova Domus Eleemosynaria Nobilis Paupertatis), which Cardinal Beaufort intended to add to the original establishment of St. Cross, was never fully completed, but there are still four brethren of the professional class on the Cardinal's foundation.

\section{(7) HOMES FOR WOMEN AND CHILDREN}

One of the earliest permanent homes for women was St. Katharine's-by-the-Tower, London. The sisters of St. John's, Reading, are described as "certyn relygyous 
women, wydowes in chast lyuyngg in God's seruyce praying nygt and day." To provide for fatherless children and widows was part of the design of Holy Trinity, Salisbury. In two hospitals outside Lincoln this particular work was carried on. Originally served by the Gilbertine Order, they became entirely eleemosynary institutions under the care of lay-sisters. Many wills about the year 1400 allude to St. Katharine's asylum or hospital for widows, orphans, and bedemen. The daughter-house was a home for waifs and strays, namely, "certain orphans placed in danger through the negligence of their friends, and deserted, and brought into the hospital of St. Sepulchre, guarded and educated there."

A further reason for the adoption of children into the hospital family was this : that when women died in confinement, their infants were frequently kept and cared for. (See p. 9.) In connection with St. Leonard's, York, mention is made of "ministering to the poor and sick and to the infants exposed there." In I280 there were twenty-three boys in the orphanage, with a woman in charge. Education was provided for them and for the thirty choristers. Two schoolmasters taught grammar and music. The Dean and Chapter were forbidden by the King on one occasion (I34I) to meddle with the grammar school in the hospital. Among the expenses in 1369 is a gratuity to the bishop of the choir-boys. This shows, says Canon Raine, that there was a "boy-bishop" at St. Leonard's as well as in the Minster.

Nor was it uncommon thus to find young and strong side by side with aged and infirm inmates. Several almshouses maintained children. Bishop Grandisson carried out his predecessor Stapeldon's intention of 
adding twelve boys to the foundation of St. John's, Exeter, and Archbishop Chichele attached a boardingschool to his bedehouse at Higham Ferrers. There were children and adult pensioners in St. Katharine's, London, and in Knolles' almshouse, Pontefract.

Some hospitals had boarders or day-boarders whose studies were conducted in neighbouring schools. St. John's, Bridgwater, maintained thirteen scholars-such as were habiles ad informandum in grammatica-who were excused from full ritual that they might keep schools daily in the town (I 298). ${ }^{1}$ In some cases, like St. Giles', Norwich, food was provided for children who were getting free education elsewhere. At St. Cross, Winchester, seven choristers were boarded and instructed. Thirteen poor scholars from the Grammar School also . received a substantial meal daily.

In other instances we find that instruction was provided without board and lodging. The lads taught in God's House, Exeter, were not inmates, like those of St. John's in that city. The master of the hospital was required to teach from three to nine boys, beginning with the alphabet and going on to the "great psalter of the holy David." In the almshouses of Ewelme and Heytesbury also there were non-resident pupils. Only the more advanced at Ewelme aspired to "the faculty of grammar." It was directed that should the schoolmaster have no more than four "childer that actually lernes gramer, besides petettes [i.e. beginners] and reders," he should assist at matins and evensong. He must so rule his scholars that none be tedious, noisome, or troublous to the almspeople. Payment was forbidden at Heytes-

1 Bishop Drokensford's Reg. p. 268. 
bury except as a free gift, or by pupils whose friends had a yearly income of over £Io. Bishop Smyth, a patron of learning, added a schoolmaster and usher to his restored almshouse at Lichfield, where very poor children were to be taught. The Grammar School connected with St. John's hospital, Banbury, became famous.

Lastly, the development of these institutions must be considered. Many of the almshouses built during the twelfth and thirteenth centuries were intended from their foundation for life-pensioners. In other cases, however, on account of necessity or expediency, the permanent home was evolved from one originally of a temporary character. Charities underwent a change during the fourteenth and fifteenth centuries. This may be attributed to various social and economic causes-the decline of leprosy, legislation regarding vagrancy, and the redistribution of wealth. As the number of lepers decreased, the alms formerly bestowed upon them were available for other necessitous persons, and some lazar-houses gradually became retreats for aged invalids. This was chiefly during the fifteenth century, but even about I285 St. Nicholas', York, is said to be "founded in the name of lepers, and for the support of the old and feeble of the city." Again, when it was realized that indiscriminate hospitality encouraged vagrancy, the character of some hospitals gradually altered. The Statute of 1388 helped to develop local administration of charity by ordaining that beggars unable to work must either remain in the town where they found themselves or return to their birthplace and abide there for life. 
The crying need for the permanent relief of genuine distress made itself heard. Langland, the poet of the people, called attention to the necessity of rebuilding hospitals. In his Vision "Truth" begs rich merchants to put their profits to good uses and "amenden mesondieux" therewith. In I4IO, and again in I4I4, the Commons suggested that new almshouses might be

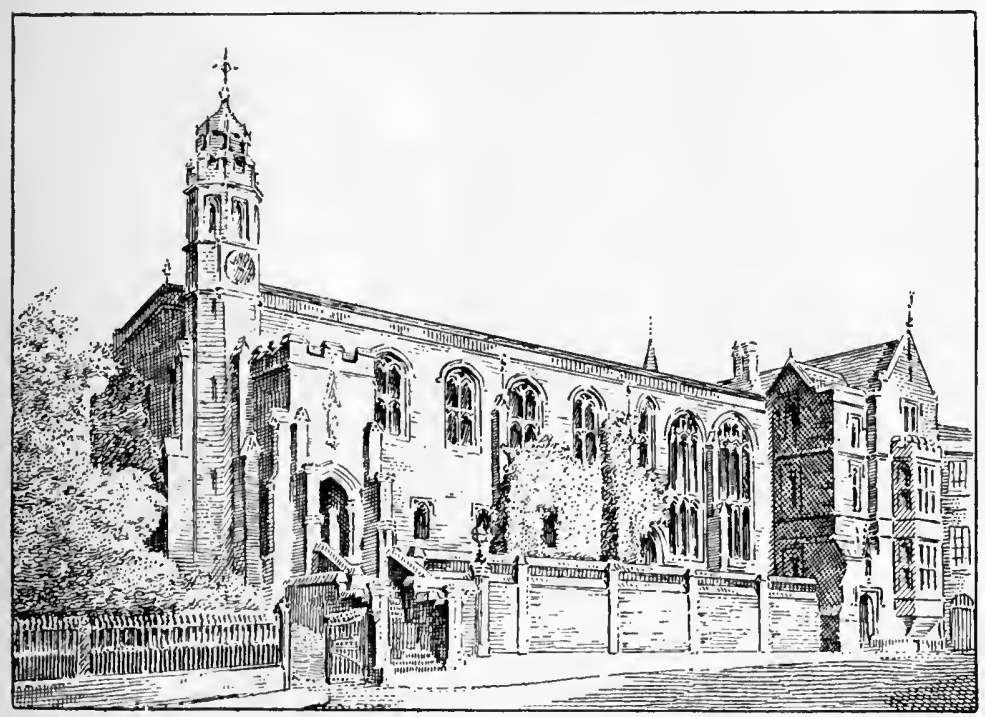

5. BEDE-HOUSE, STAMFORD

founded if some ecclesiastical property were confiscated. Although this was not done, many were provided through private liberality. By the redistribution of wealth and the rise of the middle classes, a fresh impetus was given to building. The chantry system also had an increasingly powerful influence upon the charity of this period. The newer foundations, even more explicitly than the older, were "bede-houses" or houses of prayer. All 


\section{MEDI $\approx V A L$ HOSPITALS OF ENGLAND}

charitable foundations were to a certain extent chantries. Many, alas! were solely on this account marked with the stigma of superstition, and fell under the two Acts for the dissolution of chantries : the plea of usefulness, however, happily prevailed in several cases. ${ }^{1}$ For a time the work of building almshouses ceased, but revived after a while. In ${ }_{583}$ Philip Stubbes complained that although in some places the poor were relieved in hospitals, yet more provision was required :-

"For the supplie whereof, would God there might be in euerie parish an almes house erected, that the poore (such as are poore indeede) might be maintained, helped, and relieued. For until the true poore indeed be better provided for, let them never thinke to please God." 2

1 See Chapter XVI.

2 Anatomie of Abuses, Pt. II, 43. 


\section{CHAPTER III}

\section{HOSPITALS FOR THE INSANE}

"Hospitals . . to maintain men and. zomen who had lost their wits and memory." (Rolls of Parliament, 14r4.)

TITLE is known regarding the extent and treatment of insanity during the Middle Ages. Persons "vexed with a demon" were taken to holy places in the hope that the "fiends" might be cast out. An early thirteenth-century window at Canterbury shows a poor maniac dragged by his friends to the health-giving shrine of St. Thomas. He is tied with ropes, and they belabour him with blows from birch-rods. In the second scene he appears in his right mind, returning thanks, all instruments of discipline cast away. Even in the sixteenth century we read of pilgrimage by lunatics, especially to certain holy wells.

Formerly, all needy people were admitted into the hospital, mental invalids being herded together with those weak or diseased in body. From the chronicle of St. Bartholomew's, Smithfield, we learn that in the twelfth century mad people were constantly received as well as the deaf, dumb, blind, palsied and crippled. One young man lost "his resonable wyttys" on his journey to London. He wandered about running, not knowing whither he went. Arriving in London, he was brought to the hospital and "ther yn shorte space his witte 
was recoueryd." Another patient was taken with the "fallynge euill" [epilepsy], which is described as a sickness hindering the operation of the senses. It would seem that persons subject to fits were sometimes placed in a lazar-house, for at St. Bartholomew's, Rochester (1342), was one patient "struck with the epilepsy disease."

The public did not make itself responsible for the custody of the lunatic, whose own people were required to guard him and others from harm. One of the "Customs of Bristol" (1344) orders that the goods and chattels of demented men be delivered to their friends until they come to a good state of mind (ad bonam memoriam). The sad condition of "lunatick lollers" is described by Langland, who speaks compassionately of this class of wanderers.

In London, the question of making special provision for the insane came to the front about this time, for in r369 one Denton intended to found a hospital "for poor priests and others, men and women, who in that city suddenly fell into a frenzy (in frenesim) and lost their memory," but his plan was not carried out. Stow mentions that the earliest asylum for distraught and lunatic persons was near Charing Cross, "but it was said, that some time a king of England, not liking such a kind of people to remain so near his palace, caused them to be removed farther off, to Bethlem without Bishopsgate."

St. Mary of Bethlehem was the most famous refuge for the mentally disordered. In 1403 there were confined six men deprived of reason (mente capti), and three other sick, one of whom was a paralytic patient who had been lying in the hospital for over two years. 'The good work 
done in the institution was fully recognized. A bequest was made in I419 to the sick and insane of St. Mary de Bedlam. A Patent Roll entry of 1437 speaks of "the succour of demented lunatics" and others, and of the necessity of cutting down these works of piety unless speedy help were forthcoming. The then town clerk, John Carpenter, recalled this need and remembered in his will (I44I) "the poor madmen of Bethlehem." Another citizen, Stephen Forster, desired his executors to lay out ten pounds in food and clothing for the poor people "detained" there. Gregory, citizen and mayor, describes in his Historical Collections (about 145I) this asylum and its work of mercy, and it is satisfactory to hear that some were there restored to a sound mind :-

" A chyrche of Owre Lady that ys namyde Bedlam. And yn that place ben founde many men that ben fallyn owte of hyr wytte. And fulle honestely they ben kepte in that place; and sum ben restoryde unto hyr witte and helthe a-gayne. And sum ben a-bydyng there yn for evyr, for they ben falle soo moche owte of hem selfe that hyt ys uncurerabylle unto man."

Probably the utterly incurable were doomed to those iron chains, manacles and stocks mentioned in the inventory of 1398 and quoted at the visitation of 1403 :-

"Item. vj cheynes de Iren, com vj lokkes. Item iiij peir manycles de Iren. ij peir stokkys." 1

In other parts of the country it was customary to receive persons suffering from attacks of mania into general infirmaries. At Holy Trinity, Salisbury, not only were sick persons and women in childbirth received, but mad people were to be taken care of (furiosi custodiantur donec sensum adipiscantur). This was at the

${ }^{1}$ Char. Com. Rep., xxxii. vi. 472. 


\section{MEDIÆVAL HOSPITALS OF ENGLAND}

close of the fourteenth century. In the petition for the reformation of hospitals (I4I4) it is stated that they exist partly to maintain those who had lost their wits and memory (hors de lour sennes et memoire). Many almshouse-statutes, however, prohibited their admission. A regulation concerning an endowed bed in St. John's, Coventry (1444), declared that a candidate must be "not mad, quarrelsome, leprous, infected." At Ewelme "no wood man" (crazy person) must be received; and an inmate becoming "madd, or woode" was to be removed from the Croydon almshouse.

Such disused lazar-houses as were inhabitable might well have been utilized as places of confinement. This, indeed, was done at Holloway near Bath. At what period the lepers vacated St. Mary Magdalene's is not known, but it was probably appropriated to the use of lunatics by Prior Cantlow, who rebuilt the chapel about 1489. At the close of the sixteenth century, St. James', Chichester, was occupied by a sad collection of hopeless cripples, among whom were found two idiots. A hundred years later the bishop reported that this hospital was of small revenue and "hath only one poor person, but she a miserable idiot, in it."

Bethlehem Hospital was rescued by the Lord Mayor and citizens at the Dissolution of religious houses and continued its charitable work. In 1560 Queen Elizabeth issued on behalf of this house an appeal of which a facsimile may be seen in Bewes' Church Briefs. "Sume be straught from there wyttes," it declares, "thuse be kepte and mayntend in the Hospital of our Ladye of Beddelem untyle God caule them to his marcy or to ther wyttes agayne." 


\section{CHAPTER IV}

\section{THE LAZAR-HOUSE}

"For the relief of divers persons smitten with this sickness and destitute and walking at large with in the realm." I (Holloway, 1473.)

$\mathrm{O}$

$\mathrm{N}$ the outskirts of a town seven hundred years ago, the eye of the traveller would have been caught by a well-known landmark-a group of cottages with an adjoining chapel, clustering round a green enclosure. At a glance he would recognize it as the lazar-house, and would prepare to throw an alms to the crippled and disfigured representative of the community.

It is a startling fact that there is documentary evidence for the existence of over 200 such institutions in this country in the Middle Ages, though historians disagree in their conclusions on this subject, as they do on the extent and duration of the disease itself. To some, leprosy is a phantom playing upon the imagination of a terror-stricken nation; to others, an all-devouring giant stalking through the land. One writer surmises that all the British leper-hospitals together did not exceed fifty, for "there might have been a leper in a village here and there, one or two in a market-town, a dozen or more in a city, a score or so in a whole diocese." Another says that "the number of these lazarhouses, however great, was insufficient to accommodate

${ }^{1}$ Patent 12 Ed. IV, pt. II, m. 6. 


\section{MEDI EVAL HOSPITALS OF ENGLAND}

more than a small proportion of those suffering from the disease. The rest flocked to the high roads, and exposed their distorted limbs and sores, and sought by attracting the notice of travellers to gain alms for their support."

Speaking broadly, one may say that leprosy raged from the eleventh to the middle of the thirteenth century, when it abated; that it was inconsiderable after the middle of the fourteenth ; that, though not extinct, it became rare in the fifteenth; and had practically died out by the sixteenth century, save in the extreme south-west of England.

It is commonly supposed that leprosy was introduced into this country by returning crusaders. "The leprosy was one epidemical infection which tainted the pilgrims coming thither," says Fuller; "hence was it brought over into England-never before known in this islandand many lazar-houses erected." Voltaire makes this satirical epigram :- "All that we gained in the end by engaging in the Crusades, was the leprosy ; and of all that we had taken, that was the only thing that remained with us." This theory, however, is no longer accepted, and Dr. C. Creighton expresses an opinion that it is absurd to suppose that leprosy could be "introduced" in any such way. Geoffrey de Vinsauf, the chronicler who accompanied Richard I, says, indeed, that many perished from sickness of a dropsical nature. He was an eyewitness of the famine which led to the consumption of abominable food, but there is little proof that these wretched conditions engendered leprosy among the pilgrim-warriors. Only once is a leper mentioned in his Itmerary, and then it is no less a personage than Baldwin IV, the young prince who became seventh King of Jerusalem and victor over 
Saladin. It is, moreover, an undeniable fact that there were lepers in Saxon and early Norman England. The Anglo-Saxon equivalent is found in the vocabulary attributed to Aelfric. Roger of Hoveden tells the story of a poor leper whom Edward the Confessor was instrumental in curing. Aelfward, Saxon Bishop of London, retired into a monastery because of this affliction; and Hugh d'Orivalle, Bishop of London, a Norman, died a leper in 1085. Finally, at least two lazar-houses were established within twenty years of the Conquest, and before the first Crusade.

\section{(a) Twelfth and Thirteenth Centuries}

Leprosy was rampant during the Norman period. By a happy providence, charity was quickened simultaneously by the religious movement which illuminated a dark age, so that the need was met. Two leper-houses were rivals in point of antiquity, namely, Rochester and Harbledown, both founded before I 100 . These were followed (before I135) by foundations at Alkmonton, Whitby, London, Lincoln, Colchester, Norwich, Newark, Peterborough, Oxford, Newcastle, Wilton, St. Alban's, Bury, Warwick. Within the next twenty years hospitals are mentioned at Canterbury (St. Laurence), Buckland by Dover, Lynn, Burton Lazars, Aylesbury, York, Ripon, and Northampton; there were also other early asylums at Carlisle, Preston, Shrewsbury, Ilford, Exeter, etc. The chief building period was before the middle of the thirteenth century. A glance at Appendix $B$ will show how such houses multiplied. Moreover, many not specifically described as for lepers, were doubtless originally intended for them. (Cf. Lewes, Abingdon, Scarborough, etc.) 
(b) Fourteenth Century (1300-1350)

During the first part of the fourteenth century, leprosy was widespread, but by no means as common as formerly. Directly or indirectly, testimony is borne to the fact of its prevalence by national laws, by hospital authorities and by the charitable public.

In the first place there is the witness of external legislation, which is two-fold. Schemes of taxation refer constantly to lepers (Rolls of Parliament, 1307-1324). Measures were repeatedly taken for their expulsion from towns. An ordinance was made in the Parliament of Lincoln (1315) commanding that houses founded for the infirm and lepers should be devoted to their use. The admission of other persons was now refused, as, for example, at St. Giles', London, and St. Bartholomew's, Oxford. ${ }^{1}$

There is, secondly, the phraseology of contemporary leper-house statutes, e.g. those drawn up by the Abbot of St. Alban's (1344), and by the Bishop of London for Ilford (1346). Here it is right to note a case where infected inmates were already in a minority. A summary of the history of St. Nicholas', Carlisle (I34I), includes this definite statement:- " until by lapse of time the greater part of the lepers died, when . . their places were filled by poor impotent folk." 2

Thirdly, it is evident from the gifts of charitable persons that there were still many outcasts in need of assistance. Bishop Bitton of Exeter left money to lazars in thirty-nine localities within his diocese (1307). Practi-

1 Pat. 8 Edw. II, pt. ii. m. 5. Close 9 Edw. II, m. $18 d$.

2 Pat. 5 Edw. III, pt. i. m. 49, 48. 
cally all the wills of the period allude to the presence of lepers in the neighbourhood. Although there already existed two asylums outside Rochester (St. Bartholomew's and St. Nicholas' at Whiteditch), to which bequests were continuously made until far into the next century, ${ }^{1}$ St. Katherine's hospital was founded in 1316 for lepers and other mendicants :-

" if it happe anie man or woman of the cittie of Rouchester to be uisited with lepre, or other suche diseases that longe to impotence, with unpower of pouertie, there sholde be receaued."

If leper-houses were empty, the fact is largely accounted for by the mismanagement and poverty of charitable institutions at that period. This aspect of the subject has never received adequate attention. Destitute persons were ousted to make way for paying inmates. One thirteenth-century master of St. Nicholas', York, admitted thirty-six brethren and sisters, of whom four were received pro Deo, because they were lepers, but the rest for money. This practice was sadly common, and notorious instances might be cited from Lincoln (Holy Innocents'), London (St. Giles'), and Oxford (St. Bartholomew's).

Moreover, the leper would probably not be anxious for admission, because at this time, when hospitals were barely able to supply the necessaries of life, it meant restriction without the corresponding comfort which sometimes made it welcome. It is related that in ${ }^{2} 3{ }^{1} 5$, the lepers of Kingston showed their independence by quitting the hospital and demolishing it. A Close Roll entry relating to St. Nicholas', Royston (1359), declares that the "lepers for a great while past have refused to come or to dwell

1 J. Thorpe, Custumale Roffense, p. 39 et sq. ; Reg. Roff. p. I13. 
there." About the year I350 the chronicler of St. Albar's states that at St. Julian's hospital "in general there are now not above three, sometimes only two, and occasionally one." Possibly they had rebelled against the strict life enforced: in 1353 the master and lepers were made semi-independent by grant of the abbot and convent. ${ }^{1}$

In truth, hospitals were in great straits during this distressful century, and retrenchment was necessary. Leperhouses in particular were seldom on a sound financial basis. Even if they possessed certain endowments in kind there was rarely money to spend on the fabric, and buildings became dilapidated. Experience teaches the difficulty of maintaining old-established charities. Much of the early enthusiasm had passed away, and charity was at a low ebb.

It was indeed a poverty-stricken period. Heavy taxation drained the country's resources. War, famine and pestilence were like the locust, palmerworm and caterpillar devastating the land. These were cruel times for the poor, and also for houses of charity. The mediæval tale of Sir Amiloun shows that, so long as the land had plenty, the leper-knight and his companion fared well, but that when corn waxed dear, they were driven by hunger from town to town, and could barely keep themselves alive.

A few instances will show how charity suffered. At the Harbledown leper-house (1276), voluntary offerings were so diminished that inmates were come to great want, and it was feared the sick would be compelled to leave. In I3OI the authorities of the Stafford hospital were

1 Pat. 27 Edw. III, pt. ii. m. 16. 
said to be accustomed to receive lepers with goods and chattels, but they were not bound to support them, and the prior himself had been driven away by destitution. St. Giles', Hexham, was suffering from the Scotch wars. An inquiry ordered by the archbishop (1320) showed that the numbers were reduced, that none were admitted without payment, and that they had to work hard. The allowance of bread and beer from the priory was diminished, oxen were borrowed for ploughing, and there was scarcely enough corn to sow the land. ${ }^{1}$ Wayfaring lepers had ceased to frequent St. Mary Magdalene's, Ripon (where they used to receive food and shelter), because applicants went away empty-handed (13I7); and a later inquiry showed that none came there "because it was fallen down." In 1327 , the Huntingdon lepers had barely sufficient to maintain their present company, admittance being refused to applicants solely on that account, and they were excused taxation in 1340 , because if payment were made, they would have to diminish the number of inmates and disperse them to seek their food. Civil and ecclesiastical registers alike, in issuing protections and briefs for leprous men collecting alms for hospitals, tell a tale of utter destitution.

(c) Fourteenth Century (1350-1400)

Having discussed that portion of the century which preceded the fateful year 1349, we now inquire to what extent leprosy existed during the fifty years that followed. It is no longer mentioned in legislation, and there are indications that it had come to be regarded chiefly as a question for local government: the Letter Books of the

1 Surtees Soc. 46 , ii. 130. 


\section{MEDI EVAL HOSPITALS OF ENGLAND}

Corporation of London record edicts of expulsion. There are other proofs that the number of sufferers was decreasing. If, for example, the language be compared of two Harbledown deeds, dated 1276 and 1371 , an appreciable difference can be discerned. In the first it is declared that there "a hundred lepers are confined to avoid contagion," but a century later it is merely stated that "some of these poor are infected with leprosy." It was said at Maldon in 1402 that there had been no leper-burgesses for twenty years and more. The mention of burgesses is, however, inconclusive, for there may have been mendicant lazars who would gladly have accepted the shelter of St. Giles'; but the town was not bound to support them.

The gifts and bequests of this period testify to the fact that although there were lepers-notably in the vicinity of towns-yet the institutions provided for them were small in comparison with former asylums. A new lazarhouse was built at Sudbury in I373, to accommodate three persons. Shortly before $\mathrm{r}_{3} 84$ a house for lepers and other infirm was founded at Boughton-under-Blean. ${ }^{1}$ Richard II left money to complete two hospitals near London. The will of his uncle, John of Gaunt, who died the same year (1399), indicates the smallness of existing institutions within five miles of the city, for he bequeaths to every leper-house containing five malades, five nobles, and to lesser hospitals, three nobles each.

For a time, the pestilence of 1349 had brought financial ruin to houses dependent upon charity. In London, for example, in I355, the full complement at St. Giles' should

\footnotetext{
${ }^{1}$ Cited Vict. Co. Hist. Kent.
} 
have been fourteen-it had originally been forty-but the authorities complained that they could not maintain even the reduced number, for their lands lay uncultivated "by reason of the horrible mortality." St. James' hospitalwhich used to support fourteen-was empty, save for the sole survivor of the scourge who remained as caretaker, nor does it appear to have been reorganized as a leperasylum.

This diminution in numbers may be attributed to various causes. An increase of medical knowledge with improved diagnosis, together with the strict examination which now preceded expulsion, doubtless prevented the incarceration of some who would formerly have been injudiciously classed as lazars. Possibly, too, the disease now took a milder form, as it is apt to do in course of time. Again, the Black Death (I349) had not merely impoverished leper-hospitals, but must surely have been an important factor in the decline of leprosy itself. If it reduced the population by two-thirds, or even by one-half, as is computed, it also carried off the weakest members of society, those most prone to disease. When the plague reached a lazar-house, it found ready victims, and left it without inhabitant. The same may be said of the terrible though lesser pestilences which followed $(136 i-76)$. The attempt to purify towns by sanitary measures contributed to the improvement of public health. In Bartholomew's De Proprietatibus Rerum (circa 1360 ) it is declared, among divers causes of leprosy that :- "sometyme it cometh . . . of infecte and corrupte ayre." Steps were taken in London to improve sanitation (1388) because "many and intolerable diseases do daily happen." 


\section{MEDI ÆVAL HOSPITALS OF ENGLAND}

\section{(d) Fifteenth Century}

Having admitted that leprosy was steadily declining, so that by the year 1400 it was rare, we are not prepared to echo the statement that its disappearance "may be taken as absolute." Certain lazar-houses were, indeed, appropriated to other uses, as at Alkmonton (1406), Sherburn (1434), and Blyth (1446). In remembrance of the original foundation, accommodation was reserved at Sherburn for two lepers "if they could be found in those parts" [i.e. in the Bishopric of Durham] "or would willingly come to remain there," the place of the sixtyfive lepers being now taken by thirteen poor men unable of their own means to support themselves. ${ }^{1}$ This was a period of transition, and although ruins already marked the site of many a former settlement, yet there were places where a few lepers occupied the old habitations.

Leprosy certainly lurked here and there. The testimony of wills may not be considered wholly trustworthy evidence, yet they show that the public still recognized a need. In 1426 a testator left money for four lepers to receive four marks yearly for ten years. Bequests were made to lepers of Winchester (1420); to "eche laseer of man and woman or child within Bury" (1463); to "the leprous men now in the house of lepers" at Sandwich (1466). There were, perhaps, cases where testators had little personal knowledge of the charities. We cannot, however, doubt that a real need existed when the former mayor of Newcastle leaves forty shillings to "the lepre men of Newcastell" (1429), or when John Carpenter-

1 One deed of reformation speaks of "the diminution of the means of the hospital and the small number of lepers who resort thither." (Pap. Lett. 1430-1.) 
for over twenty years town-clerk of London-bequeaths money to poor lepers at Holborn, Locks and Hackney (I44I).

In 1464, when confirming Holy Innocents', Lincoln, to Burton Lazars, Edward IV renewed Henry VI's stipulation that three leprous retainers should still be supported :"to fynde and susteyn there yerely for ever, certeyn Lepurs of oure menialx Seruauntez and of oure Heires \& Successours, yf eny suche be founde." The king relinquished some property near Holloway (Middlesex), in order to provide a retreat for infected persons. In the year 1480 there were a few lepers at Lydd, who were allowed to share in the festivities when the quarrels between Edward IV and Louis XI came to an end. The ships of the Cinque Ports had been requisitioned, including " the George" of Romney. The town-clerk of Lydd makes an entry of $4 d$. "Paid to the leperys, whenne the George was fette home fro Hethe."1

\section{(e) Sixteenth Century}

Cases of true leprosy were now of rare occurrence. Probably leper hospitals were in the main only nominally such, as a testator hints in 1519, bequeathing a legacy "to every Alms House called Lepars in the Shire of Kent." But although the social conditions of the country improved during the Tudor period, they were still low enough continually to engender pestilence. When Erasmus visited England, he was struck by the filthy habits which were prevalent; but the avengers of neglect of cleanliness were now plague and the sweating sickness. In some few cases old hospitals were

${ }^{1}$ Hist. MSS. $5^{\text {th R. R. }} 5^{27}$ a. 


\section{MEDIÆVAL HOSPITALS OF ENGLAND}

utilized for the sufferers. The plague having lately raged in Newcastle, it was recorded in the Chantry Certificate of St. Mary Magdalene's (I546) that it was once used for lepers, but "syns that kynde of sickeness is abated it is used for the comforte and helpe of the poore folks that chaunceth to fall sycke in tyme of pestilence."

The south-west corner of England was now the last stronghold of leprosy. St. Margaret's, Honiton, had been refounded about I530. A new leper-hospital was built at Newton Bushell near Exeter in 1538 :-

"for the releff of powre lazar-people, whereof grete nomber with that diseas be now infectid in that partis, to the grete daunger of infection of moche people ... for lacke of conueayent houses in the county of Devonshire for them."

Even in 1580 , none were admitted to St. Mary Magdalene's, Exeter, except "sick persons in the disease of the leprosy." About the same time it was reported that "for a long time there had been a great company of lazar-people" at Bodmin.

A few of the old hospitals were kept up in different parts. In the first year of Edward VI (1547) it was enacted that all "leprouse and poore beddred creatures" who were inmates of charitable houses should continue in the places appointed, and be permitted to have proctors to gather alms for them. The Corporation MSS. of Hereford include a notification that year of the appointment of collectors for "the house of leprous persons founded in the worship of St. Anne and St. Loye." Strype records similar licences granted to Beccles and Bury; and he also cites " "A protection to beg, granted to

\footnotetext{
1 Ecclesiastical Memorials, II, 248.
} 
the poor lazars of the house of our Saviour Jesus Christ and Mary Magdalene, at Mile-end [in Stepney], and J. Mills appointed their proctor" (I55I). The sixteenthcentury seal of this Domus Dei et S. Marie Magd. de Myle End (figured below) shows a crippled leper and an infirm woman of the hospital. In $1553, £ 60$ was given to the lazar-houses round London on condition that inmates did not beg to people's annoyance within three miles.

It has here been attempted to bring together some notes touching the extent and duration of leprosy during the Middle Ages, as affecting the provision and maintenance of leper-hospitals. Into the nature of the disease itself we have not endeavoured to inquire, that being a scientific rather than an historical study. Those who would go further into the subject must gain access to the writings of Sir James Simpson, Dr. C. Creighton, Dr. George Newman and others.

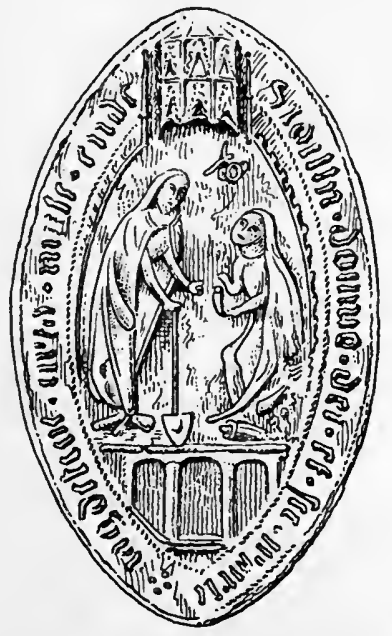

6. SEAL OF THE LAZAR-HOUSE, MILE END 


\section{CHAPTER V}

\section{THE LEPER IN ENGLAND}

" From the benefactions and possessions charitably bestowed upon the hospital, the hunger, thirst and nakedness of those lepers, and other wants and miseries with which they are incessantly afflicted . . . may be relieved."

(Foundation Charter of Sherburn.)

$\mathrm{W}$

E now turn from leper-asylums to consider the leper himself-a sadly familiar figure to the wayfaring man in the Middle Ages. He wears a sombre gown and cape, tightly closed; a hood conceals his want of hair, which is, however, betrayed by the absence of eyebrows and lashes; his limbs are maimed and stunted so that he can but hobble or crawl; his features are ulcerated and sunken; his staring eyes are unseeing or unsightly; his wasted lips part, and a. husky voice entreats help as he "extends supplicating lazar arms with bell and clap-dish."

At the outset it is necessary to state that inmates of lazar-houses were not all true lepers. Persons termed leprosi, infirmi, elefantuosi, languidi, frères malades, meselles, do not necessarily signify lepers in a strict sense. Gervase of Canterbury, writing about 1200 , speaks of St. Oswald's, Worcester, as intended for "Infirmi, item leprosi"; and these words are used synonymously in Pipe Rolls, charters, seals, etc. "Leprosy" was an elastic term as commonly used. In the statutes of one hospital, 
the patriarch Job was claimed as a fellow-sufferer- "who was so smitten with the leprosy, that from the sole of his foot to the crown of his head there was no soundness in him." A lazar was one "full of sores," and any person having an inveterate and loathsome skin-eruption might be considered infected. Disfiguring and malignant disorders were common. Victims of scrofula, lepra, lupus, tuberculosis, erysipelas (or “St. Anthony's fire”) and persons who had contracted disease as the baneful result of a life stained with sin, would sometimes take advantage of the provision made for lepers, for in extremity of destitution this questionable benefit was not to be despised. In foreign lands to-day, some are found not unwilling to join the infected for the sake of food and shelter; we are told, for example, that the Hawaiian Government provides so well for lepers that a difficulty arises in preventing healthy people from taking up their abode in the hospitals. On the other hand, it often happens that those who are actually leprous refuse to join a segregation-camp.

No one, however, can deny that leprosy was once exceedingly prevalent, and after weighing all that might be said to the contrary, Sir J. Y. Simpson and Dr. George Newman were convinced that the disease existent in England was for the most part true leprosy (elephantiasis Grcecorum).

\section{PIONEERS OF CHARITY}

One practical outcome of the religious revival of the twelfth century was a movement of charity towards the outcast. The Lazarus whom Jesus loved became linked in pious minds with that Lazarus ulceribus 


\section{MEDI $Æ V A L$ HOSPITALS OF ENGLAND}

plenus neglected by men, but now "in Abraham's bosom," and the thought took a firm hold of the heart and imagination. Abandoned by relatives, loathed by neighbours, the famished leper was now literally fed with crumbs of comfort from the rich man's table.

The work of providing for "Christ's poor," begun by the great churchmen Lanfranc and Gundulf, was carried into the realm of personal service by Queen Maud (about IIOI), the Abbot of Battle (before II7I) and Hugh, Bishop of Lincoln (about I I86). Queen Maud is the brightest ornament of the new movement. Like St. Francis of Assisi a century later, she "adopted those means for grappling with the evil that none but an enthusiast and a visionary would have taken." Aelred of Rievaulx relates how Prince David visited her and found the house full of lepers, in the midst of whom stood the queen. She washed, dried and even kissed their feet, telling her brother that in so doing she was kissing the feet of the Eternal King. When she begged him to follow her example, he withdrew smiling, afterwards confessing to Aelred :-_" I was sore afraid and answered that I could on no account endure it, for as yet I did not know the Lord, nor had His spirit been revealed to me." Of Walter de Lucy, the chronicler of Battle Abbey writes :-

" He especially compassionated the forlorn condition of those afficted with leprosy and elephantiasis, whom he was so far from shunning, that he frequently waited upon them in person, washing their hands and feet, and, with the utmost cordiality, imprinting upon them the soothing kisses of love and piety."

St. Hugh used to visit in certain hospitals, possibly those at Peterborough and Newark connected with the 
See or the Mallardry at Lincoln. ${ }^{1}$ He would even dwell among the lepers, eating with them and ministering to them, saying that he was inspired by the example of the Saviour and by $\mathrm{His}$ teaching concerning the beggar Lazarus. On one occasion, in reply to a remonstrance from his Chancellor, he said that these afflicted ones were the flowers of Paradise, pearls in the coronet of the Eternal King. ${ }^{2}$

\section{PUBLIC OPINION}

These noble pioneers were doubtless important factors in moulding public opinion. They may often have outstepped the bounds of prudence, but, as one has observed, "an evil is removed only by putting it for a time into strong relief, when it comes to be rightly dealt with and so is gradually checked." As long as possible the world ignored the existence of leprosy. The thing was so dreadful that men shut their eyes to it, until they were shamed into action by those who dared to face the evil. The Canon of the Lateran Council of I I 79 acknowledged that unchristian selfishness had hitherto possessed men with regard to lepers. We need not suppose that the heroism of those who ministered to lepers was that which boldly faces a terrible risk, but it was rather that which overcomes the strongest repulsion for hideous and noisome objects. There is no hint in the language of the chroniclers of encountering danger, but rather, expressions of horror that any should hold intercourse with such loathsome creatures. The remonstrances of Prince David and of William de Monte were not primarily on account of contagion.-_"What is it that thou doest, $\mathrm{O}$ my lady?

1 See p. 180.

2 Chron. and Mem. 37, Magna Vita, pp. 162-5. 


\section{MEDI EVAL HOSPITALS OF ENGLAND}

surely if the King knew this, he would not deign to kiss with his lips your mouth thus polluted with the feet of lepers!" "When I saw Bishop Hugh touch the livid face of the lepers, kiss their sightless eyes or eyeless sockets, I shuddered with disgust."-If St. Francis raised an objection to inmates wandering outside their precincts, it was because people could not endure the sight of them. The popular opinion regarding the contagious nature of the disease developed strongly, however, towards the close of the twelfth century. The Canon $D e$ Leprosis (Rome, I I79; Westminster, I 200) declares emphatically that lepers cannot dwell with healthy men. Englishmen begin to act consistently with this conviction. The Prior of Taunton (II74-85) separates a monk from the company of the brethren "in fear of the danger of this illness"; and the Durham chronicler mentions an infirmary for those "stricken with the contagion of leprosy."

\section{CIVIL JURISDICTION}

(a) The Writ for Removal. - The right to expel lepers was acknowledged before it was legally enforced. An entry upon the statute-book may be merely the official recognition of an established custom. The fact that where use and wont are sufficiently strong, law is unnecessary, is illustrated to-day in Japan, where public opinion alone enforces the separation of lepers. At length English sivil law set its seal upon the theory of infection by the writ De Leproso Amovendo, authorizing the expulsion of lepers on account of manifest peril by contagion. An early instance of removal occurs in the Curia Regis Rolls (1220). It is mentioned that William, son of Nicholas Malesmeins, had been consigned with the assent 
of his friends to a certain Maladria in Bidelington, where he abode for two years. This was the leper-house near Bramber, mentioned four years previously in a Close Roll as "the hospital of the infirm of St. Mary Magdalene of Bidelington."

Legislation on this subject was chiefly local. The Assizes of London had proclaimed in 1276 that "no leper shall be in the city, nor come there, nor make any stay there." Edward III supplemented existing measures by an urgent local edict for London and Middlesex. The royal proclamation sets forth that many publicly dwell among the citizens, being smitten with the taint of leprosy; these not only injure people by the contagion of their polluted breath, but they even strive to contaminate others by a loose and vicious life, resorting to houses of ill-fame, "that so, to their own wretched solace, they may have the more fellows in suffering." 1 All persons proved leprous-citizens or others, of whatever sex or condition-are to quit the city within fifteen days, "and betake themselves to places in the country, solitary, and notably distant from the city and suburbs." This order, sent to the mayor, was followed by a proclamation to the sheriff of the county. Lepers are to abandon the highways and field-ways between the city and Westminster, where several such persons sit and stay, associating with whole men, to the manifest danger of passers-by. ${ }^{2}$

This social problem continued to vex municipal authorities. A precept was issued (1369) "that no leper beg in the street for fear of spreading infection." The porters of the eight principal gates of the city were sworn

1 Riley, Memorials of London, 230.

${ }^{2}$ Close 1346 pt. i. m. $18 d$, i4 $d$, and 1 348 pt. i. m. $25 d$. 


\section{MEDIÆVAL HOSPITALS OF ENGLAND}

to refuse them admittance. (That barbers-forerunners of the barber-chirurgeons-were included among the gatekeepers in I3ro and I375, was perhaps due to their supposed capability of recognizing diseases.) If a leper tried to enter, he should forfeit his horse or his outer garment, and if persisting, be taken into custody. The foreman at "le loke" and an official at the Hackney lazar-house were also bound to prevent their entry into the city.

The " Customs of Bristol," written down by the recorder in I344, declare "that in future no leper reside within the precincts of the town." Imprisonment was the penalty-a plan of doubtful wisdom. The measures ordained by the burgesses of Berwick-on-Tweed were summary :-

"No leper shall come within the gates of the borough; and if one gets in by chance, the serjeant shall put him out at once. If one wilfully forces his way in, his clothes shall be taken off him and burnt, and he shall be turned out naked. For we have already taken care that a proper place for lepers shall be kept up outside the town, and that alms shall be there given to them."1

It was comparatively easy for the civic authorities to control the ejection of lepers when the asylum was under their supervision, as it frequently was. At Exeter, ecclesiastical leniency permitted a continuance of the custom (which was already "ancient" in II63) of allowing lepers to circulate freely in the town. In 1244 the bishop seems to have agreed with the mayor and corporation about the inadvisability of the practice; and he resigned the guardianship of the lazar-house, accepting in its stead that of St. John's hospitaí.

1 Toulmin Smith, Gilds, 24 r. 
Municipal documents record the expulsion of lepers. In Gloucester (1273), Richard, Alice and Matilda gave trouble and would remain within the town "to the great damage and prejudice of the inhabitants." John Mayn, after repeated warnings to provide for himself some dwelling outside London, was sworn to depart forthwith and not return, on pain of the pillory (1372). A Leet Roll among the records of Norwich states that "Thomas Tytel Webstere is a leper, therefore he must go out of the city" (1375). In the following instances, the infected were consigned to hospitals. Margaret Taylor came before the keepers of Beverley in the Gild Hall, and asked by way of charity permission to have a bed in the lepers' house outside Keldgate Bar, which request was granted (1394). The town-clerk of Lydd makes an entry of ten shillings "Paied for delyvere of Simone Reede unto the howse of Lazaris" (circa 1460). The manorial court sometimes dealt with such cases. That of the Bishop of Ely at Littleport recorded (I32I) :"The jurors say upon their oath that Joan daughter of Geoffrey Whitring is leprous. Therefore be she set apart."1

The law evidently had no power to touch a leper unless he made himself a source of public danger. No one interfered with him as long as he remained in a quiet hiding-place, quitting it, perhaps, only at night. Individuals, sheltered by the affection or self-interest of relatives, might never come under the ban of the law: in the Norwich records, for example, Isabella Lucas seems to have been allowed to remain at home (139I). Judge Fitz-Herbert, commenting on the writ of removal, observes

${ }^{1}$ Selden Soc., Court Baron, p. 134. 


\section{MEDI $Æ V A L$ HOSPITALS OF ENGLAND}

that it lies where a leper is dwelling in a town, and will come into the church or amongst his neighbours. ${ }^{1}$

English legislation was never severe regarding lepers. We may believe that the tolerant spirit of a certain thirteenth-century Scottish canon prevailed throughout Great Britain. Lepers, it was declared, might well fulfil their parochial obligations, but "if they cannot be induced to do so, let no coercion be employed, seeing that affliction should not be accumulated upon the afflicted, but rather their misfortunes commiserated." In France, however, upon one terrible occasion, Philip V was guilty of the abominable cruelty of burning lepers on the pretext that they had maliciously poisoned wells. Mezeray says :- " "they were burned alive in order that the fire might purify at once the infection of the body and of the soul." The report of this inhuman act reached England and was recorded both in the Chronicle of Lanercost (under date I3I8) and also by John Capgrave, wlto says :-

"And in this same yere [ ${ }^{1} 3_{18} 8$ the Mysseles [lepers] thorow oute Cristendam were slaundered that thei had mad couenaunt with Sarasines for to poison alle Cristen men, to put uenym in wellis, and alle maner uesseles that long to mannes use; of whech malice mony of hem were conuicte, and brent, and many Jewes that gave hem councel and coumfort." 3

(b) Property. - The legal status of the leper must now be examined. When pronounced a leper in early days, a man lost not only his liberty, but the right to inherit or bequeath property. A manuscript Norman law-book

1 Natura Brevium, ed. 16,52 p. $5^{84}$.

2 Wilkins, Concil. Mag. i. 616.

3 Chron. and Mem., I. 186. 
declares "that the mezel cannot be heir to any one." In the days of Stephen, for example, Brien Fitz-Count was lord of Wallingford and Abergavenny. "He had two sons, whom, being lepers, he placed in the Priory of Bergavenny and gave lands and tithes there to for their support," bequeathing his property to other kinsmen. Again, two women of the Fitz-Fulke family appeared in the King's Court (1203) in a dispute about property at Sutton in Kent: Avice urged that Mabel, having a brother, had no claim - "but against this Mabel says that he is a leper." 1 Even a grant made by such a person was void. In $\mathrm{I}_{204} \mathrm{King}$ John committed the lands of William of Newmarch to an official who should answer for them at the Exchequer, but " if he have given away any of his lands after he fell sick of the leprosy, cause the same to be restored to his barony." 2 This illustrates Bracton's statement that "a leprous person who is placed out of the communion of mankind cannot give .. . as he cannot ask," and, again, "if the claimant be a leper and so deformed that the sight of him is insupportable, and such that he has been separated... [he] cannot plead or claim an inheritance." 3

On the other hand, Lord Coke declares that "ideots, leapers \&c. may be heires," and he comments thus upon Bracton and Britton:- "if these ancient writers be understood of an appearance in person, I think their opinions are good law; for [lepers] ought not to sue nor defend in proper person, but by atturney." 4 Possibly the Norman custom of disinheritance prevailed in England at one time and then died out. The case of Adam

\footnotetext{
1 Selden Soc., 3, No. 157 .

2 Rot. Litt. Claus, 6 John m. 2 r.

${ }^{3}$ Chron. and Mem., 7o, i. 95 ; vi. 325.

4 First Institutes, p. 8a., $135^{\mathrm{b}}$.
} 


\section{MEDI ÆVAL HOSPITALS OF ENGLAND}

de Gaugy proves that in 1278 this Northumbrian baron was not liable to forfeiture. He was excused, indeed, from appearing in the presence of Edward I, but was directed to swear fealty to an official. Although spoken of as his brother's heir, Adam did not long enjoy his property. He died the same year, childless, but leaving a widow $(E v e)$, and the barony passed to a kinsman. ${ }^{1}$

The Norman maxim that the leper "may possess the inheritance he had before he became a leper" is illustrated by the story of the youthful heir of Nicholas de Malesmeins. Having attained full age, he left the hospital where he had been confined, appeared before his feudal lord, did homage, made his payment, and entered his fief. ${ }^{2}$

\section{ECCLESIASTICAL JURISDICTION}

Although leprosy was a penal offence, only laymen could be cited and dealt with by the king, mayor or feudal lord. Clerks in holy orders had to answer to their bishop. In the case of parochial clergy, the diocesan was responsible for their suspension from office, as stated by the Canon De Leprosis. Lucius III (I I8I-I I85) decreed that they must serve by coadjutors and wrote to the Bishop of Lincoln on this subject. ${ }^{3}$ The episcopal registers of Lincoln afterwards record the case of the rector of Seyton (1310). Several leprous parish priests are named in other registers, e.g. St. Neot, ${ }_{13} 14$ (Exeter), Colyton, 1330 (Exeter), Castle Carrock, 1357 (Carlisle). In the latter instance, the bishop having learned with sorrow that the rector was infected and unable to ad-

1 Inquisition, cf. Rot. Curia Scacc. Abb., i. 33.

2 Curia Regis Rolls, 72, m. $18 d$.

3 Conciliorum Omnium, ed. 1567, III, 7oo (cap. 4). 
minister the sacraments, cited him to appear at Rose with a view to appointing a coadjutor. ${ }^{1}$ It was ordered by Clement III that when clergy were thus removed, they should be supported from the fruits of their benefices. Sir Philip, the leper-priest of St. Neot in Cornwall, was allowed two shillings a week, besides twenty shillings a year for clothing. He was permitted to keep the best room in his vicarage and the adjoining chambers, except the hall. The rest of the house was partitioned off for the curate, the door between them being walled up. ${ }^{2}$

\section{EXAMINATION OF SUSPECTED PERSONS}

The duty of reporting and examining cases fell to the clergy, doctors, civil officers or a jury of discreet men. (Cf. Fig. 7.) A curiously complicated lawsuit brought into the King's Court in 1220 relates how a certain man had custody of the children of Nicholas de Malesmeins. When the eldest-born became a leper, his perplexed guardian took the young man to the King's Exchequer, and before the barons of the Exchequer he was adjudged a

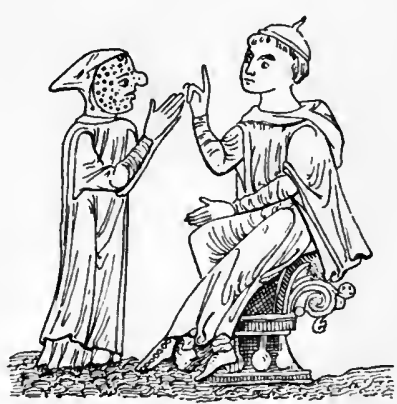

7. LEPER AND PHYSICIAN leper, and consigned to a hospital. (See pp. 52, 58.)

In ordinary cases, the leper would show himself to the parish priest as the only scholar. It was the village priest who helped the stricken maiden to enter "Badele Spital" near Darlington, and afterwards attested her

1 Reg. Welton. Cited Vict. Co. Hist.

${ }^{2}$ Reg. Stapeldon, p. 342. 


\section{0}

\section{MEDIÆVAL HOSPITALS OF ENGLAND}

cure, as related by Reginald of Durham. (See p. 97.) The register of Bishop Bronescomb of Exeter declares that " it belongs to the office of the priest to distinguish between one form of leprosy and another." It was the duty of the clergy to take cognizance of cases, but it was not always politic to interfere. In 1433 the parson of Sparham endeavoured to get a parishioner, John Folkard, to withdraw from the company of other men because he was "gretely infect with the sekeness of lepre." The vicar advertised him to depart, for "his sekenes was contagious and myght hurte moche people." After much disputing, John went off to Norwich and took an action for trespass against the parson before the sheriffs. Whereupon the vicar had to appeal in chancery. ${ }^{1}$

The writ of removal ordered the careful investigation of cases in the presence of discreet and lawful men having the best knowledge of the accused person and his disease. Probably the best was not very good, for many judged by the outward appearance only. The Bishop of Lincoln, directing the resignation of a clergyman (1310), says that he is besprinkled with the spot of leprosy. The decree of I 346 condemns "all those who are found infected with leprous spots" to be removed. Anthony Fitz-Herbert, writing in 1534 , points out that the writ is for those "who appear to the sight of all men that they are lepers," by their voice, disfigurement and noisome condition.

In medical treatises, great stress was laid on thê necessity of investigation with pondering and meditation. The Rosa Anglica of John of Gaddesden (physician to Edward II) declares that " no one is to be adjudged a leper, and separated from intercourse of mankind, until

\footnotetext{
${ }^{3}$ P.R.O. Early Chancery Proceedings, Bundle 46, No. ${ }_{5} \mathrm{~s}$.
} 
the figure and form of the face is actually changed." The contemporary French doctor, Gordon, uses almost the same words; and, repeating his precautions, observes that "lepers are at the present day very injudiciously judged." A later writer, Guy de Chauliac (circa 1363) says :-

"In the examination and judgement of lepers, there must be much circumspection, because the injury is very great, whether we thus submit to confinement those that ought not to be confined, or allow lepers to mix with the people, seeing the disease is contagious and infectious."

Sir J. Simpson gives copious extracts from Guy's Chirurgia, which has also been translated into modern French (1890). Guy describes fully the examination of a suspected person, giving in detail all possible symptoms. It may here be observed that Bartholomew Anglicus, his contemporary, enumerates among the causes predisposing to leprosy, dwelling and oft talking with leprous men, marriage and heredity, evil diet-e.g. rotten meat, measled hogs, flesh infected with poison, and the biting of a venomous worm: "in these manners and in many other the evil of lepra breedeth in man's body." Guy advises the doctor to inquire if the person under examination comes of tainted stock, if he have conversed with lepers, etc. He must then consider and reconsider the equivocal and unequivocal signs of disease. After a searching investigation-not to be confined to one daythe patient must either be set free (absolvendus) with a certificate, or separated from the people and conducted to the lazar-house.

About the time that John of Gaddesden was professor of medicine at Oxford (1307-1325), and was writing upon 


\section{MEDI $Æ V A L$ HOSPITALS OF ENGLAND}

leprosy, "experienced physicians" were summoned to examine a provincial magnate. The mayor and bailiffs of royal Winchester had been over-zealous " under colour of the king's late order to cause lepers who were amongst the healthy citizens to be expelled." It was surely a bitter hour to Peter de Nutle, late mayor of the grand old city, when his successor and former colleagues hounded him out! But there was justice for one "falsely accused"; and subsequently an order of redress was sent, not without rebuke to the civic authorities for their malicious behaviour towards a fellow-citizen :-

" as it appears, from the inspection and examination before our council by the council and by physicians expert in the knowledge of this disease, that the said Peter is whole and clean, and infected in no part of his body."

A few days later the sheriff of Hampshire was directed to make a proclamation to the same effect, so that Peter might dwell as he was wont unmolested. ${ }^{1}$

The royal mandate of 1346 reiterated the stipulation that men of knowledge should inquire into suspected cases. It therefore seems unlikely that a London baker ejected in 1372 was merely suffering from an inveterate eczema, as has been suggested. Careless as were the popular notions of disease, medical diagnosis was becoming more exact; four kinds of leprosy were distinguished, of which "leonine" and "elephantine" were the worst.

There is an interesting document extant concerning a certain woman who lived at Brentwood in 1468 . She was indicted by a Chancery warrant, but acquitted on the

${ }^{1}$ Close 6 Edw. II, m. $21 d$. 
authority of a medical certificate of health. The neighbours of Johanna Nightingale petitioned against her, complaining that she habitually mixed with them and refused to retire to a solitary place, although "infected by the foul contact of leprosy." A writ was therefore issued by Edward IV commanding a legal inquiry. Finally, Johanna appeared before a medical jury in the presence of the Chancellor. They examined her person, touched and handled her, made mature and diligent investigation, going through over forty distinctive signs of disease. She was at length pronounced "utterly free and untainted," and the royal physicians were prepared to demonstrate this in Chancery "by scientific process." 1

\section{TREATMENT OF THE BODY}

Alleviation was sometimes sought in medicinal waters. Here and there the site of a hospital seems to have been selected on account of its proximity to a healing spring, e.g. Harbledown, Burton Lazars, Peterborough, Newark, and Nantwich. In various places there are springs known as the Lepers' Well, frequented by sufferers of bygone days.

Tradition ascribes to bathing some actual cures of "leprosy." Bladud the Briton, a prehistoric prince, was driven from home because he was a leper. At length he discovered the hot springs of Bath, where instinct had already taught diseased swine to wallow: Bladud, too, washed and was clean. The virtue of the mineral waters, well known to the Romans, was also appreciated by the Saxons; possibly the baths were frequented by lepers

1 Close Roll, Rymer, ed. 1710, ix. 365. Translated, Simpson, Arch. Essays. 


\section{MEDIÆVAL HOSPITALS OF ENGLAND}

from early days, for there was long distributed in Bath "an ancient alms to the poor and leprous of the foundation of Athelstan, Edgar and Ethelred." A small bath was afterwards set apart for their use, to which the infected flocked. Leland notes that the place was "much frequentid of People diseasid with Lepre, Pokkes, Scabbes, and great Aches," who found relief. A story similar to that of Bladud, but of later date, comes from the eastern counties : a certain man, sorely afflicted with leprosy, was healed by a spring in Beccles, near which in gratitude he built a hospital.

There was rivalry between the natural water of Bath and the miraculous water of Canterbury; the latter

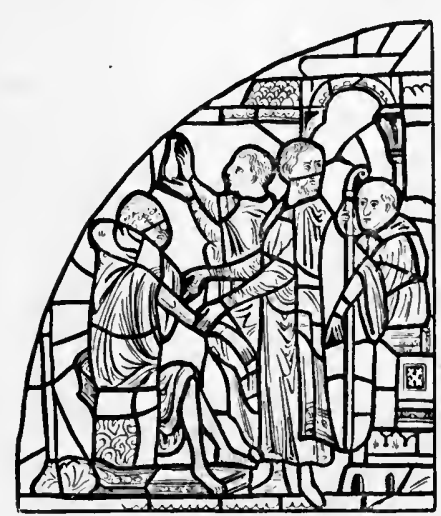

8. ELIAS, LEPER MONK consisted of a drop of St. Thomas' blood many times diluted from the well in the crypt of the cathedral. ${ }^{1}$ William of Canterbury, a prejudiced critic, is careful to relate how a leper-monk of Reading, Elias by name, went with his abbot's approval to Bath desiring to ease his pain, and there sought earnestly of the physicians whatever he was able to gather from them. "He set his hope in the warmth of the sulphur and not in the wonder-working martyr," says William. After forty days in Bath, Elias set out for Canterbury, but secretly, pretending to seek medicine in London; because (adds the chronicler) the abbot honoured

1 Chron. and Mem., 67, i. 416. 
the martyr less than he ought to have done, and might not have countenanced the pilgrimage. On his way, Elias met returning pilgrims, who gave him some of the water of St. Thomas (Fig. 8); he applied this externally and internally and became well. ${ }^{1}$ Lest any should doubt the miracle, Benedict of Canterbury tells us that many who were especially skilled in the art of medicine used to say that Elias was smitten with a terrible leprosy, and he proceeds to detail the horrible symptoms. In the end, however, William declares that he who had been so ulcerated that he might have been called another Lazarus, now appeared pleasant in countenance, as was plain to all who saw him. What the Bath doctors and Bath waters could not do, that the miraculous help of St. Thomas had achieved.

We see from the story of the monk Elias that the ministrations of the physician and the use of medicine were sought by lepers. Bartholomew says that the disease, although incurable "but by the help of God" when once confirmed, "may be somewhat hid and let, that it destroy not so soon"; and he gives instructions about diet, blood-letting, purgative medicines, plasters and ointments. Efficacious too was (we are told) the eating of a certain adder sod with leeks.

There is no information forthcoming as to the remedial treatment of lepers in hospital. The only narrative we possess is Chatterton's lively description of St. Bartholomew's, Bristol, the Roll of which he professed to find ; it satisfied Barrett, a surgeon, and a local, though uncritical, historian. A father of the Austin Friary came to shrive the lepers (for which he received ten marks) and to dress

$$
1 \text { Id. ii. } 242 .
$$




\section{6 \\ MEDI EVAL HOSPITALS OF ENGLAND}

their sores (for which he was given fifty marks) saying, "lette us cure both spryte and bodye." When barbersurgeons came for an operation- "whanne some doughtie worke ys to bee donne on a Lazar"-friars attended "leste hurte ande scathe bee done to the lepers." The friars' knowledge was such that barber-surgeons were willing to attend "wythoute paye to gayne knowleche of aylimentes and theyr trew curis."

\section{TREATMENT OF THE SPIRIT}

Disease was sometimes regarded as an instrument of divine wrath, as in the scriptural case of Gehazi. Thus Gilbert de Saunervill after committing sacrilege was smitten with leprosy, whereupon he confessed with tears that he merited the scourge of God. The popular view that it was an expiation for sin is shown in the romance of Cresseid false to her true knight. But except in signal cases of wrong-doing this morbid idea was not prominent; and the phrase "struck by the secret judgement of God" implies visitation rather than vengeance. Indeed, the use of the expression "Christ's martyrs" suggests that the leper's affliction was looked upon as a sacrifice-an attitude which illuminated the mystery of pain. St. Hugh preached upon the blessedness of such sufferers: they were in no wise under a curse, but were " beloved of God as was Lazarus."

Those responsible for the care of lepers long ago realized exactly what is experienced by those who carry on the same extraordinarily difficult work to-day, namely, that leprosy develops to a high degree what is worst in man. Bodily torture, mental anguish, shattered nerves almost amounting to insanity, render lepers wearisome 
and offensive to themselves no less than to others. These causes, together with the absence of the restraining influences of family life, make them prone to rebellious conduct, irritability, ingratitude and other evil habits. Hope was, and is, the one thing to transform such lives, else intolerable in their wintry desolation. St. Hugh therefore bade lepers look for the consummation of the promise:- "Who shall change our vile body, that it may be fashioned like unto His glorious Body." 1

Alleviation of the agonized mind of the doomed victim was undertaken first by the physician and afterwards by the priest. A recognized part of the remedial treatment advocated by Guy was to comfort the heart. His counsel shows that doctors endeavoured to act as physicians of the soul, for they were to impress upon the afflicted person that this suffering was for his spiritual salvation. The priest then fulfilled his last duty towards his afflicted parishioner :-

"The priest ... makes his way to the sick man's home and addresses him with comforting words, pointing out and proving that if he blesses and praises God, and bears his sickness patiently, he may have a sure and certain hope that though he be sick in body, he may be whole in soul, and may receive the gift of eternal salvation."

The affecting scene at the service which followed may be pictured from the form in Appendix $A$. There was a certain tenderness mingled with "the terrible ten commandments of man." The priest endeavours to show the leper that he is sharing in the afflictions of Christ. For

1 Compare the title of a modern leper-house at Kumanıto in Kiushiu, known as "The Hospital of the Resurrection of Hope" : and in Japanese Kwaishun Byöin-" the coming again of spring." 


\section{MEDI $Æ V A L$ HOSPITALS OF ENGLAND}

his consolation the verse of Isaiah is recited:- "Surely $\mathrm{He}$ hath borne our griefs and carried our sorrows, yet did we esteem Him as a leper, smitten of God and afflicted." The same passage from the Vulgate is quoted in the statutes for the lepers of St. Julian's :-_"among all infirmities the disease of leprosy is more loathsome than any . . yet ought they not on that account to despair or

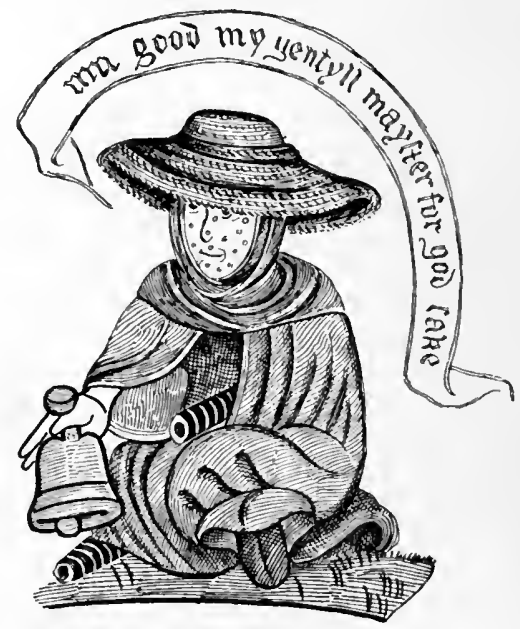

9. A LEPER

murmur against God, but rather to praise and glorify Him who was led to death as a leper."

After separation the fate of the outcast is irrevocably sealed. Remembering the exhortation, he must never frequent places of public resort, nor eat and drink with the sound; he must not speak to them unless they are on the windward side, nor may he touch infants or young folk. Henceforth his signal is the clapper, by which he gives warning of his approach and draws attention to his 
request. (Fig. 26.) This instrument consisted of tablets of wood, attached at one end with leather thongs, which made a loud click when shaken. In England, a bell was often substituted for this dismal rattle. Stow and Holinshed refer to the "clapping of dishes and ringing of bels" by the lazar. The poor creature of shocking appearance shown in Fig. 9 holds in his one remaining hand a bell. His piteous cry is "Sum good, my gentyll mayster, for God sake." This was the beggar's common appeal: in an Early English Legendary, a mesel cries to St. Francis, "Sum good for godes love."

Compelled to leave home and friends, many a leper thus haunted the highway-his only shelter a dilapidated hovel, his meagre fare the scraps put into his dish. To others, the lines fell in more pleasant places, for in the hospital pain and privation were softened by kindness. 


\section{CHAPTER VI}

\section{FOUNDERS AND BENEFACTORS}

" Hospitals . . . founded as well by the noble kings of this realm and lords and ladies both spiritual and temporal as byothers of divers estates, in aid and merit of the souls of the said founders."

(Parliament of Leicester.)

$A^{S}$ our period covers about six centuries, some rough 1 subdivision is necessary, but each century can show patrons of royal birth, benevolent bishops and barons, as well as charitable commoners. The rollcall is long, and includes many noteworthy names.

\section{FIRST PERIOD (BEFORE IO66)}

First, there is the shadowy band of Saxon benefactors. Athelstan, on his return from the victory of Brunanburh (937), helped to found St. Peter's hospital, York, giving not only the site, but a considerable endowment. (See p. 185.) Among other founders was a certain noble and devoted knight named Acehorne, lord of Flixton in the time of the most Christian king Athelstan, who provided a refuge for wayfarers in Holderness. Two Saxon bishops are named as builders of houses for the poor. To St. Oswald (Bishop of Worcester, died 992) is attributed the foundation of the hospital called after him ; but the earliest documentary reference to it is by Gervase of Canterbury (circa I 200). St. Wulstan (died 1094) pro- 
vided the wayfarers' hostel at Worcester which continued to bear his name. Wulstan, last of the Saxon founders, forms a fitting link with Lanfranc, foremost of those Norman "spiritual lords" who were to build hospitals on a scale hitherto unknown in England.

\section{SECOND PERIOD (1066-1272)}

Lanfranc erected the hospitals of St. John, Canterbury, and St. Nicholas, Harbledown; these charities remain to this day as memorials of the archbishop. His friend Bishop Gundulf of Rochester founded a lazar-house near that city. In Queen Maud, wife of Henry I, the bishop found a ready disciple. Her mother, Margaret of Scotland, had trained her to love the poor and minister to them. St. Margaret's special care had been for pilgrims, for whom she had provided a hospital at Queen's-ferry, Edinburgh. The "holy Queen Maud," as we have seen, served lepers with enthusiasm, and she established a home near London for them. (Fig. Io.) Henry I caught something of his lady's spirit. "The house of St. Bartholomew [Oxford] was

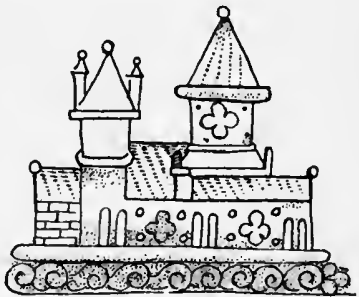

IO. "THE MEMORIAL. OF MATILDA THE QUEEN" founded by our lord old King Henry, who married the good queene Maud; and it was assigned for the receiving and susteyning of infirme leprose folk," says Wood, quoting a thirteenth-century Inquisition. Henry endowed his friend Gundulf's foundation at Rochester, and probably also "the king's hospital" near Lincoln, which had possibly been begun by Bishop Remigius; that of Colchester was built by his steward 


\section{MEDI $Æ V A L$ HOSPITALS OF ENGLAND}

Eudo at his command, and was accounted of the king's foundation. Matilda, daughter of Henry and Maud, left a benefaction to lepers at York.

King Stephen reconstructed St. Peter's hospital, York, after a great fire. (Cf. Pl. XXIV, XXV.) His wife, Matilda of Boulogne, founded St. Katharine's, London, which continues to this day under the patronage of the queens-consort. Henry II made considerable bequests for the benefit of lazars, but it is characteristic that his hospital building was in Anjou. Richard I endowed Bishop Glanvill's foundation at Strood. King John is thought to have founded hospitals near Lancaster, Newbury and Bristol. He is sometimes regarded as the conspicuous patron of lepers. Doubtless this may be partly attributed to the fact that at the outset of his reign the Church secured privileges to outcasts by the Council of Westminster (1200). There seems, however, to be some ground for his charitable reputation. Bale, in his drama Kynge Johan, makes England say concerning this king :-

"Never prynce was there that made to poore peoples use So many masendewes, hospytals and spyttle howses, As your grace hath done yet sens the worlde began."

"Gracyouse prouysyon for sore, sycke, halte and lame He made in hys tyme, he made both in towne and cytie, Grauntynge great lyberties for mayntenaunce of the same, By markettes and fayers in places of notable name.

Great monymentes are in Yppeswych, Donwych and Berye, Whych noteth hym to be a man of notable mercye." 1

Indeed, as the Suffolk satirist knew by local tradition, King John did grant the privilege of a fair to the lepers of Ipswich.

${ }^{1}$ Camden Soc., $188^{8}$, pp. 82,85 . 


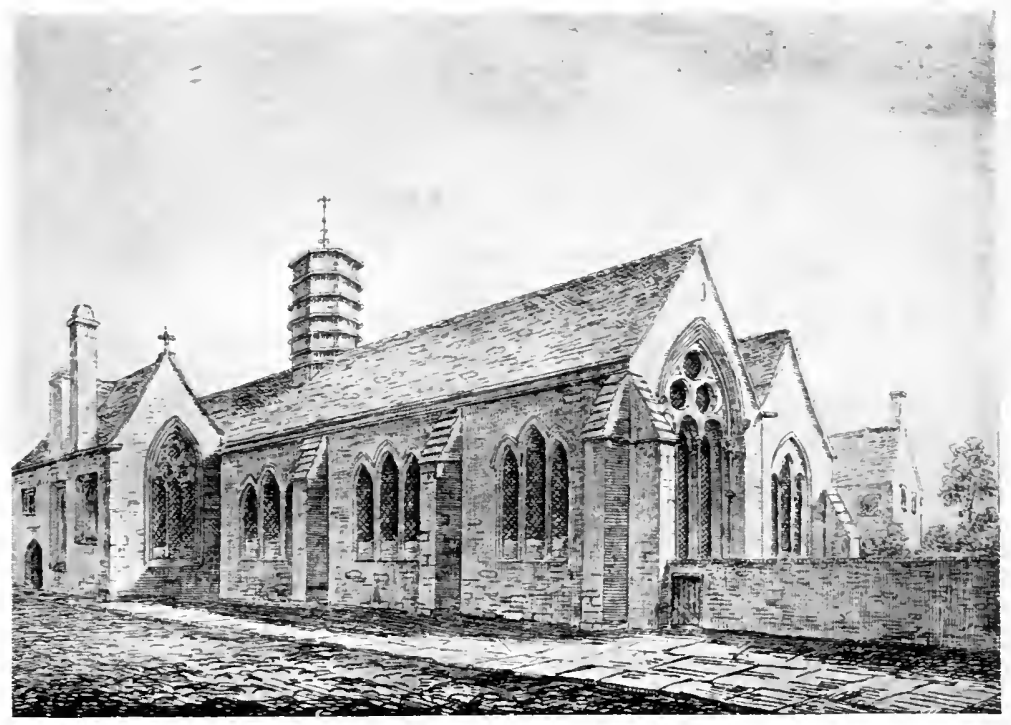

ST. BARTHOLOMEW'S, GLOUCESTER

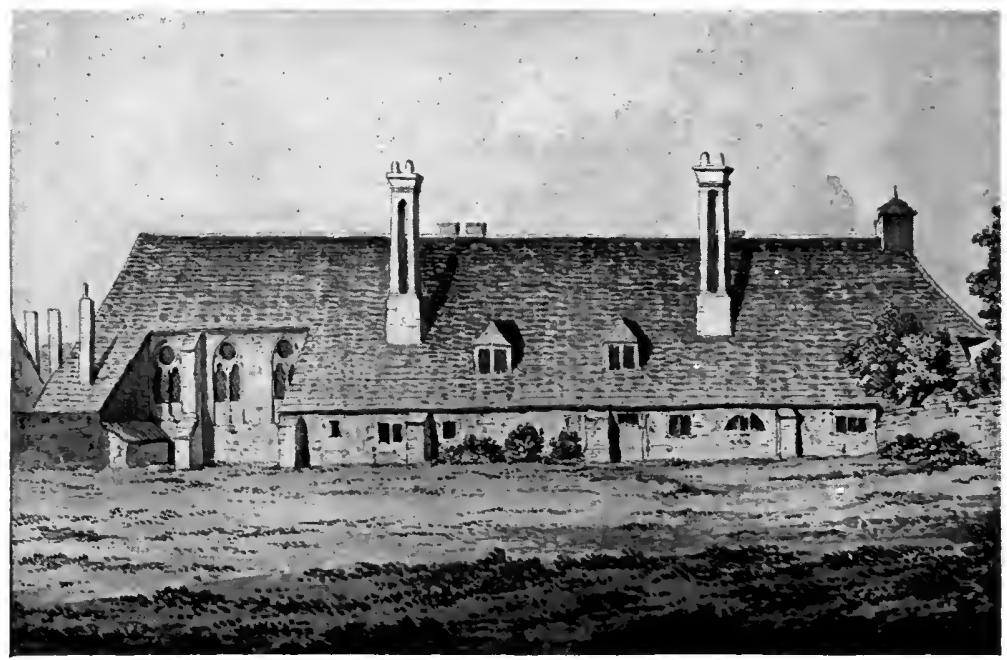

ST. MARY'S, CHICHESTER 
Henry III erected houses of charity at Woodstock, Dunwich and Ospringe, as well as homes for Jews in London and Oxford. He refounded St. John's in the latter city, and laid the first stone himself; he seems also to have rebuilt St. John's, Cambridge, and St. James', Westminster. The king loved Gloucester-the place of his coronation-and he re-established St. Bartholomew's, improving the buildings (Pl. VI) and endowment. The new hospitals of Dover and Basingstoke were committed to his care by their founders. Of Henry III's charities only that of St. James', Westminster, was for lepers ; but St. Louis, who was with him while on crusade, told Joinville that on Holy Thursday (i.e. Maundy Thursday) the king of England "now with us" washes the feet of lepers and then kisses them. The ministry of the good queen Maud was thus carried on to the fifth generation.

If history tells how Maud cared for lepers and provided for them in St. Giles', London, tradition relates that Adela of Louvain, the second wife of Henry I, was herself a leper, and that she built St. Giles', Wilton. A Chantry Certificate reports that "Adulyce sometym quene of Englande" was the founder. The present inmates of the almshouse are naturally not a little puzzled by the modern inscription Hospitium S. Egidii Adelicia Reg. Hen. Fund. The local legend was formerly to be seen over the chapel door in a more intelligible and interesting form :-

"This hospitall of St. Giles was re-edified (1624) by John Towgood, maior of Wilton, and his brethren, adopted patrons thereof, by the gift of Queen Adelicia, wife unto King Henry 


\section{MEDIÆVAL HOSPITALS OF ENGLAND}

the First. This Adelicia was a leper. She had a windowe and dore from her lodgeing into the chancell of the chapel, whence she heard prayer. She lieth buried under a marble gravestone."

Although in truth the widowed queen made a happy marriage with William d'Albini, and, when she died, was buried in an abbey in Flanders, she did endow a hospital at that royal manor-maybe to shelter one of her ladies, whose affliction might give rise to the tale of " the leprosy queen" and her ghost. When a person of rank became a leper, the terrible fact was not disclosed when concealment was possible. This is illustrated by another Wiltshire tradition-that of the endowment of the lazarhouse at Maiden Bradley by one of the heiresses of Manser Bisset, dapifer of Henry II. The story is as old as Leland's day; and Camden says that she "being herselfe a maiden infected with the leprosie, founded an house heere for maidens that were lepers, and endowed the same with her owne Patrimonie and Livetide." Margaret Bisset was certainly free from all taint of leprosy in 1237, when she sought and gained permission to visit Eleanor of Brittany, the king's cousin. She was well known at court at this time, and a Patent Roll entry of 1242 records that :- "At the petition of Margery Byset, the king has granted to the house of St. Matthew [sic], Bradeleg, and the infirm sisters thereof, for ever, five marks yearly . . . which he had before granted to the said Margery for life." Another contemporary deed (among the Sarum Documents) may support the legend of the leper-lady. It sets forth how Margaret Bisset desired to lead a celibate and contemplative life; and therefore left her lands to the leper-hospital of Maiden Bradley on condition that she herself was maintained there. 
Many famous churchmen, statesmen and warriors were hospital builders. Among the episcopal founders who figured prominently in public affairs were the following. Ranulf Flambard-" the most infamous prince of publicans" under William Rufus-founded Kepier hospital, Durham. The warlike Henry de Blois, half-brother of Stephen, erected St. Cross near Winchester. Hugh de Puiset, being, as Camden says, "very indulgently compassionate to Lepres," gathered them into his asylum at Sherburn, but it is hinted that his bounty was not altogether honestly come by. Again, "the high-souled abbot" Sampson-he who dared to oppose Prince John and also visited Richard in captivity-was the founder of St. Saviour's, at Bury St. Edmunds.

Even in the troublous days of Stephen there were barons who were tender towards the afflicted. William le Gros, lord of Holderness, was one of these. He was the founder of St. Mary Magdalene's, Newton-by-Hedon, for a charter speaks of "the infirm whom William, Earl of Albemarle, placed there." The Chartulary of Whitby relates how the earl-c" a mighty man and of great prowess and power"-was wasting the eastern parts of Yorkshire. Nevertheless he "was a lover of the poor and especially of lepers and was accustomed to distribute freely to them large alms." Abbot Benedict therefore bethought him of a plan whereby he might save the threatened cow-pastures of the abbey from devastation : he permitted the cattle belonging to the Whitby hospital to join the herds of the convent; consequently the earl was merciful to that place on account of the lepers, and the herds fed together henceforth undisturbed.

Another charitable lord was Ranulf de Glanvill- “jus- 


\section{MEDIÆVAL HOSPITALS OF ENGLAND}

ticiary of the realm of England and the king's eye "-who with his wife Berta founded a leper-hospital at West Somerton upon land granted to him by Henry II. His nephew Gilbert de Glanvill built St. Mary's, Strood, near his cathedral city of Rochester (circa II93); the loyal bishop declaring in his charter that it was founded amongst other things " for the reformation of Christianity

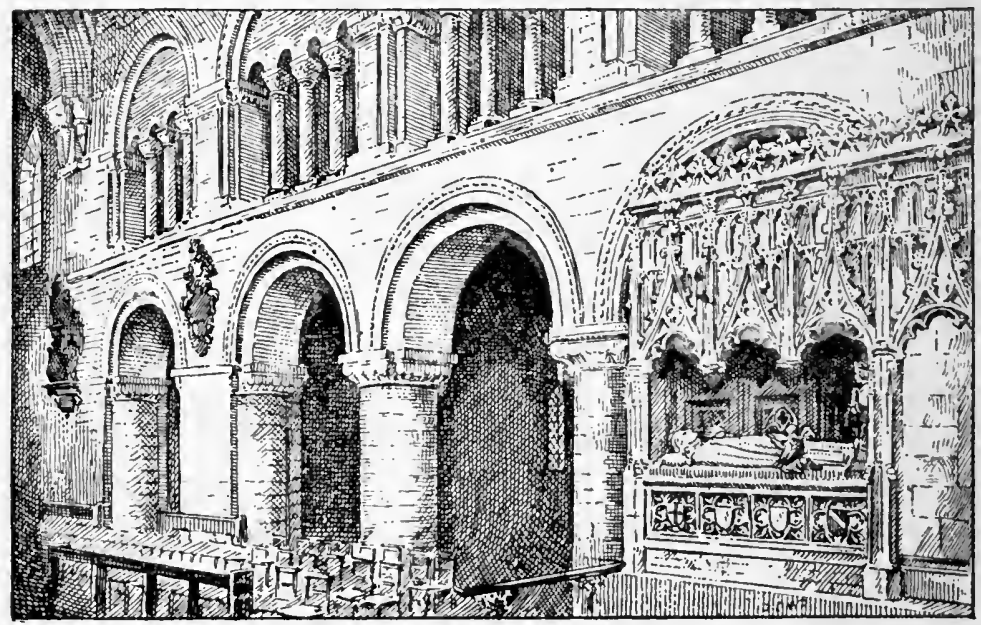

I1. THE TOMB OF RAHERE

(Founder and first prior of St. Bartholomew's)

in the Holy Land and for the liberation of Richard the illustrious king of England." After the royal captive had been freed, he endowed his faithful friend's foundation with seven hundred acres of land. Among the leading men of the day who built hospitals were Geoffrey FitzPeter and William Briwere, Peter des Roches and Hubert de Burgh, together with Hugh and Joceline of Wells. Yet another distinguished bishop of this period must be 
mentioned, namely, Walter de Suffield, who was very liberal to the poor, especially in his city of Norwich. During his lifetime he established St. Giles' and drew up its statutes. He directed that as often as any bishop of the See went by, he should enter and give his blessing to the sick, and that the occasion should be marked by special bounty. His will shows a most tender solicitude for the welfare of the house, which he commended to his successor and his executors.

Benefactors included not only men eminent in church and state, but " others of divers estates," clerical and lay commoners. Foremost of these stands Rahere, born of low lineage, but court-minstrel and afterwards priest. In obedience to a vision, he determined to undertake the foundation of a hospital. He sought help from the Bishop of London, by whose influence he obtained from Henry I the site of St. Bartholomew's, Smithfield. While many founders are forgotten, men delight to honour Rahere. The chronicler, who had talked with those who remembered him, records how he sympathized with the tribulation of the wretched, how he recognized their need, supported them patiently, and finally helped them on their way. Rahere's character is delightfully portrayed in the Book of the Foundation:-

" whoose prouyd puryte of soule, bryght maners with honeste probyte, experte diligence yn dyuyne seruyce, prudent besynes yn temperalle mynystracyun, in hym were gretely to prayse and commendable."

Other clerical founders include William, Dean of Chichester (St. Mary's), Walter the Archdeacon (St. John's, Northampton), Peter the chaplain (Lynn), Guarin the 
chaplain (Cricklade), Walter, Vicar of Long Stow, etc. Hugh the hermit was reckoned the founder of Cockersand hospital, which grew into an abbey :-

" Be it noted that the monastery was furst founded by Hugh Garthe, an heremyt of great perfection, and by such charitable almes as [he] dyd gather in the countre he founded an hospitall."

The leading townsfolk of England have long proved themselves generous. Gervase of Southampton is in the forefront of a line of merchant-princes and civic rulers who have also been benefactors of the needy. Gervase "le Riche" was evidently a capitalist, and it is recorded that he lent moneys to Prince John. His responsible office was that of portreeve ; it may be that while exercising it, he witnessed sick pilgrims disembark and was moved to help them. Certainly, about the year 1185, Gervase built God's House (Pl. VII) beside the quay, and his brother Roger became the first warden. Leland's version is as follows :-

"Thys Hospitale was foundyd by 2 Marchauntes beyng Bretherne [whereof] the one was caullyd Ge[rvasius] the other Protasius. . . . These 2 Brethern, as I there lernid, dwellyd yn the very Place wher the Hospitale is now. ... These 2 Brethern for Goddes sake cause[d] their House to be turnid to an Hospitale for poore Folkes, and endowed it with sum Landes."

Among other citizen-founders of this period may be named Walter and Roesia Brune, founders of St. Mary's, Bishopsgate, London; Hildebrand le Mercer, of Norwich; and William Prodom and John Long, of Exeter. 


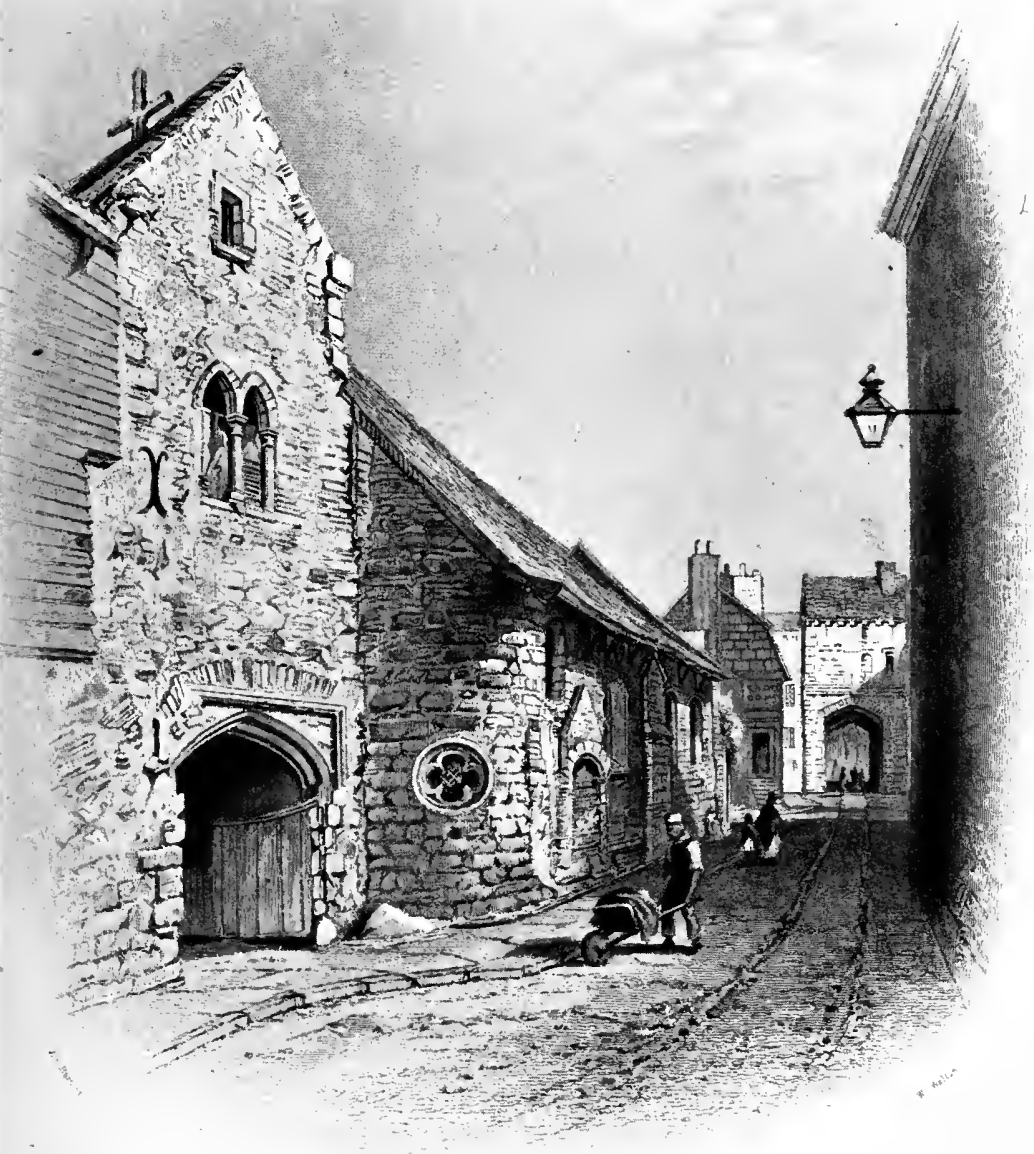

GOD'S HOUSE, SOUTHAMPTON 



\section{THIRD PERIOD (1 272-1540)}

Few royal builders or benefactors can be named at this time. Edward I, who, from various motives, set his face like a flint against the Jews, was a beneficent patron to those who were prepared to submit to Baptism; and he reorganized and endowed his father's House of Converts. His charity, however, was of a somewhat belligerent character and partook of the nature of a crusade. He was always extremely harsh towards the unconverted Jew; his early training as champion of the Cross in the Holy Land helped to make him zealous in ridding his own kingdom of unbelievers. But before finally expelling them, he did his best for their conversion, enlisting the help of the trained and eloquent Dominican brethren. Edward with justice ordained that as by custom the goods of the converts became the king's, he should henceforth "provide healthfully for their maintenance"; and he granted them a moiety of their property when they became, by Baptism, "sons and faithful members of the Church." The chevage, or Jewish poll-tax, and certain other Jewish payments, were appropriated to the Domus Conversorum, over $£ 200$ being paid annually from the Exchequer. Edward took an interest in "the king's converts" and drew up careful regulations for them. Eleanor, his consort, was a benefactor of the royal hospital near the Tower, and she was also by tradition the founder of St. John's, Gorleston.

The unhappy Richard II desired in his will that five or six thousand marks should be devoted to the maintenance of lepers at Westminster and Bermondsey. ${ }^{1}$

I Rolls of Parl. I Henry IV, vol, iii. 42 I. 
The reference to "the chaplains celebrating before them for us" seems to imply that the king was the patron if not the founder; possibly one house was that of Knightsbridge. The will of Henry VII provided for the erection of three great charitable institutions. He was at least liberal in this, that he began in his lifetime the conversion of his palace of Savoy into a noble hospital. (Pl. XIV.) Its completion at the cost of Io,000 marks was the only part of his plan carried out, and of the 40,000 marks designed to be similarly expended at York and Coventry, nothing more is heard.

The great lords of this period who were founders are led by two distinguished kinsmen and counsellors of Edward III-each a Henry of Lancaster and Steward of England. The father, when he was becoming blind, erected St. Mary's at Leicester for fifty poor (1330), and his son doubled the foundation. Richard, Earl of Arundel-the victor of Sluys-began to found the Maison Dieu, Arundel, in 1380, but he was executed on a charge of treason; and the work ceased until his son, having obtained fresh letters-patent from Henry V (1423), set himself to complete the design. Several notable veterans of the French campaign may be mentioned as hospital builders, namely, Michael de la Pole (Kingston-upon-Hull), Sir Robert Knolles (Pontefract), Walter, Lord Hungerford (Heytesbury) and William de la Pole (Ewelme); when the latter became unpopular and was executed as a traitor, his wife Alice-called on her tomb fundatrix-completed the building and endowment of God's House. (P1. XVII.)

Although the benevolence of bishops now chiefly took the form of educational institutions, some well-known prelates 


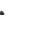




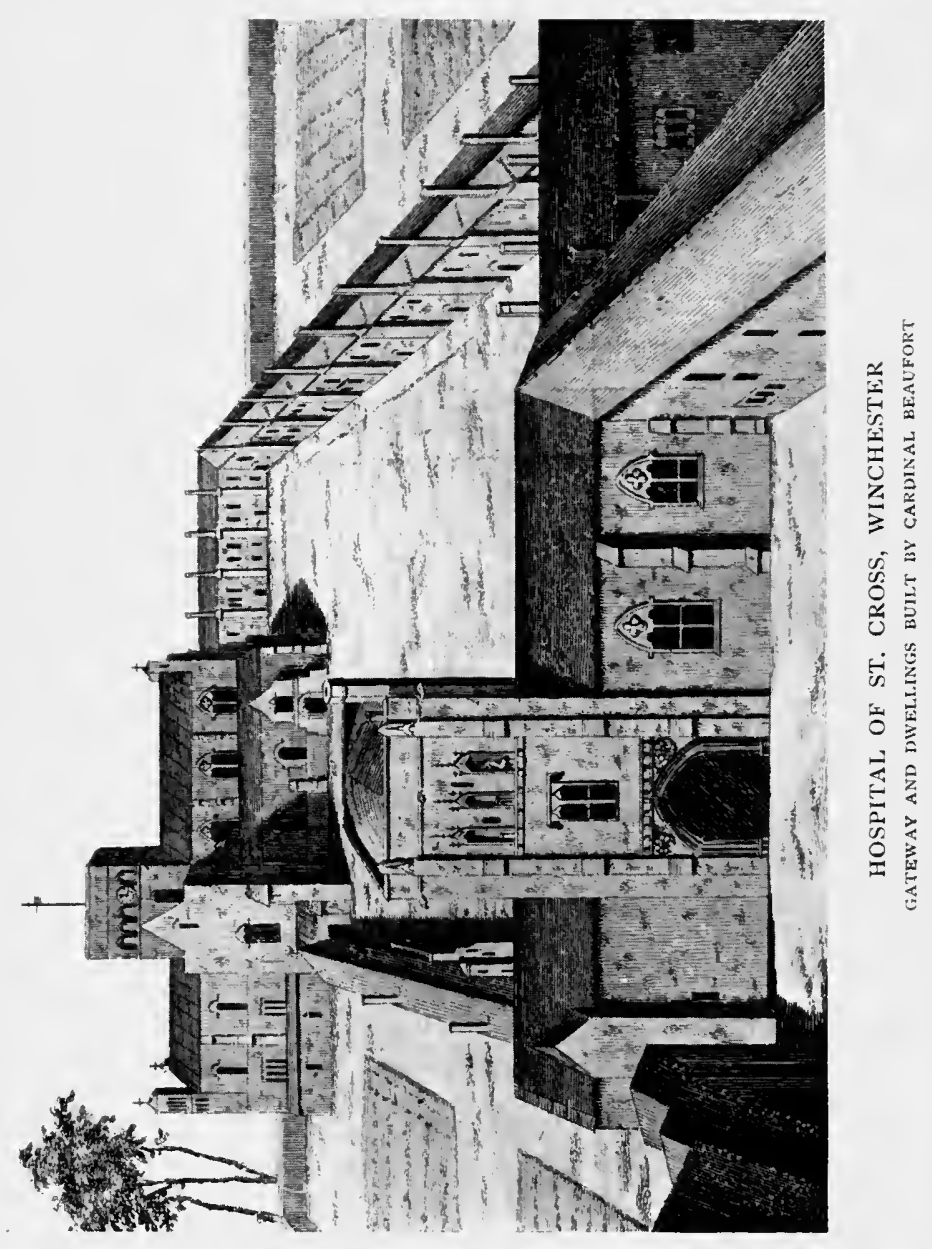


erected hospitals. Bubwith-Treasurer of England under Henry IV-planned St. Saviour's, Wells, but it was not begun in his lifetime. Beaufort-Lord Chancellor and Cardinal-refounded St. Cross, but, owing to the York and Lancaster struggle, the design was not fully carried out. His rival Chichele-the faithful Primate of Henry V -built not only All Souls, Oxford, but the bede-house at Higham Ferrers. There is a tradition that while keeping the sheep by the riverside he was met by William of Wykeham, who recognized his talents and provided for his education. He afterwards desired to found a college in the place where he was baptized, and of this the almshouse formed part. William Smyth-founder of Brasenose-restored St. John's during his short episcopate at Lichfield. When translated to Lincoln, he turned his attention to St. John's, Banbury, and bequeathed $£$ IOO towards erecting and repairing its buildings, in addition to $£ 60$ already bestowed upon it. "This man," says Fuller, "wheresoever he went, may be followed by the perfume of Charity he left behind him."

It was undoubtedly townsfolk who were the principal founders of the fourteenth and fifteenth centuries. The name of many an old merchant-prince is still a household word in his native place, where some institution remains as a noble record of his bounty. St. John's, Winchester, for example, was erected by an alderman, John Devenish, its revenues being increased by another of the family and by a later mayor; and the memory of benefactors was kept fresh by a "love-feast and merry meeting" on the Sunday after Midsummer Day. William Elsyng established a large almshouse near Cripplegate. He was a mercer of influential position, being given a licence to travel in the 


\section{MEDI EVAL HOSPITALS OF ENGLAND}

king's service beyond seas with Henry of Lancaster ; and it may have been this nobleman's charitable work in Leicester that inspired the foundation known as "Our Lady of Elsyngspital."

A more famous London mercer, Richard Whittington, proved himself the " model merchant of the Middle Ages"; Lysons records his manifold beneficent deeds. Although he did not live long enough to carry out all his schemes, his executors completed them, and in particular, the almshouse attached to St. Michael Royal. In a deed drawn up after his death (1423) and now preserved in the Mercers' Hall, is a fine pen-and-ink sketch which depicts the passing of this "father of the poor." (PI. IX.) John Carpenter and other friends stand round the sick man; nor are we left in doubt as to the significance of the group at the foot of the bed-evidently twelve bedemen, led by one who holds a rosary in token of his intercessory office-it being recorded in the document that :-

"the foresayde .worthy and notable merchaunt, Richard Whittington, the which while he leued had ryght liberal and large hands to the needy and poure people, charged streitly on his death bed us his foresayde executors to ordeyne a house of almes, after his death . . . and thereupon fully he declared his will unto us." 1

The same benefactor not only repaired St. Bartholomew's, but added a refuge for women to St. Thomas', Southwark, as is set forth by William Gregory, one of Whittington's successors in the mayoralty :-

"And that nobyl marchaunt Rycharde Whytyngdon, made a new chamby[r] with viij beddys for yong weme[n] that hadde done a-mysse in truste of a good mendement. And he com-

1 T. Brewer, Carpenter's Life, p. 26. 


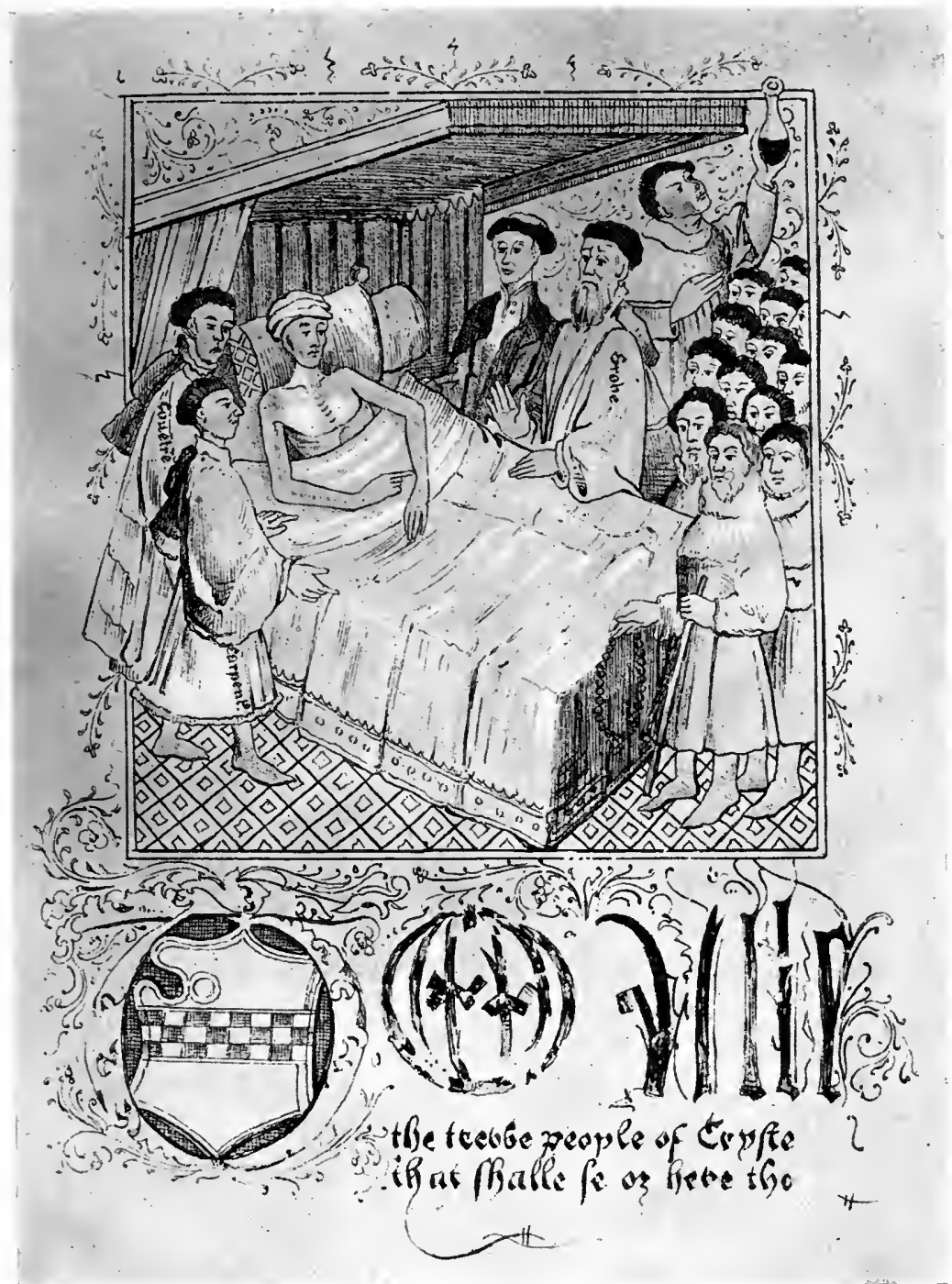

THE DEATH OF RICHARD WHITTINGTON 

maundyd that alle the thyngys that ben don in that chambyr shulde be kepte secrete with owte forthe, yn payne of lesynge of hyr leuynge; for he wolde not shame no yonge women in noo wyse, for hyt myght be cause of hyr lettyng of hyr maryage."

"Verily," we exclaim with Lysons, " there seems to be no end to the good deeds of this good man."

Nor were other places without their public-spirited townsmen. Unlike "Dick" Whittington who died childless, Thomas Ellis left twenty-three sons and daughters : nevertheless this large-hearted draper provided an almshouse for his poorer neighbours in Sandwich.

The wealth of William Browne of Stamford and of Roger Thornton of Newcastle-upon-Tyne was proverbial when Leland visited those industrial centres and saw the charities which they had established. Browne, founder of the bede-house (Fig. 5), "was a Marchant of a very wonderful Richeness." Thornton, a very poor man, reported to have been a pedlar, who rose to be nine times mayor, was remembered as "the richest Marchaunt that ever was dwelling in Newcastelle." While in this way many that were rich made offerings of their abundance, there were those, too, who gave of their penury. Such was "Adam Rypp, of Whittlsey, a poor man, who began to build a Poor's Hospital there, but had not sufficient means to finish it." His work was commended to the faithful by briefs from Bishop Fordham of Ely (139I-4).

\section{TOMBS OF FOUNDERS AND BENEFACTORS}

Many benefactors associated themselves so closely with their bedemen that they desired to be buried within the precincts of the hospital. Robert de Meulan, one of the 


\section{MEDI EVAL HOSPITALS OF ENGLAND}

Conqueror's lords, is said to have founded and endowed Brackley hospital, where his heart was embalmed. His descendant, Roger, Earl of Winchester, a considerable benefactor in the time of Henry III, "ordered a measure

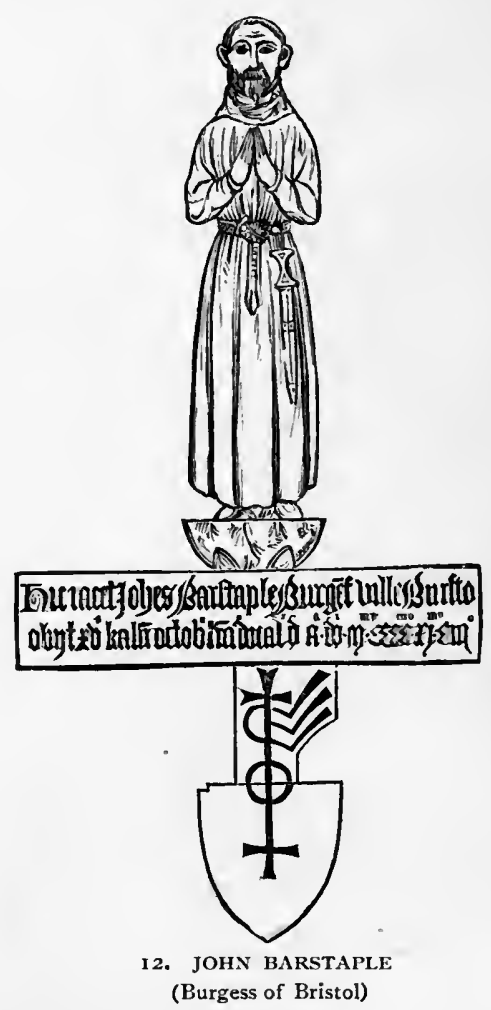

to be made for corn in the shape of a coffin, and gave directions that it should be placed on the right side of the shrine, in which the heart of Margaret his mother lay intombed," providing that it should be filled thrice in a year for ever for the use of the hospital. ${ }^{1}$ The chapel

1 Bridges' History, I, 146. 
continued to be a favourite place of interment, for Leland says:- "There ly buryed in Tumbes dyvers Noble Men and Women." Bishop Suffield directed that if he should die away from Norwich-as he afterwards did-his heart should be placed near the altar in the church of St. Giles' hospital. The blind and aged Henry of Lancaster and Leicester was buried in his hospital church, the royal family and a great company being present (1345); and there likewise his son was laid. Few founders' tombs remain undisturbed in a spot still hallowed by divine worship, but some have happily escaped destruction. Rahere has an honoured place at St. Bartholomew's. The mailed effigy of Sir Henry de Sandwich-lord warden of the Cinque Ports-remains in the humbler St. Bartholomew's near Sandwich. The fine alabaster monument of Alice, Duchess of Suffolk, is in perfect preservation at Ewelme. The rebuilt chapel of Trinity Hospital, Bristol, retains a monumental brass of the founder (Fig. 12) and his wife.

\section{AIMS AND MOTIVES OF BENEFACTORS}

It is sometimes asserted that the almsgiving of the Middle Ages was done from a selfish motive, namely, that spiritual benefits might be reaped by the donor. Indeed it is possible that the giver then, like some religious people in every age, was apt to be more absorbed in the salvation of self than in the service of others; but the testimony of deeds and charters is that the threefold aim of such a man was to fulfil at once his duty towards God, his neighbour, and himself. That he was often imbued with a true ministering spirit is shown by his personal care for the comfort of 
inmates. Doubtless the hidden springs of charity were as diverse as they are now : not every name on a modern subscription list represents one that "considereth the poor." No one could imagine, for instance, that Queen Maud and King John had a common motive in their charity to lepers; or that the bishops Wulstan and Peter des Roches were animated by the same impulse when they provided for the wants of wayfarers.

The alleged motives of some benefactors are revealed in documents. Henry de Blois, Bishop of Winchester, refers to St. Cross-" which I for the health of my soul and the souls of my predecessors and of the kings of England have founded . . . that the poor in Christ may there humbly and devotedly serve God." Herbert, Bishop of Salisbury, in making a grant to clothe the lepers of a hospital in Normandy, says that:- "Among all Christ's poor whom a bishop is bound to protect and support, those should be specially cared for whom it has pleased God to deprive of bodily power," and these poor inmates " in the sorrow of fleshly affliction offer thanks to the Lord for their benefactors with a joyous mind." Matthew Paris writes of Henry III that "he being touched with the Holy Ghost and moved with a regard to pity, ordained a certain famous hospital at Oxon."

In the case of Rahere, the foundation of St. Bartholomew's was an act of gratitude for deliverance from death, and the practical outcome of a vision and a sick-bed vow. While Rahere tarried at Rome,

" he began to be uexed with greuous sykenesse, and his doloures, litill and litill, takynge ther encrese, he drew to the extremyte of lyf. . . A Albrake owte in terys, than he auowyd yf helthe God hym wolde grawnte, that he myght lefully returne to his contray, 
he wolde make and hospitale yn recreacion of poure men, and to them so there i gaderid, necessaries mynystir, after his power."

Now and again a benefactor evinces deep religious feelings, as shown in the charter of Bishop Glanvill at the foundation of St. Mary's, Strood :-

"Bearing in mind the saying of the Lord: "I was an hungred, and ye gave Me meat; I was thirsty, and ye gave Me drink ; I was a stranger, and ye took $\mathrm{Me}$ in;' . . . And seeing that the Lord takes upon Himself the needs of those who suffer . . . we have founded a hospital in which to receive and cherish the poor, weak and infirm."

Another founder showed the zeal of Apostolic days; a layman of Stamford, Brand by name, made an offering to God and held nothing back. This we learn from a papal document (circa I I 74) :-

"Alexander the bishop to his beloved son Brand de Fossato, greeting ... we having, been given to understand . . . that you, guided by divine inspiration, having sold all you did possess, have erected a certain hospital and chappel ... where you have chose to exhibit a perpetual offering to your creator." 1

The meritorious aspect of almsgiving was sometimes uppermost. Hugh Foliot, Bishop of Hereford, in founding his hospital at Ledbury, sets forth the importance and advantage of exercising hospitality. He illustrates the point by the case of the patriarchs, who were signally rewarded for their hospitality :-

"Bearing in mind therefore that ... almost nothing is to be preferred to hospitality, and that so great is its value that Lot and

${ }^{1}$ F. Peck's Annals of Stanford, v. 15. 


\section{MEDIÆVAL HOSPITALS OF ENGLAND}

Abraham who practised it were counted worthy to receive angels for guests ... we have built a certain hospital for strangérs and poor people."

The Church continued to teach the imperative duty of almsgiving. It is stated in the will of Henry VII that in the one act of establishing a hospital the Seven Works of Mercy might be fulfilled :-

"And forasmuch as we inwardly consideir, that the vij. workes of Charite and Mercy bee moost profitable, due and necessarie for the saluation of man's soule, and that the same vij. works stand moost commonly in vj. of theim; that is to saye in uiseting the sik, mynistring mete and drinke and clothing to the nedy, logging of the miserable pouer, and burying of the dede bodies of cristen people. ... We therefor of our great pitie and compassion . . . have begoune to erecte, buylde and establisshe a commune Hospital in our place called the Sauoie ... to the laude of God, the weale of our soule, and the refresshing of the said pouer people, in daily, nightly and hourely exploytyng the said vj. works of Mercy, Pitie, and Charity."

To the hospital which he had provided, the founder looked not only for spiritual and temporal profit in this life, but above all for help to his soul in the world to come. The desire for the prayers of generations yet unborn was a strong incentive to charity. The bede-houses testify to a purposeful belief in the availing power of intercession. Thus the patrons of Ewelme speak in the statutes of "prayoure, in the whiche we have grete trust and hope to oure grete relefe and increce of oure merite and joy fynally." The same faith is expressed by the action of the merchants and mariners of Bristol in 1445 . Because

" the crafte off maryners is so auenturous that dayly beyng in ther uiages ben sore vexed, trobled and deseased and dis- 
tried, the which by gode menys of the prayers and gode werkes might be graciously comforted and better releced of such trobles,"

they wished to found a fraternity to support, within the old hospital of St. Bartholomew (Fig. I3), a priest and

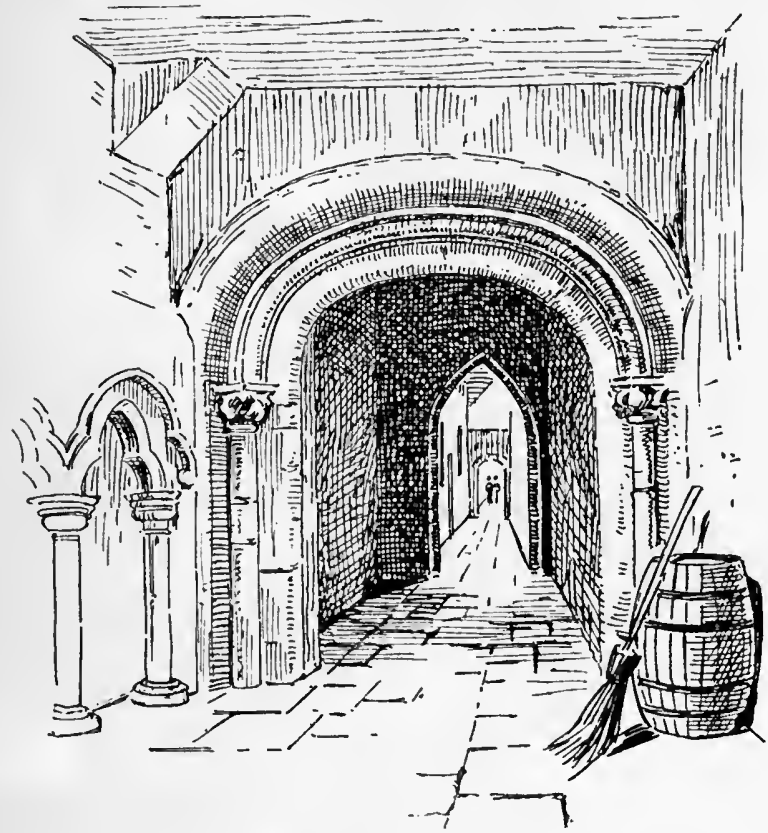

I3. ST. BARTHOLOMEW'S HOSPITAL, BRISTOL (Called in ${ }_{13}^{8} 7$ the Domus Dei by Frome Bridye)

twelve poor seamen who should pray for those labouring on the sea, or passing to and fro into their port.

An earnest desire to make the world better is shown in one foundation deed, dating probably from the middle of the fourteenth century. It concerns Holy Trinity, Salisbury, erected by Agnes Bottenham on a spot where a 


\section{MEDI $Æ V A L$ HOSPITALS OF ENGLAND}

house of evil repute had existed "to the great perils of souls":- -

"The founders, by means of the inspiration of the Holy Spirit, have ordained thirty beds to the sustentation of the poor and infirm daily resorting thither, and the seven works of charity are there fulfilled. The hungry are fed, the thirsty have drink, the naked are clothed, the sick are comforted, the dead are buried, the mad are kept safe until they are restored to reason, orphans and widows are nourished, lying-in women are cared for until they are delivered, recovered and churched."

The aim of pious benefactors was indeed the abiding welfare of their bedemen. The hard-headed, warmhearted business men of Croydon and Stamford, no less than the ladies of Heytesbury and Ewelme, expressed a hope that the Domus Dei on earth might be a preparation for the eternal House of God. In the words of the patrons of Ewelme, they desired the poor men so to live :-

"that aftyr the state of this dedely [mortal] lyf they mowe come and inhabit the howse of the kyngdome of heven, the which with oure Lordes mouth is promysed to all men the which bene pore in spirit. So be yt." 


\section{CHAPTER VII}

\section{HOSPITAL INMATES}

"To the master and brethren of the hospital of St. Nicholas, Scarborough.Request to admit John de Burgh, chaplain, and grant him maintenance for life, as John has been suddenly attacked by the disease of leprosy, and has not wherewith to live and is unable through shame to beg among Christians." (Close Roll, 1342.)

7 HOUGH a visit to a modern infirmary calls forth in 1 us, doubtless, passing thoughts of admiration for the buildings and the arrangements, what draws most of us thither is the bond of brotherhood. It is the inmates of the wards who are to us the centre of attraction. Looking upon the sufferers, we desire to know their circumstances, their complaints, their chance of cure. Nor is it otherwise in studying the history of ancient institutions. The mere site of an old hospital may become a place of real interest when we know something of those who once dwelt there, when we see the wayworn pilgrim knocking at the gate, the infirm man bent with age, the paralysed bedridden woman, and the stricken leper in his sombre gown, and realize what our forefathers strove to do in the service of others.

In many cases the link between the first founder and first inmate was very close, being the outcome of personal relations between master and servant, feudal lord and tenant. It was so in the case of Orm, the earliest hospital inmate whose name has been handed down to us. 


\section{2

This Yorkshireman, who lived near Whitby eight hundred years ago, "was a good man and a just, but he was a leper." The abbot, therefore, having pity on him, founded a little asylum, in which Orm spent the rest of his days, receiving from the abbey his portion of food and drink. In the same way Hugh Kevelioc, Earl of Chester, built a retreat outside Coventry for William de Anney, a knight of his household, which was the origin of Spon hospital for the maintenance of such lepers as should happen to be in the town.

\section{(i) PERSONS MIRACULOUSLY CURED}

In dealing with mediæval miracles it may not unnaturally be objected that we are wandering from the paths of history into the fields of fiction ; but it is absolutely necessary to allude to them at some length because they played so important a part in the romantic tales of pilgrim-patients. We shall see that sufferers were constantly being carried about in search of cure, and in some cases were undoubtedly restored to health. This was an age of faith and therefore of infinite possibilities. It would appear that "marvels" were worked not only on certain nervous ailments, but on some deep-seated diseases. It is a recognized fact that illness caused by emotion (as of grief) has oftentimes been cured by emotion (as of hope). Possibly, too, not a few of the persons restored to health were suffering from hysteria and nervous affections, which complaints might be cured by change of scene and excitement. In the Book of the Foundation is the story of a well-known man of Norwich who would not take care of his health, and therefore " hadde lost the rest of slepe," which alone keeps the nature sound and whole. His in- 
somnia became chronic, and by the seventh year of his misfortune he became very feeble, and so thin that his bones could be numbered. At length he betook himself to the relics of St. Bartholomew; there, grovelling on the ground, he multiplied his prayers and began to sleep"and whan he hadde slepte a grete while he roys up hole."

On the other hand the conviction is forced upon us that many, perhaps most, of the so-called miracles were not genuine. Some diseases might have been feigned by astute beggars. Although experienced doctors and skilled nurses to-day are quick to detect cases, cleverly simulating paralysis, epilepsy, etc., the staff in a mediæval hospital would probably not discover the deception. When one such person became the hero of a dramatic scene of healing, the officials would joyfully acknowledge his cure, without intention of fraud. The narratives come down to us through monkchroniclers, whose zeal for their home-shrines made them lend a quick ear to that which contributed to their fame. In those days people were uncritical and were satisfied without minute investigation.

There is, indeed, little information about early hospital inmates unless they were fortunate enough to receive what was universally believed in those days to be miraculous

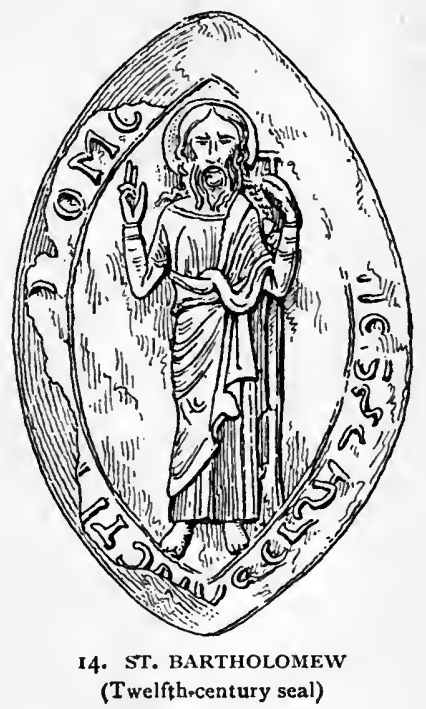




\section{MEDI $Æ V A L$ HOSPITALS OF ENGLAND}

healing. Startling incidents are related by contemporary writers, whose vivid and picturesque narratives suggest that they had met witnesses of the cures related. The twelfth-century chronicler of St. Bartholomew's, Smithfield, gives us eyes to see some of the patients of that famous hospital.

(1) Patients of St. Bartholomew's. - The cripple Wolmer, a well-known beggar who lay daily in St. Paul's, was a most distressing case. He was so deformed as to be obliged to drag himself along on all fours, supporting his hands on little wooden stools. (Cf. Pl. XX.) His story is extracted from Dr. Norman Moore's valuable edition of the faithful English version of the Liber Fundacionis, dating about the year 1400 .

"There was an sykeman Wolmer be name with greuous and longe langoure depressid, and wrecchid to almen that hym behylde apperyd, his feit destitute of naturall myght hyng down, hys legges cleuyd to his thyis, part of his fyngerys returnyd to the hande, restynge alwey uppon two lytyll stolys, the quantite of his body, to hym onerous, he drew aftir hym. ..."

For thirty winters Wolmer remained in this sad condition, until at length he was borne by his friends in a basket to the newly-founded hospital of St. Bartholomew, where his cure was wrought by a miracle as he lay extended before the altar in the church :-

“. . . and by and by euery crokidness of his body a litill \& litill losid, he strecchid un to grownde his membris \& so anoon auawntynge hym self up warde, all his membris yn naturale ordir was disposid. . . ."

The scene of this incident was, presumably, that noble building which we still see (Fig. II), and which was then 
fresh from the hand of the Norman architect and masons.

Aldwyn, a carpenter from Dunwich, once occupied a place in St. Bartholomew's. His limbs were as twisted and useless as those of Wolmer; his sinews being contracted, he could use neither hand nor foot. Brought by sea to London, the cripple was "put yn the hospitall of pore men," where awhile he was sustained. Bit by bit he regained power in his hands, and when discharged was able to exercise his craft once more.

Again the veil of centuries is lifted and we see the founder himself personally interested in the patients. A woman was brought into the hospital whose tongue was so terribly swollen that she could not close her mouth. Rahere offered to God and to his patron prayer on her behalf and then applied his remedy :-

"And he reuolvynge his relikys that he hadde of the Crosse, he depid them yn water \& wysshe the tonge of the pacient ther with, \& with the tree of lyif, that ys with the same signe of the crosse, paynted the tokyn of the crosse upon the same tonge. And yn the same howre all the swellynge wente his way, \& the woman gladde \& hole went home to here owne."

Perhaps the most startling cure was that of a maid deaf, dumb, blind of both eyes and crippled. Brought by her parents to the festival of St. Bartholomew in the year I 73, she was delivered from every bond of sickness. Anon she went "joyfull skippyng forth "; her eyes clear, her hearing repaired, "she ran to the table of the holy awter, spredyng owte bothe handys to heuyn and so she that a litill beforne was dum joyng in laude of God per- 
fitly sowndyd her wordes"; then weeping for joy she went to her parents affirming herself free from all infirmity.

In the foregoing narratives it will be noticed that hospital and shrine were adjacent. This convenient combination not being found elsewhere, incurable patients were carried to pilgrimage-places. Two of the chief wonder-workers were St. Godric of Finchale and St. Thomas of Canterbury, who both died in 11 7o. Reginald of Durham narrates the cure by their instrumentality of three inmates from northern hospitals. ${ }^{1}$

(2) The Paralytic Girl and the Crippled Youth.-A young woman who had lost the use of one side by paralysis, was brought from the hospital of Sedgefield (near Durham) to Finchale, where the same night she recovered health. The poor cripple of York was not cured so rapidly. Utterly powerless, his arms and feet twisted after the manner of knotted ropes, this most wretched youth had spent years in St. Peter's hospital. At length he betook himself as best he could to Canterbury, where he received from St. Thomas health on one side of his body. It grieved him that he was not worthy to be completely cured, but learning from many witnesses the fame of St. Godric, he hastened to his sepulchre; falling down there, he lay in weakness for some time, then, rising up, found the other side of his body absolutely recovered. The lad returned home whole and upright, and this notable miracle was attested by many who knew him, and by the procurator of the hospital.

(3) A Leper Maiden.-The touching tale of a girl who was eventually released from the lazar-house near Darling-

${ }^{1}$ Surtees Soc., Vol. 20, pp. 376, 432-3, 456-7. 
ton (Bathelspitel) is also related by Reginald, and transcribed by Longstaffe.

"There is a vill in the bishopric called Hailtune [Haughtonle-Skerne] in which dwelt a widow and her only daughter who was grievously tormented with a most loathsome leprosy. The mother remarried a man who soon began to view the poor girl with the greatest horror, and to torment and execrate her. . . . She fled for aid to the priest of the vill, who, moved with compassion, procured by his entreaties the admission of the damsel to the hospital of Dernigntune [Darlington], which was almost three miles distant, and was called Badele."

There the maiden remained three years, growing daily worse. After describing her horrible symptoms and wasted frame, the chronicler narrates her marvellous cure at Finchale. Thrice did the devoted mother take her thither until the clemency of St. Godric was outpoured and "he settled and removed the noxious humours." When at length the girl threw back the close hood, her mother beheld her perfectly sound. The scene of this pitiful arrival and glad departure was that beautiful spot at the bend of the river Weir, now marked by picturesque ruins. The complete recovery was attested by all, including the sheriff and the kind priest, Normanrus. We reluctantly lose sight of the delivered damsel, wondering whether the cruel step-father received her less roughly when she got home. It is simply recorded that never did the disease return, and that she lived long to extol the power given by God to His servant Godric.

(4) A Taunton Monk.-Seldom do we know the afterlife of such patients, but a touching picture shows us one cleansed of his leprosy, serving his former fellow-inmates. This was John King, a monk of Taunton Priory. Prior 


\section{MEDIÆVAL HOSPITALS OF ENGLAND}

Stephen tells how he was smitten with terrible and manifest leprosy, on which account he was transferred to a certain house of poor people, where he stayed for more than a year among the brethren. The prior's letter, after declaring how the fame of St. Thomas was growing throughout the world, refers to divers miracles, by one of which John was completely cured. Returning from Canterbury, he was authorized to gather alms for his former companions :-

"We ... earnestly implore your loving good will for the love of God and St. Thomas, that you listen to the dutiful prayer of our brother John, wonderfully restored to health by God, if you have power to grant it. For he earnestly begs you to help by your labour and your alms the poverty of those sick men whose company he enjoyed so long." 1

Two similar instances of service are recorded. Nicholas, a cripple child cured at St. Bartholomew's, was sent for a while to serve in the kitchen,_- "for the yifte of his helth, he yave the seruyce of his body." In the same way a blind man who had been miraculously cured by the merit of St. Wulstan (I221), afterwards took upon himself the habit of a professed brother in the hospital of that saint in Worcester. He had been a pugilist and had lost his sight in a duel, but having become a peaceable brother of mercy, he lived there honourably for a long while. ${ }^{2}$

(ii) CROWN PENSIONERS

Leaving the chronicles, and turning to state records, we find that the sick, impotent and leprous were recipients of royal favour. An early grant of maintenance was

${ }^{2}$ Chron. and Mem., 67, i. 428-9.

2 Chron. and Mem., 36, iv. p. 413 . 
made in 1235 to Helen, a blind woman of Faversham whom Henry III caused to be received as a sister at Ospringe hospital. Similar grants were made from time to time to faithful retainers, veteran soldiers or converted Jews (who were the king's wards).

Old Servants, Soldiers, etc.-The most interesting pensioners were veterans who had served in Scotland and France. The year of the battle of Bannockburn (1314), a man was sent to Brackley whose hand had been inhumanly cut off by Scotch rebels. ${ }^{1}$ There are several instances of persons maimed in the wars who were sent for maintenance to various hospitals. One of the many grants of Richard II was made- "out of regard for Good Friday" - to an aged servant, that he should be one of the king's thirteen poor bedemen of St. Giles', Wilton. Another of Richard II's retainers, a yeoman, was generously offered maintenance at Puckeshall by Henry IV. ${ }^{2}$

Jewish Converts. - The House of Converts was akin to a modern industrial home for destitute Jewish Christians, inmates being kept busily employed in school and workshop. During the century following the foundation of these "hospitals," many converts are named, Eve, for instance, was received at Oxford, and Christiana in London. Usually admitted after baptism, they were enrolled under their new names. Philip had been baptized upon St. Philip and St. James' Day, and Robert Grosseteste was possibly godson of the bishop. Converts were brought from all parts. We find John and William of Lincoln, Isabel of Bristol and her boy, Isabel of Cam-

1 Close 8 Edw. II, m. 35 d.

2 Pat. 8 Ric. II, pt. ii. m. 22 ; 9 Hen. IV, pt. ii. m. I4. 


\section{Ioo MEDI $Æ V A L$ HOSPITALS OF ENGLAND}

bridge, Emma of Ipswich, etc. ${ }^{1}$ A century later pensioners must have been immigrants, since all Jews resident in England had been expelled in 1290 . A Flemish Jew, baptized at Antwerp in the presence of Edward III, was granted permission to dwell in the London institution with a life-pension of $2 d$. a day :-

"Inasmuch as our beloved Edward of Brussels has recently abandoned the superstitious errors of Judaism . . . and because we rejoice in Christ over his conversion, and lest he should recede from the path of truth upon which he has entered, because of poverty ... we have granted to him a suitable home in our House of Converts."

Theobald de Turkie, "a convert to the Catholic Faith," was afterwards received, together with pensioners from Spain, Portugal, France, and Italy. A chamber was granted to Agnes, an orphan Jewess of tender age and destitute of friends, the child of a convert-godson of Edward II. A later inmate, of whose circumstances we would fain know more, was Elizabeth, daughter of Rabbi Moyses, called "bishop of the Jews" (I 399). Converts frequently had royal sponsors. Henry V stood godfather to Henry Stratford, who lived in the Domus Conversorum from I4I6-I44I. There was a certain risk in being called after the sovereign, nor was it unknown for the king's converts to change their names. As late as 5532 Katharine of Aragon and Princess Mary stood sponsor to two Jewesses.

(iii) INMATES OF SOME LAZAR-HOUSES

(1) Lincoln Invalids.-Near Lincoln is a spot still pointed out as the "Lepers' Field." Formerly it was known as the Mallardry or as Holy Innocents' hospital.

${ }^{1}$ Close Rolls passim.

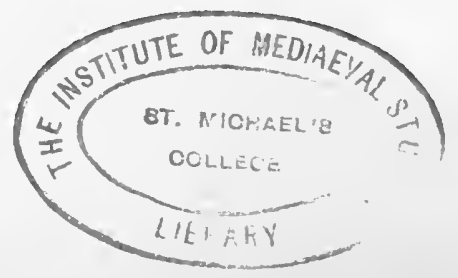


Had one visited this place in the days of Edward I, ten of the king's servants-lepers or decrepit persons-would have been found there, together with two chaplains and certain brethren and sisters. Thomas, a maimed clerk, was one of the staff, but after thirty years he incurred the jealousy of his companions, who endeavoured to ruin his character while he was absent on business. Brother Thomas appealed to the king, and justice was administered (1278). Some time afterwards the household became so quarrelsome that the king issued a writ, and a visitation was held in I291 to set matters straight. In I 290 William le Forester was admitted to the lepers' quarters, his open-air life not having saved him from disease. Dionysia, a widow, took up her abode as a sister the same year, and remained until her death, when another leper was assigned her place. An old servant of the house past work was admitted as pensioner, and also a blind and aged retainer whose faithfulness had reduced him to poverty, he having served in Scotland and having moreover lost all his horses, waggons and goods in the Welsh rebellion. But strangest of all the residents in the hospital of Holy Innocents was the condemned criminal Margaret Everard. She was not a leper, but had once been numbered among the dead. Mistress Everard, of Burgh-by-Waynflete, was a widow, convicted of "harbouring a thief, namely, Robert her son, and hanged on the gallows without the south gate of Lincoln." Now the law did not provide interment for its victims, but it seems that the Knights Hospitallers of Maltby paid a yearly sum to the lepers for undertaking this work of mercy at Canwick. ${ }^{1}$ On this memorable

1 P.R.O. Chanc. Misc. Bundle 20, No. so. 
occasion, however, the body being cut down and already removed near the place of burial-the lepers' churchyard -the woman "was seen to draw a breath and revive." We learn from a Patent Roll entry (1 284) that pardon was afterwards granted to Margaret "because her recovery is ascribed to a miracle, and she has lived two years and more in the said hospital."

(2) The Lancastrian falconer and Yorkist yeoman.-A certain Arnald Knyght, who had been falconer to Henry IV, Henry V, and Henry VI, caused a habitation to be built for himself on the site of the hospital by the Whiteditch, near Rochester, in order that there he might spend his days in divine service. In consideration of his age and of his infirmity of leprosy, Henry VI granted to Arnald and Geraldine his wife not only the building recently erected, but the lands and rents of St. Nicholas' hospital. Edward IV afterwards granted a parcel of land between Highgate and Holloway to a certain leper-yeoman "to the intent that he may build a hospital for the relief of divers persons smitten with this sickness and destitute." This man--half-founder, half-inmate--soon succumbed, for a record four years later states that "the new lazarhouse at Highgate which the king lately caused to be made for William Pole . . . now deceased" was granted for life to another leper, Robert Wylson, a saddler, who had served well "in divers fields and elsewhere." 1

(3) The Mayor of Exeter.-Shortly before 1458, St. Mary Magdalene's, Exeter, had a prominent inmate in the sometime mayor, Richard Orenge. In $1438 \mathrm{R}$ ichard

I Pat. 21 Hen. VI, pt. i. m. 35, pt. ii. m. 16; 2 Edw. IV, pt. ii. m. 6; 17 Edw. IV, pt. i. m. I. 
William, alias Richard Orenge, is mentioned as a tailor ; he is also described as being a man of French extraction and of noble family. Once he had been official patron of the asylum, but when the blow fell, he threw in his lot with those to whom he had formerly been bountiful. There, Izacke says, he finished his days and was buried in the chapel.

(4) Two Norfolk lepers. - We learn incidentally through a lawsuit that about the year 1475 the vicar of Foulsham, Thomas Wood, was in seclusion in a London lazar-house:"and nowe it is said God hathe visited the seid parsone with the sekenes of lepre and is in the Spitell howse of knygtyes brygge beside Westminster." 1 Why the priest came up from the country to Knightsbridge does not appear; it would seem, however, that the Norfolk manor was temporarily in the king's hands, so that possibly the crown bailiff procured his removal. One of the latest leper-inmates whose name is

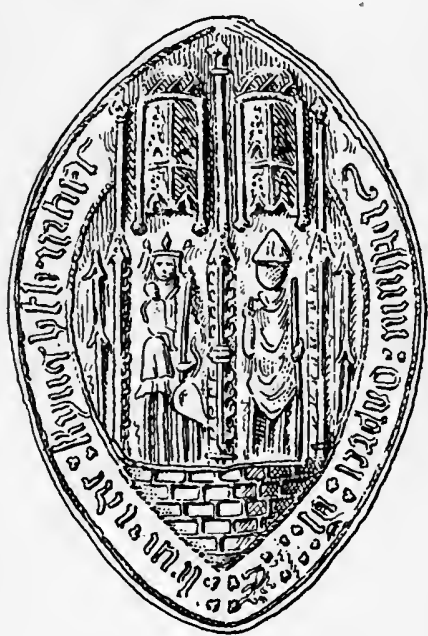

I5. SEAL OF KNIGHTSBRIDGE HOSPITAL recorded ended his days at Walsingham. The patron of the Spital-house left it in I49I to John Ederyche, a leper of Norwich, and Cecily his wife, stipulating that after their decease, one or two lepers-"men of good conversation and honest disposition "-should be maintained there.

1 P.R.O., Early Chancery Proceedings, Bundle 6o, No. 93. 


\section{(iv) SOLITARY OUTCASTS}

It must not be supposed that there were no lepers save those living in community. To use the old phrase, there was the man who dwelt in a several house and he who was forced to join the congregation without the camp. To lepers "whether recluses or living together" the Bishop of Norwich bequeathed five pounds (1256). Hermit-lazar and hospital-lazar alike fulfilled the legal requirement of separation. It may be noticed that the service at seclusion implies that the outcast may dwell alone. In early records, before the king habitually imposed "corrodies" on charitable institutions, pensioners are named who were not inhabiting lazar-houses. Philip the clerk was assigned a tenement in Portsmouth, which was afterwards granted to God's House on condition that Philip was maintained for life, or that provision was made for him to go to the Holy Land (1236). Long afterwards, in I394, Richard II pensioned a groom of the scullery from the Exchequer, but provided for one of his esquires in a hospital. ${ }^{1}$

In hermitage and hospital alike service was rendered to the leper in his loneliness. The little cell and chapel at Roche in Cornwall is said to have been a place of seclusion for one "diseased with a grievous leprosy." Since no leper might draw from a spring, his daughter Gundred fetched him water from the well and daily ministered to his wants.

Mediæval poems tell of solitary or wandering lepers as well as of those residing in communities. In the romance Amis and Amiloun, the gentle knight is stricken with

1 Pat. 2o Hen. III, m. 13 ; 17 Ric. II, pt. ii. m. 14. 
leprosy. His lady fair and bright expels him from his own chamber. He eats at the far end of the high table until the lady refuses to feed a mesel at her board- " he is so foule a thing." His presence becoming intolerable, a i:ttle lodge is built half a mile from the gate. The child Owen alone is found to serve Sir Amiloun, fetching food for his master until he is denied succour and driven away. Knight and page betake themselves to a shelter near a neighbouring market-town, and depend for a time upon the alms of passers-by. The next stage is that of wandering beggars. ${ }^{1}$

In the Testament of Cresseid the leper-heroine begged to go in secret wise to the hospital, where, being of noble kin, they took her in with the better will. She was conveyed thither by her father, who daily sent her part of his alms. But Cresseid could not be resigned to her affliction, and in a dark corner of the house alone, weeping, she made her moan. A leper-lady, an old inmate, tries in vain to reconcile her to her fate-it is useless to spurn herself against the wall, and tears do but double her woe - but in vain :-

"Thus chiding with her drerie destenye,

Weiping scho woik the nicht fra end to end."

This "Complaynt of Cresseid" is affecting in its description of the lamentable lot of a woman whose high estate is turned into dour darkness : for her bower a leper-lodge; for her bed a bunch of straw; for wine and meat mouldy bread and sour cider. Her beautiful face is deformed, and her carolling voice, hideous as a rook's. Under these sad conditions, Cresseid dwells for the rest of her life in the spital. ${ }^{2}$

${ }^{1}$ H. M. Weber, Metrical Romances, II, 269.

2 R. Henryson, Testament of Cresseid (Bannatyne Club). 


\section{CHAPTER VIII}

\section{HOSPITAL DWELLINGS}

"He" [Lanfranc] "built a fair and large house of stone, and added to it several habitations for the various needs and convenience of the men, together with an ample plot of ground." (Eadmer's History.)

THE Canterbury monk mentions the foundation of

1 Archbishop Lanfranc's two hospitals. The lepers' dwellings on the hill-side at Harbledown were merely wooden houses. The architecture of St. John's was more striking : lapideam domum decentem et amplam construxit. The edifice (palatium) was divided in two parts, to accommodate men and women. As Eadmer was living until I 24, he saw the hospital shortly after its erection. He may even have watched the Norman masons complete it, and the first infirm occupants take up their abode.

Before considering the plan of hospital buildings, it will be of interest to learn how they impressed men of those days. The twelfth-century writer of the Book of the Foundation betrays his unfeigned admiration of St. Bartholomew's. The hospital house was at a little distance from the church, which was "made of cumly stoonewerke tabylwyse." The traditional commencement of the work was that Rahere playfully acted the fool, and thus drew to himself a good-natured company of children and servants: "with ther use and helpe stonys and othir thynges profitable to the bylynge, lightly he gaderyd to 
gedyr," until at length "he reysid uppe a grete frame." When all was finished and he had set up the sign of the cross "who shulde not be astonyd, ther to se, constructe and bylyd thonorable byldynge of pite."

Matthew Paris gives sketches and brief descriptions of three hospitals in his Chronica Major. ${ }^{1}$ St. Giles', near London-"the memorial of Matilda the Queen"seems to consist of hall and chapel with an eastern tower

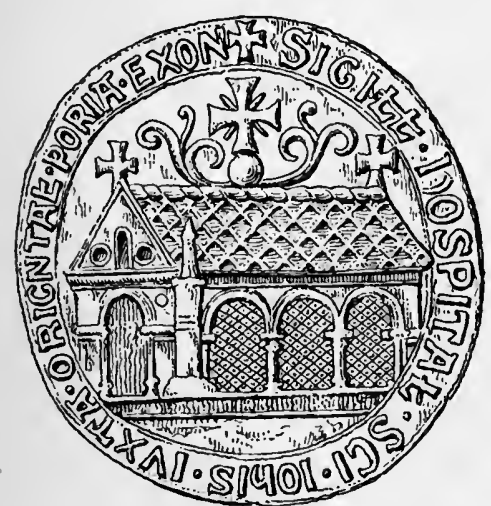

16. HOSPITAL OF ST. JOHN, EXETER

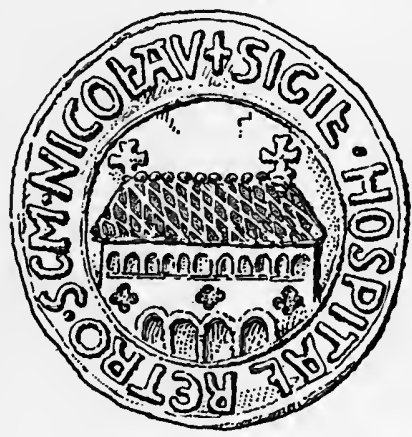

17. HOSPITAL OF ST. ALEXIS, EXETER

and another small tower at the south-west (Fig. Io); of the Domus Conversorum, London, he says, "Henry built a decent church, fit for a conventual congregation, with other buildings adjoining" (Fig. 3); St. John's, Oxford, he calls quoddam nobile hospitale. (Fig. I.) The chronicler died in 1259, and these sketches were probably made about ten years previously, when the two latter houses were newly built.

Two thirteenth-century seals depict hospitals at Exeter. Mr. Birch describes that of St. John's as "a church-like

1 Chron. and Mem., 57, iii. 262-3. 


\section{IO8 MEDI $Æ V A L$ HOSPITALS OF ENGLAND}

building of rectangular ground-plan, with an arcade of three round-headed arches along the nave, roof of ornamental shingles, and crosses at the gable-ends." The artist contrives to show not only one side, but one end, apparently the west front, with entrance. (Fig. 16.) The other seal is that of the neighbouring hospital of St. Alexis "behind St. Nicholas." (Fig. I7.) The beautiful seal of St. John's, Stafford (reproduced by the kindness of the Society of Antiquaries) shows architectural features

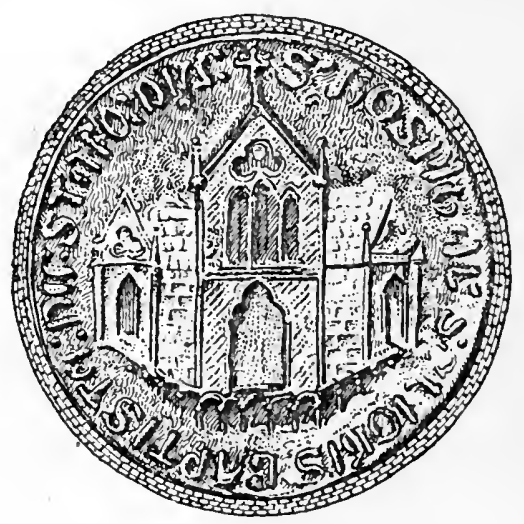

18. ST. JOHN'S, STAFFORD

of the transition period between the Early English and Decorated styles. The windows are triple-lancets with a delicately-pierced trefoil above; and an arcade runs round the base. (Fig. I8.)

Casual references to building in progress occur in records, but they give little information. As early as I 6I-3 Pipe Rolls mention works going on at the houses of the infirm at Oxford; there is one entry of over $£ 8$ spent on repairs. In $123^{2}$ timber was being sent to Crowmarsh to make shingles for the roof of the hospital 
church. Land was granted to St. Bartholomew's, Gloucester, for the widening of their chancel (1265); it is of interest to compare this fact with the elegant Early English work shown in Lysons' view. (P1. VI.) There occurs on another roll a licence to lengthen the portico of the Maison Dieu, Dover (1278).

The arrangement of most of these buildings is unknown, for frequently not a vestige remains. In many cases they grew up with little definite plan. A private dwelling was adapted, further accommodation being added as funds permitted. The domestic buildings were usually of wood and thatched, which accounts for the numerous allusions to fire. Even St. John's, Canterbury, which was chiefly of stone, was burnt in the fourteenth century, but some traces of Norman work remain. (Pl. III.)

In time of war, houses near the Border or on the South Coast suffered. The buildings of God's House, Berwickon-Tweed, were cast down by engines during a siege. The master and inmates implored aid in their sore extremity, declaring that in spite of all efforts to repair the buildings, the work was unfinished, and that they could not endure the winter without being utterly perished. ${ }^{1}$ The same year (1333) the destroyed hospital at Capelford-by-Norham was being rebuilt. St. Nicholas', Carlisle, was levelled to the ground more than once, and Sherburn was partly demolished at the time of the Battle of Neville's Cross. The same story of attack and fire comes from houses at Southampton and Portsmouth.

Before proceeding to any classification of buildings, some of the component parts may be mentioned. The precincts were often entered by a gateway beneath a

1 Cal. of Documents relating to Scotland, III, p. 199. 


\section{Io MEDI $A V A L$ HOSPITALS OF ENGLAND}

tower. (Pl. VIlI, XVI.) Sometimes, as at Northallerton, there was a hospice near the gate, especially intended for wayfarers who were too feeble to proceed; and an almonry, as at St. Cross, for the distribution of out-relief.

The mode of life in different hospitals affected their architectural arrangement. The warden and professed members of the staff were expected to live in community. The master of St. John's, Ely, was charged not to have delicate food in his own chamber, but to dine in the refectory. In most houses the rule was relaxed, and the warden came to have private apartments, and finally, a separate dwelling. (Pl. XVI, XXI.) In large institutions, the dining-hall was a fine building. The "Brethren Hall" at St. Cross (about $36 \times 20$ feet) consists of four bays, and has a handsome chestnut ceiling. (Pl. X.) The beautiful refectory at St. Wulstan's, Worcester (48 feet $x$ 25 feet 8 inches), adjoins another long, narrow hall ; these buildings present interesting features-such as the screen, a coved canopy over the dais, and a loft from which reading was given during meals. The screen, gallery and oriel are reproduced in Domestic Architecture during the Tudor Period. The title of " minstrels' gallery," given by J. $\mathbf{H}$. Parker to the screen at the western end of the hall, has been called in question; but as the same name is found at St. Cross it may be remarked that in such institutions minstrels were called in to perform on festal days, for the account rolls of St. Leonard's, York (1369), and St. John's, Winchester $^{1}$ (I390), allude to it. The hospital was a semi-secular house, and such halls were occasionally used for public affairs. Permission was granted in 1456 that the hall and kitchen of St. Katherine's Maison Dieu,

1 The original hall stands west of the chapel, and is let as a public dining-hall. 
PLATE $X$

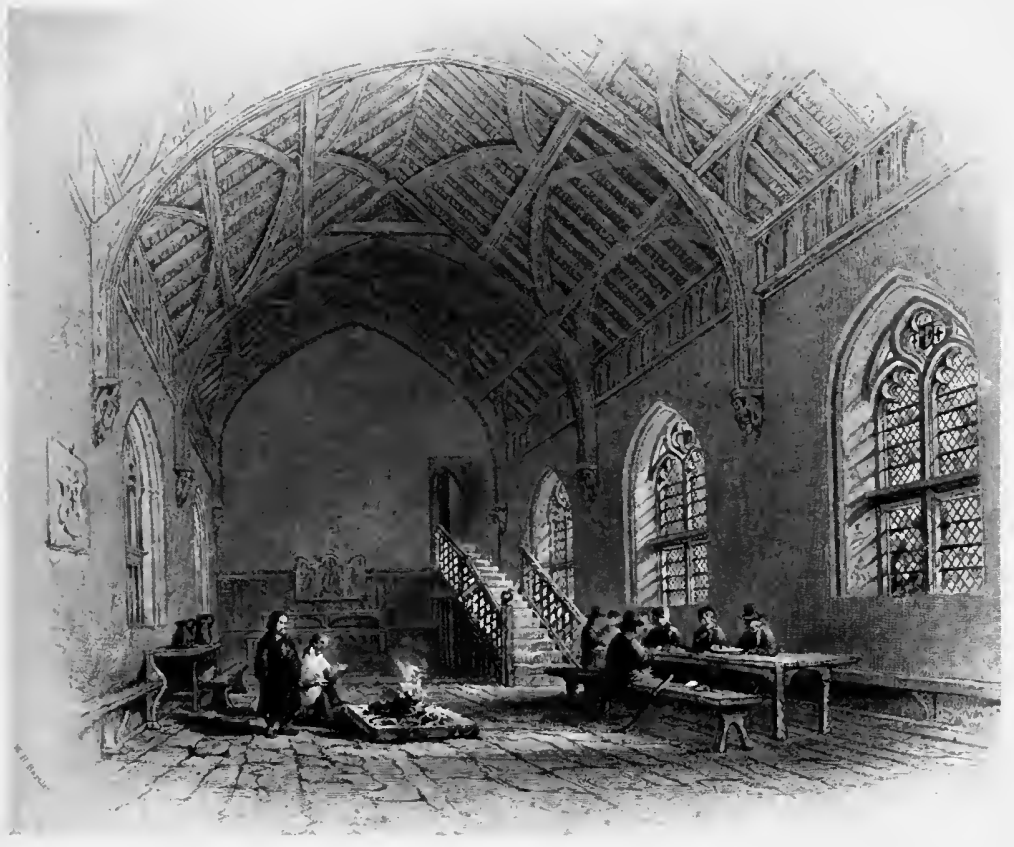

HALL OF ST. CROSS, WINCHESTER 

Newcastle, might be used by young couples for their wedding dinner and the reception of gifts, because at that time houses were not large. Leland notes that Thornton "buildid St. Katerines Chapelle, the Towne Haulle, and a Place for poor Almose Menne." If the above-mentioned kitchen was as magnificent as that of St. John's, Oxford (now incorporated into Magdalen College), a weddingfeast or civic banquet might well take place there.

The transaction of business was conducted in the chapter-house or in an audit-room. At Ewelme, for example, there was a handsome chamber above the steps leading from the almshouse into the church, and the audit-room at Stamford is still in use.

The development of hospital buildings has been admirably dealt with by F. T. Dollman. In his earlier work (Examples of Domestic Architecture, I858), he illustrates in great detail seven ancient institutions; a reprint with additions followed (I86I). The subject calls for.a more exhaustive study, which is now being undertaken by a competent architect. In this chapter nothing is attempted beyond a brief indication of the prevalent styles. Frequently, however, the original construction can be barely conjectured, for only a part is left, and that has probably suffered from alteration. Dollman distinguishes four principal modes of arrangement :-

(i) Great hall-infirmary or dormitory-with chapel at the eastern end.

(ii) As above, with chapel detached, and entered from without.

(iii) Suite of buildings, usually quadrangular; chapel apart.

(iv) Narrow courtyard. 


\section{i. HALL WITH TERMINATING CHAPEL}

(a) Infirmary.-The early form of a hospital was that of a church. A picturesque fragment of St. James',

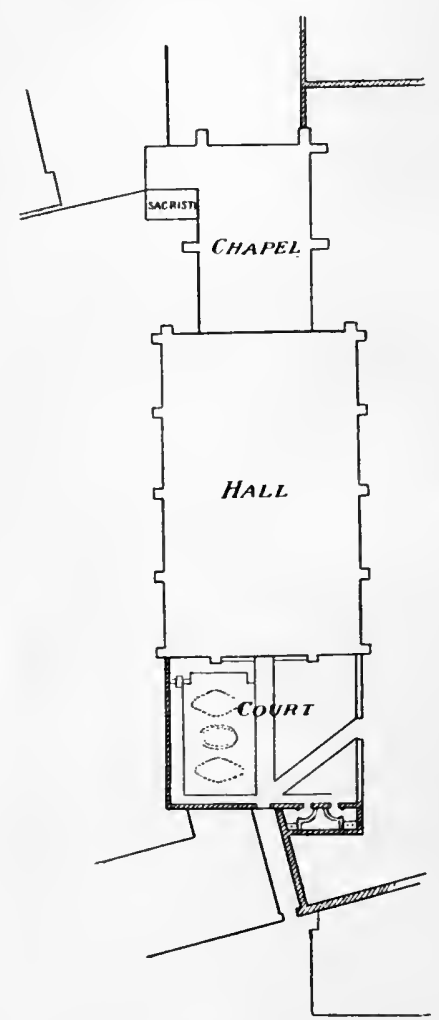

19. ST. MARY'S, CHICHESTER

Lewes, is figured in Beauties of Sussex; ${ }^{1}$ the foundations remained within memory, consisting, apparently, of nave, aisles and chancel, the dimensions of the latter being about $34 \times$ I 5 feet. From an ancient deed in the Record Office, this building is shown to have been the sick-ward with its chapel; it refers to the "sick poor in the great hall of the hospital of Suthenovere." Mention is frequently made of chapels "within the dormitory" or "in the infirmary," and of beds "in the hospital on the west of the church." The statutes of Kingsthorpe show how this arrangement met the patients' spiritual wants :-

"In the body of the house adjoining the chapel of the Holy Trinity there should be three rows of beds joined together in

length, in which the poor and strangers and invalids may lie for the purpose of hearing mass and attending to the prayers more easily and conveniently."

\footnotetext{
1 J. Rouse, 1825, Pl. 76.
} 
The finest remaining example of such an infirmary is St. Mary's, Chichester. (P1. XVIII.) It is now a great hall of four bays, and seems originally to have been longer by two bays. (See Ground-plan, Fig. 19.) The hall measures

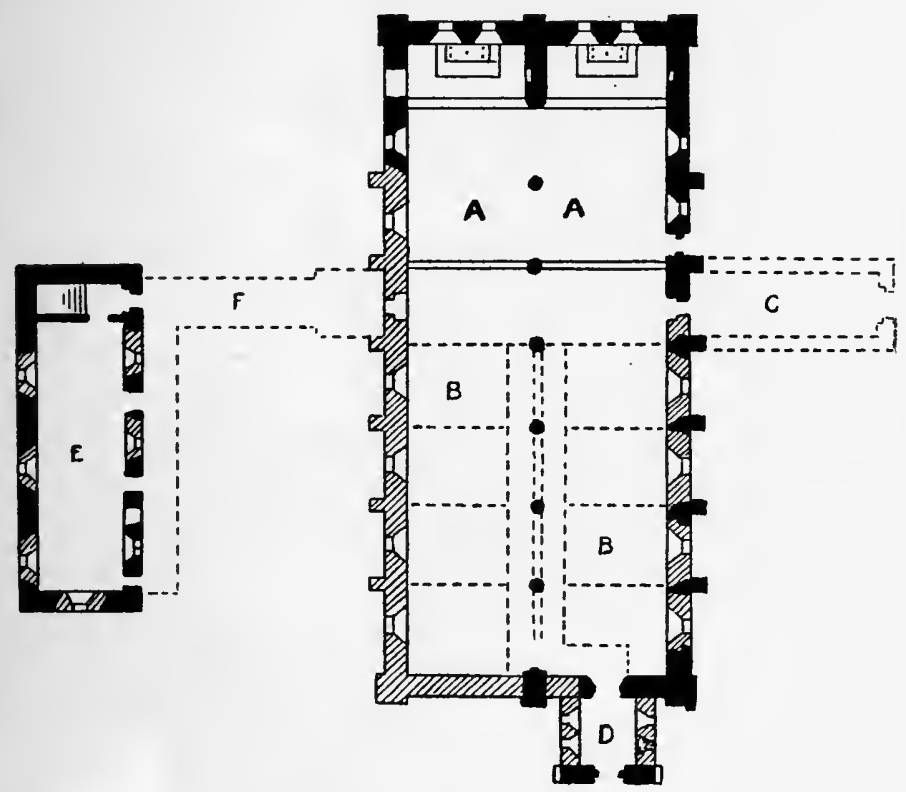

20. ST. NiCHOLAS', SALISBURY

Black. $\quad$ Extant remains (xiii. cent.).

Tint. $\quad$ Site of destroyed walls.

Dotted lines. Probable arrangement of original buildings.

$A A$. The Chapels. $B B$. Cubicles.

C. Latrines. D. Porch.

E. Old Hospital. F. Covered way.

over 84 feet, and opens into a chapel 47 feet in length. A wide and lofty roof with open timbers spans the whole building, the pitch of the roof being such that the north and south walls are unusually low. (P1. VI.) The Domus 


\section{MEDI EVAL HOSPITALS OF ENGLAND}

Dei, Portsmouth, was of similar construction. Its thirteenthcentury chapel still exists as the chancel of the Royal Garrison Church, the nave and aisles of which replace the infirmary, or "Nurcery" as it is called in one document.

The early French hospitals were usually of three wings, as at St. Jean, Angers, built by Henry II. It is probable that the same design was commonly adopted in England. St. Bartholomew's, London, had three chapels-besides those now called "St. Bartholomew's the Great" and "the Less"-and possibly these three were terminating chapels of an infirmary. At St. Nicholas', Salisbury, a double-hall opened into two chapels. (Fig. 20, Groundplan.) Here there are some traces of Early English work, which can almost be dated, for an entry of 1231 records a grant of timber, ${ }^{1}$ and Bishop Bingham completed the hospital before I 244. Buckler's sketches (P1. XV) give some idea of the charm of the existing buildings, which are mainly of the fourteenth century.

(b) Almshouse. - The infirmary-plan became a model for some of the later almshouses. A fine example remains at Higham Ferrers (about 1423). The dimensions of this building were as follows:-Hall, $63 \times 24$ feet; Chapel, I 7 feet, Io inches $\times 20$ feet. Wooden screens subdivided the dormitory; and the statutes directed that each bedeman should join in evening prayers at his chamber door. Although not so secluded as the separate-tenement type, the early arrangement was good, for inmates had the benefit of air from the spacious hall, with its fine and lofty oak ceiling. Modern examples of this cubiclesystem are still seen at Wells, St. Mary's, Chichester, and St. Giles', Norwich. In the latter case, the dormitory forms

1 Close 16 Hen. III, m. I7. 


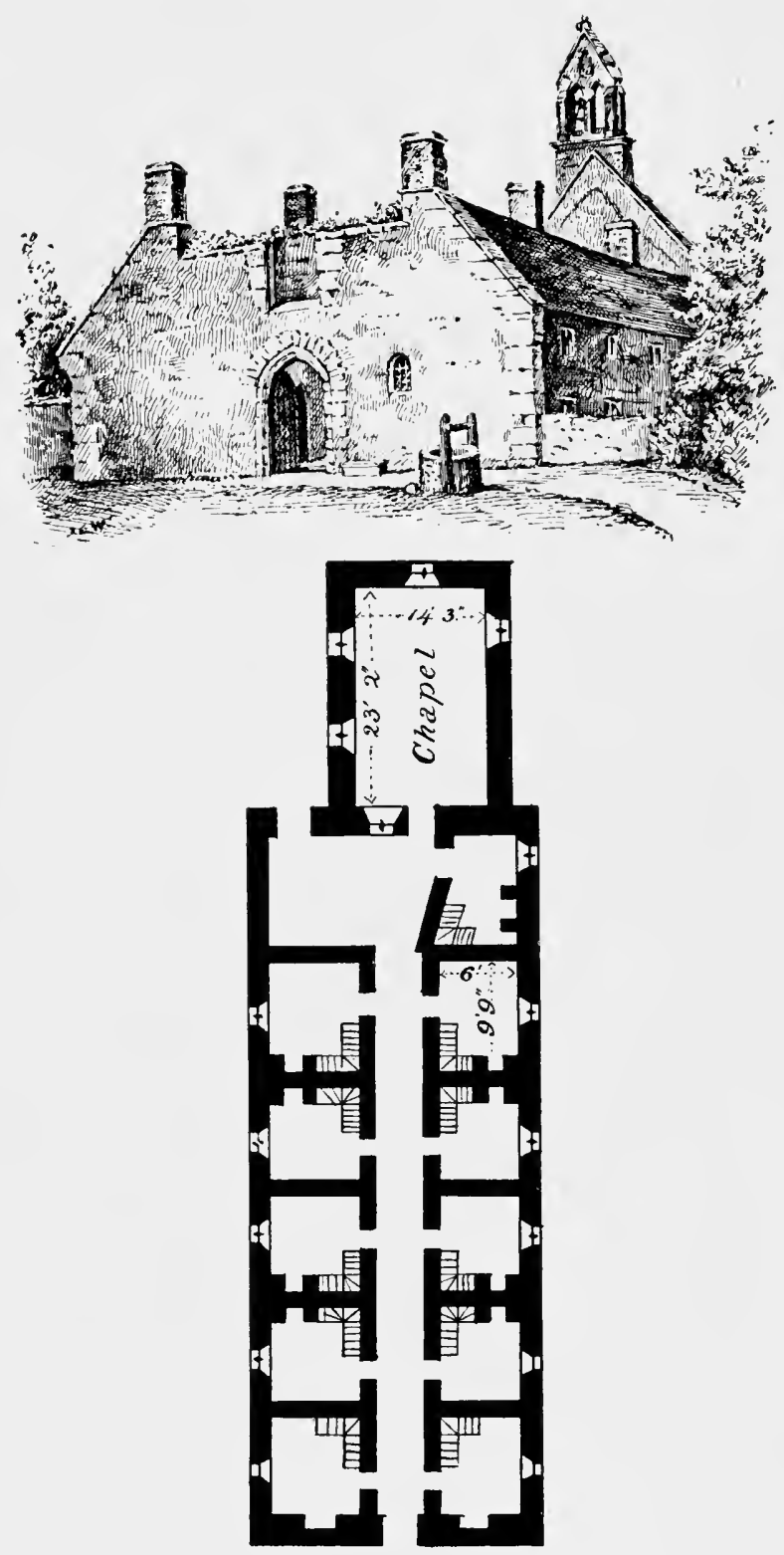

ST. MARY MAGDALENE'S, GLASTONBURY

(a) VIEW FROM THE WEST. (b) GROUND-P'I.AN 
part of a church adapted for the purpose ; the compartments communicate with a corridor-hall and are open above to the panelled ceiling of St. Helen's church with its heraldic devices. The early fifteenth-century Maison Dieu at Ripon was not unlike that of Higham Ferrers. The ruined chapel exists, with the arch which led into the domicile. By means of a partition, four men, four women and two casual guests were accommodated, and the priest had apartments at the west end.

St. Saviour's, Wells, was a contemporary foundation. Leland remarks :- "The Hospitale and the Chapelle is buildid al in lenghth under one Roofe." This interesting old dwelling-place still exists, but has lost its former character, as has also the Glastonbury almshouse for men, of which a view and ground-plan are shown on Plate XI.

Slightly different again was the plan of a two-storied block, having a chancel-like chapel with a roof of lower pitch. Sherborne almshouse (Dorset) was built thus. It opens to both stories of the adjoining domicile; this is done on the upper floor, by means of a gallery in which the women sit during service.

Later, it was customary for the chapel to extend to the height of the whole building under one roof, as at Browne's hospital, Stamford. (Fig. 5.) Although the lofty chapel corresponded in height to both stories, only the lower one-which in this case was the dormitory-communicated with it. This block formed part of a suite ranging round a quadrangle. A ground-plan and views of this imposing almshouse, with descriptions of its architectural features, are found in Wright's history. There is a striking similarity of construction between it and 


\section{II6 MEDIÆVAL HOSPITALS OF ENGLAND}

Wigston's hospital, Leicester (figured by Nichols ${ }^{1}$ ). Both were good specimens of the domestic Perpendicular style.

The earlier almshouse in Leicester, called the "Newark" (afterwards known as Trinity) was a large building. Nichols' view ( 1788$)^{2}$ shows a range of dwellings below, others above with dormer windows in the roof, clumsy chimneys, a bell-cote, and at one end a chancel-like extension. There must originally have been extensive buildings to accommodate the hundred poor. Leland says: "The large Almose House stondith also withyn the Quadrante of the Area of the College"; and of the church associated with it Camden says that "the greatest ornament of Leicester was demolished when the religious houses were granted to the king." Bablake hospital,

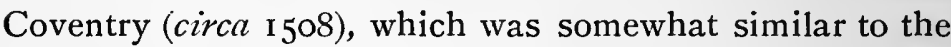
Leicester almshouse, still exists. This "Hospitall well builded for ten poore Folkes," as Leland reports, formed a simple parallelogram ; below, ambulatory, hall, diningroom, and kitchen; above, dormitories.

\section{ii. HALL WITH DETACHED CHAPEL}

Of a great hall with separate chapel, Dollman cites one instance, St. John's, Northampton. Here the hospital was a parallelogram, the chapel touching it at one corner, but not communicating with it; another detached building, sometimes called the Master's House, was probably the refectory. (Plan and details, Dollman; see also T. H. Turner, Domestic Architecture, Vol. III.) From the engraving (Frontispiece) it would seem that the Maison

1 Leicestershire, Vol. I, pt. ii. 495.

${ }^{2}$ Bibliographica Top. Brit., viii. facing p. 718. 


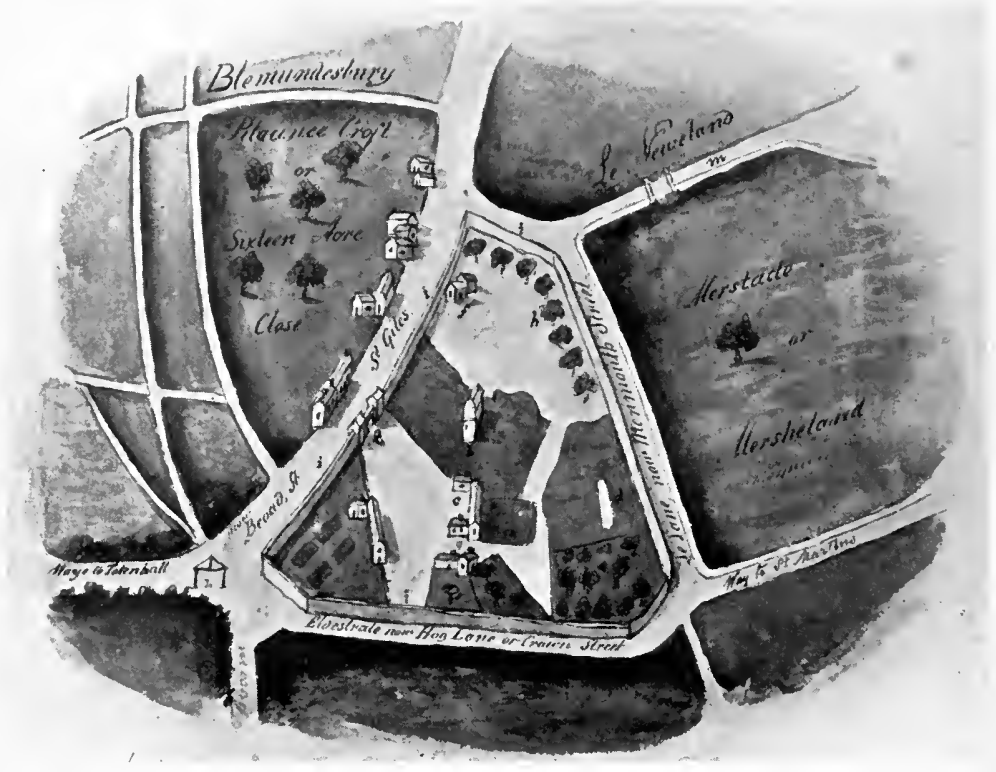

PLAN OF THE LEPER HOSPITAL OF ST. GILES, LONDON

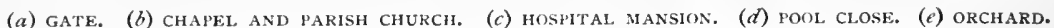

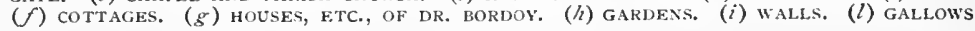
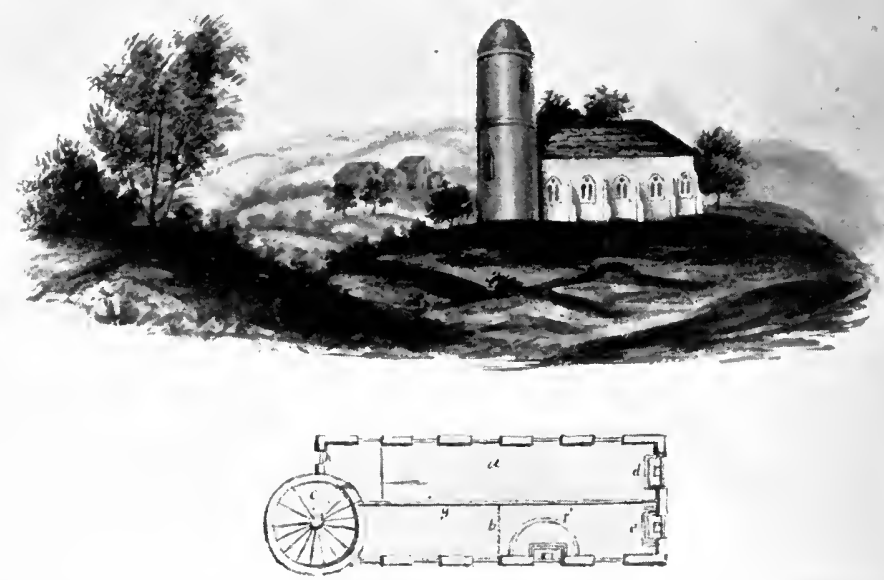

THE CHURCH OF ST. GILES IN THE FIELDS

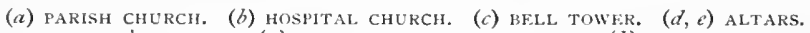

$(f)$ ST. MICHAEL'S CHAPEL. $(g)$ SCREEN DIVIDING CHURCHES. ( $h$ ) WESTERN ENTRANCE 
Dieu, Dover, was similarly designed; at the north-east angle is the chapel, three bays of which may still be seen. The various apartments existing in 1535 are mentioned in the Inventory. " "The Great Chamber called the Hoostrye" (hostelry or guest-hall) was probably the common-room and refectory, but besides trestle-tables, settle and seats, the furniture included a great bedstead and a little one; this hall contained an inner room. There were four other small bed-chambers, a fermery (infirmary) with accommodation for fifteen persons, besides day-room, kitchens, etc.

iii. GROUP OF BUILDINGS AND CHAPEL

(a) Leper-house.-Although originally lepers had a common dormitory, the plan began to be superseded as early as the thirteenth century, when a visitation of St. Nicholas', York, shows that each inmate had a room to himself. The rule at Ilford was that lepers should eat and sleep together "so far as their infirmity permitted." The dormitory afterwards gave place to tenements. The Harbledown settlement in the eighteenth century is shown in Pl. II, the buildings being named by Duncombe, master and historian of the hospital. Facing the "hospital-chapel" were the "frater-house" and domestic quarters. The chantry-house by the gateway was, doubtless, the residence of the staff. (See p. 147.) The original dwellings must have been more extensive, for they sheltered a hundred lepers. The view of Sherburn (Durham) may reproduce the later mediæval design. (Fig. 21.) In some cases a cloister ran round the buildings. The statutes of St. Julian's leper-hospital ordained " that there be no standing in the corridor (penticio), which extends in

1 M. E. C. Walcott, Arch. Cant., VII, pp. 273-8o. 


\section{8 MEDI EVAL HOSPITALS OF ENGLAND}

length before the houses of the brothers in the direction of the king's road."

The Winchester leper-house was quadrangular. It existed until $\mathrm{I} 788$, and was drawn and described in Vetusta Monumenta. (Fig. 22, P1. XXI.) A row of habitations ex-

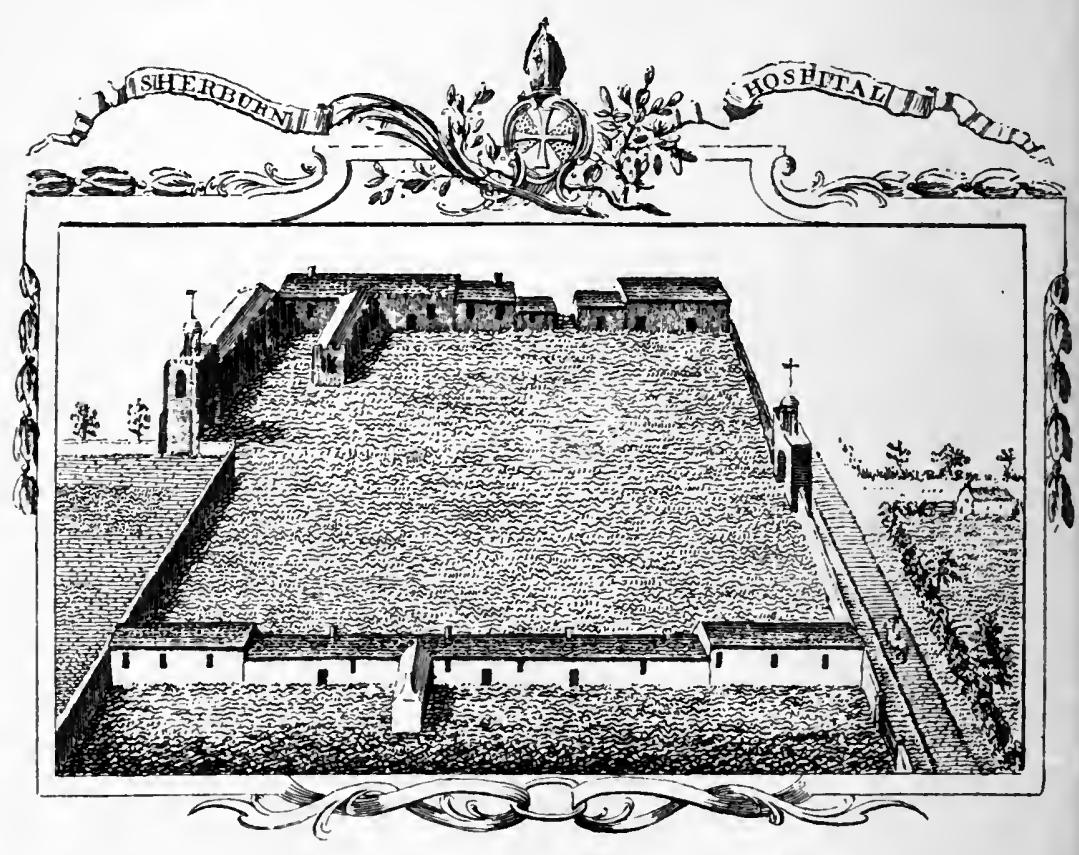

21. SHERBURN HOSPITAL, NEAR DURHAM

tended east and west, parallel to them was the chapel ; the master's house connected the two ; the fourth side being occupied by a common hall. Probably St. Bartholomew's, Oxford, was of a similar character. (Pl. XXII.) The long building which remains north of the chapel has four windows above and four below, as though to accommodate the eight brethren. When dwellings ranged round an 
enclosure, it was usual to have a well in the centre. Such "lepers' wells" may still be seen on the site of St. Mary Magdalene's, Winchester, and at Lyme Regis.

The lepers' chapel was almost invariably a detached building. Sherburn had a fair-sized church, which is

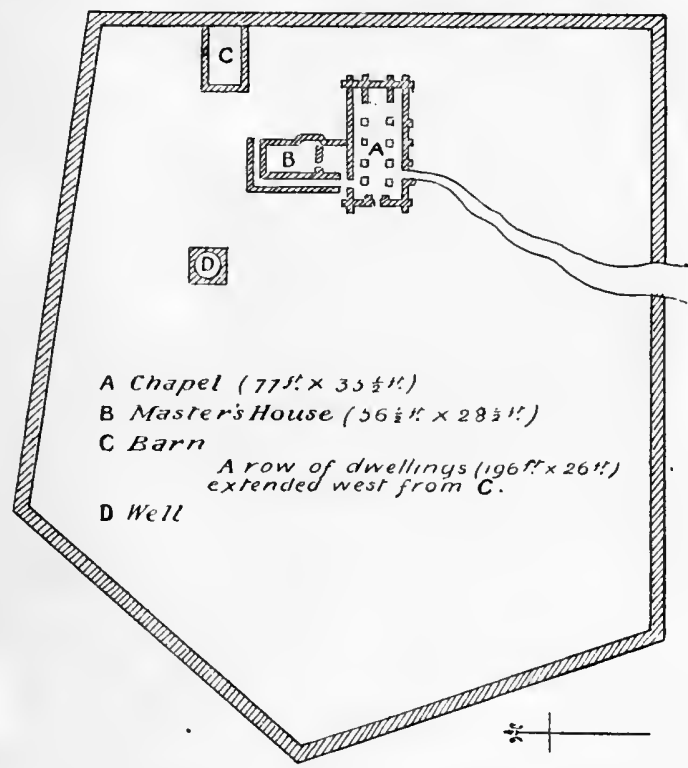

22. PLAN OF ST. MARY MAGDALENE'S, IVINCHESTER

still in use, besides two chapels, one of which communicated with the quarters of the sick (capella interior infra domum infirmorum). The above were large institutions; but at St. Petronilla's, Bury St. Edmunds-which might be described as a cottage-hospital for lepers-the chapel and hall were under one roof. The projection on the right (more clearly seen in Yates' engraving) was the 


\section{MEDI EVAL HOSPITALS OF ENGLAND}

refectory. The window of the chapel shown in Pl. XXVIII still exists, though the ruin is not in situ.

(b) Almshouse. - The modern design of almshouse, consisting of cottages each with its own fireplace and offices, developed during the fifteenth century. Thus about the year I400, Grendon's new charity in Exeter became known as the "Ten Cells." It was directed by the founder at Croydon (I443) that every inmate have "a place by himsilf in the whiche he may ligge and reste." Some of these tenement almshouses were quadrangular, whilst others consisted of a simple row of dwellings. The contemporary charities established at Ewelme and Abingdon illustrate the two variations of what was in reality the same type. The picturesque almshouse at Ewelme, dating about 1450 , is shown in Pl. XVII. The founder's intention was thus expressed in the statutes:-

"We woll and ordeyne that the minister . . . and pore men have and holde a certeyn place by them self within the seyde howse of almesse, that is to sayng, a lityl howse, a celle or a chamber with a chemeney and other necessarys in the same, in the whiche any of them may by hym self ete and drynke and rest, and sum tymes among attende to contemplacion and prayoure."

The buildings (of which Dollman gives views, groundplan, etc.) were quadrangular, consisting of sitting-rooms below, with bedrooms above.

Formerly, inmates gathered round an open hearth (compare P1. X) or in a capacious ingle-nook, like that in use at St. Giles', Norwich. The chimney-which originally signified fireplace-is a new feature indicating a change of life. At Ludlow, for example, Hosyer's almshouse was constructed with thirty-three chambers 


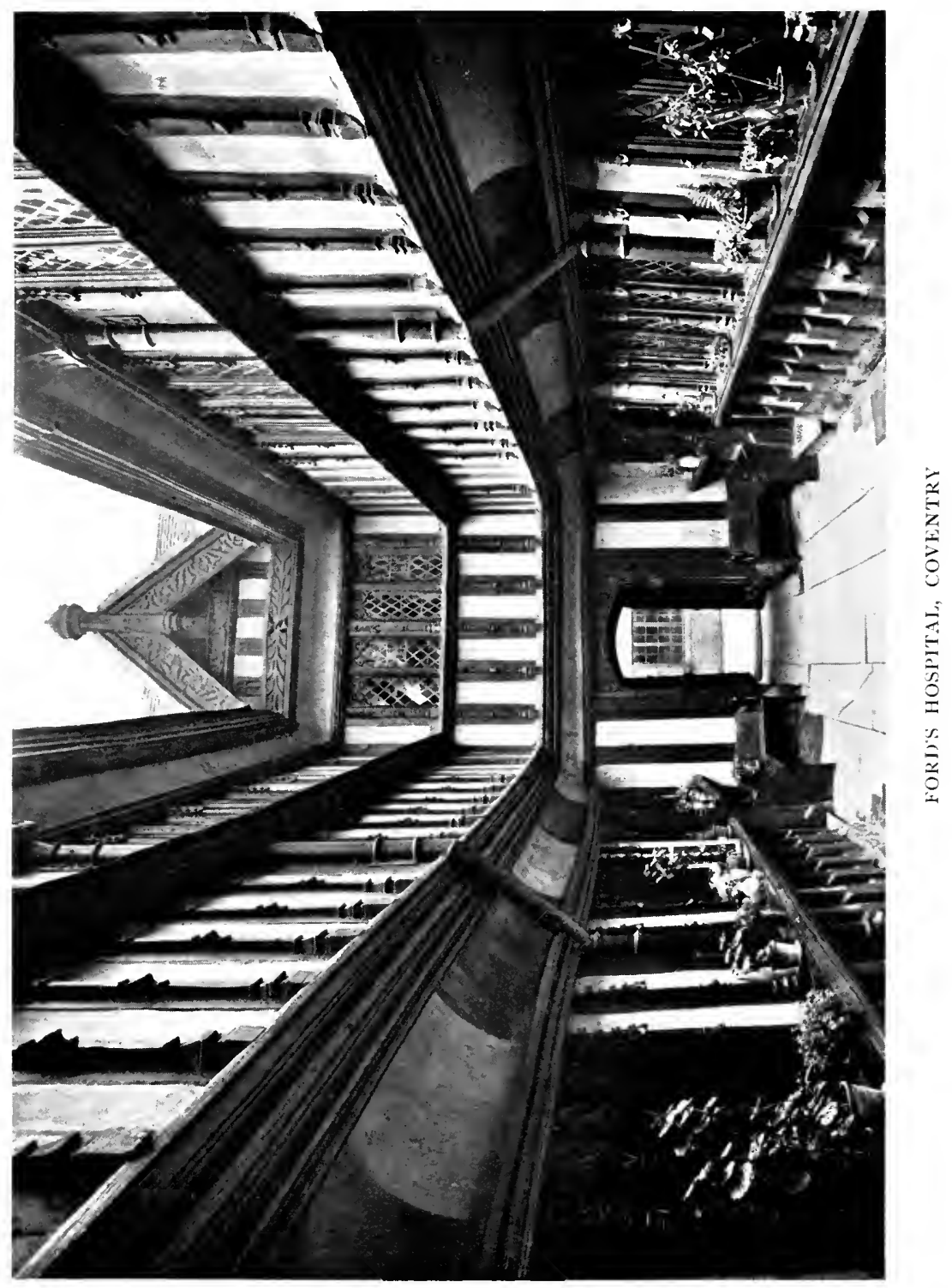


and in every chamber a chimney. Those at St. Cross are slender and unobtrusive, but the later erections at St. John's, Lichfield, are oppressive in size.

Of the simple row of tenements, a beautiful example remains at Abingdon. (Pl. XXVI.) It was founded by the Gild of the Holy Cross for thirteen impotent men and women. The present hospital consists of fourteen dwellings (with a central hall reconstructed in Jacobean times); the timbered cloister has recently been carefully repaired. The Spital Almshouse near Taunton, rebuilt by Abbot Beere about I5 Io, consists of a simple two-storied row of cottages, with a covered way in front.

\section{iv. NARROW COURTYARD}

Ford's hospital at Coventry (Pl. XIII) is placed in a class by itself. This half-timbered house is a perfect gem of domestic architecture. The oaken framework, the elaborately-carved verge-boards of the gables, the varied tracery of the windows, the slender pinnacled-buttresses, alike call for admiration. Entering the doorway, a narrow court $(39 \times 12$ feet) is reached, perhaps the most beautiful part of the building. Each dwelling communicates with the bed-chamber above, and at either end were the chapel and common hall. Dollman gives the ground-plan, etc. ; Garner and Stratton's recent work on Tudor Domestic Architecture also contains lovely plates of the western front, courtyard and rich details.

\section{CRUCIFORM PLAN}

The ground-plan of the great Savoy hospital was cruciform, which is unusual. It would appear from the 


\section{I22 MEDI EVAL HOSPITALS OF ENGLAND}

following extract from Henry VII's will, that he himself superintended the architectural design :--

"We have begoune to erecte, buylde and establisshe a commune Hospital ... and the same we entende with Godd's grace to finish, after the maner, fourme and fashion of a plat which is devised for the same, and signed with our hande."

When completed, this was one of the most notable things of the metropolis. In $\mathbf{5}_{520}$, some distinguished French visitors were entertained at a civic banquet. "In the afternoon, inasmuch as they desired amonge other things to see the hospital of Savoy and the king's chapell at the monastery of Westminster, they were conueyed thither on horseback." 1 The engraving (Pl. XIV) shows an imposing pile of buildings.

Hospital buildings were good of their kind, and the chapels were of the best that could be provided. In Leland's eyes Burton Lazars had "a veri fair Hospital and Collegiate Chirch"; Worcester could show "an antient and fayre large Chappell of St. Oswald"; St. John's, Bridgwater, was "a thing notable" even to that insatiable sight-seer. Of the finest examples, most have vanished. At St. Bartholomew's the Great, Smithfield, however, a portion survives of those "honourable buildings of pity" which astonished twelfth-century onlookers; and the noble church and quadrangles of St. Cross, Winchester (P1. VIII), show the scale upon which some were designed. The church of the Dunwich leper-house (P1. XXVIII) was Io7 feet in length. (Groundplan, Archaologia, XII.) Part of the apse remains, showing a simple arcade of semicircular arches, the 


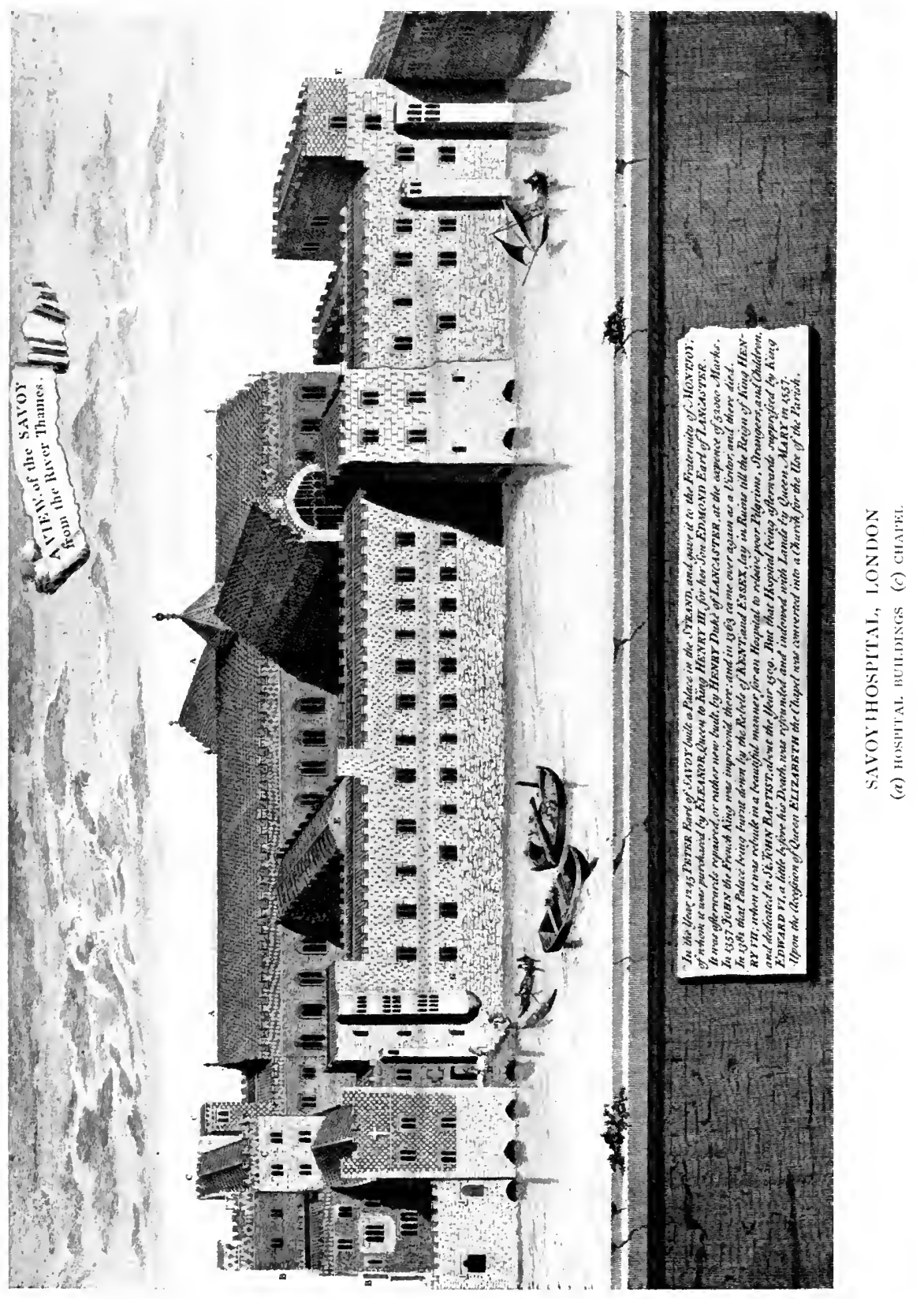



chancel being ornamented with intersecting arches. A treatise of Queen Mary's time describes this church as "a great one, and a fair large one, after the old fashion . . . but now greatly decayed." 1

The most ancient, and, from an architectural point of view, one of the most interesting chapels remaining, is that of St. Bartholomew, Rochester; the domed apse with its own arch, writes the chaplain, is rare even in the earliest Norman churches. (Ground-plan, see Journal A rch. Assoc., XI.) Norman work may be seen in chapels at Sherburn, Gloucester and Stourbridge, and in the fine hospital-hall at High Wycombe. Beautiful specimens of the Early English style remain at St. Bartholomew's, Sandwich; the Domus Dei, Portsmouth; and St. Edmund's, Gateshead. The latter chapel, built by Bishop Farnham about 1247 , is still in use, for the graceful ruin drawn by Grimm (Pl. XXX) has been restored. It is described in Boyle's Guide to Durham:-" The west front has a deeply-recessed central doorway, flanked by two tiers of arcades, whilst over these is an upper arcade, the alternative spaces of which are pierced by lancet lights", etc. The chapel at Bawtry has a fine Early English window and a handsome niche at the eastern end.

Among disused or misused chapels may be named St. Mary Magdalene's, Gloucester ; St. Laurence's, Crediton ; Stourbridge ; Poor Priests', Canterbury ; St. Mary Magdalene's, Durham ; some, like the last-named, are beyond restoration. St. Bartholomew's, Oxford, and St. James', Tamworth, long desecrated or deserted, are now being restored as houses of prayer. St. Katherine's,

I Weever, Funeral Mon., ed. I 767, p. 459 . 


\section{MEDI $A$ VAL HOSPITALS OF ENGLAND}

Exeter, has recently been given to the Church Army, for the use of the destitute poor resorting to the Labour Home.

Ancient chapels remain attached to almshouses in the following places :-

Bawtry ; Bristol (Three Kings of Cologne) ; Canterbury (St. John, St. Thomas); Chichester ; Gloucester (St. Margaret); Honiton ; Ilford ; Lichfield ; Oakham ; Ripon (St. John Baptist, St. Mary Magdalene); Rochester; Salisbury ; Sandwich ; Sherborne ; Sherburn ; Stamford; Wimborne ; Winchester (St. John's) ; Glastonbury (2); Leicester (Trinity); Tiverton; Wells.

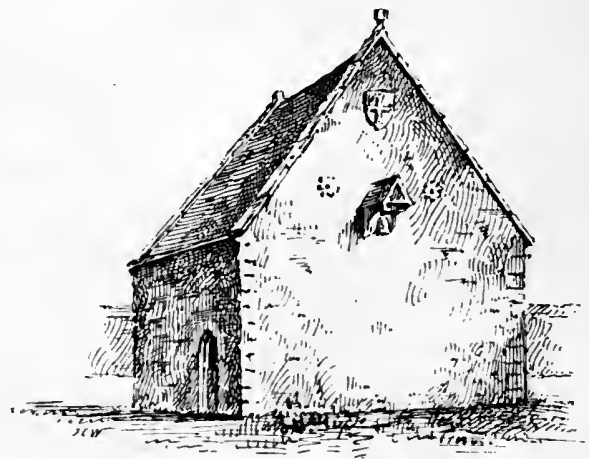

23. CHAPEL OF ABBOT BEERE'S ALMSHOUSE, GLASTONBURY (For interior see Fig. 25)

Those of Wiltón (St. John), Taddiport near Torrington, and Holloway near Bath, are now chapels-of-ease; that of St. John and St. James, Brackley, is used in connection with Grammar School and Parish Church; Roman Catholics worship in St. John's, Northampton, and French Protestants use the Anglican liturgy in 
St. Julien's, Southampton ; the chapel of the Domus Dei, Portsmouth, is part of the Garrison Church ; St. Mark's, Bristol, is the Lord Mayor's Chapel; St. Edmund's, Gateshead (Holy Trinity), and St. Cross, Winchester, are Parish Churches. 


\section{CHAPTER IX}

\section{THE CONSTITUTION}

"It is agreed amongst men of religion that order be observed, because zeithout order there is no religion." (Rules of St. John's, Nottingham.)

$\mathrm{W}$

E now turn to the inner working of the hospital and inquire how the lives of inmates were ordered. Early charitable institutions were under a definite rule, either that of the diocesan bishop or of the monastic order with which they were in touch. In the Constitutions of Richard Poore of Sarum (circa I223), one clause is headed: "Concerning the Rule of Religion, how it is lawful to found a xenodochium." Persons desiring so to do shall receive a form of government from the bishop, "since too great diversity of forms of religion brings in confusion to the church of God." Laymen therefore applied for an episcopal constitution; the burgesses of Nottingham, for instance, charged Archbishop Gray with the drawing up of an "Ordination" for St. John's (I 23I-4). Even when a community was under a monastic house, the diocesan was often asked to compile statutes, as Grossetête did for Kingsthorpe and Bishop Stratford for Ilford; but the abbot of St. Albans drew up his own code for St. Julian's. There was apparently a definite Anglican Rule, for “The Statutes of St. James' according to the Use of the Church of England" were promulgated at Canterbury in $14 \mathrm{I} 4$. 
Founders and patrons also had a voice in the matter, sometimes drawing up the rule and submitting it to their Father in God; thus the Ordinances of St. Mark's, Bristol, made by the patron and "exhibited to the Bishop" (1 268) are entered in the registers.

Most hospitals followed a definite system, at least in theory, as to admission, observation of regulations and penalties for disobedience.

\section{NOMINATION AND ADMISSION}

(a) Appointments to all offices were usually in the patron's hands. In a few privileged houses (e.g. Dover, Gloucester, Oxford, Cambridge, Norwich) the staff brothers had licence to elect their superior from amongst themselves, and to nominate him to the patron. Officials and inmates alike were admitted by a religious ceremony, of which the vow formed a prominent part. At St. Katherine's, Bedminster, the following oath was taken before induction by the master :-

"I, — , promise perpetual observance of good morals, chastity, and denial of property . . . according to the rule of the Hospital St. Katherine, near Bristol, in the diocese of Bath and Wells, which I henceforth profess as ordained by the holy fathers . . . and I will lead my life according to regular discipline."

The selection of honorary workers on the hospital staff is dealt with in one of the deeds of St. Mary's, Chichester (formerly preserved at University College, Oxford, but now in the Bodleian) :-

"If any one seeks the Hospital of St. Mary, at Chichester, let the Warden examine whether he is in sound or in infirm health. If in sound health, whether male or female, let the 


\section{I28 MEDI EVAL HOSPITALS OF ENGLAND}

Warden consider whether he is a person of good conversation, of honest life and character, likely to be useful to the House, whether in serving or labouring for the poor. If he should be found such, the Warden shall first point out to him the poverty of the House, the poorness of the food, the gravity of the obedience, and the heavy duties, which may possibly deter him and induce hin to recall his purpose. But if he perseveres in knocking, then with the counsel of the Lord Dean and the brethren of the House, he may be received in the name of the Lord, without the intervention of any money or any compact, unless he has any property of his own and is disposed to resign it into the hands of the Warden. But if the character of the man who seeks admission be insufficient he must be repelled entirely." 1

A brother or sister being admitted to St. John Baptist's, Reading, was professed in the adjoining church. Veni Creator and certain prayers were said as the candidate knelt before the altar; after the sprinkling with holy water he or she then received the habit or veil, a kiss of charity being bestowed by the rest of the household. A discourse followed upon the rules and benefits of the society. The Office for the admission of members to the staff of St. John's, Nottingham, is given in the Records of the Borough. One prayer, at the benediction of the religious habit, shows the spirit in which hospital officials were expected to enter upon their duties :-

"O Lord Jesus Christ, who didst deign to put on the covering of our mortality, we beseech the immense abundance of Thy goodness, that Thou mayst so deign to bless this kind of vestment, which the holy fathers have decreed should be borne by those who renounce the world, as a token of innocence and humility, that this Thy servant, who shall [use it], may deserve to put on Thee," etc.

${ }^{1}$ Sussex Arch. Coll., 24, pp. 41-62. 

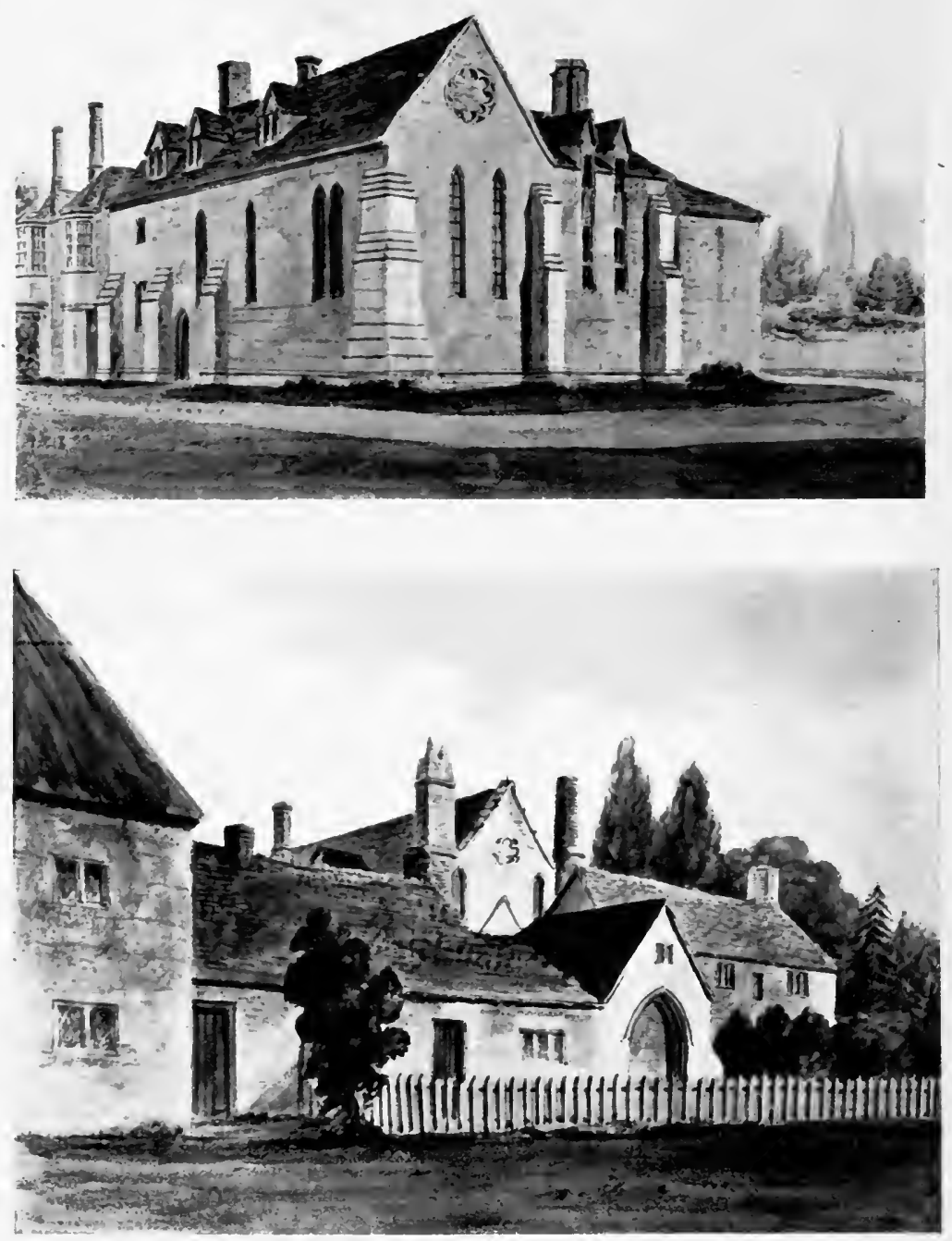

HOSPITAL OF ST. NICHOLAS, SALISBURY

(a) SOUTH-EAST VIEW. (b) WEST VIEW 
As the brother changed his dress, the Scripture was repeated concerning putting off the old man and putting on the new in righteousness. The versicles "Our help is in the name of the Lord," "Save Thy servant," etc., were also used, together with prayers for the Gift, for increase of virtue, for light and life.

(b) Almsmen, too, were usually admitted by a solemn oath. That taken at Oakham is typical :-

"I. - - the which am named into a poor man to be resceyued into this Hospital after the forme of the Statutes and ordanacions ordeyned ... shall trewly fulfille and obserue all the Statutes . . . in as moche as yey longen or touchen me to my pour fro hensuorthwardys . . . without ony fraude soe helpe me God and my Holydom and by these holy Euangelies the whiche y touche and ley my honde upon."

At Sandwich, after being sworn in, the person was introduced by the mayor to the rest of the fraternity, and was saluted by them all ; and after paying the customary gratuities, the new inmate was put in possession of his chamber.

The ancient form of admission to St. Nicholas', Salisbury, contains such injunctions as :-

"N. thu shalt be trewe and obedient to the maistre of this place.

"Item. thu shalt kepe pees yn thy self, and do thy deuoyrs that euery brother and sustre be in parfyte pees, loue and charite, eche with othre."

Few foundations have retained their religious and social life with less change than this hospital, of which Canon Wordsworth has given us a complete history. Following the old traditions, the present inmates give a new member the right hand of fellowship when he is duly installed. 


\section{I30 MEDI $Æ V A L$ HOSPITALS OF ENGLAND}

(c) Lepers, like other paupers, were admitted either at the patron's will or at the warden's discretion. The custody of the Crown hospital at Lincoln was at one time committed to the sheriffs, who were charged to notify a vacancy to the king or his chancellor "so that he might cause a leper to be instituted in place of the deceased, in accordance with the ancient constitution." Later it was stated that they were admitted of the king's gift, or by the presentation of the mayor. In some instances the right of nomination was held jointly. There were eight beds in the Hexham Spital, four being open to poor leperhusbandmen born within the Liberty, whilst the archbishop and prior might each appoint two tenants.

A patron or donor often kept the nomination to one bed or more. Thus the founder of St. Sepulchre's lazar-house, Hedon, reserved the right to present one man or woman, whole or infirm; he even made prudent provision to sustain any afflicted object allied to the patron within the fourth degree of blood. As early as i i 8o, a subscriber to St. Nicholas', Carlisle, stipulated that two lepers from Bampton should be received. According to some statutes the candidate had also to be approved by his future companions; "without the consent and will" of the Colchester lepers, no brother could gain entrance, and the same rule obtained at Dover. The little Sudbury hospital maintained three lepers; when one died or resigned, his comrades chose a third; if they disagreed, the mayor was informed, and the selection devolved upon the vicar. An examination by the warden into the candidate's condition and circumstances was sometimes ordered, as at Dover. At Harbledown sufficient knowledge of the simple formulas of the faith was required. 
To enter a leper-hospital in early days practically involved the life of a "religious," especially in hospitals attached to monastic houses. The vow of an in-coming brother at St. Julian's is given in the Appendix to Matthew Paris :-

"I, brother B., promise, and, taking my bodily oath by touching the most sacred Gospel, affirm before God and all His saints ... that all the days of my life I will be subservient and obedient to the commands of the Lord Abbot of St. Albans and to his archdeacon; resisting them in nothing, unless such things should be commanded, as would militate against the Divine pleasure. I will never commit theft, nor bring a false accusation against any one of the brethren, nor infringe the vow of chastity."

He goes on to promise that he will not hold or bequeath anything without leave; he will be content with the food, and keep the rules on pain of punishment, or even expulsion. The oath at St. Bartholomew's, Dover, is found in the register :-

"I, _- , do promise before God and St. Bartholomew and all saints, that to the best of my power I will be faithful and useful to the hospital, . . . to be obedient to my superior and have love to my brethren and sisters. I will be sober and chaste of body; and a moiety of the goods I shall die possessed of, shall belong to the house. I will pray for the peace of the church and realm of England, and for the king and queen, and for the prior and convent of St. Martin, and for the burgesses of Dover on sea and land, and especially for all our benefactors, living and dead."

After making this vow, the brother was sprinkled with holy water and led to the altar, where he received the warden's blessing on bended knees. The form of general benediction was prescribed (with special collects if the 


\section{I32 MEDI $Æ V A L$ HOSPITALS OF ENGLAND}

candidate were a virgin or a widow), and a prayer was said at the consecration of the habit. ${ }^{1}$

\section{REGULATIONS}

The general rule of poverty, chastity and obedience was supplemented by detailed statutes.

(a) Rules concerning Payment and Property.-There are some instances of compulsory payment by statute. If the candidate at Dover satisfied the warden's inquiries, he might be received into the community after paying roo shillings, or more if he could. Even then gratuities were expected; half a mark was offered to the warden and half a mark distributed among the brethren and sisters. The entrance fee sounds prohibitive, but the Liber Albus records a similar custom in London under the title Breve de $C$ solidis levandis de tenemento Leprosorum. This edict authorized the levying of Ioos. from lepers' property to be delivered to their officers for their sustenance.

Sometimes hospital statutes provided against this practice. Thus the chancellor's ordinances for St. Nicholas', York ( 1303 ), forbade the admission of any one by custom or by an agreement for money or goods, but without fear of simony the property of an in-coming brother might be received if given spontaneously and absolutely. The statutes are of special interest because evidently framed to reform abuses recently exposed; and the details of the cross-questioning by the jury and the replies of witnesses in that visitation are recorded. We learn, for example, that most of the inmates had been received for money "each for himself 20 marks more or less"; one, indeed,

1 Lieger Book, Bodl. Rawl. MS. B. 335. 
with the consent of the community, paid 23 marks (£I 5. 6s. 8d.), a considerable sum in those days. Under special circumstances the patron sometimes countenanced a bargain. Thus when a healthy candidate for admission to St. Bartholomew's, Oxford, promised repairs to the chapel, the timber of which was decayed, he was received contrary to rules by the king's express permission (I32I).

The question of the property of the warden, officials and inmates now comes before us. The staff were frequently under the three-fold vow which included poverty. The rule at St. John's, Nottingham, was as follows :-

"And no one shall be a proprietor, but if any one have any property, he shall resign it to the warden or master before seven days ... otherwise he shall be excommunicated. . . . But if it shall be found that any one has died with property, his body shall be cast out from Christian burial, and shall be buried elsewhere, his property being thrown upon him by the brethren, saying, "Thy money perish with thee."

The same enactment is found at St. Mary's, Chichester, unless, indeed, the offender make a death-bed confession. But poor people sojourning there retained their possessions, and could dispose of them by will :-

"If he has anything of his own let the warden take charge of it and of his clothes, until he is restored to health; then let them be given to him without diminution, and let him depart, unless, of his own accord, he offer the whole, or part, to the house. If he die, let his goods be distributed as he hath disposed of them. If he die intestate, let his property be kept for a year, so that if any friend of the deceased shall come and prove that he has a claim upon it, justice may not be denied to him. If no one claim within the year, let it be merged into the property of the hospital." 


\section{MEDI EVAL HOSPITALS OF ENGLAND}

A total renunciation of personal goods was required of the inmates of leper-hospitals in early days. Alms received by the wayside went into the common chest, as did money found within the enclosure; if picked up outside, the finder might keep it. The lepers of St. Julian's might not appropriate or bequeath anything without the consent of the community. A singular article in the oath of admission was this:- "I will make it my study wholly to avoid all kinds of usury, as a monstrous thing, and hateful to God." In the Dover statutes trading and usury were strictly forbidden.

The leper's clothing and furniture were all that he could call his own. In the disposal of such meagre personal effects, a precedent was found in the heriot-the best chattel of a deceased man due to the feudal lord. An ancient French deed relating to St. Margaret's, Gloucester, ordains that "when a brother or sister is dead, the best cloth that he hath the parson shall have in right of heriot." At Lynn, the bed in which he died, and his chest, if he had one, were appropriated by the hospital, as well as his best robe and hood. These rules indicate that the leper furnished his own apartment. The Office at seclusion enumerates the clothing, furniture and other articles necessary. (Appendix $A$.)

One of the questions asked by the official visitor of St. Mary Magdalene's, Winchester, was whether the goods of deceased inmates went to the works of the church after the settlement of debts. In some hospitals, the rule of poverty was not held, or it was relaxed as time went on. By the will of William Manning, lazer, of the house of Monkbridge, York ( 1428 ), he requests that half a pound of wax be burnt over his coffin; he leaves $6 d$. to the 
works going on at the Minster, $6 d$. to the Knaresburgh monks, and the residue to his wife. In the old Scottish version of Troylus and Cresseid, the latter makes her testament before dying in the spital-house. She had lived in poverty, but a purse of gold had lately been thrown to her in alms. Her cup and clapper and her ornament and all her gold the leper folk should have, when she was dead, if they would bury her. The ruby ring, given her long ago by her lover, was to be carried back to him by one of her companions.

Pensioners of the better class were expected to provide all necessary articles, and to contribute what they could to the funds. Money acquired during residence was divided, a portion being retained by the individual; at his death, either half his goods or the whole belonged to the community. The Heytesbury statutes directed :-

" that euery poreman in his first Admyssion all such moueable goodes as he hath, pottis, pannys, pewter vessel, beddyng, and other necessaries, if he haue eny such thynges, to bryng hit within into the hous. And if he haue eny quycke catell, that hit be made monay of. And halfe the saide monay to be conuerted to ye use of ye hous, and ye other halfe to ye poreman to haue to his own propre use."

The goods of a deceased member were distributed to those who should " happe to overlyve," whether "gownes, hodys, cotys, skertys, hosyn or shone." It was ordained at Higham Ferrers that when an almsman died, his goods were taken into the storehouse, and either dealt out to the other poor men, or sold to a new inmate for the benefit of the rest.

(b) Rules of Conduct. - Social intercourse within the house and with the outside world was clearly defined. Among 


\section{$13^{6}$ MEDI EVAL HOSPITALS OF ENGLAND}

habited brethren and sisters, the sexes were rigidly separated, excepting at worship or work. In the case of inmates who were not professed, men and women seem to have lived a common life, meeting in refectory, day room, etc.

As to the intercourse of lepers with the outside world, there was a curious admixture of strictness and laxity. The ordinances of early lazar-houses show that the theory of contagion had little place in their economy. They recognized that the untainted need not be harmed by slight communication with the infected. When visitors came from a distance to Sherburn they were permitted to stay overnight. The lepers of St. Julian's were allowed to see friends- "if an honest man and true come there, for the purpose of visiting an infirm brother, let him have access to him, that they may mutually discourse on that which is meet"- but no woman was admitted except a mother, sister or other honest matron. The general public was protected, inmates not being permitted to frequent the high-road or speak to passers-by (1344). At the time of seclusion, the leper was forbidden henceforth to enter church, market or tavern. At St. Julian's, the mill and bakehouse were likewise forbidden. The statutes of Lynn required that the infirm should not enter the quire, cellar, kitchen or precincts, but keep the places assigned in church, hall and court. So long as they did not eat or drink outside their own walls, lepers might roam within a defined area. The Reading lepers might never go out without a companion. At Harbledown they might not wander without permission, which was granted for useful business, moderate recreation, and in the event of the grievous sickness or death of parents and friends. 
Such rules were more a matter of discipline than of public health. It was not merely lepers who were required to keep within bounds, for ordinary almsmen had similar restrictions. At Croydon they were forbidden to walk or gaze in the streets, nor might they go out of sight of home, excepting to church.

The rules of St. Katherine's, Rochester, were drawn up by the innkeeper Symond Potyn. He stipulates that if the almsmen buy ale, it shall be consumed at home :-

"also that none of them haunt the tauerne to go to ale, but when theie have talent or desier to drynke, theire shall bye theare drynke, and bringe yt to the spitell;

"also that none of them be debator, baretor, dronkelew, nor rybawde of his tounge." 1

If any thus offend, the prior with twain good men of Eastgate shall go to the Vicar of St. Nicholas' and the founder's heirs, who "shall put them oute of the same spittle for euermore, withoute anie thing takinge with them but theare clothinge and their bedde."

(c) Supervision.-In ecclesiastical hospitals, the approved method of maintaining order was by weekly chapter, at which correction was to be justly administered without severity or favour. The injunctions at St. John's, Nottingham, were as follows :-

"They shall meet at least once in each week in chapter, and excesses shall be there regularly proclaimed and corrected by warden or master; and the chapter shall be held without talking or noise, and those who have transgressed shall humbly and obediently undergo canonical discipline."

1 Hist. of Rochester, ed. 1817 , p. 215. 


\section{MEDI $F V A L$ HOSPITALS OF ENGLAND}

At stated periods of a month or a quarter, the statutes were openly recited, usually in the vulgar tongue. After the revision of the ordinance of St. Nicholas', York, it was ordered that the keepers should read the articles aloud in their church on the eve of St. Nicholas.

Internal authority was vested in the warden, whose power was sometimes absolute; but in the case of hospitals dependent upon a religious house, grave offences were taken to head-quarters. For external supervision, the hospital was dependent upon the patron or his agents, who were supposed to inspect the premises, accounts, etc., yearly. This civil visitation was frequently neglected, especially that of the chancellor on behalf of the Crown. Abuses were apt to accumulate until a royal commission of inquiry and reformation became obligatory. Where an institution was under the commonalty, their representatives acted as visitors. At Bridport (1265), the town administered the endowment of the manorial lord; the provosts conducted a yearly investigation whether the brethren and lepers were well treated and the chaplains lived honestly. In London, there were officials who daily inspected the lazar-houses; these "overseers" and "foremen" seem to have been busy citizens who undertook this work on behalf of the corporation (1389). As late as 1536 a gentleman was appointed to the office of visitor of "the spyttel-howses or lazar cotes about thys Citye."

\section{PENALTIES}

The punishments inflicted by the warden were chiefly flogging, fasting and fines, but he could also resort to the stocks, suspension and expulsion. The regulations of 
St. Mary's, Chichester, show the discipline suggested for offenders :-

"If a brother shall have a quarrel with a brother with noise and riot, then let him fast for seven days, on Wednesdays and Fridays, on bread and water, and sit at the bottom of the table and without a napkin. . . . If a brother shall be found to have money or property concealed from the warden, let the money be hung round his neck, and let him be well flogged, and do penance for thirty days, as before."

The rules were particularly rigorous in lazar-houses. Among the lepers of Reading, if a brother committed an offence, he was obliged to sit during meals in the middle of the hall, fasting on bread and water, while his portion of meat and ale was distributed before his eyes. The penalties to which Exeter lazars were liable were fasting and the stocks. Punishment lasted one day for transgressing the bounds, picking or stealing; three days for absence from chapel, malice, or abusing a brother ; twelve days for reviling the master; thirty days for violence. At Sherburn the prior did not spare the rod. "After the manner of schoolboys" chastisement was to be meted out to transgressors, and the lazy and negligent awakened. "But if any shall be found to be disobedient and refractory, and is unwilling to be corrected with the rod, let him be deprived of food, as far as bread and water only." Equally severe was the punishment at Harbledown for careless omission of appointed prayers. Delinquents made public confession the following Friday, and received castigation. "Let them undergo sound discipline, the brethren at the hands of the prior, and the sisters from the prioress." The following day the omitted devotions were to be repeated twice. 


\section{I40 MEDI EVAL HOSPITALS OF ENGLAND}

In the case of almsmen of a later period corporal punishment was never practised. If a poor pensioner at Heytesbury, after instruction, could not repeat his prayers properly, he must be put to "a certayne bodely payne, that is to say of fastyng or a like payne." In most fifteenth-century almshouses, however, the inmates were no longer boarded, but received pocket-money, which was liable to forfeiture. An elaborate system of fines was worked out in the statutes of Ewelme. The master himself was fined for any fault " after the quality and quantitye of his crime." The fines were inflicted not only upon those who were rebellious, or neglected to clean up the courtyard and weed their gardens, but also upon those who arrived in church without their tabards, or were unpunctual :-

"And if it so be that any of theym be so negligent and slewthfull that the fyrst psalme of matyns be begon or he come into his stall that than he lese $\mathrm{i} d$., and yf any of thayme be absent to the begynnyng of the fyrst lesson that thanne he lese iid.; And for absence fro prime, terce, sext and neynth, for ich of thayme $i d$. Also if any . . . be absent from the masse to the begynnyng of the pistyll ... i $d$., and yf absent to the gospell . . . iid." etc.

Industry, punctuality and regularity became necessary virtues, since the usual allowance was but $14 d$. weekly.

The rules of the contemporary almshouse at Croydon were stringent. After being twice fined, the poor man at his third offence was to be utterly put away as "incorrectable and intolerable." When convicted of soliciting alms, no second chance was given :- " if man or woman begge or aske any silver, or else any other good ... let him be 
expellid and put oute at the first warnyng, and never be of the fellowship."

Expulsion was usually reserved for incorrigible persons. "Brethren and sisters who are chatterboxes, contentious or quarrelsome," sowers of discord or insubordinate, were ejected at the third or fourth offence. Summary expulsion was the punishment for gross crimes. The town authorities of Beverley discharged an inmate of Holy Trinity for immorality. The ceremony which preceded the expulsion of an Ilford leper is described by a writer who obtained his information from the leger-book of Barking Abbey :-

"The abbesse, beinge accompanyed with the bushop of London, the abbot of Stratford, the deane of Paule's, and other great spyrytuall personnes, went to Ilforde to visit the hospytall theere, founded for leepers; and uppon occacion of one of the lepers, who was a brother of the house, having brought into his chamber a drab, and sayd she was his sister. ... He came attyred in his lyvery, but bare-footed and bareheaded . . . and was set on his knees uppon the stayres benethe the altar, where he remained during all the time of mass. When mass was ended, the prieste disgraded him of orders, scraped his hands and his crown with a knife, took his booke from him, gave him a boxe on the chiek with the end of his fingers, and then thrust him out of the churche, where the officers and people receyved him, and putt him into a carte, cryinge, Ha rou, Ha rou, Ha rou, after him."

This public humiliation, violence and noise, although doubtless salutary, are a contrast to the statute at Chichester, where pity and firmness are mingled :-

"If a brother, under the instigation of the devil, fall into immorality, out of which scandal arises, or if he be disobedient

${ }^{1}$ Hearne, Curious Discourses, ed. 1775 , i. 249. 


\section{I42 MEDI EVAL HOSPITALS OF ENGLAND}

to the Superior, or if he strike or wound the brethren or clients . . . then, if he prove incorrigible, he must be punished severely, and removed from the society like a diseased sheep, lest he contaminate the rest. But let this be done not with cruelty and tempest of words, but with gentleness and compassion." 


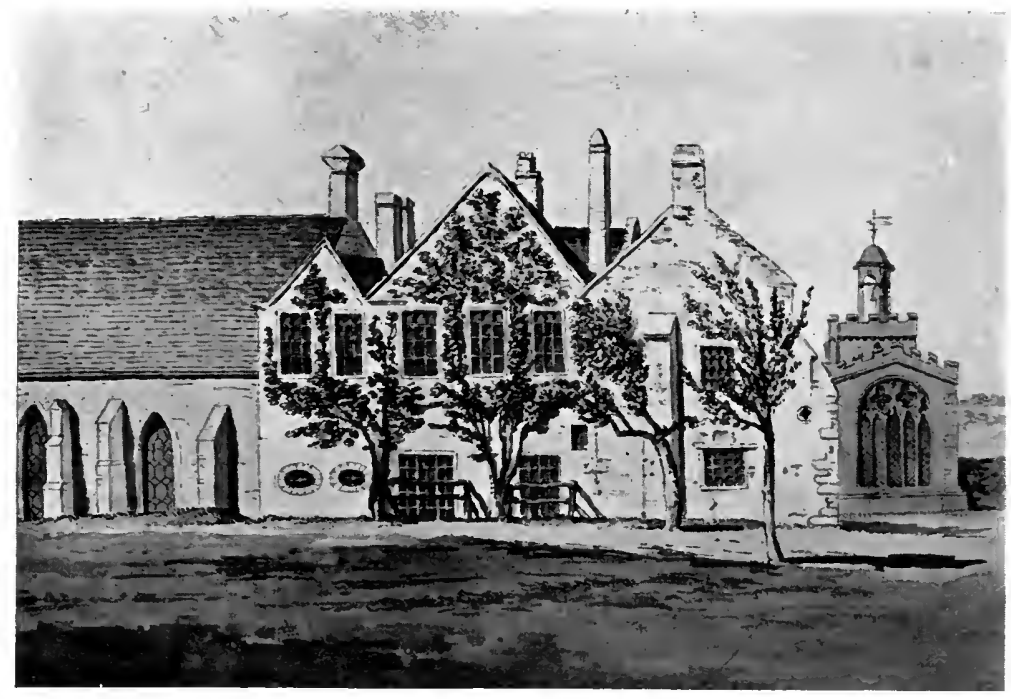

THE WARDEN'S HOUSE, SHERBURN

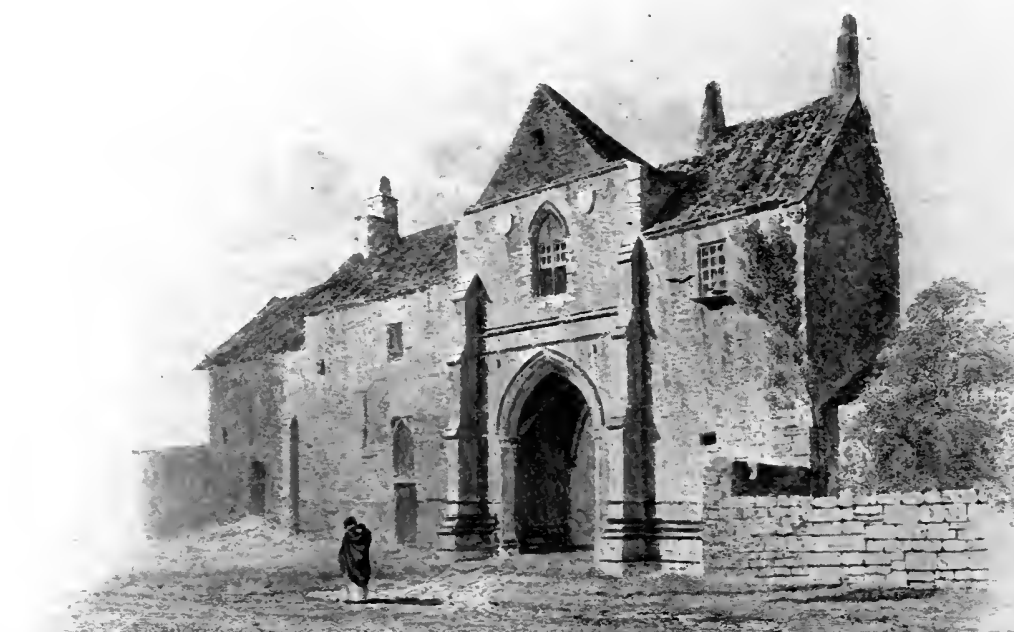

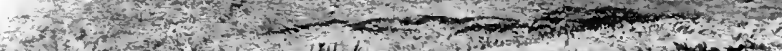

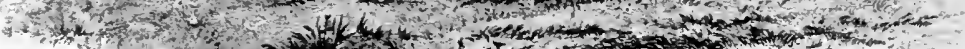

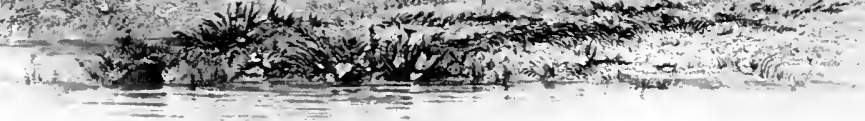

HOSPITAL OF ST, GILES, KEPIER 


\section{CHAPTER X \\ THE HOUSEHOLD AND ITS MEMBERS}

"No more brethren or sisters shall be admitted than are necessary to serve the infirm and to keep the groods of the honse." (St. John's, Nottingham.)

7 HE hospital family varied widely in size and in the

1 arrangement of its component parts, but this chapter, like the preceding, is concerned chiefly with the type of institution which had a definite organization. The establishments for infected persons will first be considered.

(i) THE LEPER HOUSEHOLD

(a) The Master.- "The guidance of souls is the art of arts," says St. Gregory: particularly difficult is the guidance of souls in ailing bodies. Lanfranc realized that men of special gifts should be selected for the care of his Harbledown lepers. He not only arranged to supply all they might need on account of the nature of their illness, but appointed men to fulfil this work "of whose skill, gentleness and patience no one could have any doubt." The Oxford statutes ordained that the master be " a compassionate priest of good life and conversation, who shall reside personally and shall celebrate mass daily, humbly and devoutly." He was required to visit the infirm, to console them as far as possible, and confer upon them the Sacraments of the Church. ${ }^{1}$ The priest

1 Close 9 Edw. II, m. $18 d$. 


\section{I44 MEDI EVAL HOSPITALS OF ENGLAND}

serving lepers was permitted to dispense rites which did not pertain to other unbeneficed clergy; thus the Bishop of London commanded the lepers' chaplain at Ilford to hear their confessions, to absolve the contrite, to administer the Eucharist and Extreme Unction. The ideal man to fill the unpleasant post of lepers' guardian as pictured in foundation deeds and statutes was hard to find: men of the type of St. Hugh and Father Damien-separated indeed by seven centuries, but alike in devotion-are rare. Two Archbishops of Canterbury witness to the scarcity in a deed referring to Harbledown (1371, 1402). After stating that clergy are required to celebrate the divine offices in St. Nicholas' Church, the document declares:-

"It may be at present, and very likely will be in future, difficult to find suitable stipendiary priests who shall be willing to have intercourse in this way with the poor people, especially as some of these poor are infected with leprosy; and this hospital was founded especially for sick persons of this sort."

The master might himself be a leper. An inquisition of 1223 showed that at St. Leonard's, Lancaster, it had formerly been customary for the brethren to elect one of the lepers as master. ${ }^{1}$ In 1342 the prior of St. Bartholomew's, Rochester, was a leper. The regulations at Ilford provided for a leper-master and secular master, but those of Dover merely said that the master may be a leper. Although the law offered privileges to communities governed by a leper-warden (see p. 196), it does not appear to have been a common custom to appoint one. In hospitals dependent upon a monastery, some monk was selected to superintend the lazar-house.

(b) The Staff.-It has been said that leper-hospitals

1 Cited Vict. Co. Hist. Lancs. ii. 165. 
THE HOUSEHOLD AND ITS MEMBERS I45

were "heavily staffed with ecclesiastics." There were indeed three at Lincoln, Ilford and Bolton to minister to ten or twelve men, but they conducted the temporal as well as spiritual affairs of the society. At Bolton, for example, the priests had to administer the manor which was held by the hospital. It was more usual to have only one chaplain in a household of thirteen. This was a favourite number, the figure being regarded with reverence as suggestive of the sacred band of Christ and His Apostles: "for thirteen is a convent as I guess," writes Chaucer. There were to be at Sherburn "five convents of lepers, that is of the number of sixty-five at the least"; five priests ministered to them, of whom one acted as confessor, and used also to visit the bedridden and read the Gospel of the day to them.

The collection of alms also fell upon the staff, for as it was said at Bridport "lepers cannot ask and gather for themselves." The procurator or proctor therefore transacted their business. It was ordained at St. Bartholomew's, Oxford, that the clerk serving in the chapel should collect alms and rents and act as proctor. The staff sometimes included other untainted persons. Two healthy brethren at this Oxford leper-house were to be skilled agricultural labourers, able also to make enclosures and cover houses.

(c) Attendants.-Domestic and farm service was also done by paid attendants. There were female-servants in the Sherburn leper-house, who undertook laundry and other work, and one old woman cared for the bedridden.

(d) Leper Inmates.-Among the larger asylums, the approximate accommodation was as follows :- Harbledown roo, Sherburn 65, St. Giles', London 40, St. Nicholas', 


\section{I46 MEDI EVAL HOSPITALS OF ENGLAND}

York 40, Thanington near Canterbury 25, Dover 20, Plymouth 20, Bodmin 19, Winchester 18. There were 13 beds at Carlisle, Exeter, Gloucester, Reading, etc. In some towns there were several small hospitals. Numbers were of course liable to fluctuation, and often apply to a company of infected and healthy persons, as at St. Nicholas', York. "They used to have, and ought to have, forty brethren and sisters, as well lepers as others; now they have thirty-two only." (1285.) By an inquisition taken in I 29I, it was reported that a former master had admitted thirty-six, of whom four were received pro Deo because they were lepers, but the rest for money. The king commanded that henceforth none should be received without special mandate, inasmuch as the funds scarcely sufficed for the multitude already maintained. The same abuse is noticeable a century earlier, for in 1164 Pope Alexander III forbade the patrons of St. James', Thanington, to admit into the sisterhood any who were not infected, for healthy women had been importunately begging admission. ${ }^{1}$ It was complained in $\mathrm{I} 32 \mathrm{I}$, that St. Bartholomew's, Oxford, was occupied by healthy and sturdy men ; and that at St. Leonard's, Lancaster, there were six whole and three lepers (1323). Both were originally intended solely for the diseased, the inmates of St. Leonard's being called by Henry III "our lepers of Lancaster."

It has been represented, as a proof that isolation was non-existent, that lepers and untainted persons lived a common life, eating and sleeping together. This was evidently not the case. The sheriff of Lincoln received orders that at Holy Innocents' "the chaplains and brethren are to reside in one house, the lepers by them-

1 Chron. and Mem., 85, pp. 75-6. 
selves and the sisters by themselves." 1 The statutes at Ilford and Dover give similar directions. The priests at Sherburn slept apart in a chamber adjoining the church, but the Harbledown staff lacked such accommodation until in $137 \mathrm{I}$ it was ordained that they should henceforth dwell in a clergy-house- "a home separate from the sick persons and near to them."

When both sexes were admitted, they lived apart, a woman with the title of prioress being selected to rule the female community. Some houses were set apart for women, e.g. Alkmonton, Thanington, Bristol (St. Mary Magdalene), Newbury (St. Mary Magdalene), Bury (St. Petronilla), Woodstock, Clattercot, Hungerford, Arundel, Westminster, whilst one left behind it the name of "Maiden" Bradley. It sometimes happened that a married couple contracted the disease. A clerk smitten with leprosy and his wife with the same infirmity were seeking admission to St. Margaret's, Hunting-

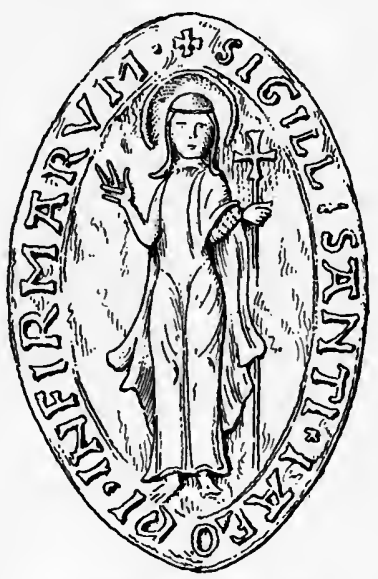

24. SEAL OF THE LEPERWOMEN OF WESTMINSTER don, in 1327 . By the Ilford statutes, no married man was admitted unless his wife also vowed chastity. On no account was a married person received at Dover without the consent of the party remaining in seculo, and then only upon similar conditions. In this connection a passing reference may be made to the marriage laws. Although by the laws of the Franks leprosy was a valid reason for

1 Pat. 12 Edw. I, m. I6. 


\section{8

divorce, later Norman laws considered separation unjustifiable; this latter was the attitude of the Church, which is given fully in the Appendix to the Lateran Council of II79. ${ }^{1}$ Yet the pathos of the leper's lot is suggested by the declaration of Amicia, a woman of Kent in 1254-that in truth at one time she had a certain Robert for husband, but that now he had long been a leper and betook himself to a certain religious house, to wit, the leper-hospital at Romney. ${ }^{2}$

For many reasons the leper-household was most difficult to control : it is small wonder that abuses crept in. Men forcibly banished were naturally loth to submit to rigorous discipline. They were persons who would never have dreamed of the religious life save by pressure of circumstances; moreover, the nature of their infirmity caused them to suffer from bodily lassitude, irritability and a mental depression bordering upon insanity ; in the life of St. Francis is a description of his ministry to a leper so froward, impious, abusive and ungrateful that every one thought him possessed by an evil spirit. London lepers were evidently not less refractory. From early days the city selected two men as keepers and overseers at St. Giles', the Loke and Hackney; these officials, who were accustomed to visit the lazar-houses daily and to chastise offenders, were granted exemption from inquests, summonses, etc., on account of this "their meritorious labour, their unpleasant and onerous occupation." (1389.) The London edict of 1346 confirms the undoubted fact that lepers are specially tempted to a loose life. Banished from the restraining influences of home and public opinion, they

1 Cap. 2, 3, vide Conciliorum Omnium, ed. I567, III, 700.

2 Assize Roll No. 36I, 39 Hen. III, m. 28. 
were found in haunts of vice. The master of the lazarhouse had no means of enforcing control. If the leper escaped and fell into evil habits none could prevent it: indeed, this did but ensure the liberty he craved, for the ultimate punishment of inmates was expulsion.

(ii) THE HOUSEHOLD OF THE INFIRMARY AND

ALMSHOUSE

(a) The Master or Warden, who was also known as prior, custos, keeper or rector, was usually a priest, but occasionally a layman. One of the early masters of St. Mark's, Bristol, was a knight, Henry de Gaunt, whose mailed effigy remains in the chapel. Crown hospitals were often served by chaplains and clerks, but the appointment of "king's servants," yeomen or knights, is noticeable during the fourteenth century.

It is rarely recorded that the custodian of the sick was a physician, but the absence of the title medicus in no way proves that he and his helpers were ignorant of medicine. In early days, indeed, it was only the clergy, religious or secular, who were trained in the faculty, and the master and his assistants must have acquired a certain intimacy with disease; they would have a knowledge of the herbals, of the system of letting blood, and other simple remedies. An important medical work, Breviarium Bartholomai, was written late in the fourteenth century by John Mirfield of St. Bartholomew's, Smithfield. He acknowledges that it is a compilation for the benefit of those who could not afford to buy the treatises whence it was derived; but he adds that part had been personally communicated to him and was supported by the experience of others. The fine manuscript copy in Pembroke 


\section{I5O MEDI EVAL HOSPITALS OF ENGLAND}

College, Oxford, includes a list of medical ingredients, herbs, etc. ${ }^{1}$

In some instances the warden is described as a physician. When the chaplain of St. John's, Bridport, was incapacitated, Master John de Brideport, physician, was deputed to act for him (1265). The Duke of Lancaster presented his foreign doctor, Pascal de Bononja, to the Preston hospital (1355). "Louis the physician," who held St. Nicholas', Pontefract (I399-140I), may be identified with Louis Recouchez, king's physician, who was then appointed to the hospital at Westminster. It is possible that visiting doctors and barber-surgeons attended hospitals. In an inventory of Elsyng Spital a debt of xxxvijs. ijd. was due to Robert the leech, and of $x s$. to Geoffrey the barber. One of the inquiries at the Dissolution of religious houses was:- "Whether the maister of the house doo use his brethren charitably when they be syke and diseased; and whether, in tyme of their sykenes, he doo procure unto them physicions."

The duties-and temptations-of a warden are suggested by the "Articles of Inquisition touching the Savoy" (I535). Not only was inquiry made whether the master visited the poor at least twice a week, and the sick twice daily, but also :-

"Whether he be mercifull, beningne and louyng to the poore; and not skoymys [squeamish] or lothesome to uisite theym or to be among theym.

"Whether he or his ministers by his sufferance do take in suche as they reken moste clene of the poore, and repell theym that they reken most sore or deseased, for auoydyng of their owne lothesomenes or contagion."

${ }^{1}$ Hist. MSS., 6th R. 550. 


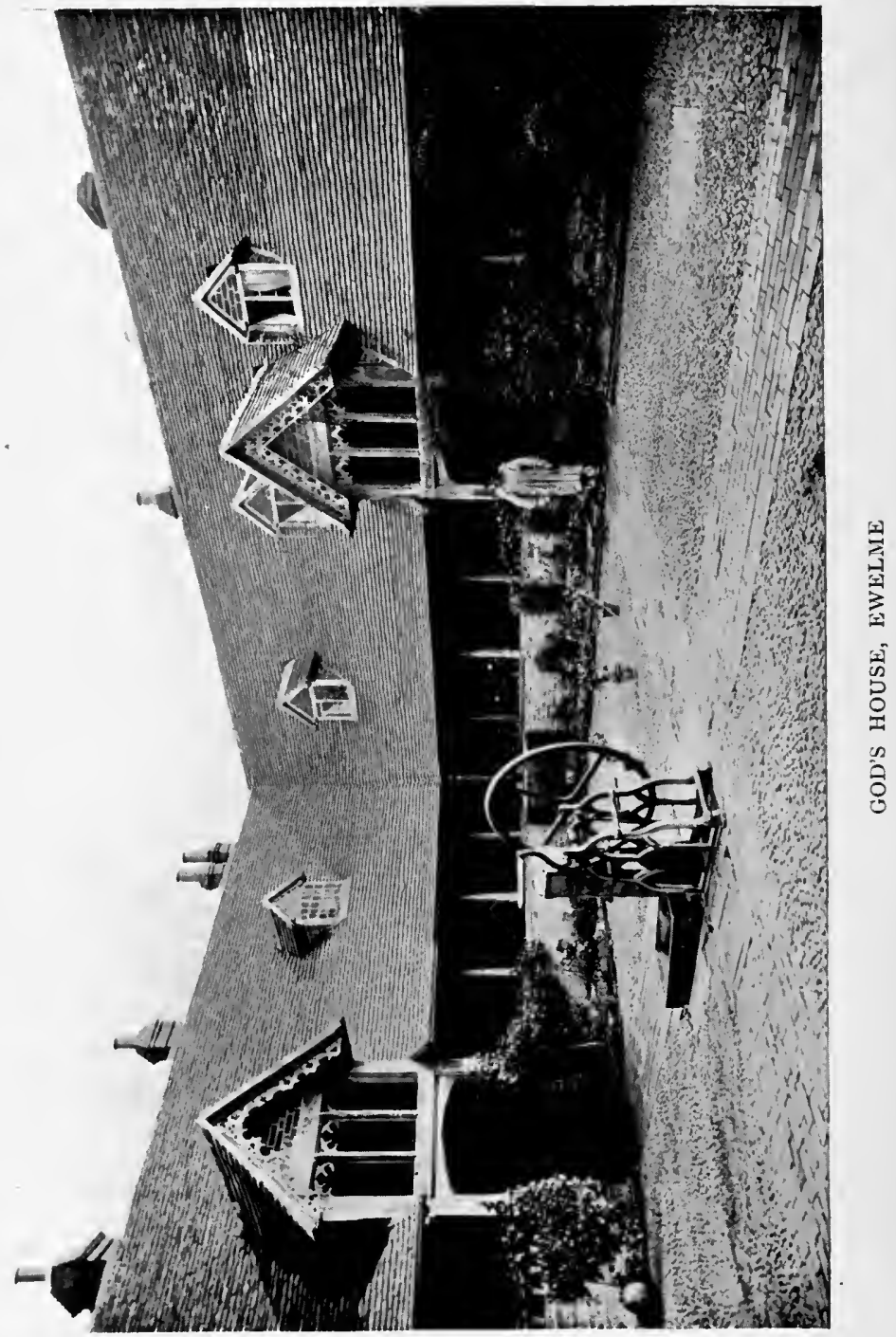


The qualifications and duties of the head of an almshouse are defined in the minute regulations of fifteenthcentury founders. The master of Ewelme must be an able and well-disposed person in body and soul, one who could counsel and exhort the poor men to their comfort and salvation. He had to conduct frequent services, and was warned to omit none-not even "for plesaunce of lorde or lady" - save "if he be let by sekenesse or prechyng of the worde of God, or by visitacion of Fadyre and modir." The master of God's House, Exeter, might not be absent more than once or twice a year, his recess never exceeding three weeks and three days. At Wells, a chaplain of commendable life, manners and learning was sought-one "circumspect and expert in spiritual and temporal things, and free from all infamous vice." The ale-house and hunting were forbidden to the warden of Heytesbury, as well as "inhonest playes, as of the Dees, cartes or of the hande-ball." He must never be absent at night, nor for long by day, although it was lawful for recreation to walk a mile or two at certain times. $\mathrm{He}$ had, indeed, little leisure, for he conducted certain services both in the chapel and parish church, and kept school, besides ruling the almshouse.

The model master did not exist only in the imagination of founders, although he occurred rarely. Among good men who are not forgotten where they fulfilled their duty, mention must be made of John de Campeden, warden and benefactor of St. Cross. His friend William of Wykeham placed him in charge of that despoiled and dilapidated institution. He ruled wisely and spent large sums upon restoration. After a faithful stewardship of twenty-eight years, his death occurred in 1410. His memorial brass 


\section{MEDI $Æ V A L$ HOSPITALS OF ENGLAND}

retains its place before the altar. The brasses of several wardens are also preserved at Greatham.

(b) The Staff: Brethren and Sisters. - These offices became in some cases mere honorary posts; there was no salary attached to them, but officials were supplied with food and clothing. The sisterships at St. Katharine'snear-the-Tower used to be given by the queen to her ladies. Of the eight sisters at St. Leonard's, York, some were workers (see p. I54), but others lived apart from the rest in a place built for them near the hospital, and were mere pensioners enjoying provision of food, clothing, fuel and bedding. Unprotected women were often glad to relinquish some little property by arrangement, and be settled for life. "Brothers" might be priests, monks or lay-brethren. The staff of St. John's, Oxford, consisted of three Augustinian chaplains-one being elected master -with six lay-brethren and six sisters. At Lechlade two brothers distinguished for kindness and courtesy were selected to exercise hospitality with charity and cheerfulness, and to watch over the sick. ${ }^{1}$ Of thirteen brethren at Kepier, six were chaplains, and the rest acted as steward, keeper of the tannery, miller, etc. The brethren of St. John's, Ely, were forbidden to play with dice, or to be present at such play, but were to give themselves to contemplation and study of Scripture, one or two being deputed to wait upon the infirm. Each lettered brother of St. Leonard's, York, was directed to study at his desk in the cloister two or three times a day.

The "proctor" was the financial agent of the community. He held an important post, and had occasionally an official seal. It was sometimes his duty to deliver a 
charity-sermon- "to preach and to collect alms." When the traffic in indulgences began, the proctor became a "pardoner." (See p. I89.) Spurious agents abounded, for the post was lucrative. A man was arrested as feigning himself proctor of St. Thomas', Canterbury ; another was convicted of receiving money, beasts, legacies and goods ostensibly for that house. ${ }^{1}$ The collector received gifts in kind, and the following appeal was put forward by St. John's, Canterbury :- " if any one wishes to give ... ring, brooch, gold, silver, cows, heifer, sheep, lamb or calf, let him send and deliver it to our proctor." Sister Mariana Swetman was licensed to collect alms on behalf of that hospital (1465), an interesting instance of a woman virtually holding the office of proctor.

Ministering women have long laboured in our infirmaries for the benefit of the sick, carrying on their works of mercy side by side with men. "The lay sisters shall observe what we have above ordained to be observed by the brethren, as far as befits their sex," decreed Archbishop Gray for St. John's, Nottingham (I24I). One of the men, corresponding to the monastic infirmarer, was responsible for the sick ward; thus a brother of Northallerton held the office of procurator infirmorum in lectulis, whilst two sisters watched by the sick, especially at night, and a third attended to household affairs. At Bridgwater, women " not of gentle birth but. still fit for the purpose" assisted in nursing; they lodged in a chamber adjoining the infirmary and were to be always careful and ready both by night

1 Pat. 6 Edw. II, pt. i. m. 15. Pat. 17 Edw. II, pt. i. m. 1o. Compare inscription upon Watts' Almshouse, Rochester (1579); poor people to be sheltered "provided they be not rogues nor proctors." The law authorizing proctors was repealed in 1597 . Cf. Fraternity of Vagabonds. 


\section{MEDI EVAL HOSPITALS OF ENGLAND}

and day to help the sick and to minister to them in all things."

The work of women among the sick developed further during the fifteenth century; they evidently took a prominent part in the management of the larger infirmaries. A lady, corresponding perhaps to the matron of to-day, was in authority at York. By a will of 1416 , money was bequeathed for distribution among the helpers and inmates of St. Leonard's at the discretion of Alice materfamilias. Long before (1276) the officers had included not only a brother called Gamel de Firmaria, but a sister named Ann medica, ${ }^{1}$ and in 1385 the principal sister was known as Matilda la hus-wyf. ${ }^{2}$ In some institutions there were already distinct ranks among nursing women. The pious poet Gower remembers in his will (1408) the staff and patients of four London hospitals; he leaves sums of money not only to the master and priests of St. Thomas', Southwark, but "to every sister professed" and "to each of them who is a nurse of the sick."

Woman's sphere in hospital life was confined to work by the bedside and domestic duties. Occasionally they were found to undertake what was not fitting. The prior of Christchurch, Canterbury, made a visitation of the daughter-hospital of St. James, Thanington, after which he issued a deed of reformation (1414). A curious clause occurs in these statutes :-

"We command that no one of the sisters . . or any other woman soever while divine service is being celebrated in the chapel should stand or sit in any way round or near the altars or should presume to serve the priests celebrating the

${ }^{1}$ Chron. and Mem., 7 I, Historians of York, iii. 202-3.

2 Arch. Journ. 1850. 


\section{THE HOUSEHOLD AND ITS MEMBERS I55}

divine offices or saying the canonical hours, since, according to the first foundation of the said hospital its chaplains or priests ought to have a clerk who ought to officiate in the aforesaid matters."

In addition to regular brethren and sisters, there were under-officials. The staff of the larger institutions included clerks in minor orders, who assisted in worship and work. In almshouses where there was no resident master, a trustworthy inmate held a semi-official post. Thus at Donnington there were thirteen pensioners, and " one at their head to be called God's minister of the poor house." When the "tutor" at Croydon went out of doors, he ordained "oon of his fellawes moost sadde [serious] and wise to occupy his occupacion for him till he come ageyne."

(c) Attendants, etc. Serving men and women were employed to wait upon the infirm and upon the staff. Lanfranc ordered that the poor of St. John's, Canterbury, should have careful servants and guardians, lest they should need anything. When the poll-tax was levied in Oxford (1380), there were twelve servants, artisans and farm-labourers working at St. John's. In the immense establishment at York there were sixteen male and female servants, besides a host of other stipendiaries-two or three cooks, bakers, brewers, smiths and carters, a ferrywoman, twelve boatmen, etc. Workingclass officials called the "man harbenger" and "woman harbenger" were employed to attend to beggars passing the night at St. John's, Sandwich. At the Maison Dieu, Dover, two women made the beds, served the poor and washed their clothes. The position of the female attendant in an almshouse is well described by the name 


\section{I56 MEDI $Æ V A L$ HOSPITALS OF ENGLAND}

"sister-huswiff" used at Heytesbury. The ideal woman to hold the post is pictured in the statutes of Higham Ferrers; of good name and fame, quiet and honest, no brawler or chider, she should be "glad to please every poor man to her power." She had minute directions as to housekeeping and other duties which would fill the day, and in illness she must visit the patients at night. The keeper of the five married couples at Ford's hospital, Coventry, was required "to see them clean kept in their persons and houses, and for dressing their meats, washing of them, and ministering all things necessary to them."

(d) The Sick and Infirm.-Having described the officials, it will be well to form some idea of the number of the infirm to whom they ministered. The largest establishment of this kind was St. Leonard's, York; and at Easter I370, there were 224 sick and poor in the infirmary, besides 23 children in the orphanage. About the same time there were 100 brothers and sisters at St. John's, Canterbury. A large number of patients were cared for in the London hospitals of St. Bartholomew, St. Thomas and St. Mary. St. Giles', Norwich, accommodated $3^{0}$ poor besides 13 aged chaplains, and 40 persons were maintained at Greatham. The majority of permanent homes were smaller, thirteen beds being a usual number. Many hospitals were obliged to reduce the number of patients as the revenues diminished. In the year I333, St. Bartholomew's, Gloucester, supported 90 sick, lame, halt and blind; but two centuries later Leland notes that it once maintained 52 , but now only $3^{2}$.

Of pilgrim, patient and pensioner, little can be recorded. Temporary inmates came and went, receiving refreshment and relief according to their needs. Some of the resident 
poor were chronic invalids, but others were not too infirm to help themselves and assist others.

The frequent attendance at prayers certainly gave the almsfolk constant occupation, and they were required to be busy at worship or work. The poor men of Croydon were charged "to occupy themsilf in praying and in beding, in hering honest talking, or in labours with there bodies and hands." Inmates at Ewelme must be restful and peaceable, attending to prayer, reading or work; their outdoor employment was to "kepe clene the closter and the quadrate abowte the welle fro wedis and all odyr unclennesse." (Pl. XVII.) It was directed at Higham Ferrers that in springtime each poor man should help to dig and dress the garden, or if absent, give the dressers a penny a day. In the same way, at Sandwich, an inmate's allowance was stopped if he failed to render such service as he could. Those brothers at Ewelme who were "holer in body, strenger and mightier" were commanded to "fauer and soccour and diligently minister to them that be seke and febill in all behofull tyme." 


\section{CHAPTER XI}

\section{THE CARE OF THE SOUL}

"The brothers and sisters must pray continually, or be engaged in work, that the devil may not find them with nothing to do."

(Statutes of St. Mary's, Chichester.)

7 HE daily life in a hospital was essentially a religious

1 life. From warden to pauper, all were expected to pay strict attention to the faith and give themselves to devotion. "The brethren and sisters serving God" were fully occupied with prayer and work. "A representation of a mediæval hospital shows the double hall, the priest is administering the last rites of the Church to one patient, the sisters are sewing up the body of another just dead, mass is being sung at the altar, a visitor is kneeling in prayer."

\section{THE SERVICES}

The offices consisted of mass and the canonical hours. All who could rise attended the chapel on bended knees, the bedridden worshipping simultaneously. Even sick people could join in the intercessions; thus the master of St. John Baptist's, Bath, agreed that the name of a late canon of Wells should be daily recited before the brethren, sisters and poor in the infirmary (1259).

(a) The Staff.-In regular hospitals helpers were directed to keep the canonical hours unless reasonably hindered,

I Besant, London, Med. Ecc., p. $25^{6}$. 


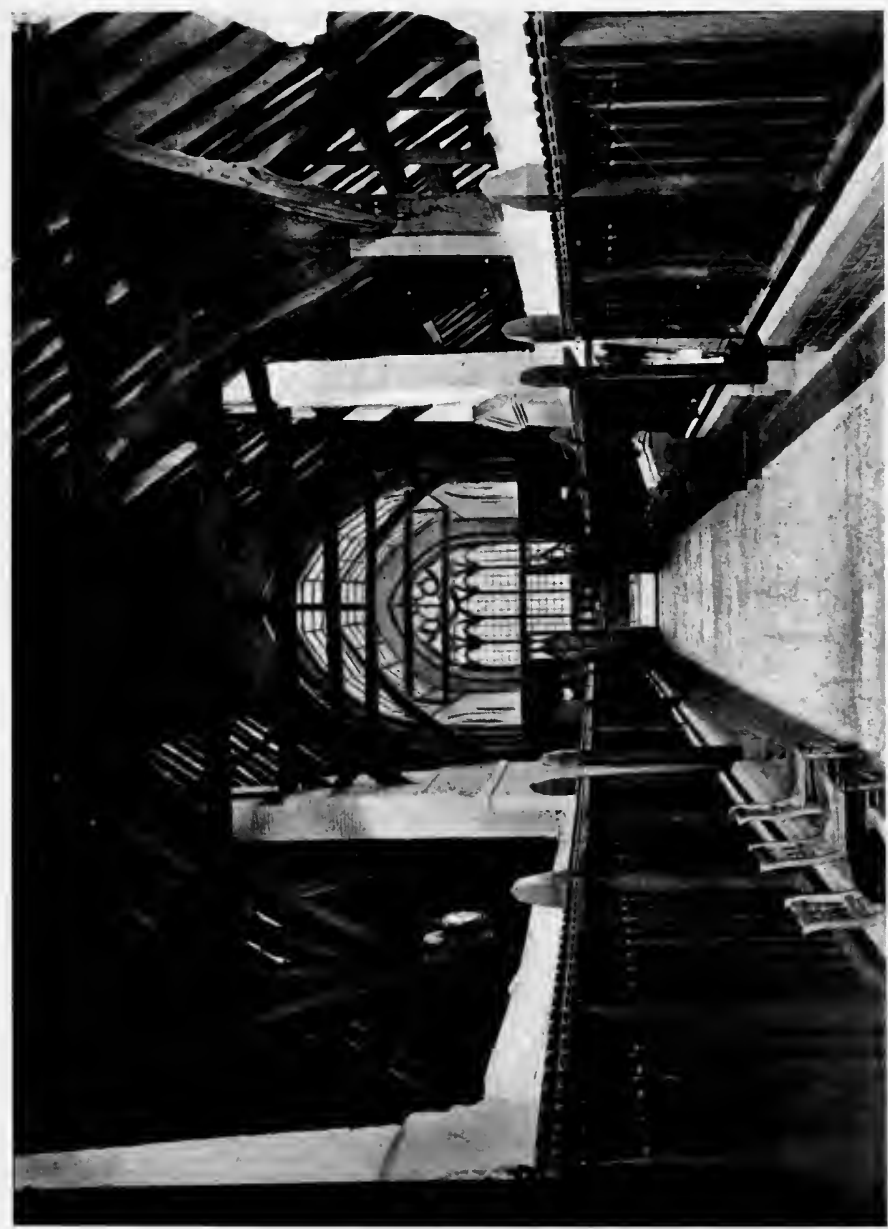

 

each being expected to pray according to his powers and education. The lettered repeated the Hours and Psalter of the Blessed Virgin, Placebo and Dirige, penitential psalms and litany. Those who did not know the offices said Paternoster, Ave Maria, Gloria Patri, and Credo. The brethren rose early for mattins; after prime and tierce, mass was celebrated; sext and none followed. They then gave themselves to household duties, until the day closed with vespers and compline. Attendance at the night offices sometimes caused them to fall sick with the cold, on which account the brethren of St. John's, Bridgwater, asked the bishop for relief ( 1526$)$. Accordingly they were allowed to hold their first service at $5 \mathrm{a} . \mathrm{m}$. in summer and 6 a.m. in winter, provided that they first rang a bell to waken travellers, workmen and others, that they might attend mass and ask God's blessing before going about their work. ${ }^{1}$

(b) Lepers. - When a leper was solemnly set apart, he was counselled to say devoutly every day Paternoster, Ave Maria, Credo in Deum, Credo in Spiritum; he was to say often Benedicite and protect himself with the sign of the Cross. In most leper-houses inmates were required to hear mass daily and keep the canonical hours. At Dover, they were instructed not only to say their two hundred Paternosters and Aves by day, but as many at night; one brother roused the slumbering by ringing the dormitory bell, and the prayers were repeated sitting erect in bed. At St. James', Chichester, a similar custom was confirmed in 1408 ; the first hour after midnight, the brethren (unless too feeble) had to rise together from their cubicles and say the night office. The prayers included not only

${ }^{1}$ W. Hunt, Diocesan ${ }^{\circ}$ Hist., pp. 158-9. $^{8}$ 
the Creed, Lord's Prayer and Salutation, but intercessions for the Catholic Church, king and queen and benefactors ; if omitted, they must be said next day. Bishop Stratford of London, in compiling regulations for Ilford (I346) writes :-

"We also command, that the lepers omit not attendance at their church . . . unless prevented by grievous bodily infirmity : they are to preserve silence there, and hear mattins and mass throughout, if they are able; and whilst there, to be intent on prayer and devotion, as far as their infirmity permits them."

At Sherburn those unfit to leave their beds were to raise themselves at the sound of the bell and join in worship, or in extreme weakness, to lie still and pray.

(c) Almsmen.-Inmates of almshouses were frequently under a solemn vow regarding religious exercises. By the oath upon admission to St. Bartholomew's, Sandwich, (P1. XIX) each individual bound himself to

" be obedient $\mathrm{w}^{\mathrm{t}}$ hooly deuocyon prayyng for the founder of this place ... and in especiall I shall be at the bedys [bedes] in the churche, and at matynys, and atte messe, and euensong and complyne, as the custome of maner is and usage-so help me God, and all holy dome, and all seints of heuen."

The offices were sometimes grouped into morning and evening worship. Potyn directed that his almsmen at Rochester should say at a certain hour morning and evening "our ladie sawter." As this Psalter of the Blessed Virgin was the standard form of worship for the unlettered, a knowledge of it was required before admission to a hospital. At Heytesbury, the examination was conducted after entrance:- "and if he cannot perfitely, we wull that he be charged to cunne [learn] sey 

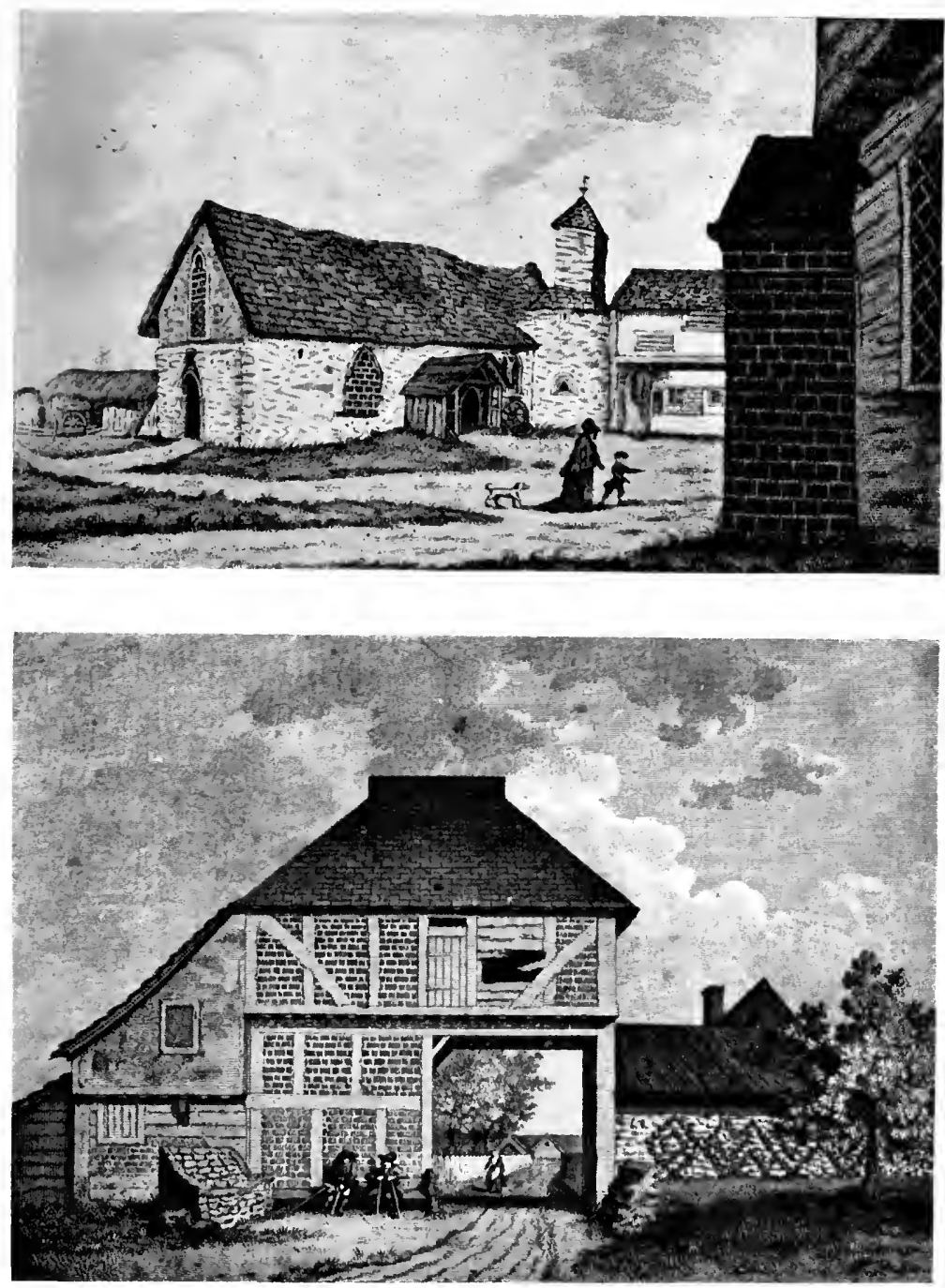

ST, BARTHOLOMEW'S HOSPITAL, SANDWICH

(a) CHAPEL. (b) GATEWAY 

ye said Sawter, his Pater Noster, Ave and Credo, as well as he canne." The keeper was to teach the ignorant, and if he were still found defective in repetition, penance was prescribed until his knowledge were amended.

"We wull also that euerich of $y^{e}$ poremen other tymes of $y^{e}$ day when they may beste entende and have leyser, sey for $y^{e}$ state and all $y^{\mathrm{e}}$ sowlis abovesaide, iij sawters of $y^{\mathrm{e}}$ most glorious Virgyne Mary. Every sawter iii times, 50 aues, with xv paternosters \& iii credes. . . And furthermore, that thei say euery day onys our Lady Sawter for all Christen soulis."

After supper when the household attended chapel, all that could joined in De Profundis " with ye versicles and orisons accustomed to be saide for dede men." At the close a bedeman said openly in English the bidding prayer.

The almsmen of Ewelme after private prayer by their bedside, attended mattins and prime soon after 6 a.m., went at 9 a.m. to mass, at 2 p.m. to bedes, at 3 p.m. to evensong and compline. About 6 o'clock the final bidding prayer was said around the founders' tombs :-

"God have mercy of the sowle of the noble prince Kyng Harry the Sext and of the sowles of my lord William sum tyme Duke of Suffolke, and my lady Alice Duchesse of Suffolke his wyfe, oure fyrst fownders, and of theyr fadyr and modyr sowles \& all cristen sowles."

The ministry of intercession was fostered in hospital chapels. A collect, breathing humble and trustful petitions, was drawn up by Wynard, Recorder of Exeter, who built God's House in that city :-

"O Lord Jesu Christ, Son of the Living God, have mercy upon Thy servant William founder of this place, as Thou wilt and as Thou knowest best; bestow upon him strong hope, 
right faith and unshadowed love, and grant to him a good end, which is a gift above all others. Amen."

The bidding prayer directed for the use of almsmen at Lichfield included petitions for the founder and for the royal family :-

"O God, who by the grace of the Holy Spirit, the Comforter, pourest the gifts of charity into the hearts of the faithful, grant to Thy servant William the bishop, our founder, and grant to Thy servants and to Thy handmaids, for whom we implore Thy clemency, health of mind and of body; that they may love Thee with all their strength, and with all joyfulness perform such things as please Thee, through Christ our Lord. Amen."

The pious custom of remembering benefactors is continued at Lambourn. The little almshouse was founded in 1501 by John Isbury, who is buried in the adjoining church. Every morning at 8, the senior almsman repeats the prayer for the soul of the founder, after which the pensioners attend mattins. The vicar recently recovered a part of the original prayer (in brass) from off the tomb.

\section{THE CHAPEL}

The life of the community centred in the chapel. Of the chaplains at St. John's, Chester, two served in the church and "the third in the chapel before the poor and feeble sustained in the said hospital." There were three chapels in St. Leonard's, York (Pl. XXV), including "St. Katherine in the sick hospital" and "St. Michael in the infirmary." Henry III was present at the dedication of the Maison Dieu, Dover, ${ }^{1}$ and again long afterwards when an altar was consecrated to St. Edmund by Richard

${ }^{1}$ Charter Roll 16 Hen. III, m. 19. 
of Chichester. Every hospital had one or more altars. Portable super-altars were occasionally kept, these being probably used when the infirmary did not adjoin the chapel.

In order to gain an idea of the external side of worship, some account of the accessories of a chapel, such as lights, decoration and ornaments, must be given. Lights were kept burning day and night before the altar. For this purpose oil lamps with rush wicks, and wax tapers were required. The two Sandwich hospitals obtained their supply of tapers thus. When the mayor and townsmen came in procession to St. Bartholomew's on the patronal festival, many bore wax lights which they left in the chapel for use during the year. St. John's hospital, not being equally favoured, arranged otherwise, for the inmates agreed that if any one reviled another with vicious language, brawling in ungodly fashion, he should pay four lb. of wax to the light of the church. The altar expenses at Holy Trinity, Bristol, included payments for standards, candlesticks and lamps. The wax-maker received $5 s$. Iod. for ten $\mathrm{lb}$. of new wax for the Sepulchre light, and $8 \frac{1}{2} d$. for a "wachyng tapir for the Sepulcre" (15 5 2). ${ }^{1}$

The chapel was adorned with paintings and carvings. The figure of St. Giles now preserved in Lincoln Cathedral was brought there from the hospital of that name. When St. Mary Magdalene's chapel, Durham, was being rebuilt, the sum of $5^{s}$. I $d$. was paid for painting an image of the patron-saint. Alabaster heads of the Baptist were kept at St. John's, Exeter, and Ewelme. The inventory and valuation of Holy Trinity, Beverley,

1 MS. in Municipal Charities Office. 


\section{I64 MEDI EVAL HOSPITALS OF ENGLAND}

enable one to picture the appearance of the sanctuary. The ornaments included an alabaster representation of the Trinity with painted wooden tabernacle, a well-carved and gilded image of the Blessed Virgin and Child (worth 40s.) with sundry small pictures and crucifixes.

Books, plate and vestments were frequently the gift of benefactors by will. The founder bequeathed to St. Giles', Norwich, "the gilt cup which was the blessed Saint Edmund's" (i.e. probably the Archbishop's); he left a Bible to the hospital and a missal to the master. Office-books were costly, the manual and missal at Holy Trinity, Beverley, being valued at $£_{4}$ each. A master of Sherburn bequeathed to that house a richlyilluminated New Testament (Argenteus Textus), besides cloths of gold and brocade. John of Gaunt gave to his Leicester foundation "his red garment of velvet embroidered with gold suns." When festal services were held at St. Mary's, Newcastle (P1. XXVII), three gold chalices were seen upon the altar, whilst the celebrant wore one of the beautifully-embroidered garments of the hospitals, which included one wrought with peacocks, another bordered with roses, and "one entire vestment of bloody velvet, woven about with a golden fringe."

Many valuables fell a prey to dishonest wardens. Frequent allusions are made to defects in the books, jewels, etc., of hospital chapels and of their being withdrawn, put into pledge, or sold. The treasures had often dwindled considerably before the final pillage, which partly accounts for entries in Chantry Surveys, etc., " plate and ornaments none." But as late as the sixth year of Edward VI, some traces remained of ornate services. St. John's, 
Canterbury, possessed ecclesiastical robes of black velvet, red velvet and white fustian, and a cope of Bruges satin. Some of these were removed, but amongst articles left for the ministration of divine service were "one cope of blewe saten of bridgs, one cope of whytt fustyan."

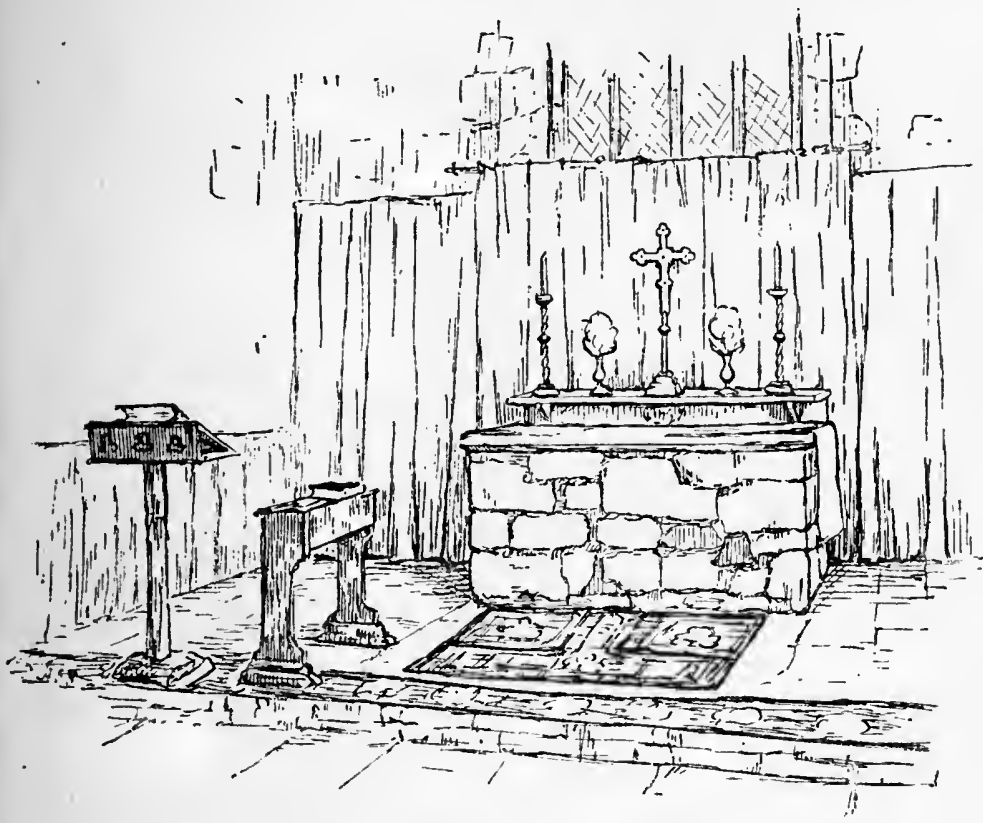

25. ANCient hospital altar, glastonbury

The fittings of such chapels have seldom survived, but original altar-stones remain in two hospitals at Ripon, as well as at Stamford and Greatham ; the ancient slab found in the floor at Trinity Hospital, Salisbury, has this year been restored to its place. The altar (Fig. 25) in the women's almshouse at Glastonbury (Fig. 23) has a recess in the masonry under the south end of the altar-slab. At 


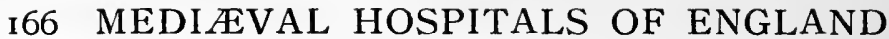

Chichester and Stamford sedilia and stalls with misericords may be seen. Wall-paintings remain at Wimborne, and fragments of ancient glass at St. Cross ; St. Mark's, Bristol ; St. Mary Magdalene's, Bath; Trinity, Salisbury; Sherborne; and Stamford. 


\section{CHAPTER XII}

\section{THE CARE OF THE BODY}

"Let there be in the infirmary thirteen sick persons in their beds, and let them be kindly and duly supplied with food and all else that shall tend to their convalescence or comfort." (Statutes of Northallerton. ${ }^{1}$ )

T considering the provision for material comfort in

1 hospitals, one must distinguish between residents and sojourners. Board and clothing had to be found for the leper or the almsman, and the sick needed food and shelter for a time. Travellers either called for doles in passing, or required supper, bed and breakfast. Upon every pilgrim, sick or well, spending the night at St. Thomas', Canterbury, four-pence was expended from the goods of the hospital. Bodily necessaries of life may be classified under the headings food, fuel, baths, bedding and clothes.

\section{FOOD}

(a) Food for resident pensioners. - There was of course a wide difference between the lot of the ill-fed lazar who lodged in some poor spital dependent upon the chance alms of passers-by, and that of the occupant of a wellendowed institution. At the princely Sherburn hospital, each person received daily a loaf (weighing five marks) and a gallon of beer; he had meat three times a week, and on other days eggs, herrings and cheese, besides

${ }^{1}$ Surtees, Vol. 56. Gray's Register, p. I8I. 
butter, vegetables and salt. The statutes laid stress upon the necessity of fresh food, and it was forbidden to eat the flesh of an animal which had died of disease. This was wise, for the constant consumption in the Middle Ages of rotten meat, decayed fish and bread made from blighted corn predisposed people to sickness and aggravated existing disease. Forfeited victuals were granted to the sick in hospitals at Oxford, Cambridge, Sandwich, Maldon, etc. The Forest law directed that if any beast were found dead or wounded, the flesh was to be sent to the leper-house if there were one near, or else be distributed to the sick and poor; Dr. Cox in his Royal Forests cites instances of the lepers of Thrapston and Cotes benefiting by this statute.

Salt meat was largely consumed, but it was insufficiently cured on account of the scarcity of salt. Bacon was a most important article of food; one of the endowments of St. Mary Magdalene's, Winchester, consisted of four flitches annually. About Christmas-tide, according to the "Customal of Sandwich," each person at St. Bartholomew's received a hog with the inwards and all its parts. The lepers at St. Albans had a similar custom, but they made their own selection for the salting-tub at Martinmas :- "we desire that the pigs may be brought forward in their presence . . a and there each, according to the priority of entering the hospital, shall choose one pig."

In some households, a meat-allowance was given to each person, perhaps two-pence a week, or a farthing a day. There were vegetarians among the residents at Southampton, for the account-rolls mention Sister Elena who for a time "ate nothing that had suffered death, 
and Sister Joan, "who does not eat flesh throughout the year." In those days of murrain they were prudent, for it is recorded that an ox was killed for consumption in the house "because it was nearly dead."

In the later almshouses the inmates received wages and provided their own victuals, which were cooked by the attendant. It was directed at Higham Ferrers :-

"That every poor man shall buy his meat upon the Saturday ... and deliver it to the woman, and she shall ask them which they will have against Sunday, and the rest she shall powder up against Wednesday; she shall upon Sunday set on the pot and make them good pottage, and shall give every man his own piece of meat and a mess of pottage in his dish, and the rest of the pottage shall be saved until Monday."

The remainder was served up on Wednesday by the careful housewife, who was directed to buy barm on Fridays for the bread-making.

Baking was done once a fortnight at St. Bartholomew's, Sandwich, the allowance to each person being seven penny loaves. The exact provision of brown and white bread is sometimes given in regulations. Oats "called La Porage" was provided for the poor in the Leicester almshouse, where there was a porridge-pot holding sixtyone gallons. Ancient cooking utensils are preserved at St. Cross, Winchester, at St. John's, Canterbury, and at Harbledown.

In most hospitals there was a marked difference between daily diet and festival fare. Festal days, twenty-five in number, were marked at Sherburn by special dinners. St. Cuthbert was naturally commemorated; his festival 


\section{I70 MEDI EVAL HOSPITALS OF ENGLAND}

in March and the day of his "Translation" in September were two-course feasts ; but the first falling in Lent, Bishop Pudsey provided for the delicacy of fresh salmon, if procurable. Both at Sherburn, and at St. Nicholas', Pontefract, there was a goose-feast at Michaelmas, one goose to four persons. The "Gaudy Days" at St. Cross were also marked by special fare.

(b) Food for casuals. -Out-door relief was provided in many hospitals. St. Mark's, Bristol, was an almonry where refreshment was provided for the poor. Forty-five lb. of bread made of wheat, barley and beans, was given away among the hundred applicants; the resident brethren " each carrying a knife to cut bread for the sick and impotent" ministered to them for two or three hours daily. A generous distribution of loaves and fishes took place at St. Leonard's, York, besides the provision of extra dinners on Sundays.

Special gifts were also provided occasionally, on founders' days or festivals. At St. Giles', Norwich, on Lady Day, one hundred and eighty persons had bread and cheese and three eggs each. Maundy Thursday was a day for almsgiving, when all lepers who applied at the Lynn hospital were given a farthing and a herring. "Obits" were constantly celebrated in this way. The eve of St. Peter and St. Paul, being the anniversary of Henry I's death, was a gala-day for lepers within reach of York; bread and ale, mullet with butter, salmon when it could be had, and cheese, were provided by the Empress Matilda's bounty, in memory of her father. The ancient glass reproduced on $\mathrm{Pl}$. XX depicts hungry beggars to whom food is being dealt out.

The Maison Dieu, Dover, kept the memorial days of 


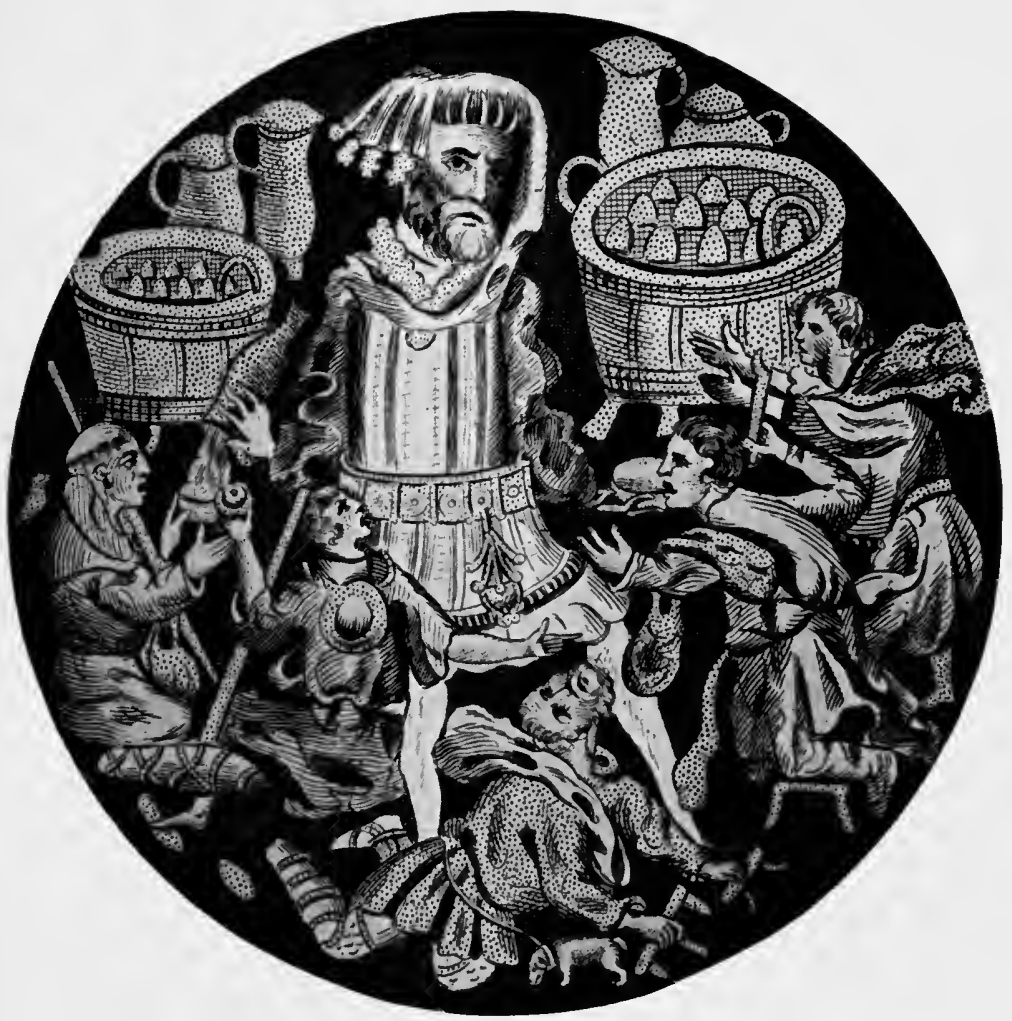

THE PEGGARS' DOLE 

Henry III and of Hubert de Burgh and his daughter. The fare and expenses on such occasions are recorded, viz.:-

"Also in the daye of Seynt Pancre yerely for the soule of Hughe de Burgo one quarter of whete

Also the same daye if it be flesshe day one oxe and if it be fisshe day ij barells of white heryng vj. viijd.

Probably the annual distribution of three hundred buns at St. Bartholomew's Hospital, Sandwich, is handed down from some ancient custom on the patronal festival, but almost all these charities came to an end at the Dissolution. The Commissioners who visited St. Cross, however, (I535) allowed the continuation of daily dinners to the hundred poor, on condition that distribution was made

" to them who study and labour with all their strength at handywork to obtain food; and in no case shall such alms be afforded to strong, robust and indolent mendicants, like so many that wander about such places, who ought rather to be driven away with staves, as drones and useless burdens upon the earth."

The "Wayfarer's Dole" still given at St. Cross is the only survival of the former indiscriminate entertainment of passers-by.

\section{FIRING AND LIGHTS}

The wood necessary for firing was collected from the vicinity by permission of the manorial lord. In Henry III's charter to St. John's, Oxford (1234), he granted wood from Shotover "to cook the portions of the poor and to warm the poor themselves." $\mathrm{He}$ also permitted the gathering of faggots for St. John's, Marlborough, one 


\section{MEDI EVAL HOSPITALS OF ENGLAND}

man going daily for dry and dead wood "to collect as much as he can with his hands only without any iron tool or axe, and to carry the same to the hospital on his back for their hearth." Early rolls record constant grants of firewood. St. Leonard's, York, was supplied with turves from Helsington Moor.

The supply of fuel was regulated by the calendar. A benefactor (circa I I 80) granted to the lepers of St. Sepulchre's near Gloucester, a load of firewood "such as a horse can carry" daily from November 1 to May 3, and thrice a week for the rest of the year. From Michaelmas to All Saints, the lepers of Sherburn-unconscious of the coalfield all around them-had for their eight fires two baskets of peat daily, after which until Easter four baskets were supplied; on festivals extra fuel was given, and at Christmas great logs were specially provided. Finally it was directed that:- "if any leprous brother or sister shall be ill so that his life is despaired of, he shall have fire and light and all things needful until he amend or pass away."

\section{BEDDING}

In early days, the sick and poor were laid on pallets of straw, but wooden bedsteads were probably introduced late in the twelfth century. A dying benefactor left to the brethren of St. Wulstan's, Worcester, the bed on which he lay and its covering of bys, or deer-skin (129r). ${ }^{1}$ A Durham founder bequeathed money to "amend the beds what tyme they shall happyne to be olde or defective" (149I). A strange civic duty was performed at Sandwich. It was customary for the mayor and townsmen, as

1 Giffard's Register, p. $3^{88 .}$ 
"visitors" of St. John's House, to examine the condition and number of the feather-beds, and bedding, and to ascertain if all was kept very clean. Where travellers came and went, it was no light task to supply fresh linen. At St. Thomas', Canterbury, an annual payment of xlvjs. viijd. was made "to Rauf Cokker keper of the seid hospitall and his wif for kepyng wasshyng of the bedds for poure peple" (I535). The same year, the inquiry made into the condition of the Savoy hospital included these items :-

"Whether the hundred beddes appoynted by the founder be well and clenely kept and repayred, and all necessaries to theym belongyng.

"Whether any poore man do lie in any shetes unwasshed that any other lay in bifore."

\section{TOILET}

Bathing and laundry arrangements are occasionally mentioned. The regulations for the Sherburn lepers direct a strict attention to cleanliness. Two bath-tubs (cunce ad balneandum) were supplied; heads were washed weekly; and two laundresses washed the personal clothing twice a week. In the fifteenth-century statutes of Higham Ferrers matters of health and toilet are detailed. None might be received "but such as were clean men of their bodies"; and if taken ill, a bedeman was removed until his recovery. Every morning the woman must "make the poor men a fire against they rise and a pan of fair water and a dish by it to wash their hands." The barber came weekly "to shave them and to dress their heads and to make them clean." When the Savoy was officially visited in 1535 , the authorities were asked 


\section{I74 MEDI $Æ V A L ~ H O S P I T A L S$ OF ENGLAND}

"whether the bathes limitted by the founder be well obserued and applyed."

As to hair-dressing, "tonsure by the ears" was commonly used by the staff. After profession at Chichester it was directed:- "then let the males be cropped below the ear ; or the hair of the women be cut off back to the middle of the neck." Among the instructions in the register of St. Bartholomew's near Dover is one about the round tonsure, and there is a marginal note as to the mode of shaving the head. The visitation of St. Nicholas', York (temp. Edward I), showed that formerly brethren and sisters were tonsured, but that Simon, recently master, had allowed them to change both habit and tonsure. ${ }^{1}$

\section{Clothing}

(a) The habit of the staff.-The dress worn by the master and his fellow-workers was usually monastic or clerical, but it varied considerably, for the priests might be regulars or seculars, the brethren and sisters religious or lay persons. Occasionally the warden was not in orders; it was directed at St. Leonard's, York, that "when the master is a layman, he shall wear the habit of the house." In an ecclesiastical type of foundation, the dress was commonly after the Augustinian fashion, consisting of black or brown robe, cloak and hood, with a cross on the outer garment; white and grey were occasionally worn by officials of both sexes. The Benedictine brethren of St. Mark's, Bristol, were clothed in a black habit with a quaint device, namely, "a white cross and a red shield with three white geese in the

1 P.R.O. Chanc. Misc. 20, No. 13. 
same." Secular clerks had more latitude in costume ; the sombre mantles were enlivened by a coloured badge, a pastoral staff at Armiston, a cross at St. John's, Bedford, etc.

(b) The almsman's gozon. - The early type of pensioner's habit is perpetuated at St. Cross. Ellis Davy, having sober tastes, provided for his poor men at Croydon that "the over-clothing be darke and browne of colour, and not staring neither blasing, and of easy price cloth, according to ther degree." This stipulation was probably copied from the statutes of Whittington's almshouse, which as a mercer he would know. The usual tendency of the fifteenth century was to a cheerful garb. The bedeman of Ewelme had "a tabarde of his owne with a rede crosse on the breste, and a hode accordynge to the same." The pensioners at Alkmonton received a suit every third year, alternately white and russet; the gown was marked with a tau cross in red. At Heytesbury the men's outfit included " 2 paire of hosyn, 2 paire of shone with lether and hempe to clowte theme, and 2 shertys"; the woman had the same allowance, with five shillings to buy herself a kirtle. The two servitors at St. Nicholas', Pontefract, wore a uniform "called white livery."

(c) The leper's dress. - The theory of the leper's clothing is described in the statutes of St. Julian's ; they ought " as well in their conduct as in their garb, to bear themselves as more despised and as more humble than the rest of their fellow-men, according to the words of the Lord in Leviticus: "Whosoever is stained with the leprosy shall rend his garments." " They were forbidden to go out without the distinctive habit, which covered them almost entirely. The outfit named in the Manual consisted of 
cloak, hood, coat and shoes of fur, plain shoes and girdle.

The hospital inmate in his coarse warm clothing was readily distinguished from the ragged mendicant. The brothers and sisters at Harbledown were supplied with a uniform dress of russet, that is to say, a closed tunic or super-tunic; the brethren wore scapulars (the short working dress of a monk), and the sisters, mantles. At St. Julian's hospital, the cut of the costume was planned; thus the sleeves were to be closed as far as the hand, but not laced with knots or thread after the secular fashion; the upper tunic was to be worn closed down to the ankles; the close black cape and hood must be of equal length. The amount of material is recorded in the case of Sherburn, viz. three ells of woollen cloth and six ells of linen. At Reading the leper's allowance was still more liberal, for the hood or cape contained three ells, the tunic three, the cloak two and a quarter; they also received from the abbey ten yards of linen, besides old leathern girdles and shoes.

Lepers were forbidden to walk unshod. At Sherburn, each person was allowed fourpence annually for shoes, grease being regularly supplied for them. Inmates of both sexes at Harbledown wore ox-hide boots, fastened with leather and extending beyond the middle of the shin. High boots were also worn by the brethren at St. Julian's "to suit their infirmity"; if one was found wearing low-cut shoes-"tied with only one knot"- - he had to walk barefoot for a season.

For headgear at Harbledown, the men used hoods, and the women covered their heads with thick double veils, white within, and black without. Hats were sometimes 
worn, both in England (Fig. 9) and in France. (Fig. 26.) In the Scottish ballad (circa I500), Cresseid is taken to the lazar-house dressed in a mantle with a beaver hat. This was probably a secular fashion.

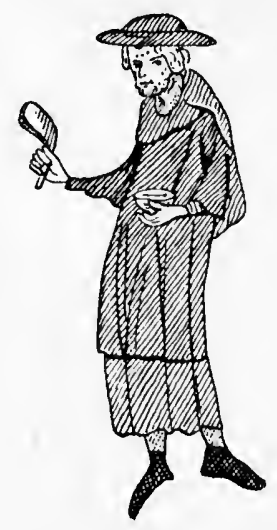

26. A LEPER

(With clapper and dish) 


\section{CHAPTER XIII}

\section{HOSPITAL FUNDS}

"To the which hospitals the founders have given largely of their moveable goods for the building of the same, and a great part of their lands and tenements therewith to sustain impotent men and women."

(Parliament of Leicester.)

ANDOWMENTS were to a certain extent supplied by the patron, but were supplemented by public charity. The emoluments included gifts of money, food and fuel, grants of property, admission fees, the profits of fairs, and collections. Receipts in kind are seldom recorded, and the changing scale of values would involve points beyond the scope of this volume. Particulars may be found in the extant manuscripts of certain hospitals and abbeys, in Valor Ecclesiasticus, etc. Extracts from the account-books of St. Leonard's, York, have been published in a lecture by Canon Raine. The finance of such an institution, with scattered and extensive property, necessitated a department which required a special clerk to superintend it, and the exchequer had its particular seal. Reports of the Historical MSS. Commission give details of the working expenses of hospitals at Southampton and Winchester.

\section{ENDOWMENTS}

(a) Endorements in money. - The earliest subscriptions are recorded in the Pipe Rolls, consisting of royal alms 

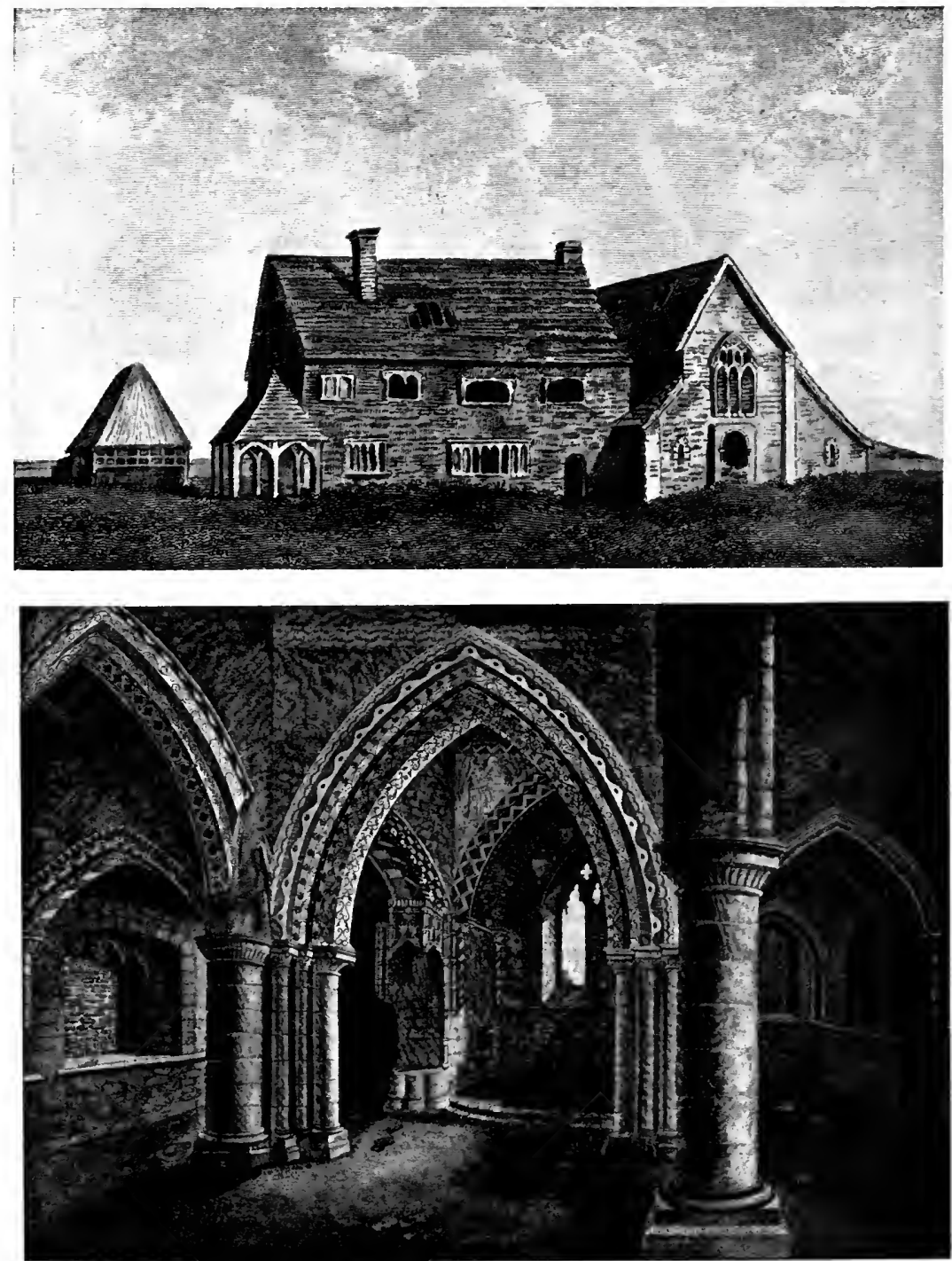

ST. MARY MAGDALENES, WINCHESTER

(a) MASTER'S HOL'SE AND CHAPEL, (b) CHAHEL 
(Eleemosynce Constitutce) paid by the Sheriff of the county from the profits of Crown lands. Three entries in the year I 58 will serve as specimens :-

Infirmis de Dudstan. xxs. Infirmis super Montem. lxs. Infirmis de Lundon. lxs.

At first sight this seems not to concern hospitals; but a closer examination proves that sums are being paid to sick communities-in fact to lazar-houses. For the lepers of Gloucester dwelt in the suburb of Dudstan, and the infected inmates of St. Mary Magdalene's, Winchester, were known locally as "the infirm people upon the hill" -now Maun Hill. The grant was paid out of the farm of the city until, in $144^{2}$, the citizens were unable to contribute that and other sums on account of pestilence and depopulation. The infirm of London were the lepers of St. Giles'; and the sixty shillings, originally granted by Henry I and Maud, was still paid in Henry VII's reign, for a writ of 1486 refers "to the hospitallers of St. Giles for their annuity of 1xs." Between the years I' 58 and I 78 subscriptions were paid to infirmi at the following places :-

Regular payments - "Dudstan," Hecham, Hereford, Lincoln, London, Maldon, Newport, Richmond, Rochester, St. Albans, St. Edmunds, Shrewsbury, "Super Montem." Occasional payments-Barnstaple, Barnwell or Stourbridge, Bradley, Burton Lazars, Chichester, Clattercot, Derby, Canterbury and Harbledown, Ely, Ilford, Leicester, Liteport, Newark, Northampton, Oxford, Saltwood, and Windsor.

Of the latter, some were grants on account of a vacant bishopric. In addition to the above, sums were given to 
leprosi of Southampton and Peterborough, and to hospitals of Gravesend, of Norwich, and " of the Queen." These contributions vary from $\mathbf{I} 2 d$. paid to Hereford up to $£ 6$ given to Hecham (Hig-

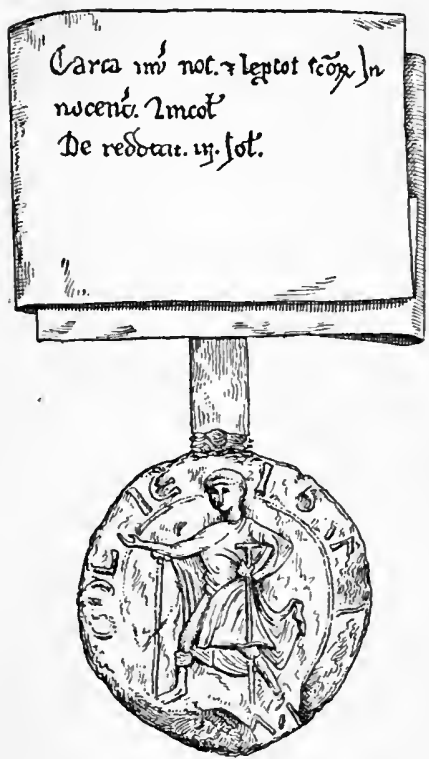

27. DOCUMENT AND SEAL OF THE LEPERS OF LINCOLN ham Ferrers). In some cases corn and clothing were also contributed. There is a contemporary representation of one of these "infirm" persons on the seal of the lepers of Lincoln, dating from the days of Henry II and St. Hugh. The document to which it is attached contains a covenant between Bullington Priory and the hospital of the Holy Innocents, Lincoln, concerning a rent of three shillings from the hospital.

Revenues also consisted largely in annual rents arising from land and house property, some being appropriated to specific works. An early grant to St. Bartholomew's, Gloucester (circa I2IO), was to be expended upon the maintenance of a lamp in the chapel, and shoes for inmates, whilst the sum of $5 d$. was to go towards the provision of five beds.

(b) Endoroments in kind.-The kings were generous in grants from royal forests. Henry III granted one old oak from Windsor to the sick of St. Bartholomew's, London (1224). He afterwards gave to St. Leonard's, 
York, "licence to take what they need in the forest of Yorkshire for building and burning, and also of herbage and pasture for flocks and anything needful for their ease, as they had in the time of Henry II." Food was also supplied by patrons, especially in what might be termed manorial hospitals, consisting generally of a grant of tithes on produce. Another form of endowment was to impropriate livings. St. Giles', Norwich, owned six manors and the advowson of eleven churches. When funds were low at Harbledown, the archbishop impropriated Reculver church, thus augmenting the income by parochial tithes. This disgusted the parishioners who sought redress, thinking it "ill to be subject to lepers."

\section{BEQUESTS}

The money chest, larder and wardrobe were replenished largely by legacies. Amongst the earliest recorded are those of Henry II and his son, William Longespée. Henry left a large sum to religious houses in England and Normandy, and particularly to lepers. Longespée bequeathed cows to lepers in the hospitals of Salisbury, Maiden Bradley and Wilton, as well as to St. John's, Wilton, and St. Bartholomew's, Smithfield (I 225). Men in humbler circumstances were likewise generous. A certain William de Paveli left I $2 d$. each to eight hospitals in Northampton, Brackley, Towcester, Newport Pagnell, Hocclive and Stra[t]ford (circa I240). ${ }^{1}$ Wills abound in references of a similar character. Early legacies were made to the hospital as a body, but when the renunciation of individual property by the staff ceased, money was given to individuals; a benefactor of St.

1 Madox, Formulare Ang., p. 424. 


\section{MEDIFVAL HOSPITALS OF ENGLAND}

Giles', Norwich, left 20 marks to the master and brethren, $40 d$. each to other officials, and $2 s$. to each bed (1357). ${ }^{1}$ Gifts were frequently made to patients; Stephen Forster desired that roos. should be given away in five city hospitals, besides five marks in pence to inmates of St. Bartholomew's, Bristol (1458). An endowment of penny doles was provided by Lady Maud Courtenay in Exeter, namely thirteen pence annually for twenty years "to xiii pore men of Symon Grendon is hous " (1464). Testamentary gifts were also made in the form of clothes, bedding, utensils, etc. The founder of St. Giles', Norwich, left to it "the cup out of which the poor children drank," probably some vessel of his own hitherto lent for the scholars daily meal.

\section{PROFITS BY TRADING}

The fair was a great institution in mediæval England, and the funds of privileged charities were assisted in this way. At Maiden Bradley the leprous women and their prior held a weekly market and an annual fair. The Chesterfield fair was exchanged for a yearly payment of six pounds of silver from the royal Exchequer, which indicates the value set upon it. The most notable hospital-fairs were that of the leper-house near Cambridge (originally held in the close and still held on Stourbridge Common), and those connected with St. Bartholomew's and St. James' near London. The story of the former has been told by H. Morley; and the "May-Fair" of St. James' leper-house was also famous. These galas were usually at the patronal festival and lasted two or three days, but occasionally these profitable festivities were carried on for a fortnight. Fairs were held at the following hospitals :- 
Aynho, Bath (Holloway), Bury (St. Nicholas, St. Saviour), Baldock, Colchester (St. Mary Magdalene), Devizes (St. James \& St. Denys), Dover (Buckland), Harting, Ipswich, Lingerscroft, Newbury, Newport, Newton Garth, Racheness, Royston (St. Nicholas), Swinestre near Sittingbourne, Thetford (St. John), Wycomb (2), etc.

This curious and interesting custom survives in connection with St. Bartholomew's, Newbury. The fair, originally granted by charter of King John (1215), ${ }^{1}$ still takes place annually on the day and morrow of St. Bartholomew (Old Style), upon lands belonging to the hospital. A "Court of Pie Powder" is held on the morrow of St. Bartholomew's day; the proctor of this ancient charity with the steward and bailiff attend, and proclamation is made opening the Court. Tolls derived from stallages are collected, together with an impost of $2 d$. on every publican in Newbury (the latter due being resisted in a few cases). The following day the Court meets again, when the proceeds are divided amongst the almsmen. ${ }^{2}$

\section{ADMISSION FEES}

A considerable pecuniary benefit accrued to hospitals by the custom of receiving contributions from newlyadmitted members of the household. In some cases a benefaction was made when persons were received into a community; thus Archbishop Wichwane as patron granted permission for a certain Gilbert and his wife to bestow their goods upon Bawtry hospital and dwell there (128I). ${ }^{3}$

1 Charter Roll 17 John, m. 8.

2 Communicated by the Town Clerk.

3 Surtees Soc., 114, p. 278. 


\section{INVOLUNTARY CONTRIBUTIONS}

Rates were levied for hospital maintenance on an organized system in some foreign countries. Sometimes a compulsory Hospital Sunday Fund was instituted, one penny being demanded from the richer, one halfpenny from the middle-class, and a loaf from lesser folk. In England, however, the only obligatory support was an occasional toll on produce, perhaps first ordered by the feudal lord, but afterwards granted by custom. The Bishop of Exeter (II63) confirmed to lepers their ancient right to collect food twice a week in the market; and alms on two other days, - a custom resented by the citizens. (Seep. 54.) King John conferred upon Shrewsbury lazars the privilege of taking handfuls of corn and flour from sacks exposed in the market (1204). By charter of the Earls, the Chester lepers were entitled to extensive tolls -upon salt, fish, grain, malt, fruit and vegetables, to a cheese or salmon from every load, and even one horse from the horse-fair. The lepers of St. Mary Magdalene's, Southampton, received "from time immemorial" a penny upon every tun of wine imported.

The mayor and commonalty of Carlisle granted every Sunday to the lepers a pottle of ale from each brew-house of the city, and a farthing loaf from every baker who displayed his bread for sale on Saturday. Their hospital was also endowed "time out of mind" with a corn-tax known as the "thraves of St. Nicholas" from every carucate of land in Cumberland. (The thrave is variously computed at twelve, twenty or twenty-four sheaves.) This county had a heavy poor-rate, for the great York hospital collected likewise from every plough working in 
the northern Archiepiscopate (Cumberland, Westmorland, Lancashire and Yorkshire). These "thraves of St. Leonard," or "Petercorn," belonged to the hospital by virtue of Athelstan's gift, which had been originally granted to him by his northern subjects in recognition of his destruction of wolves. The lands of the Durham Bishopric contributed "thraves of St. Giles" to Kepier hospital. The collection of such tolls was a constant difficulty, for it was resented by landowners, who had also the ordinary tithes to pay.

\section{(6) VOLUNTARY CONTRIBUTIONS}

(a) Donations.-At first, freewill-offerings were mainly in kind. The earliest collector whose name occurs is Alfune, Rahere's friend. While the founder was occupied at St. Bartholomew's, Alfune was wont "to cumpasse and go abowte the nye placys of the chirche besily to seke and prouyde necessaries to the nede of the poer men, that lay in the hospitall." It fell on a day that as Alfune visited the meat-market, he came to a butcher whose persistent refusal of help grieved him. After working what was regarded as a miracle, Alfune won him over, and departed with flesh in his vessel : henceforth butchers were more prompt to give their alms. Almsmen used sometimes to collect in person. It was customary for some of the brothers of St. John's House to "attend the churches in Sandwich every Sunday, with a pewter dish, soliciting money to buy meat for dinner on that day." Another brother was deputed to travel on an ass through Kent asking alms-" "and he collects sometimes ten shillings a year, sometimes a mark, above his expenses." All save richly-endowed houses were dependent upon 
casual charity. In St. Mary's, Yarmouth, it is recorded "live a multitude of poor brethren and sisters, for whose sustenance a daily quest has to be made." One of the London statutes, enrolled in Liber Albus, directs that lepers shall have a common attorney to go every Sunday into the parish-churches to gather alms for their sustenance. Lest charitable offerings should diminish when lepers were removed from sight, a clause was added to the proclamation of 1348 :- "it is the king's intention that all who wish to give alms to lepers shall do so freely, and the sheriff shall incite the men of his bailiwick to give alms to those so expelled from the communion of men." It would appear from a London will of 1369 , that special chests were afterwards provided; for bequests are then made to the alms-boxes (pixidibus) for lepers around London. Alms-boxes were carried about by collectors, and also hung at the gate or within the hospital. The proctor of the staff went on his mission with a portable money-box; upon one occasion, a false proctor was convicted of pretending to collect for St. Mary of Bethlehem, for which fraud he was pilloried, the iron-bound box with which he had paraded the streets being tied round his neck. Boxes of this kind, sometimes having a chain attached, remain in almshouses at Canterbury, Leicester and Stamford. It was directed by the statutes of Higham Ferrers that a common box with a hole in the top should be set in the midst of the dormitory so that well-disposed people might put in their charity ; at certain times also two of the poor men were to "go abroad to gather up the devotions of the brotherhood," the contents being afterwards divided.

(b) Small Subscriptions.-Some fraternities formed 
associations for the maintenance of charities. That of St. John Baptist, Winchester, helped to support St. John's hospital with the shillings contributed by its 107 members. The modern hospital of St. Leonard, Bedford, is kept up on this principle.

(c) Appeals authorized by the King.-The work of the proctor was not confined to the neighbourhood. Having first possessed himself of letters-testimonial, he journeyed in England, or even in Wales and Ireland. A "protection" or warrant was necessary, for unauthorized collectors were liable to arrest; it was in the form of a royal letter addressed to the archbishops, bishops, abbots, priors, bailiffs, lieges, etc. Henry III pleads with his subjects the cause of St. Giles', Shrewsbury :- "that when the brethren come to you to beg alms, you will favourably admit them, and mercifully impart to them your alms of the goods conferred by God upon you." Many letters-patent license the proctors, messengers or attorneys to collect in churches, or, as at St. Anthony's, Lenton (r332), in towns, fairs and markets. Sometimes the collector went forth supported by Church and State; as when the king issued mandates $(1317,1331)$ to welcome the proctor of the Romsey lepers "authorized by John, Bishop of Winchester and other prelates."

(d) Appeals authorized by the Church, as Briefs, Indulgences, etc.-Bishops likewise issued briefs, or letters of recommendation, on behalf of institutions in their own dioceses or beyond. The infirm of Holy Innocents', Lincoln, received from their diocesan a mandate (1294), ordering the parochial clergy to allow their agent to solicit alms after mass on three Sundays or festivals each year ; later, the stipulation was added, that the Cathedral 


\section{I88 MEDI EVAL HOSPITALS OF ENGLAND}

fabric fund should not suffer thereby. A typical document is found in the Winchester Register in favour of St. Leonard's, Bedford ( 1321 ). The mandate was addressed to the archdeacons, deans, rectors, vicars and chaplains, commanding them to receive accredited messengers of that needy hospital, to cause their business to be expounded by the priest during mass, after which the collection should be delivered without deduction. The brief was in force for two years and the clergy were bidden to help effectually by word and example at least once a year.

Episcopal Registers include many such documents, some being granted on special occasions, to make good losses by murrain, to enlarge premises, or to rebuild after fire, flood or invasion. Some briefs were not unlike modern appeals, with their lists of presidents and patrons ; for that on behalf of Romney hospital ( 1380 ) was signed by both archbishops and eleven bishops. It was a recognized source of raising funds. John de Plumptre in making arrangements for his almshouse at Nottingham (14I4), provided that the widows, for the bettering of their sustenance, should "have and hold an episcopal bull and indulgence... procured from the archbishops and bishops of England, Wales and Ireland."1

It is curious to watch the increase of the privileges offered. The earlier bishops remitted penance for seven or thirteen days, those of a later period, for forty days. Roman indulgences knew no such limits. The form of a papal brief (1392) was as follows :-

"Relaxation of seven years and seven quadragene to penitents who on the principal feasts of the year and those of

\footnotetext{
1 Records of Nottingham, ii. 99.
} 
St. James in the month of July and the dedication, the usual octaves and six days; and of a hundred days to those who during the said octaves and days visit and give alms for the sustentation and recreation of the chapel of St. James' poor hospital without the walls, London."

William, Lord Berkeley directed the executors of his will (1492):-

" to purchase a pardon from the court of Rome, as large as may be had, for this Chapple [Longbridge], from evensonge to evensonge, in the feast of Trinity for ever, for pleyne remission to them that will be confessed and contrite."

Offerings stimulated by such pardons were in money or in kind. A deed belonging to the Bridport Corporation sets forth that the writer has seen letters from famous ecclesiastics-including St. Thomas and St. Edmund of Canterbury-in favour of Allington leper-house, one being an indulgence of Alexander IV :-

"Item, to alle thos that gevyn broche, rynge, boke, belle, candell, vestimente, bordclothe, towelle, pygge, lambe, wolle, peny, or penyworthe, be whiche the sayde hows and hospitale is amended and mentaynde, the sayd Pope grauntethe the remission of the vijth parte of penance injunct[ed]."

Thus the questionable trade of the pardoner ${ }^{1}$ was often carried on by the hospital proctor; moreover, spurious bulls were circulated. The abuses to which the practice gave rise were recognized by Bishop Grandisson, who announced that questors collecting alms in the diocese of Exeter were forbidden to preach, or to sell fictitious privileges, or unauthorized pardons. A papal exhortation

1 The word was retained after the Reformation, e.g. 1573, "paid to a pardoner that gathered for the hospital of Plympton" (T. N. Brushfield, Devonshire Briefs). 
on behalf of St. Anne's, Colchester (I402), forbids these presents to be sent by pardoners (questuarii). Those who bought a pardon from the proctor of St. John's, Canterbury, were informed that the benefit of 30,000 Paternosters and Ave Marias was freely imparted to them. But although indulgences were liable to abuse, it must be remembered that authorized pardons extended to penitents only-to those who, being contrite, had already confessed and received absolution and penance. Upon the indulgenced feast of St. Michael, so many people flocked to St. Mary's, Leicester, that a special staff of confessors became necessary.

\section{ALMS OF PILGRIMS}

Such visits to hospitals lead to the further consideration of pilgrimage and devotion to relics, which directly affected charity. An indulgence was offered to penitents visiting Yarmouth hospital and the sacred relics therein and giving a helping hand to the poor inhabitants. The Maison Dieu at Dunwich possessed a holy cross of great reputation "whither many resorted to adore it, who bestowed much alms." When the precious relic was carried away and detained " by certain evil-wishers" connected with St. Osith's Abbey, the inmates were greatly impoverished. ${ }^{1}$ The abbot having been prosecuted, came into chancery in person and rendered the cross to the king, who restored it to the master and brethren "to remain in the hospital for ever." Holy Cross, Colchester, claimed to keep a portion of the true Cross ; an indulgence was offered by various bishops to those paying pilgrimage visits and contributing to the hospital. (See pp. 248-9.)

1 Prynne, Usurpation of Popes, p. 11 37, and Close 34 Edw. I, m. 1. 


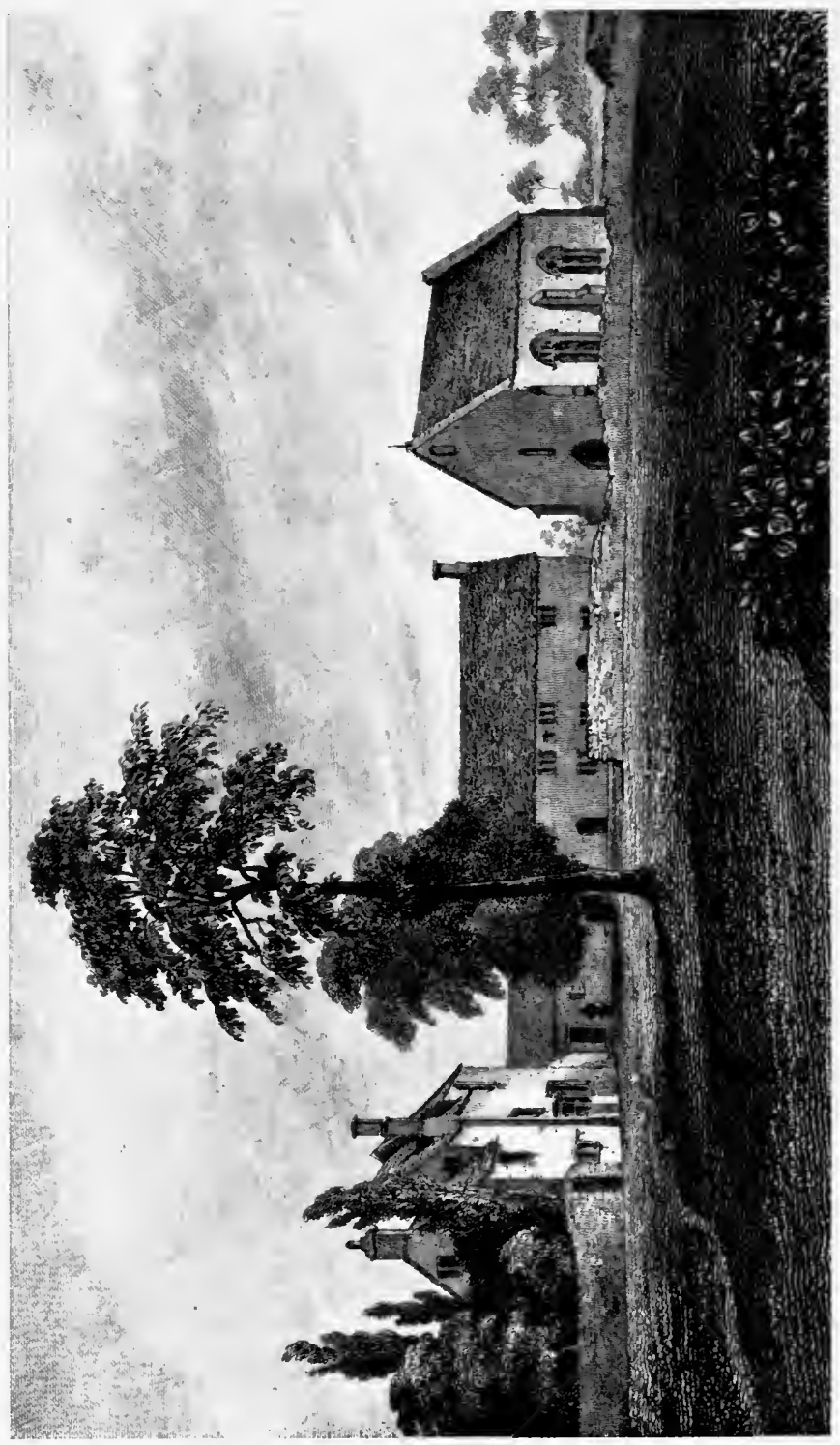

 
Other treasures visited by pilgrims were of a more personal character. Anthony à Wood found records of choice things formerly preserved in St. Bartholomew's, Oxford, whereby it was enriched :- "they were possest of St. Edmund the Confessor's combe, St. Barthelmew's skin, the bones of St. Stephen, and one of the ribbes of St. Andrew." The first and foremost of the sacred relics was evidently a personal possession of the local saint, Archbishop Edmund Rich, a native of Abingdon:"Those that were troubled with continuall headaches," (University students, perhaps) "frenzies, or light-headed, were by kembing their heads with St. Edmund's combe restored to their former health." On high days and holy days these treasures were exposed to view in the chapel. (Pl. XXII.) They were of so great value that the authorities of Oriel College, having acquired the patronage, appropriated them, "which caused great complaints from these hospitalliers."

The alms of pilgrims and other travellers were a valuable asset in the funds, for it was customary for those so journeying to spend much in charity by the way. On the penitential pilgrimage of Henry II to Canterbury (I I74) "as he passed on his way by chapels and hospitals he did his duty as a most devout Christian and son of Holy Church by confession of sin and distribution of offerings and gifts." 1 Halting at Harbledown he left the sum of forty marks, probably because the hospital belonged to the bereaved archbishopric. Long afterwards, another king-John of France-passed along the road, leaving at sundry hospitals a substantial proof of his gratitude for release from captivity. Among his

1 Chron. and Mem., 67, i. 487 . 
expenses are included gifts to "les malades de 4 maladeries depuis Rocestre jusques à Cantobérie, pour aumosne"; also to the communities of St. James', St. John's at the Northgate, St. Mary's, and Harbledown, and to the brethren of Ospringe; whilst the king gave as much as twenty nobles to the Maison Dieu, Dover,

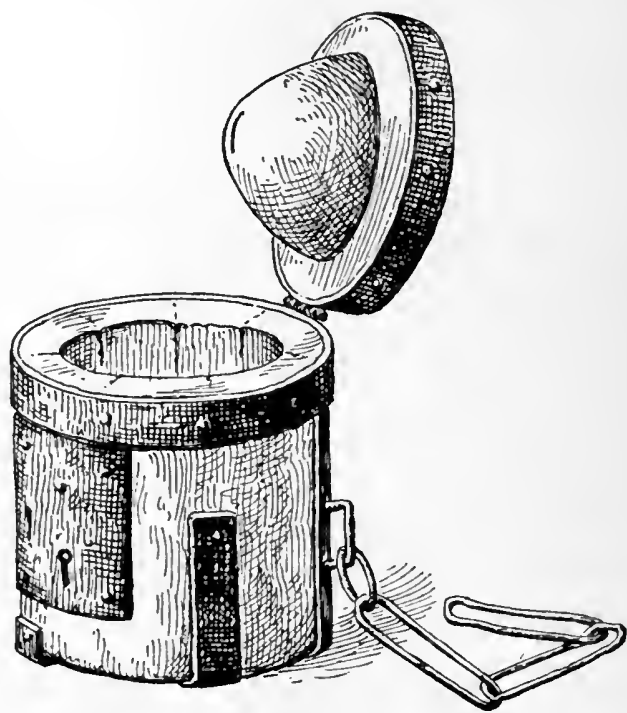

28. A hospital ALMS-Box

where he was received as a guest. ${ }^{1}$ Situated close to the highway, on the hill which eager travellers were about to climb to catch their first sight of the grand tower of Canterbury, the Harbledown lepers benefited by the gifts of pilgrims for three and a half centuries. Treasured in the hospital (P1. V) was a relic of "the glorious martyr" to whose shrine they wended. "This fragment of his

I Soc. de l'Histoire de France, 185 I, p. 194. 
shoe supports this little community of poor men," says Ogygius in the Colloquy on Pilgrimages, ${ }^{1}$ where Erasmus describes his visit to Canterbury with Dean Colet sometime before the year I519. Shortly after leaving the city, where the road becomes steep and narrow, there is, he says, a hospital of a few old men. One of the brethren runs out, sprinkles the travellers with holy water, and presently offers them the upper part of a shoe, set with a piece of glass resembling a jewel. This the strangers are invited to kiss. (Bale satirizes this custom where he says, "here ys the lachett of swett seynt Thomas shewe.") Colet is indignant, but Erasmus, to appease the injured brother, drops a coin into his alms-box. The quaint old box is still kept at Harbledown, and is figured above.

1 Pilgrimages of Walsingham and Canterbury-Ed. Nichols, 1849, p. 63. 


\section{CHAPTER XIV}

\section{RELATIONS WITH CHURCH AND STATE}

"As to other hospitals, which be of another foundation and patronage than of the King, the Ordinaries shall enquire of the manner of the foundation, estate and governance of the same . . . and make thereof correction and reformation according to the lazes of Holy Church, as to them belongeth."

(Parliament of Leicester.)

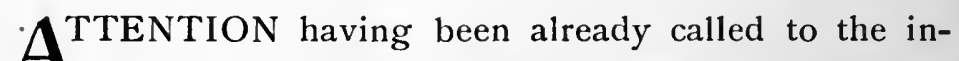
I ternal constitution of hospitals, we must now consider their relation to those in authority. The position of such a house was necessarily complicated; there arose a difficulty in reconciling its subordinate, yet partly independent character. We must see, first, how its welfare depended to a certain extent on king and bishop; secondly, its position with regard to the parochial system ; and thirdly, how far it was affected by monasticism.

(i) RELATIONS WITH THE KING AND THE BISHOP

The hospitals of England have never been exclusively in the hands of Church or State. The relations which they bore to each may be subdivided under the headings of Constitution, Jurisdiction and Finance.

(a) Constitution.-As we have seen, the Church, usually represented by the diocesan bishop, was responsible for the rule and statutes by which a hospital was guided.

(b) Jurisdiction.-In the province of administration, visitation and reform, king and bishop played their respec- 
tive parts. Speaking generally, the bishop was administrator, and the king protector; to the former, matters of religious observance and conduct were referred, to the latter, questions of temporal privilege, immunity from taxation, etc. Both had rights as "visitors." Faithfully conducted, ecclesiastical visitation might be of great use, but owing to the huge extent of dioceses, it was infrequent and inadequate, and where the king was patron, the diocesan bishop's visitation was prohibited. Under Henry III, the royal almoner undertook the keeping of Crown hospitals, but afterwards this duty fell to the Chancellor, who alone had the right of visitation; the diocesan bishop had no jurisdiction in such houses except by special arrangement, as in the Statute directing that ordinaries "by virtue of the king's commission to them directed" shall take inquisitions and return them into chancery. Royal interposition was not customary unless the king were patron; thus an order to inquire into waste at certain hospitals was cancelled because the king had erred in believing that they were founded by his progenitors. When investigations were commanded, they were committed to a local jury, who were to find by inquisition on oath of the good men of the county how far rules had been observed, and they possessed full power "to deal with the hospital as well in the head as in the members." Detailed accounts of such special visitations may be found among Chancery Miscellanea in the Record Office.

(c) Finance.-The Lateran Council of I 79 decreed that leper-communities should not pay tithe from gardens and orchards, nor of the increase of cattle, and this was ratified in the Provincial Council of Westminster in 1200 . The 
Church wished to go a step further and ordain that neither lazar-house, Domus Dei nor poor hospital should pay taxes, which was set forth by Gregory $\mathrm{X}$; entries upon Papal Registers in 1278 declare that certain English houses, including Ospringe, should share this immunity. But the decree was not necessarily accepted in England, remission of taxation being a royal prerogative; Ospringe was a Crown hospital to which exemption was renewed from time to time of the king's grace. In the cases of lazar-houses, a curious distinction was made, witnessing incidentally to national independence-" And let not the goods of lepers be taxed where they are governed by a leper" (par Sovereyn meseal). This rule occurs in the First Statute of Westminster (3 Edw. I), ${ }^{1}$ and afterwards in rolls and writs dated $\mathrm{I} 297, \mathrm{I}_{30} \mathrm{7}$, etc. ${ }^{2}$ It was evidently in allusion to this custom that, in remitting a wool-tax, it is stated that St. Bartholomew's, Rochester, was governed by a leprous prior (1342), but a few years later the king granted it freedom from taxation for ever. Many houses were freed by charter from local and general contributions and tolls.

Land-tenure may be included under finance. Before the enactment of the Statute De Religiosis, benefactors met with no hindrance in promoting any plan for endowment, but after 1279 permission was sought "to alienate land in mortmain." On payment of a small fine, communities were empowered to accept property to a certain value. This developed into the "licence to found" named in fourteenth-century rolls, and subsequently into incorporation.

1 Chron. \& Mem., 72, Reg. Malmes, i. 232.

2 Pat. ${ }_{5}$ Edw. I, pt. ii. m. I I ; Rolls of Parl. I, $239 b$. 
(ii) RELATIONS WITH THE PARISH PRIEST

Before the foundation of a hospital chapel, special permission was required from the bishop, with a guarantee that it should not interfere with the parochial system. It was necessary clearly to define privileges, lest friction should arise. Grants in civil and ecclesiastical registers include "a chapel, bell and chaplain," oblations, sepulture and "the cure of souls."

(a) Oblations.-One quarter of the offerings received at St. Katharine's, Ledbury, was reserved for parochial use. Unless some definite scheme was arranged, disputes quickly arose. A serious collision of interests occurred at Brough. The tiny hostel, founded with the sanction of bishop and archbishop (I506), developed into a pilgrimage-place. The injured vicar, with solemn ritual, cursed with bell, book and candle all concerned with such oblations as were made in the chapel. The founder, however, called forth upon his parson the archbishop's censure " as an abandoned wretch and inflated with diabolical venom for opposing so good a work." The priest in turn appealed to the Pope. At length it was agreed that 20 . yearly should be paid to the mother-church. ${ }^{1}$

(b) Public and private Worship, Bells, etc.-Agreements as to public worship on certain occasions were made between the parish and institutions within its boundary. The biographer of the Berkeley family, quoting from the episcopal register (1255), records :-

"That all the seculars in the hospitall of Longbridge, exceptinge a Cooke, and one person to kepe sick folkes, should in the spetiall solemne dayes, come to Berkeley Church and there

1 Nicolson and Burn, Antiq. of Westmorland, ed. 1777, i. 574. 


\section{MEDI EVAL HOSPITALS OF ENGLAND}

should receive all the ecclesiasticall Sacraments, (except holy bread and holy water) unles it bee by the dispensation and leave of the Vicar of Berkeley." 1

To infringe such rules meant trouble. One Easter (1439), the chaplain of St. Leonard's, Leicester, permitted two of the warden's servants

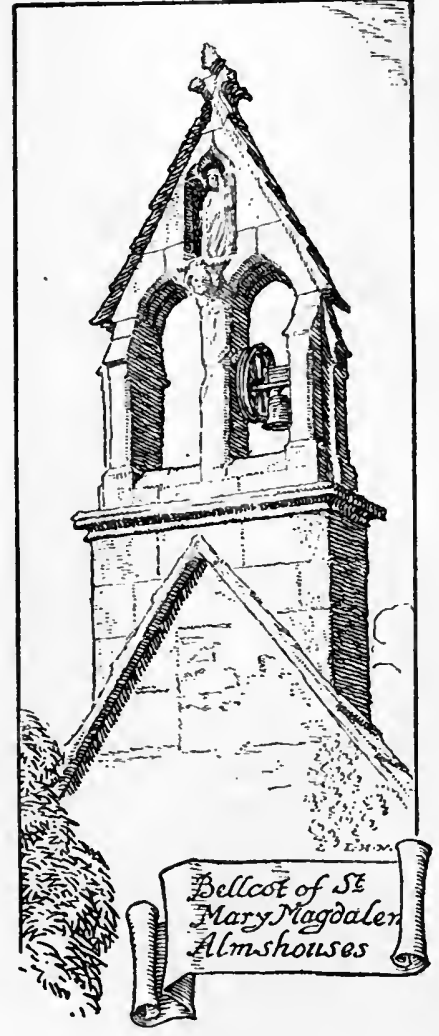

29. GLASTONBURY to receive the Sacrament from him there, instead of repairing to the parish church; but the following Sunday he was forced to do public penance.

The curious restriction of repeating divine service with closed doors and in an undertone was made at St. John's, Nottingham, when the patronal feasts were being celebrated in the parish. The rule for ordinary days was that of St. James' near Canterbury (I4I4), namely, that the can: onical hours be said audibly after the sounding of the handbells or bells according to ancient custom.

The possession of a bell in a turret required a special licence, lest outside worshippers should attend. A chapel being added to St. Mary Magdalene's, Bristol (I 226), the stipulation was made 1 J. Smyth, Livies of Berkeleys, i. 7o. 
" but the leprous women shall have no bells except handbells, and these shall not be hung up." It was agreed at Portsmouth (1229) that the two bells in God's House should not exceed the weight of those of the parish church, and should only ring at set hours. The Annals of Dunstable Monastery show how important the matter was considered :-

"In the same year (1293) the lepers of Dunstaple set up' a mighty bell outside the precincts of their house on two timbers ; but the prior ... brought that bell within our jurisdiction; which afterwards he restored to them yet so that they should by no means use that or any other bell for calling together our parishioners or other people."

(c) Burial Rights. - The privilege of sepulture rendered the community more independent, and secured to it certain fees and legacies. A popular institution like St. Leonard's, York, or St. John's, Exeter, derived benefits from the burial of benefactors. There is a will entered on the Patent Roll of I34I whereby a certain Vincent de Barnastapolia requested to be interred in the cemetery of St. Mark's, Bristol, to which house he left a considerable legacy. ${ }^{1}$ The conferring or denial of a place of sepulture seems to have been without rule, and was a matter of favour and circumstance. Thus St. Oswald's, Worcester, had a cemetery (probably because it was originally a leper-house), whilst St. Wulstan's had none.

(d) Worship and Burial of Lepers.-To lepers both chapel and graveyard were willingly granted. This was an early custom in England, as the Norman architecture of several chapels shows (e.g. Rochester, circa 1 100). The

1 Pat. I5 Edw. III, pt. i. m. I4. 
Gloucester lazars were granted burial rights before i I60, when they already possessed a chapel, the chancel of which still stands; the bishop's licence made the usual stipulation that none but lepers should be interred. ${ }^{1} \mathrm{~A}$ fresh impetus was given to spiritual provision for outcasts by the Lateran Council of II79. Pope Alexander III decreed as follows :-

"Seeing that it is very remote from Christian piety that those who seek their own and not the things of Jesus Christ do not permit lepers . . . to have churches or burial places of their own, nor to be assisted by the ministry of a priest of their own, we ordain that these lepers be permitted to have the same without any contradiction."

This privilege, it was declared, must not be prejudicial to the rights of ancient churches.

Digressing from the immediate subject of spiritual provision for the outcast, one point must be made clear. It is sometimes thought that the strict parochial discipline of mediæval England would insist upon the attendance of the leper at his parish church on certain occasions; others on the contrary suppose that the leper was excommunicate. The popular belief is that the Church provided for his worship the so-called "leper's window," frequently shown in old edifices. The existence of lowside-windows at such places as Bridgnorth and Spondon, where there were leper-colonies, is considered circumstantial evidence of their origin and purpose. But name and idea alike are of entirely modern growth, arising from a misinterpretation of a wall-painting at Windsor, which Mr. Street took to represent the com-

${ }^{1}$ Chron. and Mem., 33, i. 147. ii. 7 . 
municating of a leper through an aperture. Administration would have been both difficult and irreverent; the opening, moreover, is often so situated that any such act would be physically impossible. A manuscript chronicle, indeed, records how Blase Tupton, who was dwelling near St. Chad's, Shrewsbury, about the year I409, had a gallery made so that she might join in public worship :-

"Blase . . . cam by chance to be a leeper, and made the oryell which goythe allong the west side of the churche-yarde, throughe which she cam aloft to heare serveys throughe a doore made in the churche wale, and so passyd usually uppon the leades unto a glasse wyndowe, throughe which she dayly sawe and hard dayly serveys as longe as shee lyvyd." 1

Now Blase was doubtless a privileged person, being the daughter of the well-known townsman who had founded the almshouse adjoining St. Chad's; and though now and again a lazar might make his way to a churchyard to gaze upon the holy mysteries, it is certain that only those living in a community with a chapel and priest could be confessed and receive the Blessed Sacrament. Most antiquaries are of opinion that the popular theory of the object of lowside-windows is untenable.

Careful provision was made for the religious observances of the untainted inmates of a hospital as well as for the leprous. They might use the chapel except on the greater festivals when they were required to attend the parish church and make oblations there. At St. Mary Magdalene's, Bristol, the infected confessed to their chaplain, but the rest to the parish priest. No parishioner of Bedminster might attend the chapel on Sundays or

1 Owen and Blakeway, Hist. of Shrewsbury, 1825, ii. p. 257. 
festivals to receive the blessed bread and holy water, the distribution of which to other than inmates would infringe parochial rights. ${ }^{1}$ It was provided by the founder's statutes at Sherburn that on Sundays the lepers should receive "the sprinkling of holy water, blessed bread, and other things which are fitting."

(e).Free Chapels.-These were "places of worship exempted from all relation to the mother church and also from episcopal jurisdiction, an exemption which was an equivocal privilege, obtained immediately from the Crown, or appended to ancient manors originally belonging to the Crown."' 2 St. John's, Oxford, was a privileged proprietary chapel. The king withheld the right of visitation from the bishop of the diocese, who, in turn, seems to have refused to sanction and consecrate a graveyard. Henry III called in the Roman Pontiff to arbitrate; whereupon "the pope at the instance of the king commanded the Bishop of Lincoln to provide a burial ground for the hospital of Oxford, for the brethren of the hospital and for the poor dying therein, the indemnity of the mother church and of the king as patron being provided for." 3 The kings contrived to evade the Bishop of Lincoln's rightful authority. Edward I wrote to request Bishop Giffard of Worcester to confer holy orders upon a brother "because the same hospital is the king's free chapel where the diocesan ought to exercise no jurisdiction." The Close Roll of 1304 emphasizes the fact that the house was wholly independent and therefore "quit of payments, procurations and other exactions of the ordinary." 4

\footnotetext{
1 Chron. and Mem., 97, p. I73.

2 Chetham Soc. F. R. Raines, Lancashire Chantries.

3 Pat. 22 Edw. I, m. 3.

4 Close 32 Edw. I, m. $2 d$.
} 
RELATIONS WITH CHURCH AND STÁTE 203

A few royal hospitals were subordinate to the Crown and the papal see. That of Basingstoke, with its "free chapel of the king", was granted immunity from episcopal control by Cardinal Ottobon (1268). The Maison Dieu, Dover, was taken under immediate papal protection by a bull of Nicholas III (1277). A unique case occurs where the lay founder of an almshouse at Nottingham gained for it freedom from the jurisdiction of the ordinary or judges, and subjection alone "to St. Peter and the Apostolic See" (I402). ${ }^{1}$

(f) "The Cure of Souls."-Whereas the "free chapel" had no parochial obligations, there were hospital churches to which full parochial rights were attached. How or why such houses as St. Paul's, Norwich, and Armiston came to possess "the cure of souls" is uncertain; the little chapel of St. Mary Magdalene, Durham (now a ruin), was also a rectorial parish church. More curious is the fact that several leper-hospitals acquired this peculiar advantage. Thus in Northampton, although St. John's was "no parish church, but only for the company there inhabiting," St. Leonard's was a "liberty" having parochial rights, not only of burial, but of Baptism. St. Nicholas', York, required as master, "a fit clerk who shall be able to answer for the cure of souls belonging to the parish church of that hospital." The Lincoln leperhouse had similar rights.

(g) Almshouses and the Parish Church.-Many of the later almshouses were closely connected with the parish. At Ewelme, for example, the almsmen resorted to the church constantly, and their presence was regarded as so important that even absence on pilgrimage was depre-

1 Cal. Pap. Reg. vol. v. p. 489. 
cated. Those institutions which had no chaplain of their own were brought into close touch with the parish priest, as at Croydon, where the poor men went every day to the church to "here all manner divine service there to be songe and saide."

(h) Collegiate Foundations.-_Several large almshouses possessed collegiate rights or formed part of a college (e.g. St. Mary's, Leicester ; Shrewsbury, Tong, Heringby). Sometimes, as at Higham Ferrers, there existed side by side a parish church, a bede-house for pensioners, and a college for the priests and clerks.

(iii) RELATIONS WITH MONK, KNIGHT AND FRIAR

Inquiry must now be made concerning the relation between hospitals and monastic life. Although the religious orders directly influenced certain houses, others were totally unconnected with them. Canon Raine says that St. Leonard's, York, was more of a secular than an ecclesiastical establishment; he regards it as principally a lay institution, although religion was, of course, a strong element in its working. In this hospital "which is of no order" (says a Papal Letter, 1429) the master might be a layman.

\section{The Monastic Orders}

Here it must be borne in mind that we have nothing to do with the infirmary and guest-house within conventual walls. Only such institutions are included as had an individual, though it may be subordinate, existence. Some hospitals were founded by an abbot or prior ; these were chiefly dependent upon the mother-house for staff, income, food and clothing ; they had an individual dedica- 


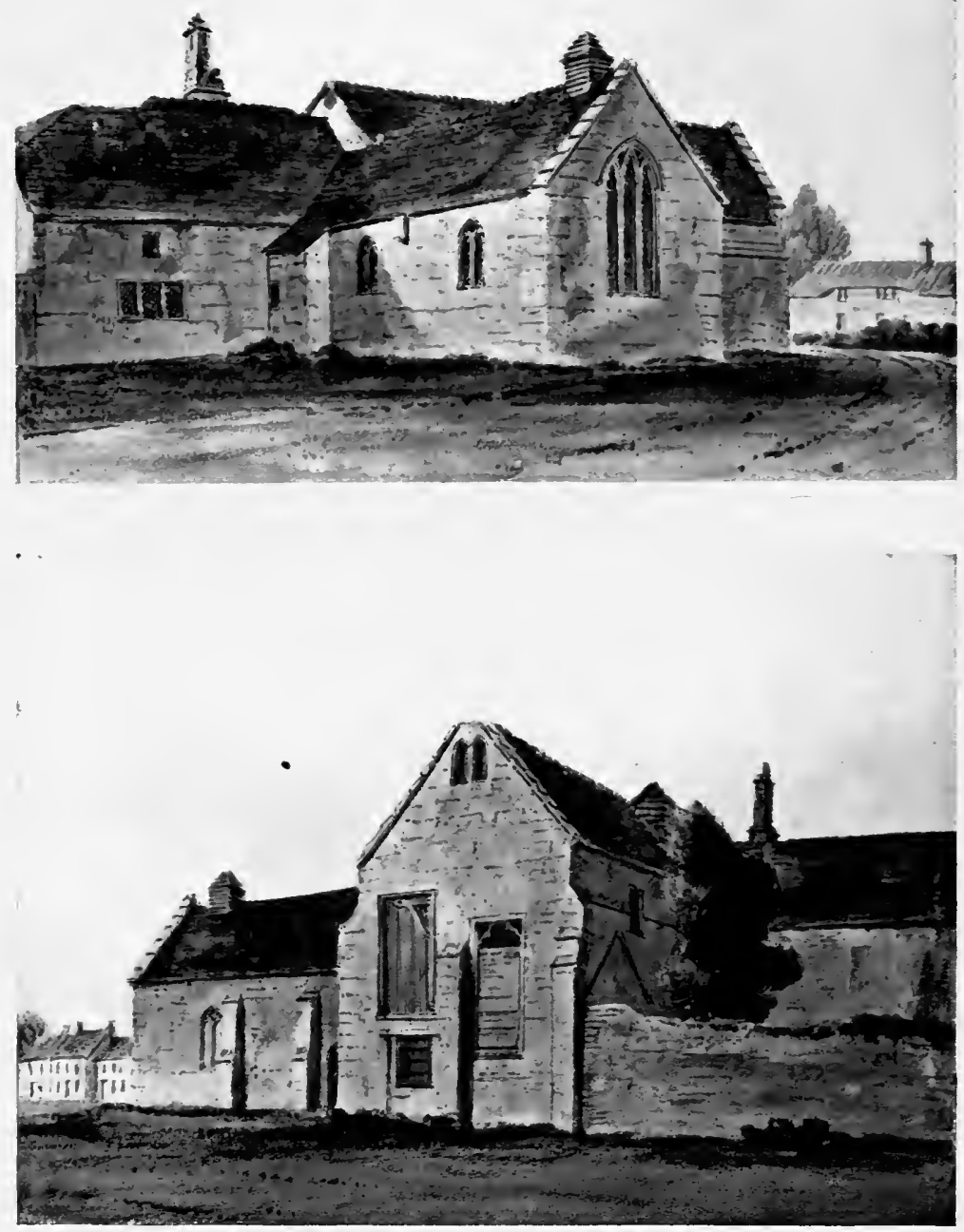

ST. JOHN'S HOSPITAI, WILTON

(a) SOUTH-EAST VIEW. (b) NORTH VIEW 
RELATIONS WITH CHURCH AND STATE 205

tion-name, but often no common seal (e.g. Bury, Peterborough). Others had a more independent existence, as indicated by the possession of separate seals (e.g. Reading, Abingdon). A community which was under the direct control of a religious house was of a more monastic type than others. There was also the hospital established by a private patron, and merely placed under the administration of some monastery; here the endowment was distinct, and the staff might or might not be members of the convent.

It is in truth often difficult to discriminate between hospital and priory ; sometimes they are indistinguishable in aim and scope. This was especially the case with the English Order of St. Gilbert; the two Gilbertine houses at Lincoln and that of Clattercot were actual infirmaries. Similarly, several foundations of the Order of the Holy Sepulchre were pilgrims' hostels served by a few canons. In certain cases hospitals developed into priories, some losing their distinctively eleemosynary character (e.g. Tandridge, Creak, Cockersand), while in others a mere change of name took place, as at Maiden Bradley. In the case of St. Bartholomew's, Smithfield, priory and hospital existed side by side, with separate organization, revenue and seals. Sometimes the titles were used interchangeably; and at Wilton the "priory" (Pl. XXIII) was merely a hospital governed by a prior.

Many institutions observed the Augustinian rule. Austin canons, according to Canon Venables, were " regular clergy, holding a middle position between monks and secular canons, almost resembling a community of parish priests living under rule." The five largest London infirmaries were served by Augustinians. 
Those of St. Thomas', Southwark, dressed after the manner of clergy of secular cathedrals and collegiate churches. The case of an Augustinian master of St. Thomas' shows that constitutions differed widely; with the Bishop of Winchester's consent, he was transferred to Sandon hospital (Surrey); but being uneasy, he applied to the pope for absolution from his vow and sought permission to live " according to the custom of Sandon." St. Bartholomew's was likewise governed by Austin canons, although a papal document states that it "has not been approved by the apostolic see and is not subject to any regular order." Elsyngspital was founded for secular clergy, but, "taught by experience", regulars were substituted within twelve years. Among other Augustinian houses may be named Newcastle (St. Mary's), Brackley, Newstead, Bridgwater, Southampton, and Dover. The Benedictine rule was followed by the staff of St, Mark's, Bristol, Strood, and of course in all hospitals under Benedictine monasteries.

\section{The Military Orders}

Of the origin and introduction of these Orders more will be said under the heading of St. John Baptist and St. Lazarus in Part Two. Here we are rather concerned with the relations which existed between the knightly brethren and hospitals in general.

(a) Knights Hospitallers and Templars.-Both Orders were the recognized guardians of travellers, and much of their work was akin to that of the hospital for wayfarers. Thus King Stephen gave the Yorkshire manor of Steynton upon Blakhommer to the Master of the Temple:- " to find a chaplain to celebrate divine service daily and to 
receive and entertain poor guests and pilgrims there, and to ring and blow the horn every night at dusk lest pilgrims and strangers should lose their way." (Richard I afterwards re-granted the land to the Hospitallers.) ${ }^{1}$ Similar hospitality was doubtless provided in all commanderies and preceptories. Although these were often called "hospitals" (e.g. at Greenham in Berks, Sutton-atHone, etc.) they are not included among the foundations enumerated in this volume.

Indeed, although these Orders exercised a certain influence upon hospitals, there was little actual intercourse. St. Cross, Winchester, was originally placed under the Knights of St. John of Jerusalem, but the connection was of short duration; the habit and cross worn by the present pensioners serve as a reminder of this fact. The patronage of St. Saviour's, Stydd by Ribchester, and St. Leonard's, Skirbeck, afterwards came into the hands of the Order. St. Thomas' hospital in Cheapside was under the Templars, but since it was not suppressed with their preceptories ( $\operatorname{circa}$ I 3 I 2), it may be classed among independent foundations. The full title remained (I340) "the master and brethren of the Knights Templars of the Hospital of St. Thomas the Martyr of Acon of Canterbury." It may be here observed that the misleading title "Commandery" often accorded to St. Wulstan's, Worcester, suggests a link with the Knights of St. John which did not exist; although, curiously enough, the masters of both the Worcester hospitals were frequently named " preceptor."

(b) Knightslof St. Lazarus.-Although, as has been said, commanderies and preceptories proper are not included, the leper-hospitals of the Order of St. Lazarus must of 
necessity find a place. The principal one was at Burton Lazars, founded by a crusading Mowbray. Two important hospitals, those of London and Lincoln, were annexed to it by Edward I and Henry VI respectively. The staff of the former are referred to (1337) as the master and brethren of St. Giles of the Order of St. Lazarus of Jerusalem in England; soon after it appeared that the master of St. Giles' was not carrying out the traditions of the charitable Knights, having "ousted the lepers and put in brethren and sisters of his Order who were not diseased." It is said that all English leper-houses were in some way subject to Burton Lazars, but in truth this was not so. It was the parent-house of cells at Carlton in Moreland, Choseley and Tilton, the property at the former place being charged with the support of four lepers, but whether maintained there or at Burton Lazars is not stated. Spondon (or Locko) was originally subordinate to a French house. In time of war, Edward III ordered that the

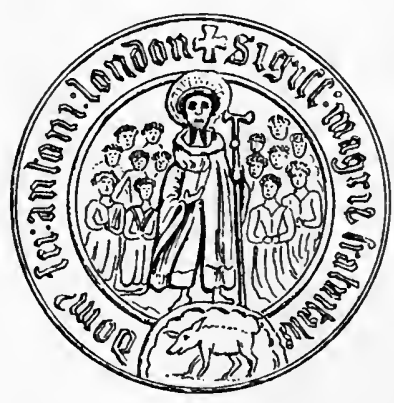

30. SEAL OF ST. ANTHONY'S, LONDON money hitherto paid over to the foreign superior, should henceforth be given to King's Hall, Cambridge (1347). That same year the master of Burton was also preceptor of "la Maudeleyne," Locko.

(c) Monks of St. Anthony.The Order of St. Anthony was likewise an offshoot of that of St. John. Two of the hospitals in honour of this saint were definitely under Antonine monks, viz. London and Hereford. St. Anthony's, London, was frequently called a 
preceptory. At first it was "alien," subject to the motherhouse of Vienne, but it afterwards became naturalized. It was stated in 1424 that on account of international war and of the Schism (i.e. in the Papacy, I378-1417) few or none of the French canons had come to England; in I43I a canon of Vienne was appointed warden, but was subsequently replaced by one of the King's clerks. St. Anthony's, York, was independent of the Order.

(d) "Alien" Hospitals. - There were other hospitals subordinate to foreign convents. The Great St. Bernard in Savoy established an offshoot at Hornchurch ; Altopassu in Italy maintained St. James', Thurlow ; the leper-house near Rye was affiliated to Fécamp. Farley, near Luton, was under Suntingfield by Boulogne; the staff were at one time brethren of the Order of St. William of the Desert. $^{1}$ The varying fortunes of the hospital near Charing Cross may be learnt from Dr. Jas. Galloway's Story of St. Mary Roncevall. Alien houses had a chequered history, being confiscated in time of war, and most were suppressed before the general Dissolution.

\section{The Friars}

By word and deed, St. Francis preached the duty of serving lepers. "He appointed that the friars of his Order, dispersed in various parts of the world, should for the love of Christ diligently attend the lepers wherever they could be found. They followed this injunction with the greatest promptitude." 2 In England, however, it would appear that there was not that close association between

1 Pat. 37 Hen. III, m. 17.

${ }^{2}$ Chron. \& Mem. 4. Monumenta Franciscana, vol. i. p. xxv., from "Mirror." 
friars and hospitals which existed in Italy. Led by national reformers, the work of tending lazars had long been carried on. The great majority of refuges for them were founded between 1084 and 1224 before the brethren arrived in this country. Speaking of the friars' labours, Green says that "their first work lay in the noisome lazarhouses," and Brewer alludes to "their training for the leper-hospitals," but there seems to be little or no definite record of such service in this country. There were, however, many individual outcasts, who had not the comfort of the hospital, and to these the new-comers may have ministered.

A few hospitals-not for lepers-were indeed appropriated to the Mendicant Orders, or served by them. The association is of the slightest, and usually of short duration. Thus the Bamburgh spital had probably disappeared when Richard II gave its chapel to the Friars Preachers, "in part remuneration for a cross made from the wood of the Holy Cross presented by them to the king " (1382). The Crutched Friars once had some connection with Holy Cross, Colchester. The relation between hospitals and the Bethlehemite and Maturin Orders was closer, and dated from the friars' first century of work. St. Mary of Bethlehem in London was founded upon land belonging to that community, members of which were its original officials. Deeds of I 348 call them "the Order of the Knighthood of St. Mary of Bethlehem"; possibly the link with the Holy Land led them to adopt this military title. Maturin or Trinitarian houses were more akin to the infirmary and pilgrim-hostel than were any other friaries; one-third of their revenue was spent in relieving local poor. Their houses (often called "hospitals") are 
not included in the present volume, save when they were not merely friaries. For example, Stephen, Archdeacon of Wilts, who was rector and patron of Easton Royal, founded there a house for indigent travellers (1246). ${ }^{1}$ The master was a Trinitarian brother, but he was presented by the patron, to whom he and the other priests owed obedience; in 1287 the same man was minister of Easton and of the house of St. Mary Magdalene by Hertford. St. Laurence's, Crediton, was served by the Hounslow Maturin convent. The almsmen of God's House, Donnington, worshipped in the adjacent Trinitarian Chapel.

To recapitulate : the hospital was a semi-independent institution, subject to royal and episcopal control in matters of constitution, jurisdiction and finance, yet less trammelled in organization than most religious houses. It formed a part of the parochial system, and had also links of one kind and another with monastic life.

${ }^{1}$ Chron. and Mem., 97, pp. 301-6. 


\section{CHAPTER XV}

\section{DECLINE OF THE HOSPITALS}

"Many hospitals . . . be now for the most part decayed, and the goods and profits of the same, by divers persons, spiritual and temporal, withdrawn and spent to the use of others, whereby many men and women have died in great misery for default of aid, livelihood and succour."

QUCH is the preamble to the Statute for the reforma$D$ tion of hospitals (1414). Responsibility for use and abuse rested with the patron, but more immediately with the warden into whose hands he committed the administration. If this chapter is necessarily devoted to the seamy side of hospital life, let no one suppose that officials were all bad, or even all careless. There were men "in whose purity of conscience the king confides," chosen for " probity, character and knowledge." Yet upright, thrifty and faithful wardens were far from common, and it does not sound hopeful when one and another was appointed "during good behaviour."

Abuses by Patrons.-On the whole hospitals were welltreated by their patrons. Their first founders especially showed both generosity and care, but in many cases the descendants became indifferent and neglected that careful selection of wardens which would have done much to avert evils. But one of the outstanding grievances against patrons was their claim to "maintenance" free of charge whenever they desired it. They and the official "visitors" 
sometimes used these institutions as hostelries for themselves and their retinue. In the regulations of St. John's, Bridgwater (1219), which the bishop drew up for the manorial lord, it is said :- "We expressly forbid that either the rich or powerful, whether of diocesan rank or ordinary people, or the ministers and stewards of the patron, should lodge, sojourn or be entertained and be a burden." It was rather to be a Domus libera Dei, founded only for the poor of Christ. The kings exercised their right to lodge at the Maison Dieu, Dover (see Frontispiece), on their journeys to France. The hospital made a complaint, however, when Edward, eldest son of Edward I, was suddenly lodged there with the chancellor and their suite by the marshal of the household.

The "corrody" was an even greater, because a permanent, burden. The privilege of board and lodging was frequently given away by patrons as a reward for service, but sometimes it was created by grant of the community itself, or sold by greedy officials. This grievance marks a period of decline. Whereas Henry III pensioned his nurses from the Exchequer, Edward I imposed upon hospitals the maintenance of old servants of the Crown, sending a former damsel of the queen-mother and her man-servant to Ospringe to be maintained for life. He appointed only to houses of royal foundation, but his son went further, demanding admission, for example, to the episcopal hospital at Worcester. Caring little that Bishop Wulstan was the founder, Edward II declares that " the hospitals in the realm were founded by the king's progenitors for the admission of poor and weak persons, and especially of those in the king's service who were unable to work." An order is sent to Oxford to admit the king's 


\section{MEDI $Æ V A L$ HOSPITALS OF ENGLAND}

chaplain to St. John's, finding him and his clerk food, drink, robes, shoe-leather, wood, litter, and a fitting dwelling-place. The Statute of $1314^{-15}$ condemned the tyrannous practice of burdening religious houses in this manner.

Edward III was checked in the first year of his reign by a more forcible enactment entitled, "There shall be no more grants of Corrodies at the King's Requests." It states that many have been hitherto grieved by such requests "which have desired them by great threats, for their clerks and other servants, for great pensions and corrodies." Edward declares that he "will no more such things desire, but where he ought"; and henceforth letters patent of this character are less numerous. Where the demand was considered unjust, resentment sometimes took the form of violence. Thus in 1341 the master of St. John's, Oxford, with eight men, assaulted and imprisoned a certain Alice Fitz-Rauf; they carried her off by night with veiled face, threw her into a filthy place, and so left her, having tảken away the writ requesting her reception into the hospital. More often a mild protest was made by officials; they acquiesce "of mere courtesy," but beg to be excused in future. Forgetting that the courtesy of one generation may be the custom of the next, the much-abused York hospital submits ( 133 I) provided the demand shall not form a precedent. Fifty years later, a strong-minded master of that house refuses to admit a man at King Richard's command, replying that it was "founded for the bed-ridden and not for the able-bodied."

Cases of oppression "by divers persons spiritual and temporal" are recorded. Even the mitred abbot of St. 
Albans was more than once at fault. In 1223 the pope commanded him not to lay burdens on the leper women of St. Mary's by virtue of patronage; and an early Chancery Proceeding shows that another abbot had oppressed the poor sick brethren and feeble folk of St. Julian's. The Rolls of Parliament reveal that an abbot of Colchester (temp. Edward I) withheld the accustomed pension and tithe from "les povere freres malades" of St. Mary Magdalene's ; by cunning and force he abstracted their common seal and muniments, and flung their charters into the fire. At Durham the inmates of St. Mary Magdalene's begged redress of grievances (temp. Edward II). Some previous almoner of the priory, they declared, had defrauded them of food and clothing; he had even obtained their muniments by bribing the guardian with the gift of a fur cloak. The prior and convent, however, endorse the petition : "but be it known that this complaint does not contain truth for the most part." 1

Monastic houses were not as zealous as formerly in the service of the needy. The great abbey of St. Augustine, Canterbury, had built and maintained the daughter hospital of St. Laurence; but in I34I this is declared to be of a foundation so weak that it falls very far short of what is sufficient for their sustenance. The lay patron of West Somerton leper-house entrusted its custody to Butley Priory on condition that the usual number of inmates were maintained. A later prior withdrew the victuals and reduced the revenue from $£ 60$ to ro marks, until after twenty years of neglect, it was said (I399) "the place where the hospital of old time was is now desolate."

1 Surtees Soc., 95, p. $23^{8}$. 
Reading Abbey, which once cherished its charitable institutions, treated them ill in later days. When Edward IV travelled through the town (I479), wrongs were reported to him, including "howsys of almes not kept"; the abbot had appropriated the endowments and destroyed the buildings. The prior and convent of Worcester themselves suppressed St. Mary's, Droitwich, in 1536, and "expelled the poor people to their utter destruction."

$\checkmark$ Contention about patronage was another very serious evil, causing continual litigation. The representatives of the first founder, and those of subsequent benefactors, fell out as to their respective claims. The Crown was ever ready to usurp patronage, on plea of foundation, wardship, voidance of See, etc. Thus from generation to generation, St. Leonard's, York, was claimed by the Crown, whereas much of its property had been a gift to the clergy of the minster by Saxon and Norman sovereigns. A jury of 1246 decided in favour of the Dean and Chapter against royal patronage, but subsequently the Crown recovered it once more. ${ }^{1}$ Such disputes were not limited to words. The See of Winchester being void, Edward II nominated a warden to St. Cross, afterwards declaring that he had recovered the presentation against the bishop. The writ was seized and the arm of the king's messenger was broken in the contest. The practice of keeping $J$ important posts unfilled was another abuse. A petition made in Parliament concerning this evil (I314-15) ${ }^{2}$ maintained that hospitals were impoverished and destroyed during vacancy by temporary guardians, in reply to which, remedy was promised. The warden of St.

${ }^{1}$ Chron. and Mem., 7r, iii. 162-5.

2 Rot. Parl., i. 303. 
Nicholas', Pontefract (in Queen Philippa's patronage), complained that during the last voidance, goods had been lost to the value of $£ 200$.

Patrons neglected personal supervision. The founders of Ewelme inserted in the statutes one clause concerning the imperative duty of visitation by their representatives; for, in their experience :-

"Diuerse places of almesse had been yfounded of grete pite and deuocion to be rewled by many ryght resonable rewlis and statutis . . . yitte for defaute of dew execucion of the same and of dew uisitacion and correccion of the brekers of them such sede howses haue bene by myslyuyng and negligence ybought to grete heuynesse and at the last to grete desolacon."

Abuse by Wardens and Officials.-Doubtless wardens were responsible for the chief part of maladministration. Misrule by incapable and untrustworthy men was as frequent as it was fatal. The masters and their deputies had not the moral qualities of wisdom and honesty to fit them for so difficuit a post. Master Hugh, warden of St. John and St. Thomas' at Stamford, reduced it to such a condition that he petitioned for liberty to resign (1299). The abbot of Peterborough committed it to a neighbouring rector until "through the blessing of God its most high guardian, it shall arrive at a more flourishing estate." After four months, however, Hugh was restored to office, and matters became worse. He defrauded the poor of their alms, locked up the rooms where strangers and sick should have been accommodated, and neglected the chapel. Meanwhile the mild abbot died; a new superior interfered and Hugh was again deposed. But having enlisted the mediation of the bishop and archdeacon, he, after a solemn oath of "reformation of all my excesses," 


\section{I8 MEDIÆVAL HOSPITALS OF ENGLAND}

was actually entrusted for the third time with the wardenship. ${ }^{1}$

A more interesting figure is the incorrigible Thomas de Goldyngton - warden of St. Nicholas', Carlisle, and St. Leonard's, Derby-who appears upon the roll as a flagrant offender, although a keen medical man. In I34I he is perilously near forfeiting his Crown appointments for acting as leech to Scottish rebels; in 1348 he " exercises the office of the surgery of the commonalty [of Derby], neglects the duties of the wardenship and has dissipated and consumed the goods and alienated the lands to the great decay of the hospital." Thomas had been previously warned after sundry visitations, for instance ( 1343 ): "the king commands the master at his peril to observe all the rules, constitutions and ordinances of the hospital [Carlisle] in their entirety." 2 It seems doubtful whether this energetic person ever became an exemplary house-surgeon and physician at that mediæval royal infirmary of Derby.

The staff like the warden defied authority, as is shown by visitation reports. The brethren and sisters of St. Nicholas', York, were cross-questioned by the jury. The general evidence was that they were living as they pleased, carrying on business, omitting services, and wandering. The sisters mostly confessed to knowing nothing, but one deposed that the brethren were disobedient; whilst the chaplain reported that "all are disobedient and do not observe humility." 3

Community life was doubtless trying to the temper, and there were occasionally disturbances serious enough

1 Peck, Annals of Stanford, ix. 32. $\quad{ }^{2}$ Pat. ${ }_{17}$ Edw. III, pt. i. m. ${ }_{25} d$.

3 Yorks. Arch. Assn. Record Series, xxiii. Inq. ii. p. 123 et sq. 
to reach the king's ears. Throughout the reign of Edward II, the name of Nicholas de Staple occurs periodically on Close Rolls. Brother Nicholas first appears as an official of the Maison Dieu, Ospringe, who had become intolerable to his fellows. The king, in response to an appeal, orders him to transfer himself promptly to St. John's, Oxford, to remain until further notice: "the king wishing to avoid damages and dangers and dilapidations of the goods of the hospital that, it is feared, will arise if Nicholas remain there any longer, on account of the dissensions between him and the other brethren." The disturber of the peace retires from parchment publicity for thirteen years, when an order is sent to retain him for life as a chaplain-brother. Finally, after a visit of twenty years to Oxford (whither he was "lately sent to stay for some time"), the life-sentence is remitted, and he is allowed to return to Ospringe. Two years before Nicholas vanishes, Oxford becomes a reformatory for another Ospringe brother, Thomas Urre, whom the king caused to be amoved on account of bad conduct, and because he excited all manner of disputes. Small wonder that a subsequent visitation of St. John's should reveal misrule, dissolute living, disobedient and quarrelsome brothers, sisters and ministers.

A few years later, the household at Newton in Holderness is in a like condition, witness the following entry :-

"Commission .. to make inquisition and certify the king whether, as he is informed, William Lulleman, chaplain, (who pretends to be deaf and for that cause has at the king's request been admitted to his hospital of Newton to have his sustenance there,) is sometimes lunatic and mad, and daily stirs up dissension between the brothers and sisters of the hospital, and 
so threatens them and the poor residing there, and bears himself so importunately that he cannot have his conversation among the master and brethren, nor can the brethren and sisters live in peace while he is conversant among them."1

The offender was then removed, but imagine with what feelings the warden of Newton received the king's messenger four years later, and unfastening the roll read as follows :-

"To the master and brethren, etc. Request to admit William Lulleman of Bernleye, chaplain, who is detained by severe sickness, and to give him maintenance for life." 1

Edward III, wishing to guard against the reception of unworthy men, forbade the master of Ospringe to admit any brother without special orders; and he removed one for notorious excesses and disobediences. ${ }^{2}$ St. Thomas', Birmingham, was found in a miserable plight, because "vile reprobates assumed the habit that they might continue their abominable lives sub velamine Religiositatis, and then forsake it, and cause themselves to be called hermits." 3 No clerk could be ordained without a "title," but hospitals were apt to offer this to unproved persons, which was fatal to the tone of the household. St. John's, Ely, was usually governed by clergy under rule, but in 1454 the Bishop of Dunkeld was collated to the mastership, because no regulars could be found capable of effecting its recovery from ruin and wretchedness.

$J$ The decline of hospitals was largely owing to the fact that many wardens were non-residents and pluralists. It was actually possible to represent one as having died;

1 Pat. 16 Edw. III, pt. ii. m. $22 d$. Close 20 Edw. III, pt. i. m. $4 d$.

2 Close 6 Edw. III, m. $29 d$.

${ }^{3}$ Lichfield Reg , 1344, Wm?. Salt, Soc. i. 
several appointments are revoked because the master is discovered to be "alive and well," so that it was by " "false suggestion that the office was reported as void." Meanwhile such men were being supported from the hospital funds; an absentee governor of God's House, Southampton, took his share of the best of its goods, living at its expense in a private mansion in the country. The king nominated to Crown foundations men constantly employed on service elsewhere, and a mastership was a mere stepping-stone to preferment.

Not only did clergy hold a benefice and hospital together, but sometimes one man held no less than three hospitals. About 1350, the "lack of clergy by reason of the pestilence" was a serious matter. On this plea the Bishop of Winchester appointed his nephew, a youth in his eighteenth year, as warden at Portsmouth; before long the latter held also the mastership of St. Cross, an archdeaconry, and two canonries. Such practices, begun of necessity, were continued in the century of lax Church life which followed. "One of the boys of the king's chapel" was given the wardenship of Ilford hospital in 1405. The mischief that happened through the plurality and non-residence of parochial and hospital clergy was at length insisted on in Parliament, when in response to the petition of the Commons, reformation was ordered (1425). St. Nicholas', Pontefract, had been "ruled by secular masters, some of whom hardly ever went there"; but in $143^{8}$ the management was undertaken by the prior of Nostell.

Dispensations from Rome were answerable for many bad appointments, as is shown by entries in the papal registers of 1427. The master of Newton Garth, for 
example, was Thomas Bourgchier-"who is in his sixteenth year only, is of a race of great nobles, and holds the said hospital, without cure, wont to be assigned to secular clerks" ; moreover it was granted that after his twentieth year he might hold two houses, resigning or exchanging them at will. This youthful official seems to have been following in the footsteps of his ambitious namesake and contemporary, who secured constant promotion and finally "wore the mitre full fifty-one years," and died Primate and Cardinal. Well might the founders of Ewelme almshouse provide that, if possible, the master should be "a degreed man passed thirty winters of age." $J$ Money was at the root of most ill-doing. Among the articles concerning ecclesiastical reform set forth by Henry $\mathrm{V}$ and published by the University of Oxford is one (No. 42) De Reformatione hospitalium, stating that the poor and needy of the hospitals have been cast out, whilst the officials convert the goods to their own purposes. The roll of "evil dispenders" is a long one.

St. Leonard's, York, is a notable example of the reduction of income by abuse and misfortune. In Canon Raine's lecture upon its history, he gives extracts from its account-books, which are here given in brief. The receipts for the year $1369-1370$ amounted to over $\mathcal{E}_{1,369}$, the expenditure to $£_{938}$. By 1409 the income had fallen to $£_{546}$. The number of patients declined proportionably, falling from 224 in 1370 to 199 in 1377 ; and though it rose to 206 in 1423 , it was reduced to 127 in 1462 . From these facts several conclusions are drawn. The industrial and self-supporting character of the hospital was relaxed because war and pestilence left England shorthanded; land was uncultivated and the hospital lost its thraves of 
corn. All this is true, but much of the misery lay at the door of the wardens. One unscrupulous master made 500 marks yearly by the traffic in pensions; in 1391 the hospital was "charged with corrodies" sold and given, oppressed by the excessive expenditure of its heads, and laden with debt, so that its remaining revenues are insufficient to support master, brethren and sisters or the poor and needy inmates, whereby the hospital is threatened with extinction." On another occasion the poor "Cremettes" (as the inmates were called ${ }^{2}$ ) made a petition to the king because their master had put the chalices and ornaments of the hospital in pledge, etc. There are preserved in the Record Office a number of documents relating to visitations of this house; these confirm the evidence of contemporary Patent Rolls.

At Gloucester the sale of pensions, jewels, corn, and even of beds, is reported; bed-money was extracted from the poor (20s. from one, and $6 s$. $8 d$. from another, who had lost his legs). Part of St. Bartholomew's was unroofed, pigs had access to it, the inmates lacked food and clothing, whilst the utmost depravity prevailed in the household (1380). One extravagant warden of God's House, Portsmouth, spent eight or nine hundred marks yearly, yet kept no hospitality :-

"butt the master will not obey to that and so seruys the powr pepull at hys pleysure, that ys, with uere cowrse bred and smaller drynke, wiche ys contrary to all good consyens."

When a warden was to be elected to the Maison Dieu, Dover (1533), a certain John de Ponte announced to Cromwell:- "The master is dead, and a great benefice

$$
{ }^{1} \text { See p. } 213 . \quad 2 \text { See p. } 242 .
$$


is fallen unto the king, with which you may oblige your friends or take it yourself, and I will serve the same." If such was the prevalent tone of those in authority, it is small wonder that Brinklow wrote about the year 1536 :"I heare that the masters of your hospitals be so fat that the pore be kept leane and bare inough." There is strong censure upon the administration of the London hospitals in the petition for their re-foundation ( 1538 ); they had been provided to relieve the poor, but " nowe a smalle nomber of chanons, preestes and monks be founden for theyr own synguler proffytt lucre and commodytye onely," and these do not regard-"the myserable people lyeing in the streete offendyng every clene person passyng by the way." About the year 1536, Robert Copland, in The hye zoay to the Spyttell hous, says :-

"For I haue sene at sondry hospytalles That many haue lyen dead without the walles And for lacke of socour haue dyed wretchedly Vnto your foundacyon I thynke contrary. Moche people resorte here and have lodgyng, But yet I maruell greatly of one thyng That in the nyght so many lodge without."

Many charitable institutions were in a languishing condition. Some, of course, had never been endowed, whilst others had only slender resources. Frequently the depreciation in money had caused a shrinkage in a onceadequate revenue; sometimes the land had been filched away by neighbouring landowners. Writing of Sherborne, Leland observes that the almshouse "stondith yet, but men get most of the land by pece meales." $\mathrm{He}$ notes the dilapidated state of houses here and there; at Beverley "ther was an Hospital of St. Nicholas, but 
it is dekayid," and at St. Michael's, Warwick, "the Buildings of the House are sore decayed." The condition of St. John's, Lutterworth, described in the Certificate of 1545, was such that no hospitality was kept $;^{1}$ there were " noe pore men within the same Hospytal remaynyng or inhabityng; and the house, with the chapel, gretly in decaye and ruyne." At Stoke-upon-Trent, it appeared that there was a priest called master of St. Loye's hospital, but he did not know to what intent or deed of charity it was founded. ${ }^{2}$ Frequently the possessions had dwindled until they barely sufficed to support a chaplain, and no charity was distributed. The Certificate of St. John's, Calne, states that abuse is apparent, because there are no paupers, but all profits go to the master ; these, however, only amounted to $66 s .5 \mathrm{~d}$. St. John's, Bedford, was worth 20s. a year, and "there is found neuer a poore person nor hath not ben by the space of many yeres." In some cases the foundation had entirely dropped out of existence, as at Winchcombe, where Leland notes that " now the Name onely of Spittle remaineth."

The Statute of I545 stated that it was well known that the governors and wardens of hospitals, or the greatest number of them, did not exercise due authority nor expend the revenues in alms according to the foundation. The avowed object of the Act was " to reduce and bring them into a more decent and convenient order."

1 It had been declining for above a century ; a Papal Letter (1435-6) states that for fifty years, on account of the diminution of its fruits, etc., there were no brethren in the hospital.

2 Aug. Off, , Chantry Certificate 40 (36). 


\section{CHAPTER XVI}

THE DISSOLUTION OF RELIGIOUS HOUSES AND ITS EFFECT UPON HOSPITALS

" The hospital . . . is like to go to utter decay. . . . For my owen part I think often, that those men which seek spoil of hospitals . . . did never read the trventy-fifth chapter of Matthew; for if they did, and believed the same, how durst they give such adventure?"

(Archbishop Grindal, letter to Burleigh, 1575.)

$\mathrm{W}$

HEN the Primate wrote thus to the Lord Treasurer, he added :- " that if any hospitals be abused (as I think some are) it were a more Christian suit to seek reformation than destruction." Although the decline of some hospitals led to the dissolution of many, it by no means follows that such a course was justifiable.

$\checkmark$ Speaking generally, charities which had outlived their usefulness had already been suppressed before the general Dissolution and their property transferred to other purposes. The leper-houses of Windsor and Huntingdon, for example, were evidently deserted and ruinous when they were annexed to Colleges at Cambridge (1462); and the hospitals of Romney, Aynho and Brackley had been appropriated to Magdalen College, Oxford (I48I-5) because they were no longer carrying out the founder's intentions. St. John's, Reading, and St. Bartholomew's, Bristol, had already been converted into schools, the latter as recently as 1532 .

In most of the existing hospitals good work was being 226 


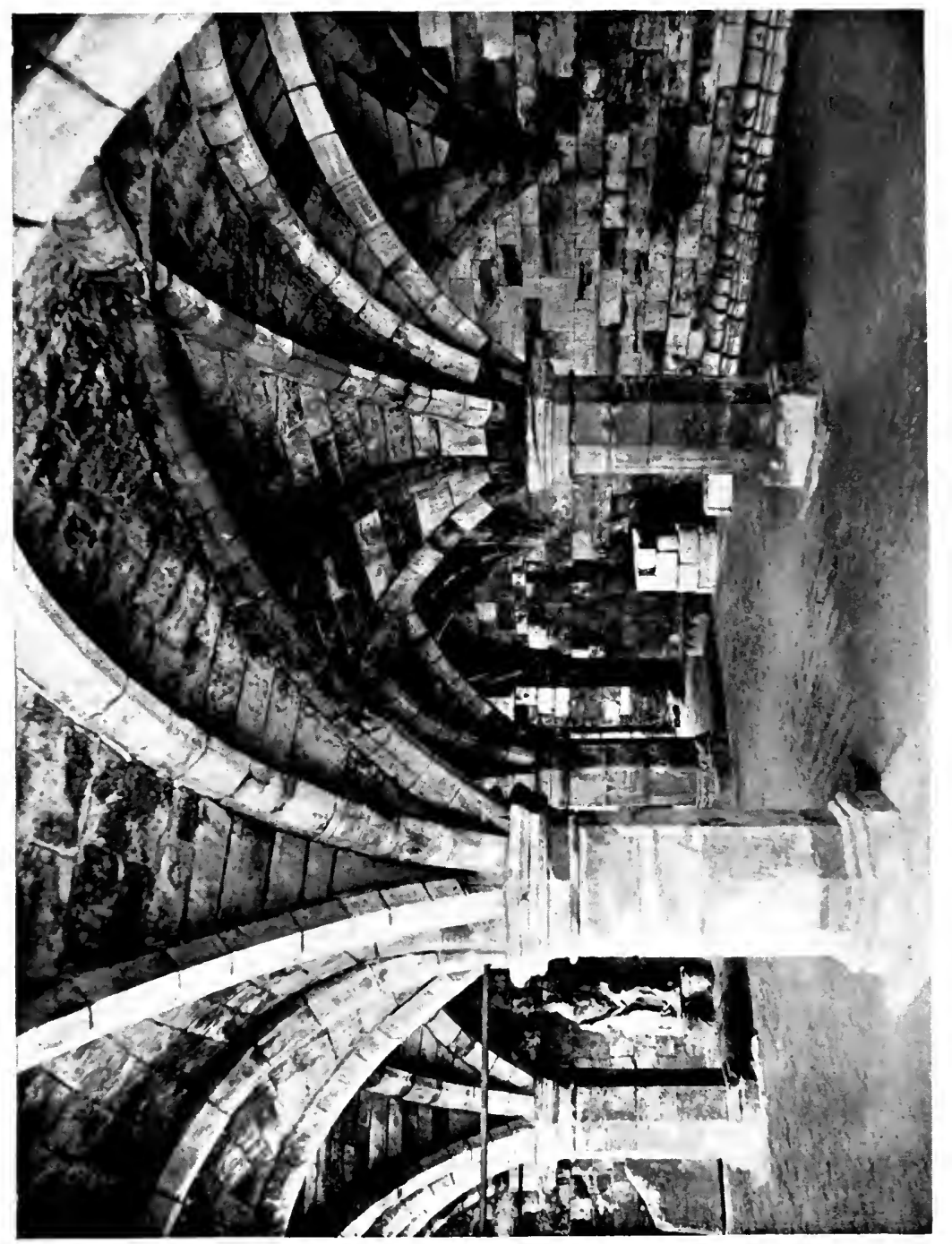

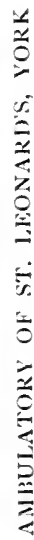


done ; the Valor Ecclesiasticus and Chantry Surveys show that money was expended upon useful charities. Layton's report of St. Mary's, Leicester, that it was "well kept and honest men therein" was true of many almshouses throughout the land. Where evils are complained of, they were not so much breaches of morality on the part of the household, as neglect and wastefulness in administration. A carefully-regulated commission to inquire into matters of finance could well have rectified abuses in ill-managed institutions. Had justice and magnanimity held sway instead of rapacity and selfishness, the old houses of mercy would have been refreshed and their utility doubled just when a far wider charity was needful on account of the annihilation of benevolent monasteries. This was done in some foreign countries. Through the protection of Gustavus Vasa, Swedish lazar-houses survived the Reformation. In Denmark, Dominican and Franciscan friaries were transformed into hospitals, and the leper-houses subsequently became places of isolation for contagious diseases. In France, where there was no ecclesiastical upheaval, decayed hospitals were reformed ( 1545 ) and put under the control of the bourgeois class ( I 56 I).

The various Acts of Henry VIII's reign show that the oppression of the poor was not at first intended. The Statute for the suppression of vagrancy (1530-I) approved the charitable work of hospitals. One clause in that of I535-6 required that those who entered into possession of the lands of religious houses should provide hospitality and service for the poor as of old. In the draft for the bill of 1539 the Commons proposed that the greater monasteries not dissolved should build bede-houses in which 
to maintain for life ten poor men over sixty years of age.

Here, indeed, was a golden opportunity to increase the benevolent institutions of the country. Much that was becoming useless might have been transformed into a great and permanent benefit. Charitable relief might have been placed under public control upon a sound religious and financial basis. But reformation too often proved to be mere destruction, as "Mors" shrewdly remarks :-

"Your pretence of putting downe abbeys, was, to amend that was amisse in them. ... It is amended euen as the deuell amended his dames legge (as it is in the prouerbe) whan he shuld haue set it ryght, he bracke it quyte in peces." 1

It is evident that the monastic system had been gradually losing its hold on the nation. The idea of partial disendowment had also been working in men's minds, no one foreseeing that the plunder of rich foundations would ultimately lead to the robbery of poor people. In I4 Io the Commons petitioned in the Parliament of Westminster that the surplus wealth of ecclesiastics might be transferred to other uses, and that destitute persons might benefit by the provision of new hospitals. Henry IV replied that he would deliberate upon the matter, and although no revised appropriation of funds then took place, he did afterwards suppress certain alien priories, a policy which was followed by Henry V. In 1414 the above proposal was renewed in the Parliament of Leicester, but the astute Chichele undertook that the clergy should supply money for the wars :- "a thrust was made at all 
Abbies," says Fuller, "which this Archbishop, as a skilful Fencer, fairly put by." In the following century Wolsey, not anticipating the wholesale destruction which was to follow, sought to dissolve certain small priories in order to assist educational institutions (1523). A contemporary writer observes that by this precedent "he did make loose in others the conscience towardes those houses."

The people desired the reformation of hospitals and an extension of the system. Sir John Oldcastle's bill in I 4 I4 proposed the foundation of new institutions each to be endowed with one hundred marks yearly. The Commons suggested that money now wasted by churchmen might maintain a standing army and also suffice to provide :-

"an hundred houses of alms, to the relief of poor people ... with oversight of two true seculars unto every house. And also with provision that every township should keep all poor people of their own dwellers, which could not labour for their living, with condition that if more fell in a town than the town could maintain, then the said almshouses to relieve such townships." 1

A similar plan was proposed by Brinklow about the year 1542. He probably uttered what was in the minds of many when he suggested measures for the re-distribution of ecclesiastical wealth. One chapter of his Complaint contains "A Godly aduisement howe to bestowe the goodes and landes of the Bisshops \&c. after the Gospell, with an admonytion to the Rulers, that they loke better upon the hospitals." A part might, he thought, be given in alms to the blind, sick and lame, to free schools, or to needy maidens for marriage portions, etc. Poor-

' Fabyan, Chronicles, ed. I811, p. 578. 


\section{MEDI EVAL HOSPITALS OF ENGLAND}

houses and parish doctors should be provided, and he adds :-

"Item, part of these forsayde goodes may be employed to this use, that in euery hundreth, good towne or citie, certein houses be mainteined, to lodge and kepe pore men in, such as be not able to labour, syck, sore, blind, and lame, and euery one of them to haue wherwith to liue, and to haue poore whole women to minister unto them. . . . Let Physycians and Chyrurgians be founde in euery suche town or cyte, where such houses be, to loke uppon the Poore in that Town, and in all other Joyninge unto it and they to lyue uppon their stipend onely, without taking any penny of their pore, uppon payne of lousing both his eares and his stipend also."

Henry VIII proposed to the Commons very much what their predecessors had suggested to Henry IV and Henry $\mathrm{V}$, omitting, nevertheless, the clause relating to a hundred new almshouses. If they would grant him the religious houses, these should not be converted to private uses, and the army would be strengthened and taxes reduced. No provision, however, was made for these projects, but the king was put in possession of the monasteries, and then of the chantries, hospitals and free chapels. The Parliament, in granting the hospitals to the king and his heirs for ever, expressed its confidence in the royal benevolence towards them and desire for their improvement :-

"The Kinges Highnes of his most godlie and blessed disposicion entendeth to have the premisses used and exercised to more godlie and uertuouse purposes and to reduce and bringe them into a more decent and convenient order, for the commoditie and welthe of this his realme and for the suertie of the subjects."

When the king went to prorogue Parliament, he seems to 


\section{DISSOLUTION OF RELIGIOUS HOUSES $23^{1}$}

have alluded in his "Oration," as set forth by Foxe, to the above expression of their hopes and wishes :-

"Surely if I, contrary to your expectation, should suffer the ministers of the church to decay ; . . . or poor and miserable people to be unrelieved; you might say that $I$, being put in so special a trust, as I am in this case, were no trusty friend to you, nor charitable man to mine even-christened, [fellow Christians], neither a lover of the public wealth, nor yet one that feared God, to whom account must be rendered of all our doings. Doubt not, I pray you, but your expectation shall be served more godly and goodly than you will wish or desire, as hereafter you shall plainly perceive."

But although Henry VIII thus professed to remember the higher court of justice, his conduct gave no evidence of it. Brinklow ventured upon a reminder in A Supplication of the Poore Commons, ${ }^{1}$ published shortly after the king's speech :-

"We beseke you (most deare Soueraine) euen for the hope you haue in the redemption of Christ, that you call to remembraunce that dreadfull daye, whan your Highnesse shall stande before the judgement seat of God in no more reputation then one of those miserable creatures which do nowe daylye dy in the stretes for lack of theyr dwe porsion."

He continues to point out in forcible language that the portion due by God's ordinance to poor impotent folk, the lame, blind, lazar and sore members of Christ-who once had been lodged in hospitals and almshouses-is now given by the king and his nobles to "reward those gnatonical elbowhangers, your chaplaines." In spite of the vehement abuse of parasitical clergy in which the above writer indulges, it was in the main lay-people rather than churchmen who divided the spoils. Fuller-who quaintly

1 Early Eng. Text Soc., 77. 


\section{MEDI $E V A L$ HOSPITALS OF ENGLAND}

writes that "this king made three meals, or (if you will) one meal of three courses, on Abbey-lands, besides what Cardinal Wolsey (the king's taster herein) had eaten beforehand"-goes on to say "yet surely more tendernesse was used to hospitalls," and finds "very few of them finally suppressed." But hospital endowments did certainly form a substantial dish at Henry's feast, to which many royal favourites were bidden. Some fell with the smaller priories (1536), a few with the greater houses ( 539 ), and others were extinguished under the Act for dissolving chantries, free chapels, hospitals, and guilds (1545); a further Act of confiscation marked the first year of Edward VI's reign (1547). In some places charities were indiscriminately swept away. A manuscript history of Gorleston records, for example, that "Henry VIII ordered that all the premises of . . . the Hospitals of St. James, St. John, St. Bartholomew, St. Luke, and the church and hospital of St. Nicholas . . . should be sold." No consistent plan was followed, but-whether under ecclesiastical or lay control-charities were destroyed or spared at will. Speaking generally, institutions in private hands were suppressed, those in the possession of corporate bodies, retained.

Few houses of Crown patronage escaped. The Commissioners, announcing to Cromwell (1537) the dissolution of certain northern monasteries, add:- "We have also altered the howse of Sancte Leonerdes in Yourke, after suche ordre and fassion as we trust shall appeir to your lordship to be to the kinges honour and contentacion." 1 In truth the alteration meant annihilation for St. Leonard's; and St. Nicholas' hospital in the same city also disap-

I Camden Soc., 1843, p. 166. 


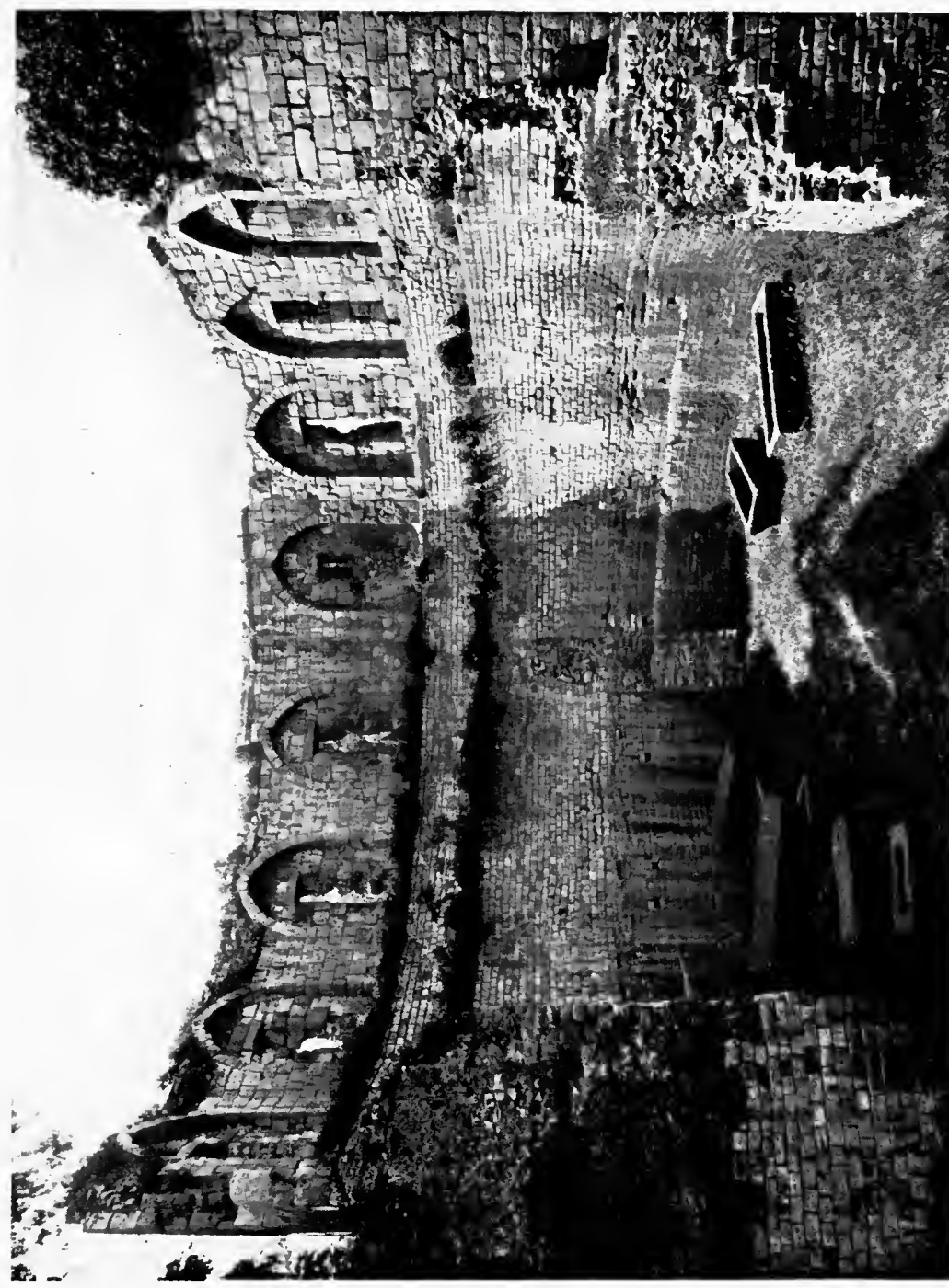

: 

peared. In London, the Savoy, fresh from the hand of the builder, was dissolved. The sisters of St. James', Westminster, surrendered (receiving life-pensions), whereupon " the king builded there a goodly Mannor, annexing thereunto a Parke." 1 The Maison Dieu, Dover, a rich foundation with good buildings near the quay, was declared suitable for a victualling yard (1544) which it eventually became.

Hospitals attached to a cathedral or see were usually, but not always, spared. In the bishopric of Durham, for example, the houses of Sherburn and Greatham survived, but neither Kepier nor the bishop's hospital at Northallerton. God's House, Portsmouth, was surrendered and became an armoury; in the Library of the Society of Antiquaries is a document of 1547 concerning "Munycions. within the Churche at Goddeshouse." 2 St. John's, Ely, was spared, yet only for a while. The episcopal hospitals at Bath and Norwich remained in use, but under the municipality.

If directly dependent upon a monastic house, the fate of a hospital was practically sealed. Take, for instance, the case of St. James', near the gate of Lewes Priory. From the monastery now demolished thirteen men and one woman had had all their living; wherefore Peter Thompson and the bedefolk begged relief (1538). ${ }^{3}$ Hospitals of lay-foundation which had been subsequently placed under monastic supervision, but with distinct endowments, fell as forming part of the sequestrated property. In some cases the Crown kept up charities for a time. The

${ }^{1}$ Stow, Survey of City of Westminster, bk. vi. p. 4 .

2 MS. Soc. Antiq. cxxix. f. 274.

${ }^{3}$ Cal. of Letters and Papers, Hen. VIII, 13. i. $3^{8} 3$. 


\section{MEDI EVAL HOSPITALS OF ENGLAND}

return of pensions in $155^{2}$ shows that sums were paid out of the tenements of Nostell Priory to inmates of St. Nicholas', Pontefract. The poor dwelling in the so-called "Kings Majesty's almshouses" at Glastonbury (formerly abbey-pensioners) were also granted weekly allowances. This was generous, for although Henry VIII and Edward VI were fond of giving their names to charitable institutions, they too often gave little else.

The two Statutes authorizing the dissolution of Chantries, etc. (I545-1547) extinguished or reduced in means, some houses of charity. When an almshouse was spared, the Crown sometimes demanded an acknowledgment; "at Beverley the rents in 1545 include a new item of $£_{4}$ paid by the town to the king and queen for the Trinity Maison Dieu. "Hospitals" were not rightfully within the scope of the second Act. Thus Foster's almshouse in Bristol being, as the certificate states :-

"for the helpynge relief and comforte of a certeyn nomber of poore people there to contynue and haue their liuinge from tyme to tyme for euer, is without the compasse of the statute and the King's Majestie not entitled thereunto by force of the same."

In the preface to the Yorkshire Chantry Surveys, it is stated that most, if not all, of the hospitals which were returned on the certificates there printed were left undissolved, save that in a few cases funds were transferred to educational purposes. Testimony is borne in $155^{2}$ to the usefulness of one of the Pontefract almshouses, where fourteen bedemen were supported :-

"Thes persons be called cremettes and le pore and agyd people, and placyd in a howse, callyd Seynt Nycoles Hospytell, 


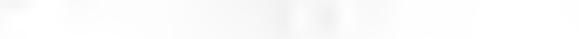

$\because \quad$

3

$\therefore$

$\vdots$

.

- 


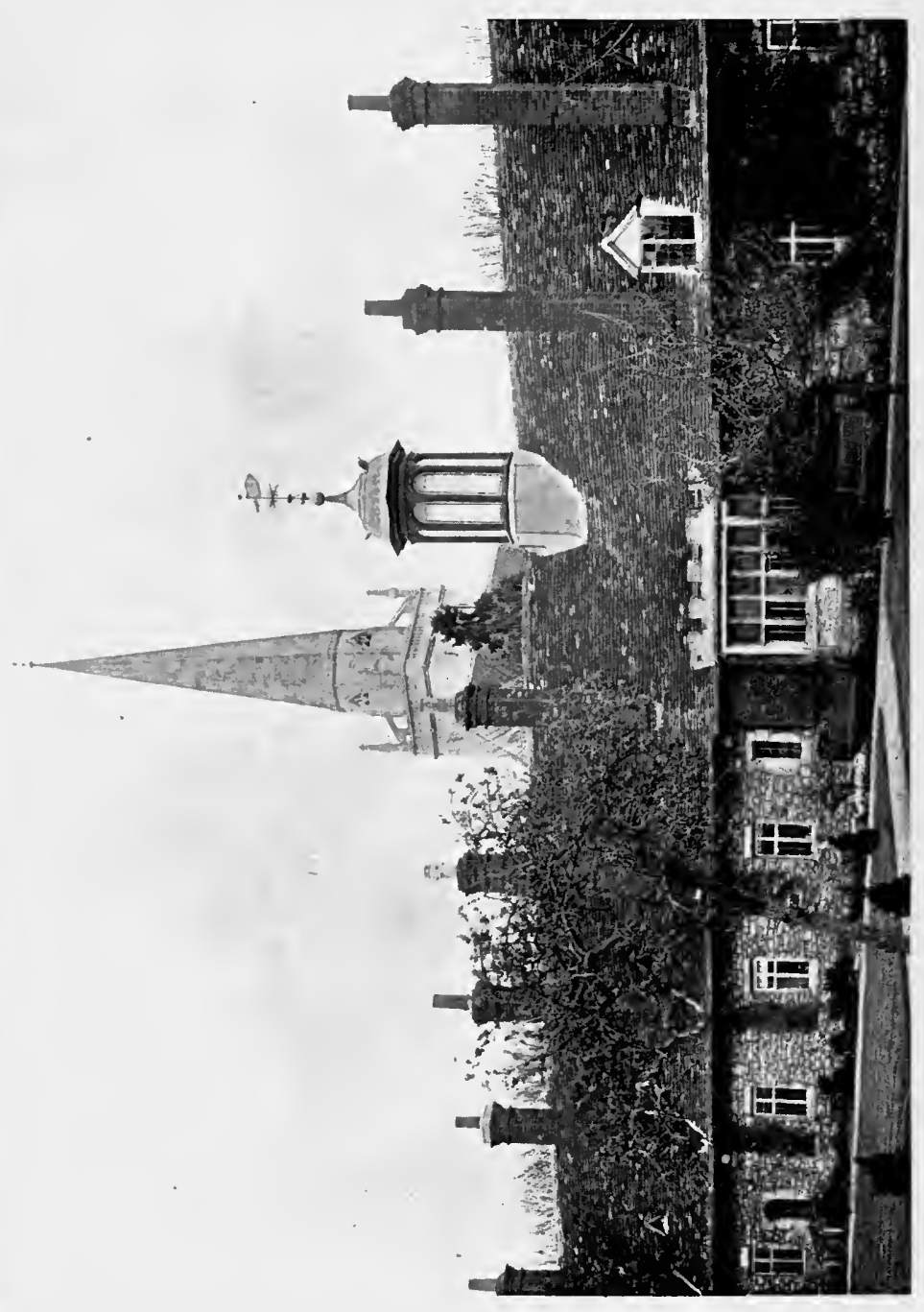

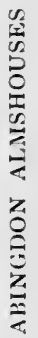


and when any of them dyeth another ys placyd in the dedes roome, and ys very convenyent to be contynuyd, as well for the helpe of the pore and agyd people of the towne as for others."

In many places, however, endowments were seized by virtue of this Act. A sixteenth-century MS. states :-

"Item, there ar within the towne and parishe of Taunton xliiijor almshowses full of poore people whereunto there was certen Lande belonginge which by the Suppression of Chaunteries was taken awaie soe that now thinhabitaunts doe beare the whole burden them selues." 1

The dissolution of fraternities also affected the maintenance of the poor. Of almshouses associated with gilds at Colchester, Stratford and Abingdon, none survived save the latter, which was incorporated by Edward VI. St. John's hospital in Winchester outlived the fraternity annexed to it. St. Thomas', York, which had been united to Corpus Christi Gild, weathered the storm, its officials afterwards diplomatically inviting the mayor and aldermen "to be brether with us in the same hospital."

Those houses were fairly secure which were already the property of municipal authorities, who indeed received fresh patronage at this time (e.g. at Canterbury, Norwich, Bath)-a policy which obtained the support of the great middle-class. At this crisis the public-spirited action of more than one corporation saved charities from extinction. In the Survey for Wiltshire (1548), quoted by Mr. Leach in English Schools at the Reformation, the following entry is made:- "There is an Hospitall within Marleborowe . . wiche the sayd mayre and commons humbly desyre the Kingis Highnes and his mooste Honourable councell

1 B. M. Add. 30277 , f. 3 . 


\section{MEDI EVAL HOSPITALS OF ENGLAND}

to conuerte into a Free scole for the inducement of youth." But before the townsmen obtained their school, it was necessary to sell the stock of plate intended to pass from mayor to mayor, "as hath byn credibly reported," says a book formerly belonging to the Chamber. To cite another example, the corporation of Bristol received St. Mark's as a "gift," that is, the sum of $£ 1000$ was paid into the treasury of the Court of Augmentations, besides an annual rent of $£_{20}$. The city obtained part of the property in return on easy terms, for, as Fuller would observe, there were "many good bargains, or rather cheap pennyworths, bought of abbey lands." It is said that more than half the purchase-money was raised by the sale of church plate.

In London, the citizens, under the leadership of the Lord Mayor, made an urgent petition to Henry VIII ( 1538 ) for the re-foundation of certain hospitals :-

"for the ayde and comforte of the poore sykke, blynde, aged and impotent persones, beyng not able to helpe theymselffs, nor hauyning any place certeyn whereyn they may be lodged, cherysshed and refresshed tyll they be cured and holpen of theyre dyseases and syknesse. For the helpe of the said poore people, we enforme your grace that there be nere and $\mathbf{w}^{t} \mathbf{y n}$ the cytye of London three hospytalls or spytells, comenly called Saynt Mary Spytell, Saynt Bartylmews Spytell, and Saynt Thomas Spytell, ... fownded of good devoc̃on by auncyent fathers, and endowed $\mathrm{w}^{\mathrm{t}}$ great possessions and rents."

The petitioners promise that if the king will grant the governance of these hospitals to them with their possessions, they shall be reformed and their usefulness increased :-

"A greatter nombre of poore nedy sykke and indygent persones shalbe refresshed maynteyned comforted fownde heled 
and cured of theyre infyrmytyes frankly and frely, by phisicions, surgeons, and appotycaryes, ... so that all impotent persones not able to labor shall be releued ... and all sturdy beggars not willing to labor shalbe punisshed, so that $\mathrm{w}^{t}$ Godd's grace fewe or no persones shalbe seene abrode to begge or aske almesse."

It appears that no response was made to this appeal until 1544. St. Mary's had been dissolved, never to be restored, St. Thomas' was deserted, and St. Bartholomew's, "vacant and altogether destitute of a master and all fellows or brethren." After six years' delay, the king heeded the petition. He was exceedingly anxious to emphasize his compassionate character and eager desire for the improvement of hospitals. If the petitioners had invited him to win the name of conservator, defender and protector of the poor, he writes as though he were indeed all these :-

"We being of the same [hospital] so seised, and, divine mercy inspiring us, desiring nothing more than that the true works of piety and charity should not be abolished there but rather fully restored and renewed according to the primitive pattern ... and the abuses, in long lapse of time lamentably occurring, being reformed, we have endeavoured ... that henceforth there be comfort to the prisoners, shelter to the poor, visitation to the sick, food to the hungry, drink to the thirsty, clothes to the naked, and sepulture to the dead administered there ... we determine to create, erect, found and establish a certain hospital."

By virtue of these letters-patent the name of the ancient institution was to be "The House of the Poor in West Smithfield of the foundation of King Henry VIII." The noble "founder" is commemorated by the gateway and by a portrait in the Common Room; whilst a window in 


\section{MEDI $F V A L$ HOSPITALS OF ENGLAND}

the hall depicts Sir R. Gresham receiving the "foundation-charter."

If the "creation" of St. Bartholomew's-after above four hundred years of usefulness-was due to Henry VIII, its preservation was due almost entirely to the good citizens of London. Its former possessions being now vested in the Crown, the king agreed by an Act of Common Council to endow it to the extent of 500 marks a year (about £333). The citizens-"thinkying it for their partes rather to litle then enough"-gladly met the offer with a similar sum annually; they also raised nearly firooo for initial expenses and opened the repaired and refitted hospital for one hundred patients. They agreed henceforth to buy and provide all manner of apothecary's ware, and all that was necessary for making salves and all other things touching physic or surgery, for the healing of inmates. From this time onwards the citizens interested themselves in this great institution which they supported nobly. It did not become a municipal hospital, but was under the guidance of the Lord Mayor and Governors.

By the same covenant the king "gave" St. Mary's of Bethlehem to the city. Stow says:- "It was an Hospitall for distracted people. . . . the Mayor and Communalty purchased the patronage thereof with all the landes and tenementes thereunto belonging, in the yeare I546, the same yeare King Henry the eight gave this Hospitall unto the Cittie." In other words, the citizens bought back that which had already been in the guardianship of the city for about two hundred years.

In "The Ordre of St. Bartholomewes"1 drawn up in

I Early Eng. Text Soc. Extra liii. App. xvi. 
I552, a report is given, so that all might know how things were administered and support the work. During the preceding five years, eight hundred persons had been discharged healed, and ninety-two had died. The charity had been carried on in spite of great difficulties, and now there was a design to increase it :-

"The Citie of their endlesse good wil toward this most necessarie succour of their pore brethren in Christ, . . . wyshe al men to be most assuredly perswaded, that if by any meanes possible thei might, they desire to enlarge the benefyght to a thousand."

A wish is expressed that all almoners and houses of alms might be stirred up to do likewise "at this tyme namely, when the mysery of the poore moste busily semeth to awake." This same year the manor of Southwark was purchased and St. Thomas' repaired, so that whereas it lately accommodated forty sick, it was reopened with 260 beds for the aged, sick and, sore. This "Hospitall of great receite for the poore, was suppressed but againe newly founded and indowed by the benevolence and charitie of the citizens," says Stow. King Edward's letters-patent (155I) describe the miserable condition of the sick poor lying and begging in the streets, "to their no small grief and pain and to the great infection and molesting of his subjects. The king desiring the health of the citizens in general no less than the cure of the sick, therefore grants permission to the mayor and corporation to undertake the work."

The work of the re-founded houses of St. Bartholomew, St. Thomas, and Bethlehem was supplemented in 1553 by Christ's Hospital for fatherless children, and Bridewell for the correction of idle vagabonds. These institutions 
were provided partly from Edward VI's private purse and partly from the dissolved Savoy Hospital and Grey Friars. Their initiation was due to the influence of Ridley, Bishop of London, who took counsel with the Lord Mayor as to the condition of the poor, and reported it to the young king. With the charitable provision after 1547 we are not, however, concerned, and only the ultimate effect of the general Dissolution remains to be shown.

For, happily, this volume is no history of obsolete institutions. The heritage of the past is to a certain extent ours to-day, and we can rejoice in the uninterrupted beneficence of St. Bartholomew's which receives in the twentieth century as in the twelfth, "languishing men grieved with various sores." Words spoken by the Prince Consort in reference to another foundation at once ancient and modern, are equally true of St. Bartholomew's and of the sister-hospital of St. Thomas :-

"It holds to this day the same honourable position in the estimation of the country which it did in the time of its first formation, exemplifying the possibility, in this happy country, of combining the general progress of mankind with a due reverence for the institutions, and even forms, which have been bequeathed to us by the piety and wisdom of our forefathers." 1

More has come down to us than perhaps we realize. Canterbury retains three venerable houses of alms. St. Mary's, Chichester; St. Nicholas', Salisbury ; and St. Giles', Norwich, are still peaceful retreats in old age. In the city of Winchester-St. Cross is not merely a monument of unchangeable usefulness, but increased funds

${ }^{1}$ Speeches, p. 104. 
DISSOLUTION OF RELIGIOUS HOUSES 24I enable it to give pensions in various parts of England to the value of $£ 1200$; the site of St. Mary Magdalene's is occupied by an isolation hospital, a portion of the original

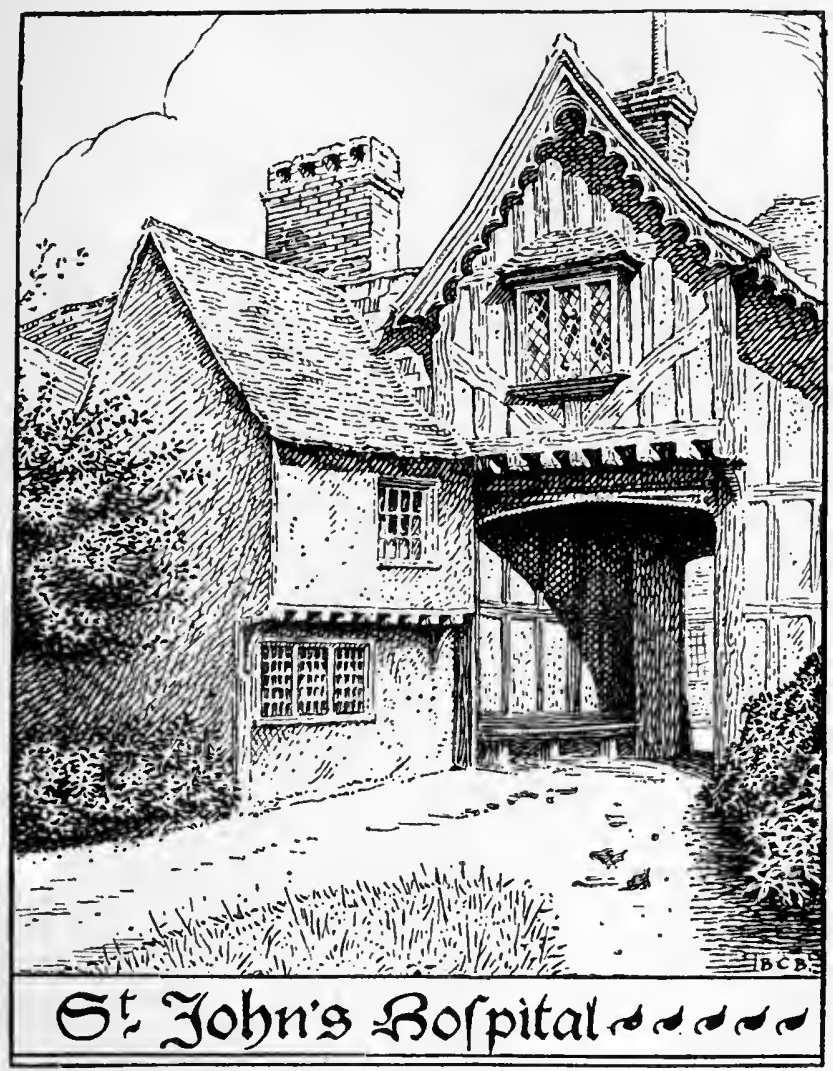

3r. GATEWAY OF ST. JOHN's, CANTERBURY

endowment maintaining a small almshouse; while St. John's has been greatly enlarged.

Even where no ancient stones bear witness, modern bricks or coins may be eloquent, for a part of the original เ6 


\section{MEDI $Æ V A L$ HOSPITALS OF ENGLAND}

endowment may be applied to a renewed institution. For instance, the funds of the demolished leper-hospital at Chichester are applied to a modern infirmary. Sums arising from the "Lazarhouse Charity" (Launceston) or "Magdalene Lands" (in Devonshire) are now and again expended upon food and fuel for the poor. And although York shows in the fragment of St. Leonard's but a memorial of fallen greatness, what appears to be a remnant of its rich revenues is still paid to thirty-one poor people, for the curious name "Cremitt Money" is surely derived from the inmates of that hospital, commonly known as "cremettes" (a corruption of eremites). The connection is clear enough in the case of the "Almsmen of St. Bartholomew" at Oxford, and "St. Nicholas' Almsmen" at Carlisle, who represent former occupants of leperhouses. Again, the relation may be intimate even when a modern charity perpetuates the ancient only by force of association and memory. St. Leonard's, Bedford, was revived in 1889 , the original charity for the sick, paralysed, and lepers having lapsed at the Dissolution. No endowments survived, but it is supported locally. The present foundation is an association of religious and philanthropic persons who supply nourishing diet to invalids in their homes and assist them when convalescent. Thus, although the sole trace of old buildings is one pillar-shaft serving as a sun-dial, the charity itself is a living memorial of the ancient hospital. ${ }^{1}$

Finally, St. Leonard's, Sudbury, and Sherburn House, Durham, illustrate to what advantage the old order may yield place to new. The income of St. Leonard's, originally designed for three lepers, supplemented by 


\section{DISSOLUTION OF RELIGIOUS HOUSES 243}

voluntary contributions, is applied to the maintenance of fourteen beds for sick patients, the hospital being fully equipped with modern medical and surgical appliances whilst maintaining the former religious traditions. Sherburn, once a home for sixty-five outcasts, was transformed into an almshouse when the scourge was removed. In that " haunt of ancient peace" many are now sheltered in time of age or chronic sickness; they worship daily in the old church ; they are visited and cheered by a master who has devoted his life to them, and whose work is a labour of love. The revenues and practical benefits of the hospital continue to increase; a modern dispensary is fitted up there, by means of which hundreds of out-patients from the neighbouring city are relieved.

"It is this renewing of itself which brings to English institutions greatness, stability, and permanence. Thus the great traditions of the past can be happily, wisely, and usefully combined with the highest aspirations of the present and future." 


\title{
PART TWO
}

\author{
NOTES ON \\ HOSPITAL PATRON SAINTS
}

"Hospitals . . founded to the honour of God and of His glorious Mother." (Parliament of Leicester.)

THE words "God's House," and "Maison Dieu" were

1 familiar enough in mediæval England. A hospital was the house of God, for therein Christ was received in the person of the needy:- "I was a stranger and ye took Me in, sick, and ye visited Me." It was also built in His Name and to His honour, for the principle underlying all dedications was, says Hooker, that they "were consecrated unto none but the Lord only." But with God's Name that of one of His saints was often associated, and by this the hospital was commonly called; thus a charter of Basingstoke ran:- "I have given and granted to God and to the glorious Virgin His Mother, and to my venerable patron St. John the Baptist the house called St. John."

The Holy Trinity.-Hospitals bearing this title are not very numerous, though it often occurs as first of a group. There are a few single dedications early in the thirteenth century, which may be partly attributed to the institution of the Feast of Trinity by St. Thomas of Canterbury. Two hundred years later it was a fairly common dedica- 
tion for almshouses. The seals depict various symbols. The "majesty" representing the Three Persons, occurs at Walsoken ; the Almighty seated upon a rainbow (Salisbury); our Lord enthroned (Berkeley); whilst a triple cross ornaments the Dunwich seal. Bonde's almsmen at Coventry bore upon their gowns "the cognizance of the Trinity."

The Holy Saviour ; Christ ; Corpus Christi.-The Second Person of the Godhead is seldom commemorated, but the dedication to the Blessed Trinity was regarded as synonymous, for the almshouse at Arundel occurs indifferently as Christ's or Holy Trinity. The Maison Dieu at York, commonly called Trinity, was properly that of the Holy Jesus-or Christ-and the Blessed Virgin, and the chantry certificate is headed "The Hospital of the Name of Jhesus and Our Blessyd Ladye." St. Saviour was the invocation of houses at Norwich and Bury, and the fair in connection with the latter charity was held at the feast of the Transfiguration. "Ye masendew of Chryste" at Kingstonupon-Hull was originally "Corpus Christi," but it is remarkable to find that rarely-preserved dedication-name upon an Elizabethan table of rules. The seal of the Holloway hospital, near London, shows Christ (with the orb) and St. Anthony.

The Holy Ghost.-This sacred title, closely associated with the mediæval charities of Germany and famous in Rome, was rarely used in England. At Sandon (Surrey) was a hospital "commonly called of the Holy Ghost,"1 though an alternative name occurs. A hidden dedication is sometimes revealed, for the houses usually known as St. Thomas', Canterbury, St. Margaret's, Taunton,

\footnotetext{
1 Pat. 14 Hen. VI, pt. i. m. 4.
} 
St. John's, Warwick, and St. John's, Hereford, are mentioned once in documents as being built in honour of the Holy Ghost as well as of the saints named; all the above instances refer to the years 1334-1353. At Lyme there was the suggestive commemoration of the "Blessed Virgin and Holy Spirit."

The Annunciation; St. Gabriel; St. Michael; The Holy Angels.-Two fourteenth-century foundations at Leicester and Nottingham commemorate the Annunciation of the Blessed Virgin. The seal of the former house depicts St. Gabriel delivering his salutation. A kindred thought underlies the dedication " to our lady St. Mary the Mother of Christ and to St. Gabriel the Archangel" at Brough. (It is noteworthy that the parish church was St. Michael's.) Another institution, built by Bishop Bronescombe of Exeter, who had a special devotion to the Archangel, left its name to Clist Gabriel. The more ancient dedication to St. Michael occurs at Whitby and elsewhere in Yorkshire. Michael de la Pole founded an almshouse at Kingston-upon-Hull, partly in honour of "St. Michael the Archangel and all archangels, angels and holy spirits." A fraternity at Brentford commemorated "The Nine Orders of Holy Angels," and in the Valor it is termed hospitalis Angelorum.

The Blessed Virgin; The Three Kings of Cologne; The Holy Innocents.-The statement referring to hospitals in general as "founded to the honour of God and of His glorious Mother" explains more than one difficult point. First, numerous as are the dedications to St. Mary, they are fewer than those of some other saints, for instance, St. Mary Magdalene. Secondly, a certain number of houses are set down as having two patrons, yet the second 


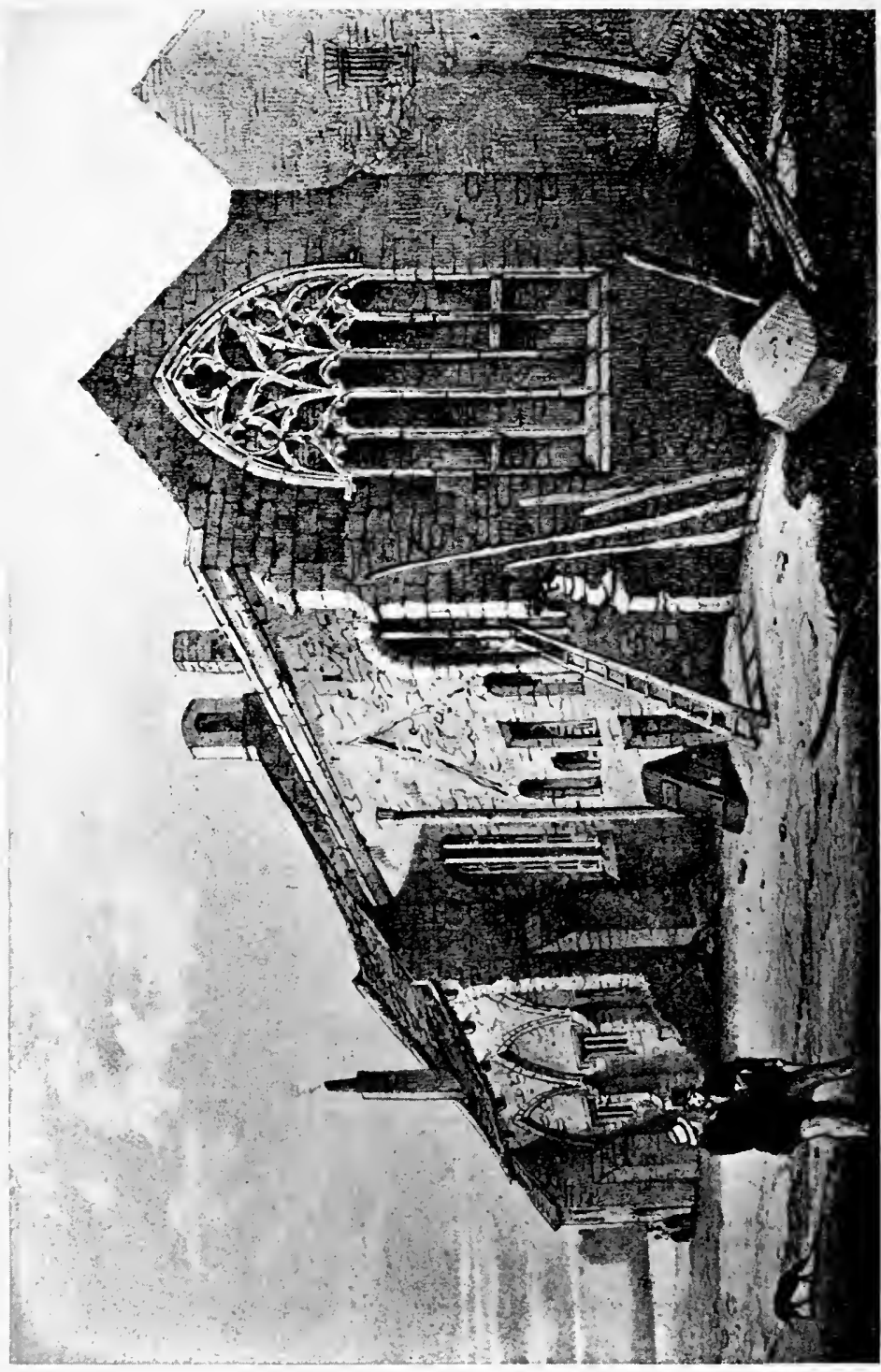

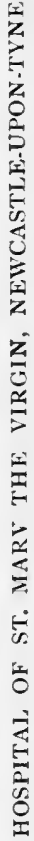


saint appears to eclipse the Blessed Virgin; that of Newport in Essex (given as St. Mary and St. Leonard) usually bore St. Leonard's name and kept its fair on his festival. In many such cases there was in truth no double dedication; and although gifts were made by charter to found a hospital at Bristol "in honour of God, St. Mary and St. Mark", later documents omit the formula and call it "the house of St. Mark."

On the other hand many houses were dedicated solely in honour of the Blessed Virgin, including five important institutions in London alone. In addition to St. Mary (without Bishopsgate), St. Mary of Roncevalles (Charing Cross) and Our Lady of Elsyng (Cripplegate), there was St. Mary's hospital or the House of Converts, - a witness to the doctrine of the Incarnate Christ,-and St. Mary of Bethlehem, a name chosen on account of the founder's intense reverence for the holy Nativity. Stow quotes the deed of gift made by Simon, "son of Mary" :-

"having speciall and singulor deuotion to the Church of the glorious Virgin at Bethlehem, where the same Virgin brought forth our Saviour incarnate ... and where [to] the same Child to us there borne, the Chiualrie of the heavenly Company sang the new Hymne Gloria in excelsis Deo."

The Holy Innocents were commemorated in the ancient leper-house outside Lincoln. The existing chapel of an almshouse in Bristol built " in the honour of God and the Three Kings of Cologne" (Leland's fanum trium regum) is the sole witness in the way of dedication in England to the veneration of the Magi. The title is said to have been the choice of an Abbot of Tewkesbury at the close of the fifteenth century. 


\section{MEDIÆVAL HOSPITALS OF ENGLAND}

Holy Cross and Holy Sepulchre.-Names commemorating the Death and Burial of the Saviour are not infrequent. The history of St. Cross, Winchester, touches that of the Knights of Jerusalem, with whom both name and badge are connected. (See p. 207.) On the common seal the master and priests are shown kneeling at the foot of the Cross; the descent from the Cross is depicted upon the walls of the church. This dedication is also appropriately associated with the hospitals usually known as St. Mary Magdalene's at Stourbridge and near Bath, the fairs of which houses were held on the festivals of the Invention and Exaltation of the Holy Cross. The chapel of St. Thomas of Acon in Cheapside-under the Knights Templars-was dedicated to St. Cross. The church attached to St. Bartholomew's, Smithfield, was probably named out of veneration for the relics of "the tree of life" which the founder used in healing (see p. 95); and once exemptions were granted "out of the king's reverence for the Holy Cross, in honour of which the church of the hospital of St. Bartholomew is dedicated." 1

The connection between St. Helen and the Holy Cross is best told in reference to the hospital at Colchester. Although authentic records only carry its history back to I25 I, an illustrious antiquity is claimed in an episcopal indulgence purporting to be issued about 1406. The tradition is quoted (but with modernized spelling) from the Antiquarian Repertory :-

"Moreover, in the year of our Lord 670, Constantine, the son of the blessed and holy woman Saint Elyn, sent his mother unto Jerusalem to inquire of the Holy Cross that our Saviour Christ Jesu died upon, likewise as it was shewed to him by 
token in the air and also by revelation of the Holy Ghost. Then the holy woman, seeing the Will of Almighty God, departed out of the town of Colchester where she was born (there where the said hospital is founded in the honour of Almighty God, the holy Cross and St. Elyn) and took her journey unto Jerusalem and there . . . did win the same Cross. -. Then the holy victorious woman gave laud and loving to God and took one part of the Holy Cross and closed it with gold and sent it to her hospital to Colchester evermore to be abiding, with her ring, her girdle, and her purse, with other 24 curious reliques."

Finally, after relating a visit of St. Thomas of Canterbury to that house, the story of the relic, inciting to devotion, pilgrimage visits and contributions, is brought up to date :-

"Also in the year of our Lord 140r, there came thieves unto the hospital by night and brake up the locks where the glorious relique was, and took it away ... then they took the blessed Holy Cross (as it was, closed in gold the weight of 2 I ounces) and cast it into the pond, but it would not sink . . . and so the folks that did pursue took it up and brought it home to the place again."

This Colchester foundation was associated with the gild of St. Cross (p. I8) and other gilds of that name maintained charities at Stratford-on-Avon, Abingdon and Hedon. In the latter place the hospital of St. Sepulchre gave its title to Newton St. Sepulchre. There were pilgrim-houses at Nottingham and Stamford with the same dedication.

St. John Baptist, St. Mary Magdalene and St. Lazarus.The cult of these saints is intertwined with the history of the Religious Military Orders of Jerusalem. The work of the Knights Hospitallers was to care for sick and 


\section{MEDIÆVAL HOSPITALS OF ENGLAND}

needy pilgrims. They maintained two important infirmaries at Jerusalem, St. John's for men, and St. Mary Magdalene's for women. Grateful guests returning from pilgrimage bore the report of these houses far and wide; thus it came to pass that, throughout Europe, hospitals unconnected with the order, were founded, and by force of association consecrated in honour of these saints. That of St. John Baptist, Lechlade, is referred to in one deed as "St. John of Jerusalem." Such " houses of St. John" were usually for travellers. One writer remarks that almost every town had a place to accommodate the sick and wayfarers, and that they "were invariably dedicated to St. John Baptist in connection with his wandering life." Although this saint did not monopolize the protection of strangers, he was certainly adopted as patron by some hundred hospitals (excluding commanderies of the Order of St. John).

Lanfranc's foundation in his cathedral city was placed by him under the patronage of St. John Baptist, on one of whose festivals (August 29) the archbishop had been consecrated. The hospital at Thetford kept a fair on that day called "The Decollation of St. John Baptist"; but the lepers of Harting celebrated their wake on June 24 , "The Nativity of St. John Baptist." The strange customs connected with this latter festival were especially observed in houses of which he was patron; in memory of St. John Baptist it was usual at Sherborne for a garland to be hung up on Midsummer Eve at the door of St. John's, which the almsmen watched till morning.

Seals usually depict the saint with his symbol of the Holy Lamb; sometimes he points to a scroll (Ecce Agnus $D e i)$. In two instances (Banbury and Bristol) a patriarchal 
cross, one of the symbols of the Knights Hospitallers, is shown ; this double-armed cross is likewise found on the gable of St. John's, Northampton, where it is considered a unique architectural feature.

St. Lazarus became the guardian of lepers partly through the influence of the Order whose aim was to relieve the sick, and especially the leprous, members of their brotherhood. They were introduced into England in Stephen's reign, when the hospital of the Blessed Virgin and St. Lazarus was founded at Burton, afterwards known as Burton St. Lazarus. The seal of this house depicts a bishop carrying in one hand a fork or trident, ${ }^{1}$ in the other a book; Dugdale ascribes the figure to St. Augustine, but Mr. de Gray Birch attributes the mitred effigy to St. Lazarus, traditional Bishop of Marseilles. Of the other dedications to St. Lazarus little is known, some being of doubtful authenticity.

The question naturally arises-why were lepers called lazars in common parlance, and why was Lazarus chosen as their patron? A curious confusion of ideas is revealed. The original person intended was he who lay full of sores at the rich man's gate. The banner of a Flemish lazaretto displays scenes from the life of this Lazarus, who appears clad as a mediæval leper, and carries a clapper. ${ }^{2}$ The same idea was familiar in England. David of Huntingdon having founded a leper-house, Aelred the chronicler prays at his death :- "Receive his soul into the bosom of Abraham with Lazarus whom he did not despise but cherished." A similar allusion occurs in Langland's

1 Probably intended to represent the clappers; compare design on seal of St. Mary Magdalene's, Winchester.

${ }^{2}$ Lacroix, Military and Religious Life, 353. 
Piers the Plowman: "And ich loked in hus lappe a lazar lay ther-ynne." The lazarus ulceribus plenus of the allegory, however, soon became associated with the historical Lazarus of Bethany. Thus a colony of northcountry lepers dwelt in Sherburn hospital founded "in

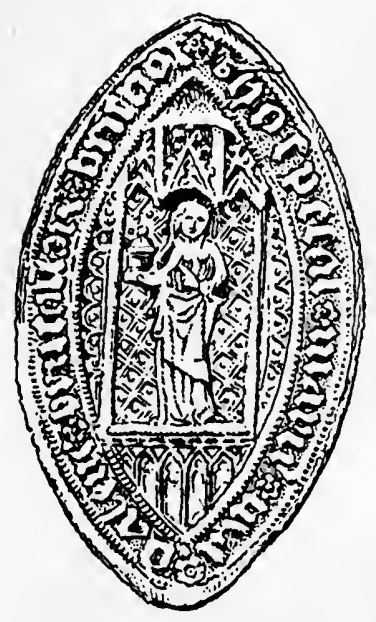

32. SEAL OF ST. MARY MAGDALENE'S, BRISTOL honour of the Saviour, the Blessed Virgin, St. Lazarus, and his sisters Mary and Martha." This dedication was abbreviated into St. Mary Magdalene, and the principal altar was in her honour. St. Mary Magdalene, universally identified with St. Mary of Bethany, was thus commonly involved in the curious double personality of St. Lazarus. In England, she was the most popular of leperpatrons, no one save St. Leonard attaining to half her number of dedications. We are told that St. Lazarus held this place in France, St. James in central Europe, St. George in the North; but in England, the Magdalene was supreme. The "Maudlin-house" was almost synonymous with leper-hospital. Place-names testify to the devotion of our forefathers to St. Mary Magdalene, and in several places "Mawdlyn lands" mark the site of a leper-colony.

St. Bartholomew had sixteen hospitals in England, chiefly in the South. An old hymn, quoted by Dr. Norman Moore, describes the Apostle's medical powers. "Lepers he cleanses"-and to him were dedicated ancient lazar-houses at Rochester, Oxford, Dover, etc. "The sick 
he restores "-the Apostle having appeared to Rahere, sick with fever in Rome (perhaps, it is suggested, upon the island of St. Bartholomew in the Tiber), he builds upon his recovery a house of healing near London, which for nearly eight hundred years has been a place of restoration. "The lunatic are made whole"-and the Book of the Foundation tells of such a cure at St. Bartholomew's:-

" ther yn a shorte space his witte was recoueryd, where a litill tyme he taried, blessyng God that to his apostles hath uouchsaf to commytte his excellent power, to hele syke, to clense lepers, and to caste owte feendys."

At St. Bartholomew's, Oxford, a relic was treasured, namely, a portion of the saint's skin. The legend of his martyrdom is depicted upon the seal of the Gloucester foundation, and he is shown knife in hand on the Rochester seal. (Tail-piece of this chapter.)

St. James.-Of all the Apostles, St. James has the largest number of hospitals, namely, twenty-six partly or wholly dedicated to him. This is doubtless due to the fact that his shrine at Compostella was the goal of Christendom, and the miracles of "Santiago" world-famous. St. James', Northallerton, was named as the direct result of a pilgrimage to Compostella in the year 1200 by Philip, Bishop of Durham. Several ports (Dunwich, Seaford, Shoreham) had houses in his honour. Hospital seals depict the saint as a pilgrim, with water-bottle and scrip, whilst one shows the token of escallop shells.

St. James \& St. John.-Whereas there was apparently no parish in England commemorating the brother-apostles, three hospitals (Aynho, Royston, and Brackley) bore this double name. About Brackley, indeed, there is some 


\section{4}

MEDI EVAL HOSPITALS OF ENGLAND

uncertainty. It occurs as "St. John and St. James" (I226), "St. James and St. John Apostle" (I227); but also as "St. John Baptist" (1301, 147r). The seal shows two figures, of which one scantily clad and bearing a palm suggests the Baptist.

St. John Evangelist \& St. John Baptist appear in conjunction at Exeter, Sherborne, Newport Pagnell, Northampton, and Leicester. The original and usual title at Exeter was St. John Baptist; but in 1354 Bishop John de Grandisson, a benefactor, mentions "St. John the Baptist and Fore-runner of Christ and St. John His Evangelist and Apostle." The seal of Northampton shows both saints with their symbols, and the appellations BAPTI and EWA are placed over the figures. On the Leicester seal the eagle of the Apostle is shown, and the scroll in its talons may represent the Ecce Agnus Dei. When

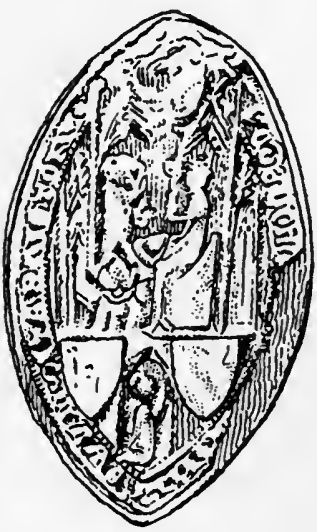

33. SEAL OF ST. MARK's, BRISTOL "St. John" occurs, the dedication commonly proves to be to the Baptist; and even where the Evangelist is expressly named, some later document reverts to his namesake, e.g. Blyth, Burford, Castle Donington, Cirencester.

St. Matthew, St. Mark, and St. Luke were not uncommemorated. "The house of St. Matthew" at Maiden Bradley, which occurs on one Patent Roll (1242), was commonly called St. Mary's ; the double dedication is mentioned in the Obituary Roll of Prior Elchester of Durham (1484), viz. : Eccles. B. Mar. et S. Math. Ap. The fair, granted 
in 1215 , was upon the vigil and feast of St. Matthew the Apostle. The name of St. Mark's, Bristol, is preserved in the existing chapel of the hospital; the seal (Fig. 33) shows the saint writing his gospel, the lion by his side. "The lepers of St. Luke the Evangelist at the bridgeend of Beghton" are mentioned in I334, but the locality is not identified. There was also a hospital of St. Luke at Gorleston.

St. Andrew; S.t. Thomas; St. Stephen.-There were dedications to St. Andrew at Flixton, Denwall, Cokesford, and Hythe. It seems probable that the last named was a re-foundation of St. Bartholomew's, for "St. Andrew" only occurs during the few years following its restoration by Hamo, Bishop of Rochester, of which See that saint was patron. It is improbable that any of the hospitals of St. Thomas were under the patronage of that Apostle, although Tanner erroneously gives an instance at Birmingham. They sprang up when St. Thomas the Martyr of Canterbury was of paramount popularity. The ambiguous "St. Thomas-on-the-Green" at Sherborne, for example, is referred to by Leland as the "free chapel of Thomas Becket." St. Stephen, the almoner of the Early Church, was the appropriate patron of several houses of charity, including three in the eastern counties. One was at Bury St. Edmunds, where there were preserved in the abbey "certain drops of St. Stephen's blood which sprung from him at such time as he was stoned." The seals of Norwich and Hempton show their patron respectively as martyr and minister.

St. Paul the Apostle; St. Paul the Hermit; St. Peter; St. Petronilla.-Although St. Peter and St. Paul are commemorated in hundreds of parish-churches, their 


\section{MEDI $Æ V A L ~ H O S P I T A L S$ OF ENGLAND}

hospitals number only nine, including those in York and London which were adjuncts of cathedrals and borrowed their dedication-names. At Norwich, St. Paul the Hermit was associated with his namesake. St. Peter and his daughter St. Petronilla were patrons of leper-houses for priests and maidens at Bury St. Edmunds. The virgin saint was famous locally and the skull of St. Petronilla or Pernell, which was preserved in the abbey, was considered efficacious in sickness. Indeed, the eastern counties were rich in her relics, for a casket from the treasury of a Norwich priory, lent to Henry III, contained, it was said, "of St. Petronella, one piece."

St. Clement; St. Lawrence.-There were dedications to

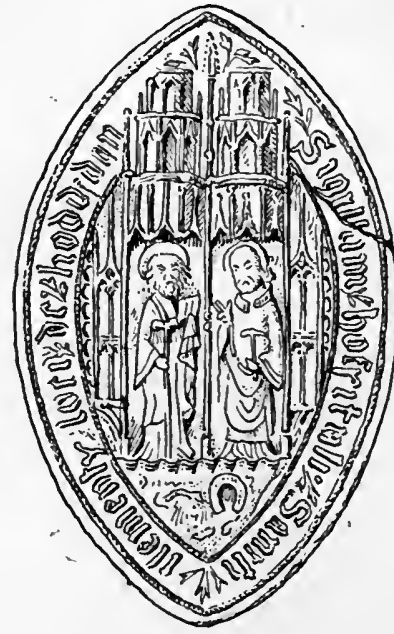

34. SEAL OF ST, Clement's, HODDESDON the Bishop of Rome in Oxford, Norwich and Hoddesdon. On one seal, the last-named house is called "the hospital of St. Clement" (Fig. 34), upon another "of St. Anthony"; both depict not only the hermit but a mitred saint in vestments, with hammer and horse-shoe. The connection with the forge is not clear, but St. Clement is referred to as patron of ironworkers in Sussex, and of blacksmiths in Hampshire. He was popularly regarded rather as the seamen's saint, and was invoked by mariners of a fraternity of St.

Clement connected with St. Bartholomew's hospital, Bristol. St. Lawrence the deacon, whose liberality to- 


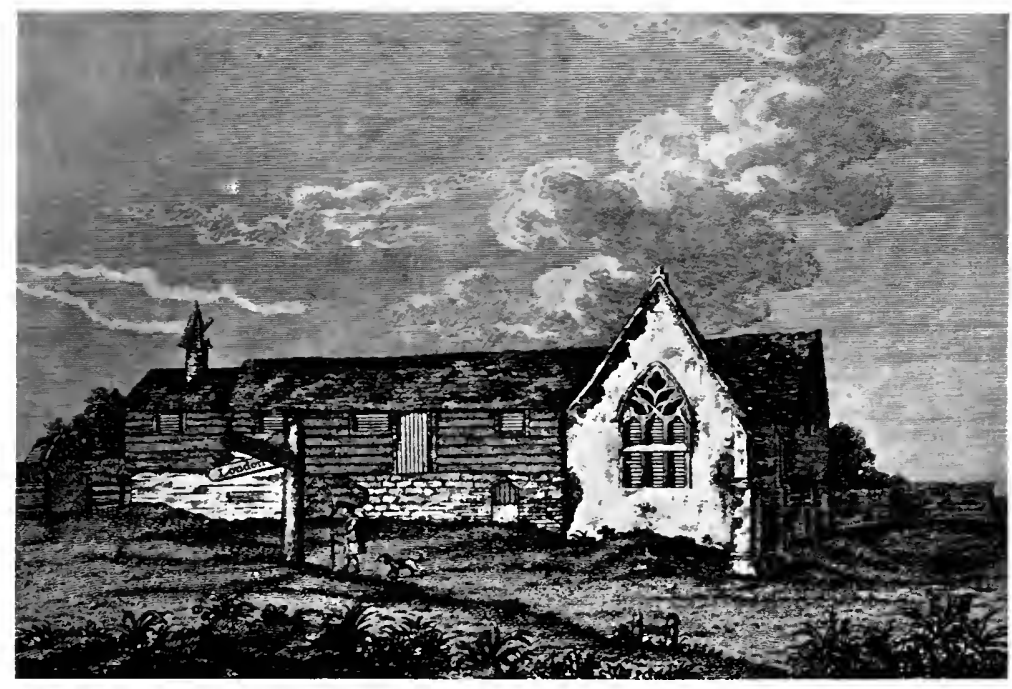

HOSPITAL OF ST. PETRONILLA, BURY ST. EDNIUNDS

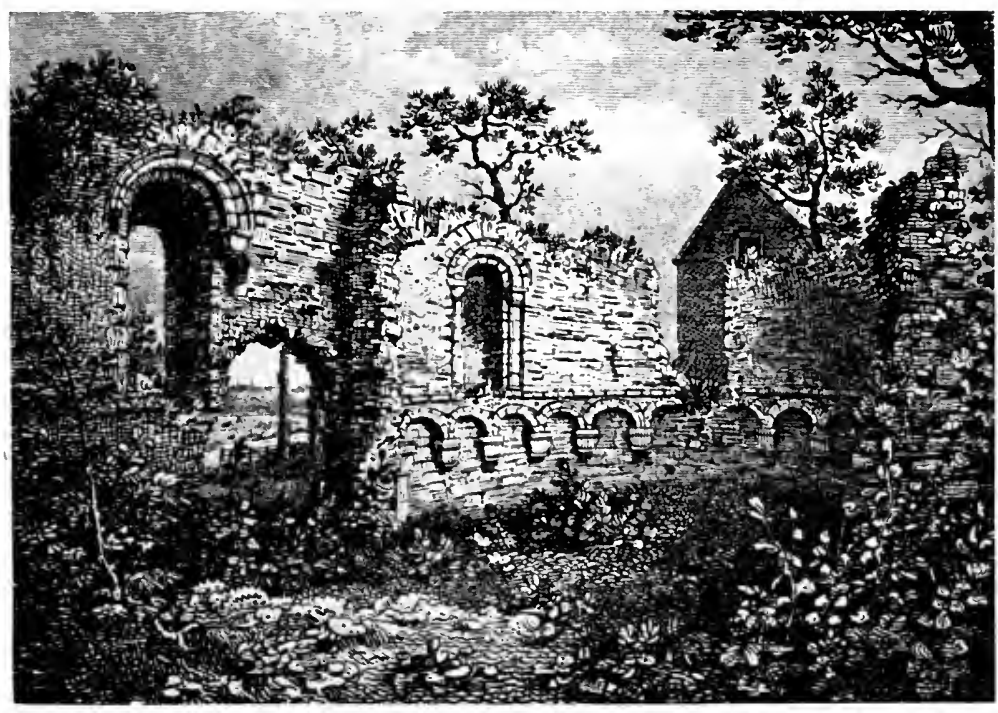

HOSPITAL OF ST, JANES, DUNWICH 

wards the sick and poor was proverbial, was guardian of twelve hospitals, chiefly for lepers. This beloved martyr of Rome was venerated in Canterbury, and the lepers dependent upon St. Augustine's Abbey were under his protection on a site now marked by St. Lawrence's Cricket Ground. "Lawrence Hill," Bristol, also preserves the memory of a leper-house. The old seal of St. Lawrence's, Bodmin, shows the martyr with his gridiron.

St. Nicholas. - The dedications in this name amount to twenty-nine, eleven being in Yorkshire. St. Nicholas', leper-house, Harbledown, was founded by the Italian Lanfranc, whose native land had just acquired the bones of the benevolent bishop, translated to Bari in 1087. The hospitals of Royston and Bury St. Edmunds kept their fairs at the festival of his "Translation." So great was his popularity that Miss Arnold-Forster remarks that if any dedication to St. Nicholas could be traced in Derbyshire, he would have the distinction of being found in every county. This one lack among the parish churches to which she refers, is supplied by the existence of a hospital in his honour at Chesterfield, and of an almshouse chapel at Alkmonton.

St. Anthony.-Whereas few churches were consecrated in memory of this hermit, twenty-one houses of charity were partly or wholly dedicated to him. His aid was invoked when pestilence ( $f e u$ sacré) wasted France, and the initiation of the Order of St. Anthony spread his fame. The French priory at Lenton maintained a hospital for "such as were troubled with St. Anthony's fire," i.e. erysipelas. An indulgence offered to contributors towards St. Anthony's in London refers to inmates "of whom 


\section{$25^{8}$ MEDI $Æ V A L$ HOSPITALS OF ENGLAND}

some are so tortured and scorched by burnings as of the pit, that being deprived of all use of their limbs, they seem to be rather horrible deformities than human beings." The saint was invoked against contagion and all diseases. In England most of his foundations were for lepers. One of the latest lazar-houses (Holloway, 1473) had a chapel of St. Anthony ; but the full title on the seal is "Holy Jesus and St. Anthony."

The seals of the London, Hoddesdon, and Holloway hospitals (Figs. 30, 34) show St. Anthony with his tau cross, bell, and pig. When it was forbidden for swine to roam in the streets, the Antonine monks retained the right to turn out their pigs, which were distinguished by a bell. Although the York hospital was not under the Order, the master claimed one pig out of every litter. As late as I538, when the London house of St. Anthony had been appropriated to Windsor, licence was given "to collect and receive the alms of the faithful, given in honour of God and St. Anthony, . . . together with swine and other beasts."

St. Augustine; St. Benedict; St. Bernard. - Whether the "hospital for lepers of St. Augustine" at Newport (Isle of Wight) should be considered a true dedication is hard to say; like the "Papey" in London it may merely have been a community under the Austin Rule. A leper-house in Norwich bore the name of St. Bennet's; although situated in St. Benedict's parish, this must be regarded as a genuine dedication, for the common seal depicts the patron. "St. Nicholas and St. Bernard's" at Hornchurch took its designation from the Great St. Bernard in Savoy. (See p. 209.) 
,

-

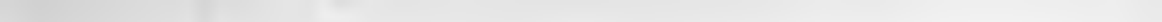




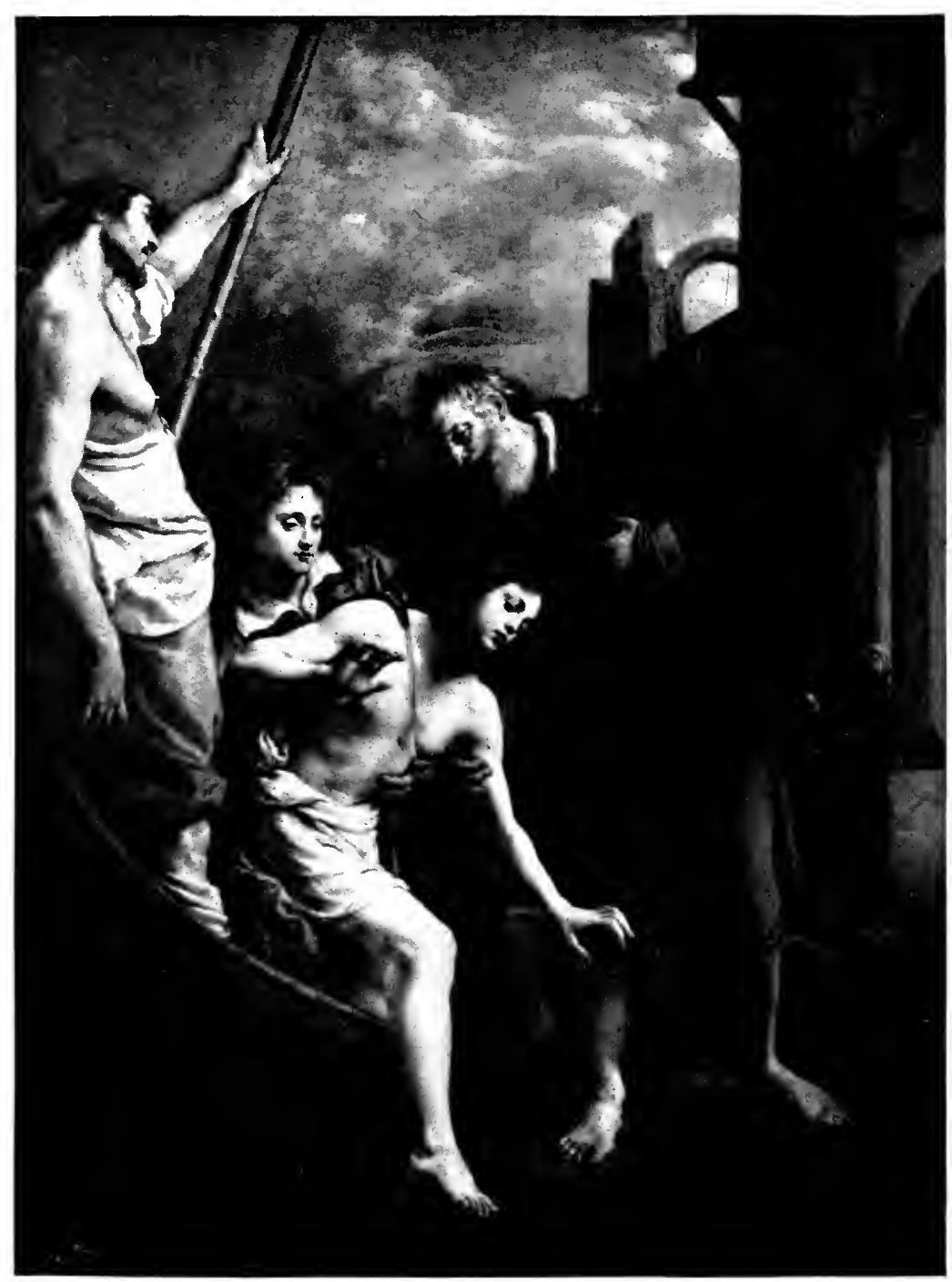

'THE HOSPITALITY OF ST, JULAIN

FROM THE PAINTNE IY C. ALAORT 
St. Julian the Hospitaller was a singularly appropriate guardian. Gervase of Southampton was himself following the example of St. Julian when he turned his home into a resting-place for travellers. Leland refers to God's House, Southampton, as "dedicate to Saynct Juliane the Bisshop," but it was rather the "good harbourer" who was renowned in mediaval England. The saint has been depicted in art helping a leprous youth out of the ferryboat and welcoming him to his house. (PI. XXIX.) At the passage of the river at Thetford was a hospital, the chapel of which commemorated St. Julian ; and the leperhouse near St. Albans was in his honour.

St. Alexis.-The story of Alexis himself is some clue to the unique dedication found at Exeter. He forsook his home for many years, and when at last he returned he was recognized by no one, but his parents welcomed the ragged stranger for the sake of their wandering son. St. Alexis was therefore regarded as the patron of mendicants.

St. George and St. Christopher.-There were hospitals of St. George at Tavistock and Shrewsbury; the latter gave his name to one of the gates and contributed his cross to the arms of the town. That of Yeovil was dedicated to "St. George and St. Christopher the Martyrs"; each pensioner was to wear upon his breast a red cross "as a sign and in honour of St. George the Martyr, patron of the house of alms." The squire of Thame put his bedemen under the care of St. Christopher, as is set forth upon his tomb:-

" that founded in the church of Thame a chantrie, vi pore men and a fraternitye, In the worship of Seynt Cristofore to be relevid in perpetuyte." 
St. Margaret; St. Katherine; St. Ursula.-There are eighteen houses in honour of St. Margaret, and they are chiefly for lepers. It is possible that in the case of Huntingdon the name may enshrine the memory of the saintly lady of Scotland, who died in 1093, although, it is true, she was not canonized until I 250 ; her son, David of Huntingdon, built St. John's in that town, and he may

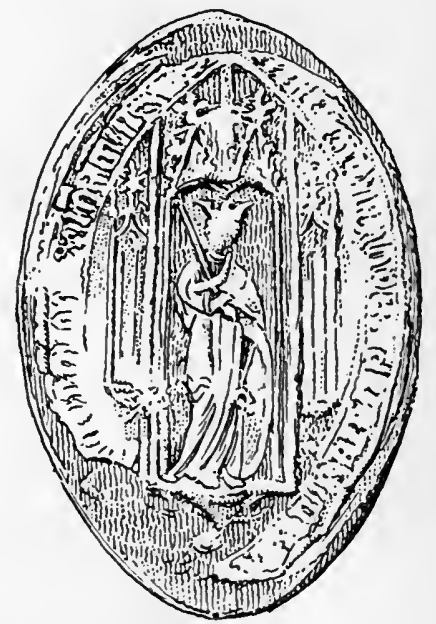

35. SEAL OF ST. KATHERINE'S, BRISTOL

have founded St. Margaret's, of which his daughter and grandson were benefactors. The hospitals dedicated to St. Katherine also number about eighteen. That royal saint was chosen by Stephen's queen as the protector of her charitable foundation for women. Katharine of Aragon obtained for this house a gift of relics, including part of the tomb of the saint sent by the Pope, "out of respect for the Hospital of St. Katharine." The seal of this house and of that at Bristol (Fig. 35) show the saint crowned, 
with sword and wheel, and the latter device was also worn on the habit. Wigston's hospital, Leicester, was named "St. Ursula and St. Catherine." Bonville's almshouse at Exeter includes in its unique dedication St. Ursula's famed companions; it was in honour of "The Blessed Virgin, the Eleven Thousand Virgins and St. Roch."

St. Anne; St. Helen.-The mother of the Blessed Virgin was commemorated at Ripon, and together with other saints at Norwich, Oakham, Stoke-by-Newark, Brentford and Hereford. St. Helen, the mother of Constantine, had hospitals at Derby and Braceford, besides that alluded to under the title "Holy Cross."

\section{SAINTS OF FRANCE}

St. Leonard.-The attitude of France to this hermitsaint was one of deep devotion. Our Norman kings and nobles shared this veneration. Foundations bearing his name at Chesterfield, Derby, Lancaster and Nottingham, had privileges in the adjoining royal forests; and St. Leonard's, Launceston, was dependent on the Duchy. The hospital at Northampton showed a crown upon its seal, and that of York (re-dedicated to this saint by Stephen) bore the arms of England. St. Leonard's, Alnwick, was erected on the spot where the Scottish king Malcolm fell. This saint had a reputation as a healer : "il était le médecin des infirmes." Some fiftyfive charitable foundations had St. Leonard for patron; they were mainly for lepers, and in certain counties (notably Derby and Northampton) even St. Mary Magdalene had to give place to him in this capacity. 


\section{MEDI EVAL HOSPITALS OF ENGLAND}

The " Hospital of St. Leonard the Confessor" in Bedford was revived twenty years ago by a band of brothers who met on St. Leonard's Day and resolved to restore the lapsed memory of this patron saint.

St. Giles; St. Theobald. - The houses of St. Giles number about twenty-five. The chief one was that "in the fields" near London. He was the cripples' (and therefore the lepers') patron, partly because he himself suffered from lameness, and partly on account of the legend of the wounded hart which fled to him, an incident depicted upon seals at Norwich, Wilton and Kepier. Another French hermit, St. Theobald, shares the dedication of the leper-house at Tavistock with St. Mary Magdalene.

St. Denys ; St. Martin ; St. Leger ; St. Laud ; St. Eligius.The hospital at Devizes built by the Bishop of Salisbury was in honour of St. James and St. Denys; the fair granted to the lepers was held on the vigil and day of St. Dionysius. The charitable St. Martin occurs, with or without St. John Baptist, at Piriho. St. Leger was commemorated at Grimsby. St. Laud (or Lo) is an alternative patron at Hoddesdon. St. Eligius (or Eloy) was venerated in houses at York, Stoke-upon-Trent, Cambridge and Hereford.

St. Louis; St. Roch.-These unique dedications are welcome among our patron saints. That to the saintly king occurs in the Ely Registers, contributions being invited in 1393 towards a chapel newly constructed at Brentford (Braynford) in honour of the Blessed Anne and St. Louis (Ludovicus) with houses for the reception of travellers. St. Roch, who ministered to the plaguestricken of Italian hospitals in the fourteenth century, 
was commemorated at Bonville's almshouse in Exeter, Rock Lane being a reminder of its chapel of St. Roch.

\section{SAINTS OF ENGLAND}

St. Oswald; St. Wulstan.-One hospital at Worcester "beareth the name of St. Oswald as a thinge dedicate of ould tyme to him." (See p. 2.) The foundation of the other is ascribed to St. Wulstan himself. The house grew in importance after the saint's canonization in the year I203, which followed a fresh display of miracles at his shrine. The possession of the faithful bishop's famous staff was disputed between hospital and priory. ${ }^{1}$

The common seal shows the patron in the act of benediction, staff in hand.

St. Godwald; St. David.-The chapel of St. Wulstan's was dedicated to St. Godwald. "Some say he was a bishop" is Leland's commentary. Miss Arnold-Forster identifies him with Gulval, hermit-bishop in Wales. St. David, the Welsh Archbishop (canonized I I 20), was commemorated at Kingsthorpe, by Northampton, the house being frequently called "St. Dewi's."

St. Brinstan; St. Chad; St. Cuthbert, etc.-Although Leland had read that "St. Brinstane foundid an hospitale at Winchester," nothing is known of it. "Here is a hospital of St. Chadde," he remarks at Shrewsbury, referring to the church and almshouse. Two dedications sometimes ascribed to St. Cuthbert, namely at Gateshead and Greatham, within "the patrimony of St. Cuthbert," hardly justify his inclusion among patrons, although he is named in the deed of gift. The same may be said

1 F. T. Marsh, Annals of St. Wulstan's, p. 5. 
of documentary allusions to St. Erkenwald, St. Hilda and St. Richard in connection with foundations at Ilford, Whitby and Chichester.

St. Ethelbert; St. Edmund, King \& Martyr ; St. Edmund, Archbishop \& Confessor.-The royal Ethelbert and Edmund are included among our saints. St. Ethelbert's, Hereford, is attached to the cathedral and shares its patron. In the case of the ten houses of St. Edmund, it is not always possible to determine whether the Saxon king is intended or Edmund Rich, Archbishop of Canterbury. The "spital on the street" in Lincolnshire and the hospital by Doncaster Bridge were in honour of the royal martyr; whilst those of Leicester and Windeham commemorated the archbishop, the latter being founded by his devoted friend, St. Richard of Chichester, who had recently attended the solemn "Translation" at Pontigny.

St. Edmund's, Gateshead, has puzzled historians because the designations vary between King, Archbishop, Bishop and Confessor. Surtees and others concluded that all had reference to one foundation, but Mr. J. R. Boyle proves that there were two with distinct endowments, and that both chapels were standing a century ago. Now it is recorded that Nicholas of Farnham was the founder of that of "St. Edmund the Bishop." A sidelight is thrown upon the subject by Mathew Paris, whose narrative of the miraculous recovery of Nicholas in I 244 through the agency of St. Edmund has escaped the notice of local topographers. The emaciated sick man bade farewell and received the last rites when he was restored by the application of a relic of the archbishop. From this incident it seems likely that the hospital was a 


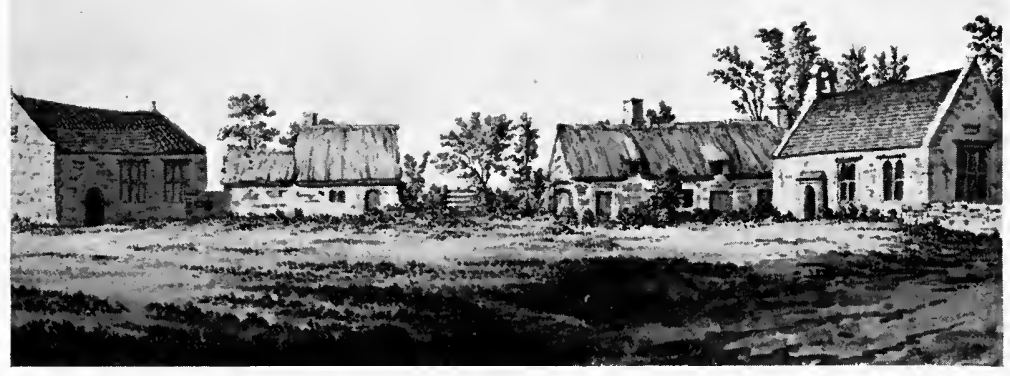

CHAPEL OF ST. EDMUND THE KING, SPITAL-ON-THE-STREET

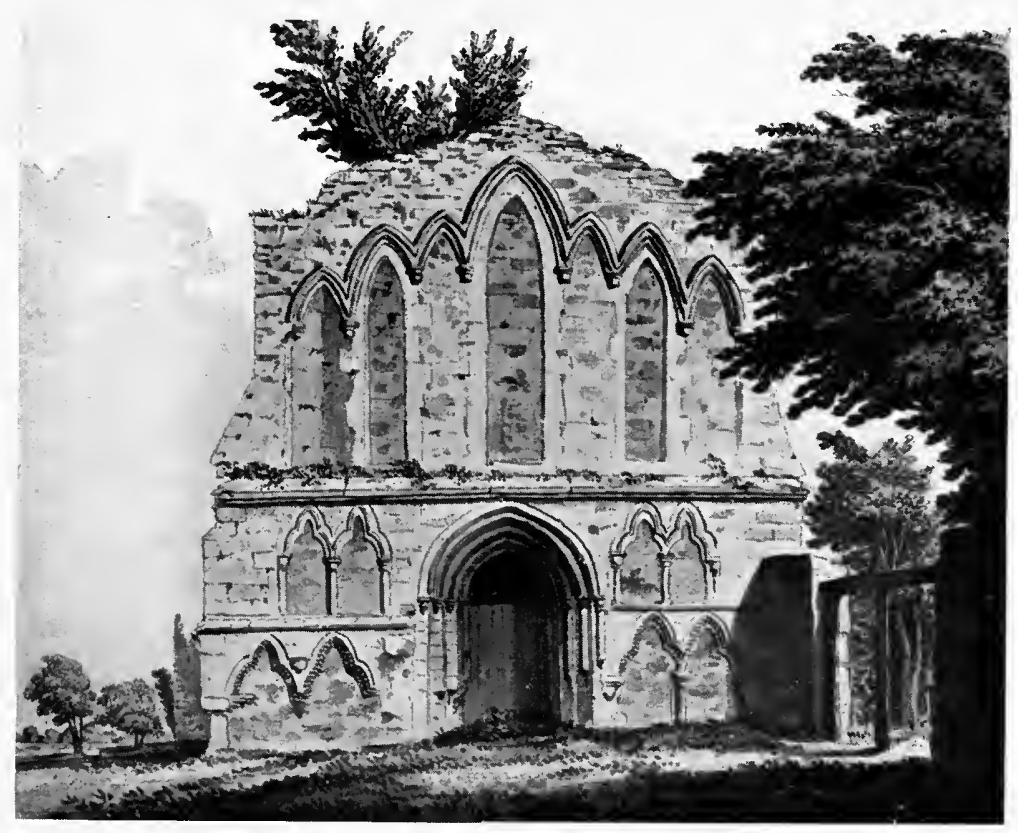

CHAPEL OF ST. EDIUND THE ARCHBISHOP, GATESHEAD 

votive offering and that it was consecrated soon after Archbishop Edmund was enrolled among the saints. The papal letter of canonization (1246) describes his beautiful character and the miraculous events which followed his death. When it declares that "he healed the swelling dropsy by reducing the body to smaller dimensions," the allusion is surely to the recent recovery of Bishop Nicholas, who had been suffering from that infirmity.
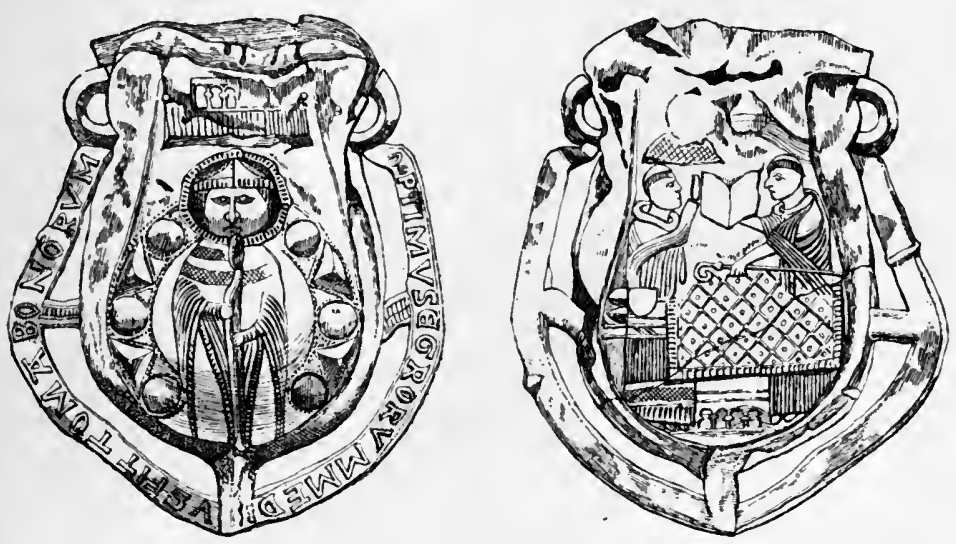

36. A PILGRIN'S SIGN

St. Thomas the Martyr of Canterbury was believed to surpass all others in powers of healing. His miracles were usually wrought by means of water mixed with a drop of the martyr's blood; this was carried away in a leaden ampulla, and its contents worked wonders. (See Fig. 8.) Others would purchase a "sign," upon which was announced in Latin :-_ For good people that are sick Thomas is the best of physicians." (Fig. 36.) Many of these pilgrims to Canterbury lodged in the hospital of 
St. Thomas (P1. II), said to have been founded by the archbishop himself, whose martyrdom is depicted on the walls of the hall. The chapel was dedicated to his special patron, the Blessed Virgin. St. Thomas', Southwark, also claimed him as founder, and two other houses were intimately connected with him. One was Becket's early home in Cheapside, enlarged by his sister Agnes and her husband, whose charter grants land " formerly belonging to Gilbert Becket, father of the blessed Thomas the Martyr . . . being the birthplace of the blessed martyr." Privileges were accorded to it long afterwards "from devotion to the saint, who is said to have been born and educated in that hospital." (This foundation was usually called St. Thomas of Acon, but it is believed that the designation had at first no connection with Acres, but rather with the original owner of the property.) The second house with family associations was at Ilford, for while Becket's sister was abbess of Barking, the lepers' chapel was reconsecrated with the addition of the name of St. Thomas.

Nor were his friends less faithful, for when Becket's chancellor Benedict (afterwards his biographer) was transferred from Canterbury to Peterborough, he completed a foundation in his honour. Probably Benedict was also concerned in the choice of name at Stamford, especially as that dependent house adopted St. John Baptist and St. Thomas as joint patrons ; for the fact that the new martyr's body was laid near the altar of the Baptist called forth from several chroniclers (as Stanley points out) the remark that St. John Baptist was the bold opponent of a wicked king. In a document relating to the Stamford house, St. Thomas is referred to as "the proto-martyr," but the claim is hard to justify. He was 
commemorated with St. Stephen at Romney, a dedication which would have given him abundant satisfaction; for previous to his flight in 1164 he celebrated, as having a special portent, the mass "in honour of the blessed protomartyr Stephen."

It is a far cry from Kent to Northumberland, but there existed at Bolton a hospital of St. Thomas. Within a few miles had been fought the Battle of Alnwick, a victory won, it was believed, as the result of the king's public penance the same day (II74). The date of foundation is not recorded, but it was begun before 1225. About the same time a hospital of St. Thomas was being built at Hereford, by one of the Warennes, whose father had bitterly opposed the then unpopular Chancellor. The new devotion to St. Thomas was fanned into flame by the magnificent ceremony of 1220 on the removal of his body to its wonderful shrine. Soon after this, a hospital was founded at Bec, and the patronage annexed to the See of Norwich; it was consecrated by Bishop Pandulph, who had taken a leading part in the "Translation," an event which was henceforth celebrated on July 7. For centuries the shrine was held in high honour. The Letter Books of Christ Church, Canterbury, record miracles in 1394 and $1445 .^{1}$ So notable was the first of these that Richard II wrote to congratulate the archbishop, acknowledging his thankfulness to "the High Sovereign Worker of miracles who has deigned to work this miracle in our days, and upon a foreigner, as though for the purpose of spreading ... the glorious fame of His very martyr," adding a pious wish that it might result in the conversion of those in error at a time when "our faith and belief

1 Chron. and Mem. 85 , iii. 27-29. 
have many more enemies than they ever had time out of mind." Such signs were, in fact, an antidote to Lollardy, as is implied by the public testimony of the Chapter to the cure of a cripple from Aberdeen in 1445 .

The kings continued to pay pilgrimage visits, and even Henry VIII sent the accustomed offerings to Canterbury. His subsequent animosity towards St. Thomas was a political move, as is shown by the report of Robert Ward in 1535 ; having spied at the hospital of St. Thomas of Acon a window depicting the flagellation of Henry II by monks at the shrine, he pointed out to Thomas Cromwell that Becket was slain "in that he did resist the king." Bale afterwards alludes thus to this burning question :-

"A trayterouse knave ye can set upp for a saynte, And a ryghteouse kynge lyke an odyouse tyrant paynte.

In your glasse wyndowes ye whyppe your naturall kynges." 1

In 1538 Henry thought it expedient to inform his loving subjects that notwithstanding the canonization of St. Thomas "there appeareth nothing in his life and exteriour conversation whereby he should be called a saint, but rather . . . a rebel and traitor to his prince." Henceforth few windows remained depicting the acts of the martyr, - though one representation of the penance of Henry II is familiar to readers at the Bodleian. The name was to be no longer perpetuated; "St. Thomas the Martyr, Southwark," becomes "Becket Spital" and then "St. Thomas the Apostle," whilst " Thomas House" is found at Northampton.

${ }^{1}$ Camden Society, Kynge Johan, p. 88. 
All Saints. - In spite of many general references to All Saints, the invocation by itself was as rare for a hospital as it was common for a church. Leland and the Valor Ecclesiasticus give the dedication of the Stamford bedehouse as "All Saints." The founder had willed that " there be for ever a certain almshouse, commonly called William Browne's Almshouse, for the invocation of the most glorious Virgin Mary and of All Saints, to the praise and honour of the Name Crucified." The almsmen's special chapel in the parish church of All Saints was in honour of the Blessed Virgin. The existing silver seal shows the Father, seated, supporting between His knees the Saviour upon the Cross, whilst the Spirit appears as a Dove.

\section{Alternative Dedications, etc.}

There is frequently an uncertainty as to the invocation, even with documentary assistance. A Close Roll entry (I 214 ) mentions a foundation at Portsmouth in honour of Holy Trinity, the Blessed Virgin, St. Cross, St. Michael and All Saints. Usually the name is simply "God's House," but often St. John Baptist or St. Nicholas. The seal seems to suggest the original designation, for it shows a Cross, with the Divine Hand, a scroll and angels. Again, God's House at Kingston-upon-Hull was called Holy Trinity or St. Michael's, or from its situation " the Charterhouse hospital"; but its full title was " in honour of God, and the most glorious Virgin Mary His Mother, and St. Michael the Archangel, and all archangels, angels and holy spirits, and of St. Thomas the Martyr, and all saints of God." It may be observed that inasmuch as the founder Michael Pole was Chancellor of England, 


\section{MEDI $F V A L$ HOSPITALS OF ENGLAND}

he looked to his predecessor in office St. Thomas as patron, no less than to his name-saint. By the foundationdeed of Heytesbury almshouse, it was in honour of "the Holy Trinity, and especially of Christ our Redeemer, the Blessed Virgin Mary His Mother, St. Katherine and all saints." The almsmen wore the letters JHU. XRT. upon their gowns. The Chantry Certificate, nevertheless, gives St. John's. The original seal shows a Cross and the name domus elimosinaria, but the post-Reformation seal has St. Katherine. Varying dedications are sometimes merely mistakes. It must, however, be remembered that occasionally hospital and chapel had different patrons, and that both were sometimes rebuilt and re-consecrated. As civil and ecclesiastical archives continue to reveal their long-hidden information, the dedication-names of many houses will doubtless come to light, together with notices of foundations at present unknown to us.

Some seventy titles of hospitals are here recorded, as compared with over six hundred different dedications of parish churches. In some instances the patron of a charitable institution bequeathed his name to a parish. At 'Tweedmouth, St. Bartholomew of the hospital was powerful enough to dispossess St. Boisil, the rightful patron of the place. The parishes of St. Mary Magdalene, Colchester, St. Giles-in-the-Fields, London, and St. Giles, Shrewsbury, have grown up round a former leper-house. Several modern churches, such as St. John's, Bridgwater, occupy the site and carry on the name of an old foundation.

In conclusion, it must be observed that since the subject of England's Patron Saints has been fully dealt with by 
Miss Arnold-Forster, no attempt has here been made to make more than passing allusions to the lives of hospital saints. The foregoing notes on saints were suggested by her Studies in Church Dedications.

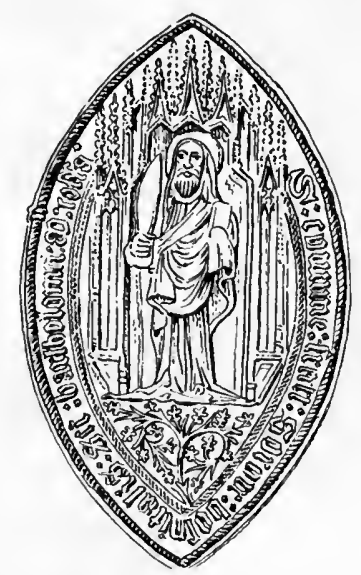

37. SEAL OF THE HOSPITAL OF ST. BARTHOLOMEW, ROCHEŚTER 



\section{APPENDIX A}

\section{OFFICE AT THE SECLUSION OF A LEPER}

[Translated from the Manuale ad Usum Insignis Ecclesia Sarum, printed in York Manual, \&ैc., Appendix, Surtees Society, Vol. 63. p. $105^{*}$.]

The Manner of casting out or separating those who are sick with leprosy from the whole. ${ }^{1}$

$\mathrm{F}$

IRST of all the sick man or the leper clad in a cloak and in his usual dress, being in his house, ought to have notice of the coming of the priest who is on his way to the house to lead him to the Church, and must in that guise wait for him. For the priest vested in surplice and stole, with the Cross going before, makes his way to the sick man's house and addresses him with comforting words, pointing out and proving that if he blesses and praises God, and bears his sickness patiently, he may have a sure and certain hope that though he be sick in body he may be whole in soul, and may reach the home ${ }^{2}$ of everlasting welfare. And then with other words suitable to the occasion let the priest lead the leper to the Church, when he has sprinkled him with holy water, the Cross going before, the priest following, and last of all the sick man. Within the Church let a black cloth, if it can be had, be set upon two trestles at some distance apart before the altar, and let the sick man take his place on bended knees beneath it between the trestles, after the manner of a dead man, although

1 This is identical with the 3 rd Ordo given in Martene, lib. iii. c.x., from the Ritual of Bourges and Sens issued by the command of Cardinal Borbonius (Henderson).

2 Domum (Henderson); or, reading Donum (with Martene, etc.) we may translate this :- " may obtain the gift of everlasting salvation." 


\section{MEDI $Æ V A L$ HOSPITALS OF ENGLAND}

by the grace of God he yet lives in body and spirit, and in this posture let him devoutly hear Mass. When this is finished, and he has been sprinkled with holy water, he must be led with the Cross through the presbytery to a place where a pause must be made. When the spot is reached the priest shall counsel him out of Holy Scripture, saying: "Remember thine end and thou shalt never do amiss." [Ecclus. vii. 36.] Whence Augustine says: "He readily esteems all things lightly, who ever bears in mind that he will die." The priest then with the spade (palla) casts earth on each of his feet, saying: "Be thou dead to the world, but alive again unto God."

And he comforts him and strengthens him to endure with the words of Isaiah spoken concerning our Lord Jesus Christ :"Truly He hath borne our griefs and carried our sorrows, yet did we esteem Him as a leper smitten of God and afflicted" [Isa. liii. 4, Vulgate]; let him say also: "If in weakness of body by means of suffering thou art made like unto Christ, thou mayest surely hope that thou wilt rejoice in spirit with God. May the Most High grant this to thee, numbering thee among His faithful ones in the book of life. Amen."

It is to be noted that the priest must lead him to the Church, from the Church to his house as a dead man, chanting the Responsorium Libera me, Domine, in such wise that the sick man is covered with a black cloth. And the Mass celebrated at his seclusion may be chosen either by the priest or by the sick man, but it is customary to say the following :-

Introitus. Circumdederunt me. Quare in Septuagesima.

Collecta. Ornnipotens sempiterne Deus, salus æeterna credentium.

Epistola. Carissimi, Tristatur quis vestrum.

Resp. Miserere mei.

Vers. Conturbata sunt. Alleluya. $V$. Qui sanat.

Si in Quadragesima, Tractus. Commovisti.

Evangelium. Intravit Jesus in Capharnaum.

Offertorium. Domine, exaudi.

Secreta et Postcommunio in communibus orationibus.

Communio. Redime, Deus, Israel ex omnibus angustiis nostris. 
When leaving the Church after Mass the priest ought to stand at the door to sprinkle him with holy water. And he ought to commend him to the care of the people. Before Mass the sick man ought to make his confession in the Church, and never again ; and in leading him forth the priest again begins the Responsorium Libera me, Domine, with the other versicles. Then when he has come into the open fields he does as is aforesaid; and he ends by imposing prohibitions upon him in the following manner :-

"I forbid you ever to enter Churches, or to go into a market, or a mill, or a bakehouse, or into any assemblies of people.

Also I forbid you ever to wash your hands or even any of your belongings in spring or stream of water of any kind; and if you are thirsty you must drink water from your cup or some other vessel.

Also I forbid you ever henceforth to go out without your leper's dress, that you may be recognized by others; and you must not go outside your house unshod.

Also I forbid you, wherever you may be, to touch anything which you wish to buy, otherwise than with a rod or staff to show what you want.

Also I forbid you ever henceforth to enter taverns or other houses if you wish to buy wine; and take care even that what they give you they put into your cup.

Also I forbid you to have intercourse with any woman except your own wife.

Also I command you when you are on a journey not to return an answer to any one who questions you, till you have gone off the road to leeward, so that he may take no harm from you; and that you never go through a narrow lane lest you should meet some one.

Also I charge you if need require you to pass over some toll-way (pedagium) through (?) rough ground (super apra), or elsewhere, that you touch no posts or things (instrumenta) whereby you cross, till you have first put on your gloves.

Also I forbid you to touch infants or young folk, whosoever they may be, or to give to them or to others any of your possessions. 


\section{MEDI EVAL HOSPITALS OF ENGLAND}

Also I forbid you henceforth to eat or drink in any company except that of lepers. And know that when you die you will be buried in your own house, unless it be, by favour obtained beforehand, in the Church."

And note that before he enters his house, he ought to have a coat and shoes of fur, his own plain shoes, and his signal the clappers, a hood and a cloak, two pair of sheets, a cup, a funnel, a girdle, a small knife, and a plate. His house ought to be small, with a well, a couch furnished with coverlets, a pillow, a chest, a table, a seat, a candlestick, a shovel, a pot, and other needful articles.

When all is complete the priest must point out to him the ten rules which he has made for him; and let him live on earth in peace with his neighbour. Next must be pointed out to him the ten commandments of God, that he may live in heaven with the saints, and the priest repeats them to him in the presence of the people. And let the priest also point out to him that every day each faithful Christian is bound to say devoutly Pater noster, Ave Maria, Credo in Deum, and Credo in Spiritum, and to protect himself with the sign of the Cross, saying often Benedicite. When the priest leaves him he says:"Worship God, and give thanks to God. Have patience, and the I.ord will be with thee. Amen." 


\title{
APPENDIX B
}

\author{
TABULATED LIST OF \\ MEDI $Æ V A L$ HOSPITALS IN ENGLAND
}

\author{
i.e. Houses for Wayfarers, Sick, Aged and Infirm, Insane, and \\ Lepers, founded before $\mathbf{5} 54$.
}

EXPLANATION OF HEADINGS, REFERENCES, SIGNS, ETC.

Dedication. When names are stated thus : "St. John [\& St. Anthony]," this signifies that the name in brackets is less frequently used.

Date. The date given is that of the first accredited reference. The foundation was frequently earlier. $c .=c i r c a ; b e f=$ before.

Founder. This term includes benefactor and re-founder.

Patron. In the majority of cases entered as "Private," the advowson was vested in the Lord of the Manor. Where two names are inserted they represent a change of patronage.

L. i.e. Leper; this denotes the nominal aim of the charity, which was not necessarily confined to lepers.

An asterisk signifies that there are considerable architectural remains (chapel, hall, etc.).

Indicates slight architectural remains(e.g. masonry, windows).

$\ddagger \quad$ This sign before a dedication-name implies that some endowment exists under that name or the name of the founder.

Seal. Denotes that either a matrix or an impression is in existence. A specimen is usually to be found in the British Museum. Soc. Antiq. refers to the Society of Antiquaries, London.

Italics. The use of italics implies uncertainty.

Foot-notes. "Patent" and "Close" refer to the printed Calendars of the Public Record Office, space not permitting of fuller details. 
278 MEDI $Æ V A L$ HOSPITALS OF ENGLAND

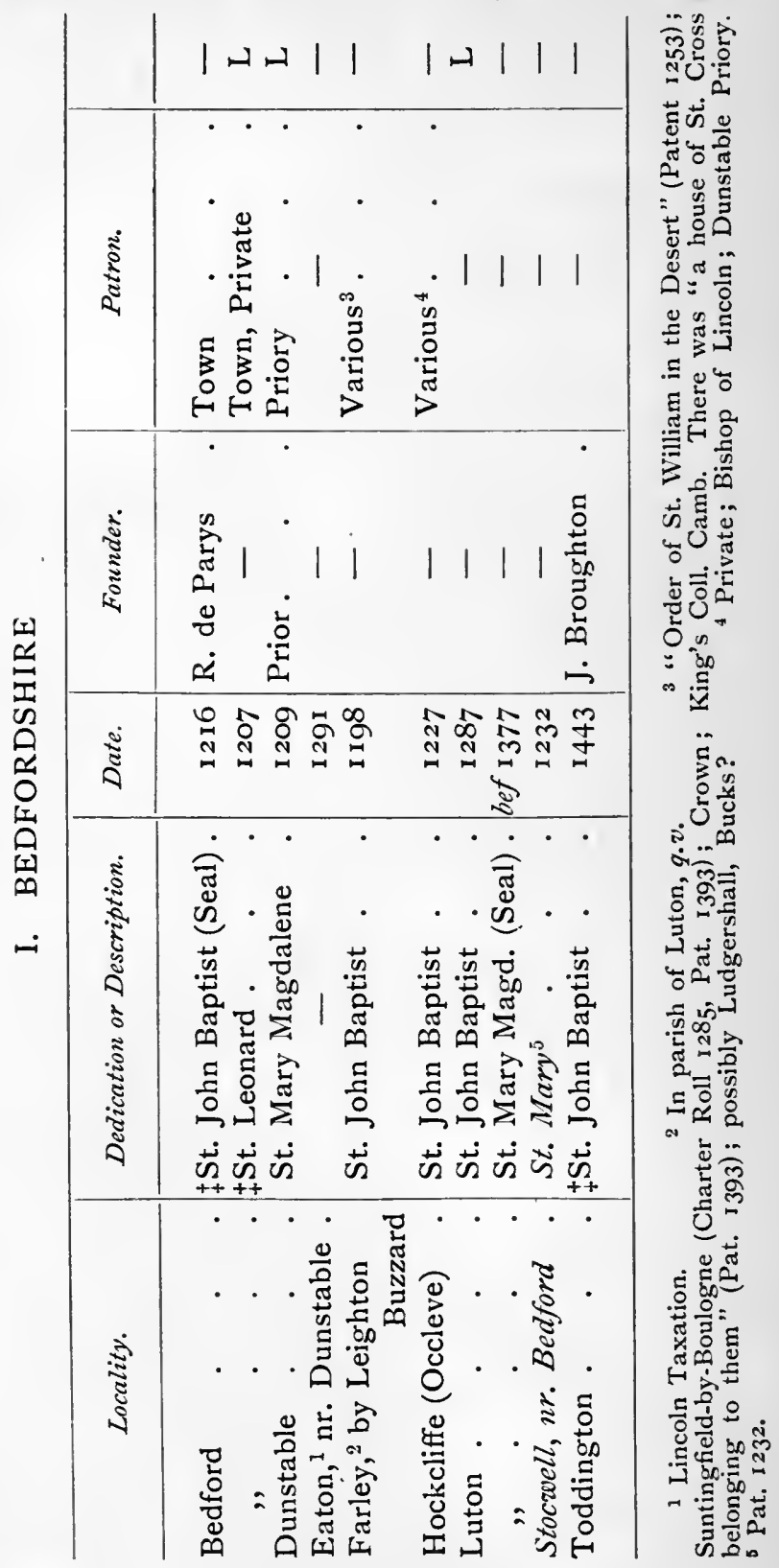




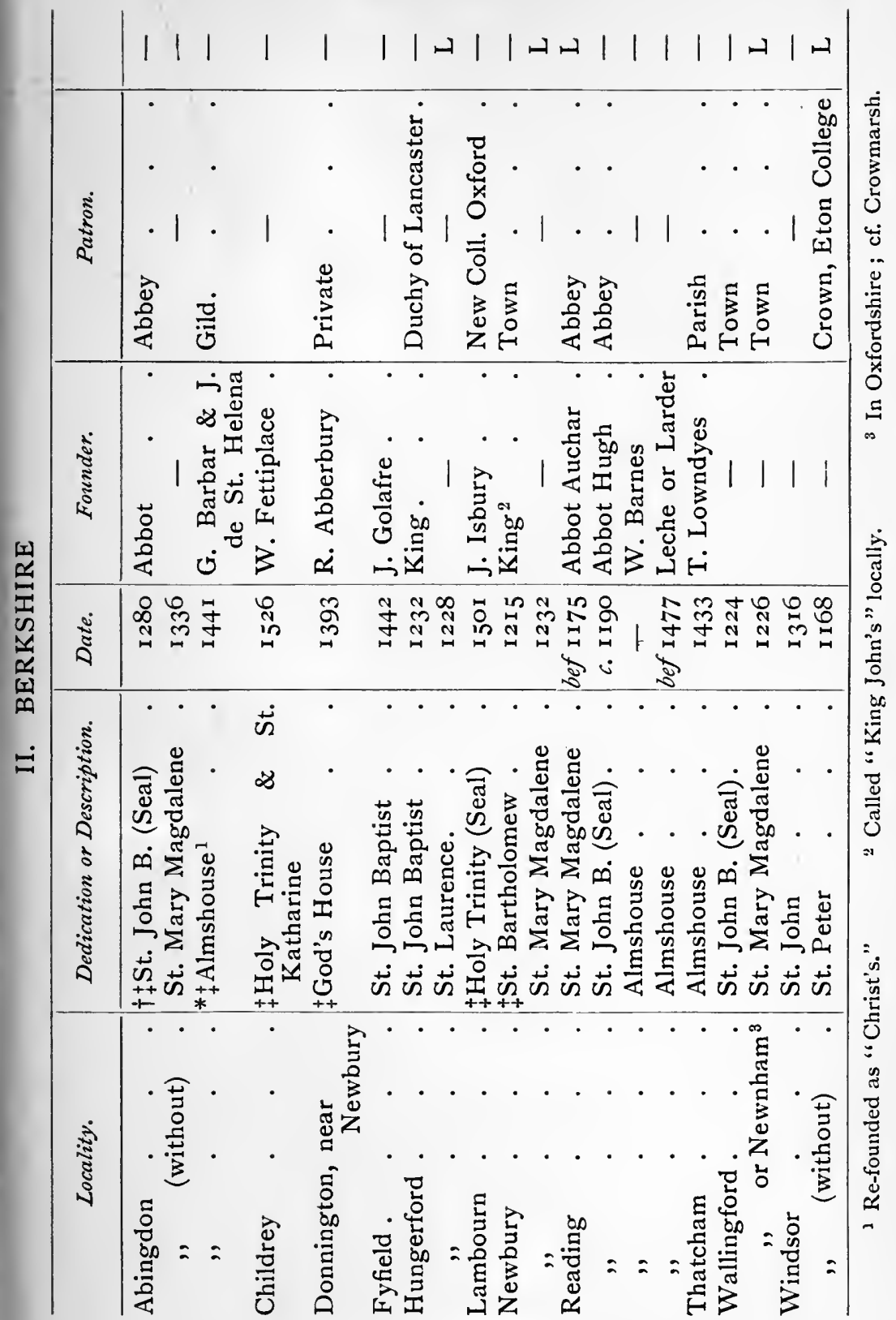


280 MEDI $Æ V A L$ HOSPITALS OF ENGLAND

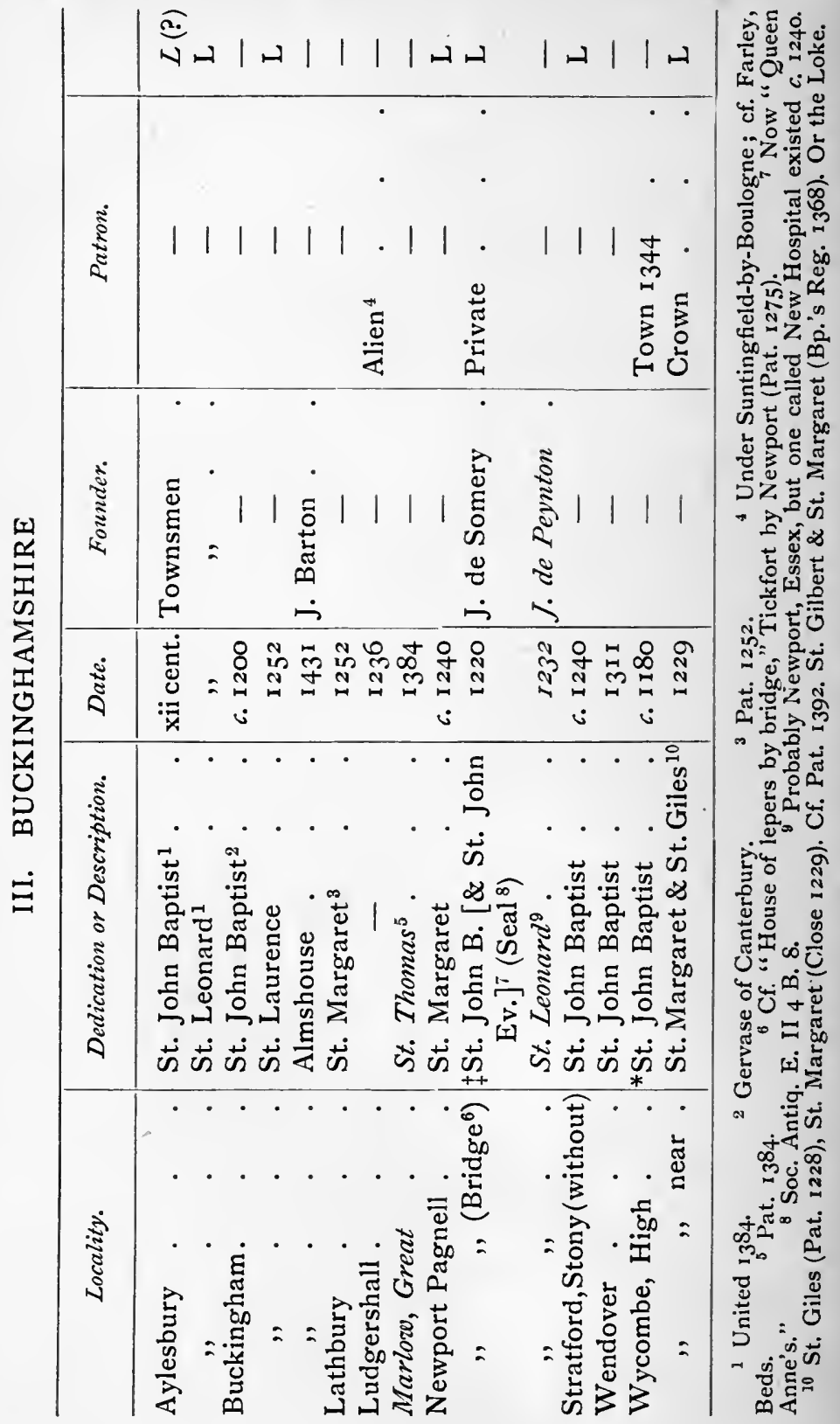


APPENDIX B

28 I

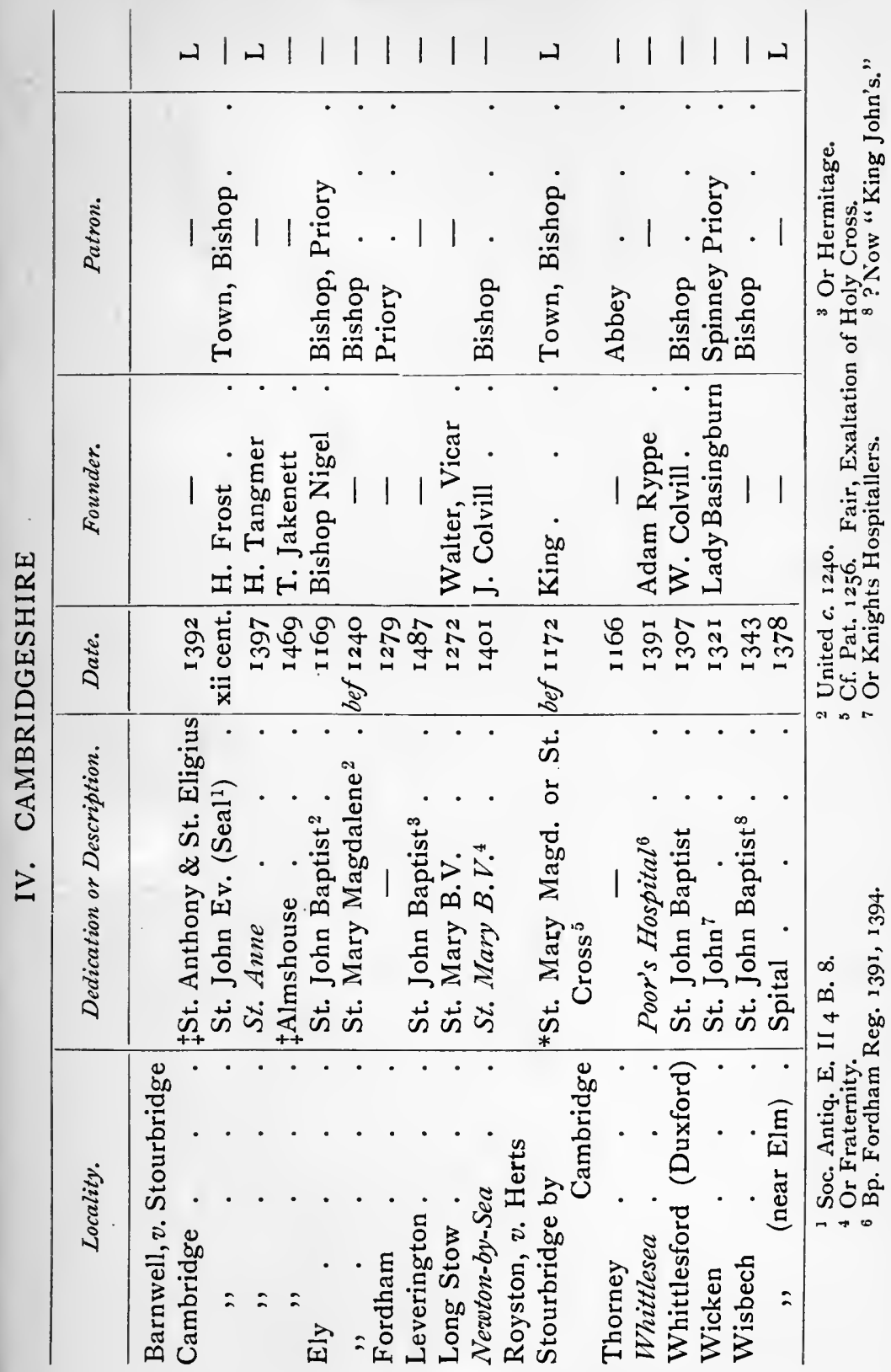


282 MEDI EVAL HOSPITALS OF ENGLAND

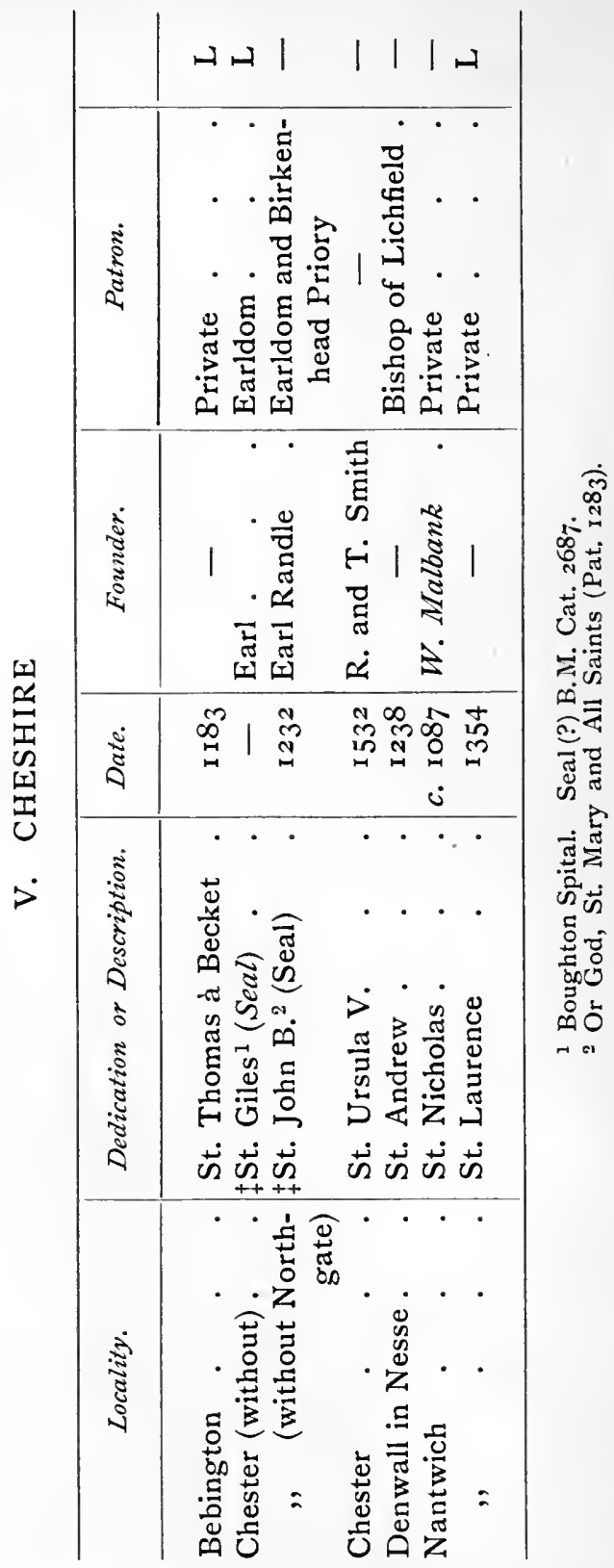




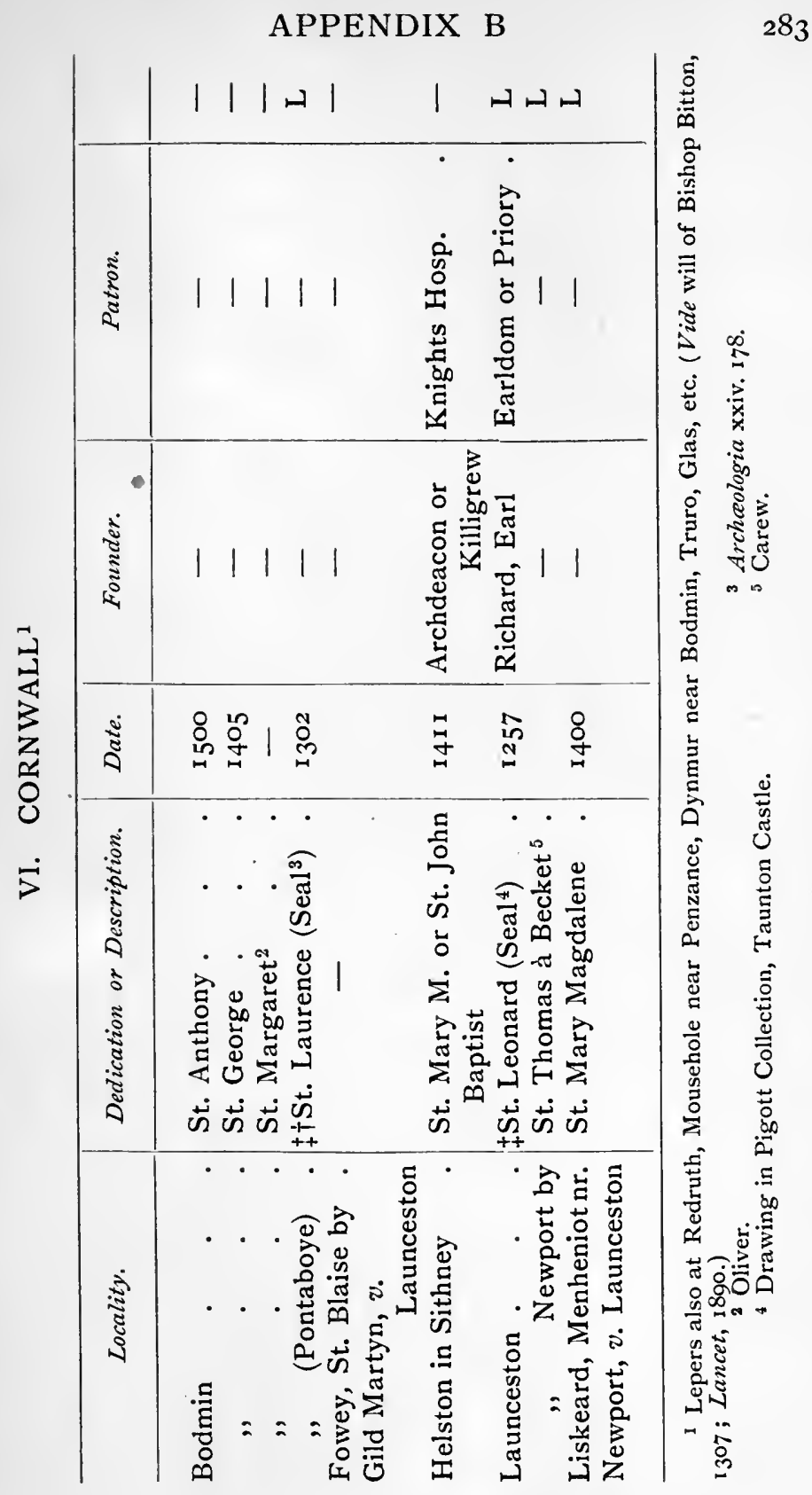




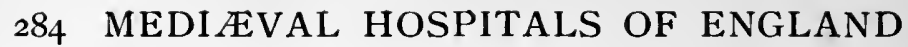

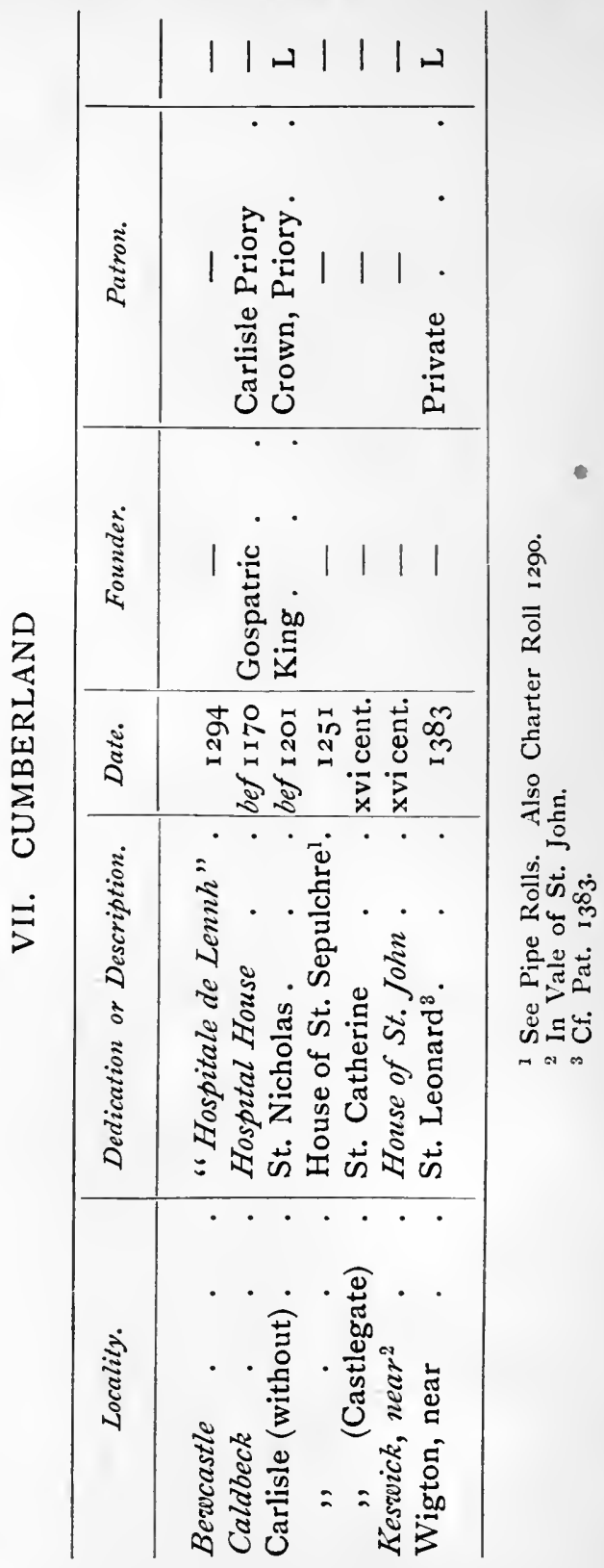


APPENDIX B

285

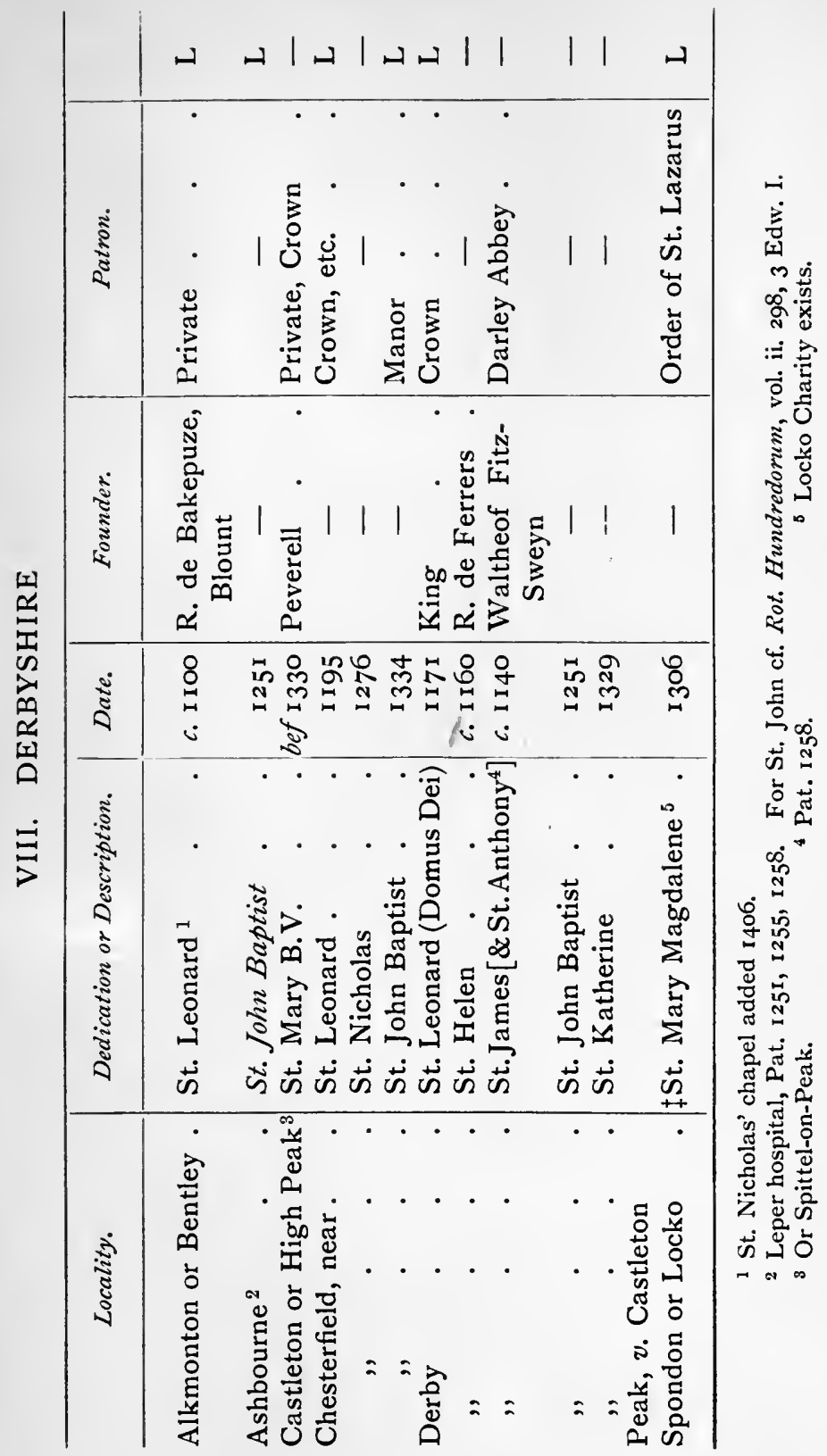


286 MEDI EVAL HOSPITALS OF ENGLAND

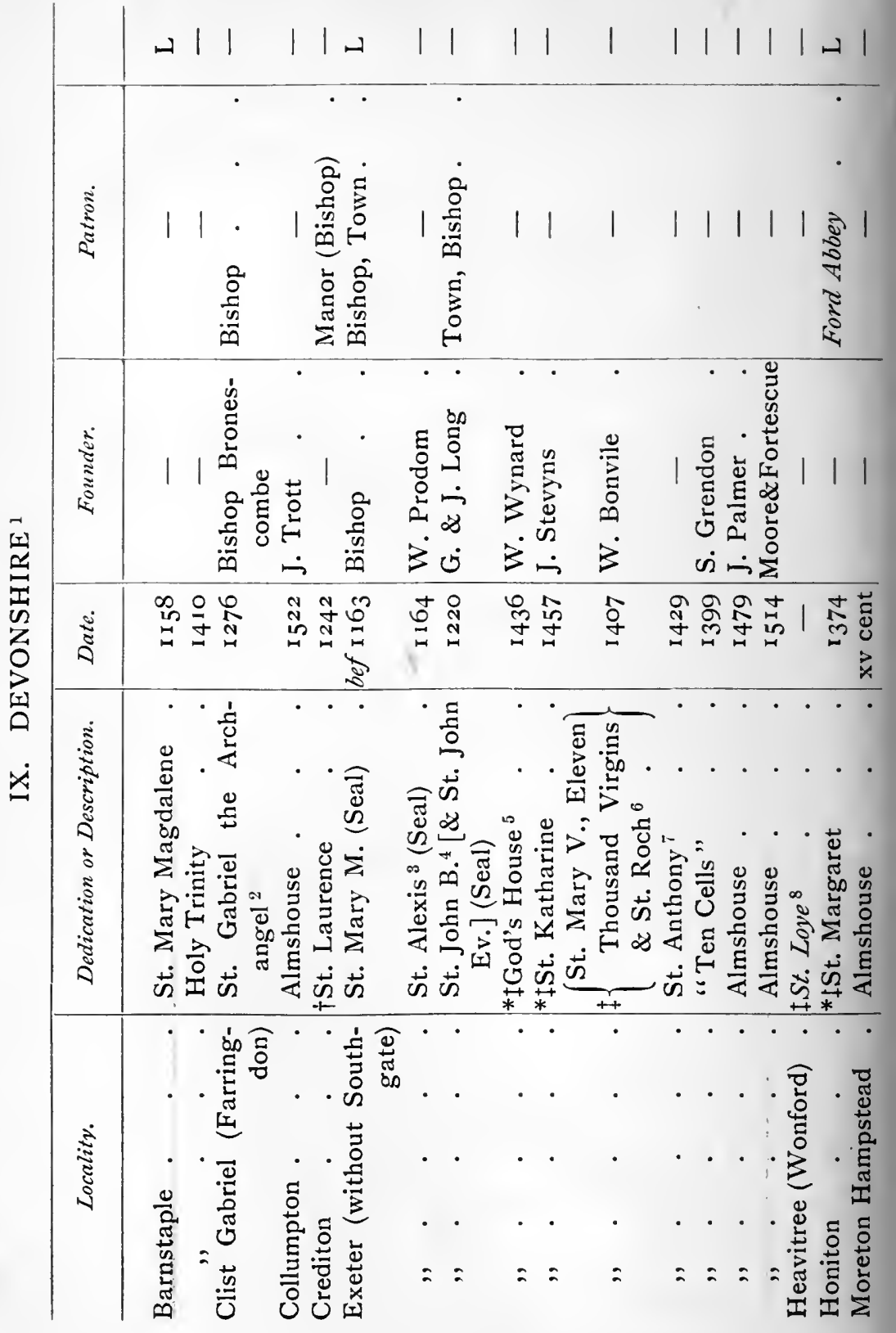




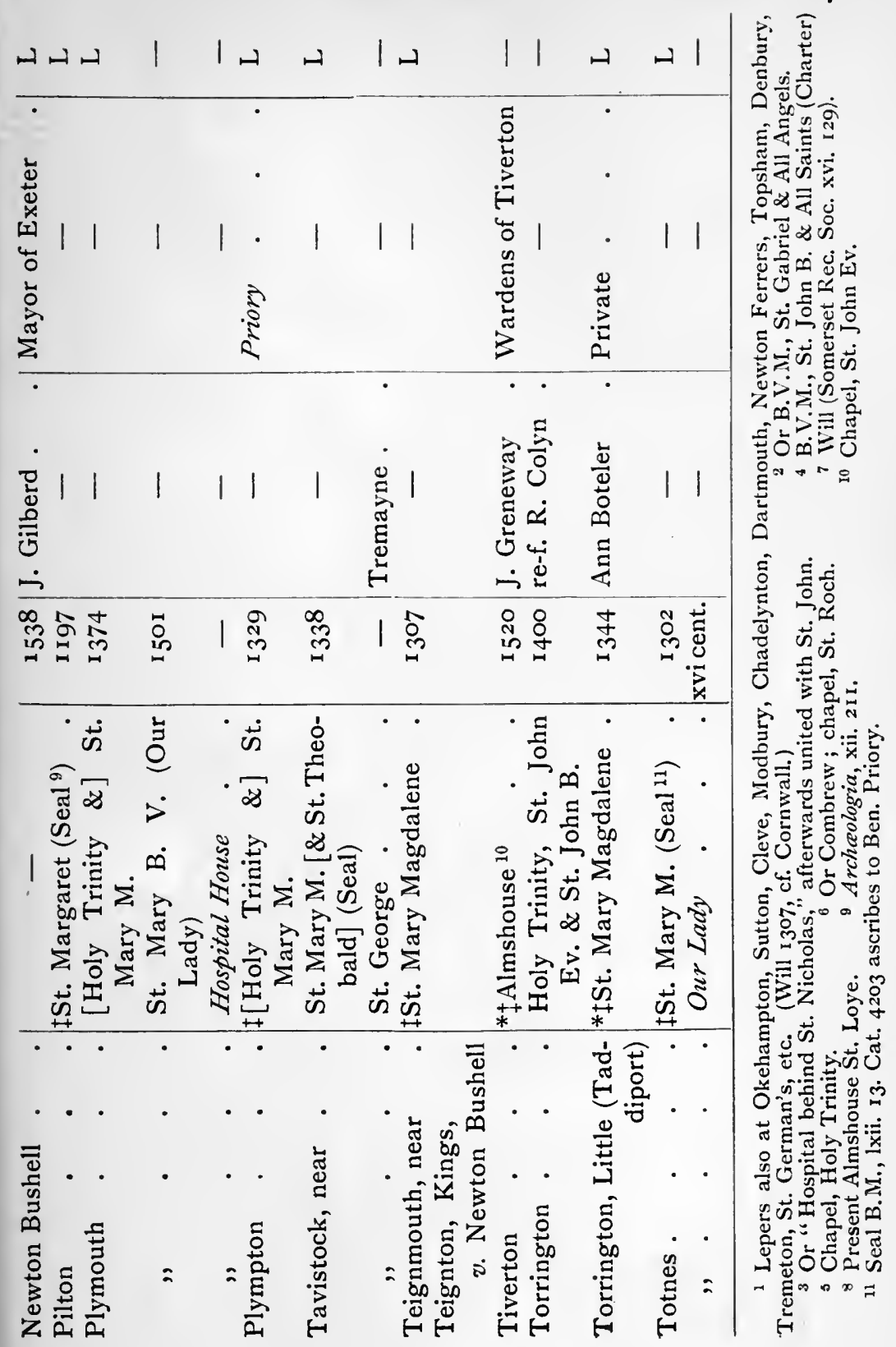


288 MEDIAVAL HOSPITALS OF ENGLAND

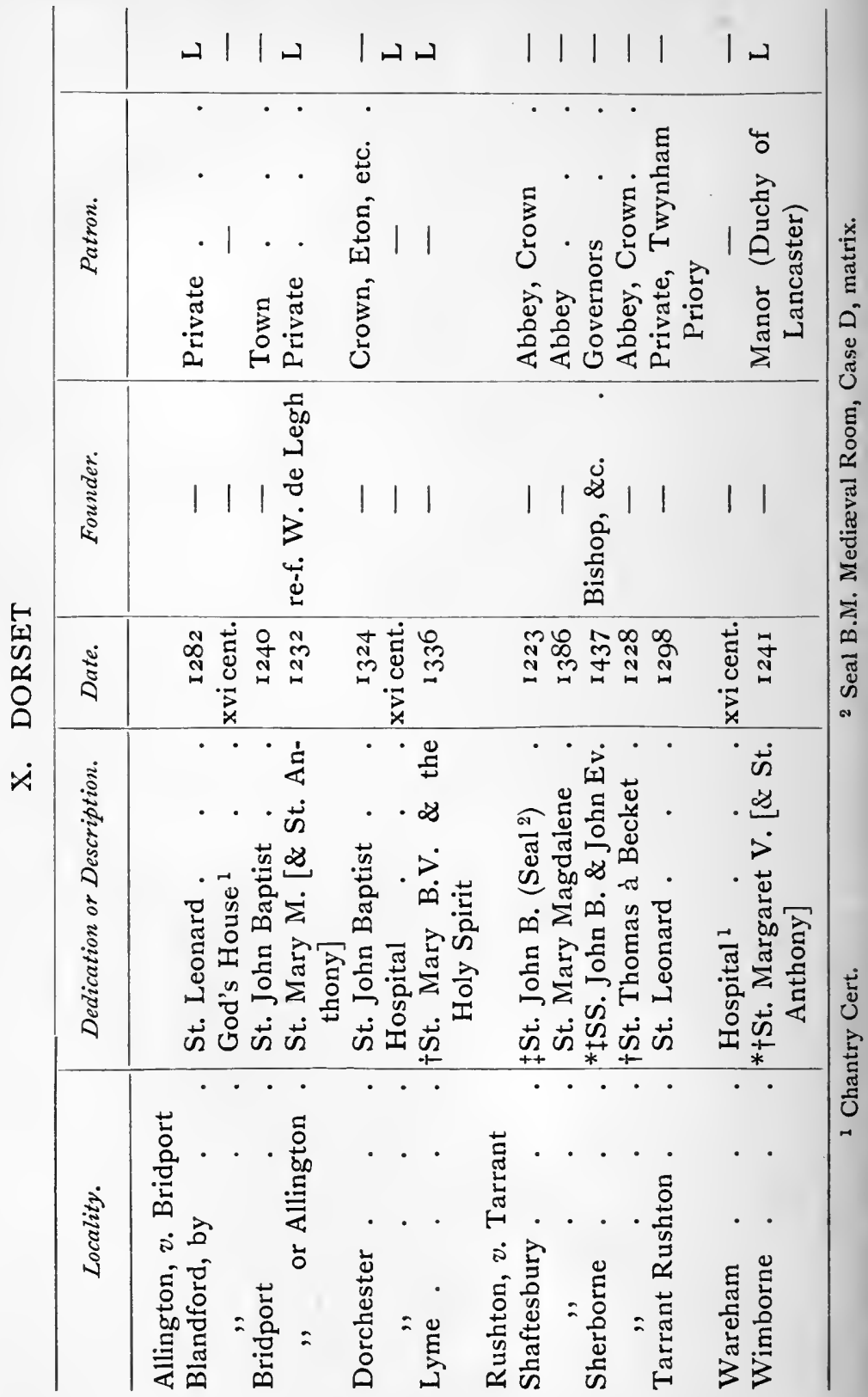


APPENDIX B

289

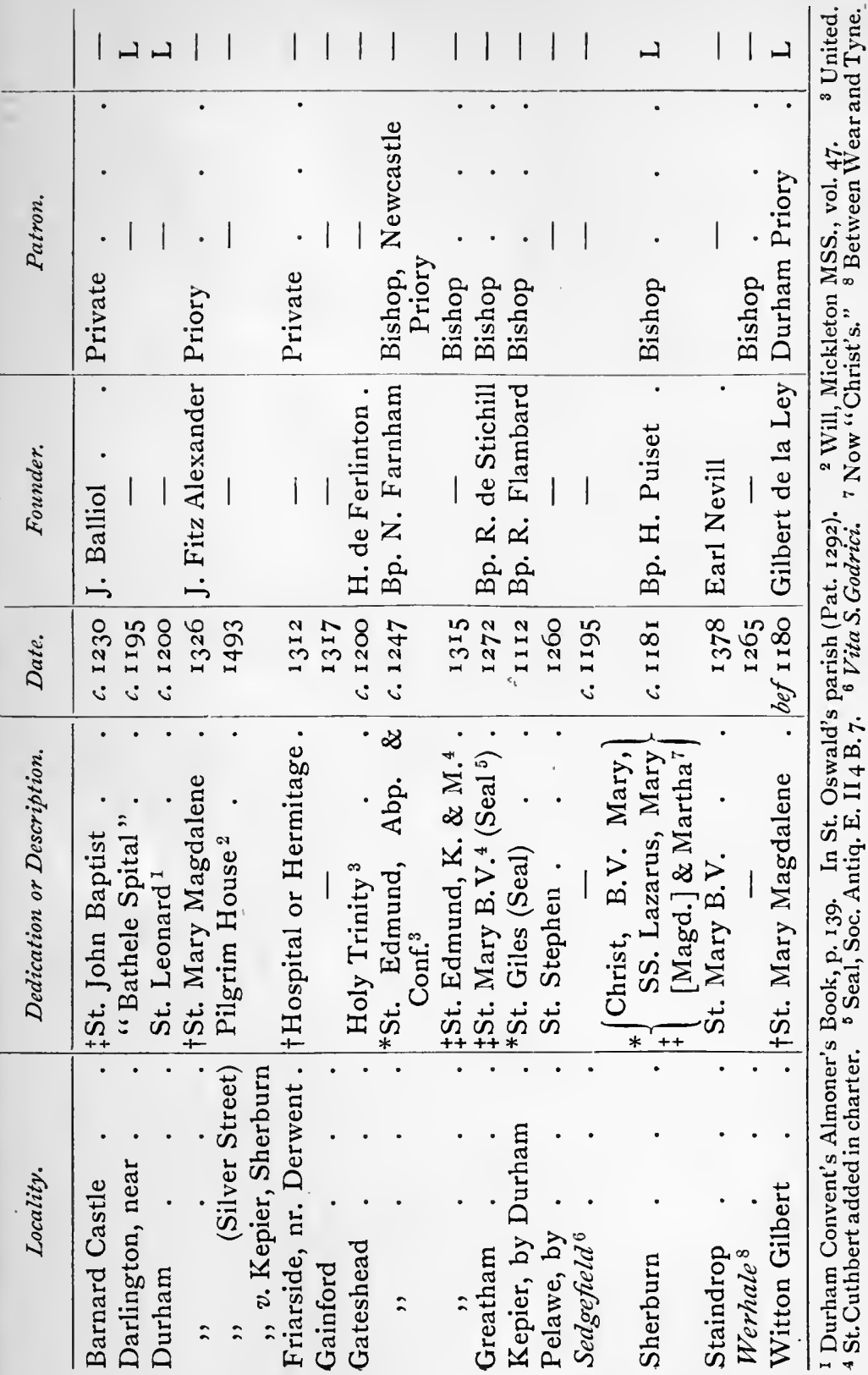


290 MEDI EVAL HOSPITALS OF ENGLAND

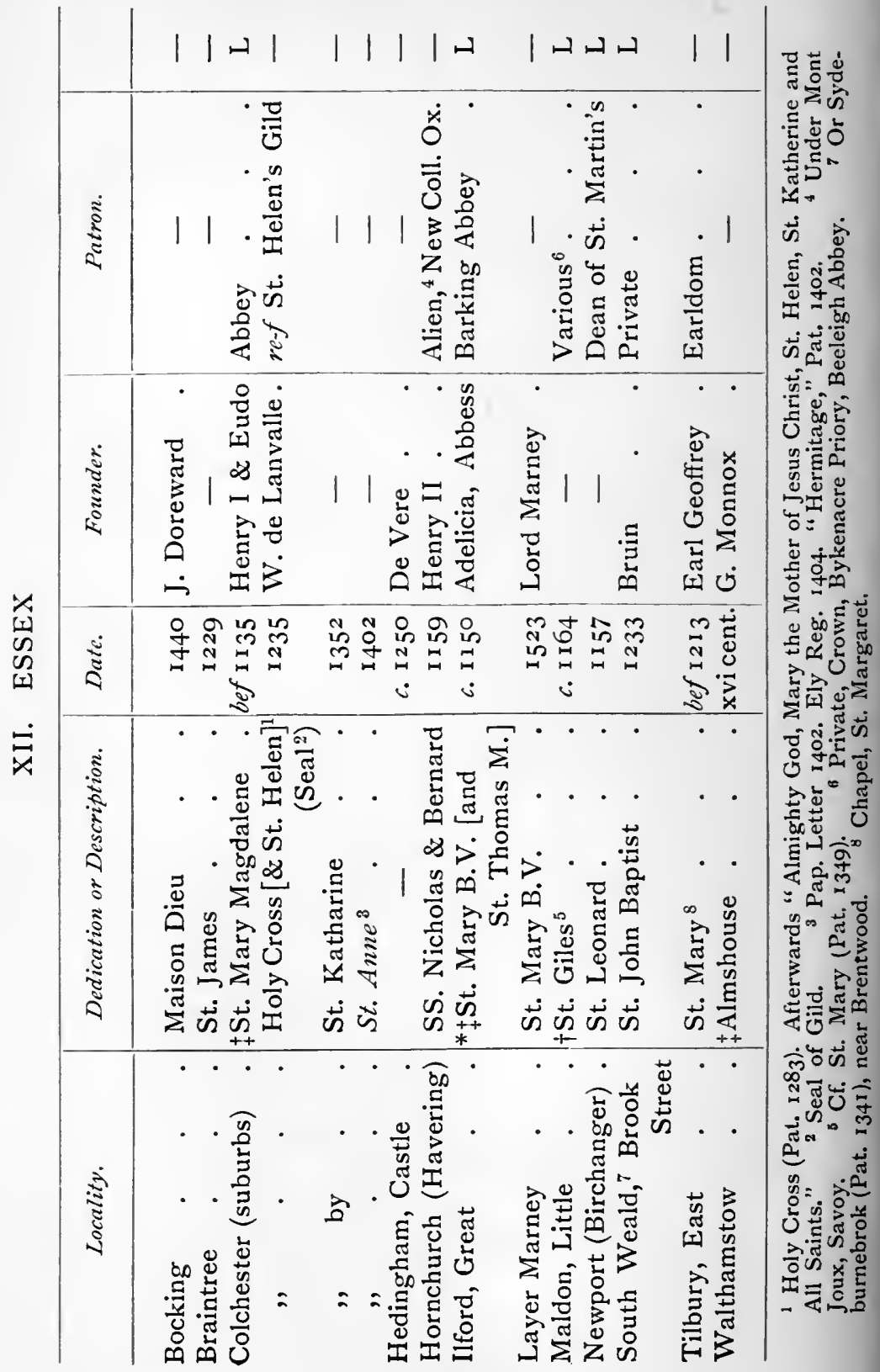




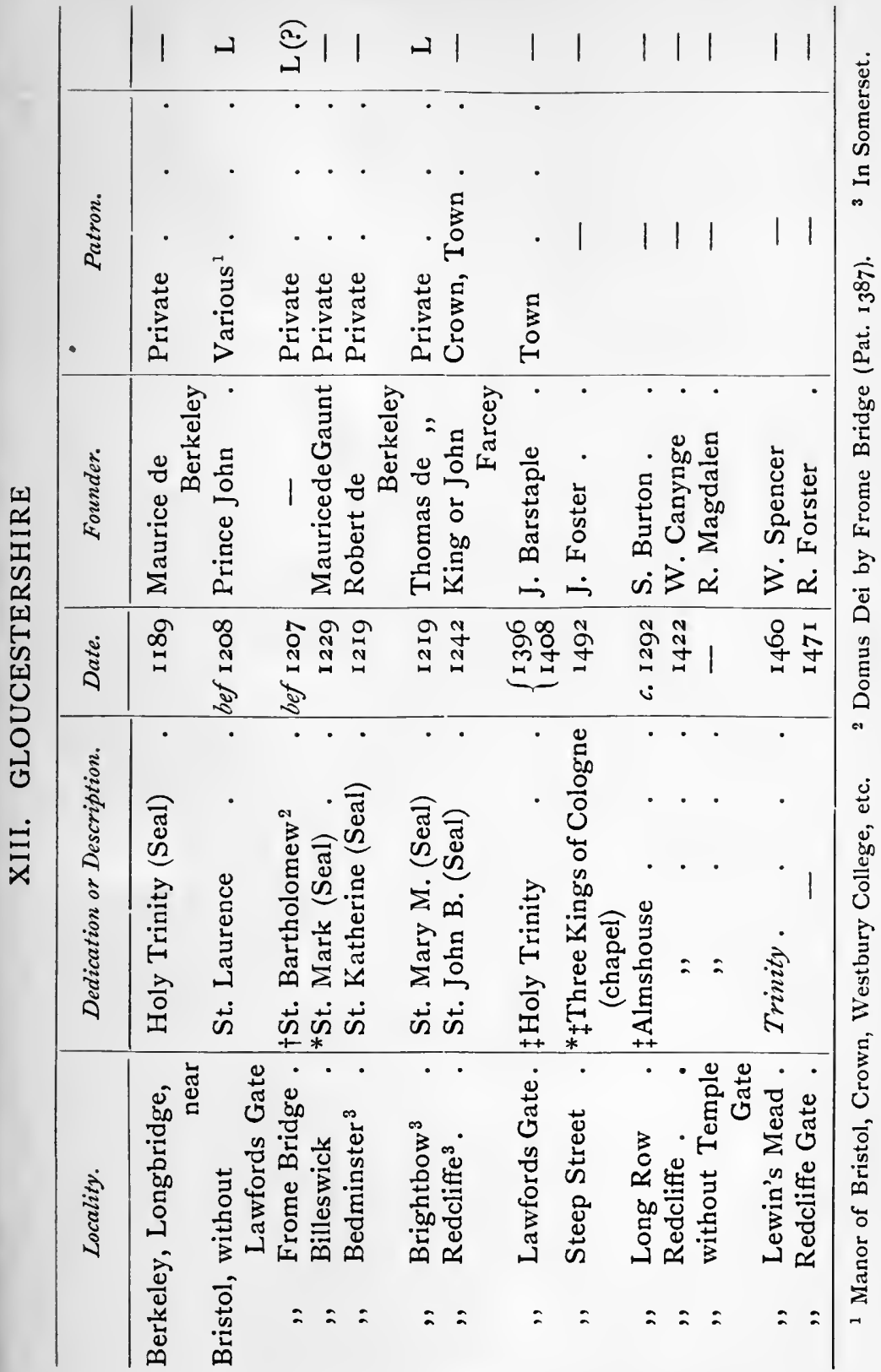




\section{MEDI $Æ V A L$ HOSPITALS OF ENGLAND}

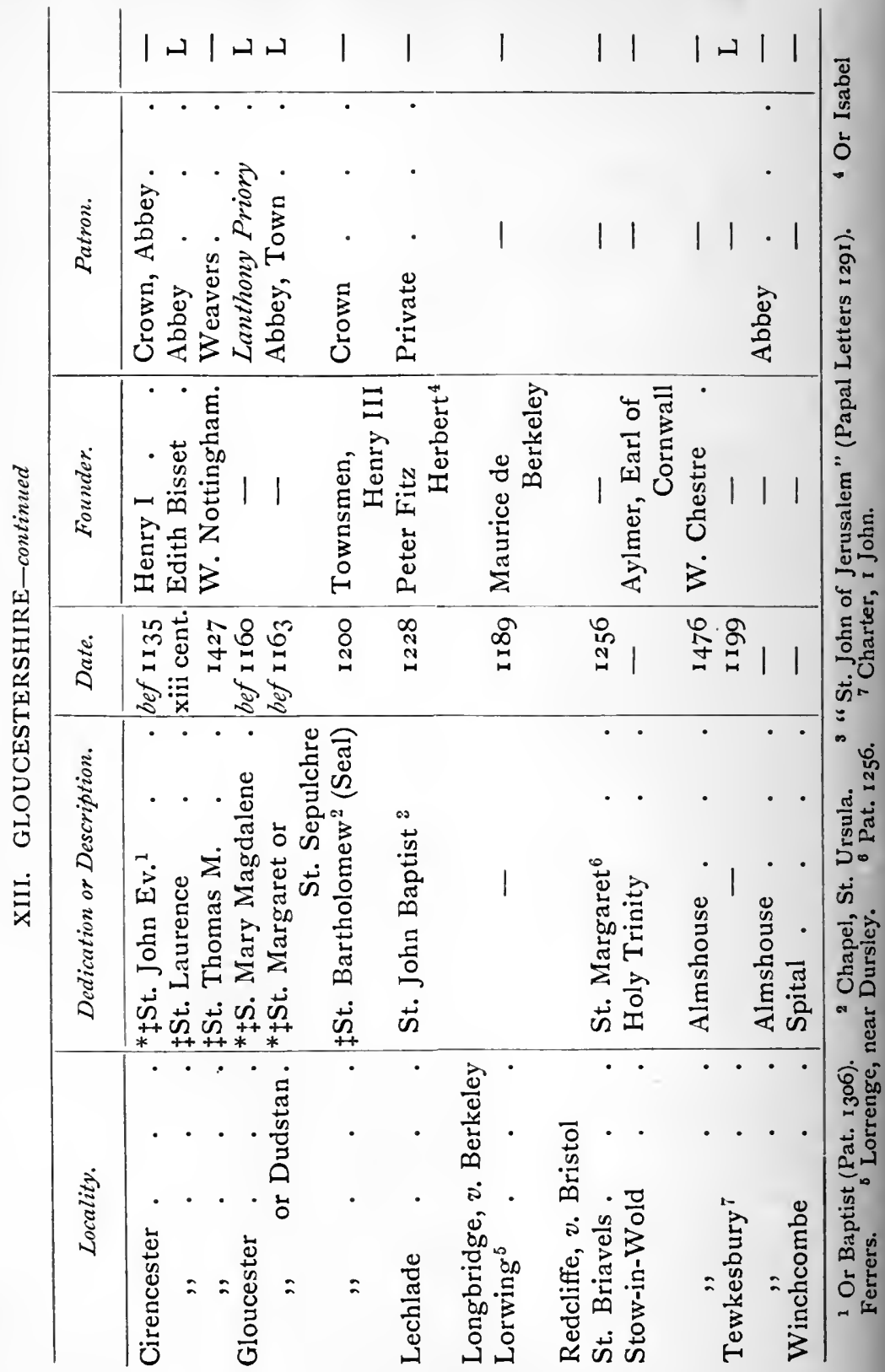


APPENDIX B

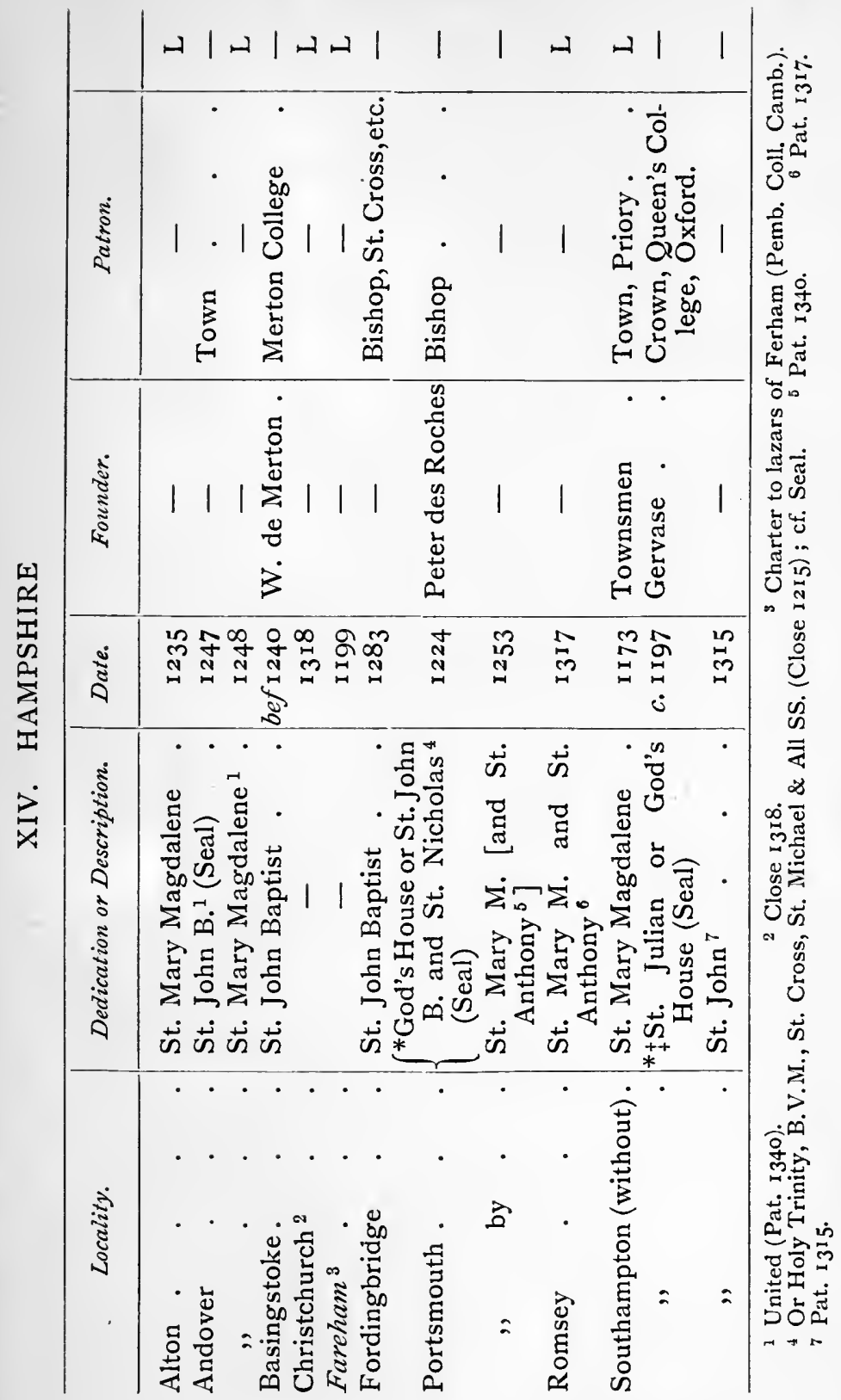


294 MEDIÆVAL HOSPITALS OF ENGLAND
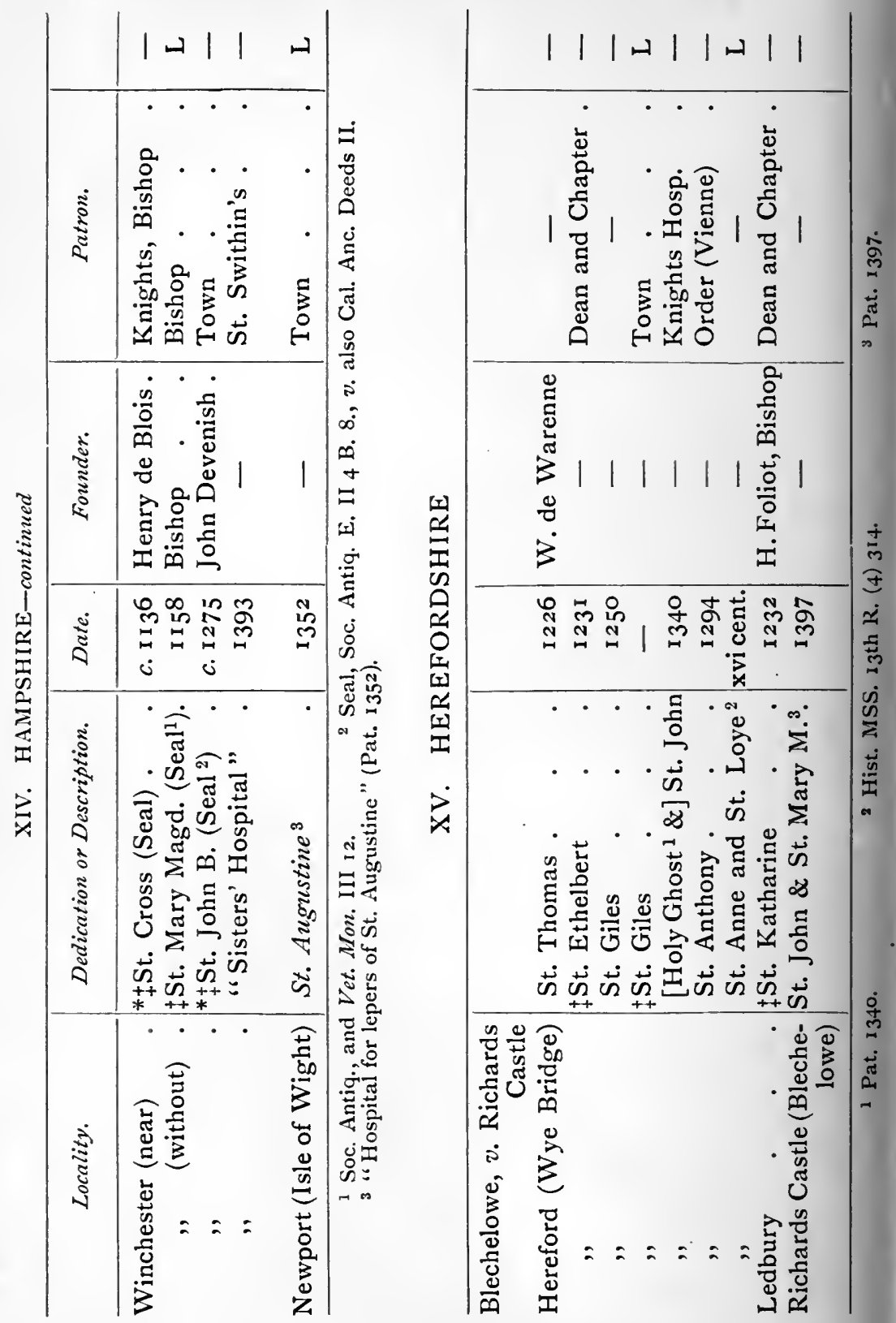


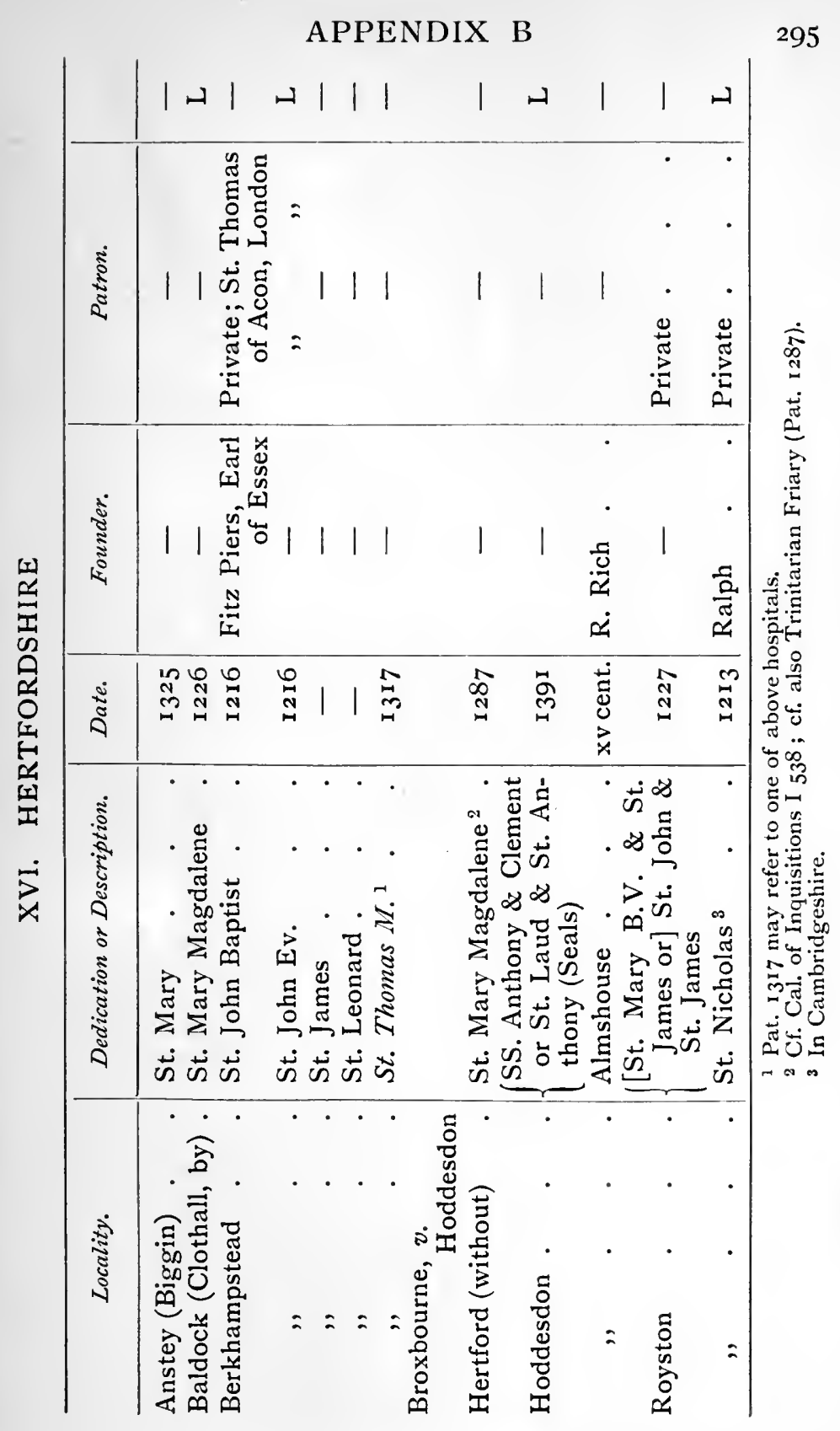


296 MEDI $Æ V A L$ HOSPITALS OF ENGLAND

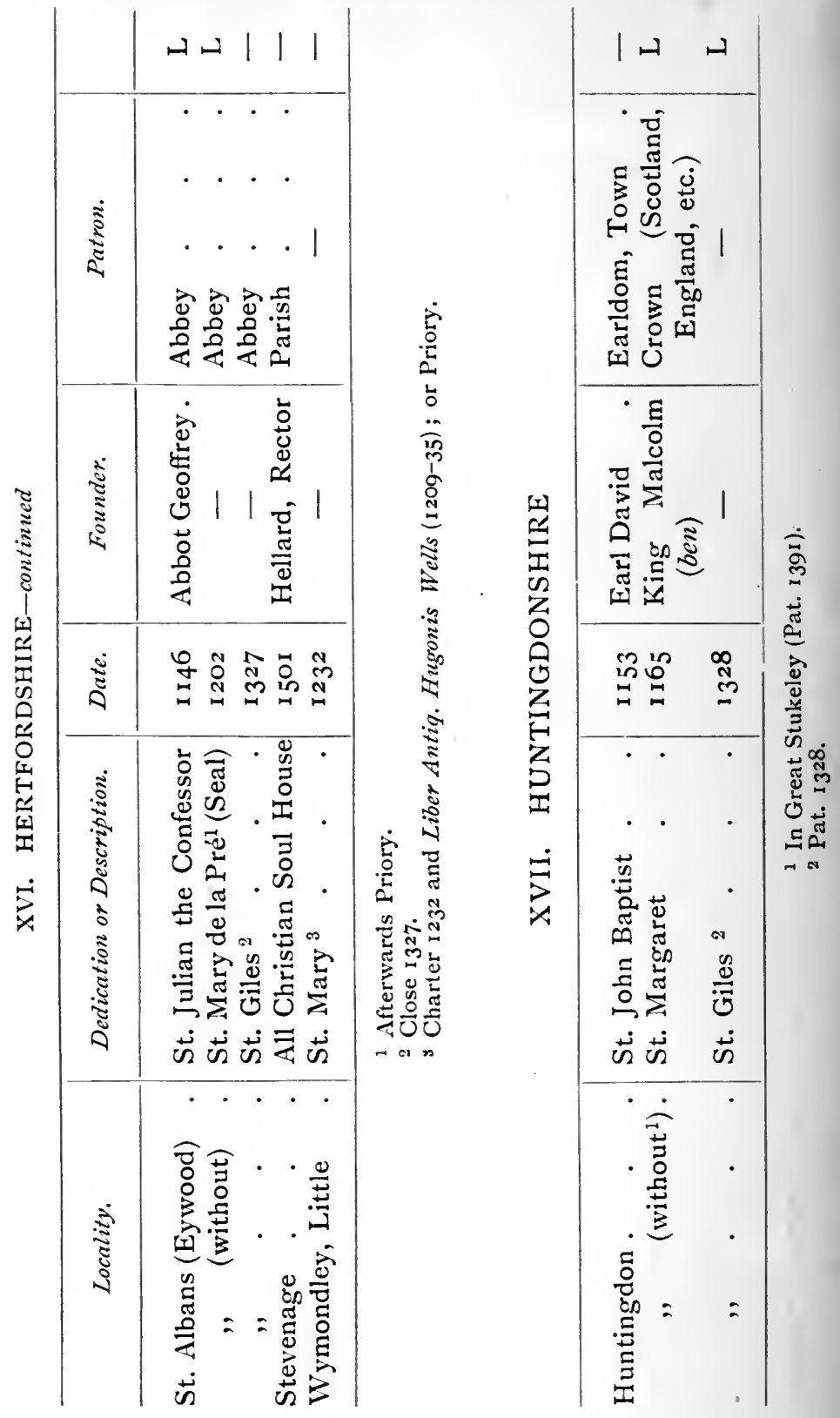




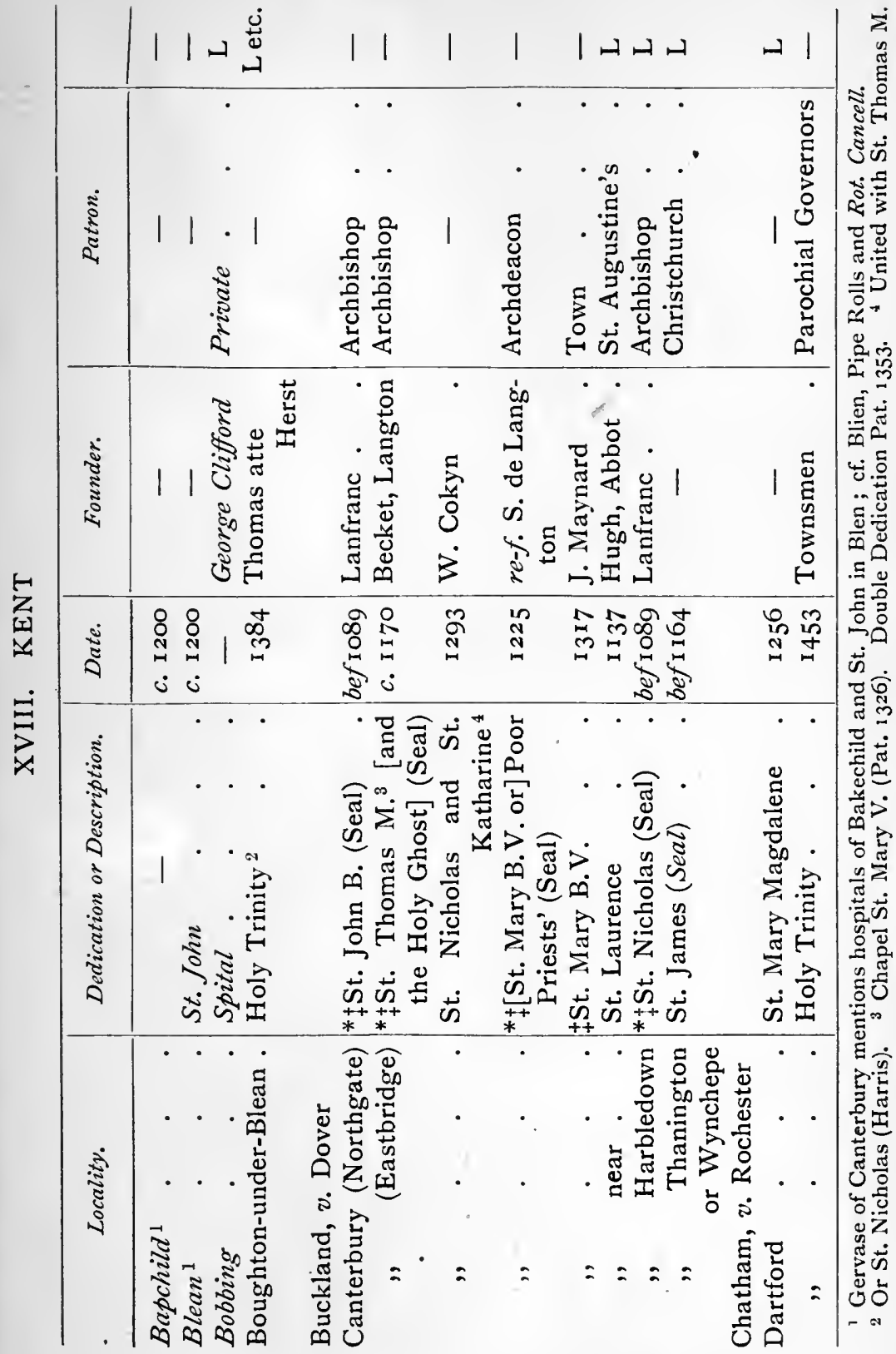


298 MEDI $A V A L$ HOSPITALS OF ENGLAND

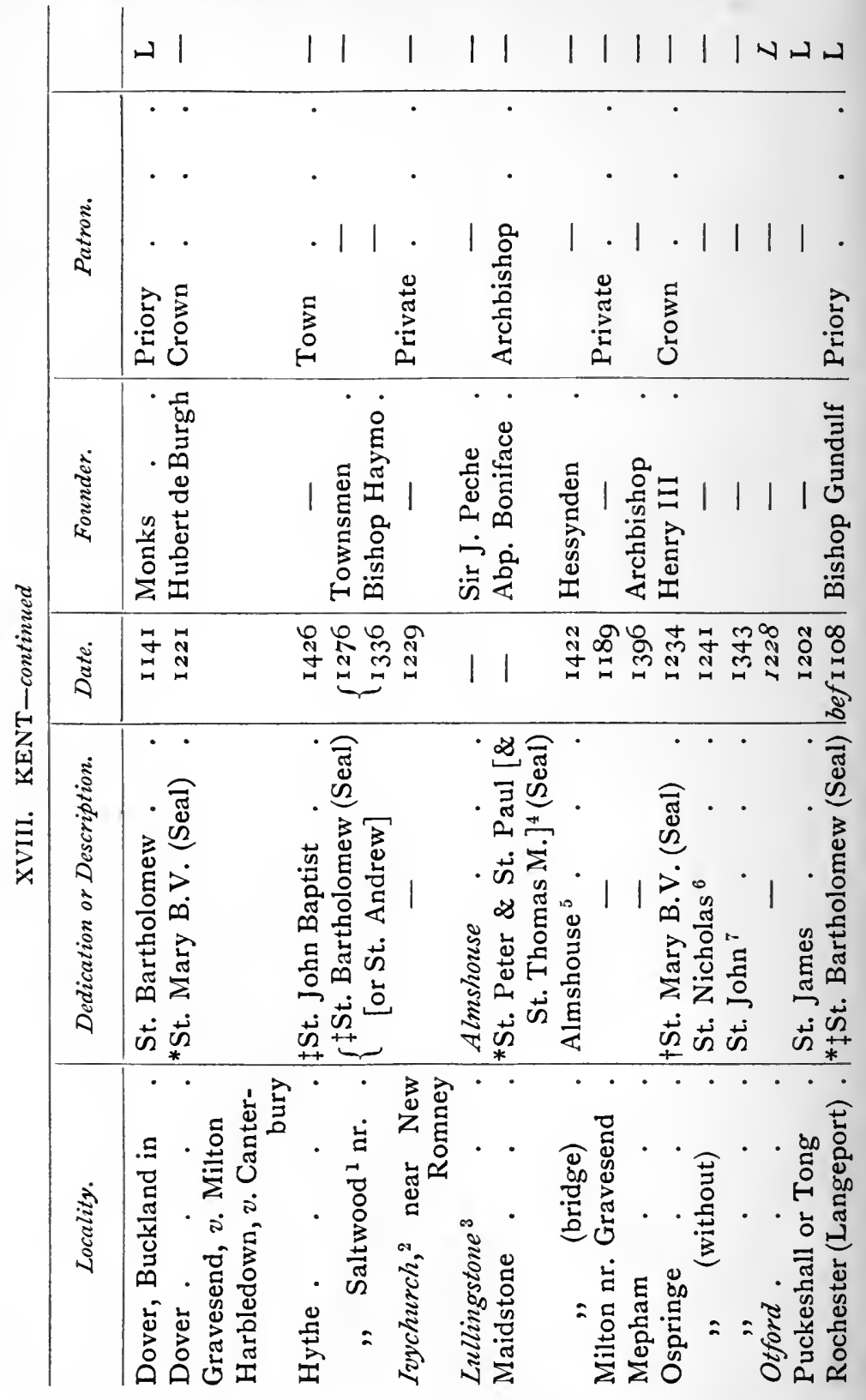




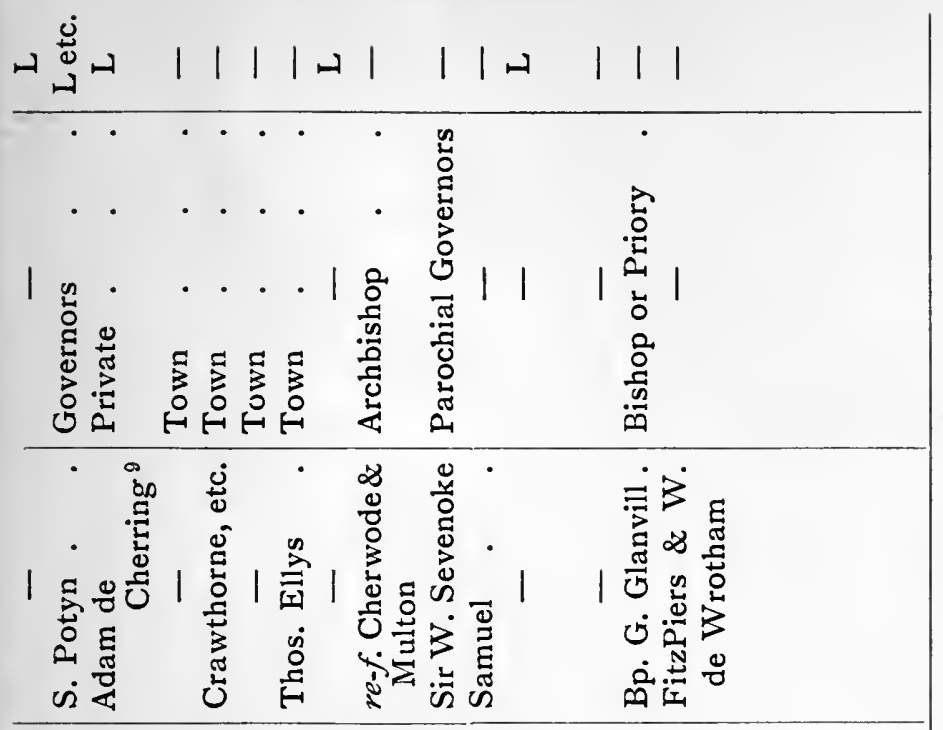

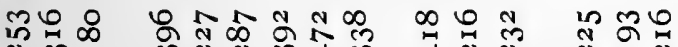

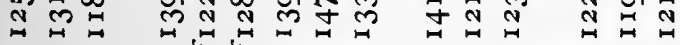
i 8

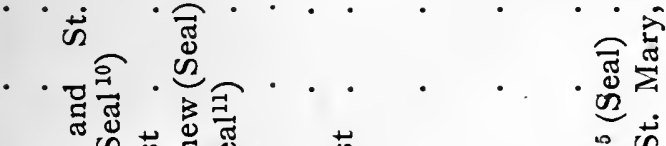

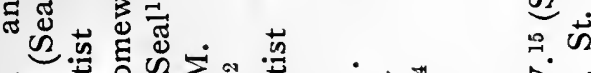

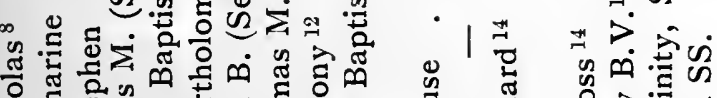

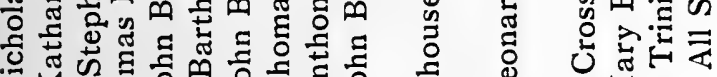

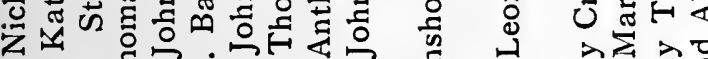

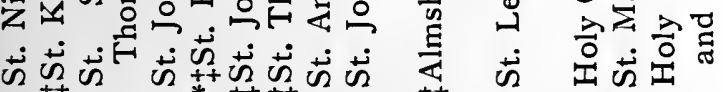

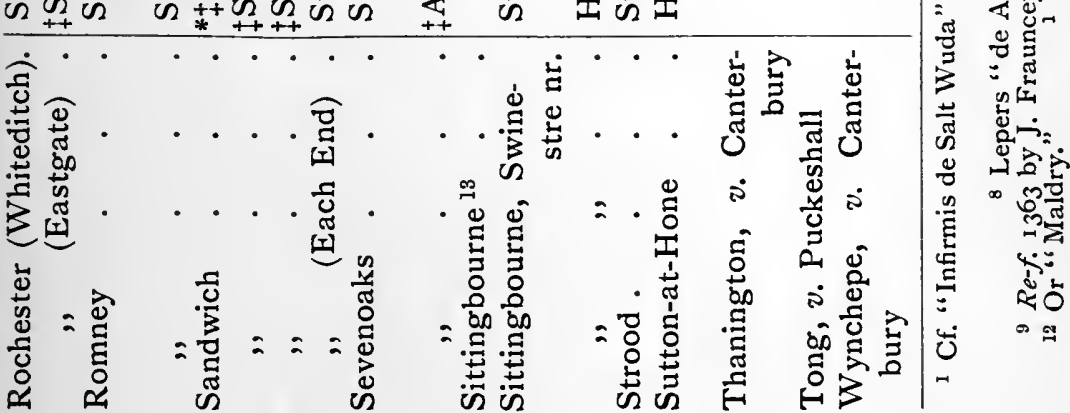




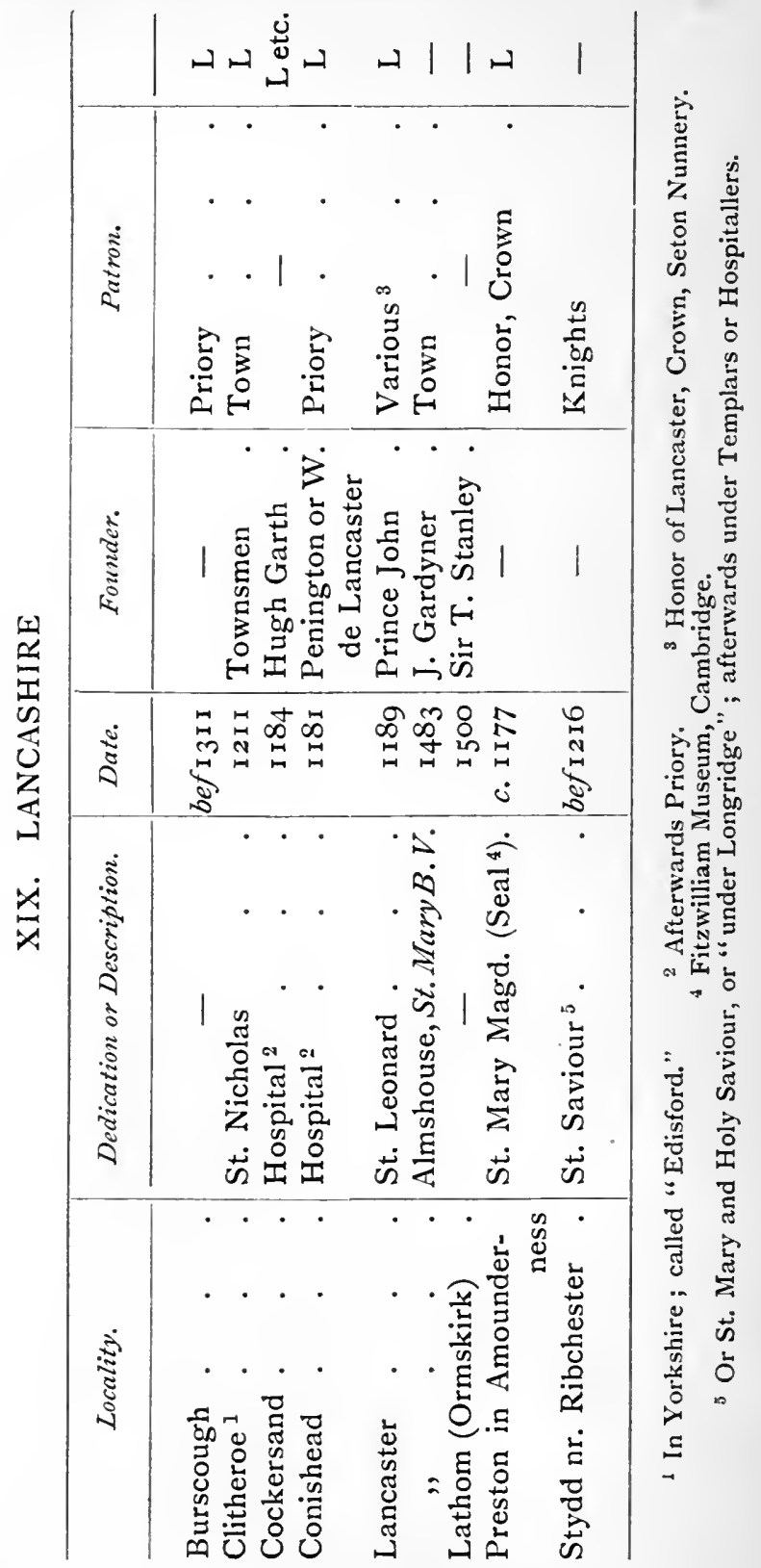




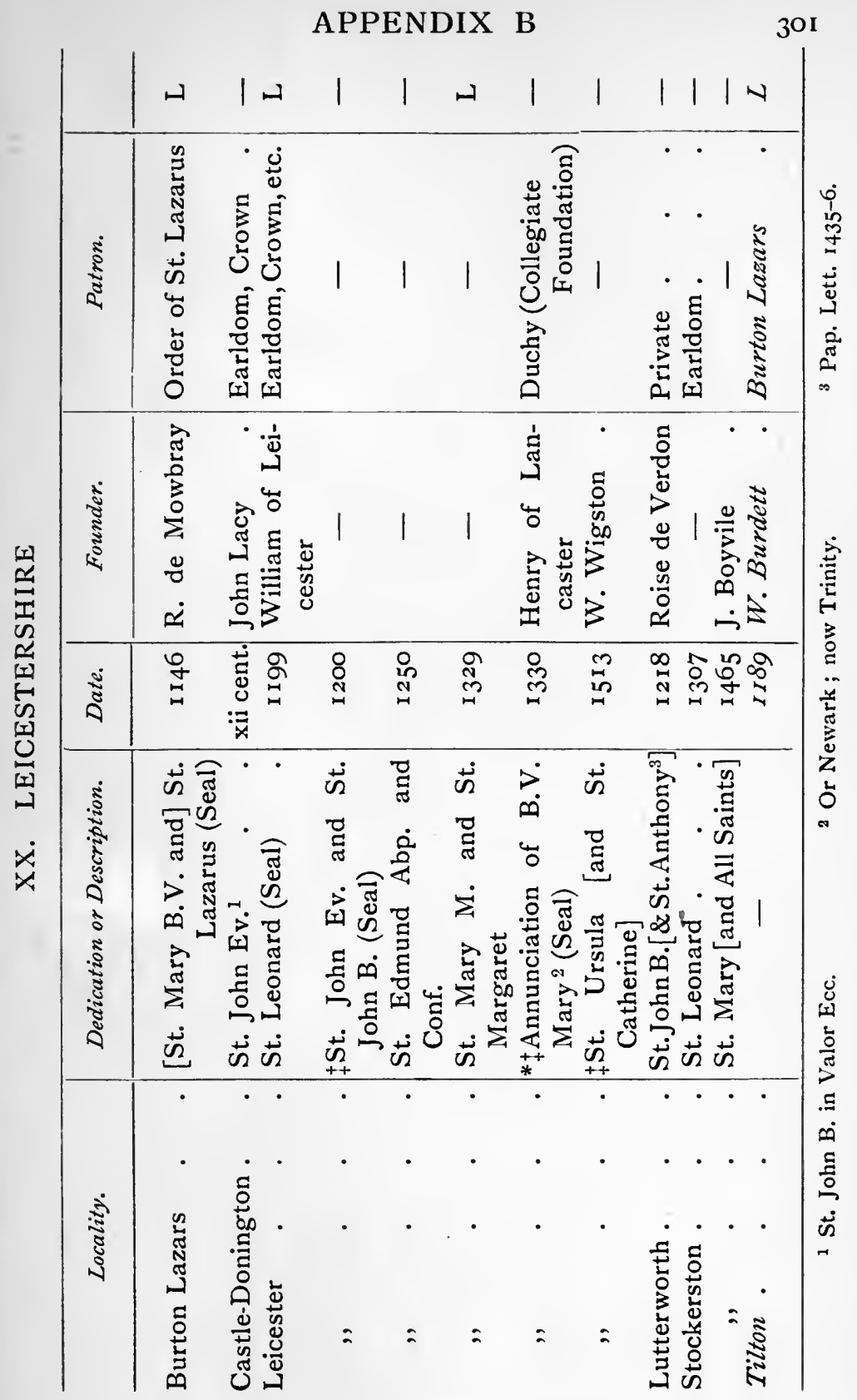


302 MEDIAVAL HOSPITALS OF ENGLAND

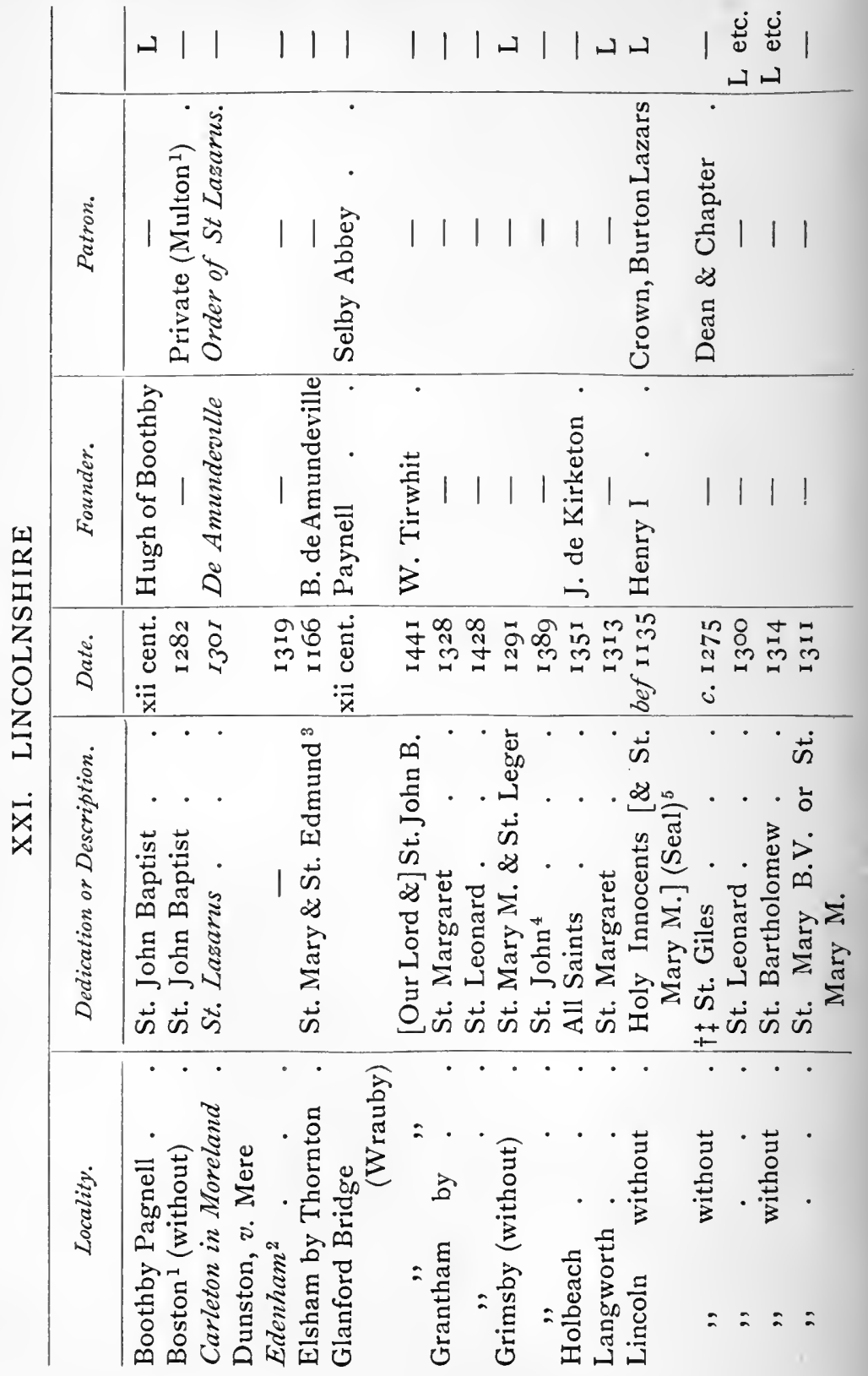




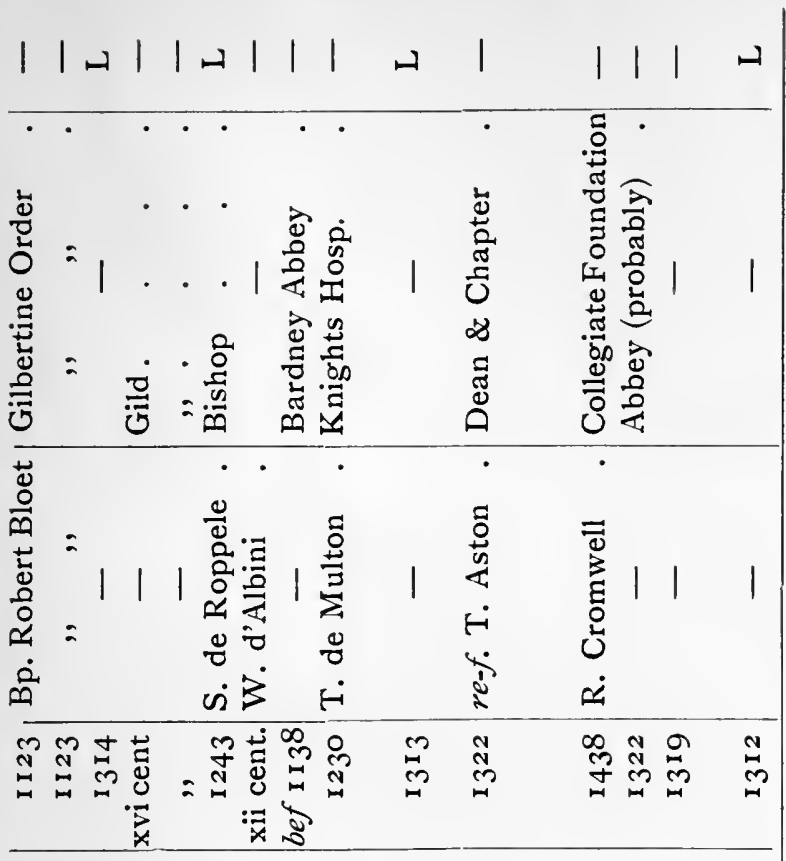

î

\&

吾

造

$\stackrel{9}{3}$

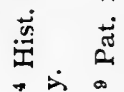

$\rightarrow$ 萦

语

. 몰

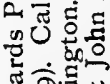

跣 $\approx$

蛮

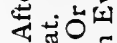

㱐

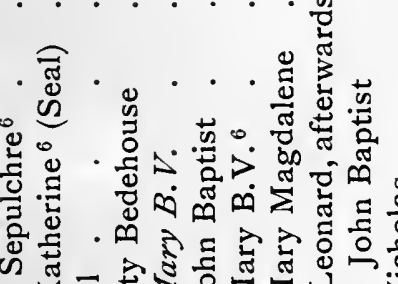
서

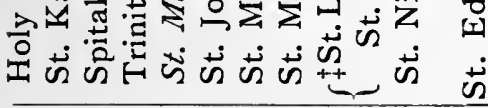

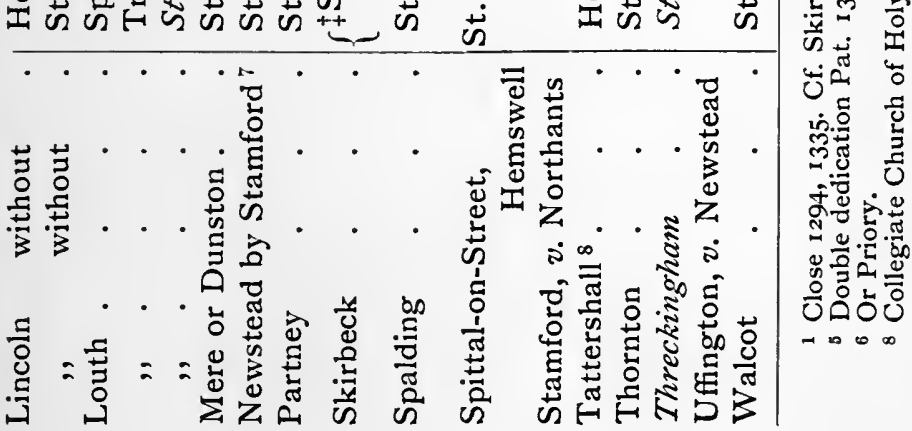


304 MEDIÆVAL HOSPITALS OF ENGLAND

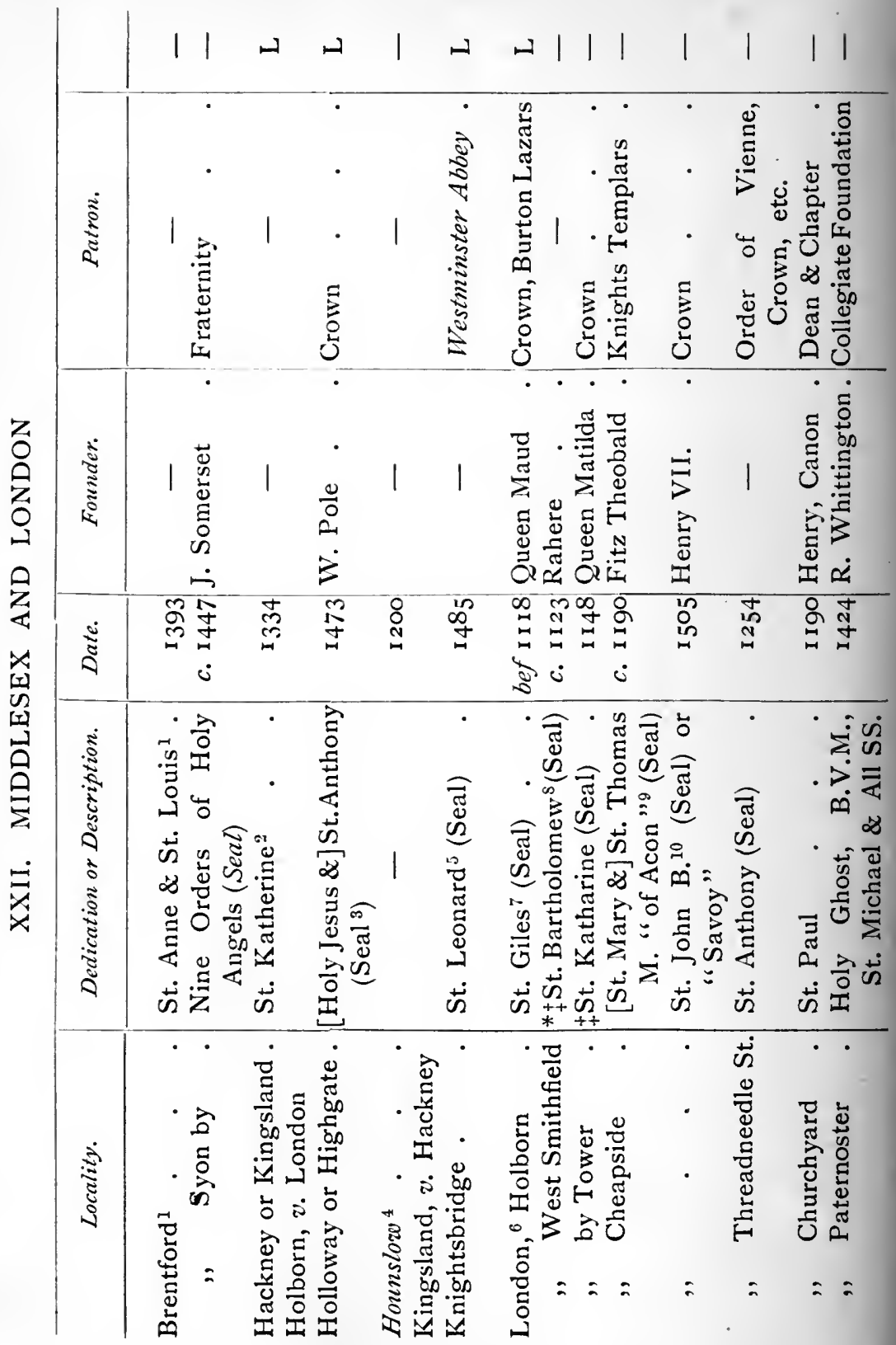




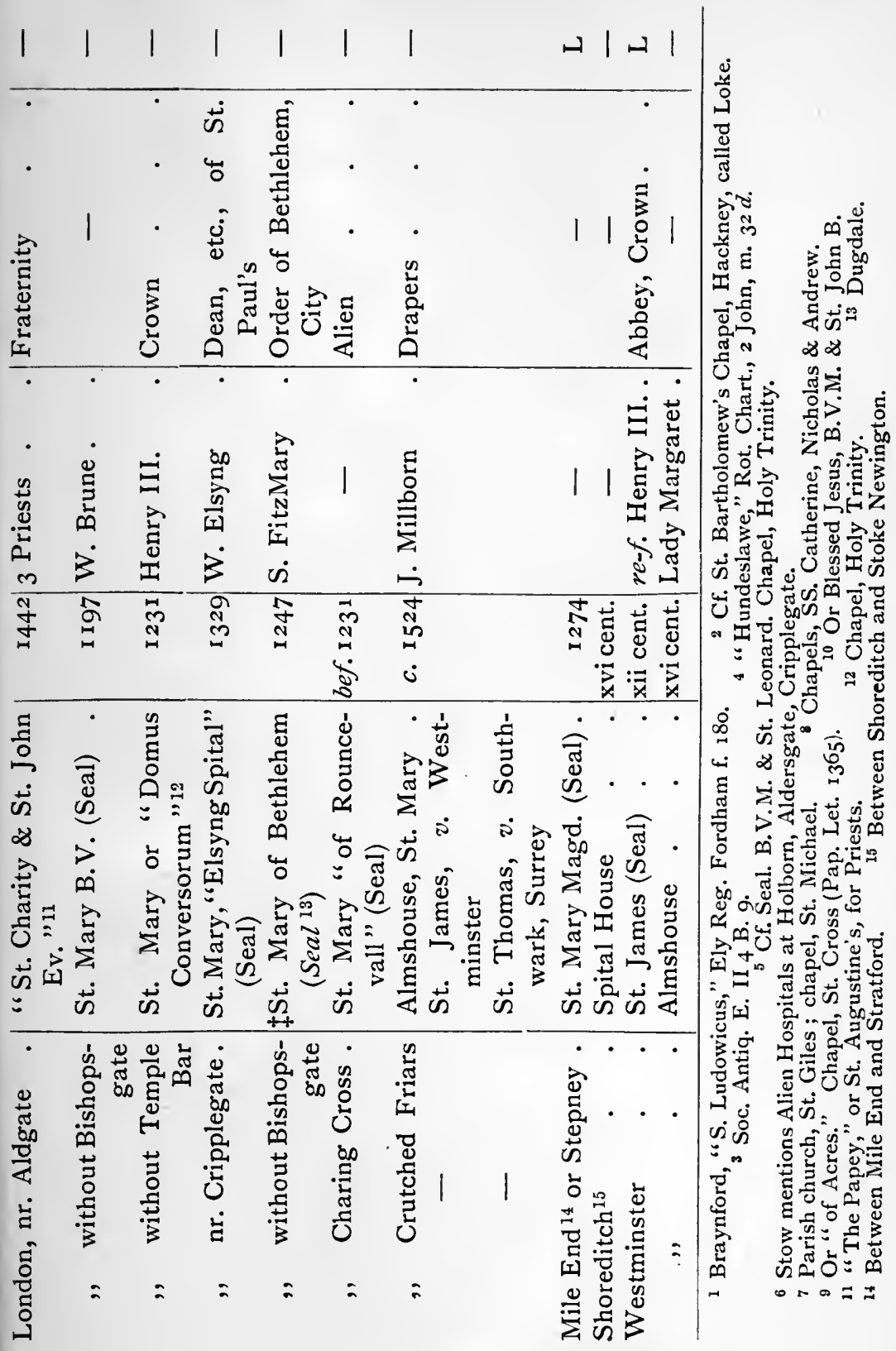


306 MEDI $Æ V A L$ HOSPITALS OF ENGLAND

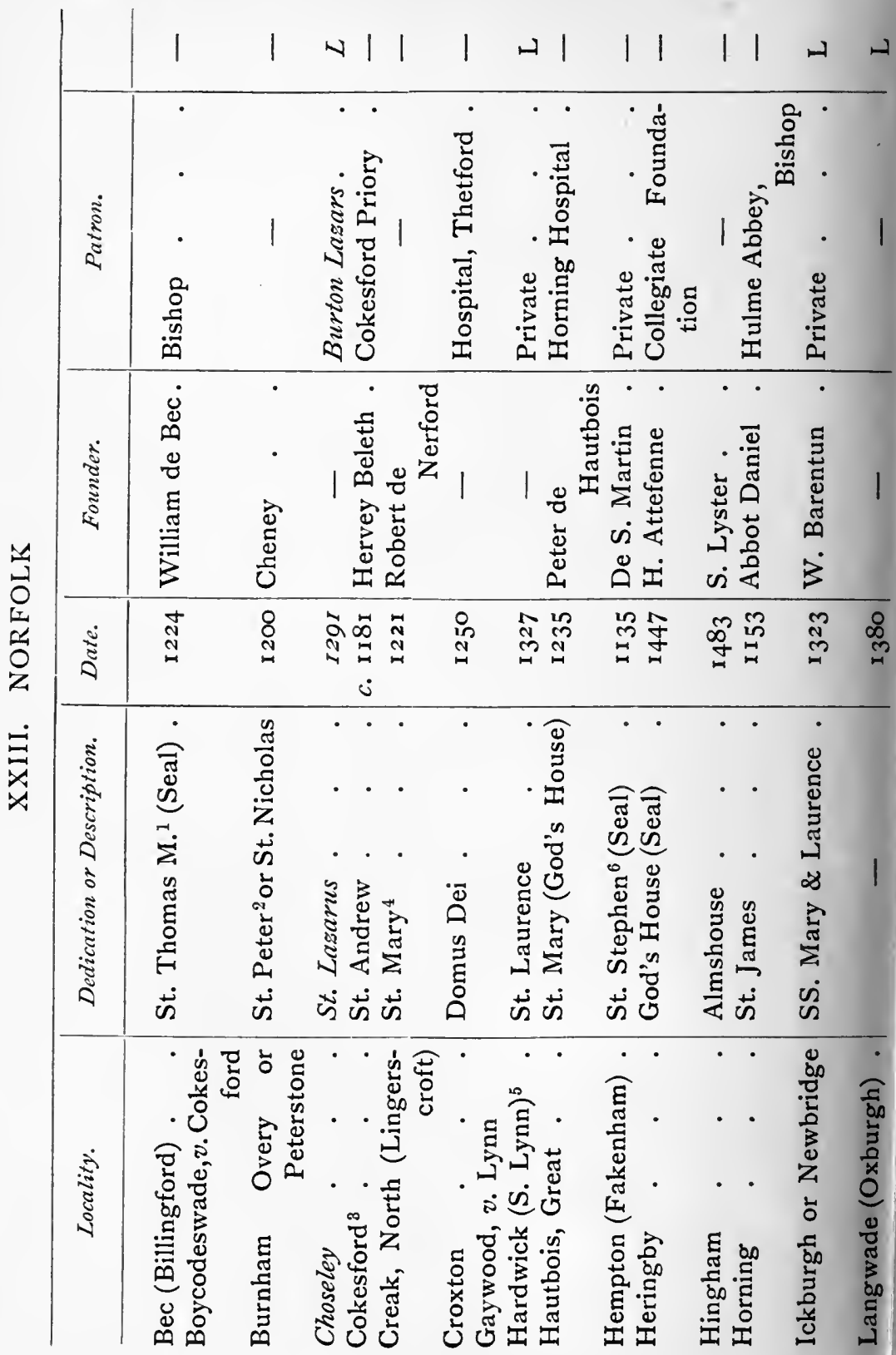


APPENDIX B

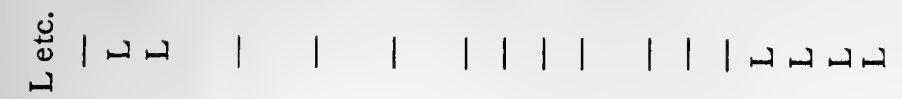

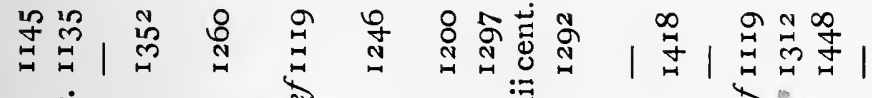

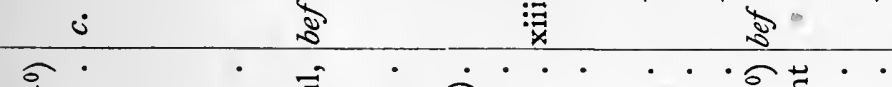

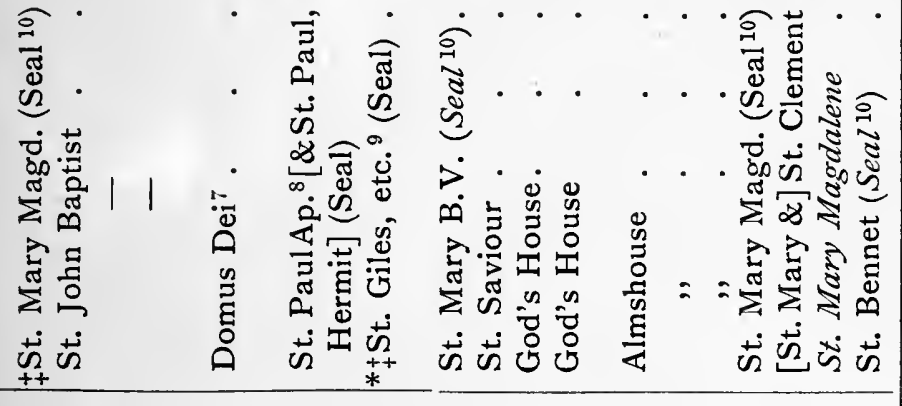
ฟี 尊 
308 MEDIÆVAL HOSPITALS OF ENGLAND

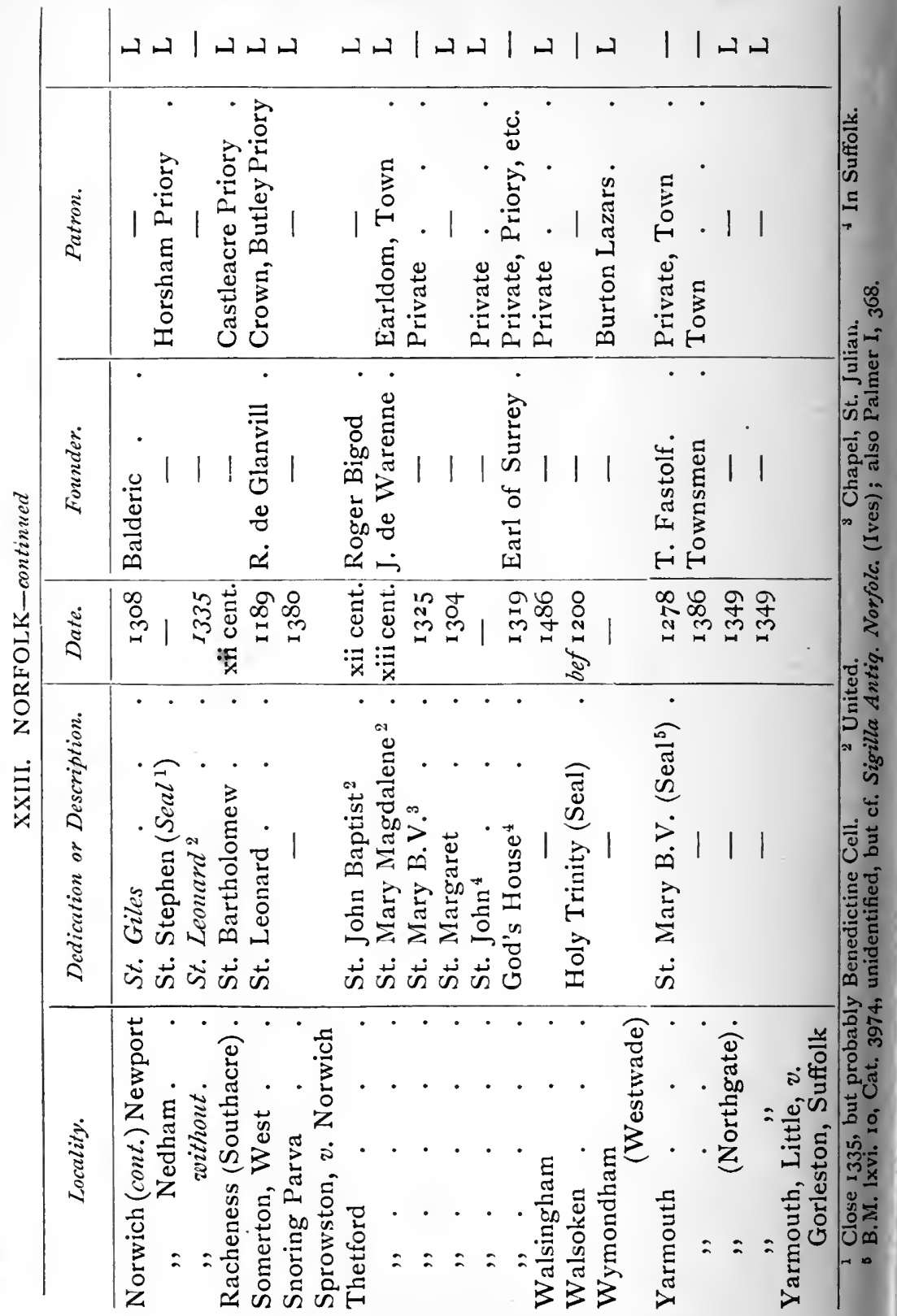




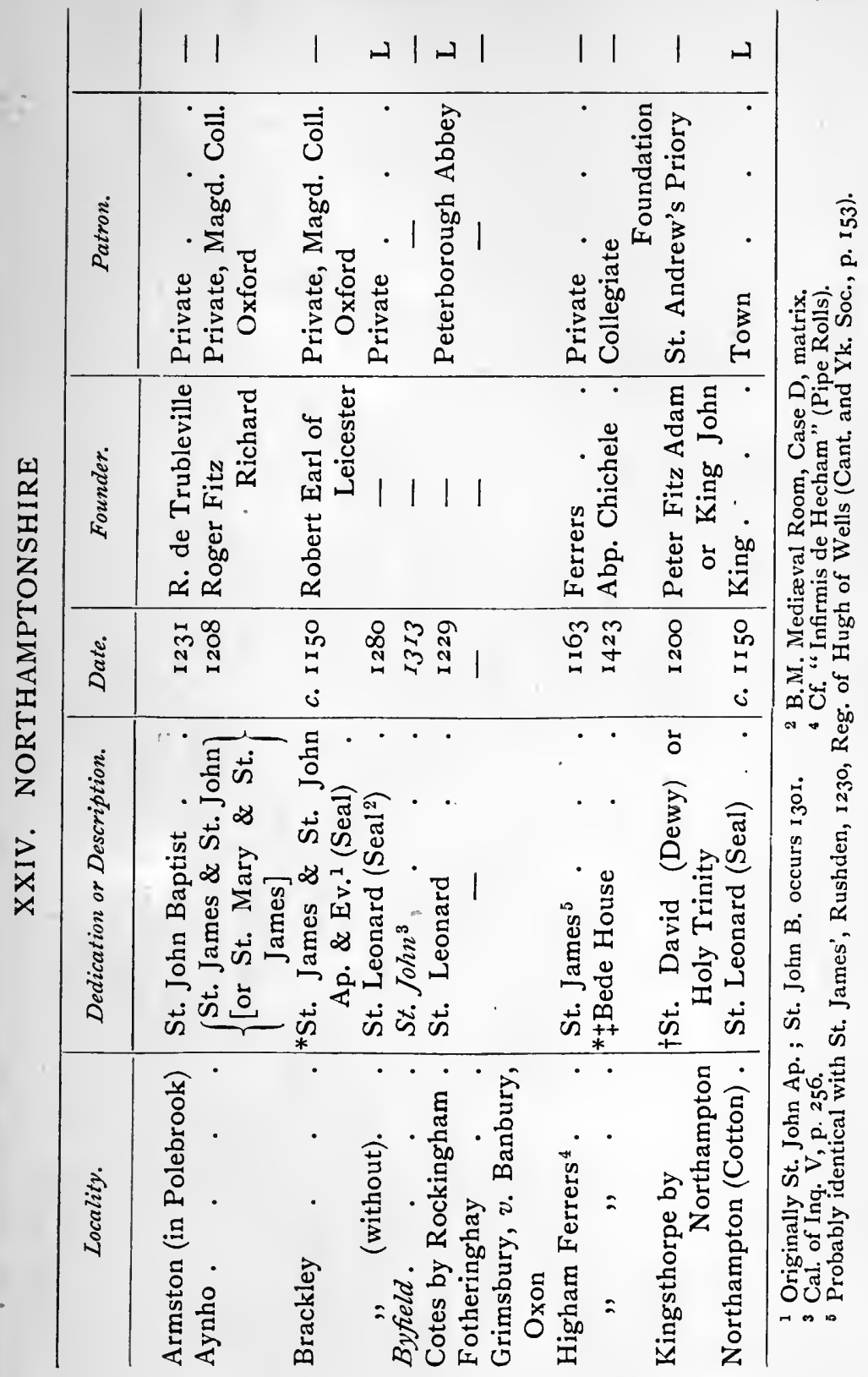




\section{Io MEDI $Æ V A L ~ H O S P I T A L S ~ O F ~ E N G L A N D$}

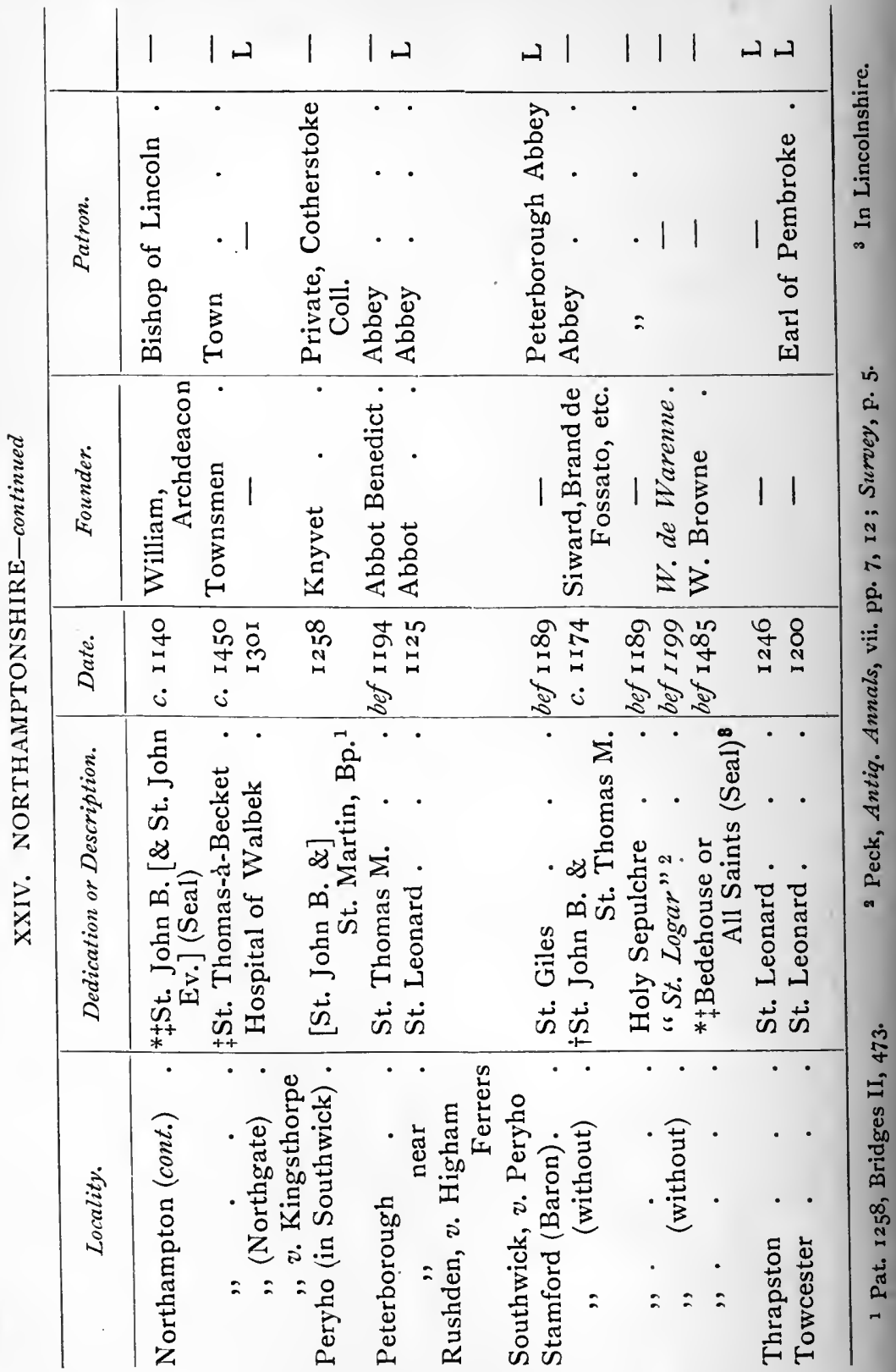




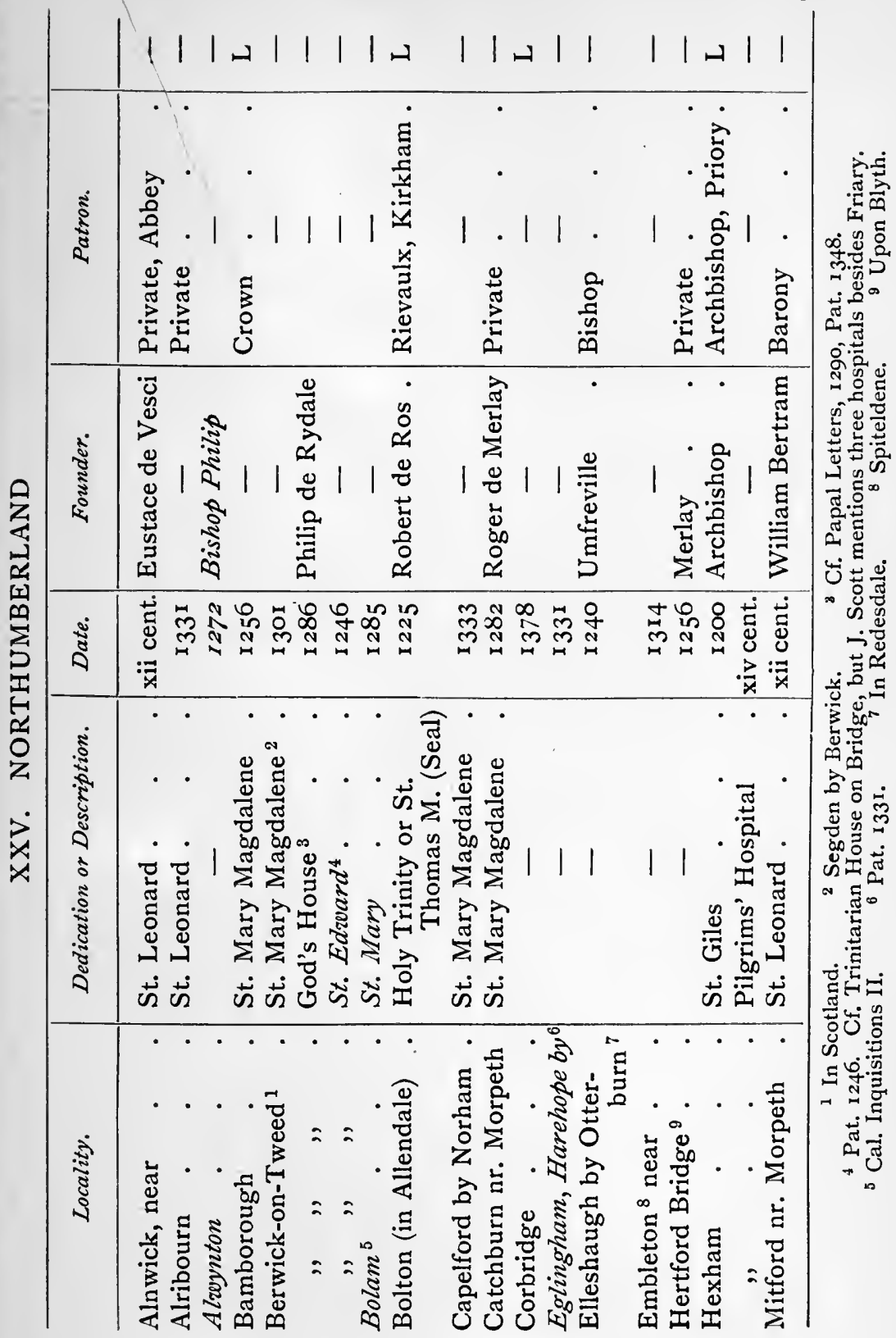




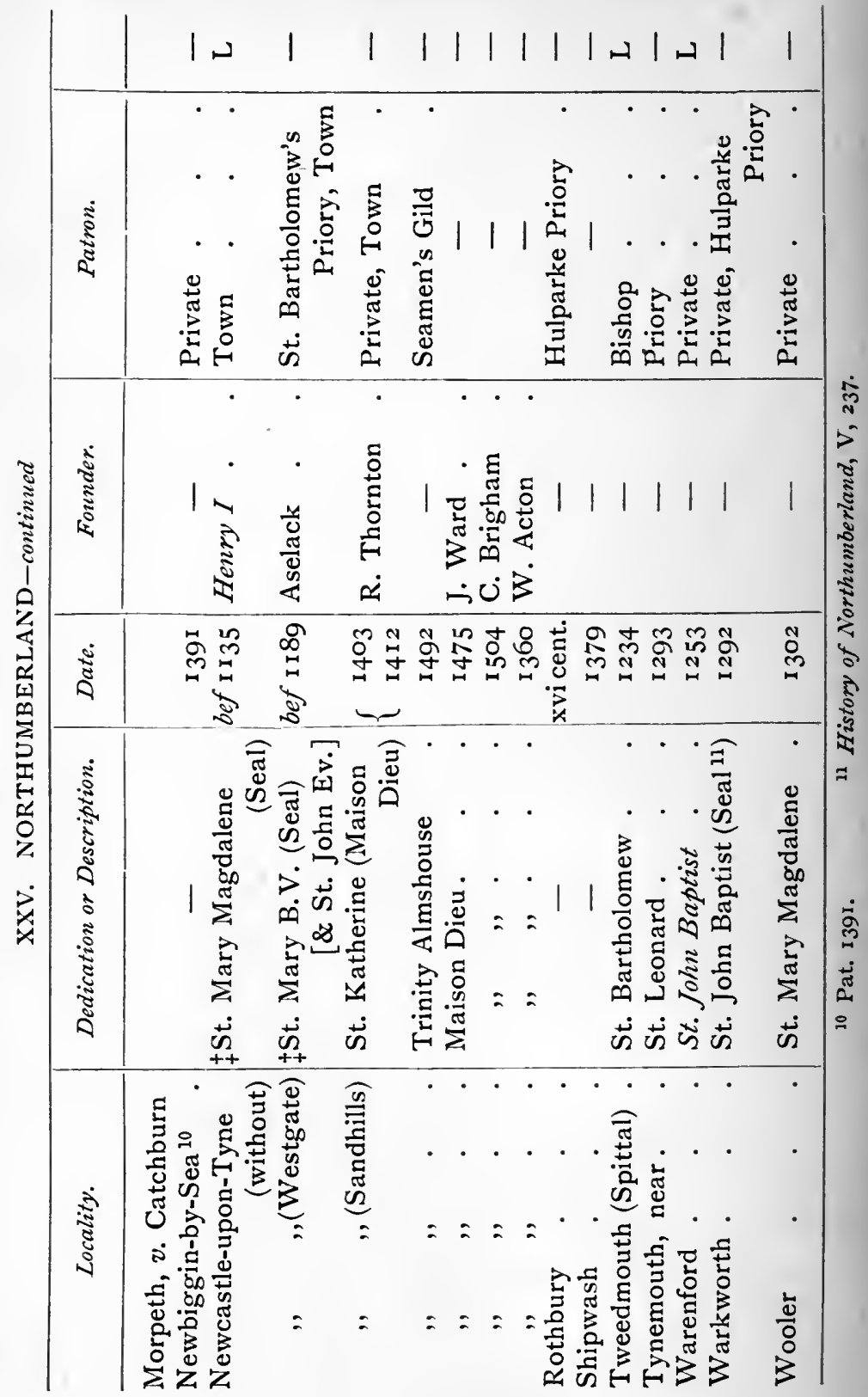


APPENDIX B

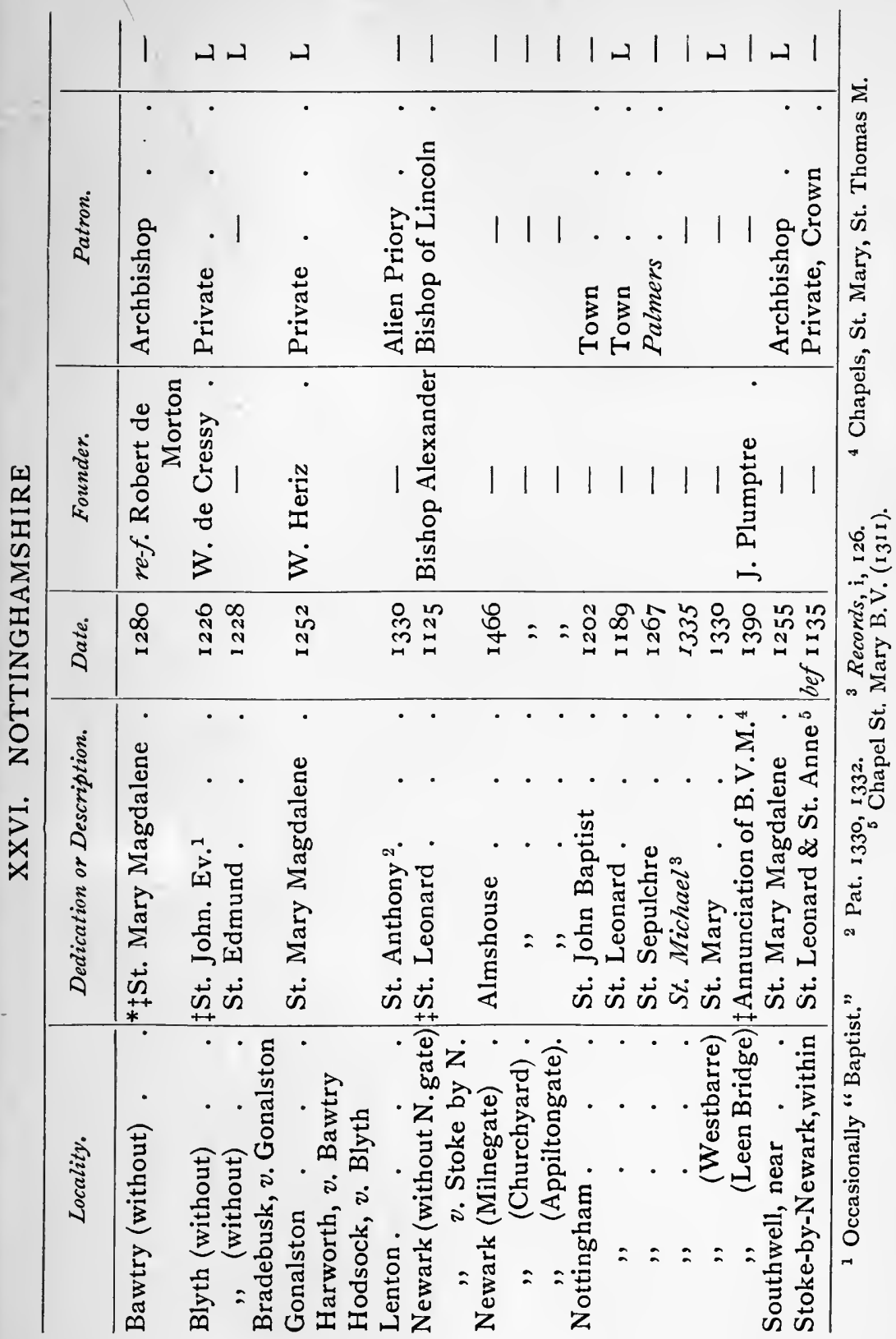


314 MEDI EVAL HOSPITALS OF ENGLAND

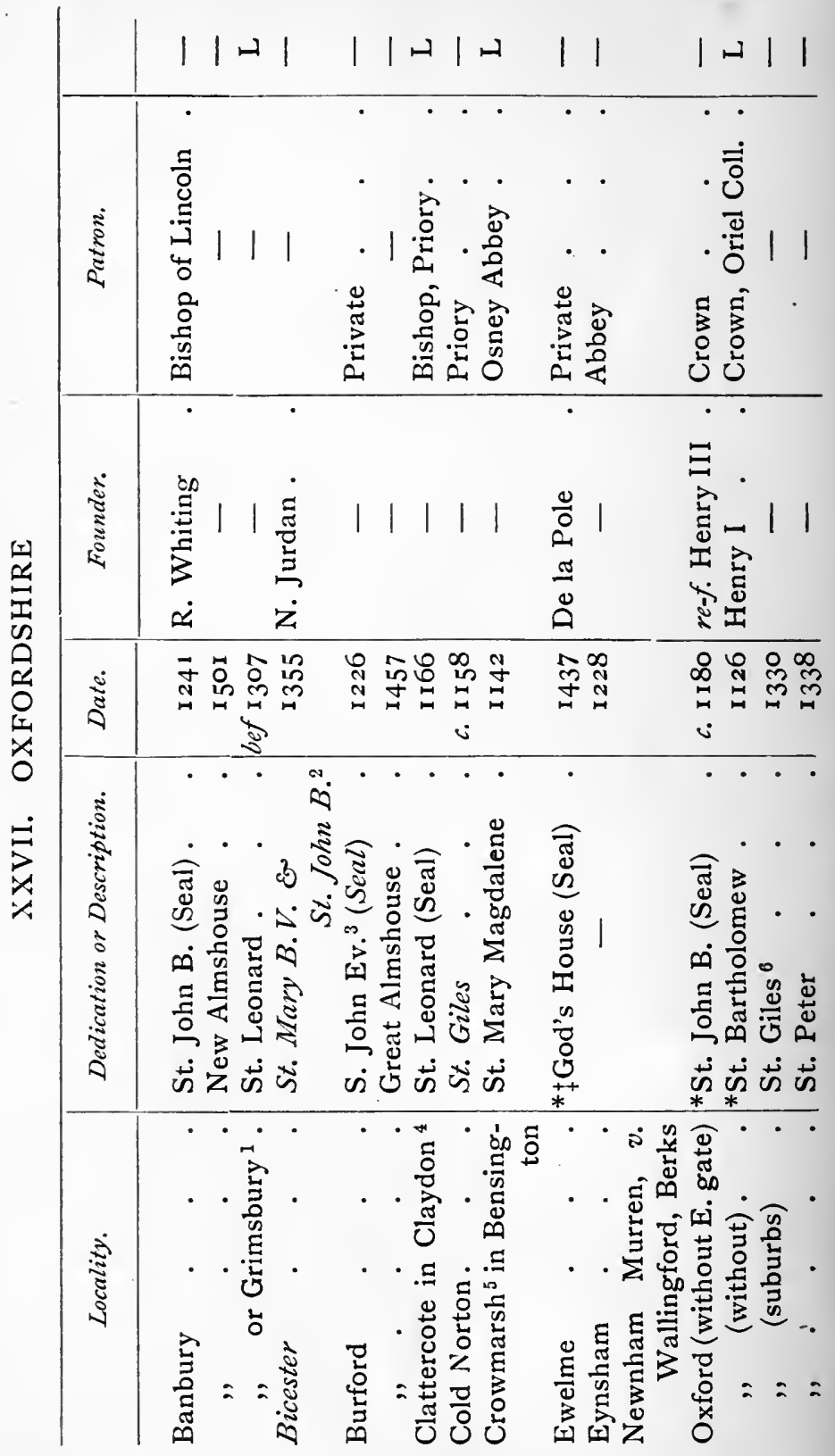


APPENDIX B
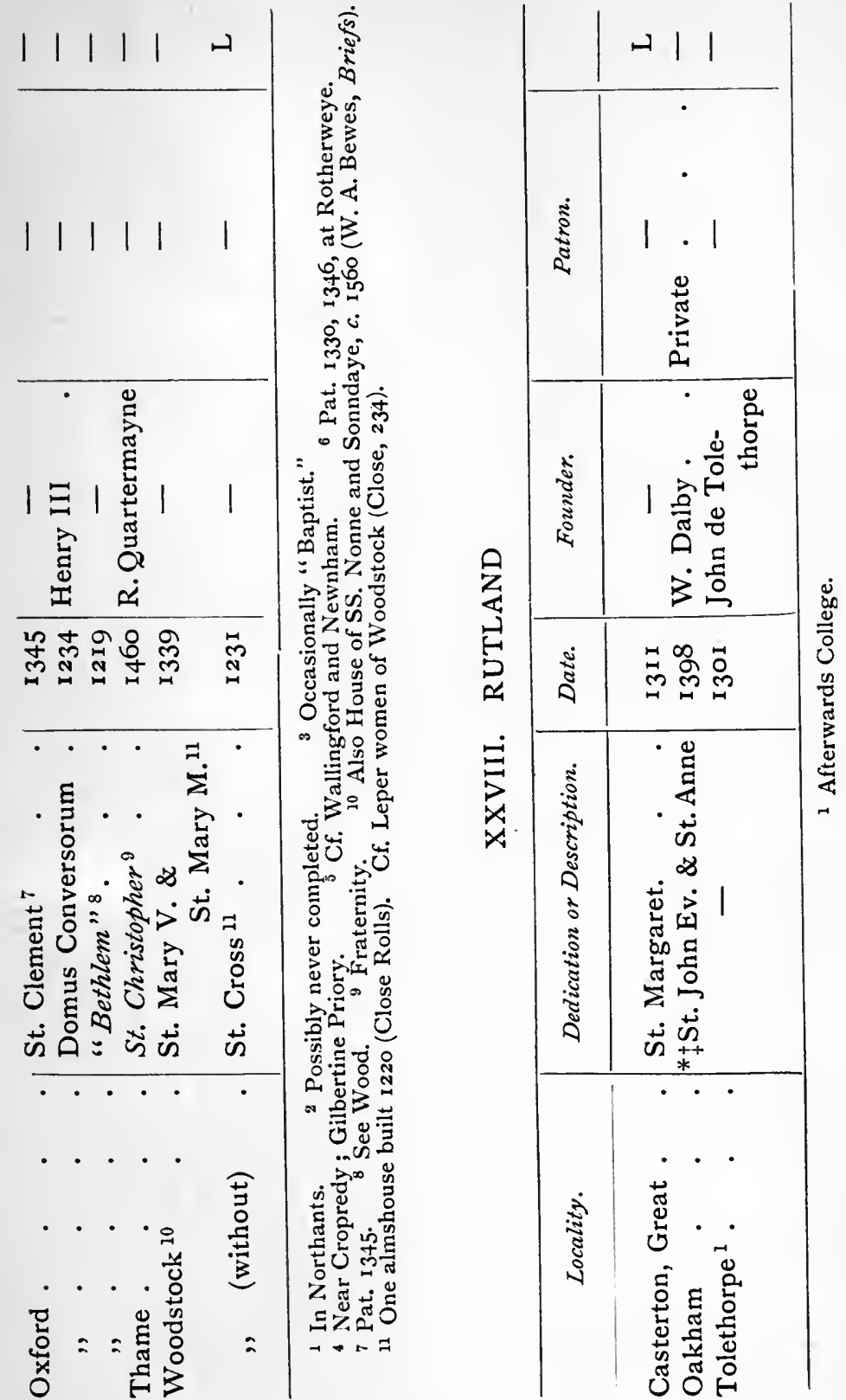

总兽

范

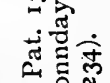

$\circ$ फั

$=$

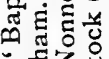

$=$ 들

的家

z 3

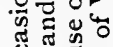

政

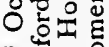

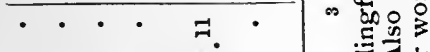

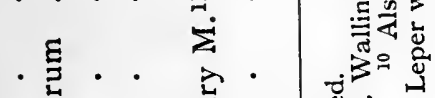

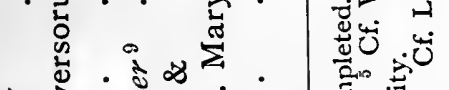

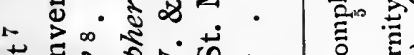

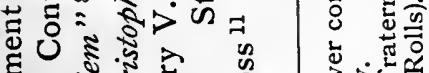

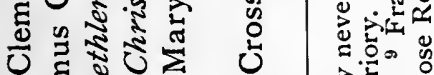

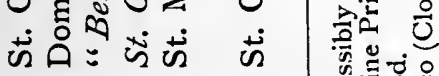

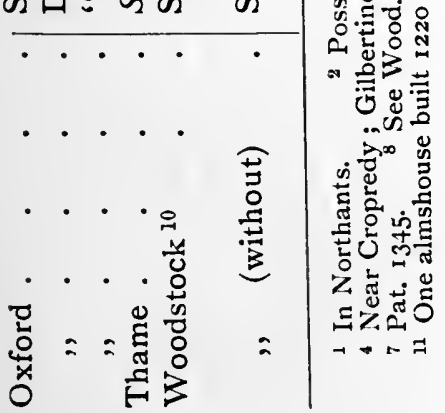

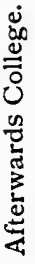




\section{MEDI EVAL HOSPITALS OF ENGLAND}

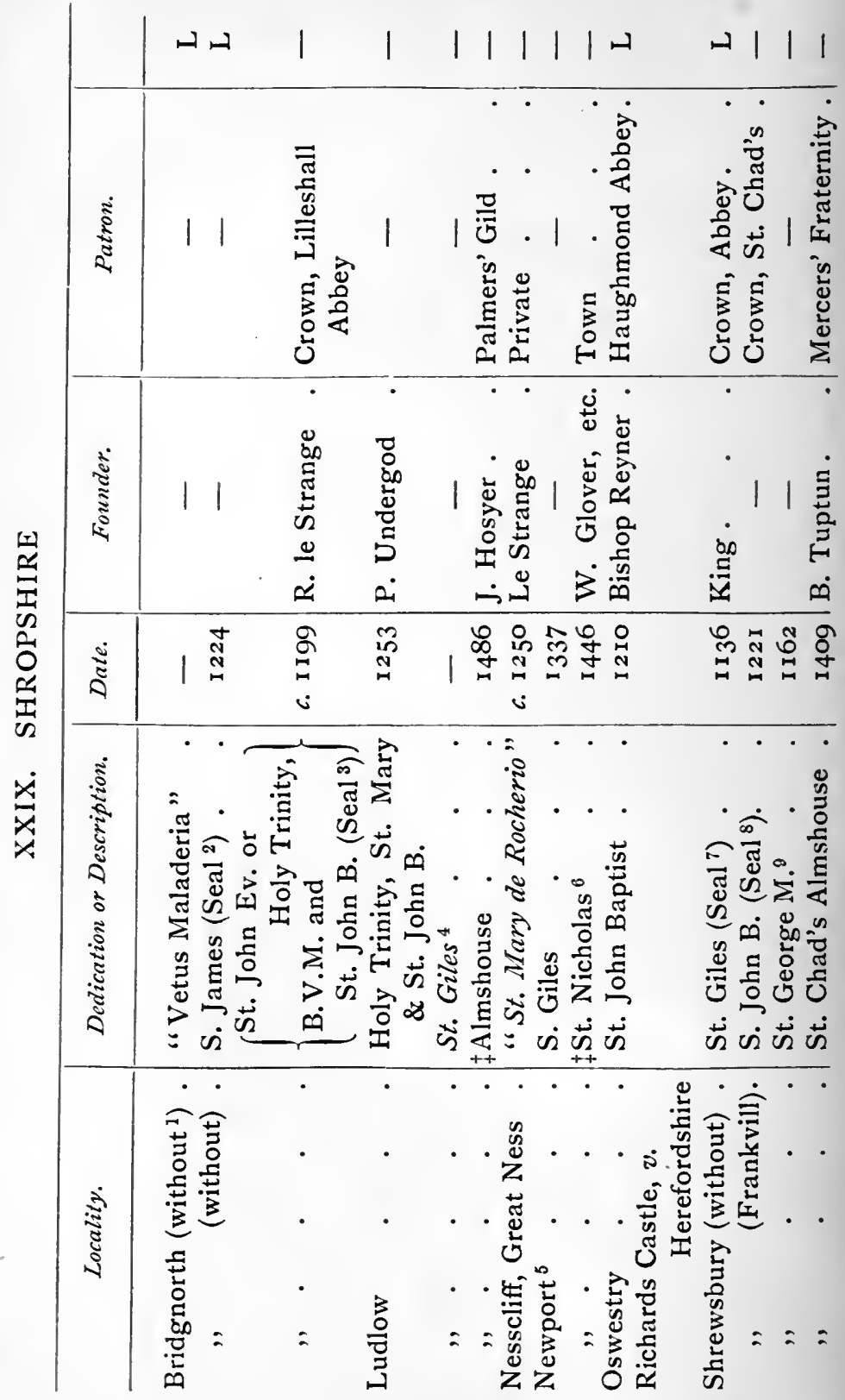




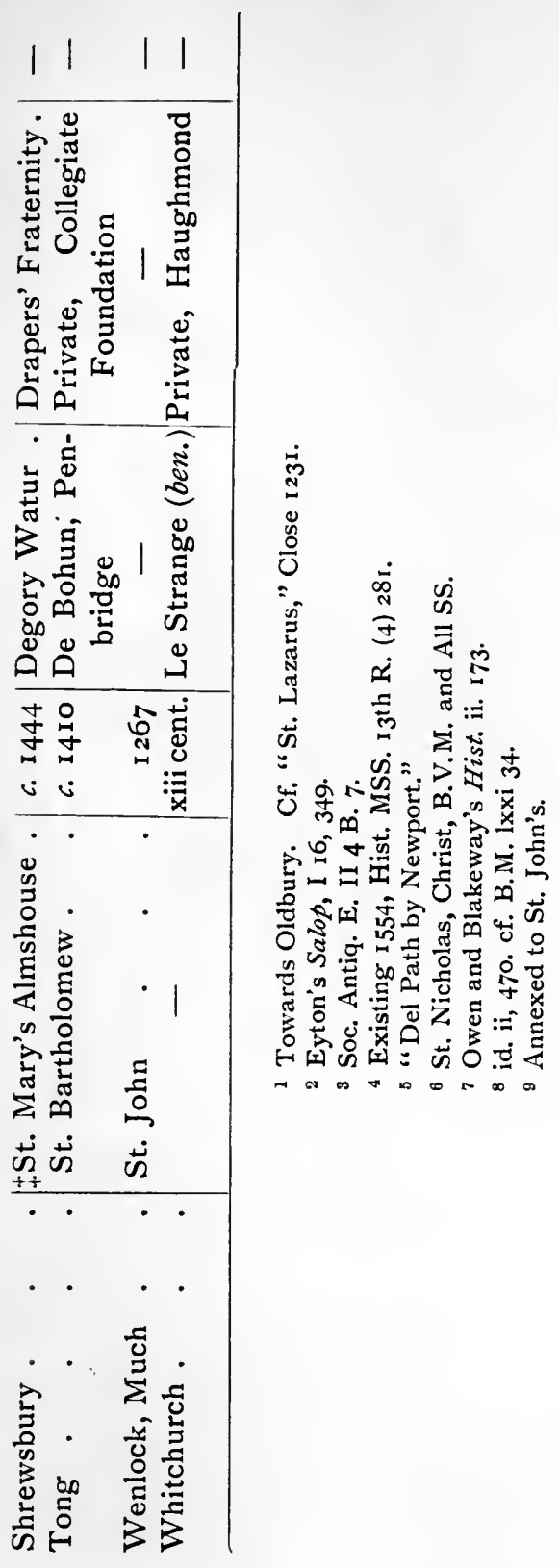


MEDI $Æ V A L$ HOSPITALS OF ENGLAND

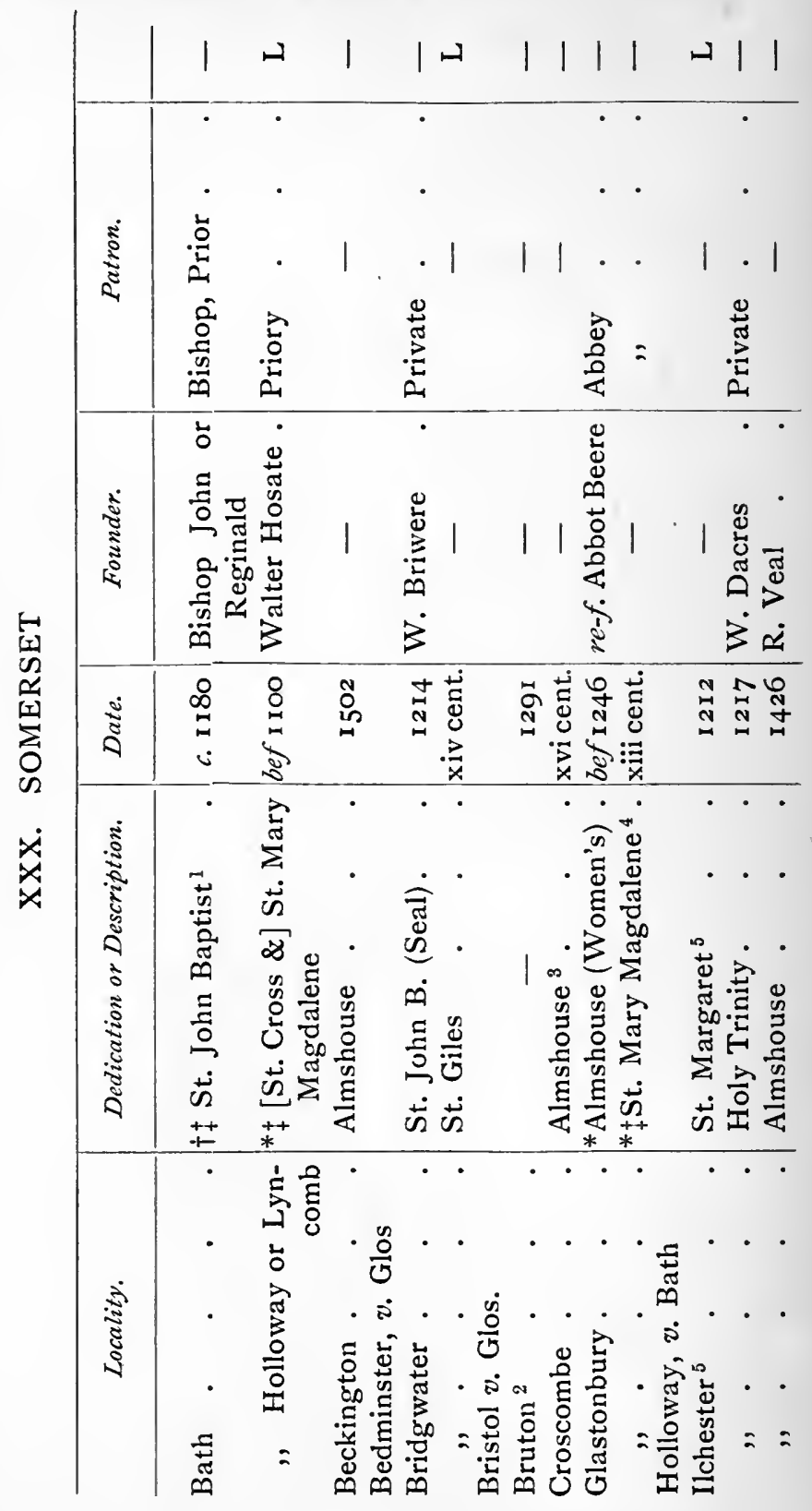




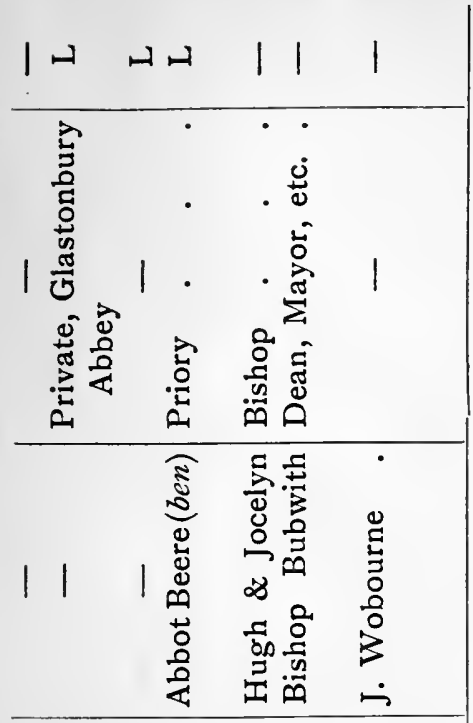

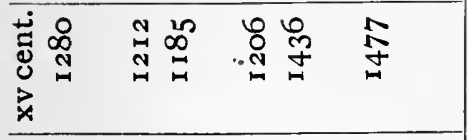

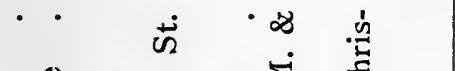

๙ थ ம $\sum_{i=1}^{0}+\frac{2}{0}$

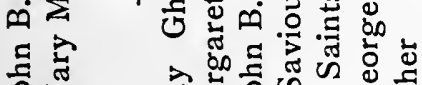

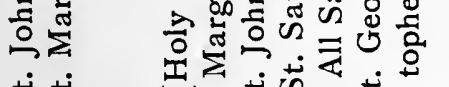

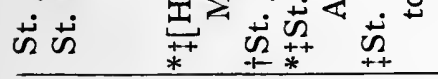

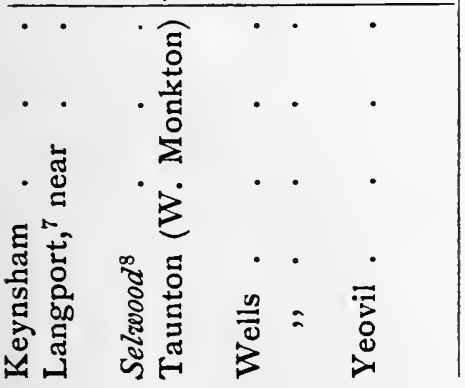

:

苟

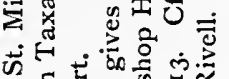

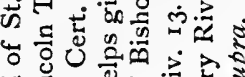

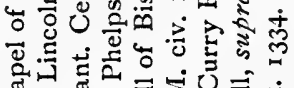

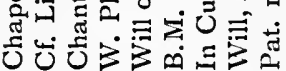
$\pi$ a $\infty+\infty<$ 


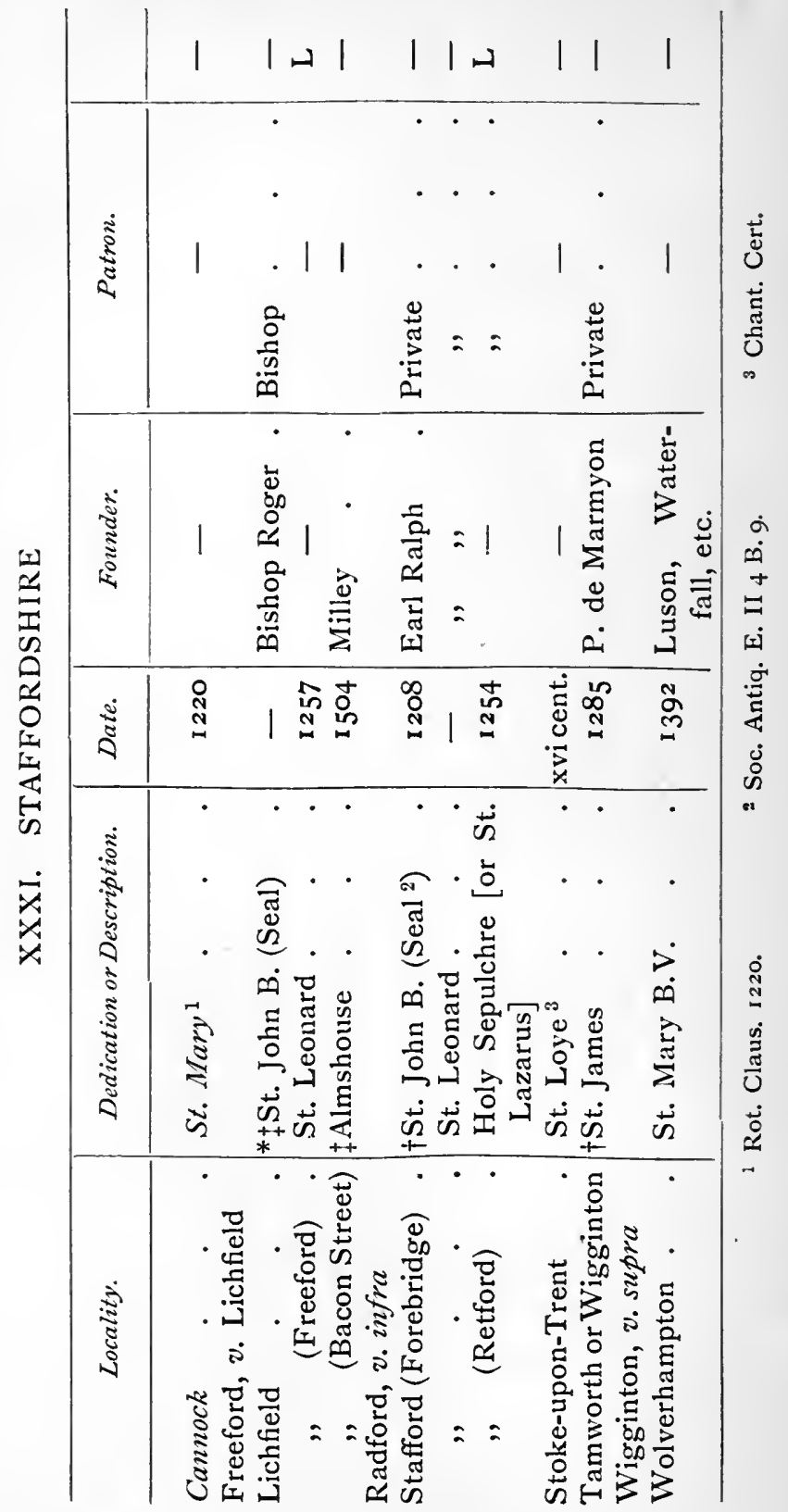




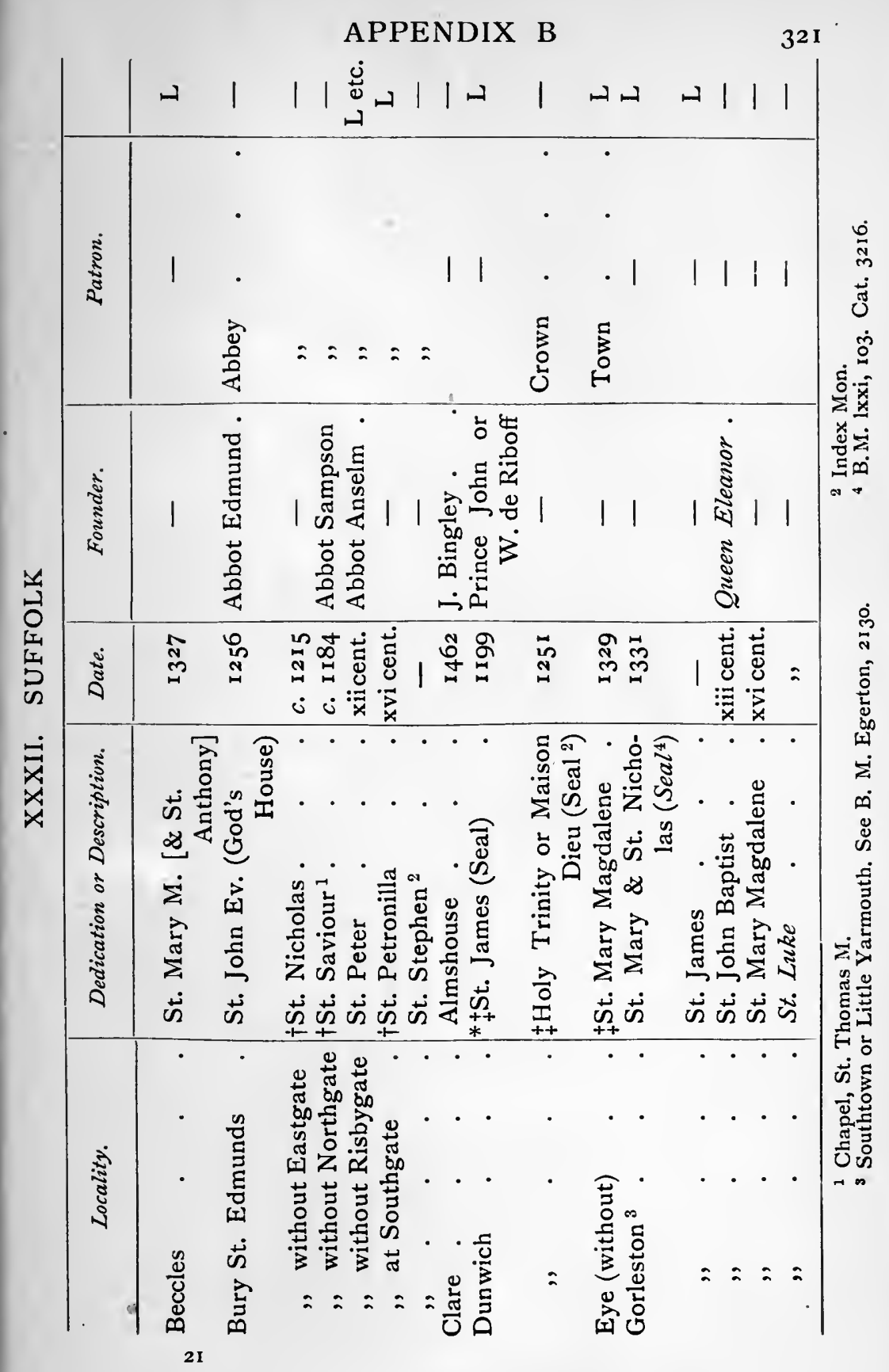




\section{MEDIÆVAL HOSPITALS OF ENGLAND}

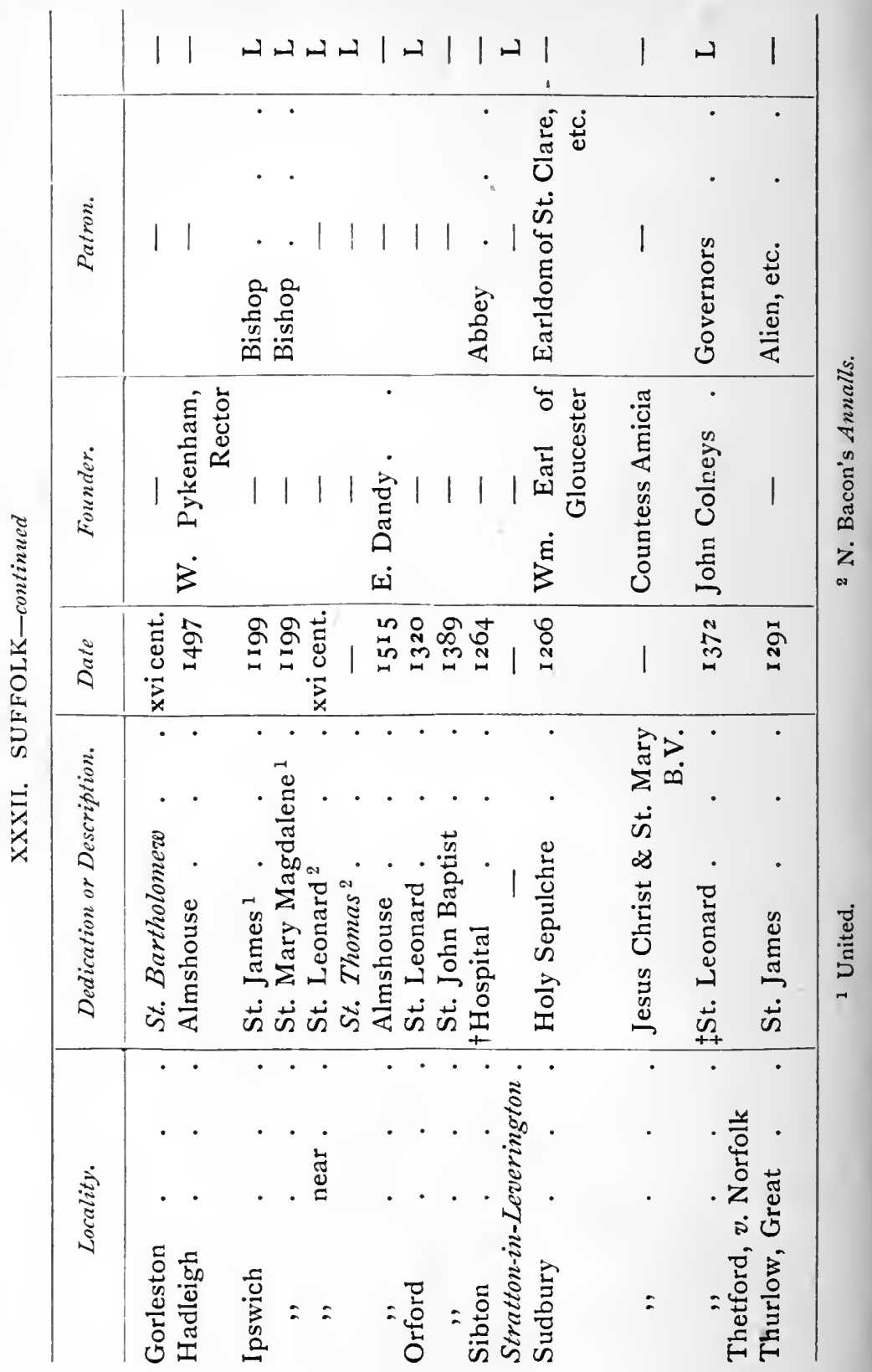


APPENDIX B

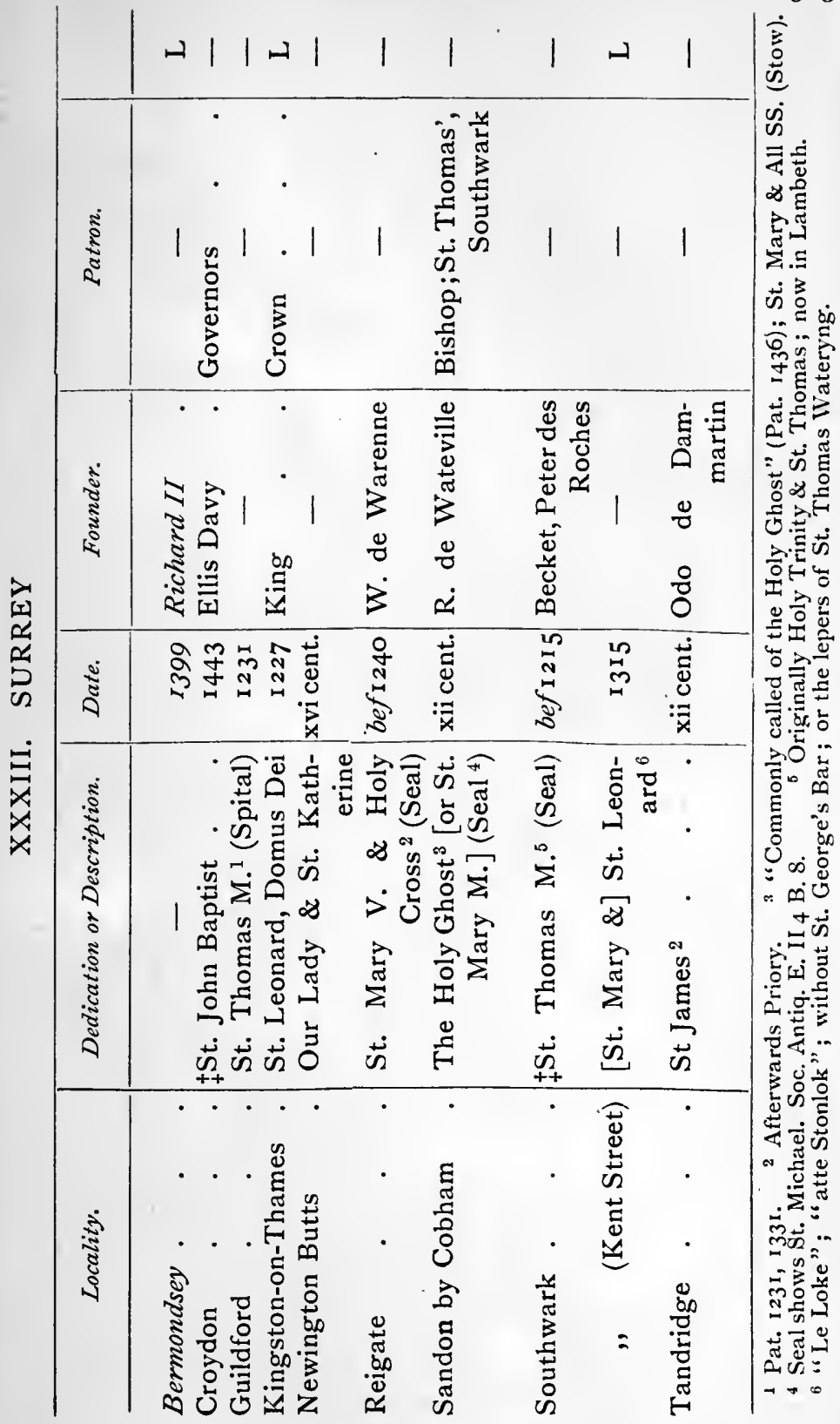


324 MEDIÆVAL HOSPITALS OF ENGLAND

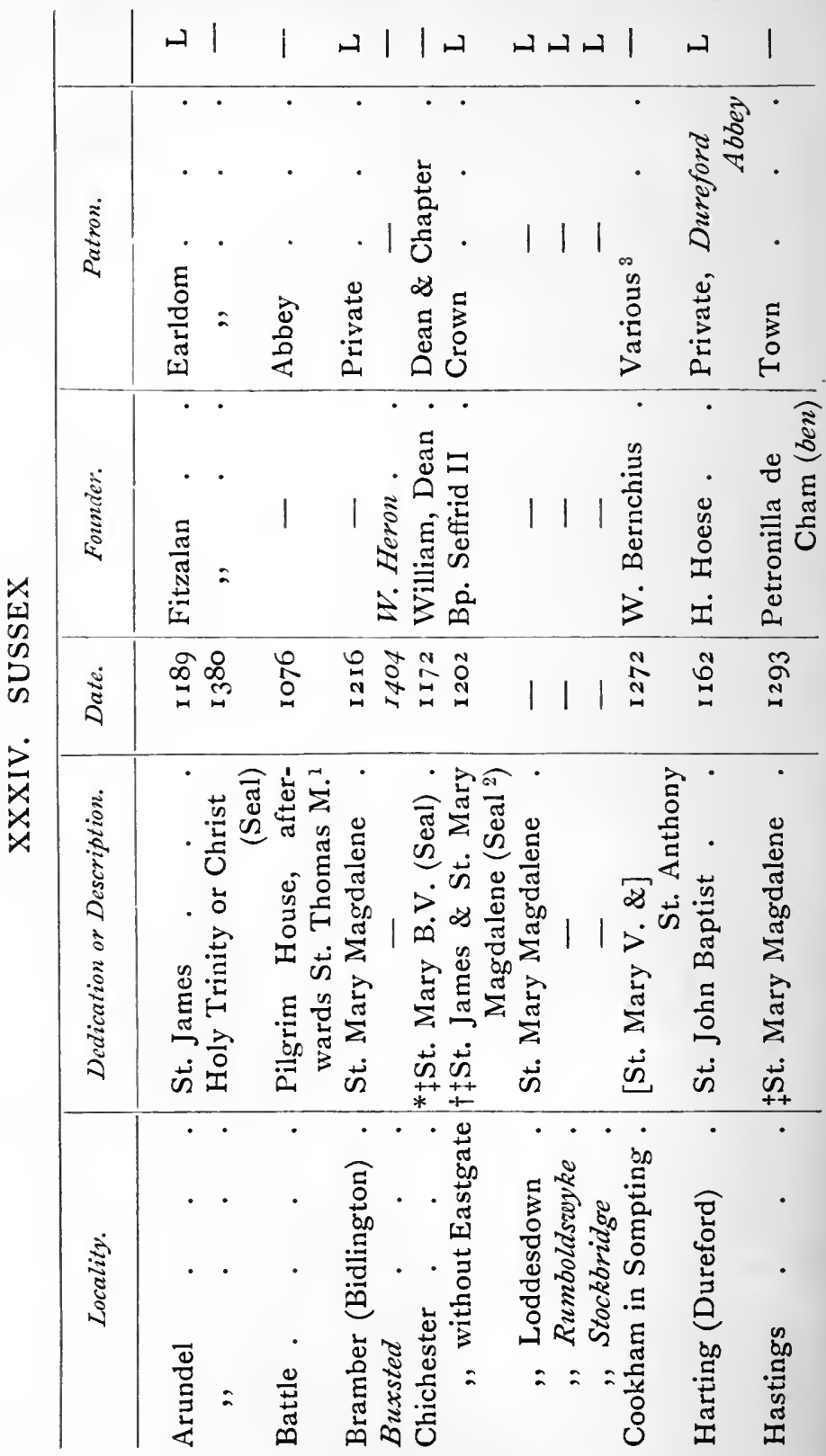




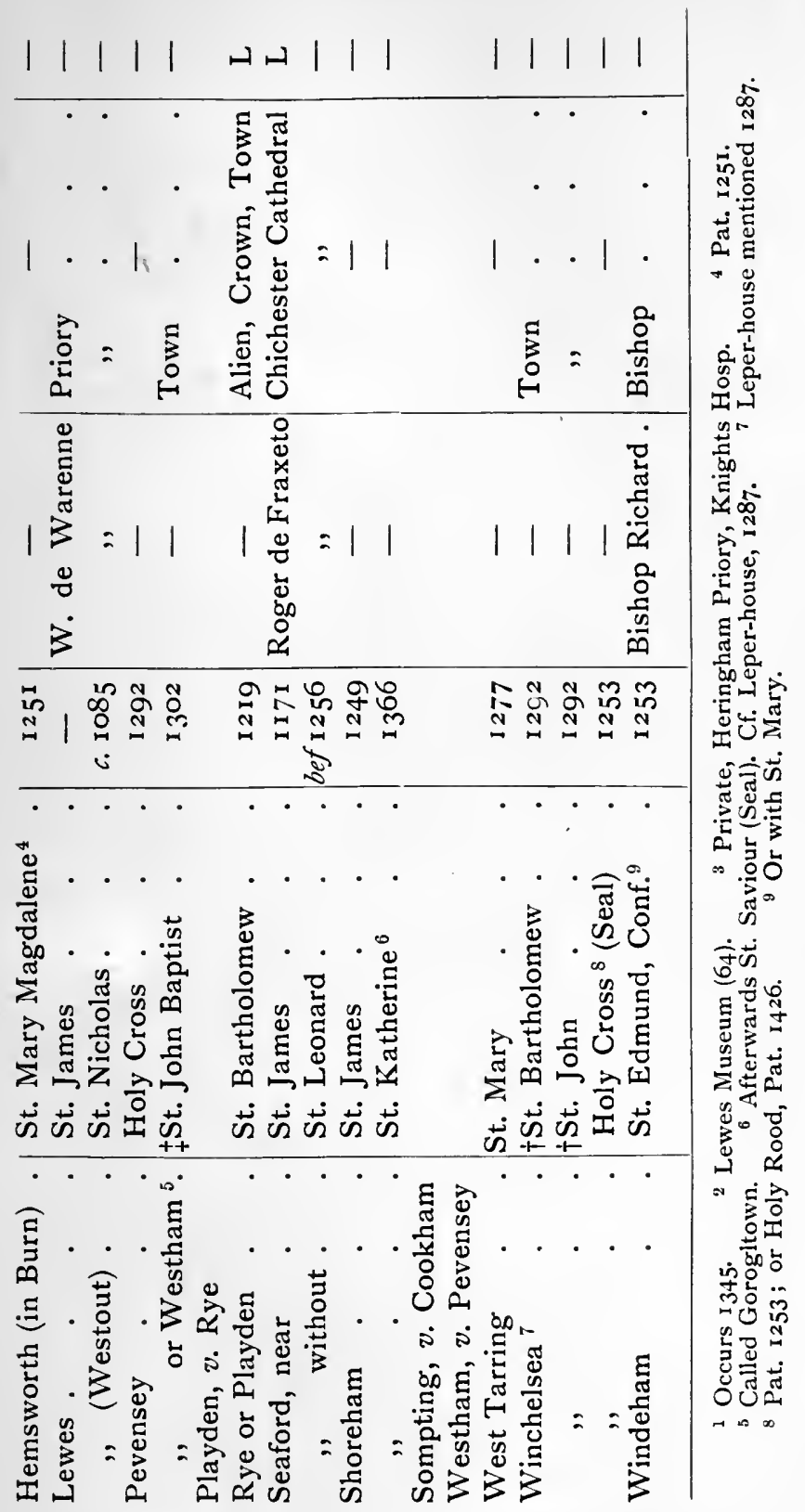




\section{MEDIÆVAL HOSPITALS OF ENGLAND}

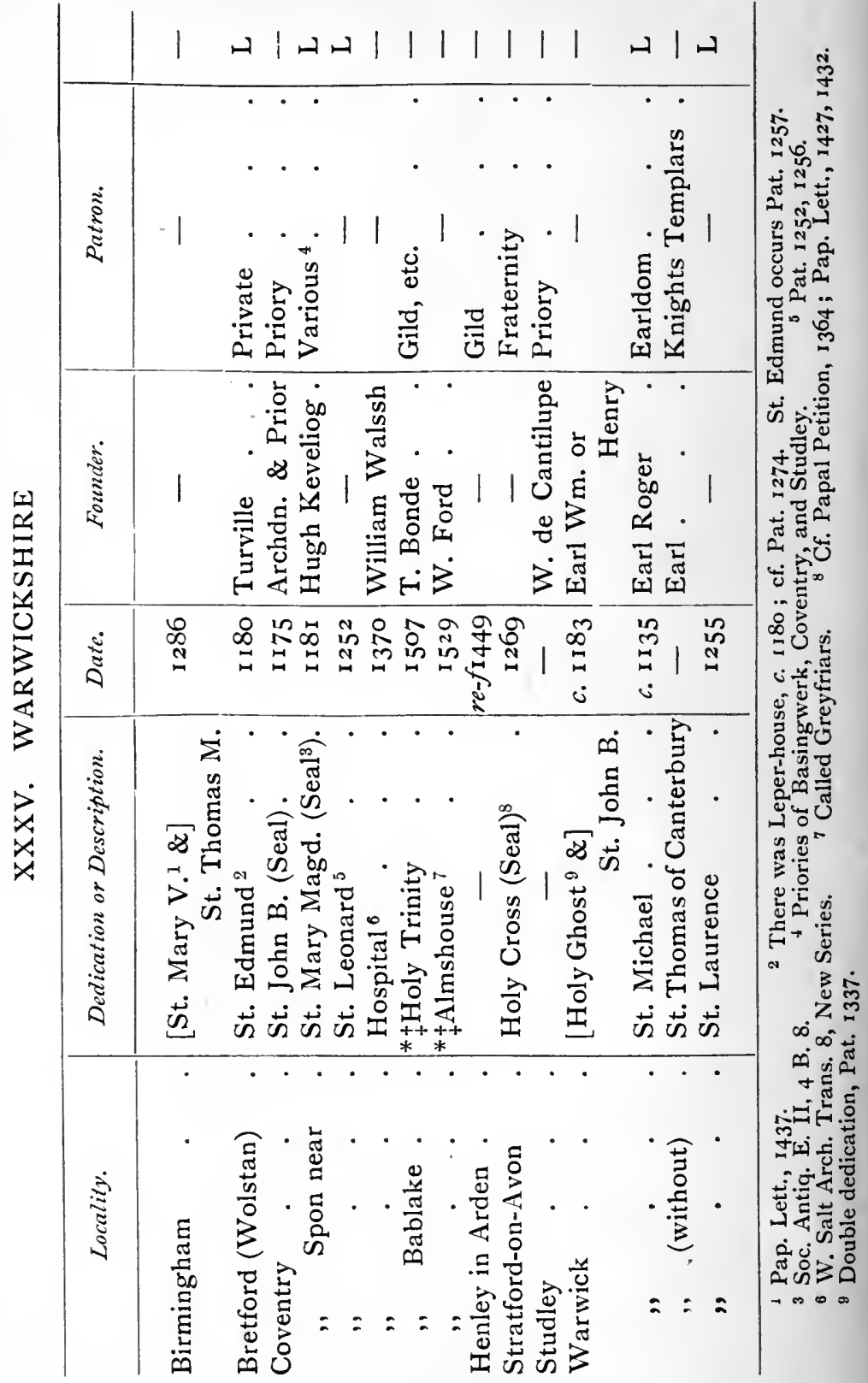




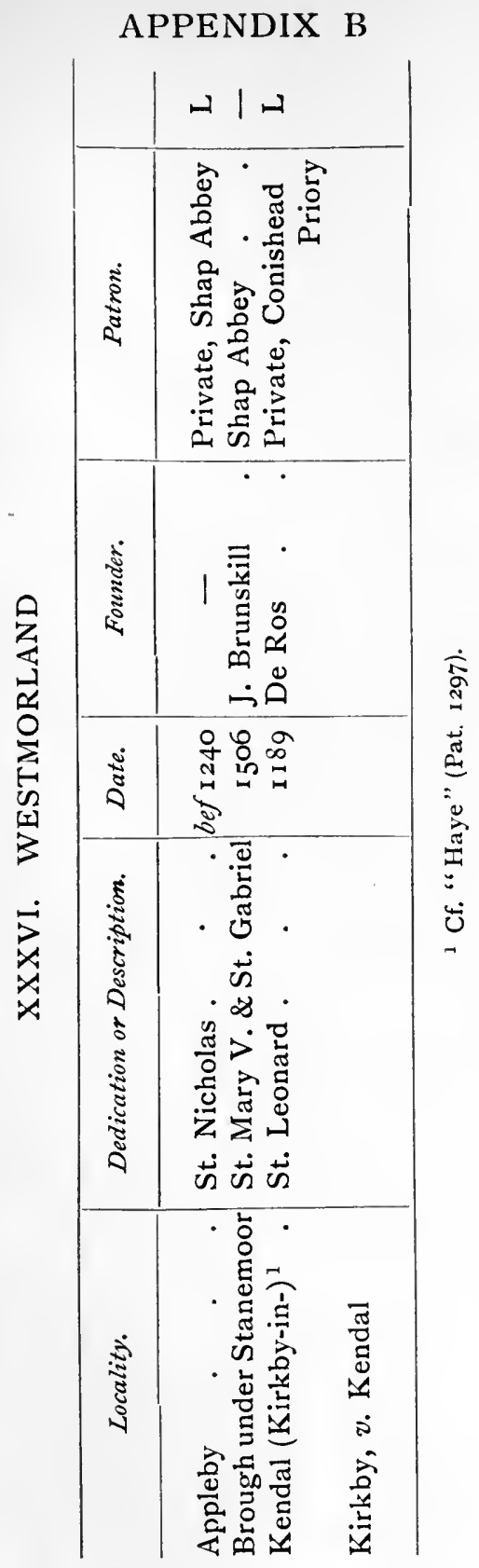


MEDI $Æ V A L$ HOSPITALS OF ENGLAND

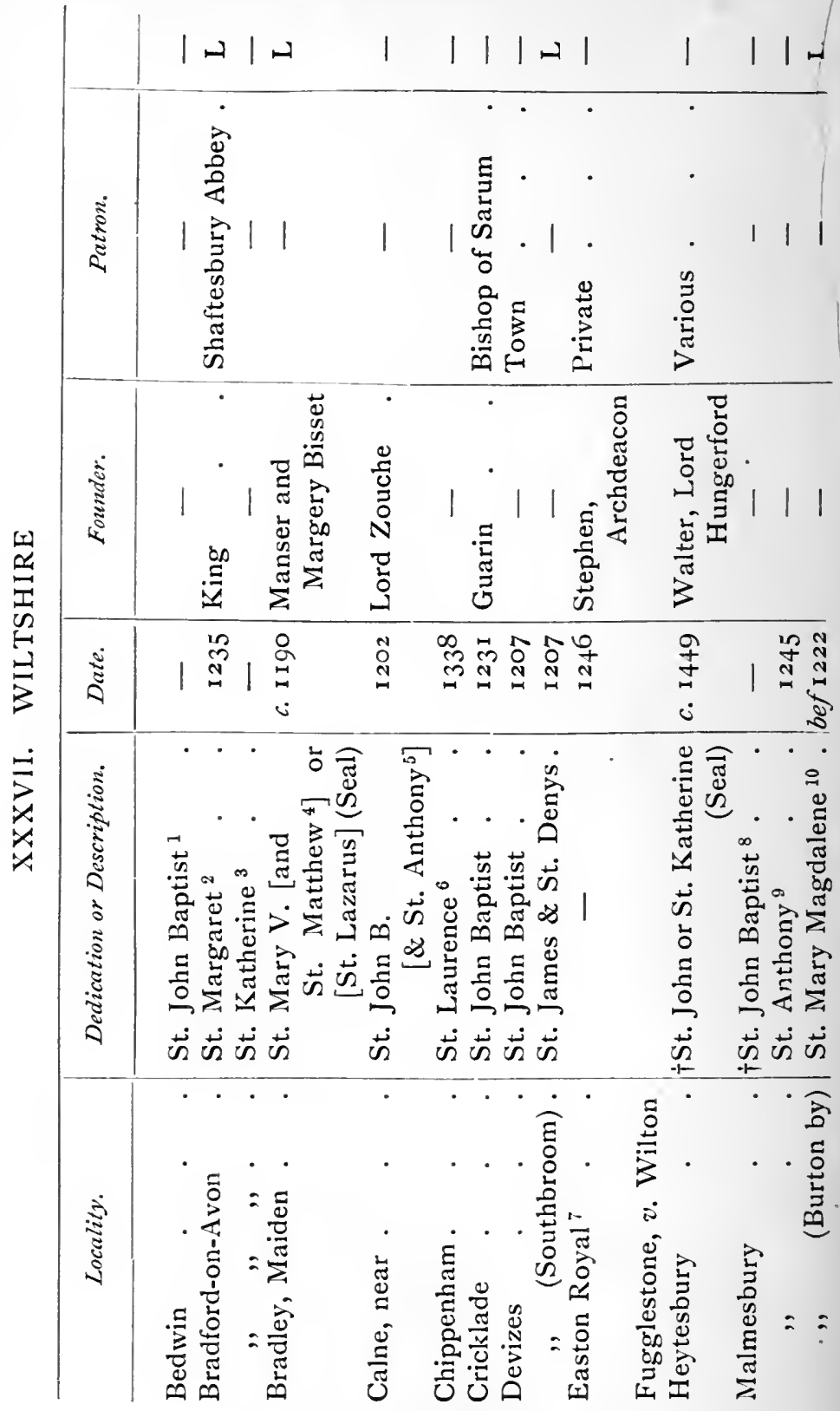




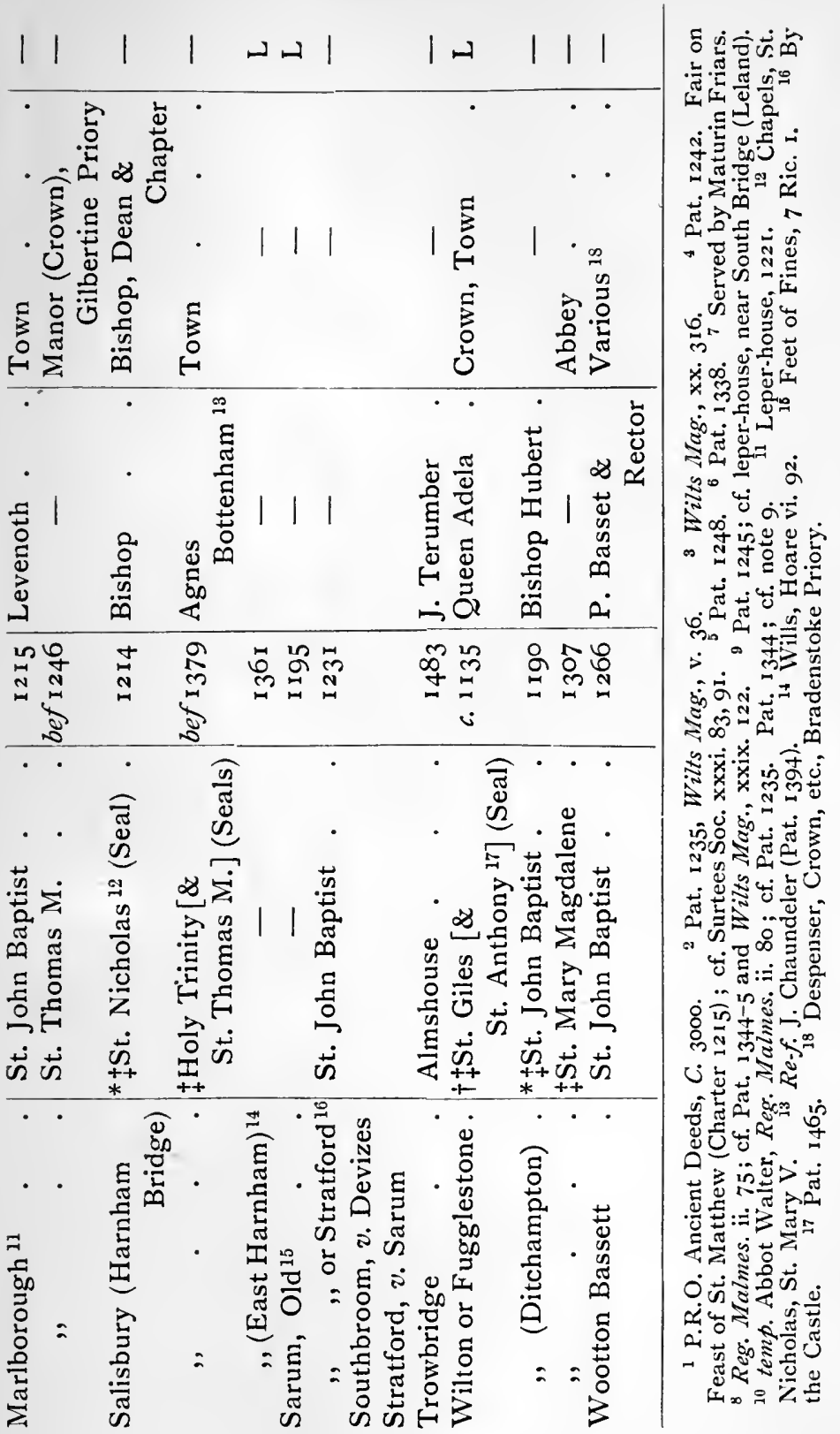




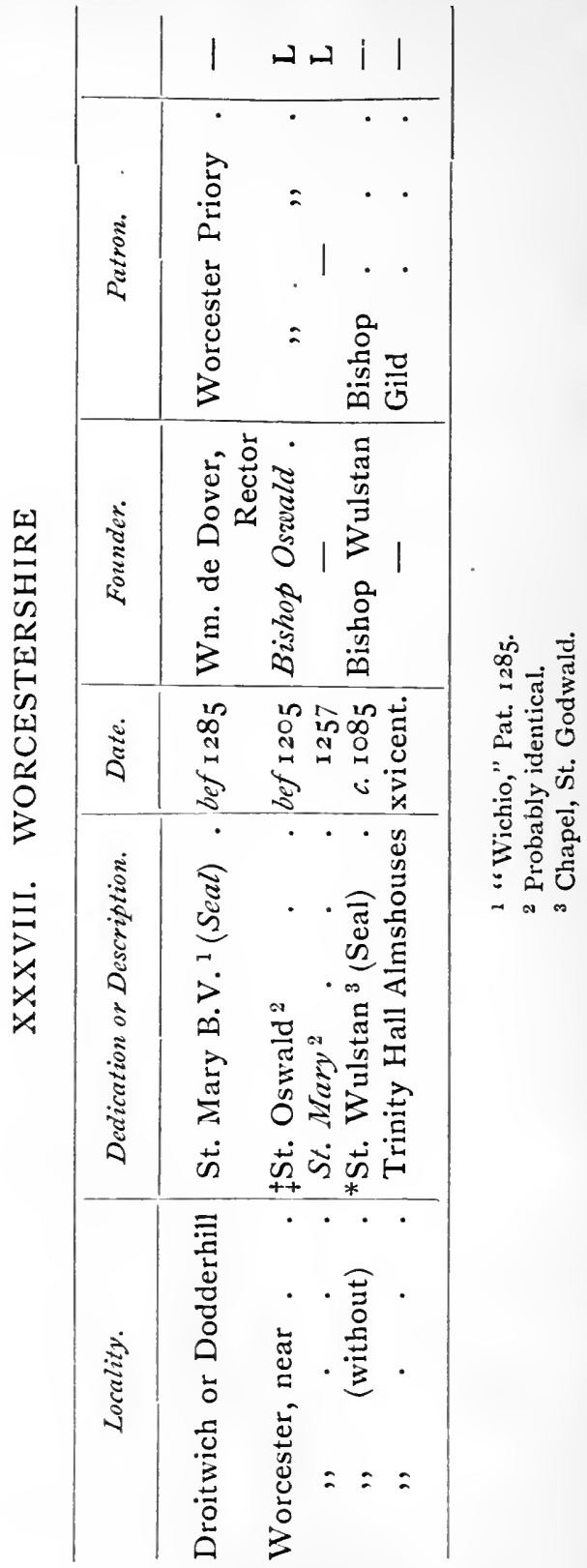




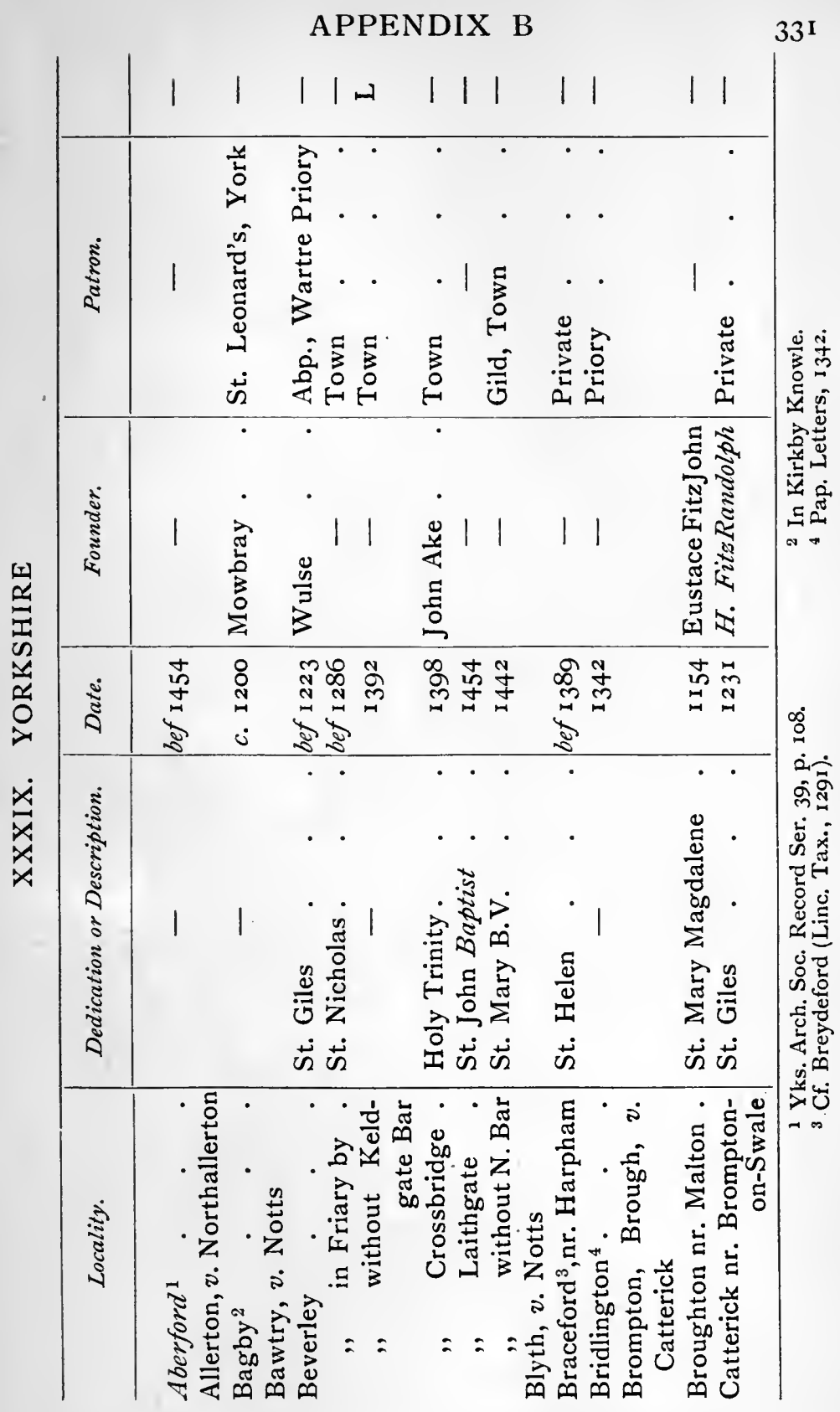


332 MEDI EVAL HOSPITALS OF ENGLAND

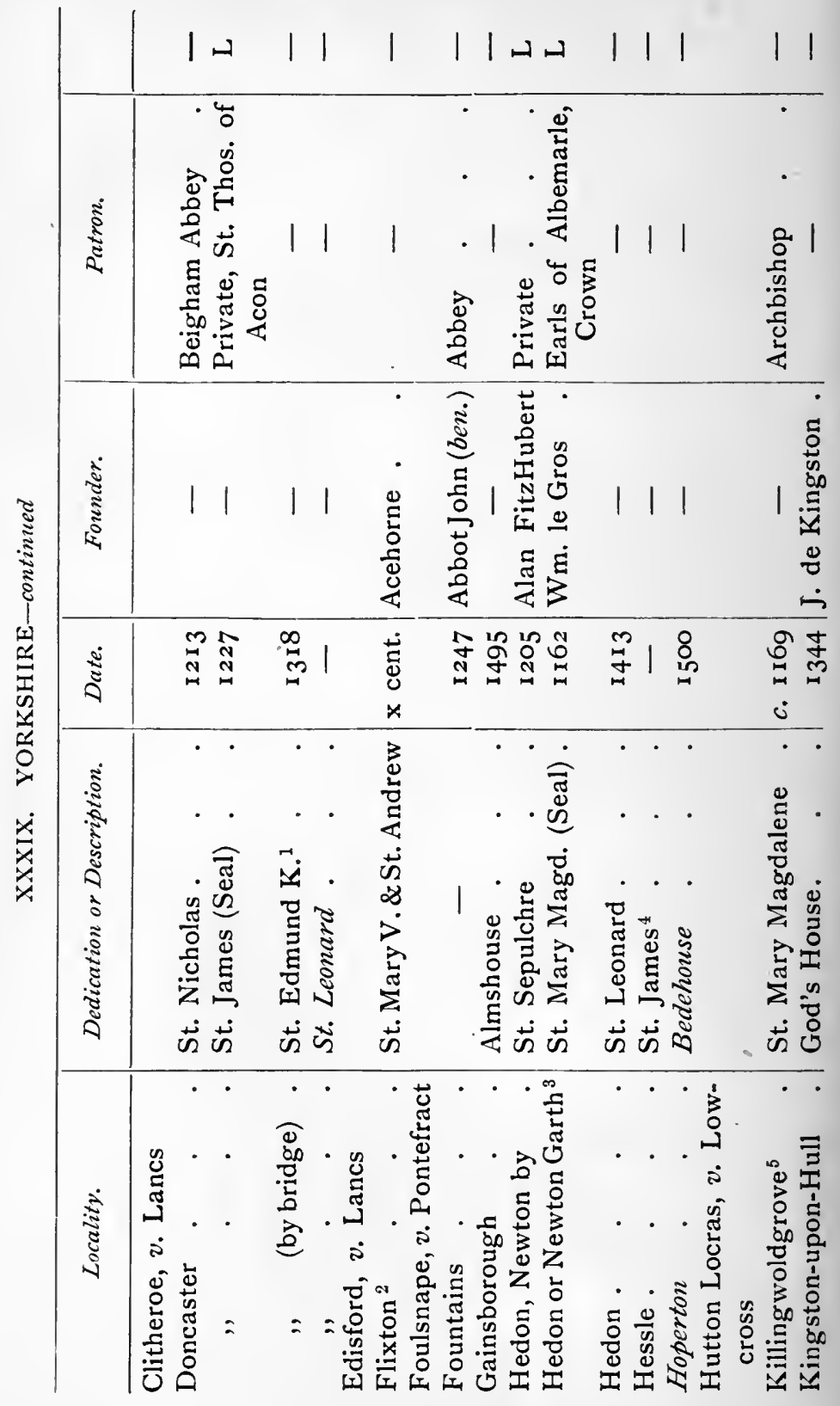



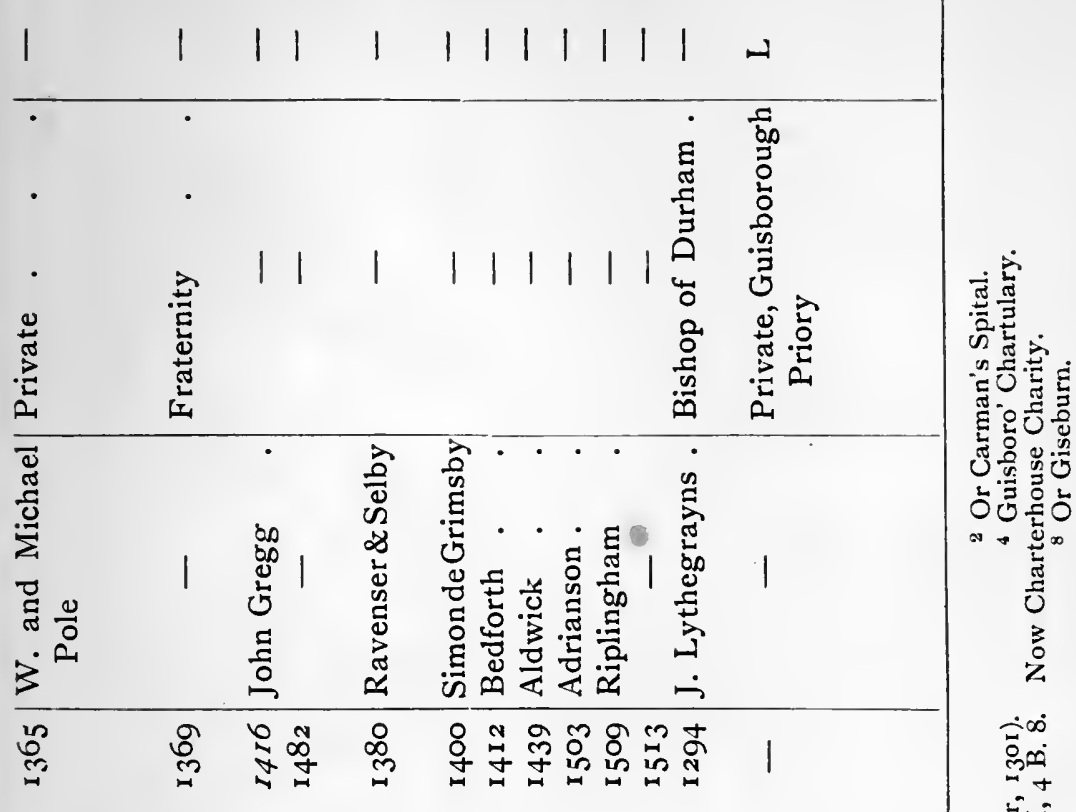

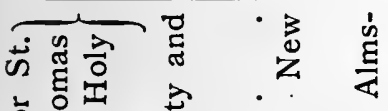

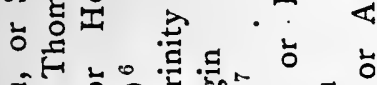

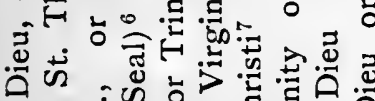

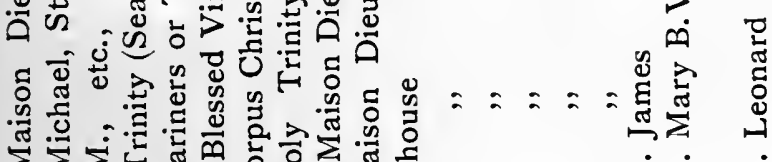

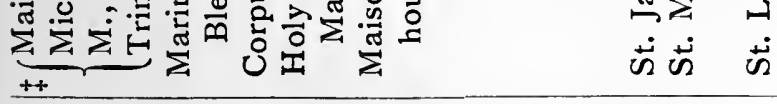

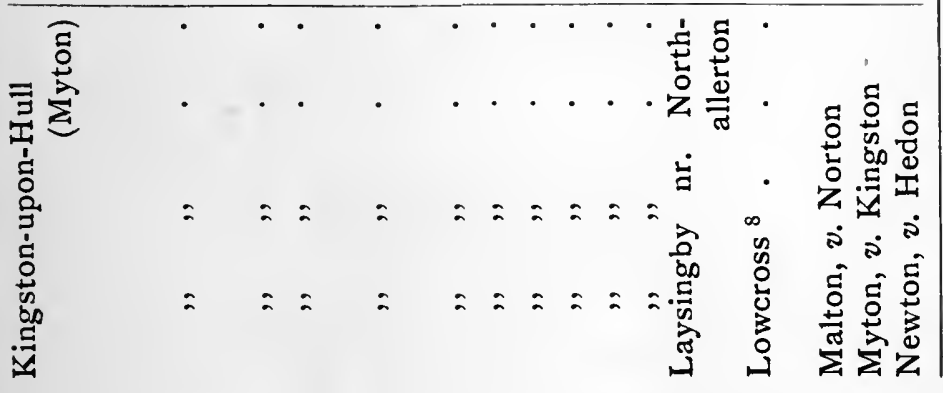




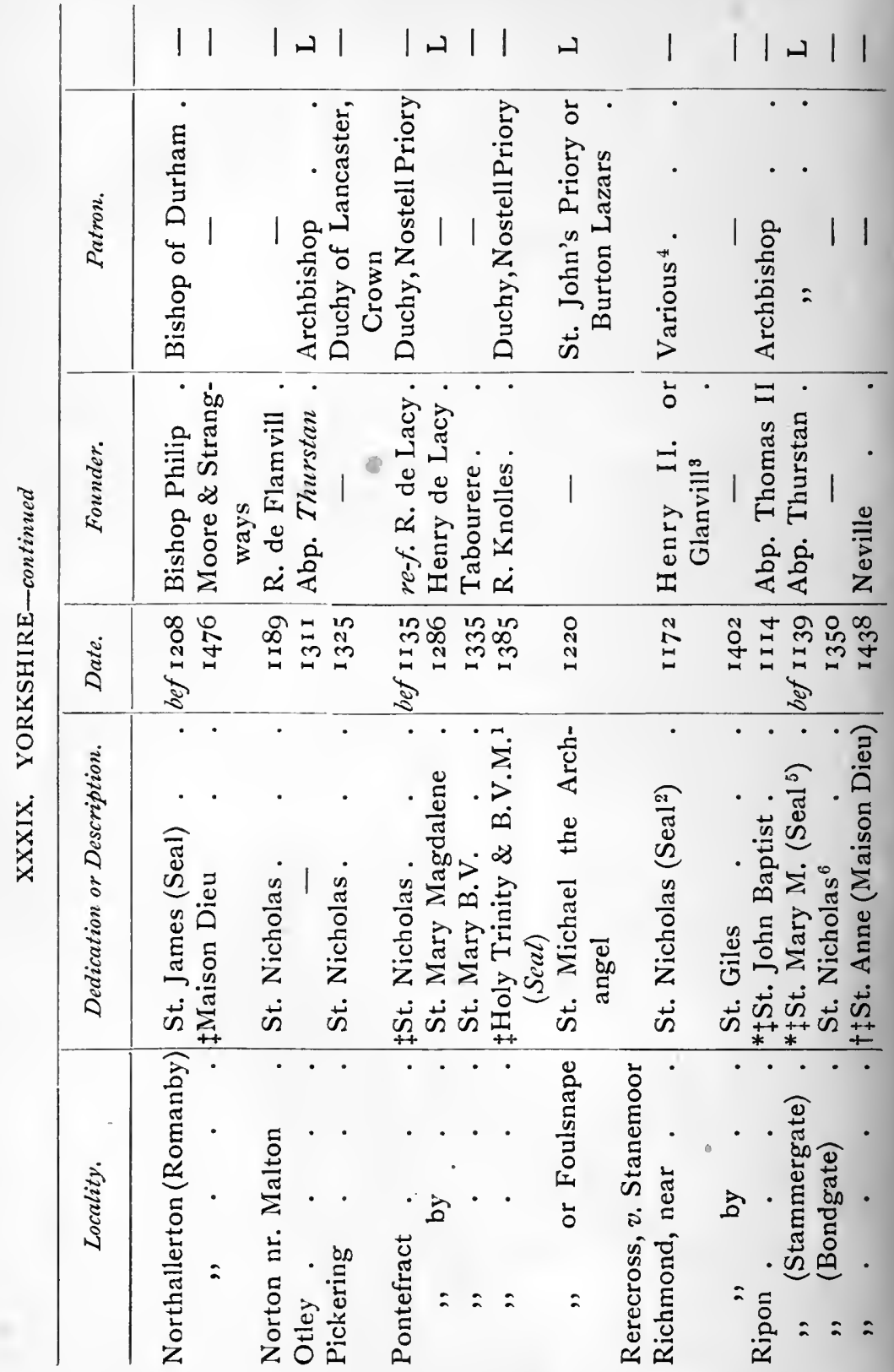




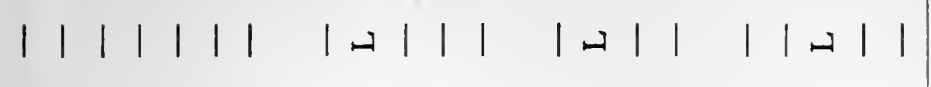
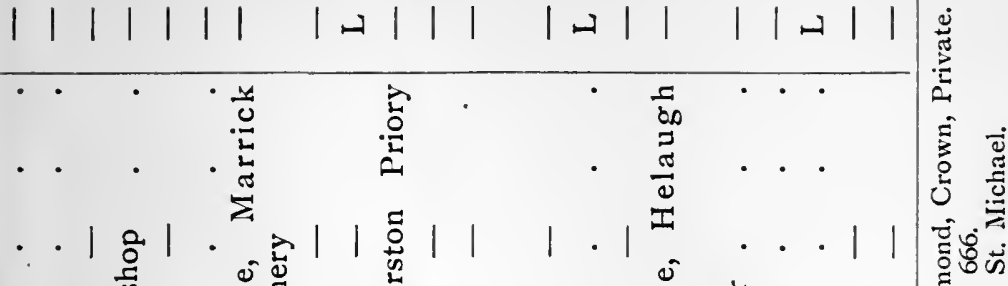

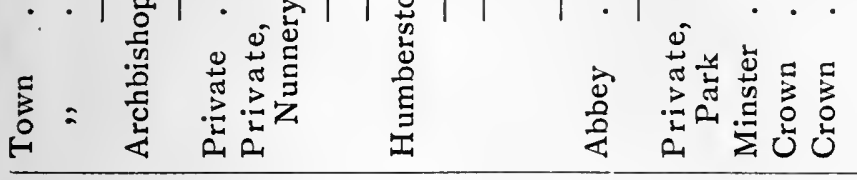

| 용 iो

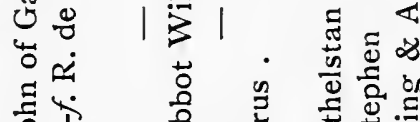
$\cdots \cdot$.

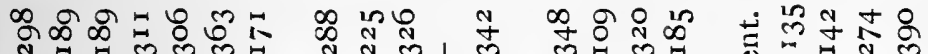

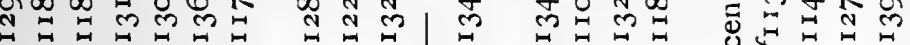
s. $x$

$=$ g.

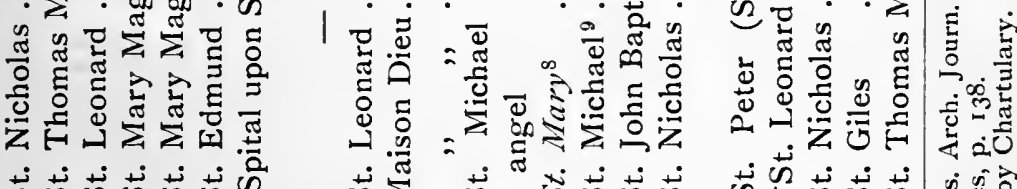

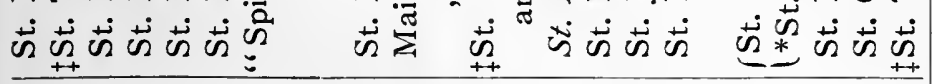

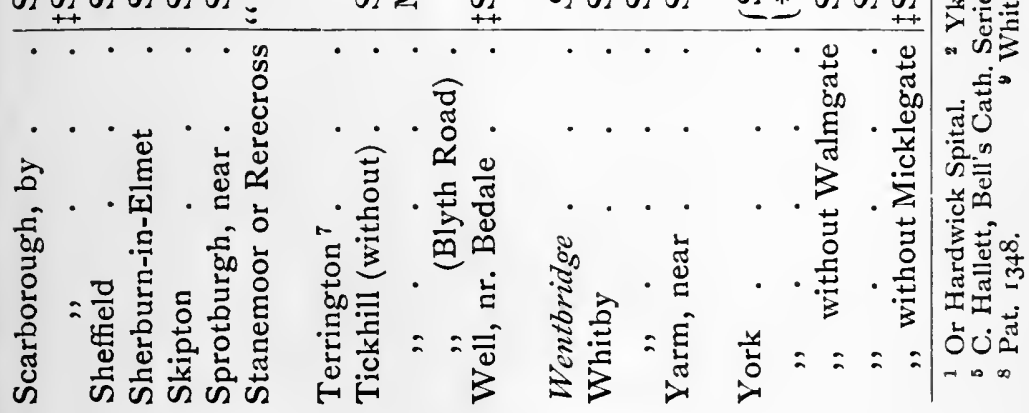


336 MEDIÆVAL HOSPITALS OF ENGLAND

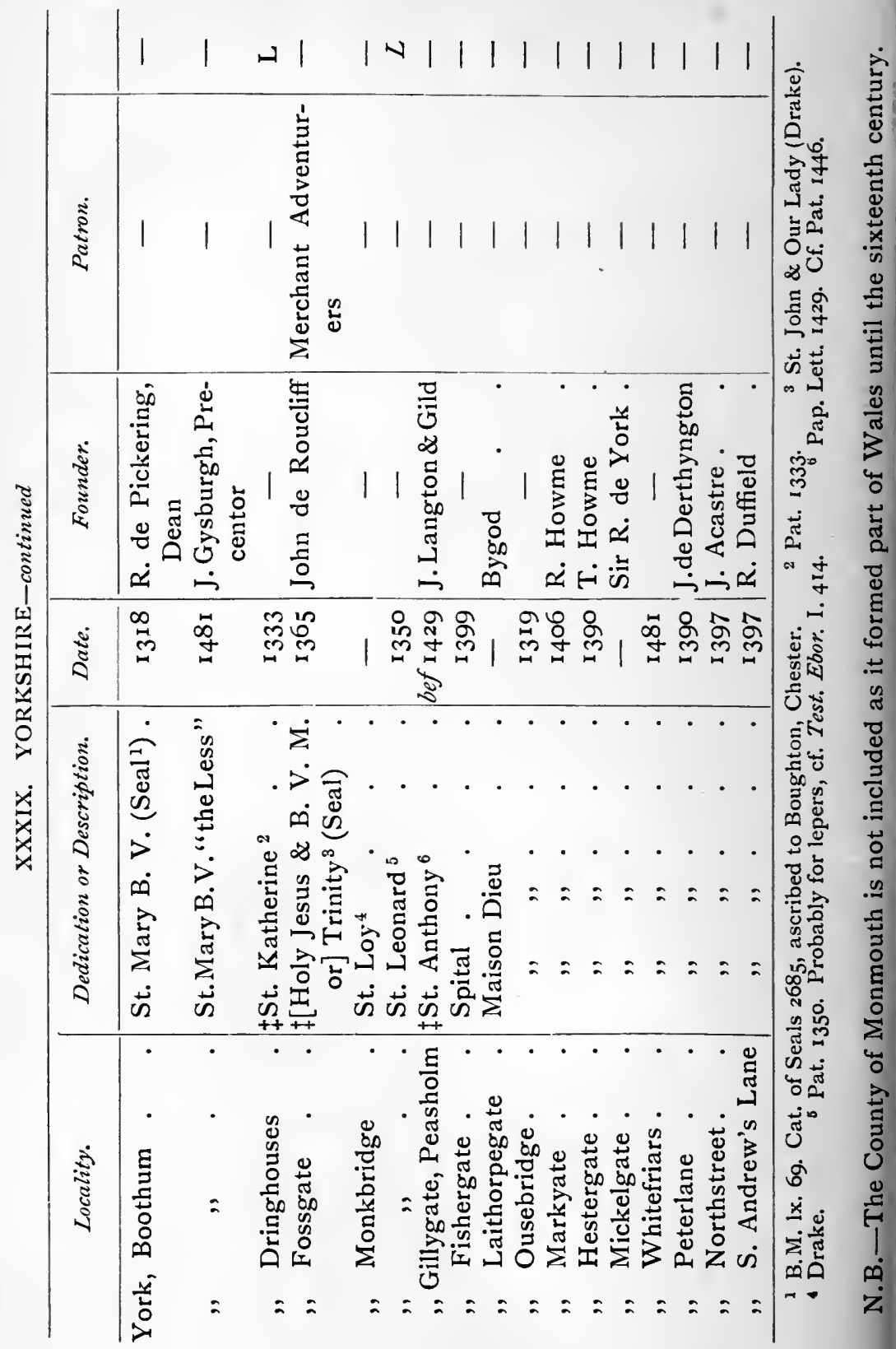




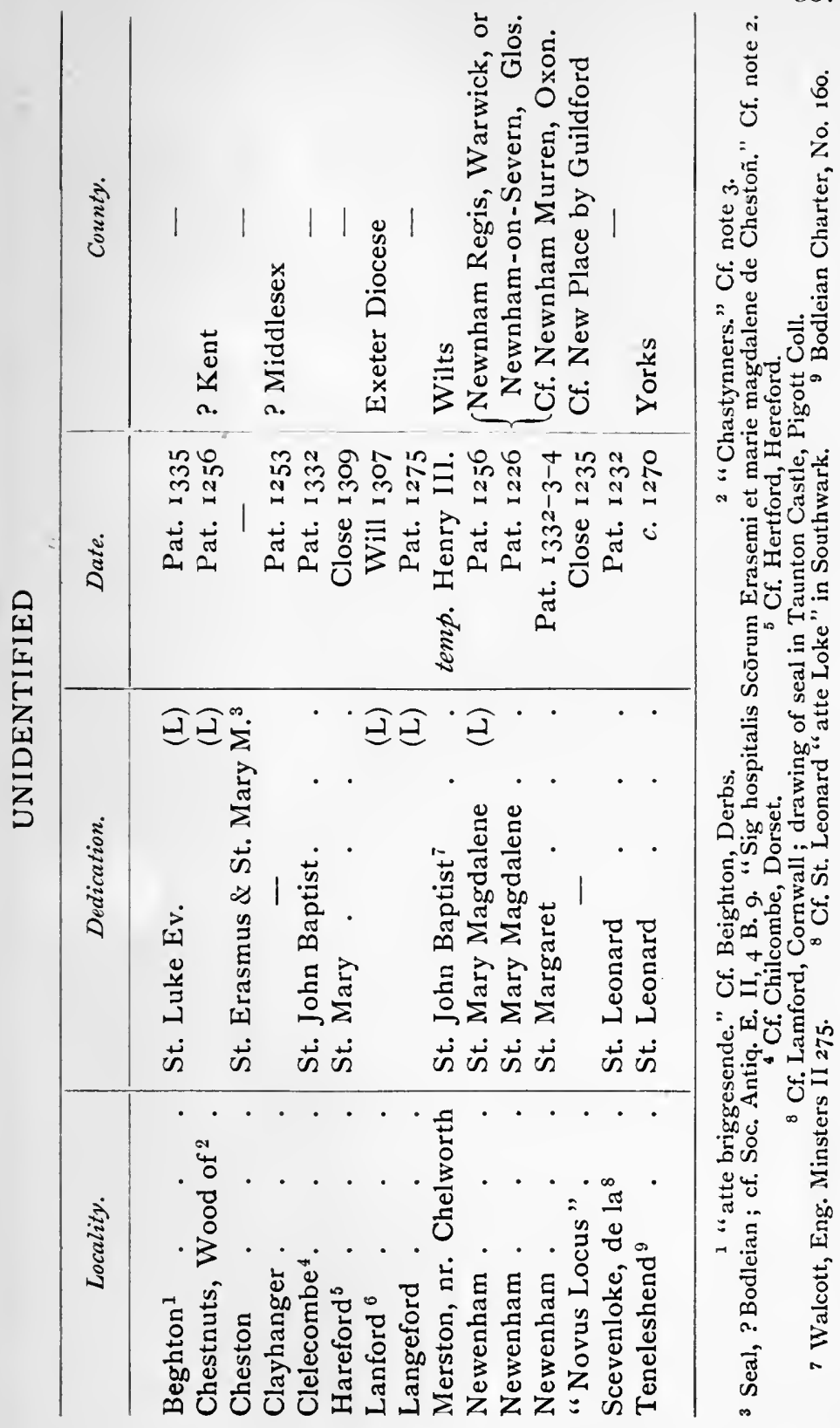





\section{BIBLIOGRAPHY}

Monasticon Anglicanum.

Notitia Monastica.

Monasticon Diacesis Exon.

Index Monasticus.

English Minsters, etc., Vol. II.

Dictionary of National Biography.

Itinerary.

Calendars of Patent and Close Rolls, Papal Registers, Chronicles and Memorials and others of Rolls Series.

Rolls of Parliament, Statutes, Valor Ecclesiasticus.

Calendar of Letter-books, London. , Wills ,

Royal Wills (Nichols). Testamenta Vetusta (Nicolas).

Hospitals and Asylums of the World [Early Systems, etc.].

Hospitals of Middle Ages, etc. [Architecture].

The Builder. Oct. 1908 to July I909 ,"

Catalogue of Seals in British Museum. I.

Studies in Church Dedications.

County Histories of Durham (Surtees), Leicester (Nichols), Wilts (Hoare), etc.

History of Northumberland, 1893 .

Victoria County History.

Hedon (J. R. Boyle, I895), Higham Ferrers (J. Cole, I838), Kingston-uponHull (G. Hadley, 1788), Newark (C. Brown, 1904), Sandwich (W. Boys, 1792), Survey of London (Stow), etc.
Dugdale.

Tanner.

G. Oliver, 1846 .

R. C. Taylor, $182 \mathrm{I}$.

M. E. C. Walcott, 1879 .

Leland, ed. Hearne.
R. R. Sharpe.

, , ,
F. T. Dollman, $185^{8}$.

Sidney Heath.

W. de Gray Birch.

F. E. Arnold-Forster, 1899.

.




\section{MONOGRAPHS ON HOSPITALS}

Canterbury. Bibliotheca Topographica

, See also Ancient Cities.

$\begin{array}{ll}\text { Chichester. } & \text { Domus Dei. } \\ \text { Croydon. } & \text { Bib. Top. Brit., II. } \\ \text { Durham. } & \text { Kepier, etc. } \\ \text { Gretham. } & \text { Collections, I77o. }\end{array}$

Kingsthorpe.

London.

,

,

,

,

,

,

Portsmouth.

Salisbury.

Sherburn.

Southampton.

Stamford.

Wells.

Winchester.

,

Worcester.

York.
St. Mary Roncevall.

Memorials of the Savoy.

St. Thomas M. of Acon.

Domus Dei.

Cartulary of St. Nicholas' Hospital (Wilts Record Soc.)

Collections, 1773 .

God's House.

Domus Dei.

Archit. History of.

Memorials of St. Cross.

Hospital , , ,

Annals of St. Wulstan's.

Account of . . St. Leonard's Brit., Vol. I, No. xxx.

\section{Book of the Foundation of} St. Bartholomew.

Domus Conversorum.

, Rolls House, etc.

J. Duncombe and

N. Battely.

J. C. Cox.

H. P. Wright, $188_{5}$.

Ducarel.

Surtees Society, Vol. 95.

C. A. Markham.

Norman Moore.

Michael Adler, 1900.

Royal Hospital of St. Katharine. F. S. Lea, I 878 .

James Galloway, 1907 .

W. J. Loftie, 1878 .

J. Watney, 1892 .

H. P. Wright, 1873 .

C. Wordsworth, 1902.

G. Allan.

J. A. Whitlock, I894.

H. P. Wright, 1890 .

J. H. Parker and T. Serel.

L. M. Humbert, 1868.

W. T. Warren.

F. T. Marsh, 1890 .

Raine, I898. 


\section{RECORDS, REGISTERS, ETC.}

Camden Soc., 1876, XI, Historical Collections [W. Gregory]. of Citizen.

Canterbury and York Society.

Exeter, Episcopal Registers of.

Pipe Roll Society.

Record Soc. of Hampshire (Winchester

$\begin{array}{lll}, \quad \text {, } & \text { Lincoln. } \\ , \quad, \quad \text { Somerset. }\end{array}$

Registers).

", ", York (Arch. Assn.), Vols. 17, 23.

Surtees Soc. (York Manual, York Wills,

Vita S. Godrici, Gray's Register, Chantry

Surveys, etc.)

Worcester Historical Society.

Ed. J. Willis Bund.

City Records of Gloucester.

Ed. F. C. Hingeston-

Randolph.

Ed. F. J. Baigent.

Ed. A. W. Gibbons.

$\begin{array}{llll}, \quad, \quad & \text { Northampton, II. } & \text { Ed. J. C. Cox. } \\ , \quad \text {, } & \text { Norwich } & \text { Ed. Hudson and Tingey, } \\ \text {, , } & \text { Nottingham. } & \end{array}$

\section{HISTORICAL MSS. COMMISSION}

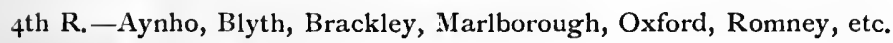
$5^{\text {th }}$ and 8 th R.-Romney.

6th R.-Bridport, Hythe, Southampton, Winchester.

9th R.-Canterbury, Ewelme.

I 2th R.-Gloucester.

14th R. - Bury St. Edmunds.

1900, Beverley. 1907, Wells, Exeter.

\section{COMMISSION FOR ENQUIRING CONCERNING CHARITIES}

R. vi, - Bath, R. viii,-Northallerton.

R. xxxii., Pt. vi._London: Bethlehem, St. Bartholomew's, St. Thomas'. 


\section{TRANSACTIONS OF SOCIETIES}

Bristol and Glos. Arch., VIII, XVII (Ciren-

E. A. Fuller.

cester).

$$
\text { " , " } \quad \mathrm{XX} \text { (Gloucester). S. E. Bartleet. }
$$

Clifton Antiq. Club, I (St. Katherine's Hospital). A. E. Hudd.

$$
\text { ," , , III (Seals). R. H. Warren. }
$$

Cumb. and Westm., X (Leper Hospitals). H. Barnes.

Arch. Cantiana, VII (Dover), VIII (Canterbury).

Arch. Eliana, I892 (Newcastle).

W. H. Knowles.

Somerset, XVIII, ii. (Taunton).

T. Hugo.

W. Salt Arch. Soc., 8 (Stafford).

T. J. de Mazzinghi.

Sussex, XXIV (St. Mary's, Chichester).

C. A. Swainson.

, LI ( , , ).

Wilts, XI (Heytesbury) X, XXVI (Wilton).

Yorks, XII (Pontefract).

\section{ON LEPROSY}

Archæological Essays, II, "On Leprosy and Leper Hospitals," etc.

British Arch. Assn., XI, 1855 .

New Sydenham Soc., Prize Essay.

History of Epidemics, Vol. I, ch. II.

Nineteenth Century, 1884, "Leprosy : Present and Past."

Leprosy and Segregation.

[Cf. Statuts d'hotels-dieu et de léproseries.

Les Maisons-Dieu et léproseries de Paris.

Un règlement intérieur de Léproserie (Noyon)

Danish Lazar-houses (New Syd. Soc.).

Die Aussatzhäuser des Mittelalters.
A. Ballard.

R. Holmes
J. Y. Simpson, ed. John Stuart, 1872 .

T. J. Pettigrew.

George Newman, 1895 .

Chas. Creighton.

Agnes Lambert.

H. P. Wright, $188_{5}$.

Léon Le Grand, 1901.

" , 1898 .

A. Lefranc, 1889.

E. Ehlers, 1901.

E. Lesser, I 896.] 


\section{GENERAL INDEX}

N.B.-Appendix B is not included in the following Index.

For references to Saints see also under Dedications.

Abbots, 9, 10, 38, 50, 75, 92, 121 , 126, 131, 141, 190, 204, 215-7, 247

Abingdon, 37, 205

almshouse, t20-1, 235, 249

Abuses, 39, 41, 141, 146, 164, 195, ch. xv, ch. xvi, passim

Acehorne, 70

Adain Rypp, 83

Adela, Queen, 73-4

Admission of inmates, 39, $4^{1}, 5^{2-3}$,

55, 59, ch. viii passim, 127 et sq.

Aelred of Rievaulx, 50, 25

Agnes Bottenham, 89

Alfune, 185

Alien houses, 208-9, 228, 257, $25^{8}$

Alkmonton, 44, 147, 175, 257

Alms, 41, 54, 64, 75, 78, 98, 134, $135,145,170$, ch. xiii ; oblations, 197

Alms-box, 186, 192-3

Alnwick, 26r, 267

Altars, 85, 128, 152, 162 et sq., $25^{2}$

Amis and Amiloun, 40, 104-5

Andrew, St., 191, v. Dedications

Anthony, St., 208-9; fire of, 49, 257 ; pigs of, $258, v$. Dedications

Architecture, ch. viii

Armiston, 175, 203

Arundel-

Holy Trinity, 19, 8o, 245

[St. James], 147

Earls of, 8o
Athelstan, 2, 64, 70

Augustine, St., $v$. Dedications, Order, Rule

Aynho, 5, 183, 226, 253

Baldock, 183

Bale, Bishop, 72, 193, 268

Bamburgh, 210

Banbury, 28, 8I, $25^{\circ}$

Barnstaple, 179

Barstaple, John, 18, 84, 85

Bartholomew, St., 93, 95, 191, v. Dedications, London

- Anglicus, 43, 6r, 65

Basingstoke, 24, 73, 203, 244

Bath-

St. John, ${ }_{158}^{8}, 233$

St. Mary M., Holloway, 34, 124 , 166, I 83,248

physicians of, 64

prior of, 34

waters, $34,63-5$

Battle, 3, 50

Bawtry, 123, 124, 183

Beaufort, Cardinal, 25, 81

Bec, 5, 267

Beccles, 46, 64

Becket, 266, 268, v. Thomas, St.

Bede-houses, I5, 18, 29

Bedford, 17

St. John, 17 n., 175, 225

St. Leonard, $187,188,242,262$

Beere, Richard, 10, 12 I, 124 


\section{MEDI EVAL HOSPITALS OF ENGLAND}

Beggars, begging-6, 10, 12-14, $25,28,53,69,140,170-1,237$, 239, 259

Bells, 197-9; leper's bell, $48,68,69$

Benedict, St., v. Dedications, Order, Rule of

Benedict of Canterbury, 65, 266

Bequests, 33, 154, 164, 172, 18 I-2, 186, 199; to lepers, ch. iv, 72, 79, 104

Berkeley (Longbridge), $189,197-8$, 245

Bermondsey, 79

Berwick-on-Tweed, 54, 109

Beverley, 6, I6, 55

Holy Trinity, 141, 163-4, 234

St. Giles, 2 n.

St. Nicholas, 224

Bidlington, 53, [59]

Bishops, 2-3, 16, 126-7, 187 et sq., ch. xiv

Bisset, Margaret, 74

Bladud, 63

Blind, 4, 12, 15, 24, 25, 3r, 80, 95, $98,156,229,231$

Blyth, 8, 44, 254

Bodmin, 46, 146, 257

Bolton (Northumberland), 145, 267

Book of the Foundation, 77,92 , 106-7, 253

Boughton-under-Blean, 42

Brackley, 8, 84-5, 99, I 24, 181, 206, 226, 253-4

Bracton, 57

Brand, 87

Brentford, fraternity, 246; hospital, 8, 261-2

Brentwood, 62

Bridgwater, 5, 27, 122, 153, I59, 206, 213,270

Bridport-

St. John, ${ }^{5}$

St. Mary M., Allington, 138 , 145,189
Briefs, 34, 41, 187 et sq.

Brinklow, (Mors), 14, 224, 228-9, $23 \mathrm{I}$

Bristol, 22, 32, 54, 88, 99

Foster's almshouse, 1 24, 234, 247

Holy Trinity, $18,85,163$

St. Bartholomew, 19, 65, 89, $182,226,256$

St. John, $25^{\circ}$

St. Katherine, 127, 260

St. Lawrence, 72, 257

St. Mark, 125, 127, 149, 166, 170, 174, 199, 206, 236, 247, 254-5

St. Mary M., 147, 198-9, 201, 252

Briwere, William, 76

Brough, II, 197, 246

Browne, William, 83, (90), 269

Bubwith, Nicholas, $17,8 \mathrm{r}$

Burgesses, founders, $78,8 \mathrm{I}-3,84$; patrons, $16-17,18,163,172-3$, 184 ; pensioners, $17,4^{2}$

Burton Lazars, 37, 63, 122, 179, 208, 25I

Bury St. Edniunds, 6, 7, 72, 179, 205, 255

St. Nicholas, 183,257

St. Petronilla, 119-20, 147,256

St. Saviour, 75, 183,245

lepers, $44,46,256$

Calne, 225

Cambridge, 99-100, 262

St. John, 73, (127, 168)

Colleges, 208, 226

v. Stourbridge

Camden, 74, 116

Canterbury, 179, 192-3

Priests' hosp., 23, 123

St. John, 15, 71, 106, 109, 1 24, $153,155,156,164-5,169,(186)$, $190,192,(240), 241,25^{\circ}$

St. Laurence, 215, 257 
Canterbury-St. Thomas, 1, 4, 7, $8,11,124,153,167,173,(240)$, $245,265-6$

Abbey, 21 5, 257

Archbishops of, 4, 7, 10, 81, $144,181,222,228-9,267, v$. Edmund, St., Thomas, St.

Priory, Cathedral, 31, 64, 192. 266-8 (Prior) 154

ข. Harbledown, Pilgrimage, Thanington

Capelford-by-Norham, 109

Capgrave, John, 56

Carlisle, 37, 38, 109, 1 30, 146, 184, 218,242

Bishop of, $5^{8}$

Carpenter, John, 33, 44, 82

Castle Carrock, $5^{8}$

Cathedral foundations, $2,16,216$, $233,256,264$

Cemetery, burial, 133, 197, 199-200, 202, cf. 276

Chantry, 24, 29-30, 232, 237-5, 259

Survey, $164,225,227,234,245$, 270

Chapel, ch. viii, 133, ch. xi, 180 , 197 et $s q$.

ornaments, $16_{3}$ et sq., 223

Chatterton, 65-6

Chaucer, 145

Chester-

St. Giles, $18+$

St. John, I62

St. Ursula, 17

Earls of, 92, 184

Chesterfield, 257, 261

Chichele, Henry, 19, 27, 81, 228-9

Chichester, I 79

St. James, 34, I 59, (264)

St. Mary, 5, 16, 77, 112, 113, 124 , ch. ix, 158, 166, 174, 240

Bishops of, $34,162-3,264, v$. Richard, St.

Dean of, 77,128
Children, cured, 4,98 ; maintained, $22-3,26-8,182$

Chroniclers, 15, 20-1, 23, 36, 37, $40,48,5^{\circ}, 5^{2}, 5^{6}, 60,64-5,86$, 92 et sq., 106-7, 131, 264-5, v. Book of Foundation

Clappers, 68-9, 135, 251 $25^{1}$ 1., 276

Clattercot, 147, 179,205

Clergy, 77, 205-6, 220-2, v. Masters, Priests

Clist Gabriel, 24, 246

Clothing, 21, 33, 134-5, I37, 140 , $15^{2}, 174-7,207,259,270,273$, 275, 276 (habit), 128-9, 1 31-2, 141

Cockersand, 78, 205

Coke, Lord, 57

Colchester-

Holy Cross, 18, 190, 210, 235, 248-9

St. Anne, 190

St. Mary M., lepers, 7 I-2, I30, $183,215,270$

Colet, Dean, 193

Colleges, 25, 81, 204, v. Cambridge, Oxford

Colyton (Devon), $5^{8}$

Commandery, 207, $25^{\circ}$

Compostella, 7, 253

Constitution, ch. ix, cl. xiv

Copland, Robert, 1 2-13, 224

Corrody, (98 et sq., 104), 21 3-4, 223

Council (Lateran), 51, 52, 148, 195 , 200 (Westminster), 195

Coventry, 12, 8o

Bablake, I 16,245

Ford's, I 21,156

St. John, 34

Crediton, 123, 211

Cricklade, $7^{8}$

Cripples, lame, etc. $-6,8,15,25$, $34,3^{6,94-6,98,99, ~ 101, ~ 156, ~} 223$, 262,268 


\section{MEDIÆVAL HOSPITALS OF ENGLAND}

Cromwell, Thomas, 223, 232, 268

Crowmarsh, 108

Croydon, 17, 34, 90, 120, 137, 140, I 55, I 57, 175, 204

Crusades, 4, 36-7, 73, 76, 79

Cuthbert, Billingham, I $1,\left(7_{72}\right)$

Darlington, 59, 97

David, Prince, 50, 251, 260

Davy, Ellis, (90, 120), 175

Deaf and dumb, 3-4, I5, 31, 95

Dedication of Hospitals-

Alexis, St., 259

All Saints, 269

Andrew, St., 255

Anne, St., 261, 262

Annunciation of B.V.M., 246

Anthony, St., 245, 256-8

Augustine, St., $25^{8}$

Bartholomew, St., 252-3

Benedict, St., $25^{8}$

Bernard, St., $25^{8}$

Brinstan, St. , 263

Chad, St., 263

Christ's, 245, 270

Christopher, St., 259

Clement, St., 256

Corpus Christi, 245

Cuthbert, St., 263

David (Dewi), St., 263

Denys, St., 262

Domus Dei, 47, 90, 244

Edmund, K.M., St., 264

Edmund, Abp., St., 264-5

Eligius (Loy), St., 262

Ethelbert, St., 264

Gabriel, St., 246

George, St., 252, 259

Giles, St., 262

God's House, 89, 90, 244-5

Godwald, St., 263

Helen, St., 248, 26 I

Holy Angels, 246

Holy Cross, $248-9$
Holy Ghost, 245-6

Holy Innocents, $246-7$

Holy Jesus, 245

Holy Saviour, 245, 252

Holy Sepulchre, 248-9

Holy Trinity, 244-5, 269, 270

James, St., 252, 253

John Baptist, St., 244, 246, 249-51, 254, 266

John Evangelist, St., 253-4

Julian, St., 259

Katherine, St., 260-1, 270

Laudus, St. , 262

Lawrence, St., 256-7

Lazarus, St. , 249-52

Leger, St., 262

Leonard, St., 247, 252, 261-2

Louis, St., 262

Loy, St., v. Eligius, St.

Luke, St., 254-5

Margaret, St., 245, 260

Mark, St., 247, 254-5

Martha, St., 252

Martin, St., 262

Mary, St., the Blessed Virgin, 244, 246-7, 251, 266, 269

Mary Magdalene, St., 47, 246, 249-52, 261

Matthew, St., 254-5

Michael, St., 246, 269

Nicholas, St., 257, $25^{8}$

Oswald, St. (Bishop), 263

Paul, Ap., St., 255-6

Paul the Hermit, St., 255-6

Peter, St., 255-6

Petronilla, St., 255-6

Roch, St., 262-3

Stephen, St., 255, 267

Theobald, St., 262

Thomas, Ap., St., 255

Thomas the Martyr of Canterbury, St., 245, 265-9

Three Kings of Cologne, 246-7

Ursula, St., 260-I 
Virgins, Eleven Thousand, 26I Wulstan, St., 263

Denwall, 255

Derby, 179, 218, 26r

Diseases, 36, 49, 54, 62, 63, 93, I 50, $168,25^{8}$

Black Death, 24, 42-3

dropsy, 4, 36, 265

elephantiasis, $48,49,5^{\circ}$

epilepsy, falling sickness, 3-4,

13, 32

erysipelas, 49, 257

fever, 4 , (86), 253

insomnia, 92-3

leprosy, ch. iv, ch. $\mathrm{v}$

paralysis, $4,24,31,32,96$

pestilence, $24,42-3,45^{-6},{ }_{179}$, 222, 257

Disendowment, 29, 228 et sq.

Dissolution, I4, I50, I7 I, 209, ch. xvi

Donnington, 19, I55, 211

Dover-

St. Bartholomew, Buckland, 4, $37,130-2,134,144,146,147$, $159,174,183,252$

St. Mary, 4, I1, 73, 109, I16-7, $127,155,162,170-1,192,203$, 206, $213,223,233$

Droitwich, 216

Dunstable, 199

Dunwich, 95

Holy Trinity, 73, 190, 245

St. James, 72, 122, 253

Durham, 6

Maison Dieu, 11, 172

St. Mary M., 123, 163, 203, 215

Bishops, diocese of, $16,44,97$, I 23, I 7o, I 85, 233, 253, 264-5

Prior of, 215,254

Eadmer, 15, 106

Easton Royal, 211

Edinburgh, 7 I
Edmund the Archbishop, St., I62, I64, 189, 19I, 264

Education, 21, 26-8, 80-1, 151, 226

Edward the Confessor, 37

- I, 2 I, 79, 208, 213

- II, 60, 213, 216

- III, 53, 80, 208, 214, 220

- IV, $45,63,102,216$

- VI, I0, 46, 164, ch. xvi

Eleanor, Queen, 79

Ellis, Thomas, 83

Elsyng, William, 24, 8I

Ely, 179

St. John, I ro, I52, 220, 233

Bishop of, 8, 5.5, 83

Endowments, ch. vi, ch. xii, ch. xiii

Erasmus, 45, 193

Eudo, 72

Ewelme, 19, 27, 34, 80, 88, 90, i I I, 120, 140, I5 I, 157, 161, 163, 175, 203, 217,222

Exeter, 3, 78

Bonville's, 26I, 263

Grendon's, 120, 182

Wynard's, 27, I5I, 161

St. Alexis, 107, 108, 259

St. John, 16, 27, 54, 107, 108, 163, 199, 254

St. Katherine, 123-4

St. Mary M., lepers, 37, 46, 54, 102-3, 139, 146, 184

Bishops, diocese of, 24, 26, 38 , $54,58,60,184,189,246,254$, Mayor of, 102

Fairs, 72, 182-3, Part II passim

Famine, 36, 40

Farley, 209

Festivals, 164, 169-71, 197-8, 202, Part II passim

Finchale, 96-7

Fitz-Herbert, Judge, 55, 60

Flixton, 2, 70, 255 


\section{MEDI EVAL HOSPITALS OF ENGLAND}

Food and drink, 33, 41, 84, 128, 131, 136-7, 139, 185, 223, ch. xii, $275^{-6}$

Forster, Stephen, 33, I82

Foulsham, 103

Founders, ch. vi, 95, 127, 161, 178 et sq., 236, 237, etc., v. Patronage

France, 261-2

hospitals in, 86, 114, 209, 227

kings of, $45,56,73,191-2,262$

lepers in, $56,72,86,147-8,177$, I $8 \mathrm{I}$

war with, 80, 99, 109, 208-9

Francis, St., 50, 52, 69, 148, 209

Fraternity, 18-19, 25, 186-7, 235, $246,256,259$

Friars, 21, 65-6, 79, 209-11, 227

Fuller, Thomas, 36, 81, 229, 231-2

Funds, ch. xii, 225, 229, 238, 242

Furniture, $117,134-5,276$ beds, etc., $8,117,134,135,137$, I 72-3, 180, 276

utensils, 1 35, 169, 173, 177, 182, 276

Gateshead, 16, 1 23, 125, 263, 264-5 Geoffrey Fitz-Peter, 76

- de Vinsauf, $3^{6}$

Gervase of Canterbury, 48

- of Southampton, 78,259

Gilds, 18, 121, 232, 235

Glanvill, Gilbert, $72,76,87$

- Ralph, 75-6

Glastonbury, 9-10, 234

St. Mary M., 115, (124), 198, (234)

Women's almshouse, 124, 165, (234)

Abbots of, 9, 10, 121, 124

Gloucester -

St. Bartholomew, 73, 109, 127 , $156,180,223,253$
St. Margaret, St. Sepulchre, I 24, 134, 146, 172

St. Mary M., 123,200 lepers of, 55, Dudstan, 179

Godric, St. , 96-7

Gorleston, 79, 232, 255

Gower, John, 154

Grandisson, John, 26, I89, 254

Gravesend, I So

Greatham, 16, 152, 156, 165, 233, 263

Gregory, St., 143

- William, 9, 25, 33, 82

Grendon, Symon, 120, 182

Grimsby, 10, 262

Grindal, Edmund, 226

Guarin, 77

Gundulf, 50, 7 I

Guy de Chauliac, 6I, 67

Hackney, 45, 54, 148

Harbledown, 37, 40, 42, 63, 71, 106, I1 $7,1_{30}, 1_{36}, 1_{39}, 1_{43}, 1_{44}$, $145,147,169,176,179,181,(186)$, $192-3,(240), 257$

Harting, $183,25^{\circ}$

Hawaii, 49

Hedon, 130, 249, v. Newton

Hempton, 255

Henry I, 71, 170, I79

- II, 72, 74, 114, 180, 181, 191, (267), 268

- III, 20, 73, 74, 99, 107, 146, 162, I $71,180,187,195,202,213$, 256

$-1 V, 99,102,228,23^{\circ}$

- V, 100, 102, 222, 228, 230

- VI, 4., 102, 161,208

- VII, 12, 8o, 88, 1 22, 179

- VIII, ro, ch. xvi, 268; Commissioners of, $171,227,232$

- de Blois, Bishop, 75, 86

- of Lancaster, 8o, 82, 85 
Henry de Sandwich, 85

Hereford-

St. Anthony, 208

St. Ethelbert, 16, 264

St. John, 246

Leper-hosp., 46, I79-80, 261

Bishop of, 87

Heringby, 204

Hertford, 211

Hexham, 5, 4I, 130

Heytesbury, I9, 27-8, 80, 9o, 135, 140, 151, 156, I60-1, 175 , 270

Higham Ferrers-

Bedehonse, 19, 27, 81, 114,115 , $135,156,157,169,173,186$, 204

lepers, ${ }^{179-80}$

Highgate, v. Holloway

Hocclive, 181

Hoddesdon, 256, 258, 262

Holderness, 2, 70, 75, 219

Holloway (Middlesex), 35, 102, 245, 258, Highgate, 45, 102

Holloway (Somerset), v. Bath

Holy Land, $7,76,104, v$. Crusades, Jerusalem

Honiton, 46, 124

Hooker, Richard, quoted, 244

Hornchurch, 209, $25^{8}$

Hospitality, ch. i, 87-8, I 52

Hubert de Burgh, 76, 171

Hugh, St., 50-1, 66, 67, 144, 180 ; "little St. Hugh," 21

- Foliot, 87

- Garth, 78

- d'Orivalle, 37

- Pudsey, 75, 170

Hungerford, I47; Lord and Lady of, 80 (9o)

Huntingdon-

St. John, 260

St. Margaret, 41, 147, 226, 260

David, Earl of, 50,25 , 260
Hye Way to the Spyttell hous, 12, 255

Hythe, 16, 255

Indulgences, 188 et $s q ., 248$

Infants maintained, 9, 26

Ilford, 37, 117, 124, 126, 141, 144,

$145,147,160,179,221,264,266$

Infirmary, 111 et sq., $117,149,153$,

I54, 162, 167, $25^{\circ}$

Infirmi, 48, 179

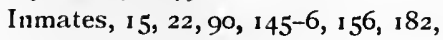

239

named, ch. v, ch. vii, 134, 183, etc.

Insane, 4, ch. iii, 57, 90, 219, 238, 253

Inventory of hospital, $117,16_{3}$

Ipswich, 72, 100, 183

Isbury, John, 162

Japan, 52, $67 \mathrm{n}$.

Jerusalem, 36, 248-5o, v. Knights of St. John

Jews, 19-23, 56, 73, 79, 99-100

John Baptist, St., 163, 206-7, v. Dedications

John, King of England, 57, 72, 75, $78,86,18_{3}, 18_{4}, v$. Bale

- King of France, 191-2

- of Campeden, I $5^{1}$

- of Gaddesden, 6o, 6r

- of Gaunt, 42, 164

- Mirfield, 149

Jurisdiction, ch. xiv

Katharine of Aragon, 100, 260

Kepier, 16, 75, I 52, 185, 233, 262

Kingsthorpe, 112, 126, 263

Kingston (Surrey), 39

Kingston-upon-Hull-

Corpus Christi, 245 
Kingston-upon-Hull-

Maison Dieu, 8o, 246, 269

fraternity, 19

Knghtsbridge, 8o, 103

Knights of St. John, 101, 206-7, 248, 249-5 1

- of St. Lazarus, 207-8

- Templars, 206-7, 248

Knolles, Robert, 8o

Lambourn, 162

\section{Lancaster-}

St. Leonard, $72,144,146,261$

Dukes of, 80, 82, 150, $v$. John of Gaunt

Lanfranc, $5^{\circ}, 71,106,143,155,250$, 257

Langland, 29, 32, 25 I-2

Launceston, 242, 26I

Lazar, 49, 251-2, v. Leper

Lazarus, St., 66, 207-8, v. Dedications

- the beggar, 49, 51, 65, 251-2

Lechlade, $5_{52}^{2}, 25^{\circ}$

Ledbury, 5, 197

Legislationecclesiastical, $5^{\mathrm{I}}, 5^{2}, 5^{6}, 5^{8-9}$ local, $4 \mathrm{I}-3,53,55,132,148$, 186 national, $3^{8}, 46,52,5^{6-8}$

Leicester, I 79, 198, 254, 264

St. Mary, Trinity, 80, 116,124 , I64, 169, 190, 204, 227, 246

Wigston's hosp., 116, I86, 26 I Parliament of, $v$. Parliament

Leland, John, Itinerary of, $2 \mathrm{n}$,, I 1, 19, 22-3,64, 74, 78, 85, 1 I I, II $5,116,122,156,224,225,247$, $255,259,(263), 269$

Lenton, 187,257

Leper-houses, ch. iv, i $17-9$, passim

Lepers, 4 , ch. iv, ch. v, izo et $s q$., I 43-9, I67-70, I 72, I 73, г75-7, I 79-80, 184, 209-10, 262, etc., $273^{-6}$ charity to, 37 , ch. v, ch. vi, 209-10

examination of, $43,59-63$

expulsion of, $\mathbf{5}^{2}$ et $s q$., ch. vii, 186 illustrations of, $47,59,64,68$, 177,180

laws, 52 et sq., v. Legislation married, 58, 102, 103, 134-5, $147-8,275$

miraculous cures, $64,97-8$

named, $36,37, \mathrm{ch} . \mathrm{v}, 74, \mathrm{ch}$. vii,

I34, I4 I, 148, 201

services for, 67, 159-60, 199-201,

$203,273^{-6}$

Leprosy, supra-

contagion, $5^{1-2}, 98,{ }^{1} 3^{6}, 275^{-6}$

decline of, 28, 34, 36, 42-7, 226

extent, $35^{-6}$

Lewes, 37, I 12,233

Lichfield-

St. John, 28, 81, I 24, I62

Bishop of, 28, 81, 162

Lincoln, $3^{8}$

Holy Innocents, lepers, 37, 39, 45, 5I, 71, 100-2, 130, 145-7, 179, 180, 187, 203, 208, 247

St. Giles, 24, 163

St. Katherine, 26, 205

St. Sepulchre, 26, 205

Bishops of, 58, 60, 71 , 187, 202, v. Hugh, St., Robert Grussetête

Cathedral, $16_{3}, 187-8$

Jews of, 21, 99

Lingerscroft, Creak, 183,205

London, 6, 12-14, 31, 32, 43, 53, I 48, 205

Bedlam, v. St. Mary of Bethlehem

Domus Conversorum, 19-23, $73,79,99-100,107,247$

Elsyng Spital, 24, 82, I5o, 206, 247

Papey, 25, $25^{8}$ 
Queen's hosp., 180

St. Anthony, 208-9, 257-8

St. Bartholomew, ch. i passim, $31,76,77,82,85,86,92$ et sq., 98, 106-7, 114, 122, 149, 156, I 80-2, $185,205-6,236-40,248$, 253

St. Giles, Holborn, 38, 42, 45, $71,73,107,145,148,179,208$, 262, 270

St. James, $v$. Westminster

St. Katharine-by-the Tower, 25, 27. 72, 79, 152, 260

St. Mary of Bethlehem, 32-4, I 86, 2 10, 238-9, 247

St. Mary without Bishopsgate, $5,8,78,{ }^{6} 6,(205), 236-7$, 247

St. Mary of Roncevall, 209, 247

St. Paul's almshouse, $16,25^{6}$

St. Thomas of Acon, 207,248 , 266, 268

St. Thomas, v' Southwark

Savoy, 12, 80, 88, 12I-2, 150, $173,233,240$

Whittington's almshouse, 82, 175

Bishops of, $37,38,77$, I 26.141 , $144,160,240$

Cathedral, St. Paul's, 16, 94, 256 ; Dean of, 141

Jews, v. Domus Conversorum

Lepers in or near, $42-3,45,47$, $53,55,62,138,148,179,186$, v. St. Giles (supra), Hackney, Holloway, Knightsbridge, Mile End, Westminster

Lord Mayor, citizens, 6, 34, $4^{\mathrm{I}-2,52}, 53,138,23^{8}$

Long Stow, 78

Louis, St., 73, v. Dedications

Ludlow, i8, 120

Lunatics, 4, ch. iii, 90, 219. 253
Lutterworth, 225

Lydd, 45, 55

Lyme Regis, 1 19, 246

Lynn, lepers of St. Mary M., I6, $77,134,136,170$

Madmen, $\%$. Insane

Maiden Bradley, 74, 147, 179, 181, 182, 205, 254

Maison Dieu, 29, 72, 244, etc.

Maldon, 42, 168, 179

Mallardry, 51, 53, 100, 192

Manual (Sarum), 175, 273

Margaret of Scotland, St., 71, 260

Marlborough, I7 1-2, 235-6

Master (Warden, etc.), $21,27,78$, 110,116 , ch. ix, ch. $x, 161,164$, 174, 182, 196, 198, 203, 204, 248, ch. xiv.

Matilda of Boulogne, 72

- the Empress, 72, 170

- v. Maud

Matthew Paris, 20-21, 23, 86, 107, I 31, 264-5

Maud, Queen, 50, 71, 86, 107, 179

Maundy Thursday, 73, 170

Medical writers -

Bartholomew, 43, 61, 65

Gordon, 6i

Guy de Chauliac, 61, 67 John of Gaddesden, 6o, 6r John Mirfield, 149

Medicine, $64,65,149-50,238$

"Meselle," 48, 57, 69, 105, v. Leper Mile End, 46-7

Miracles of healing, 3, 64-5, 92 et sq., $97,98,102,267-8$

Monasteries, 3, 11, 41, 50, 57, 74, 75, 78, 97, 122, 1 31,204 et sq., $21_{5}-6,227-8,232,233,234,256$, $266, v$. Ablot, Alien Houses, Prior 
Newark, 5o, 63, 179

Newbury-

St. Bartholomew, 72, 183

St. Mary M., 147

Newcastle-upon Tyne, 19

St. Katherine, (83), 1 I0-I

St. Mary B. V., 164, 206

St. Mary M., lepers, $44,4^{6}$

Mayor of, 44,83

Newport (Essex), I 79, I 83,247

- (Isle of Wight), $25^{8}$

-- Pagnell, 181, 254

Newstead, 206

Newton Bushell, 46

- Garth (Holderness), 75, I83, 219, 221, v. Hedon

Nicholas of Farnham, 16, 123, 264-5

Norman period, 3, 37, Io9, 123, 199

Northallerton-

almshouse, I I

St. James, I6, I 10, 153, 167, 233, 253

Northampton, I79, I 8 I

St. John, 16, 77, 116, 124, 203, 25 I, 254

St. Leonard, 203, 261

Norwich, 78, 180, 255, 256, 258

St. Giles, 24, 27, 77, 85, I 14 , I $20,127,156,164,170,18 \mathrm{r}$, $182,233,240,26 \mathrm{r}, 262$

St. Paul, 203, 256

St. Saviour, $(78), 245$

Bishops of, 77,85 , 104, 267

lepers, 55, 103, 104

Nottingham-

Plumptre's almshouse, 188,203 , 246

St. Jolın, 16, I26, I28, I 33, เ 37 , $143,153,198$

St. Leonard, 26 $\mathrm{r}$

St. Sepulchre, 249

Nurses, $153-4, v$. Sisters, Women
Oakham, 124, 129, 26I

Offices, $z$. Services

Order of-

Holy Sepulchre, 205

Holy Trinity, Maturin, 210-I I

Mendicant, 209-I I

St. Anthony, 208-9, 257-8

St. Augustine, 152, 205-6, $25^{8}$

St. Benedict, 174,206

St. Gilbert, 26, 205

St. John of Jerusalem, 206-7, 249-50

St. Lazarus, $207-8,25$ I

St. Mary of Bethlehem, 2 ro

St. William, 209

The Temple, 206-7, 248

Orphans, 26, 90, 100, 239

Ospringe, 73, 99, 192, 196, 213, 219

Oswald, St., 7o, v. Dedications

Oxford, 6r, 108, 155, 179, 222, 256

Donus Conversorum, 22, 73, 99

St. Bartholomew, 38, 39, 7 , I $8,123,133,143,145,146,191$, $242,25^{2-3}$

St. John, I, 5, 73, (86), 107, II I, I 27, I 52, 155, 168, I 7 I, 202, 2 เ $-4,219$

Colleges, 24, 8I, I I I, 127, 14950, 19I, 226

Pardoner, I53, I 89

Parliament, 29, 38, 196, 214, 216 , $22 \mathrm{I}, 225, v$ : Statutes

of Leicester, 8, I5, 31, 34, 70, I $78,194,2$ เ2, 228, 244

Patronage, 21 2-7, v. Founders-

Cathedral, I5-6, 216, 256, 264

Crown, 7 I, 130, (146), 202, 216 , $217,23^{2-3}, 261$

Episcopal, 15-6, 179, 183, 216, 233

Town, I 5-1 7, 73, I30, I6 $3,172-3$, $235-40$ 
Penalties, 54, 55, $13^{8}$ et sq., 16r, 163

Pestilence, $v$. Diseases

Peter, Bishop of Winchester, 76,86 Chaplain, 77

Mayor of Winchester, 62

Peterborough, 50, 63, 205, 266 lepers, 50,180

Philip, Bishop of Durham, 16, 253

Philippa, Queen, 217

Physicians (leech, surgeon), 4, 59$67,149-50,218,230,237,265$, v. Medical writers

Pilgrim, ch. i, 65, 71, 78, 167, 1902, 205, 207, 249, 265

poem called, 5 sign, 265

Pilgrimage, ch. i, 31, 190 et sq., 197, 203, 249

Bury St. Edmunds, 6, 7

Canterbury, 1, 4, 7, 10, 11, 64$5,96,98,19 \mathrm{I}-3,265,268$

Compostella, 7, 253

Finchale, 96-7

Glastonbury, 9-10

Holy Land, 4, 7, 36, 104, $25^{\circ}$

Rome, I, 3, 7, 8

Walsingham, 5,7

Pipe Rolls, 48, I 78-80

Plumptre, John, 188, (203)

Plymouth, 146

Pole, Alice, 8o, 85, (90), 16I

Michael, 8o, 246, 269

William, 80, $16 \mathrm{I}$

Pontefract-

Knolles' hospital, 27, 80

St. Nicholas, 2n., 150, 170,175 , $217,221,234$

Pope, $7,58,59,87,146$, I88, ch. xiv, 221, 260

Portsmouth-

God's House, 104, II 3-4, 123 , I 25, 199, 22 I, 233, 269

[St. Mary M.], 109

23
Potyn, Symond, 137, 160

Poverty, 14, 29, 40, 239, v. Beggars, begging

Prayers for benefactors, 29, 70, 82, $86,88,131$, I 60, I 6 I -2

Preston, I50

Priests (chaplains, etc.) -

hospital staff, 19, I15, ch. $\mathrm{x}, 174-5,21 \mathrm{I}, 224, v$. Clergy, Master

parochial clergy, I7, 58-6o, 67, 78, го3, 1 3о, 137, 187-8, 197-8, 204,2 I I, 273-6

leprous, 58-9, 9r, Io3, $25^{6}$

sick and poor, 23-5, 32, 156 , $213-4,219-20$

Prior, 76, I 30, I 54, I99, 204, 205, $215-6,221,254$

Proctor, 46-7, 96, I 45, 152-3, 186, I87, I 89

Puckeshall, 99

Racheness, 183

Rahere, 76, 77, 85, 86, 95, 106, 185 , (248), 253

Ranulf Flambard, 16,75

Reading-

St. John, 25, 128 , (205), 226

[St. Mary M.], lepers, 136, 139, I46, 176

Elias, monk of, 64-5

Reformation of hospitals, 34, I94-5, $212,221,222,226,229,23^{6-9}, v$. Visitation

Reginald of Durham, 52, 6o, 96-7 Relics, 190-3, 255, 256, 260, 263 , 264

of Holy Cross, 95, 190, 210 , 248-9

of St. Bartholomew, 93, I91, 253

Richard, St., I62, 264

- I, 36, 72, 76, 207 


\section{MEDI EVAL HOSPITALS OF ENGLAND}

Richard II, 42, 79, 99, 104, 210 , 214,267

- Orenge, 102-3

Richmond, 179

Ripon-

St. Anne, I 15, I65, 26r

St. John B., I 24

St. Mary M., 5, 41, I24, I65

Robert Grossetête, 99, I 26

- de Meulan, 83

— de Stichill, 16

Roche, I04

Rochester, I53 $\mathbf{n}$.

St. Bartholomew, 32, 37, 39, 7 I, 123, 1 24, I44, (179), 196, (199), $25^{2-3}, 271$

St. Katherine, 17, 39, 137, 160

St. Nicholas, 39, I02

Bishops of, 7I, 76, 87, 255

infirm, lepers, 39, 7I, 102, I79, 192

Roger of Hoveden, 37

- Earl of Winchester, 84

Rome, I, 3, 7, 8, 86, 188, 22 1, 245, $253,256,257, v$. Council, Pope

Romney, 45 ; leper-hospital, I48, I $88,226,267$

Romsey, I87

Royston-

SS. John and James, 253

St. Nicholas, 39, 183,257

Rule of religion, $126,13 \mathrm{I}, 220, v$. Orders

of St. Augustine, 152, 174, 2056,258

of St. Benedict, 1 74, 206

Rye, I 7, 209

Sacraments, 143-4, 198, 201, 203, 274-5

St. Albans, 6

St. Julian, lepers, 40, 68, I17, $131,134,136,168,175,176$, I 79, 2 I5, 259
St. Mary, 215

Abbot of, 40, 126, I31, 214-5

St. Neot (Cornwall), 58-9

Salisbury-

Holy Trinity, 8, 26, 33, 89, $165-$ 6,245

St. Nicholas, 5, I6, I I3, I14, 124, 129

Bishop of, $16,86,114,126,262$ lepers, i $8 \mathrm{I}$

Saltwood, 179

Sampson, Abbot, 75

Sandon (Surrey), 206, 245

Sandwich, 17

St. Bartholomew, 19, 85, 123 , 124, 129, 160, 163, 168, 169, 171

St. John, II-12, I55, (I57), 163, 168, $172-3,185$

St. Thomas, 83

lepers, 44

Sarum, Use of, 3, 273

Saxon period, $2-3,37,63-4,70-1$

Scarborough, 16, 37, 91

Schools, 22-3, 26-8, 151, 226

Scotland-

lepers in, $5^{6}$

war with, 41, 99, 101, 109, 218

Seaford, 253

Seals, 18, 47, 93, 103, 107, 108, 147, I52, 178, I80, 205, 208, Part II passim

Seamen, 9, 19, 88-9

Sedgefield, 96

Services, $67,140,143-4,151$, ch. $x i$ of admission, I 28-9, 1 $31-2$

at seclusion, 104, 1 34, 1 36, 273-6 at expulsion, I $14 \mathrm{I}$

Seven Works of Mercy, 88, 90, 237 Sherborne (Dorset)-

St. John, I I 5, 166, 224, 250, 254

St. Thomas, 255

Sherburn (Durham), 44, 48, 75, rog, I17, I1 $8,119,123,124,136,139$, 
145, 147, ch. xi, ch. xii, 202, 233 , $242-3,252$

Shoreham, 253

Shrewsbury-

St. Chad, 201, (204), 263

St. George, 259

St. Giles, lepers, 179, 184, 187, 270

Shrines, v. Pilgrimage, Relics

Simon Fitz-Mary, 247

Sisters, 99, 101, 136, 142, 146, 147, $152-6,168-9,233, v$. Women

Skirbeck, 207

Smyth, Bishop, 28, 81, I62

Soldiers, 8, 9, I3, 99

Southampton-

God's House, St. Julian, I I, 78 , I 25, 168, 178, 206, 22 1, 259

St. Mary M., lepers, 16, 180, 184

Southwark, St. Thomas, 22, 82, I $54,156,206,236-40,266,268$

Sparham (Norfolk), 60

Spital-on-the-Street, 264

Spondon, 200, 208

Springs, Healing, 31, 63-4

Stafford-

St. John, Io8

[St. Sepulchre, Retford], 40-I

Staindrop, 25

Stamford-

Bede-house, 29, 83,90, II I, i I 5 , I 24, 165-6, 186, 269

SS. John and Thomas, 5, (87), 217,266

St. Sepulchre, 249

Statutes, 8, 194-6, 212, 214, 225, 227, 234, v. Legislation, Parliament, Vagrancy

of hospitals, 7, 34, 38, 77, ${ }^{3} 3^{2}$ et sq., 143, 147, 151, 154, I $_{57}$, 217,218 , etc.

Stephen, St., I91, v. Dedications

- King, 57, 72, 75, 206, 26I
Stephen, Archdeacon, 2 I I

Stoke-upon-Trent, 225, 262

Stourbridge, 123, 179, 182, 248

Stow, John, 69, 233, 239, 247

Stratford-on-Avon, 24, 235, 249

- Stony, I8r

Strood, 4, 72, 76, 206

Stubbes, Philip, $3^{\circ}$

Stydd by Ribchester, 207

Sudbury, 42, I30, 242

Supplication of Poore Commons, I4, $23 \mathrm{I}$

Swinestre, $\mathrm{I} 8_{3}$

Tamworth, 123

Tandridge, 205

Taunton, 235

St. Margaret, Spital, (?98), I 2 I, 245-6

monk of, 97 ; prior of, 52,98

Tavistock, 259, 262

Testament of Cresseid, 66, I05, I 35, I 77

Thame, 19, 259

Thanington, St. James (Canterbury), 146, 147, 154, 192, 198

Thetford-

St. John, $183,25^{\circ}$

St. Mary, 5, 259

Thomas the Martyr, St., 4, I 89 , $244,249, \approx$. Dedications

Jubilee of, 7 , Io miracles of, $65,96,98,267-8$

relics of, $64,192-3,265$

shrine of, $4,31,266-8, v$. Pilgrimage

sign of pilgrimage, 265

Thornton, Roger, 83 , I I I

Thrapston, I68

Thurlow, 209

Tiverton, 124

Tong (Salop), 204

Torrington (Taddiport), 124 


\section{MEDI $Æ V A L$ HOSPITALS OF ENGLAND}

Towcester, 181

Tweedmouth, 270

Vagrancy, 6-7, 10, 13, 14, 28, 171, 227, 239

Visitation of hospitals (inquisitions), $33,41,132,138,150,173$, $174,195,202,218$

Volt aire, quoted, 36

Wallingford, 16, 57

Walsingham, 5, 7, 103

Walsoken, 245

Walter de Lucy, $5^{\circ}$

- de Suffield, 77, 85 (164, 182)

- Archdeacon, 77

- Vicar, 78

Warden, v. Master

Warwick, St. John, 246; St. Michael, 225

IVayfarers, ch. i, 70, 110, 167, 171, 206, 207, 211, v. Pilgrim, Vagrancy

Well, lepers', 63, 104, 119, 276, v. Springs, Healing

Wells, ${ }_{15}^{8}$

St. Saviour, Bubwith's, $17,8 \mathrm{r}$, $114,115,124,151$

Bishops of, $76,8 \mathrm{r}$

Westminster, 6, 53, 79, 122

St. James, 43, 73, 147, 150, 182, $188-9,233$

Council of, $5^{2}, 7^{2}$

Statute of, 7

West Somerton, 76, 215

Whitby, 75, 92, 246, 264

Whittington, Richard, 82-3, 175

Whittlesea, 83

William, Dean, 77

- Earl of Albemarle, 75

- Earl of Salisbury, 181

- of Canterbury, 64-5

- de Monte, $5^{1-2}$

- of Wykeham, 8I, I5I
Wills, of benefactors, $v$. Bequests, of inmates, 133,134

Wilton, 17

St. Giles, 73, 99, 125 (181), 262

St. John, 124, 181, 205

Wimborne, I 24, 166

Winchcomb, 225

Winchelsea, 17

Winchester, 3, 263

St. Cross, 75, 81, 86, 110, 121 , $122,125,151,166,169,170$, I 7 I, 175, 207, 216, 221, 240, 248

St. John, 81, 110, 124, 178, 187, 235, 241

St. Mary M., lepers, 118, 119, 134, 146, 168, 179, 241, $251 \mathrm{n}$.

Bishop of, $187,206,216,221, v$. Beaufort; Henry; Peter ; William of Wykeham

Earl of, 84

Mayor of, 62, 81

Windeham, 24, 264

Windsor, $180,25^{8}$

lepers of, 179,226

Wolsey, Cardinal, 229, 232

Women-

inmates, $8-9,12,13,25,26,33$, $74,82-3,90$, ch. vii, 132, 139, I46, 147,176

on staff, '1 $39,145,147,152$ et sq., 168-9, 173,174

Woodstock, 73, 147

Worcester-

St. Oswald, 2, 48, 70, 1 22, 199, 263

St. Wulstan, 2, 24, 70-1, 98, I I0, 172

Bishop of, 127, 202, supra

Wulstan, St., 2, 24, 70-1, 86, 98, v. Dedications

IVycomb, High [St. John], I23, $18_{3}$ [St. Margaret], 183

Wynard, William, 161 


\section{INDEX}

Yarmouth, 186, 190

Yeovil, 259

York, 2, 3, 12, 72, 8o

Holy Trinity, 245

Monkbridge, 134

St. Leonard or St. Peter, 2, 26, 70, 72, 96, I10, I52, I 54-6, 162, 1 70, $172,174,178,180-1,184-5$, 199, 204, 214, 216, 222-3, 232, $242,256,261$

St. Loy, 262
St. Mary, Bootham, 24

St. Nicholas, lepers, 28, 39, 1 1 7, 132, 138, 145-6, (170), $174,203,218,232$

St. Peter, v. supra

St. Thomas, 235

Archbishop of, 41, 126, 130,153 , I83, 197

Dean of, 24, 26, 216

Minster, 2, 26, 216 
PRINTED BY

WILLIAM BRENDON AND SON, LTD.

PLYMOUTH 



\section{THE ANTIQUARY'S BOOKS}

Demy 8vo. 7s. 6d. net each.

"The 'Antiquary's Books' makes an excellent commencement in the first volume. It is in outward respects a shapely demy octavo in scarlet cloth, well printed, illustrated with thirty or forty plates."-Pall Mall Gazette.

"The publishers have been fortunate in securing the services of the Rev. Dr. Cox, one of the most learned and painstaking of antiquaries, as general editor of the series. Antiquarian books too often are as dry as matchwood, but there is no reason why they should be so, and the present volume abundantly testifies to this."-Birmingham Post.

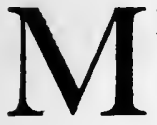

ESSRS. METHUEN are publishing a series of volumes dealing with various branches of English Antiquities.

It is confidently hoped that these books will prove to be comprehensive and popular, as well as accurate and scholarly; so that they may be of service to the general reader, and at the same time helpful and trustworthy books of reference to the antiquary or student. The writers will make every endeavour to avail themselves of the most recent research.

The series is edited by the well-known antiquary, J. Charles Cox, LL.D., F.S.A., Member of the Royal Archæological Institute, Corresponding Member of the British Archæological Association, and Council Member of the Canterbury and York Record Society, and of the British Numismatic Society. Each book is entrusted to an expert in the selected subject, and the publishers are fortunate in having secured the services of distinguished writers.

A special feature is made of the illustrations, which will vary, according to the requirements of the subjects, from 50 to 150 . Some are in colour. The type is large and clear, the length of each volume is about 320 pages.

ENGLISH MONASTIC LIFE

Third Edition By ABBOT GASQUET, O.S.B., D.D., Рн.D., D.Litr. With 42 Illustrations, 5 Maps, and 3 Plans.

"This delightful book, so full of quaint learning, is like a painted window, through which, if one looks, one may see the old world of the Middle Ages as that world must have shown itself to a monk."-Daily News.

"Curiously interesting and highly instructive." - Puncb.

"An extremely interesting summary of the laws which governed the religious and domestic life in the great monasteries."- Yorkshire Post.

REMAINS OF THE PREHISTORIC AGE IN ENGLAND By BERTRAM C. A. WINDLE, Sc.D., F.R.S., F.S.A. With 94 Illustrations by Edith Mary Windle

"It gives a tabulated list of such remains ; divided into counties, and subdivided into earthworks, barrows, camps, dykes, megalithic monuments, and so on, with detailed explanations; to these are added a list of museums in which specimens of prehistoric remains are preserved. Confining himself almost entirely to accepted facts in the science of archæology, the Professor devotes no more space to what he describes as theory spinning about the dates of various epochs than is necessary to present the subject with completeness, especially on its geological side. Mrs. Windle's excellent illustrations throughout the volume add greatly to its value." - rorkshirs Post. 


\section{THE OLD SERVICE-BOOKS OF THE ENGLISH}

CHURCH. By CHRISTOPHER WORDSWORTH, M.A., AND HENRY LITTLEHALES

With 38 Plates, 4 of which are in Colour

"It is infinitely more than 2 fascinating book on the treasures of past ages. It is the history of the making of a great and living book. The illustrations are most beautifully reproduced." -St. James's Gazette.

"Scholars will find that its pages are thoroughly trustworthy. The introduction yields a great deal of unusual knowledge pertaining to the subject. The illustrations are exceptionally numerous and creditable in execution for a book of moderate price, and are reproductions in facsimile from English originals. All save two are, we believe, given here for the first time."-Atbenaum.

\section{CELTIC ART IN PAGAN AND CHRISTIAN TIMES} By J. ROMILLY ALLEN, F.S.A.

\section{With 44 Plates and $8 \mathrm{I}$ Illustrations in the text}

"Unquestionably the greatest living authority on the Celtic Archæology of Great Britain and Ireland, he writes as only a master of his subject can. An admirable piece of work." -St. James's Gazette.

"The letterpress and pictures are remarkably good throughout: both author and publishers are to be congratulated on the issue of so attractive and useful a book." - Atbenaum.

\section{SHRINES OF BRITISH SAINTS}

By J. CHARLES WALL

\section{With 28 Plates and 50 Illustrations in the text}

"The present volume may be said to be of a slightly more popular character than that on 'Old Service Books,' but the same wide research and careful compilation of facts have been employed, and the result will be, to the general reader, equally informatory and interesting." - Academy.

"The shrines have for the most part passed away. What they were like may be learned from this volume."-Mancbester Guardian.

"This is a good subject and one that is well handled by Mr. Wall."-Atbenaum.

\section{ARCHÆOLOGY AND FALSE ANTIQUITIES} By ROBERT MUNRO, M.A., M.D., LL.D., F.R.S.E., F.S.A. Scot.

\section{With I 8 Plates, a Plan, and 63 Illustrations in the text}

"The author passes in review the more conspicuous instances of sham antiquities that have come to light since the beginning of the second half of the last century in Europe and in America."-Westminster Gazette.

"He provides us with an account of all the most famous attempts made by sinful men to impede the progress of archæology by producing forged antiquities; and he points out a number of examples of the way in which Nature herself has done the felony, placing beneath the hand of the enthusiastic hunter of remains objects which look as if they belonged to the Stone Age, but which really belonged to the gentleman next door before he threw them away and made them res nullius." -Outlook.

\section{THE MANOR AND MANORIAL RECORDS} By NATHANIEL J. HONE. With 54 Illustrations

"This book fills a hitherto empty niche in the library of popular literature. Hitherto those who desired to obtain some grasp of the origin of manors or of their administration had to consult the somewhat conflicting and often highly technical works. Mr. Hone has wisely decided not to take anything for granted, but to give lucid expositions of everything that concerns manors and manorial records."-Guardian.

"We could linger for a long while over the details given in this delightful volume, and in trying to picture a state of things that has passed away. It should be added that the illustrations are well-chosen and instructive." - Country Life.

"Mr. Hone presents a most interesting subject in a manner alike satisfying to the student and the general reader."-Field. 
By J. HARVEY BLOOM, M.A., Rector of Whitchurch With 93 Illustrations

"The book forms a valuable addition to the scholarly series in which it appears. It is admirably illustrated."-Scotsman.

"A careful and methodical survey of this interesting subject, the necessary illustrations being numerous and well done."-Outlook.

"Presents many aspects of interest, appealing to artists and heraldic students, to lovers of history and of antiquities."-Westminster Gazette.

"Nothing has yet been attempted on so complete a scale, and the treatise will take rank as a standard work on the subject."-Glasgow Herald.

\section{THE ROYAL FORESTS OF ENGLAND}

\section{By J. CHARLES COX, LL.D., F.S.A.}

With 25 Plates and 23 Illustrations in the text

"A vast amount of general information is contained in this most interesting book." Daily Chronicle.

"The subject is treated with remarkable knowledge and minuteness, and a great addition to the book are the remarkable illustrations."-Evening Standard.

"The volume is a storehouse of learning. The harvest of original research. Nothing like it has been published before." - Liverpool Post.

THE BELLS OF ENGLAND

Second Edition By CANON J. J. RAVEN, D.D., F.S.A., of Emmanuel College, Cambridge. With 60 Illustrations

"The history of English bells, of their founding and hanging, of their inscriptions and dedications, of their peals and chimes and carillons, of bell legends, of bell poetry and bell law, is told with a vast amount of detailed information, curious and quaint." - Tribune. "The illustrations, as usual in this series, are of great interest."-Country Life.

\section{THE DOMESDAY INQUEST}

By ADOLPHUS BALLARD, B.A., LL.B., Town Clerk of Woodstock. With 27 Illustrations

"In point of scholarship and lucidity of style this volume should take a high place in the literature of the Domesday Survey." - Daily Mail.

[Liverpool Post.

"Replete with information compiled in the most clear and attractive fashion."

"The author holds the balance freely between rival theories."-Birmingham Post.

"Most valuable and interesting."-Liverpool Mercury.

"A brilliant and lucid exposition of the facts."-Standard.

"A vigorous and independent commentary."-Tribune.

PARISH LIFE IN MEDIÆVAL ENGLAND Second Edition By ABBOT GASQUET, O.S.B., D.D., Рн.D., D.Litt. With 39 Illustrations

"A rich mine of well-presented information." - World.

"A captivating subject very ably handled."-Illustrated London Nequs.

"A worthy sequel to the Abbot's scholarly work on monastic life." - Liverpool Post.

"Essentially scholarly in spirit and treatment." -Tribune.

THE BRASSES OF ENGLAND

Second Edition

By HERBERT W. MACKLIN, M.A., St. John's Coll. Cambridge. Fresident of the Monumental Brass Society With 85 Illustrations

"There is no volume which covers the ground so fully as this study."

"Mr. Macklin writes with enviable lucidity."-Standard. Birmingham Post.

"Reveals the value of English brasses as historical documents."-Westminster Gazette.

"The illustrations are plentiful and excellent."-Spectator. 
By J. CHARLES COX, LL.D., F.S.A., \& A.HARVEY,M.B. With I 2 I Illustrations

"A mine of carefully ordered information, for the accuracy of which Dr. Cox's name on the title page is a sufficient guarantee."-Athenaum.

"This new volume fully maintains the high repute of its predecessors. Dr. Cox is one of our ablest ecclesiologists, and he and Mr. Harvey have collected a mass of valuable information of the greatest importance to antiquaries and architects. . . There is a fine index of seventy-five columns, truly a pious work." - The Architectural Review.

"This volume is one of the 'Antiquary's Books' series, and is more than worthy of its distinguished association. There has been an unsparing expenditure of time and labour upon it." -Spectator.

FOLK-LORE AS AN HISTORICAL SCIENCE

By GEORGE LAURENCE GOMME. Clerk to the London County Council

With 28 Illustrations

"No one will read Mr. Gomme's thoughtful treatise without being the better able to understand the significance of popular tales and customs." - Scotsman.

"A learned and most interesting volume. We can imagine no more fascinating subject for study."-Daily Mail.

"An excellent piece of work."-Dundee Advertiser.

"All will find much that stimulates thought and adds to the inherent attractiveness of tradition."-Athenaum.

ENGLISH COSTUME

By GEORGE CLINCH, F.G.S.

With many Illustrations

In this important work an attempt is made to trace the origin and development of all the chief phases of English Costume from prehistoric times down to the end of the eighteenth century. Illuminated MSS, sepulchral effigies, monumental brasses, ancient statuary, medirval wills, inventories, and the contents of the chief museums, are the authorities upon, which the author has relied in his attempts to get at the actual facts about this interesting subject. The result is a volume containing a large amount of original and valuable information. The book is primarily intended for the use of the antiquary and the artist, but the accurate and precise information which it gives, and the abundant illustrations and diagrams with which the text is interspersed, can hardly fail to make "English Costume" a valuable hand-book for the promoters of historical pageants and theatrical representations.

These Volumes will follow

THE GILDS AND COMPANIES OF LONDON By GEORGE UNWIN

HERALDRY. BY THOMAS SHEPARD

THE ROMAN OCCUPATION. By JOHN WARD, F.S.A. CASTLES AND WALLED TOWNS OF ENGLAND By ALFRED HARVEY, M.B.

SCHOOLS IN MEDIEVAL ENGLAND

By A. F. LEACH

THE MEDIÆVAL HOSPITALS OF ENGLAND By MISS ROTHA M. CLAY

OLD ENGLISH INSTRUMENTS OF MUSIC By F. W. GALPIN, M.A., F.L.S.

METHUEN \& CO., 36 ESSEX STREET, LONDON, W.C. 


\section{A CATALOGUE OF BOOKS}

\section{PUBLISHED BY METHUEN}

\section{AND COMPANY: LONDON}

\section{ESSEX STREET \\ W.C.}

\section{O N T E N T S}

\begin{tabular}{|c|c|c|c|}
\hline & & & AGE \\
\hline eneral Literature, . & . & - & $2-24$ \\
\hline Ancient Cities, & . & • & 24 \\
\hline Antiquary's Books, & . & . & 25 \\
\hline Arden Shakes peare, & . & . & 25 \\
\hline Beginner's Books, . & . & - & 26 \\
\hline Business Books, . & . & . & 26 \\
\hline Byzantine Texts, . & - & - & 26 \\
\hline Churchman's Bible, & - & - & 26 \\
\hline Churchman's Library, & . & . & 27 \\
\hline Classical Translations, & & . & 27 \\
\hline Classics of Art, & . & . & 27 \\
\hline Commercial Series, & - & - & 27 \\
\hline Connoisseur's Library, & & - & 28 \\
\hline Handbooks of English C & Churc & & \\
\hline History, & . & - & 28 \\
\hline Illustrated Pocket Libra & aryo & & \\
\hline Plain and Coloured B & 3ooks & & 28 \\
\hline Junior Examination Se & eries, & & 29 \\
\hline Junior School-Books, & . & - & 29 \\
\hline Leaders of Religion, & & - & 30 \\
\hline Library of Devotion, & & - & 30 \\
\hline Little Books on Art, & . & . & $3^{\mathbf{x}}$ \\
\hline Little Galleries, & - & - & $3 \mathbf{I}$ \\
\hline Little Guides, . & . & - & 32 \\
\hline
\end{tabular}

Little Library, $\quad 32$ Little Quarto Shakespeare, 33 Miniature Library, . . 33 New Historical Series, . 34 New Library of Medicine, . 34 New Library of Music, . . 34 Oxford Biographies, . . 34 Romantic History, . . 34 School Examination Series, 35 School Histories, . . . 35 Simplified French Texts, - 35 Simplified German Texts, . 35 Six Ages of European History, ${ }_{3}^{6}$ Standard Library, . . . 36 Textbooks of Science, . . $3^{6}$ Textbooks of Technology, . 37 Handbooks of Theology, . 37 Westminster Commentaries, $\quad 37$

Fiction, - . . - 37-45

Books for Boys and Girls, 45 Novels of Alexandre Dumas, 46 Methuen's Sixpenny Books, 46

SEPTEMBER I 909 


\section{A CATALOGUE OF}

\section{MESSRS. METHUEN'S}

\section{P U B L I C A T I O N S}

In this Catalogue the order is according to authors. An asterisk denotes that the book is in the press.

Colonial Editions are published of all Messrs. Methuen's Novels issued at a price above $2 s$. $6 \boldsymbol{d}$., and similar editions are published of some works of General Literature. Colonial editions are only for circulation in the British Colonies and India.

All books marked net are not subject to discount, and cannot be bought at less than the published price. Books not marked net are subject to the discount which the bookseller allows.

Messrs. METHuEn's books are kept in stock by all good booksellers. If there is any difficulty in seeing copies, Messrs. Methuen will be very glad to have early information, and specimen copies of any books will be sent on receipt of the published price plus postage for net books, and of the pubIished price for ordinary books. I.P.L. represents Illustrated Pocket Library.

\section{Part I.-General Literature}

Abraham (George D.). THE COMPLETE MOUNTAINEER. With 75 Illustrations. Second Edition. Demy 8vo. 15 s. net.

Acatos (M. J.). See Junior School Books. Addleshaw (Percy). SIR PHILIP SIDNEY. With 12 Illustrations. Demy 8vo. ros. $6 d$. net.

Adeney (W. F.), M.A. See Bennett (W. H.) Ady (Cecilia Mi.). A HISTORY OF MILAN UNDER THE SFORZA. With 20 Illustratious and a Map. Demy 8vo. ros. $6 d$. net.

Aeschylus. See Classical Translations.

Ainsworth (W. Harrison). See I.P.L.

Aldis (Janet). THE QUEEN OF LETTER WRITERS, MARQUISE JE Sévigne, Dame de Bourbilly, $1626-96$ With 18 Illustrations. Second Edition. Demy 8vo. I2s. 6 d. net.

Alexander (William), D.D. Archbishop of Armagh. THOUGHTS AND COUNSELS OF MANY YEARS. Demy $x 6 m 0.2 s$. $6 d$.

Alken (Henry). See I.P.L.

Allen (Charles c.). See Textbooks of Technology.

Allen (L. Jessie). See Little Books on Art.

Allen (J. Romilly), F.S.A. See Antiquary's Books.

Almack (E.), F.S.A. See Little Books on Art.

Amherst (Lady). A SKETCH OF EGYPTIAN HISTORY FROM THE EARLIEST TIMES TO THE PRESENT DAY. With many Illustrations and Maps. $A$ New and Cheaper Issue Demy 8vo. 7s. 6d. net.

Anderson (F. M.). THE STORY OF THE BRITISH EMPIRE FOR CHILDREN. With 42 Illustrations. Cr. 8vo. 2s.
Anderson (J. G.), B.A., NOUVELLE GRAMMAIRE FRANÇÁISE, A L'USAGE DES ECOLRS ANGLAISES. Crown $8 v o .2 s$.

EXERCICES DE GRAMMAIRE FRANCAISE. Cr. 8vo. Is. $6 d$.

Andrewes (Bishop). PRECES PRIVATAE. Translated and edited, with Notes, by F. E. BrightMan. M.A., of Pusey House, Oxford. Cr. 8vo. 6s. See also Library of Devotion.

'Anglo-Australian.' AFTER-GLOW MEMORIES. Cr. 8vo. 6s.

Anon. THE BUDGET, THE LAND AND THE PEOPLE. Second Edition. Crown 8vo. $6 d$. net.

HEALTH, WEALTH, AND WISDOM. Crown 8\%o. is. net.

THE WESTMINSTER - PROBLEMS BOOK. Prose and Verse. Compiled from The Saturday Westminster Gazette Com. petitions, 1904-roo7. Cr. 8vo. 3s. 6d. net.

VENICE AND HER TREASURES. With many Illustrations. Round corners. Fcap. 8vo. 5s. net.

Aristotle. THE ETHICS OF. Edited, with an Introduction and Notes by JoHs Burnet, M.A., Cheaperissue. Demy 8vo. ros. 6 d. net.

Asman (H. N.), M.A., I.D. See Junior School Books.

Atkins (H. G.). See Oxford Biographies.

Atkinson (C. M.). JEREMY BENTHAM. Demy 8vo. 5s. net.

Atkinson (C. T.), M.A., Fellow of Exeter College, Oxford, sometime Demy of Magdalen College. A HISTORY OF GERMANY, from $\times 713$ to $\times 8 \times 5$. With 35 Maps and Plans Demy 8vo. I5s. net. 


\section{General Literature}

Atkinson (T. D.). ENGLISH ARCHITECTURE. With 196 Illustrations. Feap. 8vo. 35. 6d, net.

A GLOSSARY OF TERMS USED IN ENGLISH ARCHITECTURE. With 265 Illustrations. Second Edition. Fcap. 800. 3s. 6d. net.

Atteridge (A. H.). NAPOLEON'S BROT HER S. With 24 Illustrations. Demy 800. I8s. net.

Auden (T.), M.A., F.S.A. See Ancient Cities.

Aurelius (Marcus). WORDS OF THE ANCIENT WISE. Thoughts from Epictetus and Marcus Aurelius. Edited by W. H. D. Rouse, M.A., Litt. D. Fcep. 8vo. 3s. $6 d$. net.

See also Standard Library.

Austen (Jane). See Standard Library, Little Library and Mitton (G. E.).

Aves (Ernest). CO.OPERATIVE INDUSTRY, Crown 8vo, 5s. net.

Bacon (Francis). See Standard Library and Little Library.

Bagot (Richard). THE LAKES OF NORTHERN ITALY. With 37 Illustrations and a Map. Fcap. 8vo. 5s. net.

Bailey (J. C.), M.A. See Cowper (W.).

*Bain (R. Nisbet). THE LAST KING OF POLAND AND HIS CONTEMPORARIES. With I6 Illustrations. Demy $8 v 0$. ros. $6 d$. net.

Baker (W. G.), M.A. See Junior Examination Series.

Baker (Julian L.), F.I.C., F.C.S. See Books on Business.

Balfour (Graham). THE L I F E O F ROBERT LOUIS STEVENSON. With a Portrait. Fourth Edition in one Volume. Cr. 8vo. Buckram, 6s.

Ballard (A.), B.A., LL.D. See Antiquary's Books.

Bally (S. E.). See Commercial Series.

Barham (R. H.). See Little Library.

Baring (The Hon. Maurice). WITH THE RUSSIANS IN MANCHURIA. Third Edition. Demy 8vo. 7s. 6d. net.

A YEAR IN RUSSIA. Second Edition. Demy 8vo. Ios. 6d. ret.

RUSSIAN ESSAYS AND STORIES. Second Edition. Cr. 8vo. 5s. net. Also published in a Colonial Edition.

Baring-Gould (S.). THE LIFE OF NAPOLEON BONAPARTE. Withnearly 200 Illustrations, including a Photogravure Frontispiece. Second Edition. Wide Royal 8vo. Ios. 6d. net.

THE TRAGEDY OF THE CASARS: A Study of THE Characters of THE Casars of the Julian and Claudian Houses. With numerous Illustrations from Busts, Gems, Cameos, etc. Sixth Edition. Royal 8vo. Ios. $6 d$. net.

A BOOK OF FA IRY TALES, With numerous Illustrations by A. J. GASKIN.
Second Edition. Cr. 8vo. Buckram. 6s., also Medium 8vo. $6 d$.

OLD ENGLISH FAIRY TALES. With numerous Illustrations by F. D. BEDFORD. Third Edition. Cr. 8vo. Buckram. 6s.

THE.VICAR OF MORWENSTOW. Revised Edition. With a Portrait. Third Edition. Cr. $8 v 0$. 35. $6 d$.

OLD COUNTRY LIFE. With 69 Illustrations. Fifth Edition LargeCrown \&vo. 6s.

A GARLAND OI COUNTRY SONG: English Folk Songs with their Traditional Melodies. Collected and arranged by $S$. BARING-Govld and H. F. ShePPARD. Demy 4 to. 6s.

SONGS OE THE WEST: Folk Songs of Devon and Cornwall. Collected from the Mouths of the People. ByS. BARING-GouLD, M.A., and H. FleETwood Sheppard, M.A. New and Revised Edition, under the musical editorship of CECIL J. Shary. Large Imperial 8vo. 5s. net.

A BOOK OF NURSERY SONGS AND RHYMES. Edited by S. BAR1NG-Gould. Illustrated. Second and Cheaper Edition. Large Cr. 8vo. 2s. 6d. net.

STRANGE SURVIVALS: Some Charters IN THE History OF MAN. Illustrated. Third Edition. Cr. 8vo. 2s. 6rd. net.

YORKSHIRE ODDITIES : INCIDENTS AND. Strange Events. Fifth Edition. Cr. 8vo. 2s. 6d, net.

THE BARING-GOULD SELECTION READER. Arranged by G. H. Rose. Illustrated. Crozen 8zo. is. $6 d$.

THE BARING-GOULD CONTINUOUS READER. Arranged by G. H. Rose. Illustrated. Crown 8vo. 1s. $6 \mathrm{~d}$.

A. BOOK OF CORNWALL. With 33 Illustrations. Second Edition. Cr. 8vo. 6s.

A BOOK OF DARTMOOR. With 60 Illustrations. Second Edition. Cr. 8vo. 6s.

A BOOK OF DEVON. With 35 Illustrations. Thind Edition. Cr. $8 v 0$. $6 s$.

A BOOK OF NORTH WALES. With 49 Illustrations. Cr. 8vo. 6s.

A BOOK OF SOUTH WALES. With 57 Illustrations. Cr. 8vo. 6s.

A BOOK OF BRITTANY. With 69 Illustrations. Second Edition Cr. 8vo. $6 \mathrm{~s}$.

A BOOK OF THE RHINE: From Cleve to Mainz. With 8 Illustrations in Colour by TREvOR HADDEN, and 48 other Illustrations. Second Edition. Cr. 8vo. 6s.

A BOOK OF THE RIVIERA. With 40 Illustrations. Cr. $8 v 0$. $6 s$.

A BOOK OF THE PYRENEES. With 25 Illustrations. $C r .8 v o$. $6 s$.

See also Little Guides.

Barker (Aldred F.). See Textbooks of Technology.

Barker (E.), M.A. (Late) Fellow of Merton College, Oxford. THE POLITICAL THOUGHT OF PLATO AND ARIS. TOTLE. Demy 8vo. Ios. 6d. net.

Barnes (W. E.), D.D. See Churchman's Bible. 
Barnett (Mrs. P. A.). See Little Library. Baron(R. R. N.), M.A. FRENCH PROSE COMPOSITION. Fourth Editiot. $\mathrm{Cr}$. 8vo. 2s. 6d. K'ey, 3s. ret.

See also Junior School Books.

Barron (H. M.), M.A., Walham College, Oxford. TEXTS FOR SERMONS. Wiih a Preface by Canon Scott Holland. Cr. 8vo. 3s. $6 \mathrm{~d}$.

Bartholomew (J. G.), F.R.S.E See Robertson (C. G.).

Bastable (C. F.), LL.D. THE COMMERCE OF NATIONS. Fourth Ed. Cr. 8vo. 2s. $6 d$.

Bastian (H. Charlton), M.A.,M.D., F.R.S. THE EVOLUTION OF LIFE. With Diagrams and many Photomicrographs. Demy 8vo. 7s. 6d. net.

Batson (Mrs. Stephen). A CONCISE HANDBOOK OF GARDEN FLOWERS. Fcap. 8vo. 3s. 6d.

THE SUMER GARDEN OF PLEASURE. With 36 Illustrations in Colour by Osmund Pittman. Wide Demy 8vo. I5s. net.

Bayley (R. Child). THE COMPLETE PHOTOGRAPHER. With over IOo Illustrations. With Note on Direct Colour Process. Third Edition. Demy 8vo. Ios. 6 d. net.

Beard (IV. S.). EASY EXERCISES IN ALGEBRA FOR BEGIN NERS. Cr. 8vo. 1s. 6d. With Answers. 1s. $9 d$.

See also Junior Examination Series and Beginner's Books.

Beckett (Arthur). ITHE SPIRIT OF THE DOWNS : Impressions and Reminiscences of the Sussex Downs. With 20 Illustrations in Colour by Stanley Inchbold. Demy 8vo. Ios. 6d. net.

Beckford (Peter) THOUGHTS ON HUNTING. Edited by J. Отно PAGet, and Illustrated by G. H. JALLAND. Second Edition. Demy 8vo. 6s.

Beckford (William). See Little Library.

Beeching (H. C.), M.A., Canon of Westminster. See Litrary of Devotion.

Beerbohm (Max). A BOOK OF CARICATURES. Imperial 4 to. 21s. net.

Begbie (Harold). MASTER WORKERS. Illustrated. Demy8vo. 75.6 d. net.

Behmen (Jacob). DIALOGUES ON THE SUPERSENSUAL LIFE. Edited by Bernard Holland. Fcap. 8vo. 3s. 6d.

Bell (Mrs. Arthur G.). THE SKIRTS OF THE GREAT CITY. With I6 Illustrations in Colour by Arthur G. Bell, 17 other Illustrations, and a Map. Second Edition. Cr. 8ro. $6 s$.

Belloc (H.) PARIS. With 7 Maps and a Frontispiece in Photogravure. Second Edition, Revised. Cr. 8vo. 6s.

HILLS AND THE SEA. Second Edition. Crown 8vo. 6s.

ON NOTHING AND KINDRED SUBJECTS. Second Edition. Fcap. 8vo. $5 s$. *ON EVERYTHING. Fcap. 8vo. ${ }^{5 s}$. MARIE ANTOINETTE. With 35 Portraits and Illustrations, and 22 Maps. Demy $8 v 0$. iss. net.

THE PYRENEES. With 46 Sketches by the Author, and 22 Maps. Second Edition. Demy 800 . 7s. 6d. net.

Bellot (H. H.L.), M.A. See Jones (L. A. A.).

Bennett (Joseph). FORTY YEARS OF MUSIC, 3865-1905. With 24 Illustrations. Demy 8vo. 16s. net.

Bennett (W. H.), M.A. A PRIMER OF THE BIBLE." Fifth Edition. Cr. $8 v 0$. 2s. 6 d.

Bennett (W. H.) and Adeney (W. F.). A BIBLICAL INTRODUCTION. With a concise Bibliography. Fifth Edition. Cr. 8vo. $75.6 d$.

Benson (Archbishop) GOD'S BOARD. Communion Addresses. Second Edition. Fcap. 8vo. 3s. 6d. net.

Benson (A. C.), M.A. See Oxford Biographies.

Benson (R. M.). THE WAY OF HOLINESS. An Exposition of Psalm cxix. Analytical and Devotional. Cr. 8vo. 5 s.

Bernard (E. R.), M.A., Canon of Salisbury THE ENGLISH SUNDAY: ITS ORIGINS and 1Ts Claitus. Frap. 8vo. Is, $6 d$.

Berry (W. Grinton), M.A. FRANCE SINCE WATERLOO. With I6 Illustrations and Maps. Cr. 8vo. $6 \mathrm{~s}$.

Beruete (A. de). See Classics of Art.

Betham-Edwards (Miss). HOME LIFE IN FRANCE. With 20 Illustrations. Fifth Edition. Crown 8vo. 6s.

Bethune-Baker (J. F.), M.A. See Handbooks of Theology.

Bindley (T. Herbert), B.D. THE OECU. MENICAL DOCUMENTS OF THE FAITH. With Introductions and Notes. Second Edition. Cr. 8vo. 6s. net.

Binns (H. B.) THE LIFE OF WALT WHITMAN. Illustrated. Demy 8vo. ros. $6 d$. net.

Blnyon(Mrs. Laurence). NINETEENTH CENTURY PROSE. Selected and arranged by. Crowts 8vo. $6 s$.

Binyon (Laurence). THE DEATH OF ADAM AND OTHER POEMS. Cr. 8vo. $3^{s .6}$ d. net.

See also Blake (William).

Birch (Walter de Gray), LL.D., F.S.A. See Connoisseur's Library.

Birnstingl (Ethel). See Little Books on Art. Blackmantle (Bernard). See I.P.L.

Blair (Robert). See I.P.L.

Blake (William). THE LETTERS OF WILLIAM BLAKE, TOGETHER WITH LIFE BY Frederick TATHAN. Edited from the Original Manuscripts, with an Introduction and Notes, by $A R C H 1 B A L D G$. B. Russell. With 12 Illustrations. Demy 8vo. 7s. 6d. net.

ILLUSTRATIONS OF THE BOOK OF JOB. With General Introduction by LAURENCE Binyon. Quarto. 21s. net. See also I.P.L., and Little Library. 
Bloom (J. Harvey), M.A. See Antiquary's Books.

Blouet (Henri). See Beginner's Books.

Boardman (T. H.), M.A. See French (W.).

Bode (Wilhelm), Ph.D. Bee Classics of Art.

Bodley (J. E. C.) THE CORONATION OF EDWARD VII. Demy 8vo. 2is. net. By Command of the King.

Body (George) D.D. THE SOUL'S PILGRIMAGE : Devotional Readings from the Published and Unpublished writings of George Body, D.D. Selected and arranged by J. H. BURN, B.D., F.R.S.E. Demy r6mo. 2s. 6d.

Bona (Cardinal). See Library of Devotion.

Bonnor(Mary L.). See Little Books on Art.

Boon (F. C.)., B.A. See Commercial Series.

Borrow (George). See Little Library.

Bos (J. Rltzema). AGRICULTURAL ZOOLOGY. Translated by J. R. AisswORTH DAvis, M.A. With 155 Illustrations. Second Edition. Cr. 8vo. 3s. 6d.

Botting (C. G.), B.A. EA SY GREEK EXERCISES. Cr. 800 . 2s.

See also Junior Examination Series.

Boulting (W.) TASSO AND HIS TIMES. With 24 Illustrations. Demy 8vo. 105. $6 d$. net.

Boulton (E. S.), M.A. GEOMETRY ON MODERN LINES. Cr. 8vo. 2s.

Boulton (WIlliam B.). SIR JOSHUA REYNOLDS, P.R.A. With 49 Illustrations. Second Edition. Demy 8vo. 7s.6d. net.

Bovlil (W. B. Forster) HUNGARY AND THE HUNGARIANS. With I6 Illustrations in Colour by William PASCOE, 12 other Illustrations and a Map. Demy 8vo. 7s. 6d. net.

Bowden (E. M.). THE IMITATION OF BUDDHA : Being Quotations from Buddhist Literature for each Day in the Year. Fifth Edition. Cr. 16 mo. 2s. $6 d$.

Bower (E.), B.A. See New Historical Series.

Boyle (W.). CHRISTMAS AT THE ZOO. With Verses by W. BOYLE and 24 Coloured Pictures by H. B. Neilson. Super Royal 16 mo. 25 .

Brabant (F. G.), M.A. RAMBLES IN SUSSEX. With 30 Illustrations. Crown 8vo. 6s. See also Little Guides.

Bradley (A. G.). ROUND ABOUT WILT. SHIRE. With Is Illustrations, in Colour by T. C. GoTCH, 16 other Illustrations, and a Map. Second Edition. Cr. 8vo. 6s.

THE ROMANCE OF NORTHUMBER. LAND. With 16 Illustrations in Colour by Frank Southgate, R.B.A., and 12 from Photographs. Second Edition. Demy 8vo. 7 s. $6 d$ net.

Bradley (John W.). See Little Books on Art.

Braid (James), Open Champion, Ig01, rgo5 and 1906. ADVANCED GOLF.' With 88 Photographs and Diagrams. Fifth Edition Demy 8vo. tos. 6d. net.
Braid (James) and Others. GREAT GOLFERS IN THE MAKING. Edited by HENRY LEACH. With 24 Illustrations. Second Edition. Demy 8vo. 7s. 6d. net.

Brallsford (H. N.). MACEDONIA: ITS RACES AND THEIR FUTURE. With 32 lllustrations and 2 Maps. Demy $8 v 0$. I2s. 6 d: net.

Brentano (C.). See Simplified German Texts.

Brightman (F. E.), M.A. See Andrewes (Lancelot).

*Brock (A. Clutton). SHELLEY : THE MAN AND THE POET. With 12 Illustrations. Demy 8vo. 7s. 6d. net.

Brodrlck (Mary) and Morton (A. Anderson). A CONCISE DICTIONARY OF EGYPTIAN ARCHEOLOGY, A HandBook for Students and Travellers. With 80 Illustrations and many Cartouches. Cr. 8vo. 3s. $6 d$.

Brooks (E. E.), B.Sc. (Lond.), Leicester Municipal Technical School, and James (W.H. N.), A.M.I.E.E., A.R.C.Sc., Municipal School of Technology, Manchester. See Textbooks of Technology.

Brown (S. E.), M.A., B.Sc., Senior Science Master at Uppingham. A PRACTICAL CHEMISTRY NOTE - BOOK FOR MATRICULATION AND ARMY CAN DIDATES. Easy Experiments on the Commoner Substances. Cr. 4 to. Is. 6 d. net.

Brown(J. Wood), M.A. THE BUILDERS OF FLORENCE. With 74 Illustrations by Herbert Railton. Demy 4 to. 18 s. net.

Browne (Sir Thomns). See Standard Library.

Browneli (c. L.). THE HEART OF JAPAN. Illustrated. Third Edition. Cr. 8vo. 6s. Also Medium 8vo. 6d.

Browning (Robert). See Little Library.

Bryant (Walter W.), B.A., F.R.A.S., F.R. Met. Soc., of the Royal Observatory, Greenwich. A HISTORY OF ASTRONOMY. With 47 Illustrations. Demy 8vo. 7s. 6 d.net.

Buckland (Francis T.).' CURIOSITIES OF NATURAL HISTORY. Illustrated by $H$. B. Neilson. Cr. $8 v 0.3 s .6 d$.

Buckton (A. M.) THE BURDEN OF ENGELA. Second Edition. Cr. 8vo. $3^{s}$. 6d. net.

EAGER HEART : A Mystery Play. Seventh Edition. Cr. 8vo. Is. net

KINGS IN BABYLON : A Drama. Cr. $8 v 0$. is. net.

SONGS OF JOY. Cr. 8vo. rs. net.

Budge (E. A. Wallis). THE GODS OF THE EGYPTIANS. With over 100 Coloured Plates and many Illustrations. Two Volumes. Royal 8vo. E3, 3s. net.

* Buist Massac (H.). THE COMPLETE AERONAUT. With many Illustrations. Demy 8zo. 12s. 6d. net.

Bull (Paul), Army Chaplain. GOD AND OUR SOLDIERS. Second Edition. Cr. 8 ov. 6s. 
Balley (Miss). See Dilke (Lady).

Bunyan (John). THE PILGRIM'S PROGRESS. Edited, with an Introduction by C. H. FIRTH, M.A. With 39 Illustracions by $R$. AnNing Bell. Crown 820 . $6 s$. See also Standard Library and Library of Devotion.

Burch (G. J.), M.A., F.R.S. A MANUAL OF ELECTRICAL SCIENCE. Illustrated. Cr. 8r'o. is.

Burgess (Gelett). GOOPS AND HOW TO BE THEM. Illustrated. Small 4 to. $6 s$.

Burke (Edmund). See Standard Library.

Burn (A. E.), D.D., Rector of Handsworth and Prebendary of Lichfield. See Handbooks of Theology.

Burn (J. H.), B. D., F. R.S. E. THE CH U R C H M A N'S TREASURY OF SONG: Gathered from the Christian poetry of all ages. Edited by. Fcap. 8vo. 3s. 6d. net. See also Library of Devotion.

Burnet (John), M.A. See Aristotle.

Burns (Robert), THE POEMS. Edited by ANDrew Lang and W. A. Craigie. With Portrait. ThirdEdition. Wide Demy 8vo, gilt top. $6 s$.

See also Standard Library.

Burnside (W. F.), M.A. OLD TESTAMENT HISTORY FOR USE IN SCHOOLS. Third Edition. Cr. 8vo. 3 s. 6.7 . Burton (Alfred). See I.P.L.

Bury (J. B.), M.A., Litt. D. See Gibbon (Edward).

Bussell (F. W.), D.D. CHRISTIAN THEOLOGYAND SOCIAL PROGRESS (The Bampton Lectures of x905). Demy 8vo. Ios. $6 d$. net.

Butler (Joseph), D.D. See Standard Library.

Butlin (F. M.). AMONG THE DANES. With 12 Illustrations in Colour by ELLEN Wilkinson, and 25 from Photographs. Demy 8vo. 7s. 6d. net.

Cain (Georges), Curator of the Carnavalet Museum, Paris. WALKS IN PARIS. Translated by A. R. Allinson, M.A. With a Frontispiece in Colour by MAXWEII Armfield, and 118 other Illustrations. Demy 8vo. 7s. 6d. net.

Caldecott (Alfred), D.D. See Handbooks of Theology.

Calderwood (D. S.), Headmaster of the Normal School, Ediniburgh. TEST CARDS IN EUCLID AND ALGEBRA. In three packets of 40, with Answers. 1s. each. Or in three Books, price $2 d$., $2 d$., and $3 d$.

Cameron (Mary Lovett). OLD ETRURIA AND MODERN TUSCANY. With 32 Illustrations. Crown 8vo. 7s. 6d. net.

Cannan (Edwin), M.A. See Smith (Adam). Canning (George). See Little Library.

Capey (E. F. H.). See Oxford Biographies. Carden (Robert W.). THE CITY OF GENOA. With 12 lllustrations in Colour by William Parkinson, and 20 other Iflustrations. Demy 8vo. Ios. 6d. net.
Careless (John). See I.P.L.

Carlyle (Thomas). THE FRENCH REVOLUTION. Edited by C. R. L. Fletcher, Fellow of Magdalen College, Oxford. Three Volumes. Cr. 8vo. t8s. THE LETTERS AND SPEECHES OF OLIVER CROMWELI. With an Introduction by C. H. FirTh, M.A.; and Notes and Appendices by Mrs. S. C. Lomas. Three Volumes. Demy 8vo. 18s. net.

Carlyle (R. M. and A. J.), M.A. See Leaders of Religion.

Carmichael (Philip). ALL"ABOUT PHILIPPINE. With 8 Illustrations. Cr. 8vo. 2s. $6 d$.

Carpenter(Margaret Boyd). THECHILD IN ART. With so Illustrations. Second Edition. Large Cr. 8vo. 6 s.

* Carter (George), M.A. THE STORY OF MILTON'S 'PARADISE LOST:' Crown 8vo. Is. $6 d$.

Cavanagh (Francis), M.D. (Edin.). See New Library of Medicine.

Celano(BrotherThomas of). THE LIVES OF FRANCIS OF ASSISI. Translated by A. G. Ferrers Howell. With a Frontispiece. Cr. 8vo 5s. net.

Chambers (A. $M$. ) A CONSTITUTIONAL HISTORY OF ENGLAND. Crower 8vo. $6 \mathrm{~s}$.

Chamlsso (A. von). See Simplified German Texts.

Chandler (Arthur), Bishop of Bloemfontein. ARA CELI : AN Essay in Mrstical Theology. Third Edition. Crown 8vo. 3s. $6 d$. net.

Channer (C. C.) and Roberts (M. E.). IACEMAKING IN THE MIDLANDS, PAST AND PRESENT. With 17 fullpage Illustrations. $C r .8 v o$. 2s. $6 d$.

Chapman (S. J.). See Books on Business.

Chatterton (Thomas). See Standard Library.

Chesterfield (Lord), THE LETTERS OF THE EARL OF CHESTERFIELD TO HIS SON. Edited, with an Introduction by C. Strachey, with Notes by, $A$. Calthrop. Two Volumes. Cr.8vo. 12s. Chesterton(G.K.). CHARLES DICKENS. With two Portraits in Photogravure. Fifth Edition. Cr. 8vo. $6 s$.

ALL THINGS CONSIDERED. Fourth Edition. Fcas. 8vo. 5s.

TREMENDOUS TRIFLES. Frap. 800 . 55.

Childe (Charles P.), B.A., F.R.C.S. See New Library of Medicine.

Cicero. See Classical Translations.

Clapham (J. H.), Professor of Economics in the University of Leeds. THE WOOLLEN AND WORSTED INDUSTRIES. With 2x Illustrations and Diagrams. $C r$. 8 in. 6s.

Clarke(F. A.), M.A. See Leaders of Religion. Clausen (George), A.R.A., R.W.S. SIX LECTURES UN PAINIING. With 16 


\section{General Literature}

Illustrations. Third Edition. Large Post 8vo. 3s. 6 d. net.

AIMS AND IDEALS IN ART. Eight Lectures delivered to the Students of the Royal Academy of Arts. With.32 Illustra. tions. Second Edition. Large Post 8vo. 5s. net.

Clay (Rotha Mary). See Antiquary's Books.

Cleather (A. L.). See Wagner (R).

Clinch (G.), F.G.S. See Antiquary's Books and Little Guides.

Clough (W. T.) and Dunstan (A. E.). See Junior School Books and Textbooks of Science.

Clouston (T. S.), M.D., C.C.D., F.R.S.E. See New Library of Medicine.

Coast (W. G.), B.A. EXAMINATION PAPERS IN VERGIL. Cr. 8vo. 2s.

Cobb (W. F.), M.A. THE BOOK OF PSALMS : with an Introduction and Notes. Demy 8vo. ros. 6d. net.

* Cockshott (Winlfred), St. Hilda's Hall, Oxford. THE PILGRIM FATHERS, Their Church and Colony. With 12 Illustrations. Demy 8vo. 7s. 6 d. net.

Collingwood (W. G.), M.A. THE LIFE OF JOHN RUSKIN. With Portrait. Sixth Edition. Cr. 8vo. 2s. 6d. net.

Collins (W. E.), M.A. See Cburchman's Library.

Colvill (Helen H.). ST. TERESA OF SPAIN. With zo Illustrations. Demy 8vo. 7s. 6d. net.

Combe (William), See I.P.I.

Conrad (Joseph). THE MIRROR OF THE SEA: Memories and Impressions. Third Edition. Cr. $8 z 0$. $6 s$.

Cook (A. M.), M.A., and Marchant (E. C.) M.A. PASSAGES FOR UNSEEN TRANSI,ATION. Selected from Latin and Greek Literature. Fourth Ed. Cr.8vo. $3 s .6 d$.

LATIN PASSAGES FOR UNSEEN TRANSLATION, $\mathrm{Cr} .800$. Is. $6 \mathrm{~d}$.

Cooke-Taylor (R. W.). THE FACTORY SYSTEM. Cr. 8vo. 2s. $6 d$.

Coolldge (W. A. B.), M.A. THE ALPS. With many Illustrations. Demy 8vo. 7s. 6 d. net.

Cooper (C. S.), F.R.H.S. See Westell (W.P.)

Corkran (Alice). See Little Books on Art

Cotes (Rosemary). DANTE'S GARDEN With a Frontispiece. Secord Edition. Fcab. 8vo. 2s. 6d.; leather, 3s. 6d. net.

BIBLE FLOWERS. With a Frontispiece and Plan. Frap. 8vo. 2s. 6d. net.

Cotton (Charles). See I.P.L. and Little Library.

Coulton (G. G.). CHAUCER AND HIS E N G A N D. With 32 Illustrations. Second Edition. Demy 8vo. Ios. 6d. net.

Cowley (Abraham). See Little Library.

Cowper (William). THE POEMS. Edited with an Introduction and Notes by J. C. BaILEv, M.A. Illustrated, including two unpublished designs by WiLliam Blake. Demy 8vo. Ios. 6d. net.
Cox (J. Charles). See Ancient Cities, Antiquary's Books, and Little Guides.

Cox (Harold), B.A., M.P. IANI NATIONALIZATION AND LANI TAXATION. Second Edition revised. Cr. 8vo. 3s. 6d. net.

Crabbe (George). See Little Library.

Craik (Mrs.). See Little Library. Crane (C. P.), D.S.O. See Little Guides. Crane (Walter) R.W.S. AN ARTIST'S REMINISCENCES. With 233 Illustrations by the Author and others from Photographs. Second Edition. Demy 8vo. r8s. net.

INDIA IMPRESSIONS. With 84 Illus trations from Sketches by the Author. Second Edition. Demy 8vo. 7s. 6d. net.

Crashaw (Richard). See Little Library.

Crlspe (T. E.), K.C. REMINISCENCES OF A K.C.' With Portraits. Demy 8vo. ros. 6d. net.

Cross (J. A.), M.A. THE FAITH OF THE BIBLE. Fap. 8vo. 2s. 6d. net.

*Crowley (Ralph H.). THE HYGIENE OF SCHOOL LIFE. Cr. 8vo. 3s. 6d. net.

Cruikshank(G.). THE LOVING BAL LAD OF LORD BATEMAN. With II Plates. Cr. I6mo. Is. 6 d. net.

Crump (B.). See Waguer (R.).

Cruttwell (C. T.), M.A., Canon of Peterborough. See Handbooks of English Church History.

Cunynghame (H. H.), C.B. See Connoisseur's Library.

Cutts (E. L.), D.D. See Leaders of Religion. Daniell (G. W.), M.A. See Leaders of Religion.

Dante (Alighieri). LA COMMEDIA DI DANTE. The Italian Text edited by Paget Toyneee, M.A., D.Litt. Cr.8vo. 6s.

THE DIVINE COMEDY. Translated by H. F. CARY. Edited with a Life of Dante and Introductory Notes by PAGET ToyNBee, M.A., D. Litt. Demy $8 v 0$. $6 d$.

THE PURGATORIO OF DANTE. Translated into Spenserian Prose by $\mathrm{C}$. Gordon Wright. With the Italian text. Fcap. 8vo. 2s. 6d. net.

See also Little Library, Toynbee (Paget), and Vernon (Hon. W. Warren)

Darley (George). See Little Library.

D'Arcy (R. F.), M.A. A NEW TRIGON. OMETRY FOR BEGINNERS. Witl numerous diagrams. Cr. 8vo. 2s. $6 d$.

Daudet (AIphonse). See Simplified French Texts.

Davenport (Cyril). See Connoisseur's Library and Little Books on Art.

Davenport (James). THE WA SH. BOURNE FAMIIY. With I5 Illustrations and a Map. Rogal 800 . 2Is. net.

Davey (Richard.) THE PAGEANT OF LONDON. With 40 Illustrations in Colour by John Fulleyloye, R.I. In Two Volumes. Demy 8vo. 15s. net.

See also Romantic History.

Davies (Gerald S.). See Classics of Art. 
Davies (W. 0. P.). See Junior Examination Series.

Davis (H. W. C.), M.A., Fellow and Tutor of Balliol Coliege. ENGLAND UNDER THE NORMANS AND ANGEVINS : Io66-1272. With Maps and Illustrations. Denty 8v0.1 ros. 6d. ret.

Daw son (Nelson). See Connoisseur's Library. Dawson (Mrs. Nelson). See Little Books on Art.

Deane (A. C.). See Little Library.

Deans (Storry R.) THE TRIALS OF FIVE QUEENS: KATHARINE OF Aragon, Anne Boleyn, Mary Ouren of Scots, Marie Antoinette and CaroLINE OF BRUNSwICK. With I2 Illustrations. Demy 8vo. tos. 6d. net.

Dearmer (Mabel). A CHILD'S LIFE OF CHRIST. With 8 rllustrations in Colour by E. Fortescue-Brickdale. Large $C r$. 8vo. $6 s$.

* D'Este(Margaret). IN THECANARIES WITH A CAMERA. Illustrated. $C r$. $8 v 0$ 7s. $6 d$. net.

Delbos(Leon). THE METRIC SYSTEM. Cr. 8vo. $2 s$.

Demosthenes. AGAINST CONON AND CALLICLES, Edited by F. DARWIN Swif , M.A. Second Edition. Fcap. 8vo. $2 s$.

Dlckens (Charles). See Little Library, I.P.L., and Chesterton (G. K.)

Dickinson (Emily). POEMS. Cr. 8vo. 4s. 6d. net.

Dlckinson (G. L.) M.A., Fellow of King's College, Cambridge. THE GREEK VIEW OF LIFE. Sixth Edition. Cr. 8vo. 2s. 6a.

Dilke (Lady), Bulley (Miss), and Whitley (Miss). WOMEN'S WORK. Cr. 8vo. 2s. $6 d$.

Dillon (Edward), M.A. See Connoisseur's Library, Little Books on Art, and Classics of Art.

Ditchfield (P. H.), M.A., F.S.A. THE STORY OF OUR ENGLISH TOWNS. With an Introduction by Augustus Jessopp, D.D. Second Edition. Cr. 8vo. 6s,

OLD ENGLISH CUSTOMS: Extant at the Present Time. Cr. 8vo. $6 s$.

ENGLISH VILLAGES. With $x \infty$ Illustra. tions. Second Edition. Cr. 8vo. 2s.6d. net.

THE PARISH CLERK. With 3 . Illustrations. Third Editior. Demy $8 v 0$. 75. 6d. net.

THE OLD-TIME PARSON. With I7 Illustrations. Second Edition. Demy8vo. 7s. 6d. net.

Dixon (W. M.), M.A. A PRIMER OF TENNYSON. Third Edition. Cr. $8 v 0$. 2s. $6 d$.

ENGLISH POETRY FROM BLAKE TO BROWNING. Second Edition. Cr. 8vo. 2s. $6 d$.

Dobbs (W. J.), M.A. See Textbooks of Science.

Doney (May). SONGS OF THE REAL. Cr. 8vo. 3s. 6d. net.
Douglas (Hugh A.). VENICE ONFOOT. With the Itinerary of the Grand Canal. With 75 Illustrations and II Maps. Fcap. 8vo. 5s, net.

Douglas (James). THE MAN IN THE PULPIT. Cr. 8vo. 2s. 6d. net.

Dowden (J.), D.D., Lord Bishop of Edin. burgh. FURTHER STUDIES IN THE PRAYER BOOK. Cr. 8vo. $6 s$.

See also Churchman's Lihrary.

Drage (G.). See Books on Business.

Driver (S. R.), D.D., D.C.L., Regius Professor of Hebrew in the University of Oxford. SERMONS ON SUBJECTS CONNECTED WITH THE OLD TESTAMENT. Cr. 8vo. $6 s$.

See also Westminster Commentaries.

Dry (Wakellng). See Little Guides.

Dryhurst (A. R.). See Little Books on Art.

* Duff (Nora). MATILDA OF TUSCANY. With many Illustrations. Demy 8vo. Ios. $6 d$. net.

Duguid (Charles). See Books on Business.

Dumas (Alexandre). THE CRIMES OF THE BORGIAS AND OTHERS With an Introduction by R. S. GARNETT. With o Illustrations. $C r .8 v 0$. $6 s$

THE CRIMES OF URBAIN GRANDIER AND OTHERS. With 8 Illustrations. Cr. 8vo. $6 s$.

THE CRIMES OF THE MAROUISE DE BRINVILLIERS AND OTHERS. With 8 Illustrations. Cr. $8 v 0$. 6 s.

THE CRIMES OF ALI PACHA AND OTHERS. With 8 Illustrations. Cr. 8vo. $6 s$.

MY MEMOIRS. Translated by E. M. WALLER. With an Introduction by ANDREW LANG. With Frontispieces in Photogravure. In six Volumes. Cr. 8vo. 6s. each volume. VOI. I. $1802-1821$. VOL. IV. $1830-183$ I. VOL. II. $1822-1825$. VOL. V. $1831-183 e$. VOL. III. 1825-1830. VoL. VI. I832-1833. MY PETS. Newly translated by A. R. AlLiNson, M.A. With I 6 Illustrations by V. LEсомте. Cr. 8vo. 6r. See also Simplified French Texts.

Duncan (David) D.Sc, LL.D. THE LIFE AND LETTERS OF HERBERT SPENCER. With I7 Illustrations. Demy 8vo. $\times 5 s$.

Dunn (J.T)., D.Sc., and Mundella (V. A.). GENERAL ELEMENTARY SCIENCE With II4 Illustrations. Second Edition. Cr. 8vo. 3s. $6 d$.

Duni-Pattison (R. P.). NAPOLEON'S MARSHALS. With zolllustrations. Demy 8vo. Second Edition. 12s. 6d. net.

Dunstan (A. E.), B.Sc. (Lond.). See Textbooks of Science, and Junior School Books.

Durham (The Earl of). A REPORT ON CANADA. With an Introductory Note. Demy 8vo. 4s. 6r. net.

Dutt (W. A.). THE NORFOLK BROADS. With coloured Illustrations by FrANK Southgate, R.B.A. Second Edition. Cr. 8vo. $6 s$. 


\section{General. Literature}

WILD LIFE IN EAST ANGLIA. With 16 Illustrations in colour by FrANK South. GATE, R.B.A. Second Edition. Demy 8vo. 7s. 6d. net.

SOME LITERARY ASSOCIATIONS OF EAST ANGLIA. With I6 Illustrations in Colour by W. Dexter, R.B.A., and 16 other Illustrations. Demy 8vo. Ios. $6 \mathrm{~d}$. net. See also Little Guides.

Earle(John), Bishop of Salisbury. MIICROCOSMOGRAPHIE, OR A PIECE OF THE WORLD DISCOVERED. Post 16 mo. $2 s$. net.

Edmonds (Major J. E.), R.E.; D.A.Q.-M.G. See Wood (W. Birkbeck).

Edwardes (Tickner). THE LORE OF THE HONEY BEE. With; 24 Illustrations. Cr. 8vo. 6s.

Edwards (Clement), M.P. RAILWAY NATIONALIZATION. Second Edition, Revised. Crown 8vo. 2s. 6d. net.

Edwards (W. Douglas). See Commercial Series.

Egan (Plerce). See I.P.I.

Egerton (H. E.), M.A. A HISTORY OF BRITISH ' COLONIAL ' POLICY. Second Ed., Revised. Demy 8vo. 7s.6d. net.

Ellaby (c. a.). See Little Guides.

Ellerton (F. Q.). See Stone (S. J.).

Epictetus. See Aurelius (Marcus).

Erasmus. A Book called in Latin EN CHIRIDION MILITIS CHRISTIANI, and in English the Manual of the Christian Knight. Fcap. 8vo. 3s. 6d. net.

Erckmann-Chatrian. See Simplified French Texts.

Evagrius. See Byzantine Texts.

Ewald (Carl). TWO LEGS, AND OTHER Stories. Translated from the Danish by Alexander Teixeira de Mattos. Illustrated by Augusta GuEst. Large $\mathrm{Cr}$. $8 v o$. $6 s$.

Ezekiel. See Westminster Commentaries

Facon (H. T.), B.A. See Junior Examination Series.

Falrbrother (W. H.), M.A. THE PHILOSOPHY OF T. H. GREEN. Second Edition. Cr. 8ro. 3s. $6 d$.

Fea (Allan). THE FLIGHT OF THE KING. With over 70 Sketches and Photographs by the Author. New and revised Edition. Demy 8vo. 7s. 6d. net.

SECRET CHAMBERS AND HIDING. PLACES. With 80 Illustrations. New and revised Edition. Demy 8vo. 7s. 6d. net.

JAMES 11. AND HIS WIVES. With 40 Illnstrations. Deme 8vo. 1os. 6d. net.

Fell (E. F. B.). THE FOUNDATIONS OF LIBERTY. Cr. 8vo. 5s. net.

Ferrier (Susan). See Little Library.

Fidter (T. Claxton), M.Inst. C.E. See Books on Business.

Fielding (Henry). See Standard Library.

Finn (S.W.), M.A. See Junior Examination Series.

Firth (J. B.). See Little Guides.

Firth (C. H.) M.A. Regius Professor of Modern History at Oxford. CROM.
WELL'S ARMY: AHistory of the English Soldier during the Civil Wars, the Commonwealth, and the Protectorate. Cr. 8vo. 6s.

"Firth (Edith E.). See Beginner's Books and Junior School Books.

FltzGerald (Edward). THE RUBÁIYÁT OF OMAR KHAYYÁM. Printed from the Fifth and last Edition. With a Com. mentary by Mrs. STEPHEN BATSON, and a Biography of Omar by E. D. Ross. Cr. 8vo. 6s. See also Miniature Library.

FitzGerald (H. P.). A CONCISE HAND. BOOK OF CLIMBERS, TWINERS, AND WALL SHRUBS. Illustrated. Fcap. 8vo. 3s. 6d. net.

Fitzpatrick (S. A. O.). See Ancient Cities. Flecker (W. H.), M.A., D.C. L., Headmaster of the Dean Close School, Cheltenham. THE STUDENT'S PRAYER BOOK. The TExt of MIorning And Evening Prayer and Litany. With an Introduction and Notes. Cr. 8vo. 2s. 6 d.

Fletcher (C. R. L.), M.A. See Carlyle (Thomas).

Fletcher (J. S.). A BOOK OF YORKSHIRE. With 16 Illustrations in Colour by IVAl Paget and Frank Southgate, R.B.A., 16 other Illustrations and a Map. Demy 8vo. 7s. 6i. net.

Flux (A. W.), M.A., IVilliam Dow Professor of Political Economy in M'Gill University, Montreal. ECONOMIC PRINCIPLES. Demy 8vo. 7s. 6d. net.

Foat (F. W. G.), D.Litt., M.A. A LONDON READER FOR YOUNG CITIZENS. With Plans and Illustrations. $C r$. 8v0. Is. $6 d$.

Ford (H. G.), M.A., Assistant Master at Bristol Grammar School. See Junior School Books.

Forel (A.). THE SENSES OF INSECTS. Translated by Macleod Yearsley. With 2 Illustrations. Demy 8vo. ros. 6d. net.

Fortescue (Mrs. G.). See Little Books on Art.

Fouqué (La Motte). SINTRAM AND HIS COMPANIONS. Translated by A. C. FARQuharson. With 20 lllustrations by Edmund J. Sullivan, and a Frontispiece in Photogravure from an engraving by AlBrecht Dürer. Demy 8vo. 7s. 6d. net. Ilalf White Vellum, ros. 6d. net. See also Simplified German Texts.

Fraser (J. F.). ROUND THE WORLD ON A WHEEL. With roo Illustrations. Fifth Edition Cr. 8vo. $6 s$.

French(W.), M.A. See Texthooks of Science.

Freudenreich (Ed. von). DAIRY BACTERIOLOGY. A Short Manual for Students. Translated by J. R. AinsworTH Dayis, M.A. Second Edition. Revised. Cr. 8vo. 2s. 6 .

Fursdon (F. R. M). FRENCH AND ENGLISH PARALLELS. Fcap. $8 v 0$. 3s. $6 d$. net.

Fyvle (John). TRAGEDY QUEENS OF THEGEORGIAN ERA. With 16 Illustrations. Second Ed. Demy8vo. 12s.6a.net. 
Gallaher (D.) and Stead (W. J.). THE COMPLETE RUGBY FOOTBALLER, ON THE NEW ZEALAND SYSTEM. With 35 Illustrations. Second Ed. Demy 8vo. Ios. 6d. net.

Gallichan (W. M.). See Little Guides.

Galton(Sir Francis), F.R.S.; D.C.L., Oxf.; Hon. Sc.D., Camb.; Hon. Fellow Trinity College, Cambridge. MEMORIES OF MY LIFE. With 8 Illustrations. Third Edition. Demy 8vo. ros. 6d. net.

Gambado (Geoffrey, Esq.). See I.P.L.

Garnett (Lucy M. J.). THE TURKISH PEOPLE: Their Social Life, Religious Beliefs and In STITUTIONS, AND Domestic LIFE. With 21 Illustrations. Demy $8 v 0$. ros. $6 d$. net.

Gaskell (Mrs.). See Little Library, Standard Library and Sixpenny Novels.

Gasquet, the Right Rev. Abbot, O.S.B. See Antiquary's Books.

Gee (Henry), D.D., F.S.A. See Handbooks of English Church History.

George(H. B.), M.A., Fellow of New College, Oxford. BATTLES OF ENGLISH HISTORY. With numerous Plans. Fourth Edition Revised. Cr. 8vo. 3s. $6 d$.

A HISTORICAL GEOGRAPHY OF THE BRITISH EMPIRE Fourth Edition. Cr. 8vo. 3s. 6d.

Gibbins (H. de B.), Litt.D., M.A. IN. DUSTRY IN ENGLAND : HISTORI. CAL OUTLINES. With 5 Maps. Fifth Edition. Demy 8vo. xos. 6 d.

THE INDUSTRIAL HISTORY OF ENGLAND. With Maps and Plans. Fifteenth Edition, Revised. Cr. 8vo. 35.

ENGLISH SOCIAL REFORMERS Second Edition. Cr. $8 v 0$. 2s. $6 d$.

See also Hadfield (R. A.)., and Commercial Series.

Gibbon (Edward). MEMOIRS OF MY LIFE AND WRITINGS. Edited by G. BirkBeck Hill, Ll.D Cr. 8vo. $6 s$.

*THE DECLINE AND FALL OF THE ROMAN EMPIRE. Edited, with Notes, Appendices, and Maps, by J. B. Bury. M.A., Litt.D., Regius Professor of Modern History at Cambridge. Illustrated. In Seven Volumes. Demy 8vo. Gilt top. Eack ros. 6d. net.

Gibbs (Phillp). THE ROMANCE OF GEORGE VILLIERS : FIRST DUKE OF BUCKINGHAM, AND SOME MEN AND WOMEN OF THE STUART COURT. With 20 Illustrations. Second Edition. Demy 8zo. rss. net.

Gibson (E. C. S.), D.D., Lord Bishop of Gloucester. See Westminster Commentaries, Handbooks of Theology, and Oxford Biographies.

Gilbert (A. R.). See Little Books on Art.

Gloag (M. R.) and Wyatt (Kate M.). A BOOK OF ENGLISH GARDENS. With 24 Illustrations in Colour. Desny 8vo. xos. 6d. net.

Glover (T. R.), M.A., Fellow and Clastical Lecturer of St. John's College, Cambridge. THE CONFLICT OF RELIGIONS IN THE EARLY ROMAN EMPIRE. Third Edition. Demy 8vo. 7s. 6d. net.

Godfrey (Elizabeth). A BOOK OF REMEMBRANCE. Being Lyrical Selections for every day in the Year. Arranged by. Second Edition. Fcap. 8vo. 2s. 6a. net.

ENGLISH CHILDREN IN THE OLDEN TIME. With 32 Illustrations. Second Edition. Demy 8vo. 7s. 6d. net.

Godley (A. D.), M.A., Fellow of Magdalen College, Oxford. OXFORD IN THE EIGHTEENTH CENTURY. With $\times 6$ Illustrations. Second Edition, Demy 8vo. 7s. 6 d. net.

Also publisbed in a Colonial Edition.

LYRA FRIVOLA. Fourth Edition. Frap. 8vo. 2s. 6 d.

VERSES TO ORDER. Second Edition. Fcap. 8vo. 2s, 6d.

SECOND STRINGS. Fcap. 8vo. 2s. $6 \mathrm{~d}$. Goldsmith (Oliver). See I.P.L. and Standard Library.

Goll (August). CRIMINAL TYPES IN SHAKESPEARE. Authorised Translation from the Danish by Mrs. Charles WeEkes. Cr. 8vo. 5s. net.

Gomme (G. L.). See Antiquary's Books.

Gordon (Lina Duff) (Mrs. Aubrey Waterfield). HOME LIFE IN ITALY: LETTERS FROM THE A PENNiNES. With $x_{3}$ Illustrations by AUBREV WATERFIELD and 15 IlluStrations from Photographs. Secord Edition. Demy 8vo. ros. 6d. net.

Gorst (Rt. Hon. Sir John). See New Library of Medicine.

Gostling (Frances M.). THE BRETONS AT HOME. With 12 lllustrations in Colour by Gaston Fanty Lescure, and 32 from Photographs. Demy 8vo, 1 10s. $6 d$. net.

Goudge (H. L.), M.A., Principal of Wells Theological College. See Westminster Commentaries.

Graham (Harry). A GROUP OF SCOT. TISH WOMEN. With 16 Illustrations. Second Edition. Demy 8vo. ros. 6d. net.

Graham (P. Anderson). THE RURAL EXODUS. The Problem of the Village and the Town. Cr. 8vo. 2s. $6 \mathrm{~d}$.

Grahame (Kenneth). THE WIND IN THE WILLOWS. With a Frontispiece by GraHAM ROBERTSON. Fourth Edition. Cr. 8vo. 6s.

Granger (F. S.), M.A., Litt.D. PSYCHOLOGY. Third Edition. Cr. 8vo. 2s. $6 d$. THE SOUL OF A CHRISTIAN. Cr. 8vo. 6s.

Gray (E. M'Queen). GERMAN PASSAGES FOR UNSEEN TRANSLATION. $C r$. 8vo. 2s. $6 d$.

Gray (P. L.), B.Sc. THE PRINCIPLES OF MAGNETISM AND ELECTRICITY. With I81 Diagrams. Cr. 8vo.' 3s. 6d.

Green (G. Buckland), M.A., late Fellow of St. John's College, Oxon. 'NOTES ON 
GREEK AND LATIN SYNTAX. Second Ed, revised. Crown 8vo. 3s. $6 d$.

Green (Mary Anne Everett). ELIZA. BETH; ELECTRESS PALATINE AND QUEEN OF BOHEMIA. Revised by her Niece S. C. Lomas. With a Prefatory Note by A. W. WARD, Litt.D. Demy 8 vo. ros. 6 d. net.

Greenidge (A.H. J.), M.A., D.Litt. A HISTORY OF ROME: From the Tribunate of Tiberius Gracchus to the end of the Jugurthine War, B.c. 133-104. Demy 8vo. Ios. 6d. net.

Gregory (Miss E. C.). See Library of Devotion.

Grubb(H. C.). See Textbooks of'Technology.

Gwynn (Stephen), M.P. A HOLIDAY IN CONNEMARA. With 16 Illustrations. Demy 8vo. ros. $6 d$. net.

Hadfield (R. A.) and Gibbins (H. de B.) A SHORTER WORKING DAY. Cr. 8vo. 2s. 6d.

*Hall (Cyril). THE YOUNG CARPEN. TER. With Diagrams, and Illustrations. Cr. 8vo. 5 s.

Hall (Hammond). THE YOUNG ENGINEER: OR MODERN ENGINES AND THE1R MODELS. With 85 Illustrations. Second Edition. Cr. 8vo. 5 s.

Hall (Mary). A WOMAN'S TREK FROM THE CAPE TO CAIRO. With 64 Illustrations and 2 Maps. Second Edition. Demy 8vo. 16s, net.

Hamel (Frank). FAMOUS FRENCH SA L O S. With 20 Illustrations. Third Edition. Demy 8vo. 12s. 6d. net.

Hannay (D.). A SHORT HISTORY OF THE ROYAL NAVY. Vol. I., 1217-x688. Vol. II., 1689-1815. Demy 8vo. Each 7s.6d. net.

Hannay (James O.), M.A. THE SPIRIT AND ORIGIN OF CHRISTIAN MONASTICISM. Cr. 8vo. $6 s$.

THE WISDOM OF THE DESERT. Fcap. 8vo. 33. 6d. net.

Hardie(Martin). See Connoisseur's Library.

Hare (A. T.), M.A. THE CONSTRUCTION OF LARGEINDUCTION COILS. With 35 Illustrations. Demy 8vo. 6s.

Harker (Alfred), M.A., F.R.S., Fellow of St. John's College, and Lecturer in Petrology in the University of Cambridge. THE NATURAL HISTORY OF IGNEOUS ROCKS. With II2 Diagrams and 2 Plates. Demy 8vo. r2s. 6d. net.

Harper (Charles G.). THE AUTOCAR ROAD-BOOK. In three Volumes. Crown 8vo. Each 7s. 6 d. net.

Vol. 1.-SOUTH OF THE THAMES.

Harvey (Alfred), M.B. See Ancient Cities and Antiquary's Books.

Hawthorne(Nathaniel). See Little Library.

*Headley (P. W.). DARWINISM AND MODERN SOCIALISM. Cr. $8 v 0.5$ s. net.

Heath (Frank R.). See Little Guides.
Heath (Dudiey). See Connoisseur's Library. Henderson (B. W.), Fellow of Exeter College, Oxford. THE LIFE AND PRINCIPATE OF THE EMPEROR NERO. Illustrated. Nezv and cheaper issue. Demy 8vo. 7s.6d. net.

AT INTERVALS. Fcap 8vo. 2s. 6d. net.

Henderson (M. Sturge). GEORGE MEREDITH : NOVELIST, POET, REFORMER. With a Portrait in Photogravure. Second Edition. Crown 8vo. 6s.

Henderson (T. F.). See Little Library and Oxford Biographies.

Henderson (T. F.), and Watt (Francis). SCOTLAND OF TO-DAY. With 20 Illustrations in colour and 24 otber Illus. trations. Second Edition. Cr. 8vo. $6 s$.

Henley (W. E.). ENGLISH LYRICS. CHAUCER TO POE, 1340.1849. Second Edition. Cr. 8vo. 2s. 6d. net.

Henley (W. E.) and Whibley (C.) A BOOK OF ENGLISH PROSE, CHARACTER, AND INCIDENT, 1387-1649. Cr. $8 v 0$. 2s. 6 d. net.

Herbert (George). See Library of Devotion. Herbert of Cherbury (Lord). See Miniature Library.

Hett (Walter S.), B.A. A SHORT HIS. TORY OF GREECE TO THE DEATH OF ALEXANDER THE GREAT. With 3 Maps and 4 Plans. $C r .8 v o$. $3 s .6 d$.

Hewlng (w. A. S.) B.A. ENGLISH TRADE AND FINANCE IN THE SEVENTEENTH CENTURY. Cr.8vo. 2s. 6 .

Hewitt (Ethel M.) A GOLDEN DIAL. A Day Book of Prose and Verse. Fipa. 8vo. 2s. 6d. net.

Hey (H.), Inspector, Surrey Education Committee, and Rose (G. H.), City and Guilds Woodwork Teacher. A WOODWORK CLASS-BOOK. Pt. I. Illustrated. 4 to. 2s.

Heywood (W.). See St. Francis of Assisi. Hill (Clare). See Textbooks of 'Technology. *Hill (George Francis). ONE HUNDRED MASTERPIECES OF SCULPTURE. with yor Illustrations. Demy 8vo. Ios. $6 d$. net.

Hill (Henry), B.A., Headmaster of the Boy's High School, Worcester, Cape Colony. A SOUTH AFRICAN ARITHMETIC. Cr. 3vo. 3s. $6 d$.

Hind (c. Lewis). DAYS IN CORNIVALL. With 16 Illustrations in Colour by WiLLiAM PAscor, and 20 other Illustrations and $a$ Map. Second Edition. Cr. 8v0. 6s.

Hirst (F. W.) See Books on Business.

Hobbouse (L. T.), late Fellow of C.C.C., Oxford. THE THEORY OF KNOW: LEDGE. Demy 8vo. Ios. 6 d. net.

Hobson (J. A.), M.A. INTERNATIONAL TRADE : A Study of Economic Principles. Cr. 8vo. 2s. 6 d. net.

PROBLEMS OF POVERTY. An Inquiry 
into the Industrial Condition of the Poor. Seventh Edition. Cr. 8vo. 2s. 6d.

THE PROBLEM OF THE UNEM PLOYED. Fourth Edition. Cr.8zo. 2s.6d. Hodgetts (B. A. Brayley). THE COURT OF RUSSIA IN THE NINETEENTH CENTURY. With 20 Illustrations. Two Volumes. Demy 8vo. 24s. net.

Hodgkin (T.), D.C.L. See Leaders of Religion.

Hodgson (Mrs. W.) HOW TO IDENTIFY OLD CHINESE PORCELAIN. With $4^{\circ}$ Illustrations. Second Edition. Post 8vo. 6s.

Holden-Stone (G. de). See Books on Business.

Holdich (Sir T. H.), K.C.I.E., C. B., F.S.A. THE INDIAN BORDERLAND, 1880 1000. With 22 Illustrations and a Map. Second Edition. Demy 8 zo. Ios. 6d. net. Holdsworth (W. S.), D.C.L. A HISTORY OF ENGLISH LAW. In Four Volumes. Vols. I., II., III. Demy 8vo. Each Ios. $6 d$. net.

Holland (Clive). TYROL AND ITS PEOPLE. With 6 Illustrations in Colour by ADRian STOkES, and 3 I other Illustrations. Demy 8vo. 1os. $6 d$. net.

Holland (H. Scott), Canon of St. Paul's. See Newman (J. H.).

Hollings (M. A.), M.A. See Six Ages of European History.

Hollway-Calthrop (H. C.), late of Balliol College, Oxford : Bursar of Eton College. PETRARCH : HIS LIFE, WORK, AND TIMES. With 24 Illustrations. Demy 800. 12s. $6 d$. net.

Holmes ('T. Scott). See Ancient Cities.

Holyoake (G. J.). THE CO-OPERATIVE MOVEMENT OF TO-DAY. Fourth Ed. Cr. 8vo. 2s. 6d.

Hone (Nathanie] J.). See Antiquary's Books.

Hook (A.) H U M A I T Y AND ITS PROBLEMS. Cr. 8vo. 5s. net.

Hoppner. See Little Galleries.

Horace. See Classical Translations.

Horsburgh (E. L. S.), M.A. LORENZO THE MAGNIFICENT: AND FLORENCE IN HER Golden Age. With 24 Illustrations and 2 Maps. Second Edition. Demy 8vo. 15s. net.

WATERLOO : With Plans. Second Edition. Cr. 8v0. 55 .

See also Oxford Biographies.

Horth (A. C.). See Textbooks of Technology.

Horton (R. F.), D.D. See Leaders of Religion.

Hosie (Alexander). MANCHURIA. With $3^{\circ}$ Illustrations and a Map. Second Edition. Demy 8vo. 7s. 6d. net.

How (F. D.). SIX GREAT SCHOOI MASTERS. With $1_{3}$ Illustrations. Second Edition. Deny 8vo. 7s. 6d.

Howell (A. G. Ferrers). FRANCISCAN DAYS. Being Selections for every day in the year from ancient Franciscan writings. Cr. 8vo. 3s. 6d. net.

Howell (G.). TRADE UNIONISM-NEW AND OLD. Fourth Edition. Cr. 8vo. 2s. 6 d.
Huggins (Sir William), K.C.B., O.M., I.C.L., F.R.S. THE ROYAL SOCIETY; OR, Science in the State and in THE Schools. With 25 Illustrations. Wide Royal 8vo. 4s. 6d. net.

Hughes (C. E.). THE PRAISE OF SHAKESPEARE. An English Aritho. logy. With a Preface by Sidnex Lez. Demy $8 z 0$. 3s. 6d. net.

Hugo (Victor). See Simplified French Texts.

* Hulton (Samuel F.) THE CLERK OF OXFORD IN FICTION. With iz Illustrations. Demy 8vo. I5s. net.

Hume (Martin), M.A. See Romantic His. tory.

Hutchinson (Horace G.) THE NEW FOREST. lllustrated in colour with 5o Pictures by Walter Tyndale and 4 by LuCY KEMP.WELCH. Third Edition. Cr. 8vo. 6s.

Hutton (A. W.), M.A. See Leaders of Religion and Library of Devotion.

Hutton (Edward). THE CITIES OF UMBRIA. With 20 Illustrations in Colour by A. PISA, and 12 other Illustrations. Third Edition. Cr. 8 wo. 6 s.

THE CITIES OF SPAIN. With 24 Illus. trations in Colour, by A. W. Rimington, 2o other Illustrations and a Map. Third Edition. Cr. 8vo. 6s.

FLORENCE AND THE CITIES OF NORTHERN TUSCANY, WITH GENOA. With 16 Illustrations in Colour by William PARKINSON, and $x 6$ other Illustrations. Second Edition. Cr. 8vo." 6s.

ENGLISH LOVE POEMS. Edited with an Introduction. Fcap. 8vo. 3s. 6d. net.

COUNTRY WALKS ABOUT FLORENCE. With 32 Drawings by Adelaide Marchi and 20 other Illustrations. Fcap. $8 z 0$. 5s. net.

$1 \mathrm{~N}$ UNKNOWN TUSCANY.' With an Appendix by. William Heywoon. With 8 Illustrations in Colour and 200 others. Second Edition. Demy 8vo. 7s. 6d. net.

* ROME. With 16 Illustrations in Colour by MAXwell ARMField, and 12 other Illustrations. Cr. 8vo. $6 s$.

Hutton (R. H.). See Leaders of Religion.

Hutton (W. H.), M.A. THE LIFE OF SIR THOMAS MORE. With Portraits after Drawings by Holbein. Second Edition. Cr. 8vo. 5 s.

See also Leaders of Religion.

Hyde (A. G.) GEORGE HERBERT AND HIS TIMES. With 32 Illustrations. Demy 8vo. ros. 6d. net.

Hyett (F. A.). FLORENCE : HER HISTORY AND ARt to the Fall of the Republic. Demy 8vo. 7s. 6d. net.

Ibsen (Henrik). BRAND. A Drama. Translated by WiLliAM WiLson. Third Edition. Cr. 8vo. 3s.6d.

Inge (W. R.), M.A., Fellow and Tutor of Hertford College, Oxford. CHRISTIAN MYSTICISM. (The Bampton Lectures of 1899.) Demy 8vo. 12s. 6d. net. See also Library of Devotion. 
Innes (A. D.) M.A. A HISTORY OF THE BRITISH IN INDIA. With Maps and Plans. Cr. 8vo. 6s.

ENGLAND UNDER THE TUDORS. With Maps. Second Edition. Demy $8 v 0$. ros. 6 d. net.

* Innes (Mary). SCHOOLS OF PAINT. ING. With 76 Illustrations. Cr. $8 v 0$. 5s. net.

Isalah. See Churchman's Bible.

Jackson (C. E.), B.A. See Textbooks of Science.

Jackson (S.), M.A. See Commercial Series, Jackson (F. Hamilton). See Little Guides. Jacob (F.), M.A. See Junior Examination Series.

Jeans (J. Stephen). TRUSTS, POOLS, AND CORNERS AS AFFECTING COMMERCE AND INDUSTRY. $C r$ 8v0. 25. 6 d. See also Books on Business.

Jebb (Camilla). A STAR OF THE SALONS: JULIE DE LESPINASSE. With 20 Illustrations. Demy 8vo. Ios. 6 d. net.

Jeffery (Reginald W.), M.A. THE HISTORY OF THE THIRTEEN COLONIES OF NORTH AMERICA $x_{497 \cdot 1763}$. With 8 Illustrations and a Map. Demy 8vo, 7s.6d. net.

Jeffreys(D. Gwyn). DOLLY'STHEATRI. CALS. Super Royal 16mo. 2s. $6 d$.

Jenks (E.) M.A. B.C.L. AN OUTLINE OF ENGLISH LOCAL GOVERNMENT. Second Ed. Revised by R. C. K. ENSOR, M.A. Cr. 8vo. 2s. 6 d.

Jenner (Mrs. H.). See Little Books on Art.

Jennings (A. C.), M.A. See Handbooks of English Church History.

Jennings (Oscar), M.D. EARLY WOODCUT INITIALS. Demy 4 to. 2Is. net.

* Jerningham (Charles Edward). THE MAXIMS OF MARMADUKE, Crown 8vo. 5 s.

Jessopp (Augustus), D.D. See Leaders of Religion.

Jevons (F. B.), M.A., Litt.D., Principal of Hatfield Hall, Durham. RELIGION IN EVOLUTION. Cr. 8vo. 3s. 6d. net. See also Churchman's Library and Handbooks of Theology.

Johnson (A. H.), M.A. See Six Ages of European History.

Johnston (Sir H. H.), K.C.B. BRITISH CENTRAL AFRICA. With nearly 200 Illustrations and Six Maps. Third Edition. Cr. 4 to. 18 s. net.

Jones (Hi.). See Commercial Series.

Jones (H. F.). See Textbooks of Science.

Jones (L. A. Atherley), K.C., M.P., and Bellot (Hugh H. L.). M.A., D.C.I THE MINER'S GUIDE TO THE COAI MINES REGULATION ACTS AND THE LAW OF EMPLOYERS AND WORKMEN. Cr. 8vo. 2s. $6 d_{\text {. }}$ net.

COMMERCE IN WAR. Royal8vo. 2Is. net. Jones (R. Compton) M. A. POEMS OF THE INNER LIFE. Selected by. Thirteenth Edition. Fcap.8vo. 2s. 6d. net.
Jonson (Ben). See Standard Library.

Julian (Lady) of Norwich. REVELA. TIONSOF DIVINE LOVE. Ed.by GRACE Warrack, Third Ed. Cr. 8vo. 3s. 6d.

Juvenal. See Classical Translations.

'Kappa.' LET YOUTH BUT KNOW : A Plea for Reason in Education. Cr. $8 v 0$. 35. 6 d. net.

Kaufmann (M.), M.A. SOCIALISM AND MODERN THOUGHT. Second Edition Revised and Enlarged. Cr. 8vo. 2s. 6d. net.

Keats (John). THE POEMS. Edited with Introduction and Notes by E. de SÉLINCOURT, M.A. With a Frontispiece in Photogravure. Second Edition Revised. Demy 8vo. 7s. 6d, net.

REALMS OF GOLD. Selections from the Works of. Fcap. 8vo. 35. 6d net.

See also Little Library and Standard Library.

Keble (John). THE CHRISTIAN YEAR. With an Introduction and Notes by W. LOCK, D.D., Warden of Keble College. Illustrated by R. Anning Bell. Third Edition. Ficap. 8v0. 3s. $6 d$.; padded morocco, 5 s. See also Library of Devotion.

Kelynack (T. N.), M.D., M.R.C.P. See New Library of Medicine.

Kempls (Thomas d). THE IMITATION OF CHRIST. With an Introduction by Dean Farrar. Illustrated by C. M. Gere. Third Edition. Ficap.8v0. 3s. 6d.; padded morocco. 5 s.

Also Translated by C. BiGg, D.D. Cr. 8vo. 3s. $6 d$.

See also Montmorency (J. E. G. de). Library of Devotion, and Standard Library.

Kennedy (James Houghton), D.D., Assistant Lecturer in Divinity in the University of Dublin. See St. Paul.

Kerr (S. ParnelI). GEORGE SELWYN AND THE WITS. With 16 Illustrations. Demy 8vo. 12s. 6d. net.

Kimmins (C. W.), M.A. THE CHEMIS TRY OF LIFE AND HEALTH. Illns. trated. Cr. 8vo. 2s. $6 d$.

Kinglake (A. W.). See Little Library.

Kipling (Rudyard). BARRACK-ROOM BALLADS. 9rth Thousand. Tzuentysixth Edition. Cr. 8vo. 6s. Also Fcap. $8 v 0$, Leather. 55.

THE SEVEN SEAS. 79th Thousand. Fifteenth Edition. Cr. 8vo. 6s. Also Fcap. 8vo, Leather. 55.

THE FIVE NATIONS. 66th Thousand. Fifth Edition. Cr. 8vo. 6s. Also Ficap. 8vo, Leather. 5 s.

DEPARTMENTAL DITTIES. Seventeenth Edition. Cr. 8vo. 6s. Also Fcap. 8vo, Leather. 55.

Knight (Albert E.). THE COMPLETE CRICKETER. With 5o Illustrations. Demy 8vo. 7s. 6d. net.

Knowling (R. J.), M.A., Professor of New Testament Exegesis at King's College, London. See Westminster Commentaries. 
Knox (Winlfred F.). THE COURT OF A SAINT. With r6 Illustrations. Demy $8 v 0$. ros. $6 d$. net.

Kropotkin (Prince). THE TERROR IN RUSSIA. Seventh Edition. Cr. Svo. $2 d$. net.

Laboulaye (Edouard). See Simplified French Texts.

Lamb (Charles and Mary), THE WORKS. Edited by E. V. LuCAS. Illustrated. In Seven Volumes. Demy 8vo. 7s.6d.each.

See also Little Library and Lucas (E. V.)

Lambert (F. A. H.). See Little Guides.

Lambros (Professor S. P.). See Byzantine Texts.

Lane-Poole (Stanley). A HISTORY OF EGYPT IN THE MIDDLE AGES. With ror Illustrations and a Map. Cr. 8vo. $6 s$.

Langbridge(F.), M.A. BALLADSOF THE BRAVE: Poems of Chivalry, Enterprise, Courage, and Constancy. Third Edition. Cr. 8vo. 2s. 6d.

Lankester (Slr E. Ray), K.C.B., F.R.S. SCIENCE FROM AN EASY CHAIR. With many Illustrations, of which 2 are in Colour. Cr. 8vo. 6s.

Law (William). See Library of Devotion and Standard Library.

Leach (Henry). THE SPIRIT OF THE LINKS. $\mathrm{Cr} .800 .6 s$.

See also Braid (James).

Le Braz (Anatole). THE LAND OF PARDONS. Translated by Frances $M$. Gostring. With 12 Illustrations in Colour by T. C. GoTCH, and 40 other Illustrations. Third Edition. Crown 8vo. 6s.

Lees (Beatrice). See Six Ages of European History.

Lees (Frederick). A SUMMER IN TOURAINE. With I2 Illustrations in Colour by Maxwell Armfield, and 87 from Photographs. Also a Map. Second Edition. Demy 8vo. ros. 6d. net.

Lehmann(R. C.), M.P. THE COM PLETE OARSMAN. With 59 Illustrations. Demy 8vo. ros. $6 d$. net.

Lewes (V. B.), M.A. AIR AND WATER. Illustrated. Cr. 8vo. 2s. $6 d$.

Lewis (B. M. Gwyn). A CONCISE HANDBOOK OF GARDEN SHRUBS. With 20 Illustrations. Fcap. 8 vo. $3^{\text {s. } 6 \text { d, net. }}$

Lindsay (Lady Mabel). ANN1 DOMINI : A Gospel Study. In Two Volumes. Super Royal 8vo. ros. net.

Lindsay (W. M.), Fellow of Jesus College, Oxford. See Plautus.

Lisle (Fortunéede). See Little Bookson Art.

Littlehales (H.). See Antiquary's Books.

Llewellyn (Owen) and Raven-Hill (L.). THE SOUTH-BOUND CAR. With 85 Illustrations. Crown 8vo. 6s.

Lock (Walter), D.D., Warden of Keble College. ST. PAUL, THE MASTERBUILDER. Second Ed. Cr. 8vo. 3s. $6 d$. THE BIBLE AND CHRISTIAN LIFE. Cr. 8vo. 6s.

See also Keble (J.) and Leaders of Religion.
Locker (F.). See Little Library.

Lodge (Sir oliver), F.R.S. THE SUB STANCE OF FAITH, ALLIED WITH SCIENCE: A Catechism for Parents and Teachers. Ninth Ed. Cr.8vo. 2s net.

MAN AND THE UNIVERSE: A STUDY OF THE INFLUENCE OF THE ADVANCE IN SCIENTIFIC KNOWLEDGE UPON OUR UNDERSTANDING OF CHRIsTIANITY. Sixth Edition. Demy 8vo. 7s. 6d. net.

*THE SURVIVAL OF MAN : A STUDY OF Unrecognised Human Faculty. Demy 8vo. 7s, 6d. net.

Lodge (Eleanor C.). See Six Ages of European History.

Lofthouse (W. F.), M.A. ETHICS AND ATONEMENT. With a Frontispiece. Demy 8vo. 5s. net.

Longfellow (H. W.). See Little Library.

Lorimer (George Horace). LETTERS FROM A SELF-MADE MERCHANT TO HISSON. Seventeenth Edition. Cr. 8v0. 3s. $6 d$.

OLD GORGON GRAHAM. Second Edition. Cr. 8vo. 6s.

* Lorimer (Norma). BY THE WATERS OF EGYPT. With 12 Illustrations in Colour by BENTON Fletcher, and other Illustrations. Demy 8vo. r6s, net.

Lover (Samuel). See 1.P.L.

Lucas (E. V.). THE LIFE OF CHARLES LAMB. With 28 Illustrations. Fourth and Revised Edition in One Volume. Demy 800 . $7 s, 6 d$. net.

A WANDERER IN HOLLAND. With 20 Illustrations in Colour by HeRBert Marshalt, 34 Illustrations after old Dutch Masters, and a Map. Ninth Edition. Cr. 8vo. $6 s$.

A WANDERER IN LONDON. With $x 6$ Illustrations in Colour by NELSON DAwson, 36 other Illustrations and a Map. Seventh Edition. Cr. 8vo. 6s.

A WANDERER IN PARIS. With 16 Illustrations in Colour by Waltre Dexter, and 32 from Photographs after Old Masters. Second Edition. Cr. 8vo. 6s.

THE OPEN ROAD : a Little Book for Wayfarers. Fifteenth Edition. Fcap. 8v0. 5s.; India Paper, 7 s. $6 d$.

THE FRIENDLY TOWN : a Little Book for the Urbane. Fourth Edition. Fcap. 8vo. 5s.; India Paper, 7s. $6 d$.

FIRESIDE AND SUNSHINE. Fourth Edition. Ficap. 8vo. 5 s.

CHARACTER AND COMEDY. Fourth Edition. Fcap. 8vo. 55 .

THE GENTLEST ART. A Choice of Letters by Entertaining Hands. Fifth Edition. Fcap. 8vo. 5s.

A SWAN AND HER FRIENDS. With 24 Illustrations. Demy 8vo. 12s. $6 d$. net.

HER IN FINITE VARIETY : A FEMININE Portrait Galcery. Fourth Edition. Fcap. 8vo. 5 s.

LISTENER'S LURE: AN OBLIOUE NARRATION. Fifth Edition. Fcap. 8vo. 5 s. 
*goOd COMPaNY: A Rally of MEN. Ficap. 8vo. $5 s$.

ONE DAY AND ANOTHER: A VOLUME OF ESSAYS. Fcap. 8vo. $5 s$.

OVER BEMERTON'S: AN EASY-GoING Chronicle, Sixth Edition. Ficap.8vo. 5 s. net.

See also Lamb (Charles).

uuclan. See Classical Translations.

Lyde (L. W.), M.A. See Commercial Series.

Lydon (Noel S.) A PRELIMINARY GEOMETRY. With numerous Diagrams.

Cr. 8vo. Is.

See also Junior School Books.

Lyttelton (Hon. Mrs. A.). WOMEN AND THEIR WORK, Cr. 8vo. 2s. 6d.

M. (R.) THE THOUGHTS OF LUCIA HALIDAY. With some of her Letters. Edited by R. M. Fcap. 8vo. 2s. 6d. net.

Macaulay (Lord). CRITICAL AND HISTOR ICAL ESSAYS. Edited by F. C. MONTAGUE, M.A. Three Volumes. Cr. 8vo. 18 s.

M'Allen (J. E. B.), M.A. See Commercial Series.

McCabe (Joseph) (formerly Very Rev. F. ANTONY, O.S.F.). THE DECAY OF THE CHURCH OF ROME. Demy 8vo. 7s, 6d. net.

MacCunn (Florence A.). M A R Y STUART. With 44 Illustrations, in cluding a Frontispiece in Photogravure. New and Cheaper Edition. Large Cr. 8vo. 6s.

See also Leaders of Religion.

McDermott (B. R.). See Books on Business.

McDougall (William), M.A. (Oxon., M.B. (Cantab.). AN INTRODUCTION TO SOCIAL PSYCHOLOGY. Cr.8vo. 5s.net. $M$ 'Dowall(A.S.). See Oxford Biographies.

MacFie (Ronald C.), M.A., M.B. See New Library of Medicine.

Mackay (A. M.), B.A. 'See Churchman's Library.

Mackenzie (W. Leslie), M.A. M.D., D.P.H., etc. THE HEALTH OF THE SCHOOL CHILD. Cr. 8vo. 2s. $6 d$.

Macklln (Herbert W.), M.A. See Antiquary's Books.

M'Neile (A. H.), B.D. See Westminster Commentaries.

'Mdlle Morl' (Author of). ST. CATHERINE OF SIENA AND HER TIMES. With 28 Illustrations. Second Edition. Demy 8vo. 7s. 6d. net.

Maeterlinck (Maurice). THE BLUE BIRD: A Fairy Play in Five Acts. Translated by Alexander Teixera DE Matros. Second Edition. Fcap. $8 v 0$. Deckle Edges. $3 s .6$ d. net.

Magnus (Laurie), M.A. A PRIMER OF WORDSWORTH. Cr. 8vo. 2s. $6 d$.

Mahaffy (J. P.), Litt.D. A HISTORY OF THE EGYPT OF THE PTOLEMIES. With 70 Illustrations. $C r .8 v 0$. $6 s$.

Maitland (F. W.), M.A., LL.D. ROMAN CANON LAW IN THE CHURCH OF ENGLAND. Royal 8vo. 7s. 6d.

Major(H), B.A., B.Sc. A HEALTH AND
TEMPERANCE READER. Cr. 8vo. Is.

Malden (H. E.), M.A. ENGLISH RE. CORDS. A Companion to the History of England. Cr. 8vo. 3s. $6 d$.

THE RIGHTS AND DUTIES OF A CITIZEN. Seventh Editiox. Cr. 8vo. Is. $6 d$.

See also School Histories.

Marchant (E. C.), M.A., Fellow of Peterhouse, Cambridge. A GREEK ANTHO. LOGY SecondEdition. Cr. 8vo. 3s.6d. See also Cook (A. M.).

Marett (R. R.), M.A., Fellow and Tutor of Exeter College, Oxford. THE THRESHOLD OF RELIGION. $\mathrm{Cr}$. 8vo. $35.6 d$ net.

Marks (Jeannette), M.A. ENGLISH PASTORAL DRAMA from the Restoration to the date of the publication of the 'Lyrical Ballads' (1660-1798). Cr. 8vo. 5s. net.

Marr (J. E.) F.R.S., Fellow of St John's College, Cambridge. THE SCIENTIFIC STUDY OF SCENERY. Third Edition. Revised. Illustrated. Cr. 8zo. 6s.

AGRICULTURAL GEOLOGY. Illustrated. Cr. 8vo. 6s.

Marriott (Charles). A SPANISH HOLIDAY. With 8 Illustrations by $A$. M. FOWERAKER, R.B.A., and 22 other Illustrations. Demy 8vo. 7s. 6d. net.

Marriott (J. A. R.), M.A. THE LIFE AND TIMES OF LORD FALKLAND. Witb 23 Illustrations. Second Edition. Demy $8 v 0$. 7s. 6d. net.

See also Six Ages of European History.

Marvell (Andrew). See Little Library.

Masefield (John). SEA LIFE IN NEL. SON'S TIME. With I6 lllustrations. $\mathrm{Cr}$. 8710. 3s. 6d. net.

ON THE SPANISH MAIN: or, SOME ENGLISH FORAYS IN THE ISThMUS OF Darien. With 22 Illustrations and a Map. Demy 8vo. Ios. 6 d. net.

A SAILOR'S GARLAND. Selected and Edited by. Second Ed. Cr. 8vo. 3s.6d. net. AN ENGLISH PROSE MISCELLANY. Selected and Edited by. Cr. 8vo. $6 s$.

Maskell (A.). See Connoisseur's Library.

Mason (A. J.), D.D. See Leaders of Religion.

Masterman (C. F. G.), M.A., M.P. TENNYSON Á A' RELIGIOUS TEACHER. Cr. 8vo. 6s.

THE CONDITION OF ENGLAND. Second Edition. Cr. 8vo. 6s.

Masterman (J. H. B.), M.A. See Six Ages of European History.

Matheson (E. F.). COUNSELS OF LIFE. Feap. 8vo. 2s. 6d. net.

Maude (J. H.), M.A. See Handbooks of English Church History.

May (Phil). THE PHIL MAY ALBUM. Second Edition. 4 to. Is. net.

Mayne (Ethel Colburn). ENCHANTERS OF MEN. With 24 Illustrations. Demy 8vo. Ios. 6d. net. 
Meakin (Annette M. B.), Fellow of the Anthropological Institute. WOMIAN IN TRANSITION. Cr. 8vo. $6 s$.

Galicia: The Switzerland of Spain. With ro5 Illustrations and a Map. Demy 800 . 12s. 6. net.

* Medley (D. J.), M.A., Professor of History in the University of Glasgow. ORIGINAL ILIUSTRATIONSOF ENGLISH CON. STITUTIONAL HISTORY, COMPRISING A Selected NuMber OP THE Chref Charters and Statutes, Cr.800. 7s.6d. net.

Mellows (Emma S.). A SHORT STORY OF ENGLISH LITERATURE. Cr. 8vo. 3s. 6 .

Mérimée (P.). See Simplified French Texts.

Methuen (A. M. S.), M.A. T H E TRAGEDY OF SOUTH AFRICA. Cr. 8vo. 2s. net. Also Cr. 8vo. 3d. net.

ENGLAND'S RUIN : DISCUSSED IN FOURteen LetTers to a Protectionist. Ninth Edition. Cr. 8vo. 3d. net.

Meynell (Everard). CORO' AND HIS FRIENDS. With 28 Illustrations. Demy $8 v 0$ ros. 6 d. net.

Miles (Eustace), M.A. LIFE AFTER LIFE: OR, THE THEORY OF REINCARNATion. Cr. 8vo. 2s. 6d. net.

THE POWER OF CONCENTRATION : How to ACQU1RE IT. Third Edition. Cr. 800.35 .6 . net.

Millais (j. G.). THE LIFE AND LET. TERS OF SIR JOHN EVERETT MI LIAIS, President of the Royal Academy. With many Illustrations, of which 2 are in Photogravure. New Edition. Demy $8 v 0$. 7s. 6d. net. See also Little Galleries.

Milln (G. P.). PICTORIAL GARDENING. With 2r Illustrations. Crown $8 v o$. 3s. 6 d. net.

Millis (C. T.), M.I.M.E. See Textbooks of Technology.

Milne (J. G.), M.A. A HISTORY OF EGYPT UNDER ROMAN RULE. With 143 Illustrations. $C r .820$. $6 s$.

Milton (John). A DAY BOOK OF MILTON. Edited by R. F. TOWNDROw. Ficap. 8vo. 2s. $6 d$. net.

See also Little Library and Standard Library.

Minchin (H. C.),M.A. See Peel (R.).

Mitchell(P. Chalmers), M.A. OUTLINES OF BIOLOGY. With 74 Illustrations. Second Edition. Cr. 8vo. 6s.

Mitton (G. E.). JANE AUSTEN AND HER TIMES. With 21 Illustrations. Second and Cheaper Edition. Large Cr. $8 \pi 0$. $6 s$.

Moffat (Mary M.), QUEEN LOUISA OF PRUSSIA. With 20 Illustrations. Fourth Edition. Crown 8vo. 6s.

Moil (A.). See Books on Business.

Moir (D. M.). See Little Library.

Molinos (Dr. Michael de), See Library of Devotion.

Money (L. G. Chiozza), M.P. RICHES
AND POVERTY. Eighth Edition 'Demy 8vo. 5s. net. Also $\mathrm{Cr}$. 8vo. is. net.

Montagu (Henry), Earl of Manchester. See Library of Devotion.

Montaigne. A DAY BOOK OF. Edited by C. F. Pond. Fcap. 8vo. 2s. 6d. net.

Montgomery (H. B.) THE EMPIRE OF THE EAST. With a Frontispiece in Colour and 18 other Illustrations. Second Edition. Demy 8\%o. 7s. 6d. net.

Montmorency (J. E. G. de), B.A., LL.P. THOMAS A KEMPIS, HIS AGE AND BOOK. With 22 Illustrations. Second Edition. Demy 8vo. 7s.6d. net.

Moore (H. E.). BACK TO THE LAND. Cr. 8 vo. 2s. $6 d$.

*Moore (T. Sturge). ART AND LIFE. lllustrated Cr. 8vo. 5s. net.

Moorhouse (E. Hallam). NELSON'S LADY HAMILTON. With $5 x$ Portraits. Second Edition. Demy 8vo. 7s. 6d. net.

Moran(Clarence G.). See Books on Business. More (Sir Thomas). See Standard Library. Morfill (W. R.), Uriel College, Oxford, A HISTORY OF RUSSIA FROM PETER THE GREAT TO ALEXANDER II. With I 2 Maps and Plans. Cr. 8vo. 3s. 6d.

Morich (R. J.). See School Examination Series.

Morley (Margaret W.), Founded on. THE BEE PEOPLE. With 74 Illustrations. Sq. Crown 8vo. 2s. $6 d$.

LITTLE MITCHELL: THE STORY OF A Mountain SQutrRel told by Himself. Witb 26 Illustrations. Sg. Cr. 8vo. $2 s .6 d$.

Morris (J.). THE MAKERS OF JAPAN. With 24 lllustrations. Demy 8vo. r2s. $6 d$. net.

Morris (Joseph E.). See Little Guides.

Morton (A. Anderson). See Brodrick(M.).

Moule (H. C. G.), D.D., Lord Bishop of Dur-

ham. See Leaders of Religion.

Muir (M. M. Pattison), M.A. THE CHEMISTRY OF FIRE. Illustrated. Cr. 8vo. 2s, 6d.

Mundella (V. A.), M.A. See Dunn (J. T.). Munro(R.), M.A., LL.D. See Antiquary's Books.

Musset (Alfred de). See Simplified French Text.

Myers (A. Walls), THE COMPLETE LAWN TENNIS PLAYER. With 90 Illustrations. Second Edition. Demy8vo. ros. 6 d. net.

Naval Officer (A). See I. P. L.

Newman (Ernest). See New Library of Music.

Newman (George), M.D., D.P.H.,F.R.S.E。 See New Library of Medicine.

Newman (J. H.) and others. See Library of Devotion.

Newsholme (Arthur), M.D., F.R.C.P. See New Library of Medicine.

Nichols (Bowyer). See Little Library.

Nicklin (T.), M.A. EXAMINATION PAPERSIN THUCYDIDES. Cr. 8vo. $2 s$.

Nimrod. See I. P. L.

Norgate (G. Le Grys). THE LIFE OF 


\section{General Literature}

SIR WALTER SCOTT. With 53 Illustrations by JENNYWYLIE Demy 8vo. 7s.6d. net.

Norway (A. H.). NAPLES. PAST AND Present. With 25 Coloured Illustrations by MaURice GReiffenhagen. Third Edition, Cr. 8ro. 6s.

Novalis. THE DISCIPLES AT SAIS AND OTHER Fragments. Edited by Miss UNA Birch. Fcap. 8vo. 3s. 6d. net.

Officer (An). See I. P. L.

Oldfield (W. J.), M.A., Prebendary of Lincoln. A PRIMER OF RELIGION. Based on the CATEChism of the ChURCh of England. Crozen 8vo. 2s. $6 d$.

Otdham (F. M.), B.A. See Textbooks of Science.

Oliphant (Mrs.). See Leaders of Religion.

Ollver, Thomas, M.D. See New Library of Medicine.

Oman(C. W. C.), M. A., Fellow of All Souls' Oxford. A HISTORY OF THE ART OF WAR IN THE MIDDLE AGES. Illustrated. Demy 8vo, Ios. 6a'. net.

ENGLAND BEFORE THE CONQUEST. With Maps. Demy $8 v 0$. ros. $6 d$. ret. Oppé (A. P.). See Classics of Art.

Ottley (R. L.), D.D. See Handbooks of Theology and Leaders of Religion.

Overton (J. H.). See Leaders of Religion.

Owen (Douglas). See Books on Business.

Oxford (M. N.), ofGuy's Hospital. A HAND. BOOK OF NURSING. Fifth Edition. Cr. 8vo. 3s. $6 d$.

Pakes (W. c. c.). THE SCIENCE OF HYGIENE. Illustrated. Demy 8vo. I5s.

Parker (Eric). THE BOOK OF THE ZOO; BY DAY AND Night. With 24 Illustrations from Photographs by HENRY IRving. Cr. 8vo. 6s.

Parker (Gilbert), M.P. A L O V E R'S DIARY. Fcap. 8vo. 5 s.

Parkes (A. K.). SMALL LESSONS ON GREAT TRUTHS. Fcap. 8vo. Is. $6 d$.

Parkinson (John). PARADISI IN SOLE PARADISUS TERRESTRIS, OR A GARDEN OF ALL SORTS OF PLEASANT FLOWERS. Folio. $£_{3}$, zs. net.

Parsons (Mrs. C.). GAR RICK AND HIS CIRCLE. With 36 Illustrations. Second Edition. Demy 8vo. 32s. 6 d. net.

THE INCOM PARABLE SIDDONS. With 20 Illustrations. Demy 8vo. 32s. 6 d. net.

Pascal. See Library of Devotion.

Paston (George). SOCIAL CARICATURE IN THE EIGHTEENTH CENTURY. With 214 Illustrations. Imperial Quarto. L2, $^{2} 2 \mathrm{~s}, 6 \mathrm{~d}$. net.

LADY MARY WORTLEY MONTAGU AND HER TIMES With 24 Illustrations. Second Edition. Demy 8vo. 15 s. net.

See also Little Books on Art and I.P.L.

Patmore (K. A.). THE COURT OF LOUIS XIII. With I6 Illustrations. Demy 8vo. ros, $6 d_{\text {. net. }}$

Patterson (A. H.). NOTES OF AN EAST COAST NATURALIST. Illustrated in Colour by F. Southgate, R.B.A. Second Edition. Cr. 800. 6s.
NATURE IN EASTERN NORFOLK. With 12 Illustrations in Colour by FraNk Southgate, R.B.A. Second Edition. Cr. 8vo. $6 s$.

WILD LIFE ON A NORFOLK ESTU. ARY. With 40 Illustrations by the Author, and a Prefatory Note by Her Grace the Duchess OF BedFord. Demy $8 v 0$. ros. $6 d$. net.

*MAN AND NATURE ON TIDAL WATERS. With Illustrations by the Author. Cr. 8vo. 6s.

Peacock (Netta). See Little Books on Art.

Peake (C. M. A.), F.R.H.S. A CON CISE HANDBOOK OF GARDEN ANNUAL AND BIENNIAL PLANTS. With 24 Illustrations. Fcap. 8vo. 3s. 6d. net. Peel (Robert), and Minchin (H. C.), M. A. OXFORD. With 100 Illustrations in Colour. Cr. 8vo. 6s.

Peel (Sidney), late Fellow of Trinity College, Oxford, and Secretary to the Royal Commission on the Licensing Laws. PRACTI. CAL LICENSING REFORM. Seconc Edition. Cr. 8zo. Is. $6 d$.

Pentin (Herbert), M.A. See Library of Devotion.

Petrie(W.M.Flinders), D.C. L., LL.D., Professor of Egyptology at University College. A HISTORY OF EGYPT. Fully Illustrated. In six volumes. Cr. 8vo. 6s, each.

Vol. 1. From the EARLIEST Kings TO XVITH Dynasty. Sixth Edition.

VOL. 1I. THE XVIITH AND XVIIITH Dynasties. Fourth Edition.

Voi. III. XIXTh to XXXTh Dynasties.

VOL. IV. EgYrT UNDER THE PTOLEMAIC DYNASTY. J, P. MAHAFFY, Litt. D.

Vol. v. EGYPT UNDER ROMAN RULE. J.G. MILNE, M.A.

Vol. Yi. EgYPT IN THE MIDDLE AGES. Stanley Lanf.-Poole, M.A.

RELIGION AND CONSCIENCE IN ANCIENT EGYPT. Lectures delivered at University College, London. Illustrated. Cr. 8vo. 2s. $6 d$.

SYRIA AND EGYPT, FROM THE TELI EL AMARNA LETTERS. Cr. 8vo, 2s. $6 d$

EGYPTIAN TALES. Translated from the Papyri. First Series, rvth to Xuth Dynasty. Edited by W. M. Flinders Petrie. Illustrated by TrISTRaM ELLIS. Second Edition. Cr. 8vo. 3s. 6 d.

EGYPTIAN TALES. Translated from the Papyri. Second Series. Xvinth to XIxth Dynasty. Illustrated by Tristram Elis. Crown 8vo. 3s. $6 d$.

EGYPTIAN DECORATIVE ART. A Course of Lectures delivered at the Royal Institution. Illustrated. Cr. 8vo. 3.s. $6 d$.

Phillips (W. A.). See Oxford Biographies.

Phillpotts (Eden). MY DEVON YEAR. With $3^{8}$ Illustrations by J. LEY PETHYBRIDGE. Second and Cheaper Edition. Large Cr. 8vo. Es.

UP - ALONG AND DOWN - ALONG. Illustrated by CLAUDE SHEPPERSON. Cr. 4 to. 5s. net. 
Phythlan (J. Ernest). TREES IN NATURE, MYTH, AND ART. With 24 Illustrations. Cronen 8vo. $6 s$.

Plarr (VIctor G.). M.A. See School Histories.

Plato. See Standard Library.

Plautus. THE CAPTIVI. Edited, with an Introduction, Textual Notes, and a Commentary, by W. M. Lindsay, Fellow of Jesus College, Oxford. Demy 8vo. ros.6d.net.

Plowden-Wardlaw (J. T.), B.A. See School Examination Series.

Podmore (Frank). MODERN SPIRITUALISM. Two Volumes. Demy 8vo. 2rs. net.

MESMERISM AND CHRISTIAN SCIENCE: A Short History of Mental Healing. Demy 8vo. ros. $6 \%$. net.

Pollard (Alice). See Little Books on Art.

Pollard (Alfred W.). THE SHAKESPEARE'S FOLIOS AND QUARTOS. With numerous Facsimiles. Folio. One Guinea net.

Pollard(Eliza F.). See Little Books on Art. Pollock (David), M.I.N.A. See Books on Business.

Potter (M. C.), M.A., F.L.S. A N ELEMENTARY TEXT-BOOK OF AGRICULTURAL BOTANY. Illustrated. Third Edition. Cr. 8vo. 4s. 6 d.

Power (J. O'Connor). THE MAKING OF AN ORATOR. Cr. 8vo. 6s.

Price (Eleanor C.). A PRINCESS OF THE OLD WORLD. With 2I Illustrations. Demy 8vo. r2s. 6d. net.

Price (L. L.), M.A., Fellow of Oriel College, Oxon. A HISTORY OF ENGLISH POLITICAL ECONOMY FROM ADAM SMITH TO ARNOLD TOYNBEE. Fifth Edition. Cr. 8vo. 2s. $6 d$.

Protheroe (Ernest). THE DOMINION OF MAN. GEOGRAPHY IN JTS HUMAN Aspect. With 32 full-page Illustrations. Second Edition. Cr.8vo. 2s.

Psellus. See Byzantine Texts.

Pullen-Burry (B.). IN A GERMAN COLONY; or, FouR WERKS IN NEW BRITAIN. With 8 Illustrations and 2 Maps. Cr. 8vo. 5s. net.

Pycraft (w. P.). BIRD LIFE. With 2 Illustrations in Colour by G. E. LONGE, and others from Drawings and Photographs. Demy 8vo. ros. 6d. ret.

'Q' (A. T. Quiller Couch). THE GOLDEN POMP. A Procession of ENGLISH LYRICS FROM SURREY TO SHIRLEY. Second and Cheaper Edition. Cr. 8vo. 2s. 6 d, net.

G. R. and E. S. MR. WOODHOUSE'S CORRESPONDENCE. Cr.8vo. 6s. Also published in a Colonial Edition.

Rackham (R. B.), M.A. See Westminster Commentaries.

Ragg (Laura M.). THE WOMEN ARTISTS OF BOLOGNA. With 20 Illastrations. Demy 8vo. 7s. 6d. net.

Ragg (Lonsdale). B.D., Oxon. DANTE
AND HIS ITALY. With 32 Illnstrations. Demy $8 v 0$. res. 6d. net.

Rahtz (F. J.), M.A., B.Sc. HIGHER ENGLISH. Fourth Edition. Cr. $8 v 0$. 3s. $6 d$.

JUNIOR ENGLISH. Second Edition. $\mathrm{Cr}$. 8vo. rs. $6 d$.

Randolph (B. W.), D.D. See Library of Devotion.

Rannie (D. W.), M.A. A STUDENT'S HISTORY OF SCOTLAND. Cr.800, 3s. $6 d$. WORDSWORTH AND HIS CIRCLE With 20 Illustrations. Demy 8vo. 12s. $6 d$. net.

Rashdall (Hastings), M.A., Fellow and Tutor of New College, Oxford. DOCTRINE AND DEVELOPMENT. $C r$. 8vo. 6s.

Raven (J. J.), D.D., F.S.A. See Antiquary's Books.

Raven - Hill (L.). See Llewellyn (Owen).

Rawlings (Gertrude Burford). COINS AND HOW TO KNOW THEM. With 206 Illustrations. Second Edition. Cr. 8vo. 6s.

Rawstorne (Lawrence, Esq.). See I.P.I. Raymond (Walter). See School Histories. Rea (Lillan). THE LIFE AND TIMES OF MARIE MADELEINE COUNTESS OF LA FAYETTE. With 20 Illustrations. Demy 8vo. ros. 6d. net.

Read (C. Stanford), M.B. (Lond.), M.R.C.S. L.R.C.P. FADS AND FEEDING. $C r$. 8vo. 2s. $6 d$.

Real Paddy (A). See I.P.I.

Reason (W.), M.A. UNIYERSITY AND SOCIAL SETTLEMENTS. Edited by Cr. 8vo. 2s. 6d.

Redpath (H. A.), M.A., D.Litt. See Westminster Commentaries.

Rees (J. D.), C.I.E., M.P. THE REAL INDIA. Second Edition. Demy 800. ros. 6d. net.

Reich (EmII), Doctor Juris. WOM A N THROUGH THE AGES. With 36 Illus trations. Two Volumes. Demy 8vo. 2rs, net. Reynolds (Sir Joshua). See Little Galleries. Rhodes (W. E.). See School Histories.

Ricketts (Charles). See Classics of Art.

Richardson (Charles). THECOMPLETE FOXHUNTER. With 46 Illustrations, of which 4 are in Colour. Second Edition. Demy 800. 12s. 6d. net.

Rlchmond (Wilfrid), Chaplain of Lincoln's Inn. THE CREED IN THE EPISTLES. Cr. 8vo. 2s. 6d. net.

Riehl(W. H.). See Simplified German Texts. Roberts (M. E.). See Channer (C. C.).

Robertson (A.), D.D., Lord Bishop of Exeter. REGNUM DEI. (The Bampton Lectures of rgor). A New and Cheaper Edition. Demy 8vo. 7s. 6d. net.

Robertson (C. Grant). M.A., Fellow of All Souls' College, Oxford. SELECT STATUTES, CASES, AND CONSTI. TUTIONAL DOCUMENTS, $1660-1832$. Demy 8vo. Ios. $6 d$. net. 
Robertson (C. Grant) and Bartholomew (J. G.), F.R.S.E., F.R.G.S. A HIS. TORICAL AND MODERN ATLAS OF THE BRITISH EMPIRE. Demy Quarto. 4s. 6 d. net.

Robertson(Sir G. S.), K.C.S.I. CHITRAL: THE STORY OF A MiNOR Siege. With 8 Illustrations. Third Edition. Demy 8vo. Ios, $6 d$. net.

Robinson (Cecilia). THE MINISTRY OF DEACONESSES. With an Introduc. tion by the late Archbishop of Canterbury. Cr. 8vo. 3s. 6d.

Roblnson (F, S.). See Connoisseur's Library.

Rochefoucauld (La). See Little Library.

Rodwell (G.), B.A. NEW TESTAMENT GREEK. A Course for Beginners. With a Preface by Walter Lock, D.D., Warden of Kehle College. Fcap. 8vo. 3s, $6 d$.

Roe (Fred), OLD OAK F URNITURE. With many Illustrations by the Author, including a frontispiece in colour. Second Edition. Demy 8vo. Ios. fid. net.

Rogers (A. G. L.), M.A. See Books on Business.

Roland. See Simplified French Texts.

Romney (George). See Little Galleries.

Roscoe (E. S.). See Little Guides.

Rose (Edward). THE ROSE READER. Illustrated. Cr. 8vo. 2s. 6d. Also in 4 Parts. Parts I. and II. 6d. each; Part III. 8d. Part IV. rod.

Rose (G. H.). See Hey (H.) and BaringGould (S).

Rowntree (Joshua). THE IMPERIAL DRUG TRADE. A RE-STATEMENT OF THE OPIUM QUESTION. Third Edition Revised. Cr. 8vo. 2s, net.

Royde-Smith (N. G.). THE PILLOW BOOK: A GARNER OF MANY MOODS. Collected by. Second Edition. Cr. 8vo. $4 s .6$. net.

POETS OF OUR DAY. Selected, with an Introduction, by. Fcap. 8vo. 55.

Ruble (A. E.), D.D. See Junior School Books.

Rumbold (The Right Hon. 5 Sir Horace). Bart., G. C. B. G. C. M. G. TH E AUSTRIAN COURT IN THE NINETEENTH CENTURY. With I6 Illus. trations. Demy 8vo. I8s. net.

Russell (Archibald O. B.). See Blake (William.)

Russell (W. Clark). THE LIFE OF ADMIRAL LORD COLLINGWOOD. With 12 Illustrations by F. BRANGWYN. Fourth Edition. Cr. 8vo. 6 s.

Ryiey (M. Beresford). QUEENS OF THE RENAISSANCE. With 24 Illustrations. Demy 8vo. Ios. $6 d$. ret.

Sainsbury (Harrington), M.D. F.R.C.P. PRI NCI PIA THERAPEUTICA. Demy 8vo. 7s. 6 d. net. See also New Library of Medicine.

St. Anselm. See Library of Devotion.

St. Augustine. See Library of Devotion.

St. Bernard. See Library of Devotion.
St. Cyres (Viscount) See Oxford Biographies.

St. Francis of Assisi. THE LITTLE FLOWERS OF THE GLORIOUS MESSER, AND OF HIS FRIARS. Done into English, with Notes by WILLIaM Heywood. With 40 Illustrations from Italian Painters. Demy 8vo. 5s. net.

See also Library of Devotion and Standard Library.

St. Francis de Sales. See Library of Devotion.

St. James. See Churchman's Bible and Westminster Commentaries.

St. Luke. See Junior School Books.

St. Mark. See Junior School Books and Churchman's Bible.

St. Matthew. See Junior School Books.

St. Paul. SECOND AND THIRD EPISTLES OF PAUL THE APOSTLE TO THE CORINTHIANS. Edited by JAMES Houghton Kennedy, D.D., Assistant Lecturer in Divinity in the University of Dublin. With Introduction, Dissertations, and Notes by J. Schmitr. Cr. 8z:o. 6s. See also Churchman'sj Bible and Westminster Commentaries.

'Sakl' (H. Munro). REGINALD. Second Edition. Ficap. 8vo. 2s. 6d. net.

Salmon (A. L.). See Little Guides.

Sanders (Lioyd). THE H OLL A N D HOUSE CIRCLE. With 24 Illustrations. Secord Edition. Demy 8vo. 12s. 6d. net. Sathas (C.). See Byzantine Texts.

Schmitt (John). See Byzantine Texts.

Schofield (A. T.), M.D., Hon. Phys. Freidenham Hospital. See New Library of Medicine.

Scudamore (Cyril). See Little Guides.

Scupoli (Dom. L.). See Library of Devotion.

Ségur (Madame de). See Simplified French Texts.

Sélincourt (E. de.) See Keats (John).

Séllncourt (Hugh de). GREAT RALEGH With I 6 Illustrations. Demy $8 v 0$. ros. $6 d$. net.

Sells (V. P.), M.A. THE MECHANICS OF DAILY LIFE. Illustrated. Cr. 8vo. 2s. 6 d.

Selous (Edmund). TOMMY SMITH'S ANIMALS. Illustrated by G. W. ORD. Eleventh Edition. Fcap. 8vo. 2s. 6d. School Edition, Is. 6 d.

TOMMY SMITH'S OTHER ANIMALS Illustrated by Augusta Guest. Fifth Edition. Fcap. 8vo. 25 6d.

School Edition, 1s. 6d.

Senter (George), B.Sc. (Lond.), Ph.D. See Textbooks of Science.

Shakespeare (William)

THE FOUR FOLIOS, $1623 ; 2632 ; 166_{4}$;

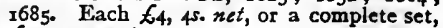
fi2, 12s. net.

Folios 2, 3 and 4 are ready.

THE POEMS OF WILLIAM SHAKESPEARE. With an Introduction and Notes 
by George Wyndham. Demy 8vo. Buck. ram, gilt top, 10s. $6 d$.

See also Arden Shakespeare, Standard Library and Little Quarto Shakespeare.

Sharp (A.). VICTORIAN POETS. $\mathrm{Cr}$. 8vo. 2s. $6 d$.

Sharp (Cecil). See Baring-Gould (S.).

Sharp (Ellzabeth). See Little Books on Art.

Shedlock (J. S.) THE PIANOFORTE SONATA. Cr. 8vo. $5^{5}$.

Shelley (Percy B.). See Standard Library.

Sheppard (H. F.), M.A. See Baring. Gould (S.)

Sherwell (Arthur), M.A. LIFE IN WEST LONDON. Third Edition. Cr. $8 v 0$. 2s. $6 d$.

Shipley (Mary E.). AN ENGLISH CHURCH HISTORY FOR CHILD. REN. With a Preface by the Bishop of Gibraitar. With Maps and Illustrations. Cr. 8vo. Each part 2s. 6d. net.

ParT I.-To the Norman Conquest.

PART II.-To the Reformation.

Sichel (Walter). See Oxford Biographies.

Sidgwick (Mrs. Alfred). HOME LIFE IN GERMANY. With 16 Illustrations. Second Edition. Demy 8vo. ros. 6 d. net.

Sime (John). See Little Books on Art.

Simonson (G. A.). FRA N C ESCO GUARDI. With 4I Plates. Imperial 4to. $\ell_{2}, 2 s$. net.

Sketchley (R. E. D.). See Little Books on Art.

Skipton (H. P. K.). See Little Books on Art.

Sladen (Douglas). SICILY: The New Winter Resort. With over 200 Illustrations. Second Edition. Cr. 8vo. 5s. net.

Smallwood (M. G.). See Little Books on Art.

Smedley (F. E.). See I.P.L.

Smith (Adam). THE WEALTH OF NATIONS. Edited with an Introduction and numerous Notes by EDwin CanNan, M.A. Trvo volumes. Demy 8vo. 21s. net. Smith (H. Bompas), M.A. A N E W JUNIOR ARITHMETIC. Crown 8vo. Without Answers, 2s. With Answers, 2s. $6 d$. Smith (H. Clifford). See Connoisseur's Library.

Smith (Horace and James). See Little Library.

Smith (R. Mudie). THOUGHTS FOR THE DAY. Edited by. Fcap. 8vo. 3s. $6 d$. net.

Smith (Nowell C.). See Wordsworth (W).

Smith (John Thomas). A BOOK FOR

A RAINY DAY: Or, Recollections of the Events of the Years r766-r833. Edited by WiLfred WhitTen. Illustrated. Wide Demy 8vo. 12s. 6d. net.

Snell (F. J.). A BOOK OF EXMOOR. Illustrated. $\mathrm{Cr} .8 v 0$. $6 s$.

Snowden (c. E.). A HANDY DIGEST OF BRITISH HISTORY. Demy 8vo. 4s. $6 d$. Sophocles. See Classical Translations.

Sornet (L. A.), and Acatos (M. J.) See Junior School Books.

\section{Southey (R.). ENGLISH SEAMEN} Edited by David Hannay.

Vol. I. (Howard, Clifford, Hawkins, Drake, Cavendish). Second Edition. Cr. 820. 6s.

Vol. ir. (Richard Hawkins, Grenville, Essex, and Raleigh). Cr. 8vo. 6s.

See also Standard Library.

Souvestre (E.). See Simplified French Texts. Spence (C. H.), M.A. See School Examina. tion Series.

Spicer (A. Dykes), M.A. THE PAPER TRADE. A Descriptive and Historical Survey. With Diagrams and Plans. Demy 8vo. 12s. 6d. net.

Spooner (W. A.), M.A. See Leaders of Religion.

Spragge (W. Horton), M.A. See Junior School Books.

Staley (Edgcumbe). THE GUILDS OF FLORENCE. Illustrated. Second Edition. Royal 8vo. 16s. net.

Stanbridge (J. W.), B.D. See Library of Devotion.

'Stancliffe'. GOLF DO'S AND DONT'S. Second Edition. Fcap. 8vo. Is.

Stead (D. W.). See Gallaher (D.).

Stedman (A. M. M.), M.A.

INITIA LATINA : Easy Lessons on Elementary Accidence. Eleventh Edition. Fcap. 8vo. Is.

FIRST LATIN LESSONS. Eleventh Edition. Cr. 8vo. 2s.

FIRST LATIN READER. With Notes adapted to the Shorter Latin Primer and Vocabulary. Seventh Edition. $18 \mathrm{mo}$. Is. $6 d$.

EASY SELECTIONS FROM CASAR. The Helvetian War, Fourth Edition. r8mo. rs.

EASY SELECTIONS FROM LIVY. The Kings of Rome. Second Edition. r $8 \mathrm{mo}$. Is. 6 d.

EASY LATIN PASSAGES FOR UNSEEN TRANSLATION. Twelfth Ed. Ficap. 8v0. Is. 6d.

EXEMPLA LATINA. First Exercises in Latin Accidence. With Vocabulary. Fourth Edition. Cr. 8vo. Is.

EASY LATIN EXERCISES ON THE SYNTAX OF THE SHORTER AND REVISED LATIN PRIMER. With Vocabulary. Twelfth Edition. Cr. $8 v 0$. Is. $6 d$. KEV, 3s. net.

THE LATIN COMPOUND SENTENCE: Rules and Exercises. Second Edition. Cr. 8vo. 1s. 6d. With Vocabulary. 2s.

NOTANDA QUAEDAM : Miscellaneous Latin Exercises on Common Rules and Idioms. Fifth Edition. Ficap. 8vo. rs. 6d. With Vocabulary. 2s. KEY, 2s. net.

LATIN VOCABULLARIES FOR REPETITION: Arranged according to Subjects. Sixteenth Edition. Fcap. 8vo. Is. $6 d$.

A VOCABULARY OF LATIN IDIOMS. I8mo. Fourth Edition. $\mathrm{rs}$. 


\section{GENERAL LITERATURE}

STEPS TO GREEK. Fourth Edition. $18 \mathrm{mo}$. Is.

A SHORTER GREEK PRIMER. Third Edition. Cr. 8vo. 1s. 6 d.

EASY GREEK PASSAGES FOR UNSEEN TRANSLATION, Fourth Edition, re. vised. Ficap. 8vo. Is. $6 d$.

GREEK VOCABULARIES FOR REPETITION. Arranged according to Subjects. Fourth Edition. Ficap. 8vo is 6 .

GREEK TESTAMENT SELECTIONS For the use of Schools. With Introduction, Notes, and Vocabulary. Fourth Edition. Fcap. 8vo. 2s. $6 d$.

STEPS TO FRENCH. Ninth Edition. 18 mo. $8 d$.

FIRST FRENCH LESSONS. Winth Edition. Cr. 8vo. 15.

EASY FRENCH PASSAGES FOR UN. SEEN TRANSLATION, Sixth Edition. Ficap. 8vo. Is. 6 d.

EASY FRENCH EXERCISES ON ELEMENTARY SYNTAX. With Vocabulary. Fourth Edition. Cr. 8vo. 2s. 6d. KEY. 3s. net.

FRENCH VOCABULARIES FOR RE. PETITION : Arranged according to Subjects. Fourteenth Edition. Fcap. 8vo. Is. See also Scbool Examination Series.

Steel (R. Elliott), M.A., F.C.S. THE WORLD OF SCIENCE. With 147 Illustrations. Second Edition. Cr. 8vo. 2s. 6 d. See also School Examination Series.

Stephenson (C.), of the Technical College, Bradford, and Suddards (F.) of tbe Yorkshire College, Leeds. A TEXTBOOK DEALING WITH ORNAMENTAL DESIGN FOR WOVEN FABRICS. With 66 full-page Plates and numerous Diagrams in the Text. Third Edition. Demy 8vo. 7 s. $6 d$.

Sterne (Laurence). See Little Library.

Steuart (Katherine). BY ALLA N WATER. Second Edition. Cr. 8vo. 6s.

RICHARD KENNOWAY AND HIS FRIENDS. A Sequel to 'By Allan Water.' Demy 8vo. 7s.6d. net.

Stevenson (R. L.) THE LETTERS OF ROBERT LOUIS STEVENSON TO HIS FAMILY AND FRIENDS. Selected and Edited by SiDNey Colvin. Eighth Edition. 2 vols. Cr. 8vo. $12 s$.

VAILIMA LETTERS. With. an Etched Portrait by William Strang. Seventh Edition. Cr. 8vo. Buckram. 6s.

THE LIFE OF R. L. STEVENSON See Balfour (G.).

Stevenson (M. 1.). FROM SARANAC TO THE MARQUESAS. Being Letters written by Mrs. M. I. Stevenson during 1887-88. Cr. 8vo. 6s. net.

LETTERS FROM SAMOA, 1891-95. Edited and arranged by $M$. C. BALFour With many lllustrations. Second Edition $\mathrm{Cr}$. 8vo. 6s. net.

Stoddart (Anna M.). See Oxford Biographies.
Stokes (F. G.), B.A. HOURS WITH RABELAIS. From the translation of SiR T. Urquhart and P. A. Motteux. With a Portrait in Photogravure. Cr. 8vo. 3s. $6 d$. net.

Stone (S. J.). POEMS AND HYMNS With a Memoir by F. G. Ellerton, M.A. With Portrait. Cr. 8vo. $6 s$.

Storr (Vernon F.), M.A., Canon of Winchester. DEVELOPMENT AND DIVINE PURPOSE Cr. 8vo. 5s. net.

Story (Alfred T.). A M E R I C A N SHRINES IN ENGLAND. With 4 IIlustrations in Colour, and 19 other Illustrations. Crown 8vo. 6s.

See also Little Guides.

Straker (F.). See Books on Business.

Streane (A. W.), D.D. See Churchman's Bible.

Streatfeild (R, A.). MODERN MUSIC AND MUSICIANS. With 24 Illustrations. SecondEd. Demy 8vo. 7s. 6 d. net. See also New Library of Music.

Stroud (Henry), D.Sc., M.A. ELEMEN TARY PRACTICAL PHYSICS. With II5 Diagrams. Second Edit., revised. Cr. 8vo. 4s. $6 d$.

Sturch (P.), Staff Instructor to the Surrey County Council. MANUAL TRAINING DRAWING (WOODWORK). With Solutions to Examination Questions, Orthographic, Isometric and Oblique Projection. With 50 Plates and 140 Figures. Foolscap. 5s. net.

Suddards (F.). See Stephenson (C.).

Surtees (R. S.). See I.P.L.

Sutherland (William). OLD AGE PEN. SIONS IN THEORY AND PRACTICE, WITH SOME FOREIGN EXAMPLES. Cr. 8vo. 3s. 6 d. net.

*Swanton (E. W.), Member of the British Mycological Society. FUNGI AND HOW TO KNOW THEM. With 16 Coloured Plates by M. K. SpitTal, and 32 Black and White Plates. Cr. $8 v 0$. 5s. net.

Symes (J. E.), M.A. THE FRENCH REVOLUTION. SecondEdition. Cr.8vo. 2s. 6 d.

Sympson (E. Mansel), M.A., M.D. See Ancient Cities.

Tabor (Margaret E.). THE SAINTS IN ART. With 20 Illustrations. Fcap. 8vo. 3s. 6 d. net.

Tacitus. AGRICOLA. Edited by R. F. Davis, M.A. Cr. 8vo. 25.

GERMANIA. By the same Editor. $C r$. 8vo. 2s. See also Classical Translatuons.

Tallack(W.). HOWARD LETTERS AND MEMORIES. Demy 8vo. ros. 6 d. net.

Tatham (Frederick). See Blake (William).

Tauler (J.). See Library of Devotion.

Taylor (A. E.). THE ELEMENTS OF METAPHYSICS. Second Edition. Demy 8vo. Ios. 6 d. net.

Taylor (F. G.), M.A. See Commercial Series. Taylor (I. A.). See Oxford Biographies. 
Taylor (John W.). THE COMING OF THE SAINTS. With 26 Illustrations. Demy 8vo. 7s. 6d. net.

Taylor (T. M.), M.A., Fellow of Gonville and Caius College, Cambridge. A CONSTITUTIONAL AND POLITICAL HISTORY OF. ROME. To the Reign of Domitian. Cr. 8vo. 7s, 6d.

Teasdale-Buckell ( $\boldsymbol{\sigma}_{\text {. T. }}$ ). THE COMPLETE SHOT. With 53 Illustrations. Third Edition. Demy 8vo. 12s. 6d. net.

Tennyson (Alfred, Lord). EARLY POEMS. Edited, with Notes and an Introduction, by J. Churton Collins, M.A. Cr. 8vo. 6s.

IN MEMORIAM, MAUD, AND THE PRINCESS. Edited by J. Churton Collins, M.A. Cr. 8vo. 6s.

See also Little Library.

Terry (C. S.). See Oxford Biographies.

Terry (f.' j.), B.A. ELEMENTARY LATIN. Cr. 8vo. 2s.

TEACHER'S HANDBOOK TO ELEMENTARY LA'TIN. Containing the necessary supplementary matter to Pupil's edition. Cr. 8vo. 3s. 6 d. net.

Thackeray (W. M.). See Little Library.

Theobald (F. V.), M.A. INSECT. LIFE. Illustrated. Second Edition Revised. Cr. 8vo. 2s. $6 d$.

Thibaudeau (A. C.). BONAPARTE AND THE CONSULATE. Translated and Edited by G. K. ForTesoue, LL.D. With I2 Illustrations. Demy $8 v 0$. Ios. 6 d. net.

Thompson (A. H.). See Little Guides.

Thompson (Francis). S E L E C T E D POEMS OF FRANCIS THOMPSON. With a Biographical Note by Wilfrid Meynel. With a Portrait in Photogravure. Second Edition. Fcap. 8vo. 5s. net.

Thompson (A. P.). See Textbooks of Tecbnology.

*Thomson (J. M.), Fenow and Dean of Divinity of Magdalen College, Oxford. JESUS ACCORDING TO ST. MARK Cr. 8vo. $5 s$.

Tileston (Mary W.). DAILY STRENGTH FOR DAILY NEEDS. Sixteenth Edition. Medium I6mo. 2s. 6d. net. Also an edition in superior binding, $6 \mathrm{~s}$.

Tompkins (H. W.), F.R.H.S. See Little Books on Art and Little Guides.

Toynbee (Paget), M.A., D.Litt. IN THE FOOTPRINTS OF DANTE. A Trea sury of Verse and Prose from the works of Dante. Small Cr. $8 v o$. 4s.6d. net.

DANTE IN ENGLISH LITERATURE: FROM CHAUCER TO CARY. Two vols. Demy $8 v 0$. 21s. net.

See also Oxford Biographies and Dante.

Tozer (Basil). THE HORSE IN HISTORY. With 25 Illustrations. Cr. 8vo. 6s.

Tremayne (Eleanor E.). See Romantic History.

Trench (Herbert). DEIRDRE WEDDED, AND OTHER POEMs. Second and Revised Edition. Large Post 8vo. 6s.
NEW POEMS. Second Edition. Large Post 800.65

APOLLO AND THE SEAMAN. Large Post 8vo. Paper, is. 6d. net; cloth, 2s $6 d$. net.

Trevelyan (G. M.), Fellow of Trinity College, Cambridge. ENGLAND UNDER THE STUARTS. With Maps and Plans. Third Edition. Demy 8va. ros. 6d. net.

ENGLISH LIFE THREE HUNDRED YEARS AGO : Being the first two chapters of England under the Stuarts. Edited by J. TuRral, B.A.. Cr. $8 v 0$ is.

Triggs (Inigo H.), A.R.I.B.A. TOWN PLA N N I G : PAST, PRESEMT, AND Possible. With r73 Illustrations. Wide Royal 8vo. I5s. net.

Troutbeck (G. E.). See Little Guides.

Tyler (B. A.), B.A., F.C.S. See Junior School Books.

Tyrrell-Gill (Frances). See Little Books on Art. .

Unwin (George). See Antiquary's Books.

Vardon (Harry). THE COM PLETE GOLFER. With 63 Illustrations. Tenth Edition. Demy 8vo. ros. 6 d. net.

Vaughan (Henry). See Little Library.

Vaughan (Herbert M.), B.A. (Oxon.). THE LAST OF THE ROYAL STUARTS, HENRY STUART, CARDINAL, DUKE OF YORK. With oo Illustrations Second Edition. Demy 8vo. ros. 6d. net.

THE MEDICI POPES (LEO X AND CLEMENT VII. With 20 Illustrations. Demy 8vo. I5s. net.

THE NAPLES RIVIERA. With 25 Illus trations in Colour by MAURICE GREIFFENHAGEN. Second Edition. Cr. 8vo, 6s.

Vernon (Hon. W. Warren), M.A. READINGS ON THE INFERNO OF DANTE. With an Introduction by the Rev. Dr. MOORE. In Two Volumes. Second Edition. Cr. 8 vo. 15 s. net.

READINGS ON THE PURGATORIO OF DANTE. With an Introduction by the late DEAN ChURCH. In Two Volumes. Third Edition. Cr. 8vo. I 5s, net.

READINGS ON THE PARADISO OF DANTE. With an Introduction by the Bishop of Ripon. In Two Volumes. Second Edition. Cr. 8vo. I ss. net.

Vincent (J. E.). THROUGH EAST ANGLIA IN A MOTOR CAR. With 16 Illustrations in Colour by FrANK South. GATE, R.B.A., and a Map. Cr. 8vo. 6s.

Voegelin (A.), M.A. See Junior Examination Series.

WaddelI (Col. L. A.), LL.D., C.B. LHASA AND ITS MYSTERIES. 'With a Record of the Expedition of 1903-1904. With 155 Illustrations and Maps. Third and Cheaper Edition. Medium 8vo. 7s. 6d. net. Wade (G. W.), D.D. OLD TESTAMENT HISTORY. With Maps. Sixth Edition. Cr. 8vo. $6 s$.

Wade (G. W.), D.D., and Wade (J. H.), M.A. See Little Guides.

Wagner (Richard). RICHARD WAG. 
NER'S MUSIC DRAMAS: Interpretations, embodying Wagner's own explanations. By Alice leighton Cleather and Basil Crump. In Three Volumes. Fcap 8vo. 2s. 6d. each.

Vol. I.-THE RiNG OF the Nibelung. Third Edition.

Vol. 1t. - PARSiFal, LOHENGRIN, and The Holy Grail.

Vol. III. - TRISTAN AND ISOLDE.

Waineman (Paul). A SUMMER TOUR IN FINLAND. With $x 6$ Illustrations in Colour by Alexander FederLey, 16 other Illustrations and a Map. Demy 8vo. sos. 6 d. net.

Walkley (A. B.). DRAMA AND LIFE. Cr. $820.6 s$.

Wall (J. C.). See Antiquary's Books.

Wallace-Hadrill (F.), Second Master at Herne Bay College. REVISION NOTES ON ENGLISH HISTORY. Cr. 8vo. $1 . s$.

Walters (H. B.). See Little Books on Art and Classics of Art.

Walton (F. W. M.A. See School Histories.

Walton (Izaak) and Cotton (Charles). See I.P.L. and Little Library.

Waterbouse (Elizabeth). WITH THE SIMPLE-HEARTED : Little Homilies to Women in Country Places. Second Edition. Small Pott 8vo. 2s. net.

COMPANIONS OF THE WAY. Being Selections for Morning and Evening Read. ing. Chosen and arranged by ELizABETH WATERhouse. Large Cr. 8vo. 5s. net.

THOUGHTS OF A TERTIARY. Small Pott 8vo. Is. net.

See also Little Library.

Watt (Francis). See Henderson (T. F.)

Weatherbead (T. C.), M.A. EXAMINATION PAPERS IN HORACE. Cr. 8vo.2s. See also Junior Examination Series.

*Webb (George W.), B.A. A SYSTEM. ATIC GEOGRAPHY OF THE BRITISH ISLES. With Maps and Diagrams. $C r$. 8vo. Is.

Webber (F. C.). See Textbooks of Technology.

*Weigall (Arthur E. p.). A GUIDE TO THE ANTIQUITIES OF UPPER EGYPT: From Abydos to the Sudan Frontier. With 67 Maps, and Plans. Cr. 8vo. 7s. 6d. net.

Weir (Archibald), M.A. AN INTRO. DUCTION TO'THE HISTORY OF MODERN EUROPE. Cr. 8vo. $6 s$.

Welch (Catharine). THE L I T T E DAUPHIN. With 16 Illustrations. $C r$. 8vo. $6 s$.

Wells (Sidney H.) See Textbooks of Science.

Wells (J.), M.A., Fellow and Tutor of Wadham College. OXFORD AND OXFORD LIFE. Third Edition. Cr. 8vo 3s.6d.

A SHORT HISTORY OF ROME. Ninth Edition. With 3 Maps. Cr. 8vo. $3^{s .6 d}$. See also Little Guides.

Wesley (John). See Library of Devotion

Westell (W. Perclval). THE YOUNG NATURALIST. With 8 Coloured Plates by C. F. Newall, and many other Illustrations. Cr. Evo. 6s.

Westell (W. Perclval), F.L.S., M.B.O.U. and Cooper (C. S) F.R.H.S. THE YOUNG BOTANIST. With 8 Coloured and $6_{3}$ Black and White Plates drawn from Nature, by C. F. Newall. Cr. 8vo. $35.6 d$. net.

Whibley (C.). See Henley (W. E.).

Whibley (L.), M.A., Fellow of Pembroke College, Cambridge. GREEK OLIGARCHIES : THEIR ORGANISATION AND CHARACTER. Cr. $8 v o .6 s$.

White (Eustace E.). THE COMPLETE HOCKEY PLAYER. With 32 Illustrations. Secord Edition. Demy 8vo. 5s. net. White (George F.) Lient.-Col. A CENTURY OF SPAIN AND PORTUGAL. Demy 8vo. 12s. 6d. net.

White (Gllbert). See Standard Library.

Whitfleld (E. E.), M.A. See Commercial Series.

Whitehead (A, W.). GAS P ARD DE COLIG N $\mathbf{Y}$, ADMIRAL OF FRANCE. With 26 Illustrations and ro Maps and Plans. Demy 8vo. 12s. 6.. net.

Whiteley (R. Lloyd), F.I.C., Principal of the Municipal Science School, West Bromwich. AN ELEMENTARY TEXTBOOK OF INORGANICCHEMISTRY. Cr. 8vo. 2s. 6d.

Whitley (Miss). See Dilke (Lady).

Whitilng (Miss L..), late Staff Teacher of the National Training School of Cookery. THE COMPLETE COOK. With 42 Illustrations. Demy 8vo. $75,6 d$. net.

Whitten (W.). See Smith (John Thomas).

Whyte (A, G.), B.Sc. See Books on Business.

Wilberforce (Wilfrid). See Little Books on Art.

Wilde (Oscar). DE PROFUNDIS. Twelfth Edition. Cr. 8vo. 5s. ret.

THE WORKS OF OSCAR WILDE. In 12 Volumes. Ficap. 8vo. 5s. ret each volume.

I. The Duchess of Padua. II. Lady WINDERMERE'S FAN. III. A WOMAN OF No Importance. 1V. ThE IMPORTANCE OF BEING Earnest. v. AN IDEAL HusBAND. vi. DE PROFUNDIS and Prison LETTERS, VII. INTENTIONS, VIU. ESSAYS. 1X. A House of Pomegranates. $X$. LORD ARTHUR Savile's Crime and the Portratt of Mr. W. H. XI. POEMS. xir. Salome, a Florentine Tragedy, and La Sainte Courtisane

Wilkins (W. H.), B.A. THE ALIEN INVASION. Cr. 8vo. 2s. $6 d$.

Williams (H. Noel). T H E WO M E N BONAPARTES. The Mother and three Sisters of Napoleon. With 36 Illustrations. In Tzuo Volumes Demy 8vo. 24s net.

A ROSE OF SAVOY : Marie AdelétDe of SAYoY, DUChESSE DE BOURGoGNe, MOTHER oF Louis xv. With a Frontispiece in Photogtavure and 16 other Illustrations. Demy 8vo. I5s. net. 
Villiams (A.) PETROL PETER: or Pretty Stories and Funny Pictures. Illustrated in Colour by A. W. Mills. Demy 4to. 3s. 6 d. net.

Williamson (M. O.)., M.A. See Ancient Cities.

Williamson (W.), B.A. See Junior Examination Series, Junior School Books, and Beginner's Books.

Wilmot-Buxton (E. M.), F. R. Hist. S. MAKERS OF EUROPE. Outlines of European History for the Middle Forms of Schools. With 12 Maps. Tenth Edition. Cr. 8vo. 3s. $6 d$.

THE ANCIENT WORLD. With Maps and Illustrations. $C r .8 v o$. 3s. $6 d$.

A BOOK OF NOBLE WOMEN. With x6 Illustrations. Cr. 8vo. 3s. $6 d$.

A HISTORY OF GREAT BRITAIN : FROM THE COMING OF THE ANGLes TO THE YEAR 1870 . With 20 Maps. Cr. 8vo. $3 s .6 d$. See also Beginner's Books and $\mathrm{New}$ Historical Series.

Wlison(Bishop.). See Library of Devotion.

Wllson (A. J.). See Books on Business.

Wilson (H. A.). See Books on Business.

Wilton (Rlchard), M.A. I Y R A PASTORALIS: Songs of Nature, Church, and Home. Pott 8vo. 2s. 6d.

Wlnbolt (S. E.), M.A. EXERCISES IN LATIN ACCIDENCE Cr. 8vo, Is. $6 d$.

LATIN HEXAMETER VERSE: An Aid to Composition. Cr. 8vo. 3s. $6 d$. KEv, 5s. net.

Windle (B. C. A.), D.Sc.,F.R.S., F.S.A. See Ant zquary's Books, Little Guides, Ancient Cities, and School Histories.

Wood (Slr Evelyn), F. M., V.C., G.C.B., G.C.M.G. FROM MIDSHIPMAN TO FIELD-MARSHAL. With Illustrations, and 29 Maps. Fifth and Cheaper Edition. Deny 8zo. 7s. 6d. net.

THE REVOLT IN HINDUSTAN. $1857-$ 59. With 8 Illustrations and 5 Maps. Second Edition. Cr. 8vo. $6 s$.

Wood (J. A. E.). See Textbooks of Technology.

Wood (J. Hickory). DAN LENO. Illustrated. Third Edition. Cr. 8vo. 6s.

Wood (W. Birkbeck), M.A., late Scholar of Worcester College, Oxford, and Edmonds (Major J. E.), R.E., D.A.Q.M.G. A HISTORY OF THE CIVIL WAR IN
THE UNITED STATES. With an Introduction by $\mathrm{H}$. SPENSER WILKINSON. With 24 Maps and Plans. Secord Edition. Demy 8vo. 12s. 6d. net.

Wordsworth (Chrlstopher), M.A. See Antiquary's Books.

Wordsworth (W.). THE POEMS OF. With an Introduction and Notes by Nowez. C. SMrTh, late Fellow of New College, Oxford. In Three Volumes. Demy 8vo. rs ret.

POEMS BY WILLIAM WORDSWORTH.

Selected with an Introduction by STOPFORD A. Brooke. With 40 Illustrations by $\mathbf{E}$. H. New, including a Frontispiece in Photogravure. Cr. 8vo. 7s. 6d. ret. See also Little Library.

Wordsworth (W.) and Coleridge (S. T.). See Little Library.

Wright (Arthur), D.D., Fellow of Queen's College, Cambridge. See Churchman's Library.

Wright (C. Gordon). See Dante.

Wright (J. C.). TO-DAY. Thoughts on Life for every day. Demy I6mo. Is. 6d. net.

Wright (Sophle). GERMAN VOCABU LARIES FOR REPETITION. Fcap. 8vo. Is. $6 d$.

Wyatt (Kate M.). See Gloag (M. R.).

Wylde (A. B.). MODERN ABYSSINIA. With a Map and a Portrait. Demy $8 v 0$. I5s. net.

Wyllie (M. A.). NORWAY AND ITS FJORDS. With 16 Illustrations, in Colour by W. L. WYLLIE, R.A., and 17 other Illustrations. Crowen 8vo. 6s.

Wyndham (George). See Shakespeare (William).

Yeats (W. B.). A BOOK OF IRISH VERSE. Revised and Enlarged Edition. Cr. 8vo. 3s. 6d.

Young (Filson). THE COM P LETE MOTORIST. With $x_{3} 8$ Illustrations. New Edition (Seventh), with many additions. Demy. 8vo. 12s. 6d. net.

THE JOY OF THE ROAD: An Appreciation of the Motor Car. With a Frontispiece in Photogravure. Small Demy 8vo. 55. net.

Zacharlah of Mitylene. See Byzantine Texts.

Zimmern (Antonia). WHAT DO WE KNOW CONCERNING ELECTRICITY? Fcap. 8vo. rs. 6d. net.

\section{Ancient Cities}

General Editor, B. C. A. WINDLE, D.Sc., F.R.S.

\section{Cr. 8vo. 4s. 6d. net.}

Bristor. - By Alfred Harvey, M.B. Illus- Edinburgh. By M. G. Williamson, M.A. trated by E. H. New.

Canterbury. By J. C. Cox, LL.D., F.S.A. Illustrated by B. C. Boulter.

Chester. By B. C. A. Windle, D.Sc. F.R.S. Illustrated by E. H. New.

Duslin. ByS.A. O. Fitzpatrick. Illustrated by W. C. Green.

Illustrated by Herbert Railton.

Lincols. By E. Mansel Sympson, M.A., M.D. Illustrated by E. H. New.

Shrewsbury. By T. Auden, M.A., F.S.A. Illustrated by Katharine $M$. Roberts

Wells and Glastonbury. ByT. S. Holmes. Illustrated by E. H. New. 


\section{General Literature}

\section{The Antiquary's Books}

\section{General Editor, J. CHARLES COX, LL.D., F.S.A}

\section{Demy 8vo. 7s. 6d. net.}

ARCHEOLOGY AND FALSE ANTIQUities. By R. Munro, LL.D. With 8 r Illustrations.

Bells of England, The. By Canon J. J. Raven, D.D., F.S.A. With 60 Illustrations. Second Edition.

Brasses of England, The. By Herbert W. Macklin, M.A. With 85 Illustrations. Second Edition.

Celtic Art in Pagan and Christian Times. By J. Romilly Allen, F.S.A. With 44 Plates and numerous Illustrations. Domesday Inquest, The. By Adolpbus Ballard, B.A., LL. B. With 27 Illustrations.

English Church Furniture. By J. C. Cox, LL.D., F.S.A., and A. Harvey, M.B. With I2x Illustrations. Second Edition.

ENGIISH Costume. From Prebistoric Times to the End of the Eighteenth Century. By George Clinch, F.G.S. With $1_{31}$ Illustrations.

English Monastic Life. By the Right Rev. Abbot Gasquet, O.S.B. With 50 Illustrations, Maps and Plans. Third Edition.

English Seals. By J. Harvey Bloom. With 93 Illustrations.
Folk-Lore as an Historical Science. By G. L. Gomme. With 28 Illustrations.

Gilds and Companies of London, The. By George Unwin. With 37 Illustrations.

Manor and Manorial Records, The. By Nathaniel J. Hone. With 54 Illustrations.

Medreyal Hospitals of England, The. By Rotba Mary Clay. With many Illus. trations.

OlD Service Books of the ENglish Church. By Christopher Wordsworth, M.A., and Henry Littlehales. With 38 Coloured and other Illustrations.

PaRish Life in Mediaval ENGland. By the Right Rev. Abbott Gasquet, O.S.B. With 39 Illustrations. Second Edition.

Remains of THE Prehistoric AGE IN England. By B. C. A. Windle, D.Sc., F.R.S. With 94 Illustrations. Second Edition.

Royal Forests of England, The. By J. C. Cox, LL.D., F.S.A. With 25 Plates and 23 other Illustrations.

Shrines of British Saints. By J. C. Wall. With 28 Plates and 50 other Illustrations.

\section{The Arden Shakespeare}

\section{Demy 8vo. 2s. 6d. net each volume.}

An edition of Shakespeare in single Plays. Edited with a full Introduction, Textual Notes, and a Commentary at the foot of the page.

All's Well That Ends Well, Edited by W. O. Brigstocke.

Antony and Cleopatra. Edited by R. H. Case.

Crmbeline. Edited by E. Dowden.

Comedy of Errors, The. Edited by Henry Cuningham.

Hamlet. Edited by E. Dowden. Second Edition.

Julius Cazsar. Edited by M. Macmillan.

King Henry y. Edited by $H$. A. Evans.

King Henry yı. PT. I. Edited by H. C. Hart.

KING Henry vi. Pt. Il. Edited by H. C. Hart and C. K. Pooler.

KING LeAR. Edited by W. J. Craig.

King Richard II. Edited by A. H. Thompson.

Life and Death of King John, The. Edited by Ivor B. John.

Love's LaBour's Lost. Edited by H. C. Hart.
* Macbeth. Edited by H. Cuningham.

Measure for Measure. Edited by H. C. Hart.

Merchant of Venice, The. Edited by C. K. Pooler.

Merry Wives of Windsor, The. Edited by H. C. Hart.

A Midsummer Night's Dream. Edited by H. Cuningham.

OThello. Fdited by H. C. Hart.

Pericles. Edited by K. Deighton.

Romeo AND JULIET. Edited by Edward Dowden.

Taming of. The Shrew, The. Edited by R. Warwick Bond.

Tempest, The. Edited by M. Luce.

Timon of Athens. Edited by K. Deighton.

Titus ANDronicus. Edited by $\mathrm{H}$. B. Baildon.

Trollus aNd Cressida. Edited by $K$. Deighton.

Two Gentlemen of Verona, The. Edited by R. W. Bond.

TwELFTH Night. Edited by M. Luce. 


\section{The Beginner's Books}

Edited by W. WILLIAMSON, B.A.

Easy Dictation and Spelling. By W. Williamson, B.A. Seventh Ed. Fcap.8vo. Is. EASY EXERC1SES IN AR1THMETIC. Arranged by W. S. Beard. Third Edition. Fcap. 8vo. Without Answers, 1s. With Answers. Is. $3 d$.

Easy French Rhymes. By Henri Blouet. Second Edition. Illustrated. Fcap. 8vo. is. AN EAsy PoETry Book. Selected and arranged by W. Williamson, B.A. Second Edition. Cr. 8vo. xs.

EASY STORIES FROM ENGLISH History. By E. M. Wilmot-Buxton, F.R.Hist.S. Fifth Edition. Cr. 8vo. Is.

A First History of Greece. By E. E. Firth. With 7 Maps. Cr. 8vo. xs. $6 d$.

Stories froN Roman History. By E. M. Wilmot-Buxton. Second Edition. Cr. $8 v 0$. Is. $6 d$.

Stories from the Old Trstament, By E. Wilmot-Buxton. Cr. $8 v 0$. Is. $6 d$.

\section{Books, on Business}

Cr. 8vo. 2s. 6d. net.

Automobile Industry, The. G. Holden-

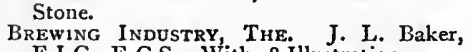
F.I.C., F.C.S. With 28 Illustrations.

Business of Advertising, The. C. G. Moran, With II Illustrations.

BusiNess SIDE OP AGRICULTURE, THE. A. G. L. Rogers.

Business of Insurance, The. A. J. Wilson.

Ciyit Engineering. C. T. Fidler. With 15 Illustrations.

Cotron Industry and Trade, The. S. J. Chapman. With 8 Illustrations.

The Electrical Industry: Lighting, Traction, and Power. A. G. Whyte,

iron Trade of Great Britain, The. J.

S. Jeans. With 12 Illustrations.

Law in Business. H. A. Wilson.

Mining and Mining Inyestments. A. Moil.

Money Market, The. F. Straker.

Monopolies, Trusts, and Kartells. F. W. Hirst.

Ports and Docks. Douglas Owen.

RaIlways. E. R. MicDerrmott.

Shipbuilding Industry The: Its History, Practice, Science, and Finance. David Pollock, M.I.N.A.

Stock Exchange, The. C. Duguid. Second Edition.

Trade Unions. G. Drage.

\section{Byzantine Texts}

Edited by J. B. BURY, M.A., Litt.D.

The Syriac Chronicle known as That of Zachariah of Mitylene. Translated by F. J. Hamilton, D.D., and E. W. Brooks. Demy 8vo. 12s. 6d. net.

Eyagrius. Edited by L. Bidez and Léon Parmentier. Demy 8vo. Ios. 6 d. net.

The History of Psellus. Edited by $C$. Satbas. Demy 8vo. x5s. net.

Ecthesis Chronica and Chronicon ATHENARUM. Edited by Professor S. P. Lambros. Demy 8vo. 7s. 6d. net.

The Chronicle of Morea. Edited by John Schmitt. Demy 8vo. I5s, net.

\section{The Churchman's Bible}

General Editor, J. H. BURN, B.D., F.R.S.E.

Fcap. 8vo. Is. 6d. net each.

The Epistie of St. Paul the Apostle ro
the Galatians. Explained by A. W. THE Galatians. Explained by
Robinson, M.A. Second Edition.

Ecclesiastes. Explained by A. W. Streane, D.D.

The Epistle of St. Padl the Apostle to The Philippians. Explained by C. R. D. Biggs, D.D. Second Edition.

The Epistle of St. James. Explained by H. W. Fulford M.A.

IsaIAH, Explained by W. E. Barnes, D.D. Truo Volumes. With Map. 2s. net each. The EPISTLE of ST. PAUl The A postle ro THE EPHESIANS. Explained by G. H. Whitaker, M.A.

ThB Gospel According to St. MARK. Explained by J. C. Du Buisson, M.A. 2s. 6 d. net.

The EPISTle of Paul the Apostle ro The Colossians and Philemon. Explained by H. J. C. Knight. 2s. net. 


\section{General Literature}

\section{The Churchman's Iibrary}

General Editor, J. H. BURN, B.D., F.R.S.E.

Crown 8vo. 3s. 6d. each.

The Begrnnings of English Christianity. By W. E. Collins, M.A. With Map.

ThE Churchman's InTroduction to ThF Ord Testament. By A. M. Mackay, B.A. Second Edition.

Evorution. By F. B. Jeyons, M.A., Litt.D.

Some New Testament Problems. By Artbur Wright, D.D. $6 s$.

The Workmanship of THe Prayer Book: Its Literary and Liturgical Aspects. By J. Dowden, D.D. Second Edition, Revised and Enlarged.

\section{Classical Translations}

Crowen 8 ro.

Aeschylus-The Oresteian Trilogy (Agamem- Horace-The Odes and Epodes. Translated non, Choëphoroe, Enmenides). Translated by Lewis Campbell, LL. D. 5 s.

CiCERo-De Oratore I. Translated by E. N. P. Moor, M.A. Second Edition. 3s. $6 d$.

Cicero-The Speeches against Cataline and Antony and for Murena and Milo. Translated by $H_{\text {. }} \mathrm{E}$. D. Blakiston, M.A. $5 s$.

Cicero-De Natura Deorum. Translated by F. Brooks, M.A. $3 s, 6 d$.

Cicre-De Officiis. Translated by G. B. Gardiner, M.A. 2s. $6 d$. by A. D. Godley, M.A. 2s.

Lucian-Six Dialogues Translated by S. T. Irwin, M.A. $3 s .6 d$.

SopHocLES-Ajax and Electra. Translated by E. D. Morshead, M.A. 2s. $6 d$.

TAcitus-Agricola and Germania. Translated by R. B. Townshend. 2s. $6 d$.

Juvenal-Thirteen Satires. Translated by S. G. Owen, M.A. $2 s .6 d$.

\section{Classics of Art}

\section{Edited by DR. J. H. W. LAING}

Wide Royal 8vo. Gilt top.

The Art of the Grezks. By H. B. Walters. Rubens. Edward Dillon, M.A. With a With 112 Plates and is Illustrations in the Text. 12s. 6d. net.

Florentine Sculptors of The RenNaisANCE. Wilhelm Bode, Ph.D. Translated by Jessie Haynes. With 94 Plates. 12s. 6d. net.

Ghirlandaio. Gerald S. Davies, Master of the Charterhouse. With 5o Plates. Second Edition. ros. $6 d$.

* Michelangrio. Gerald S. Davies, Master of the' Charterhouse. With I26 Plates. 12s. 6 d. net.

\section{Commercial Series}

\section{Crown 8 vo.}

British Commerce and Colonies from A Short Commercial Arithmetic. By F. Elizabeth to Victoria. By H. de B. Gibbins, Litt. D., M.A. Fourth Edition. $2 s$.

Commercial Examination Papers. By $\mathrm{H}$. de B. Gibbins, Litt.D., M.A. rs. $6 d$.

The Economics of Commerce, By $\mathrm{H}$. de B. Gibbins, Litt.D., M.A. Second Edition. Is. $6 d$.

A German Commercial Rrader. By S. E. Bally. With Vocabulary. $2 s$.

a Commercial Geography of the British EmpIRE. By L. W. Lyde, M.A. Seventh Edition. 2s.

A Commercial Geography of Foreign Nations. By F. C. Boon, B.A. 2s.

A Primer of Bosiness. By S. Jackson, M.A. Fourth Edition. Is. $6 d$. G. Taylor, M.A. Fourth Edition. 1s. $6 d$.

FrenCH COMMERcial CoRrespondence. By S. E. Bally. With Vocabulary. Fourth Edition. 2s.

German Commercial Corraspondence. By S. E. Bally. With Vocabulary. Secont Edition. 2s. $6 d$.

A French Commercial Reader. By S. E. Bally. With Vocabulary. Second Edition. 2s. PRECIS Writing and OfFice CorrespondENCR. By E. E. Whitfield, M.A. Second Edition. 2s.

An Entrance Guide to Professions and Business. By H. Jones. is. $6 d$.

The PrinCIPLes of BoOK-KEePING BY Double ENTRY. By J. E. B. M'Allen, M.A. $2 s$.

Commercial Law. By W. Douglas Edwards. Second Edition. $2 s$. 


\section{The Connoisseur's Library \\ Wide Royal 8vo. 25s. net.}

Mezzotints. By Cyril Davenport. With 40 European Enamels. By Henry. H. CunyngPlates in Photogravure.

PORCELAIN. By Edward Dillon. With xg Plates in Colour, 20 in Collotype, and 5 in Photogravure.

Miniatures. By Dudley Heath. With 9 Plates in Colour, $I_{5}$ in Collotype, and $I_{5}$ in Photogravure.

Ivories. By A. Maskell. With 80 Plates in Collotype and Photogravure.

ENGLish Furniture. By F. S. Robinson. With 160 Plates in Collotype and one in Photogravure. Second Edition.

ENGlish Coloured Books. By Martin Hardie. With 28 Illustrations in Colour and Collotype.

hame, C.B. With 54 Plates in Collotype and Half-tone and 4 Plates in Colour.

Goldsmiths' and Silyersmiths' Work. By Nelson Dawson. With 51 Plates in Collotype and a Frontispiece in Photogravure. Second Edition.

Glass: By Edward Dillon. With 37 Illustrations in Collotype and $x_{2}$ in Colour.

Seals. By Walter de Gray Birch. With 52 Illustrations in Collotype and a Frontispiece in Photogravure.

Jewellery. By H. Clifford Smith. With 50 Illustrations in Collotype, and 4 in Colour. Second Edition.

\section{Handbooks of English Church History}

Edited by J. H. BURN, B. D. Crown 8vo. 2s. $6 d$. net.

The Foundations of the English Church. The Mediaval Church and the Papacy J. H. Maude. \begin{tabular}{l|l} 
The Saxon Church and the Norman Con- & $\begin{array}{l}\text { *The Refrormation Period. By Henty } \\
\text { Gee. }\end{array}$ \\
Quest. C. T. Cruttwell. & By
\end{tabular}

\section{The Illustrated Pocket Library of Plain and Coloured Books}

\section{Fcap 8vo. 3s. 6d. net each volume.}

\section{COLOURED BOOKS}

Old Colonked Books. By George Paston. The History of Johnny Quak Genus : the With 16 Coloured Plates. Ficap. 8vo. 2s, net.

The Lire and Death of John MytTon, EsQ. By Nimrod. With 18 Coloured Plates by Henry Alken and T. J. Rawlins. Fourth Edition.

The Life of a Sportsman. By Nimrod. With 35 Coloured Plates by Henry Alken.

HaNDLEY Cross. By R. S. Surtees. With I7 Coloured Plates and roo Woodcuts in the Text by John Leech. Second Edition.

Mr. Sponge's Sporting Tour. By R. S. Surtees. With I $_{3}$ Coloured Plates and 90 Woodcuts in the Text by John Leech.

JorRocks' Jaunts and Jollities. By R. S. Surtees. With $x_{5}$ Coloured Plates by $\mathbf{H}$. Alken. Second Edition.

Ask Mamma. By R. S. Surtees. With I3 Coloured Plates and 70 Woodcuts in the Text by John Leech.

The Analysis of the Hunting Field. By R. S. Surtees. With 7 Coloured Plates by Henry Alken, and 43 Illustrations on Wood.

The Tour of Dr. Syntax in Search of the Picturesque. By William Combe. With 30 Coloured Plates by T. Rowlandson.

The Tour of Doctor Syntax in Search of Consolation. By William Combe. With 24 Coloured Plates by T. Rowlandson.

THE THIRD TOUR OF DOCTOR SYNTAX IN Search of a Wife. By William Combe. With 24 Coloured Plates by T. Rowlandson. Little Foundling of the late Dr. Syntax. By the Author of 'The Three Tours.' With 24 Coloured Plates by Rowlandson.

ThE ENGLISH DANCE OF DEATH, from the Designs of T. Rowlandson, with Metrical Illustrations by the Author of 'Doctor Syntax." Two Volumes.

This book contains 76 Coloured Plates.

The Dance of Life: A Poem. By the Author of 'Doctor Syntax.' Illustrated with 26 Coloured Engravings by T. Rowlandson.

Lire in LoNDoN: or, the Day and Night Scenes of Jerry Hawthorn, Esq., and his Elegant Friend, Corinthian Tom. By Pierce Egan. With 36 Coloured Plates by I. R. and G. Cruikshank. With numerous Designs on Wood.

REAL LIFE IN LONDON : or, the Rambles and Adventures of Bob Tallyho, Esq., and his Cousin, The Hon. Tom Dashall. By an Amateur(Pierce Egan). With 3 I Coloured Plates by Alken and Rowlandson, etc. Two Volumes.

The Life of AN Actor. By Pierce Egan. With 27 Coloured Plates by Theodore Lane, and several Designs on Wood.

THE VICAR OF WAKEFIELd. By Oliver Goldsmith. With 24 Coloured Plates by T. Rowlandson.

The Military Adventures of Johnny Newcome. By an Officer. With $x_{5}$ Coloured Plates by T. Rowlandson. 


\section{GenERAL Literature}

Il.lustrated Pocket Library of Plain and Coloured Books-continued.

The National. Sports of Great Britain. With Descriptions and 50 Coloured Plates by Henry Alken.

The Adyentures of a Post Captain. By A Naval Officer. With 24 Coloured Plates by Mr. Williams.

Gamonia : or, the Art of Preserving Game ; and an Improved Method of making Plantations and Covers, explained and illustrated by Lawrence Rawstorne, Esq. With 15 Coloured Plates by T. Rawlins.

An ACademy for Grown Horsemrn: Containing the completest Instructions for Walking, Trotting, Cantering, Galloping, Stumbling, and Tumbling. Illustrated with 27 Coloured Plates, and adorned with a Portrait of the Author. By Geoffrey Gambado, Esq.

\section{PIAIN BOOKS}

ThE Grave: A Poem. By Robert Blair. Illustrated by 12 Etchings executed by Louis Schiavonetti from the original Inventions of William Blake. With an Engraved Title Page and a Portrait of Blake by T. Phillips, R.A. The illustrations are reproduced in photogravure.

Ir.LuSTRATIONS OF THE BOOK OF Јов. Invented and engraved by William Blake.

These famous Illustrations $-2 I$ in number -are reproduced in photogravure.

Windsor Castle By W. Harrison Ainsworth. With 22 Plates and 87 Woodcuts in the Text by George Cruikshank.
REAL, LIFE IN IRELAND, or, the Day and Night Scenes of Brian Boru, Esq., and his Elegant Friend, Sir Shawn O'Dogherty. By a Real Paddy. With Ig Coloured Plates by Heath, Marks, etc.

The Adventures of JohnNy Newcome in THE NAvY. By Alfred Burton. With 16 Coloured Plates by T. Rowlandson.

The Old English Squire: A Poem. By John Careless, Esq. With 20 Coloured Plates after the style of T. Rowlandson.

The ENGLish Spy. By Bernard Blackmantle. An original Work, Characteristic, Satirical, Humorous, comprising scenes and sketches in every Rank of Society, being Portraits of the Illustrious, Eminent, Eccentric, and Notorious. With 72 Coloured Plates by R. Cruikshank, and many Illustrations on wood. Two Volumes. 7s. net.

ThE. Tower of London. By W. Harrison Ainsworth. With 40 Plates and 58 Woodcuts in the Text by George Cruikshank.

Frank Fairlegh. By F. E. Smedley. With 30 Plates by George Cruikshank.

HANDY ANDY. By Samuel Lover. With 24 Illustrations by the Author.

The COMPLeat ANGLer. By Izaak Walton and Charles Cotton. With $\mathrm{r}_{4}$ Plates and 77 Woodcuts in the Text.

The P1CKwick PApers. By Charles Dickens. With the 43 Illustrations by Seymour and Phiz, the two Buss Plates, and the 32 Con. temporary Onwhyn Plates.

\section{Junior Examination Series}

Edited by A. M. M. STEDMAN, M.A. Fcap. 8vo. Is.

Junior Algebra Examination Papers. By Junior Geography Examination Papers. S. W. Finn, M.A.

JunioR ARITHMETIC EXamination PAPERS. By W. S. Beard. Fifth Edition.

Jonior ENGLish Examination PAPERS. By W. Williamson, B.A. Seeond Edition.

Junior French Examination Papers. By Ju F. Jacob, M.A. Second Edition.

JUNIOR GENERAI. IN FORMATION EXAMINaTION PApers. By W. S. Beard. KEY, 3s. 6 d. net. By W. G. Baker, M.A.

Junior German Examination Papers. By A. Voegelin, M.A.

Junior GREEK Examination Papers. By T. C. Weatherhead, M.A. KEY, 3s. $6 d$. net. Junior Latin Examination Papers. By C. G. Botting, B.A. Sixth Edition. KEY, 3s. $6 d$. net.

* Junior History Examination Papers. By W. O. P. Davis.

\section{Methuen's Junior School-Books}

Edited by O. D. INSKIP, LL.D., and W. WILLIAMSON, B.A.

A Class-Book of Dictation Passages. By W. Williamson, B.A. Fourteenth Edition. Cr. 8v0. Is. $6 d$.

ThE Gospel ACCORding to St. MATTHEW. Edited by E. Wilton South, M.A. With Three Maps. Cr. $8 v 0$. rs. $6 d$.

The Gospel AccordingtoSt. Mark. Edited by A. E. Rubie, D.D. With Three Maps. Cr. 800 . 1s. $6 d$.

A Junior English Grammar. By W. William. son, B.A. With numerous passages for varsing and analysis, and a chapter on Essay Writing. Fourth Edition. Cr. 8vo. 2s.

A Junior Chemistry. By E. A. Tyler, B.A., F.C.S. With 78 Illustrations. Fourth Edition. Cr. 8vo. 2s. $6 d$.

The Acts of The Apostles. Edited by A. E. Rubie, D.D. Cr. $8 v o$. $2 s$. 
Methuen's Junior School Books-continued.

A Junior French Grammar. By L. A. The Gospel According to St. Luke. With Sornet and M. J. Acatos. Third Edition. Cr. 8vo. 2s.

Elementart Experimental Science. PhySics by W. T. Clough, A.R.C.Sc. (Lond.), F.C.S. CHemistry by A. E. Dunstan, B.Sc. (Lond.), F.C.S. With 2 Plates and I54 Diagrams. Seventh Edition. Cr.8zo. 2s. $6 d$.

A Junior Geometry. By Noel S. Lydon. With 276 Diagrams. Seventh Edition. Cr. 8vo. 25 .

Elementary Experimental Chemistry. By A. E. Dunstan, B.Sc. (Lond.), F.C.S. With 4 Plates and Iog Diagrams. Third Edition. Cr.8vo. $2 s$.

A Junior French Prose: By R. R. N. Baron, M.A. ThirdEdition. Cr.8vo. 2s. an Introduction and Notes by William Wiltiamson, B.A. With Three Maps. $\mathrm{Cr}$. 8vo. $2 s$.

The Fikst Book of Kings. Edited by A. E. Rubie, D.D. With \& Maps. Cr. 8vo. 2s.

A Junior Greek History. By W. H. Spragge, M.A. With 4 Illustrations and 5 Maps. Cr. 8vo. 2s. $6 d$.

A Schoor latin Grammar. By H. G. Ford, M.A. Cr. 8vo. 2s. 6d.

A Junior Latin Prose. By H. N. Asman, M.A., B.D. Cr. 8vo. 2s. $6 d$.

* Elem rentary Experimental Electricity AND Matinetism. By W. T. Clough, A.R.C.Sc. (Lond.), F.C.S. With 200 Illustrations and Diagrams. Cr. 8vo. 2s. 6d.

ENGI.ISE Litrerature For Schools. By Edith E. Firth. Cr. 8vo. 2s. $6 d$.

\section{Ieaders of Religion}

Edited by H. C. BEECHING, M.A., Canon of Westminster. With Portraits. Cr. 8vo. 2s. net.

Cardinal Newman. By R. H. Hutton. JoHn Wesley. By J. H. Overton, M.A. Bishop Wilberforce. By G. W. Daniell, M.A.

Cardinal Manning. By A. W. Hutton, M.A. Charles Simeon. By H. C. G. Moule, D.D. John Knox. By F. MacCunn. Second Edition. JoHN Howe. By R. F. Horton, D.D. Thomas Ken. By F. A. Clarke, M.A.

GEORGE FoX, THE QUAKER. ByT. Hodgkin, D.C.L. Third Edition.

JoHN KEBLE. By Walter Lock, D.D.
Thomas Chalmers. By Mrs. Oliphant. LANCELOT ANDREwES. By R. L. Ottley, D.D. Second Edition.

Augustink of Canterbury. By E...L. Cutts, D.D.

William Laud. By W. H. Hutton, M.A. Third Edition.

John Donne. By Augustus Jessopp, D.D.

Thomas Cranmer. By A. J. Mason, D.D.

Bishop Latimer. By R. M. Carlyle and A. J. Carlyle, M.A.

Bishop Butler. By W. A. Spooner, M.A.

\section{The Library of Devotion}

With Introductions and (where necessary) Notes.

Small Pott 8vo, cloth, 2s.; leather, 2s. 6d. net.

The Confessions of St. Augustine. Edited by C. Bigg, D.D. Sixth Edition.

THE IMITATION OF CHRist : called also the Ecclesiastical Music. Edited by C. Bigg, D.D. Fifth Edition.

The Christian Year. Edited by Walter - Lock, D.D. Fourth Edition.

LYRA INNOCENTIUM. Edited by Walter Lock, D.D. Second Edition.

The Temple. Edited by E. C. S. Gibson, D.D. Second Edition.

A Book of Devotions. Edited by J. W. Stanbridge. B.D. Second Edition.

a Serious Call to a Devout and Holy LiFE. Edited by C. Bigg, D.D. Fourth Ed.

A Guide to Eternity. Edited by J. W. Stanbridge, B.D.

Thr INNER WAY. By J. Tauler. Edited by

A. W. Hutton, M.A.
ON the Love of God. By St. Francis de Sales. Edited by W. J. Knox-Little, M.A. The Psalms of David. Edited by B. W. Randolph, D.D.

Lyra Apostolica. By Cardinal Newman and others. Edited by Canon Scott Holland, M.A., and Canon H. C. Beeching, M.A.

The SONG of Songs. Edited by B. Blaxland, M.A.

The Thoughts of Pascal. Edited by $C$. S. Jerram, M.A.

A Manual of Consolation from the Saints and Fathers. Edited by J. $\mathrm{H}$. Burn, B.D.

*Devotions from the Apocrypha. Edited, with an Introduction, by Herbert Pentin, M.A. 


\section{General Literáture}

The Library of Devotion-continued.

*The Spiritual Combat. By Dom Lorenzo Scupoli. Newly translated, with an Introduction and Notes, by Thomas Barns, M.A.

The Devotions of St. Anselm. Edited by C. C. J. Webb, M.A.

Grace Abounding to the Chief of SinNERS. By John Bunyan. Edited by S. C. Freer, M.A.

Bishop Wilson's Sacra Privata. Edited by A. E. Burn, B. D.

LYRA SACRA : A Book of Sacred Verse. Edited by Canon H. C. Beeching, M.A. Second Edition, revised.

A DAY BOOK FROM THE SAINTS AND FATHERS. Edited by J. H. Burn, B.D.

A LitTle Book of Heavenly Wisdom. A Selection from the English Mystics. Edited by E. C. Gregory.

Light, LifE, and Love. A Selection from the German Mystics. Edited byW.R.Inge, M.A.

An Introduction to The Devout Life. By St. Francis de Sales. Translated and Edited by T. Barns, M.A.

The LitTle Flowers of THE Glorious MESSER ST. Francis aND OF HIS Friars. Done into English by W. Heywood. With an Introduction by $\mathbf{A}$. G. Ferrers Howell.
Manchester AL Mondo: a Contemplation of Death and Immortality. By Henry Montagu, Earl of Manchester. With an Introduction by Elizabeth Waterhouse Editor of 'A Little Book of Life and Death.'

The Spiritual Guide, which Disentangles the Soul and brings it by the Inward Way to the Fruition of Perfect Contemplation and the Rich Treasure of Internal Peace. Written by Dr. Michaelde Molinos, Priest. Translated from the Italian copy, printed at Venice, 1685 . Edited with an Introduction by Kathleen Lyttelton. And a Note by Canon Scott Holland.

Devotions for Every DAy of THE WeEk AND The Great Festivals. By John Wesley. Edited, with an Introduction by Canon C. Bodington.

Preces Privatae. By Lancelot Andrewes, Bishop of Winchester. Selections from the Translation by Canon F. E. Brightman. Edited, with an Introduction, by A. E. Burn, D.D.

Horae Mvsticae: A Day Book from the Writings of Mystics of Many Nations. Edited by E. C. Gregory.

\section{Little Books on Art}

With many Illustrations. Demy I6mo. 2s. 6d. net.

Each volume consists of about 200 pages, and contains from 30 to 40 Illustrations, including a Frontispiece in Photogravure.

ALBRECht DURER. J. Allen. ARTS OF JAPAN, ThE. E. Dillon.

Bookplates. E. Almack.

Botticell. Mary L. Bonnor.

Burne-Jones. F. de Lisle.

Christ in ARt. Mrs. H. Jenner.

Claude. E. Dillon.

Constable. H. W. Tompkins.

Corot. A. Pollard and E. Birnstingl.

Enamels. Mrs. N. Dawson.

Frederic Leighton. A. Corkran.

Grorge Romnev. G. Paston.

GreEK ART. H. B. Walters.

GreUze AND Boucher. E. F. Pollard

HolbeIN. Mrs. G. Fortescne.
Illuminated ManUscripts. J. W. Bradley. JeWELlERY. C. Davenport.

JOHN HOPPNER. H. P. K. Skipton.

Sir Joshua Rey nolds. J. Sime.

Millet. N. Peacock.

Miniatures. C. Davenport.

OUR LADY in ART. Mrs. H. Jenner.

Raphael. A. R. Dryhurst. Second Edition.

Rembrandt. Mrs. E. A. Sharp.

TuRner. F. Tyrrell-Gill.

VANDYck. M. G. Smallwood.

Velasquez. W. Wilberforce and A, R. Gilbert.

WATrs. R. E. D. Sketchley.

\section{The Little Galleries}

\section{Demy I6mo. 2s. 6d. net.}

Each volume contains 20 plates in Photogravure, together with a short outline of the life and work of the master to whom the book is devoted.
A Little Gallery of Reynolds.
A LitTle Gallibry of Romney.
A Littre Gallery of Millais.
A LitTlle Galleky of HoppNer. 


\section{The Iittle Guides}

With many Illustrations by E. H. NEw and other artists, and from photographs.

Small Polt 8vo, cloth, 2s. 6d. net.; leather, 3s. 6d. net.

The main features of these Guides are ( $\mathrm{r}$ ) a handy and charming form ; ( 2 ) illustrations from photographs and by well-known artists; (3) good plans and maps ; (4) an adequate but compact presentation of everything that is interesting in the natura. features, history, archæology, and architecture of the town or district treated.

Cambridge and its Colleges.
Thompson. Second Edition. $\quad$ H. $\left.\right|_{\text {Kent. G. Clinch. }} ^{\text {Hertordirise. H. Tompkins. }}$

ENGLISH LAKRS, THE. F. G. Brabant.

ISLE OF WIGHT. THE. G. Clinch.

MALVER Country, The B. C. A. Windle.

North Wales. A. T. Story.

OXFORD AND ITS COLleges. J. Wells. Eighth Edition.

Shakespeare's Country. B. C. A. Windle. Third Edition.

St. Paul's Cathedral. G. Clinch.

Westminster Abery. G. E. Troutbeck. Second Edition.

Buckinghamshire. E. S. Roscoe.

Cheshire. W. M. Gallichan.

Cornwall. A. L. Salmon.

Derbyshire. J. C. Cox.

Devon. S. Baring-Gould.

Dorset. F. R. Heath. Second Edition.

Essex. J. C. Cox.

HAM PSHIRE. J. C. Cox.

\author{
KeRRY. C. P. Crane. \\ MidDLesex. J. B. Firth. \\ Monmouthshire. G. W. Wade and J. $H$. \\ Wade. \\ NORFOLK. W. A. Dutt. \\ Northamptonshire. W. Dry. \\ OXFORDSHIRE. F. G. Brabant. \\ SomerseT. G. W. and J. H. Wade. \\ SufFolk. W. A. Dutt. \\ SuRREY. F. A. H. Lambert. \\ Sussex. F. G. Brabant. Second Edition. \\ Yorkshire, THB EAST Riding. J. E. \\ Morris. \\ YoRkshiRe, The North Riding. J. E. \\ Morris. \\ Brittany. S. Baring-Gould. \\ NORMANDY. C. Scudamore. \\ Rome. C. G. Ellaby. \\ SicrL.Y. F. H. Jackson.
}

\section{The Little Library}

With Introductions, Notes, and Photogravure Frontispieces.

Small Pott 8vo. Each Volume, cloth, is. 6d. net; leather, 2s. 6d. net.

Anon. A LITTLE BOOK OF ENGLISH LYRICS. Second Edition.

Austen (Jane). PRIDE AND PREJUDICE. Edited by E. V. LucAs. T zoo Vols.

NORTHANGER ABBEY. Edited by E. V. LuCas.

Bacon(Francis). THE ESSAYS OF LORD BACON. Edited by EDWARD WRIGHT.

Barham (R. H.). THE INGOLDSBY LEGENDS. Edited by J. B. ATLAY. Two Volumes.

Barnett (Mrs. P. A.). A LITTLE BOOK OF ENGLISH PROSE. Second Edition.

Beckford (William). THE HISTORY OF THE CALIPH VATHEK. Edited by E. Denison Ross.

Blake (William). SELECTIONS FROM W I L I A M B L A K E. Fdited by M. Perugini.

Borrow (George). LAVENGRO. Edited by F. Hindes Groome. Two Volumes.

THE ROMANY RYE. Edited by JoHN SAM PSON.

Browning (Robert). S E L E C T I O N S FROM TIE EARLY POEMS OF
ROBERT BROWNING. Edited by W. Hali Griffin, M.A.
Canning (George). SELECTIONS FROM THE ANTI-JACOBIN : with GEORGE CAnning's additional Poems. Edited by LLOYD SANDERS.

Cowley (Abraham). THE ESSAYS OF ABRAHAM COWLEY. Edited by H. C. Minchin.

Crabbe (George). SELECTIONS FROM GEORGE CRABBE. Edited by A. C. Deane.

Craik (Mrs.). J O H N H A L I F A X, GENTLE M A N. Edited by ANNiE Matheson. Tivo Volumes.

Crashaw (Richard). THE ENGLISH POEMS OF RICHARD CRASHAW. Edited by Enward HuTToN.

Dante (Alighieri). THE INFERNO OF DANTE. Translated by H. F. CARY. Edited by Paget Toynbee, M.A., D. Litt.

THE PURGATORIO OF DANTE. Translated by H. F. CARY. Edited by PAGET TOYN BEE, M.A., D. Litt.

THE PARADISO OF DANTE. Translated by H. F. CARY. Edited by PAGET ToYNBEE, M.A., D.Litt.

Darley (George). SELECTIONS FROM THE POEMS OF GEORGE DARLEY. Edited by R. A. Strentreild. 


\section{General Literature}

The Litrug Library-continued.

Deane (A. C.). A LITTLE BOOK OF LIGHT VERSE.

Dickens (Charles). CHR ISTMAS BOOKS. Two Volumes.

Ferrier (Susan). MARRIAGE. Edited by A. GOODRTCH - FREER and LORD IDDESLETGK. Two Volumes.

THE INHERITANCE. Truo Volumes.

Gaskell(Mrs.). CRANFORD. Edited by E. V. LuCAS. Second Edition.

Hawthorne (Nathanlel). THE SCARLET LETTER. Edited by PERCY DEARMER.

Henderson (T. F.). A LITTLE BOOK OF SCOTTISH VERSE.

Keats (John). POEMS. With an Introduction by $\mathrm{L}$. BinYon, and Notes by $\mathrm{J}$. MASEFIELD.

Kinglake (A. W.). EOTHEN, With an Introduction and Notes. Second Edition.

Lamb (Charles). ELIA, AND THE LAST ESSAYS OF ELIA. Edited by E. V. LUCAS

Locker (F.). LONDON LYRICS. Edited by A. D. GodLEY, M.A. A reprint of the First Edition.

Longfellow (H. W.). S E L ECT I ON S FROM LONGFEILLW. Edited by L. M. F AITHFULI

Marvell (Andrew). THE POEMS OF ANDREW MARVELL. Edited by E. WRIGHT.

Milton (John). THE MINOR POEMS OF JOHN MILTON. Edited by H. C. BEECHING, M.A.

Molr(D. M.). MANSIE WAUCH. Edited by T. F. HENDERSON

Nichols (j. B. B.). A LITTLE BOOK OF ENGLISH SONNETS.
Rochefoucauld (La) THE MIAXIMS OF LA ROCHEFOUCAULD. Translated by Dean Stanhope. Edited by G. H. POWELL.

Smlth (Horace and James)。 RE JECTED ADDRESSES. Edited by A. D. GODLEY, M.A.

Sterne (Laurence). A SENTIMENTAL JOURNEY. Edited by H. W. PaUL.

Tennyson (Alfred, Lord). THE EARLY POEMS OF ALFRED, LORD TENNY. SON. Edited by J. Churton Collins, M. A I N M EMORIAM. Edited by H. C. BEECHING, M.A.

THE PRINCESS. Edited by ElizabeTh WORDSWORTH.

MAUD. Edited by ElIzABETH WordSWORTH.

Thackeray (W. M.). VA N I T Y FAIR. Edited by S. GwYNn. Three Volumes.

P E N DE N N I S. Edited by S. GWYNN. Three Volumes.

ESMOND. Edited by S. GwYNN.

CHRISTMAS BOOKS. Edited by S. GWYNN.

Vaughan (Henry). THE POEMS OF HENRY VAUGHAN. Edited by EDWARD HuTTON.

Walton (lzaak) THE COMPLEAT ANGLER. Edited by J. BUCHAN

Waterhouse (Elizabeth). A LITTLE BOOK OF LIFE AND DEATH. Edited by. Twelfth Edition.

Wordsworth $(W$.$) . SELECTIONS FROM$ WORDSWORTH. Edited by NOWELL C. Sмгтн.

Wordsworth (W.) and Coleridge (S. T.). LYRICAL BALLADS. Edited by GEORGE SAMPSON.

\section{The Little Quarto Shakespeare}

Edited by W. J. CRAIG. With Introductions and Notes.

Pott 16 mo. In 40 Volumes. Leather, price is. net each volume.

Mahogany Revolving Book Case. Ios. net.

\section{Miniature Library}

Reprints in miniature of a few interesting books which have qualities of humanity, devotion, or literary genius.

Euphranor: A Dialogue on Youth. By Edward FitzGerald. From the edition published by W. Pickering in $185 x$. Demy 32 mo. Leather, 2s, net.

The Life of EDward, LORD HERBERT OF Cherbury. Written by himself. From the edition printed at Strawberry Hill in the year 1764. Demy 32mo. Leather, 2s. net.
Polonius: or Wise Saws and Modern Instances. By Edward FitzGerald. From the edition published by W. Pickering in 1852. Demy 32mo. Leather, 2s. net.

THE RUBAiyat of OMar Khayyám. By Edward FitzGerald. From the Ist edition of 1859 , Fourth Edition. Leather, is. net. 


\section{A New Historical Series}

Edited by the Rev. H. N. ASMAN, M.A., B.D.

*Stories from Ancient History. By E. *Stories from Modern History. By E. M. Bower, B.A. Cr. 8vo. Is. 6d. $\quad$ Wilmot-Buxton, F.R.Hist.S. Cr.8vo. Is.6d.

\section{The New Library of Medicine}

\section{Edited by C. W. SALEEBY, M.D., F.R.S. Edin. Demy $8 v 0$.}

CARE OF THE BODY, THE. F. Cavanagh. Second Edition. 7s. 6 d. net.

ChILDREN of THE NATION, ThE. Right Hon. Sir John Gorst. 7s. 6 d. net.

Control op a Scourge, The: or, How Cancer is Curable. Chas. P. Childe. 7s. 6d. net.

Diseases of Occupation. Sir Thomas Oliver. ros. 6 d. net.

DRINK ProbLeM, THE, in its Medico-Sociological Aspects. Edited by T. N. Kelynack. 7s. $6 d$. net.
Drugs and the Drug Habit. H. Sainsbury. Functional Nerve Diseases. A. T. Schofield. $7 s, 6 d$. net.

Hygiene of Mind, The. T. S. Clouston. Fifth Edition. 7s. 6d. net.

INFANT MORTALITY. George Newman. 7s. 6d. net.

Prevention of Tuberculosis (ConsumpTION), The. Arthur Newsholme. Ios. $6 d$. net.

*Air and Health. Ronald C. Macfie, M.A. M.B. 7s. 6d. net.

\section{The New Library of Music}

Edited by ERNEST NEWMAN. Demy 8vo. 7s. 6d. net.

Hugo Wolf. By Ernest Newman. With Handel. By R. A. Streatfeild. With 12 氵3 Illustrations. Illustrations.

\section{Oxford Biographies}

Fcap. 8vo. Each volume, cloth, 2s. 6d. net; leather, 3s. 6d. net.

Dante Alighier1. By Paget Toynbee, M.A., Robert Burns. By T. F. Henderson. D. Litt. With I2 Illustrations. Third Edition. With 12 Illustrations.

Girolamo Savonarola. By E. L. S. Horsburgh, M.A. With I2 Illustrations. Second Edition.

JoHN HOwaRD. By E. C. S. Gibson, D.D., Bishop of Gloucester. With I Illustrations. Alfred Tennyson. By A. C. Benson, M.A. With 9 Illustrations. Second Edition.

StR Walter Raleigh. By I. A. Taylor. With I2 Illustrations.

Erasmus. By E. F. H. Capey. With I2 Illustrations.

Thr Young Pretender. By C. S. Terry. With I2 Illustrations.

Chatham. By A. S. M'Dowall. With 12 Illustrations.

Francis of Assisi. By Anna M. Stoddart. With 26 Illustrations.

Canning. By W. Alison Phillips. With I2 Illustrations.

Beaconsfield. By Walter Sichel. With 12 Illustrations.

Johann Wolfgang Goethe. By H, G. Atkins. With I6 Illustrations.

Francois Fenelon. By Viscount St Cyres. With I2 Illustrations.

\section{Romantic History}

\section{Edited by MARTIN HUME, M.A. With Illustrations. Demy $8 v o$.}

A series of attractive volumes in which the periods and personalities selected are such as afford romantic human interest, in addition to their historical importance.

The First Governess of the Netherlands, Margaret of Austria. Eleanor E. Tremayne. Ios. $6 d$. net. Two English QuenNs AND Philip Martiu
Hume, M.A. I5s, net.

The Nine Days' QueEn. Richard Davey. With a Preface by Martin Hume, M.A. With 12 Illustrations. ros. 6 d. net. 


\section{General Literature}

\section{School Examination Series}

Edited by A. M. M. STEDMAN, M.A. Crown 8vo. 2s. 6d.

Examination Papers in English History. By J. Tait Plowden-Wardlaw, B.A.

French Examination Papers. By A. M. M. Stedman, M.A. Fifteenth Edition.

KEY. Sixth Edition. 6s. net.

GenRRAL KNOWLEDGE EXAMINATION PAPERS. By A. M. M. Stedman, M.A. Sixth Edition.

KEY. Fourth Edition. 7s. net.

Girman Examination Papers. By R. J. Morich. Seventh Edition.

KEY. Third Edition. 6s. net.

\author{
Greek Examination Papers. By A. M. M. \\ Stedman, M.A. Ninth Edition. \\ KEY. Fourth Edition. 6s. net. \\ History and Geography Examination \\ PAPERS. By C. H. Spence, M.A. Third \\ Edition. \\ Latin Examination Papers. By A. M. M. \\ Stedman, M.A. Fourteenth Edition. \\ KEY. Seventh Edition. 6s. net. \\ Physics Examination Papers. By R. E. \\ Steel, M.A., F.C.S.
}

\section{School Histories}

\section{Illustrated. Crown 8vo. Is, $6 d$.}

A School History of WARWickshire. By A School History of SuRRey. By F. E B. C. A. Windle, D.Sc., F.R.S.

A SchOol HISTORY OF SOMERSET. By

$\begin{array}{ll}\text { Walter Raymond. Second Edition. } & \\ \text { A Schoor History of Leroor History of Midplesex. By V. G. }\end{array}$ W. E. Rhodes, M.A.

\section{Simplified French Texts}

Edited by T. R. N. CROFTS, M.A.

\section{Fcap 8vo. Is.}

Asdalcah. By Edouard Laboulaye. Adapted by J. A. Wilson.

* Deux Contes. By P. Mérimte. Adapted by J. F. Rhoades.

*Edmond Dantès. By A. Dumas. Adapted by M. Ceppi.

Jran Valjean. By Victor Hugo. Adapted by F.W. M. Draper, M.A.

LA Bataille de Watrerloo. By ErckmannChatrian. Adapted by G. H. Evans.

La Bourllie au Miel. By A. Dumas. Adapted by P. B. Ingham, M.A.

La Chanson de Roland. Adapted by $\mathrm{H}$. Rieu, M.A. Second Edition.

LE ConSCRIT DE I813. By Erckmann-Chatrian. Adapted by H. Rieu.

Le Docteur Matheus. By Erckmann. Chatrian. Adapted by W. P. Fuller, M.A. *Le Duc de Beaufort. By A. Dumas. Adapted by P. B. Ingham, M.A.

L'EQUIPAGE DE LA BELIE-NiverNAISE. By Alphonse Daudet. Adapted by T. R. N. Crofts, M.A.

L'Histoire d'une Tulipe. By A. Dumas. Adapted by T. R. N. Crofts, M.A. Second Edition.

L'Histoire de Pierre et Camille. By'A. de

Musset. Adapted by J. B. Patterson, M.A.
MÉmoIRES DE CADichon. By Madam de Séggur. Adapted by J. F. Rhoades.

* D'A jaccio a Saint Helène. By A. Dumas. Adapted by F. W. M. DRAPER, M.A.

Remy Le Chevrier. By E. Souvestre. Adapted by E. E. Chottin, B-es-L.

\section{Simplified German Texts}

Edited by T. R. G. CROFTS, M.A. Fcap. 8vo. is.

Der Muller am Rhintn. By C. Brentano. Die Nothelfer. By W. H. Riehl. Adapted Adapted by Florence A. Ryan.

Die Geschichte von Peter Schlemihl. ByA.v. Chamisso. Adapted by R. C. Perry.

by P. B. Ingham, M.A.

Undine und Huldbrand. By La Motte Fouqué. Adapted by T. R. N. Crofts, M.A. 


\section{Six Ages of European History}

Edited by A. H. JOHNSON, M.A. With Maps. Crown 8vo. 2s. 6d.

AGE OF THE ENLIGHTENED Despot, The, r660.I789. A. H. Johnson.

Central. Period of the Midde Age, The, 918-1273. Beatrice A. Lees.

Dawn of Medieval Nurope, the, 476-918. J. H. B. Masterman. End of The Middle AGE, The, r273-1453.

Europe in Renaissance and ReformaTion, r453-1659. M. A. Hollings.

REMAKING OF MODRRN EUROPE, THE, 1789. 1878. J. A. R. Marriott.

\section{Methuen's Standard Library}

Cloth, Is, net; doublevolumes, Is. 6d.net. Paper, 6i. net; double volume, is. net.

The Meditations of Marcus Aurelios. Translated by R. Graves.

Sense ANd Sensimilitv. ane Austen.

Essays and Counsels and The New Atlantis. Francis lancon, Lord Verulam.

Religio Medici and UiN Burial. Sir Thomas Browne. The taxt collated by A. R. Waller.

The Pilgrim's Progress. jubn Bunyan. Reflections on the French Revolution. Edmund Burke.

The Poems and Songs of Robert Burns. Double Volume.

The ANalogy of Religion, Natural and REVEALED. Joseph Butler.

Miscellaneous Poems. T. Chatterton.

The Rowley Poems. T. Chatterton.

TOM Jones. Henry Fielding. Treble Vol.

Cranford. Mrs. Gaskell.

The Poemsand Plays of Oliver Goldsmitir.

Thr Case is Altered. Every Man in His Humour. Every Man OUt of His Humour. Ben Jonson.

Cynthia's Revels. Poetaster. Ben Jonson.
The Porms of john Keats. Double volume. "'he Text has been collated by $E$. de Selincourt.

On the IMITATT: ne CHRist. By Thomas à Kempis. 1. isiation by C. Bigg.

a Serious Callo a Devout and Holy LiFE. W. Law.

Paradise Lost. John Milion.

Eikonoklastes AND THE T TNURE OF KINGS and Magistrates. John Milton.

Utopia And Poems. Sir Thomas More.

The Republic of Plato. Translated by Sydenham and Taylor. Double Volume. Translation revised by W. H. D. Rouse.

The LitTle Flowers of St. Francis. Translated by W. Heywood.

The Works OF William Shakespeare. In ro volumes.

The Poems of Percy Bvsshe Shelley. In 4 volumes. With Introductions by C. D. Locock.

The LifE of Nelson. Robert Southey.

The Natural. Historyand Antiquities of Selborne. Gilbert White.

\section{Textbooks of Science}

Edited by G. F. GOODCHıLD, M.A., B.Sc., and G. R. MILLS, M.A.

\section{Fully Illustrated.}

Complete School Chemistry, The. By F.
M. Oldham, B.A. With 126 lllustrations. M. Oldham, B.A. With 126 Illus
Third Edition. Cr. $8 v 0$. 4s. $6 d$.

Elementary Science for Pupil Teachers. Physics Section. By W. T. Clough, A.R.C.Sc. (Lond.), F.C.S. Chrmistry Section. By A. E. Dunstan, B.Sc. (Lond.), F.C.S. With 2 Plates and ro Diagrams. Cr. 8vo. 2s.

Examples in Elementary Mechanics, Practical, Graphical, and Theoretical. By W. J. Dobbs, M.A. With 52 Diagrams. Cr. 8 vo. 5 s.

Examples in Physics. By C. E. Jackson, M.A. Cr. 8vo. 2s. $6 d$.

First Year Physics. By C. E. Jackson,M.A. With $5 x$ Diagrams. Cr. 8vo. Is. $6 d$.

Outlines of Physical Chemistry. By George Senter, B.Sc. (Lond.), Ph.D. With many Diagrams. Cr. 8vo. 3s. $6 d$.
Organic Chemistrv, AN, For Schools aNd Technical Institutes. By A. E. Dunstan, B.Sc. (Lond.), F.C.S. With many Illustrations. $C r .8 v o$. 2s. $6 d$.

Plant Life, Studies in Garden and School. By Horace F. Jones, F.C.S. With 320 lllustrations. Cr. 8vo. $3 s, 6 d$.

Practical Chemistry. Part I. W. French, M.A. Fifth Edition. Cr. 8vo. rs. $6 d$.

Practical Chemistry. Part il. W. French, M.A., and T. H. Boardman, M.A. Cr. $8 v 0$. Is. $6 d$.

* Practical Chemistry for Schools and Technical Institutes, A. By A. E. Dunstan, B.Sc. (Lond.), F.C.S. Cr. 8vo. 35.6 d. Practical Mechanics. $\mathrm{S}$. $\mathrm{H}$. Wells. Fourth Edition. Cr. 8vo. 3s. 6d.

Technical ARithmetic and Geometry. By C. T. Millis, M.I.M.E. Cr. $8 v 0$. 3s. $6 d$. 


\section{General Literature}

\section{Textbooks of Technology \\ Fully Illustrated.}

Bullders' Quantities. By H. C. Grubb. Cr. 8vo. 4s. $6 d$.

Carpentry and Joinery. By F. C. Webber. Fifth Edition. Cr. 8vo. 3s. $6 d$.

ELectric Light and Power: An Intro. duction to the Study of Electrical Engineering. By E. E. Brooks, B.Sc. (Lond.). and W. H. N. James, A.M.I.E.E., A.R.C.Sc. Cr. $8 v 0.4 s .6 d$.

Enginerring Workshop Practice. By C. C. Allen. Cr. $8 v 0.35 .6 d$.

How to Make a Dress. By J. A. E. Wood. Fourth Edition. Cr. 8vo. Is. 6 d.

Instruction in Cookery. A. P. Thomson. Cr. 8vo. 2s. $6 d$.

InTRoduction to the Study of Textilf Design, An. By Aldred F. Barker. Demy 8zo. 7s. $6 d$.

Millinery, Theoretical and Practical. By Clare Hill. Fourth Edition. Cr. 8vo. 2s. Repousse Metal Work. By A. C. Horth. Cr. 8vo. 2s. $6 d$.

\section{Handbooks of Theology}

The Doctrine of The Incarnation. By R. L. Ottley, D.D. Fourth Edition revised. Demy 8vo. I2s. 6d.

A History of Early Christian Doctrine. By J. F. Bethune-Baker, M.A. Demy 8vo. 10s. $6 d$.

AN INTRoductión to THE History OF Religion. By F. B. Jevons. MI.A. Litt.D. Fourth Edition. Demy 8vo. sos. $6 d$.

AN INTRODUCTION TO THE HISTORY OF THE Creeds. By A. E. Burn, D.D. Demy 820. Ios. $6 d$.

The Philosophy of Religion in England And America. By Alfred Caldecott, D.D. Demy 8vo. ros. $6 d$.

The XXXIX. ARticles of the Chúrch of England. Edited by E. C. S. Gibson, D.D. Sixth Edition. Demy 8vo, 12s. 6d.

\section{The Westminster Commentaries}

General Editor, WALTER LOCK, D.D., Warden of Keble College, Dean Ireland's Professor of Exegesis in the University of Oxford.

The Acts of the Apostles. Edited by R. The Book of Ezekiel. Edited H. A. Red. B. Rackbam, M.A. Demy 8vo. Fourth Edition. ros. 6d.

The First Epistle of Padr, the Aposti TO тHE Corinthians, Edited by $\mathbf{H}$. L. Goudge, M.A. Second Ed. Demy8vo. 6s.

A Commentarv on Exodus. By A. $H$. $M$ 'Neile, B.D. With a Map and 3 Plans. Demy 8vo. 10s. 6d. path, M.A., D.Litt. Demy $8 v 0$. Ios. $6 d$.

The Book of Genesis. Edited with Intro duction and Notes by S. R. Driver, D.D. Seventh Edition Demy 8vo. ros. 6 d.

The BOOK OF Jo B. Edited by E. C. S. Gibson, D.D. Second Edition. Demy 8vo. $6 s$.

The Epistle of St. James. Edited with Introduction and Notes by R. J. Knowling, D.D. Demy 8vo. 6s.

\section{Part II.-Fiction}

Albanesi (E. Maria). SUSANNAH AND ONE OTHER. Fourth Edition. $\mathrm{Cr}$. 8vo. 6s.

THE BLUNDER OF AN INNOCENT Second Edition. Cr. 8zo. 6 s.

CAPRICIOUS CAROLINE. Second Edition. Cr. 8vo. 6s.

LOVE AND LOUISA. Second Edition. Cr. 8vo. 6s. Also Medium 8vo. 6d.

PETER, A PARASITE. Cr. 8vo. $6 s$.

THE BROWN EYES OF MARY. Third Edition. Cr. 8vo. 6s.

1 KNOW A MAIDEN Third Edition Cr. 8vo. 6s. Also Medium 8vo. 6d.
THE INVINCIBLE AMELIA: OR, THB Polite Anventuress. Third Edition. Cr. 8vo. 3s. 6 d.

Annesley (Maude). THIS DAY'S MADNESS. Cr. 8vo. $6 \mathrm{~s}$.

Anstey (F.). A BAYARD FROM BENGAL. Medium 8vo. 6d.

Austen (Jane). PRIDE AND PREJU. DICE. Medium 8vo. 6d.

Aveling (Francis). ARNOUL THE ENG LISHMAN, Cr. 8vo. 6 s.

Bagot (Richard). A ROMAN MYSTERY. Third Edition. Cr. 8vo. 6s. Also Medium 8vo. $6 d$. 
THE PASSPORT. Fourth Edition. $\mathrm{Cr}$. 8vo. 6s.

TEMPTATION. Fifth Edition. Cr. $8 v 0$. $6 s$.

ANTHONY CUTHBERT. Fourth Edition Cr. 8vo. 6s.

LOVE'S PROXY. A New Edition. Cr. 8vo. $6 s$.

DONNA DIANA. Second Edition. 8vo. 6s. Also Medium 8vo. 6d.

CASTING OF NETS. Truelfth Edition. $C r$. 8vo. 6s. Also Medium 8vo. 6d.

Balfour (Andrew). BY STROKE OF SWORD. Medium 8vo. 6 d.

Ball (Oona H.) (Barbara Burke), THEIR OXFORD YEAR. With 16 Illustrations Cr. 8vo. 6s.

BARBARA GOES TO OXFORD. With 16 Illustrations. Third Edition. Cr. 8vo. 6s.

Baring-Gould (S.). ARMINELL. Fifth Edition. Cr. 8vo. 6s.

Also Medium 8vo. $6 d$.

URITH. Fifth Edition. Cr. 8vo. 6s. Also Medium 8vo. $6 d$.

IN THE ROAR OF THE SEA. Seventh Edition. Cr. 8vo. 6s. Also Medium 8vo. $6 d$.

CHEAP JACK ZITA. Medium 8vo. $6 d$.

MARGERY OF QUETHER. Third Edition. Cr. 8vo. 6s.

THE QUEEN OF LOVE. Fifth Edition. Cr. 8vo. 6s. Also Medium 8vo. 6d.

JACQUETTA. Third Edition. Cr.8vo. 6s.

KITTY ALONE. Fifth Eaition. Cr.8vo. 6s. Also Medium 8vo. 6 d.

NOÉMI. Illustrated. Fourth Edition. Cr. 8vo. 6s. Also Medium 8vo. 6d.

THE BROOM-SQUIRE. Illustrated. Fifth Edition. Cr. 8vo. $6 s$.

Also Mediunt 8vo. $6 d$.

DARTMOOR IDYLLS. Cr. 8vo. $6 s$.

GUAVAS THE TINNER. Illustrated. Second Edition, Cr. 8vo. 6s.

BLADYS OF THE STEWPONEY. Illus. trated. Second Edition. Cr. 8vo. 6s.

PABO THE PRIEST. Cr. 8vo. 6s.

WINEFRED. Illustrated. Sccond Edition. Cr. 8vo. 6s. Also Medium 8ro. 6d.

ROYAL GEORGIE. Illustrated. $\mathrm{Cr} .8 v 0.6 \mathrm{~s}$. CHRIS OF ALL SORTS. Cr. 8vo. $6 s$. IN DEWISLAND. Second Ed. Cr. 8vo. 6s. THE FROBISHERS. Crown $8 v 0$. $6 s$. Also Medium 8vo. $6 d$.

DOMITIA. Illus. Second Ed. Cr. 8vo. 6s. MRS. CURGENVEN OF CURGENVEN. Crown 8vo. 6s.

LITTLE TU'PENNY. Medium 8vo. $6 d$. FURZE BLOOM. Medium 8vo. $6 d$.

Barnett (Edith A.). A WILDERNESS WINNER. Second Edition. Cr. 8vo. Gs.
Barr (James). LAUGHING THROUGH A WILDERNESS. Cr. 8vo. $6 s$.

Barr (Robert). IN THE MIDST OF ALARMS. Third Edition. Cr. 8vo. $6 s$. Also Medium 8vo. $6 d$.

THE COUNTESS TEKLA. Fourth Edition. Cr. 8vo. 6s.

Also Medium 8vo. 6d.

THE MUTABLE MANY. Third Edition. Cr. 8vo. 6s. Also Medium 8vo. 6d.

THE TEMPESTUOUS PETTICOAT. Illustrated. Third Edition. Cr. 8vo. 6s.

JEN IE BAXTER JOURNALIST. Medium 8vo. $6 d$.

Begbie (Harold). THE CURIOUS AND DIVERTING ADVENTURES OF SIR JOHN SPARROW; or, THE PROGRESS OF AN OPEN MIND. 'With a Frontispiece. Second Edition. Cr. 8vo. 6s.

Belloc (H.), EMMANUEL BURDEN, MERCHANT. With 36 Illustrations by G.K. Chesterton. Second Ed.Cr.8vo. 6s.

A CHANGE IN THE CABINET. Second Edition. Cr. 8vo. 6s.

Benson (E. F.) DODO : A DeTaIL OF THE Day. Fifteenth Edition. Cr. 8ro. 6s. Also Medium 8vo. $6 d$.

THE VINTAGE. Medium 8vo. $6 d$.

Benson (Margaret). SUBJECT TO VANITY. Cr. 8vo. 3s. 6d.

Birmingham (George A.). THE BAD TIMES. Second Edition. Cr. 8vo. 6s.

SPANISH GOLD. Fourth Edition. Cr. 8vo. $6 s$.

THE SEARCH PARTY. Cr. 8vo. $6 s$.

Bowles (G. Stewart). A GUN-ROOM DITTY BOX. Second Ed. Cr.8vo. rs. 6 .

Bretherton (Ralph Harold). $\mathrm{THE}$ MILL. Cr.8vo. $6 s$.

AN HONEST MAN. Second Edition. $C r$. 8vo. 6s.

Brontë (Charlotte). SHIRLEY. Medikm 8vo. $6 \%$.

Burton (J. Bloundelle). ACROSS THE SALT SEAS. Medium 8vo. 6d.

Caffyn (Mrs.) ('Iota'). ANNE MAULE. VERER. Medium 8vo. 6d.

Campbell (Mrs. Vere). F ER R I B Y. Second Edition. Cr.8vo. 6s.

Capes (Bernard). THE EXTRAOR. DINARY CONFESSIONS OF DIANA PLEASE. Third Edition. Cr. 8vo. 6s.

A JAY OF ITALY. Fourth Ed. Cr.8vo. 6s. LOAVES AND FISHES. Second Edition. Cr. 8vo. 6s.

A ROGUE'S TRAGEDY. Second Edition. Cr. 8vo. 6s.

THE GREAT SKENE MYSTERY. Second Edition. Cr. 8vo. 6s.

THE LOVE STORY OF ST. BEL. Second Edition. Cr. 8vo. 6s. 


\section{Fiction}

THE LAKE OF TINE. Medium 8vo. 6d. Carey (Wymond). LOVE THE JUDGE. Second Edition, Cr.8vo. 6s.

Castle (Agnes and Egerton). FLOWER $O$ ' THE ORANGE, and Other 'Tales. With a Frontispiece in Colour by $\mathbf{A}$. $\mathrm{H}$. Buckland. Third Edition. Cr. 8vo. 6s.

Charlton (Randal). M A V E. Second Edition. Cr. 8vo. 6s.

THE VIRGIN WIDOW. Cr. 8vo. 6s.

Chesney (Weatherby). THE MYSTERY OF A BUNGALOW. Second Edition. Cr. 8vo. 6s.

Clifford (Mrs. W. K.). THE GETTING WELL OF DOROTHY. Illustrated by Gordon BRowne. Second Edition. Cr. 8zo. 35. $6 d$.

A FLASH OF SUMMER. Medium 8vo. $6 d$. MRS. KEITH'S CRIME. Medium 8vo. $6 d$. Conrad(Joseph). THE SECRET AGENT: A Simple Tale. Fourth Ed. Cr. 8vo. 6s.

A SET OF SIX. Fourth Edition. Cr. 8vo. 6s.

Corbett (Jullan). A BUSINESS IN GREAT WATERS. Third Edition. Cr. 8vo. 6s. Also Medium 8vo. 6d.

Corell (Marle). A ROMANCE OF TWO WORLDS. Twenty-Ninth Ed. Cr.8vo. 6s. VENDETTA. Twenty-Seventh Edition. Cr. 8vo. $6 s$.

THELMA. Thirty-Ninth Ed. Cr. 8vo. 6s. ARDATH : THE STORY OF A DEAD SELF. Nireteenth Edition. Cr. 8zo. 6s. THE SOUL OF IILITH. Sixteenth $E d i$ tion. Cr. 8vo. 6s.

WORMWOOD. Sixteenth Ed. Cr.8zo. 6s.

BARABBAS: A DREAM OF THE WORLD'S TRAGEDY. Forty-Fourth Edition. Cr. 8vo. 6s.

THE SORROWS OF SATAN. Fifty-Fifth Edition. Cr. 8vo. 6s.

THE MASTER CHRISTIAN. Twelfth Edition. I77th Thousand. Cr. 8v0. 6s.

TEMPORAL POWER: A STUDY IN SUPREMACY. Second Edition. isoth Thousand. Cr. 8vo. 6s.

GOD'S GOOD MAN : A SIMPLE LOVE STORY. Thirteenth Edition. I5oth Thousand. Cr. 8 vo. 6 s.

HOLY ORDERS: THE TRAGEDY OF A Quiet LifE. Second Edition. roth Thousand. Crown 8vo. 6s.

THE MIGHTY ATOM. Twenty-seventh Edition. Cr. 8vo. $6 \mathrm{~s}$.

BOY : a Sketch. Eleventh Edition. Cr. 8vo. $6 s$.

CAMEOS. Thirteenth Edition. Cr. 8vo. 6s.

Cotes (Mrs. Everard). See Duncan (Sara Jeannette).

Cotterell (Constance). THE VIRGIN AND THE SCALES. Illustrated. Second Edition. Cr. 8vo. 6s.
Crockett (S. R.), LOCHINVAR. Illus trated. Third Edition. Cr. 8zo. 6s. Also Medium 8vo. $6 d$.

THE STANDARD BEARER. Cr. 8vo. $6 s$. Croker (Mrs. B. M.). THE OLD CAN. TONMENT. Cr. 8vo. 6 s.

JOHANNA. Second Edition. Cr.8vo. $6 s$. Also Medium 8vo. $6 d$.

THE HAPPY VALLEY. Fourth Edition. Cr. 8vo. 6s.

A NINE DAYS' WONDER. Third Edition. Cr.8vo. 6s.

PEGGY OF THE BARTONS. Seventh Ed. Cr. 8vo. 6s. Also Medium 8vo. 6d. ANGEL. Fifth Edition. Cr. 8vo. 6s. Also Medium 8vo. $6 d$.

A STATE SECRET. Third Edition. $C r$. 8vo. 3s. 6d. Also Medium 8vo. 6d.

KATHERINE THE ARROGANT. Fifth Edition. Cr. 8vo. 6s.

Crosbie (Mary). DISCIPLES. Second Ed. Cr. 8vo. 6s.

Cuthell (Edith E.) ONLY A GUARD. ROOM DOG. Illustrated by W. PARKINson. Crown 8vo. 3s. $6 d$.

Dawson (Warrington). THE SCAR. Second Edition. Cr. 8vo. 6s.

THE SCOURGE Cr. 8vo. 6s.

Deakin (Dorothea). THE YOUNG COLUMBINE. With a Frontispiece by Lewis Baumer. Cr. 8zo. 6 s.

Deane (Mary). THE OTHER PAWN. Cr. 8vo. 6s.

Doyle (A. Conan). ROUND THE RED LAMP. Eleventh Edition. Cr. 8vo. $6 s$. Also Medium 8vo. 6d.

Dumas (Alexandre). See page 46.

Duncan (Sara Jeannette) (Mrs. Everard Cotes). THOSE DELIG H T F U AMERICANS. Medium 8vo. $6 d$.

A VOYAGE OF CONSOLATION. Illus trated. Third Edition. Cr. 8vo. 6s. Also Medium 8vo. $6 d$.

COUSIN CINDERELLA. Second Edition. Cr. 8v0. 6s.

THE BURNT OFFERING. Cr. 8vo. 6s. EIdridge(George D.). IN THE POTTER'S HOUSE. Cr. 8vo. $6 s$.

EIlot (George). THE MILL ON THE FLOSS. Medium 8vo. $6 d$.

Erskine (Mrs. Steuart). THE MAGIC PLUMES. Cr. 8vo. 6s.

Fenn (G. Manville). SYD BELTON ; or, The Boy who would not go to Sea. Illus trated by Gordon Browne. Second Ed. Cr. 8vo. 3s. 6d.

Findiater (J. H.). THE GREEN GRAVES OF BALGOWRIE. Fifth Edition. Cr. 8vo. 6s. Also Medium 8vo. 6d.

THE LADDER TO THE STARS. Second Edition. Cr. 8vo. 6 s. 
Findlater (Mary). A NARROW WAY. Third Edition. Cr. 8vo. 6s.

OVER THE HILLS. Second Edition. Cr. 8vo. 6s.

THE ROSE OF JOY. Third Edition. Cr. 800. 6s.

A BLIND BIRD'S NEST. With 8 Illustrations. Second Edition. Cr. 8vo. 6s.

Fitzpatrick (K.) THE WEANS AT ROWALLAN. Illustrated. Second Edition. Cr. 8wo. 6s.

Francis (M. E.). (Mrs. Francis Blundell). STEPPING WESTWARD. Second Edition. Cr. 8vo. 6s.

MARGERY O' THE MILL. Third Edition. Cr. 8\%o. 6s.

HARDY-ON-THE-HILL. Third Edition. Cr. 8vo. 6s.

GALATEA OF THE WHEATFIELD. Second Edition. Cr. 8vo. $6 s$.

Fraser (Mrs. Hugh). THE SLAKING OF THE SWORD. Second Edition. Cr. 8vo. 6s.

GIANNELLA. Cr. 8vo. $6 s$.

IN THE SHADOW OF THE LORD. Third Edition. Croan 8vo. 6s.

Fry (B. and C.B.). A MOTHER'S SON. Fifth Edition. Cr. 8vo. $6 \mathrm{~s}$.

Fuller-Maitland (Ella). B L A N C H E ESMEAD. Second Edition. Cr.8vo. 6s.

Gallon (Tom). RICKERBY'S FOLLY. Medium 8vo. 6d.

Gaskell (Mrs.). CRANFORD. Medium 8.0. $6 d$.

MARY BARTON. Medium 8vo. $6 d$.

NORTH AND SOUTH. Medium 8vo. $6 \%$.

Gates(Eleanor). THE PLOW-IVOMAN. Cr. 8vo. 6s.

Gerard (Dorothea). HOLY MATRI. MONY. Medium 8vo. $6 d$.

MADE OF MONEY. Medium 8vo. $6 d$.

THE IMPROBABLE IDYL. Third Edition. Cr. 8vo. 6s.

THE BRIDGE OF LIFE. Cr. 8vo. $6 s$.

THE CONQUEST OF LONDON. Medium $8 v 0.6 d$.

Gibbs (Philip). TIE SPIRIT OF REVOLT. Second Edition. Cr. 8vo. 6s.

Gissing(George). THE TOWN TRAVELLER. Medium 8vo. $6 d$.

THE CROWN OF LIFE. Cr. $8 v o$. $6 s$. Also Medium 8zo. $6 d$.

Glanville (Ernest). THE INCA'S TREASURE. Illustrated. Cr. 8vo. 3s. $6 d$. Also Medium 8zo. $6 d$.

THE KLOOF BRIDE. Medium 8vo. 6d. Gleig (Charles). BUNTER'S CRUISE. Illustrated. Cr. 8vo. $3 s .6 d$. Also Medixm 8vo. 6d.

Grimm (The Brothers). GRIMM'S FAIRY TALES. IIIustrated. Medium 8vo. $6 d$.
Haig (J. c.). IN THE GRIP UF THE TRUSTS : A STORY OF 1914. Cr. $8 v 0$. is. net.

Hamliton (M.). THE FIRST CLAIM. Second Edition. Cr.8vo. 6s.

Harraden (Beatrice). IN VAR Y ING MOODS. Fourteenth Edition. Cr. 8vo. 6s. THE SCHOLAR'S DAUGHTER: Fourth Edition. Cr. 8vo. $6 s$.

HILDA STRAFFORD and THE REMITTANCE MAN. Truelfth Ed. Cr. 800 . 6s.

INTERPLAY. Fifth Edition. Cr. 8vo. 6s.

Harrod (F.) (Frances Forbes Robertson). THE TAMING OF THE BRUTE. Cr. 8vo. 6s.

Hart (Mabel). SISTER K. Cr. 8vo. $6 s$.

Hichens (Robert). THE PROPHET OF BERKELEY SQUARE. Second Edition. Cr. 8vo. 6s.

TONGUES OF CONSCIENCE. Third Ectition. Cr. 8vo. 6s.

FELIX. Sixth Edition. Cr. 8vo. 6s.

THE WOMAN IVITH THE FAN. Seventh Edition. Cr. 8vo. 6s.

BYEWAYS. $C r$. 8vo. $6 s$.

THE GARDEN OF ALLAH. Eighteenth Edition. Cr. 8vo. 6s.

THE BLACK SPANIEL. Cr. 8vo. 6s.

THE CALL OF THE BLOOD. Seventh Edition. Cr. 8vo. 6s.

BARBARY SHEEP. Second Edition. Cr. 8vo. 3s. 6d.

Hope (Anthony). THE GOD IN THE CAR. Eleventh Edition. Cr. 8vo. $6 \mathrm{~s}$.

A CHANGIE OF AIR, Sixth Ed. Cr.800. 6s. Also Medium 8vo. 6d.

A MAN OF MARK. Sixth Ed. Cr. 800. 6s. Also Medium 8vo. 6d.

THE CHRONICLES OF COUNT AN. TONIO. Sixth Edition. Cr. $8 v 0$. $6 s$. Also Medium $8 v o$. $6 d$.

PHROSO. Illustrated by H. R. MiLlar. Eighth Edition. Cr. 8vo. 6s. Also Medium 800. 6d.

SIMON DALE. Illustrated. Eighth Edition. Cr. 8vo. 6s.

THE KING'S MIRROR. Fourth Edition. Cr. 8vo. 6s.

QUISANTE. Fourth Edition. Cr. 8vo. 6s. THE DOLLY DIALOGUES. Cr. $8 v 0$. $6 s$. Also Medium 8vo. 6d.

A SERVANT OF THE PUBLIC. Illus trated. Fourth Edition. Cr. 800. 6 s.

TALES OF TWO PEOPLE. With a Frontispiece by A. H. Buckland. Third Ed. Cr. 8vo. 6s.

THE GREAT MISS DRIVER. With a Frontispiece by A. H. BuckLand. Fourth Edition. Cr. 8vo. 6s. 
Hornung (E. W.). DEAD MEN TELL NO TǍLES. Medium 8vo. $6 d$.

Housman (Clemence). THE LIFE OF SIR AGLOVALE DE GALIS. Cr. 8vo. $6 s$.

Hueffer (Ford Madox). AN ENGLISH GIRL: A Romance. Second Edition. Cr. 8vo. 6s.

MR. APOLLO: A Just Possible Storv. Second Edition. Cr. 8vo. 65.

Hutten (Baroness von). THE HALO. Fifth Edition. Cr. 8vo. 6s.

Hyne (C. J. Cutcllffe). MIR. HORROCKS, PURSER. Fourth Edition. Cr. 8vo. 6s.

PRINCE RUPERT, THE BUCCANEER, lllustrated. Third Edition. Cr. 8vo. 6s.

Ingraham (J. H.). THE THRONE OF DAV1D. Medium 8vo. 6d.

Jacobs (W. W.). MANY CARGOES. Thirty-first Edition. Cr. 8vo. 3s. 6d.

SEA URCHINS. Fifteenth Edition. Cr. 8vo. 3s. $6 d$.

A MASTER OF CRAFT. Illustrated by WILI Owes. Eighth Edition. Cr. 8vo. $3^{s}, 6 d$.

LIGHT FREIGHTS. Illustrated by WILL OwEN and Others. Seventh Edition. Cr. 8v0. $35.6 d$.

THE SKIPPER'S WOOING. Ninth Edition. Cr. 8vo: 3s. 6d.

AT SUNWICH PORT. Illustrated by Will Owen. Ninth Edition. Cr.8vo. 3s.6d.

DIALSTONE LANE. Illustrated by WILL Owkn. Seventh Edition. Cr. 8vo. 3s. 6 d.

ODD CRAFT. Illustrated by WILL OWEN. Third Edition. Cr. 8vo. 3s. 6d.

THE LADY OF THE BARGE. Illustrated. Eighth Edition. Cr. 8vo. 3s. 6d.

SALTHAVEN. Illustrated by WILL OWEN. Second Edition. Cr. 8vo. 3s. $6 \mathrm{~d}$.

SAILORS' KNOTS. Cr. 8 vo. 35. $6 d$.

James (Henry). THE SOFT SIDE. Second Edition. Cr. 8vo. 6s.

THE BETTER SORT. Cr. 8vo. 6s.

THE GOLDEN BOWL. Third Edition. Cr. 8vo. 6s.

Keays (H. A. Mitchell). HE THAT EATETH BREAD WITH ME. Cr. 8vo. $6 s$.

Kester(Vaughan). THE FORTUNES OF THE LANDRAYS. Cr. 8vo. $6 s$.

Lawless (Hon. Emily). WITH ESSEX IN IRELAND. Cr. $8 v 0$. $6 s$.

Le Queux (William). THE HUNCH. BACK OF WESTMINSTER. Third Ed. Cr. 8vo. 6s. Also Medium 8vo. 6d.

THE CLOSED BOOK. Third Edition. Cr. 8vo. 6s.

THE VALLEY OF THE SHADOW. Illustrated. Third Edition. Cr. 8vo. 6s. BEHIND THE THRONE. Third Edition. Cr. 8vo. 6s.
THE CROOKED WAY Second Edition. Cr. 8vo. 6s.

Levett-Yeats (S. K.). ORRAIN. Secord Edition. Cr. 8vo. 6s. Also Medium 8vo. $6 d$.

THE TRAITOR'S WAY. Medium 8zo. 6d.

Linton(E. Lynn). THE TRUE HISTORY OF JOSHUA DAVIDSON. Medium 8v0. $6 d$.

London (Jack). WHITE FANG. With a Frontispiece by CharLes Rivingston BulL. Sixth Edition. Cr. 8vo. 6s.

Lubbock. (Basil). DEEP SEA WAR RIORS. Illustrated. Second Edition. Cr. 8vo. 6s.

*Lucas (St. John). THE FIRST ROUND. Cr. 8vo. 6s.

Lyall (Edna). DERRICK VAUGHAN, NOVELIST. 43rd Thousand. Cr. $8 v 0$. 3s. $6 d$. Also Medium 8vo. $6 d$.

Maartens (Maarten). THE NEW RELIGION: A MODERN NOVEL. Third Edition. Cr. 8vo. 6s.

BROTHERS ALL; MORE Stories OF Dutch Peasant Life. Third Edition. Cr. 8vo. 6s.

THE PRICE OF LIS DORIS. Cr. 8vo. $6 s$.

M'Carthy (Justin H.). THE LADY OF LOYALTY HOUSE. Illustrated. Third Edition. Cr. 8vo. $6 s$.

THE DRYAD. Secord Edition. Cr.8vo. 6s.

THE DUKE'S MOTTO. Third Edition. Cr. 8vo. 6s.

Macdonald (Ronald). A HUMAN TRINITY. SecondEdition. Cr. 8vo. 6s.

Macnaughtan (S.). THE FORTUNE OF CHRISTINA M'NAB. Fourth Edition. Cr. 8vo. 6s.

Malet (Lucas). COLONEL ENDERBY'S WIFE. Fourth Edition. Cr. 8vo. 6s. A COUNSEL OF PERFECTION. Second Edition. Cr. 8vo. 6s. Also Medium 8vo. $6 d$.

THE WAGES OF SIN. Sixteenth Edition. Cr. 8vo. 6s.

THE CARISSIMIA. Fifth Ed. Cr.8vo. 6s. Also Medium 8vo. $6 d$.

THE GATELESS BARRIER. Fifth Edition. Cr. 8vo. 6s.

THE HISTORY OF SIR RICHARD CALMADY. Seventh Edition. Cr.8vo. 6s.

Mann (Mrs. M. E.). OLIVIA'S SUMMER. Second Edition. Cr. 8vo. 6s.

A LOST ESTATE. $A$ New Ed. Cr. 8vo. 6s. Also Medium 8vo. $6 d$.

THE PARISH OF HILBY. $A$ New Edition. Cr. 8vo. 6s.

THE PARISH NURSE. Fourth Edition. Cr. 8vo. 6s.

GRAN'MA'S JANE. Cr. 800. $6 s$. 
MRS. PETER HOWARD. Second Edition. Cr. 8vo. 6s. Also Medium 8vo. 6d.

A WINTER'S TALE. A New Edition. Cr. 8vo. 6s. Also Medium 8vo. 6d. ONE ANOTHER'S BURDENS. $A$. New Edition. Cr. 8vo. $6 s$.

Also Medium 8vo. $6 d$.

ROSE AT HONEYPOT. Third Ed. Cr. 8vo. 6s.

THERE WAS ONCE A PRINCE. Iliustrated by M. B. MAan. Cr. 8vo. 3s. $6 d$.

WHEN ARNOLD COMES HOME. Illus. trated by M. B. MANN. Cr. 8 vo. 3s. $6 d$.

THE EGLAMORE PORTRAITS. Thira Edition. Cr. 8vo. 6s.

THE MEMORIES OF RONALD LOVE. Cr. 8vo. 6s.

THE SHEEP AND THE GOATS. Third Edition. Cr. 8vo. 6s.

A SHEAF OF CORN. Second Edition. Cr. 8vo. 6s.

THE HEART-SMITER. Second Edition. Cr. 8vo. 6s.

AVENGING CHILDREN. Cr. 8vo. 65.

THE PATTEN EXPERIMENT. Medium 870. $6 d$.

THE CEDAR STAR. Mediwm 8vo. 6d.

Marchmont (A. W.). MISER HOADLEY'S SECRET. Medium 8vo. $6 d$.

A MOMENT'S ERROR. Medium 8vo. 6d.

Marriott (Charles). GENEVRA. Second Edition. Cr. 8vo. 6s.

Marryat (Captain). PETER SIMPLE Medium 8vo. 6d.

JACOB FAITHFUL. Medium 8vo. $6 d$.

Mar3h (Richard). THE TWICKENHAM PEERAGE. Second Edition. Cr.8vo. 6s. Also Medium 8vo. $6 d$.

THE MARQUIS OF PUTNEY. Second Edition. Cr.8vo. 6s.

IN THE SERVICE OF LOVE. Third. Edition. Cr. 8vo. $6 s$.

THE GIRL AND THE MIRACLE. Third Edition. Cr. 8vo. 6s.

THE COWARD BEHIND THE CURTAIN. Cr. 8vo. $6 s$.

THE SURPRISING HUSBAND. Second Edition. Cr. 8vo. 6s.

A ROYAL INDISCRETION. Cr. 8vo. 6s. A METAMORPHOSIS. Medium 8vo. $6 d$. THE GODDESS. Medium 8vo. $6 d$.

THE JOSS. Medium 8vo. $6 d$.

Marshall (Archibald). MANY JUNES. Second Edition. Cr. 8vo. 6s.

THE SQUIRE'S DAUGHTER. Cr. 8vo. 6s.

Mason (A. E. W.). CLE M E N T I N A. Illustrated. Third Edition. Cr.8vo. 6s. Also Medium 8vo. 6d.

Mathers(Helen). HON EY. Fourth Ed. Cr. 8vo. 6s. Also Medium 8vo. 6d.
GRIFF OF GRIFFITHSCOURT. Second Edition. Cr. 8vo. 6s.

Also Medium 8vo. $6 d$.

THE FERRYMAN Second Edition. Cr. 8vo. 6s.

TALLY-HO! Fourth Edition. Cr. 800. 6s. SAM'S SWEETHEART. Medium 8vo.' $6 d$. Maud (Constance). A DAUGHTER OF FRANCE. With a Frontispiece. Second Edition. Cr. 8vo. 6s.

Maxwell(W. B.). VIVIEN. Winth Edition. Cr. 8vo. 6s.

THE RAGGED MESSENGER. Third Edition. Cr. 8vo. $6 s$.

FABULOUS FANCIES. Cr. 8vo. $6 s$.

THE GUARDED FLAME. Seventh Edition. Cr. 8vo. 6s.

ODD LENGTHS. Second Ed. Cr. 8vo. 6s. HILL RISE. Fourth Edition. Cr. 8vo. 6s.

THE COUNTESS OF MAYBURY : BETWEEN YOU AND I. Fourth Edition. Cr. 8vo. 6s.

Meade (L. T.). DRIFT. Second Edition. Cr. 8vo. 6s. Also Medium 8vo. 6d.

RESURGAM. Second Edition. Cr. 8io. 6s. VICTORY. Cr. 8vo. 6s.

A GIRL OF THE PEOPLE. Illustrated. Fourth Edition. Cr. 8vo. 3s. 6 d.

HEPSY GIPSY. Illustrated. Cr. 800. 2s. 6d. THE HONOURABLE MISS: A STORY OF an Old-Fashioned Town. Illustrated. Secord Edition. Cr. 8vo. 3s. $6 d$.

Melton (R.). CASAR'S WIFE. Second Edition. Cr. 8vo. 6s

Meredith (Ellis). HEART .OF MY HEART. Cr. 8vo. 6s

Miller (Esther). LIVING LIES. Third Eatition. Cr. 8vo. .6s.

Also Medium 8vo. $6 d$.

Mitford (Bertram). THE SIGN OF THE SPIDER. Illustrated. Sixth Edition. Cr. 8vo. 3s. 6d. Also Medium 8vo. 6d.

IN THE WHIRL OF THE RISING. Third Edition. Cr. 8vo. 6s.

THE RED DERELICT. Second Edition. Cr. 8vo. 6s.

Molesworth(Mrs.). THE RED GRANGE. Illustrated. Second Edition. Cr. $8 v 0$. 3s. 6 d.

Montgomery (K. L.). COLONEL KATE. Second Edition. Cr. 8vo. 6s.

Montresor (F. F.). THE ALIEN. Third Edition. Cr. 8vo. 6s.

Also Medium 8vo. $6 d$.

Morrison (Arthur). TALES OF MEAN - STREETS. Severth Edition. Cr.8vo. 6s. A CHILD OF THE JAGO. Fifth Edition. Cr. 8vo. 6s.

THE HOLE IN THE WALL. Fourth Edi. tion. Cr. 8vo. 6s. Also Medium 8vo. 6d. 


\section{Fiction}

TO LONDON TOWN. Second Ed. Cr. 8vo. 6s.

DIVERS VANITIES. Cr. 8vo. $6 s$.

Nesblt (E.). (Mrs. H. Bland). THE RED HOUSE Illustrated fourth Edition. Cr. 8vo. 6s. Also Medium 8vo. 6d.

Noble (Edward). LORDS OF THE SEA. Second Edition. Cr. 8vo. Gs.

Norris (W. E.), HARRY AND URSULA: A STORY WITH Two SIDES to IT. Second Edition. Cr. 8vo. 6s.

HIS GRACE. Medium 8vo. $6 d$.

GILES INGILBY. Medium 8vo. 6d.

THE CREDIT OF THE COUNTY. Medium 8vo. 6d.

LORD LEONARD THE LUCKLESS. Medium 8vo. 6d.

MATTHEIV AUSTIN. Medium 8vo. 6d.

CLARISSA FURIOSA. Medium 8vo. $6 d$.

Oliphant (Mrs.). THE LADY'S WALK. Medium 8vo. $6 d$.

SIR ROBERT'S FORTUNE. Medium 8vo. $6 d$.

THE PRODIGALS. Medium 8vo. $6 d$.

THE TWO MARYS. Medium 8vo. 6d.

Ollivant (Alfred). OWD BOB, THE GREY DOG OF KENMUIR. With a Frontispiece. Eleventh Ed. Cr. 8vo. 6s.

Oppenhelm (E. Phillips). MASTER OF MEN. Fourth Edition. Cr.8vo. 6s. Also Medium 8vo. $6 d$.

Oxenham (John). A WEAVER OFWEBS. With 8 illustrations by MAURICE GREIFPENHAGEN. Fourth Edition. Cr. 8vo. 6s.

THE GATE OF THE DESERT. With a Frontispiece in Photogravure by HAROLD Copping. Fifth Edition. Cr. 8vo. 6s.

PROFIT AND LOSS. With a Frontispiece in photogravure by HAROID COPPiNG. Fourth Edition. Cr. 8vo. 6s.

THE LONG ROAD. With a Frontispiece in Photogravure by Harold Copring. Fourth Edition. Cr. 8vo. 6s.

THE SONG OF HYACINTH, AND OTHER STORIES. Second Edition. Cr. 8vo. 6s.

MY LADY OF. SHADOWS. Fourth Edition. Cr. 8vo. 6s.

Paln (Barry). LINDLEY KAYS. Third Edition. Cr. 8vo. 6s.

Parker (Gllbert). PIERRE AND HIS PEOPLE. Sixth Edition. Cr. 8v0. 6s.

MRS. FALCHION. Fifth Edition. Cr. 8vo. $6 s$.

THE TRANSLATION OF A SAVAGE. Third Edition. Cr. 8vo. $6 s$.

THE TRAIL OF THE SWORD. Illustrated. Tenth Edition. Cr. 8vo. $6 s$. Also Medium 8vo. $6 d^{2}$
WHEN VALMOND CAME TO PONTIAC The Story of a Lost Napoleon. Sixth Edition. Cr. 8vo. 6s.

Also Medium 8vo. $6 d$.

AN ADVENTURER OF THE NORTH. The Last Adventures of 'Pretty Pierre. Fourth Edition. Cr. 8vo. 6 s.

THE SEATS OF THE MIGHTY. Illustrated. Sixteenth Edition. Cr. 8vo. 6s.

THE BATTLE OF THE STRONG: a Romance of Two Kingdoms. Illustrated. Sixth Edition. Cr. 8vo. 6s.

THE POMP OF THE LAVILETTES. Third Edition. Cr. $8 v 0.3^{3.6}$.

Also Medium 8vo. 6d.

NORTHERN LIGHTS. Cr. 8vo. 6s.

*Pasture (Mrs. Henry de la). THE TYRANT. Cr. 8vo. 6s.

Patterson (J. E.). WATCHERS BY THE SHORE. Second Edition. Cr. 8vo. 6s.

Pemberton (Max). THE FOOTSTEPS OF A THRONE. Ill"strated. Third Edition. Cr. 8vo. $6 s$.

Also Medium 8vo $6 d$.

I CROWN THEE KING. With Illustrations by Frank Dadd and A. Forrestier. Cr. $8 v 0$. $6 s$.

Also Medium 800. 6 .

LOVE THE HARVESTER: A STORY OF THE SHIRES. Illustrated. Third Edition. Cr. 8vo. 3s. $6 d$.

Phlllpotts (Eden). LYING PROPHETS Third Edition. Cr. 8vo. 6s.

CHILDREN OF THE MIST. Fifth Edition. Cr. 8vo. 6s.

Also Medium 8vo. 6d.

THE HUMAN BOY. With a Frontispiece Sixth Edition. Cr. 8vo. 6 s.

Also Medium 8vo. $6 d$.

SONS OF THE MORNING. Second Edition. Cr. 8vo. 6s.

THE RIVER. Third Edition. Cr. 8vo. os. Also Mediwm 8vo. $6 d$.

THE AMERICAN PRISONER. Fourth Edition. Cr. 8vo. 6s.

THE SECRET WOMAN. Fourth Edition. Cr. 8v0. 6s.

KNOCK AT A VENTURE. With a Frontispiece. Third Edition. Cr. 87'o. $6 s$.

THE PORTREEVE. Fourth Ed. Cr.8vo. 6s. THE POACHER'S WIFE. Second Edition. Cr. 8vo. 6s. Also Medium 8vo. 6d.

THE STRIKING HOURS. Second Edition. Crown 8vo. $6 s$.

THE FOLK AFIELD. Crown 8vo. 6s.

Pickthall (Marmaduke). SAÏD THE FISHERMAN. Seventh Ed. Cr. 800. $6 s$. BRENDLE. Second Edition. Cr. 8vo. 6s. THE HOUSE OF ISLAM. Third Edition. Cr. 8vo. 6s. 
'Q' (A. T. Quiller Couch). THE WHITE WOLF. Second Edition. Cr.8vo. 6s. Also Medium 8vo. $6 d$.

THE MAYOR OF TROY. Fourth Edition. Cr. 8vo. 6s.

MERRY-GARDEN, AND OTHER STORIES. Cr. 8vo. 6s.

MAJOR VIGOUREUX. Third Edition. Cr. 8vo. 6s.

Querldo (Israel). TOIL OF MEN. Translated by F. S. ARnold. Cr. 8vo. 6s.

Rawson (Maud Stepney). THE ENCHANTED GARDEN. Fourth Edition. Cr. 8vo. 6s.

THE EASY GO LUCKIES : OR, ONE WAY of Living. Second Edition. Cr. 8vo. 6s.

HAPPINESS. $C r$. 8vo. $6 s$.

Rhys (Grace). THE WOOING OF SHEILA. Second Edition. Cr. 8vo. 6s.

THE BRIDE. Cr. 6 o. 6s.

Ridge W. Pett). LOST PROPERTY. Second Edition. Cr. 8vo. 6s. Also Medium 8vo. $6 d$.

ERB. Second Edition. Cr. 8vo. 6s. Also Medium 8vo. 6d.'

A SON OF THE STATE. Second Edition. Cr. 8vo. 3s. 6d. Also Medium 8vo. 6d.

A BREAKER OF LAWS. A New Edition. Cr. 8vo. 3s. $6 d$.

MRS. GALER'S BUSINESS. Illustrated. Second Edition. Cr. 8vo. 6s.

THE WICKHAMSES. Fourth Edition. Cr. 8vo. 6s.

NAME OF GARLAND. Third Edition. Cr. 8vo. 6s.

SPLENDID BROTHER. Second Edition. Cr. 8vo. 6s.

GEORGE and THE GENERAL. Medium 8vo. $6 d$.

Ritchie (Mrs. Davld G.). MAN AND THE CAS S OCK. Second Edition. Cr. 8vo. 6s.

Roberts (c. G. D.). THE HEART OF THE ANCIENT WOOD. Cr. $8 v 0$. 3s. $6 d$.

Robins (Elizabeth). THE CONVERT. Third Edition. Cr. 8vo. 6s.

Rosenkrantz (Baron Palle). T H E MAGISTRATE'S OWN CASE. Cr. 8vo. $6 s$.

Russell (W. Clark). IIY DANISH SWEETHEART. Illustrated. Fifth Edition. Cr. 8vo. 6s. Also Medium 8vo. $6 d$.

HIS ISLAND PRINCESS. Illustrated. Second Edition. Cr. 8vo. 6s. Also Medium 8vo. 6d.

ABANDONED. Second Edition. Cr. 8vo. 6s. Also Medium 8vo. 6d.

MASTER ROCKAFELLAR'S VOYAGE. lllustrated by GORDON BROWNE. Fourth Edition. Cr. 8vo. 3s. 6 d.
A MARRIAGE AT SEA. Medium 8vo. 6d. Ryan (Marah Ellis). FOR THE SOUL OF RAFAEL. Cr. 8 vo. $6 s$.

Sandys (Sydney). JACK CARSTAIRS OF THE POWER HOUSE. With 4 Illustrations by STANLEY L. WoOd. Cr. 8vo. $6 s$.

Sergeant (Adeline). THE PASSION OF PAUL MARILLIER. Crown 80o. 6s.

THE QUEST OF GEOFFREY D A R R E L L. Cr. 8vo. $6 s$.

THE COMING OF.THE RANDOLPHS. Cr. 8vo. 6s.

THE PROGRESS OF RACHAEL. Cr.' 8vo. 6s.

BARBARA'S MONEY. Medium 8vo. 6d. THE MASTER OF BEECH WOOD. Medium 8vo. 6d.

THE YELLOW DIAMOND. Second Ed. Cr. 8vo. Gs. Also Medium 8vo. 6d.

THE LOVE THAT OVERCAME. Medium 8vo. $6 d$.

Shelley(Bertha). ENDERBY. Third Ed. Cr. 8vo. 6s.

Sidgwick (Mrs. Alfred). THE KINSMAN. With 8 Illustrations by $\mathrm{C}$. E. Brock. Third Edition. Cr. 8vo. 6 s.

THE SEVERINS. Cr. 8vo. 6s.

Smith (Dorothy V. Horace). M I S MONA. Cr. 8vo. 3s. 6d.

Sonnichsen (Albert), DEEP-SEA VAGA. BONDS. Cr. 8vo. 6s.

Stewart (Newton V.). A SON OF THE EMPEROR: BEING PASSAGES FROM THE Life of ENzio, King of Sardinia and CORsICA. Cr. 8vo. 6s.

Sunbury (George). THE HA'PENNY MILLIONAIRE. Cr. 8vo. 3s. 6d.

Surtees (R. S.). HANDLEY CROSS. Illustrated. Medium 8vo. 6d.

MR. SPONGE'S SPORTING TOUR. Illustrated. Medium 8vo. 6d.

ASK MAMMA. Illus. Medium $8 v 0$. $6 d$.

Swayne (Martin Lutrell). THE BISHOP AND THE LADY. Second Edition. Cr. 8vo. 6s.

Thurston (E. Temple). MIRAGE. Fourth Edition. Cr. 8vo. 6s.

Underhill (Evelyn). THE COLUMN OF DUST. Cr. 8vo. 6s.

Urquhart (M.). A TRAGEDY IN COMMONPLACE. Second Ed. Cr. 8vo. 6s. Vorst (Marie Van). THE SENTIMEN. TAL ADVENTURES OF JIMMY BUL. STRODE. Cr. 8vo. 6s.

IN AMBUSH. $C r$. 8vo. 6s.

Walneman (Paul). TH E B A Y O F L I L A C S: A Romance from Finland. Second Edition. Cr. 8ro. 6s.

THE SONG OF THE FOREST. Cr. $8 v 0$. 6s. 
Walford (Mrs. L. B.). M R S M I T H. Medium 8vo. 6 d.

THE BABY'S GRANDMOTHER. Medium 8vo. 6d.

COUSINS. Medium 8vo. $6 d$.

TROUBLESOME DAUGHTERS. Medium 8vo. $6 d$.

Wallace (General Lew). B E N-H U R. Medium 8vo. $6 d$.

THE FAIR GOD. Medium 8vo. 6d.

Waltz (Elizabeth c.). THE ANCIENT LANDMARK: A KENTUCKY ROMANCE. Cr. 8vo. 6s.

Watson (H. B. Marriott). TWISTED EGLANTINE Illustrated. Third Edition. Cr. 8\%0. 6s.

THE HIGH TOBY : Being further Chapters in the Life and Fortunes of Dick Ryder, otherwise Galloping Dick. With a Frontispiece. Third Edition. Cr. 8vo. 6s.

A MIDSUMMER DAY'S DREAM. Third Edition. Crown 8vo. 6s.

THE CASTLE BY THE SEA. Second Edition. Cr. 8vo. 6s.

THE PRIVATEERS. Illustrated. Second Edition. Cr. 8vo. 6s.

A POPPY SHOW : Being Divers and Diverse Tales. Cr. $8 v 0.6 s$.

THE FLOWER OF THE HEART. Third Edition. $C r$. 8vo. 6s.

THE ADVENTURERS. Medium 8vo. 6\%.

Webling (Peggy). THE STORY OF VIRGINIA PERFECT. Third Edition. Cr. 8vo. 6s.

Weekes (A. B.). THE PRISONERS OF WAR. Medium 8ro. 6d.

Wells (H. G.). THE SEA LADY. $C r$. 8vo. 6s. Also Medium 8vo. $6 d$.

Weyman (Stanley). UNDER THE RED ROBE. With Illustrations by R. C. WoODviLLe. Twert $v$-Second Ed. Cr. 8vo. 6s.

Whitby (Beatrice). THE RESULT OF AN ACCIDENT. Second Edition. Cr. 8vo. 6s.

White (Percy). THE SYSTEM. Third Edition. Cr. 8vo. 6s.
A PASSionate PILGRIM. Medium 8vo. $6 d$.

LOVE AND THE WISE MEN. Cr. $8 v 0$. 6s.

Williams (Margery). THE BAR. Cr. 8vo. 6s.

Williamson (Mrs. C. N.). THE A DVENTURE OF PRINCESS SYLVIA. Second Edition Cr. 8wo. 6s.

THE WOMAN WHO DARED. Cr. $8 v 0$. $6 s$.

THE SEA COULD TELL. Second Edition. Cr. 8zo. 6s.

THE CASTLE OF THE SHADOWS. Third Edition. Cr. 8vo. 6s.

PAPA. Cr. 8vo. 6s.

Williamson (C. N. and A. M.). THE LIGHTNING CON DUCTOR: The Strange Adventures of a Motor Car. With r6 Illustrations. Seventeenth Edition. $\mathrm{Cr}$. 8vo. 6s. Also Cr. Svo. Is. net.

THE PRINCESS PASSES: A Romance of a Motor. With $\times 6$ Illustrations. Ninth Edition. Cr. 8vo. 6s.

MY FRIEND THE CHAUFFEUR. With 16 Illustrations. Tenth Edit. Cr. 8vo. 6s. LADY BETTY ACROSS THE WATER. Tenth Edition. Cr. 8vo. 6s.

THE CAR OF DESTINY AND ITS ERRAND IN SPAIN. With 77 Illustrations. Fourth Edition. Cr. 8vo. 6s.

THE BOTOR CHAPERON. With a Frontispiece in Colour by A. H. BuCKLAND, 16 other Illustrations, and a Map. Fifth $E d i$ tion. Cr. 8vo. 6s.

SCARLET RUNNER. With a Frontispiece in Colour by A. H. BUCKLAND, and 8 other Illustrations. Third Ed. Cr. 8vo. 6s.

SET IN SILVER. With a Frontispiece. Second Edition. Cr. 8vo. 6s.

Wyllarde (Dolf). THE PATHWAY OF THE PIONEER (Nous Autres). Fourth Edition. Cr. 8vo. 6s.

Yeldham (C. C.). DURHAM'S FARM. Cr. 8ะ0. 6s.

\section{Books for Boys and Girls}

Illustrated. Crown 8vo. 3s. 6d.

The Getting Well of Dorothy. By Mrs. The Red Grange. By Mrs. Molesworth. W. K. Clifford. Second Edition.

A GiRL of THE Phople. By L. T. Meade. Fourth Edition.

OnLY a Guard-Room Dog. By Edith E. Cuthell.

Master Rockatellar's Voyage. By W. Clark Russell. Fourth Edition.

Hepsy Gipsy. By L. T. Meade. 2s. $6 d$.

The Honourable Miss. By L. T. Meade. Secord Edition.

There was once a Prince. By Mrs. M. E. Mann.

Srd Belton: Or, the Boy who would not go When Arnold comes Home. By Mrs. M. E. to Sea. By G. Manville Fenn. Second Ed. Mann. 


\section{The Novels of Alexandre Dumas \\ Medium 8vo. Price 6d. Double Volumes, Is.}

Acté.

The Adventures of Captain Pamphile. Amaury.

The Bird of Fatr.

ThE Black TUlip.

The Castle of Eppstein.

Catherine Blum.

Cecile.

The Chevalier D'Harmental. (Double volume.) Is.

Chicot the Jester.

Conscience.

'The Convict's Son.

The Corsican Brothers; and Otho the ARCHER.

Crop-Eared Jacquot.

DOM Gorenflot.

The Fatal Combat.

The Fencing Master.

FERnande.

Gabriel, Lambert,

GEORGES.

THE GREat Massacre.

HENRI DE NAVARRE.
HÉLÈnE DE Chaverny.

THE HoROSCOPE.

Louise de lA VALLikRE. (Double volume.)

Is.

The Man in the Iron Mask. (Double volume.) Is.

Maltre adam.

The Mouth of Hell.

NANON. (Double volume.) rs.

Pauline; Pascal Bruno; and Bontekoe.

Père la Ruine.

The Prince of Thieves.

The Reminiscences of Antony.

ROBIN HOOD.

The Snowball and Sultanetta.

SVLVANDIRE.

Tales of the Supernatural.

Tales of Strange Adventure.

The Three Musketeers. (Double volume.) Is.

The Tragedy of Nantes.

TwEnTy Years After. (Double volume.) is. THE WILD-DUCK SHOOTER.

THE WOLF-LEader.

\section{Methuen's Sixpenny Books}

Medium 8vo.

\section{Albanesi (E. Maria). LOUISA.}

I KNOW A MAIDEN.

Anstey (F.). A BAYARD OF BENGAL.

Austen (J.). PRIDE AND PREJUDICE.

Bagot (Richard). A ROMAN MYSTERY. CASTING OF NETS.

DONNA DIANA.

Balfour (Andrew). BY STROKE, OF SWORD.

Baring=GouId (S.). FURZE BLOOM.

CHEAP JACK ZITA.

KITTY ALONE.

URITH.

THE BROOM SQUIRE.

IN THE ROAR OF THE SEA.

NOÊMI.

A BOOK OF FAIRY TALES. Illustrated. LITTLE TU'PENNY.

WINEFRED.

THE FROBISHERS.

THE QUEEN OF LOVE.

ARMINELL.

Barr (Robert). JENNIE BAXTER.

IN THE MIDST OF ALARMS.

THE COUNTESS TEKLA.

THE MUTABLE MANY.

Benson (E. F.). DODO.

THE VINTAGE.

Brontē (Charlotte). SHIRLEY.
Brownell (c. L.). THE HEART OF JAPAN.

Burton (J. Bloundelle). ACROSS THE SALT SEAS.

Caffyn (Mrs.). ANNE MAULEVERER. Capes (Bernard). THE I,AKE OF WINE.

Clifford (Mrs. W. K.). A FLASH OF SUMMER.

MRS. KEITH'S CRIME.

Corbett (Julian). A BUSINESS IN GREAT WATERS.

Croker (Mrs. B. M.). ANGEL.

A STATE SECRET.

PEGGY OF THE BARTONS.

JOHANNA.

Dante (Alighieri). THE D I V I NE COMEDY (Cary).

Doyle (A. Conan). ROUND THE RED LAMP.

Duncan (Sara Jeannette). A VOYAGE OF CONSOLATION.

THOSE DELIGHTFUL AMERICANS.

Eliot (George). THE MILL ON THE

Flndlater (Jane H.). THE GREEN GRAVES OF BALGOWRIE.

Gallon (Tom). RICKERBY'S FOLLY.

Gaskell (Mrs.). CRANFORD.

MARY BARTON.

NORTH AND SOUTH. 


\section{Fiction} Gerard (Dorothea). HOLY MATRI-
MONY.

THE CONOUEST OF LONDON.

MADE OF MONEY.

Gissing(G). THE TOWN TRAYELLER. THE CROWN OF LIFE.

Glanville (Ernest). THE I NCA'S TREASURE.

THE KLOOF BRIDE.

Glelg (Charles). BUNTER'S CRUISE.

Grimm (The Brothers). GRIMM'S FAIRY TALES.

Hope (Anthony). A MAN OF MARK.

A CHANGE OF AIR.

THE CHRONICLES OF COUNT ANTONIO.

PHROSO

THE DOLLY DIALOGUES.

Hornung (E. W.). DEAD MEN TELL NO TALES.

Ingraham (J. H.). THE THRONE OF DAVID.

Le Queux (W.). THE HUNCHBACK OF WESTMINSTER.

Levett-Yeats (S. K.). THE TRAITOR'S WAY.

ORRAIN.

Llnton (E. Lynn). THE TRUE HISTORY OF JOSHUA DAVIDSON.

Lyall (Edna). DERRICK VAUGHAN.

Malet (Lucas). THE CARISSIMA.

A COUNSEL OF PERFECTION.

Mann (Mrs. M. E.). MRS. PETER HOWARD.

A LOST ESTATE.

THE CEDAR STAR.

ONE ANOTHER'S BURDENS.

THE PATTEN EXPERIMENT

A WINTER'S TALE.

Marchmont (A. W.). MISER HOAD. LEY'S SECRET.

A MOMENT'S ERROR.

Marryat (Captain). PETER SIMPLE. JACOB FAITHFUL.

Marsh (Rlchard). A METAMORPHOSIS THE TWICKENHAM PEERAGE.

THE GODDESS.

THE JOSS.

Mason (A. E. W.). CLEMENTINA.

Matiners (Helen), HONEY.

GRIFF OF GRIFFITHSCOURT, SAM'S SWEETHEART.

Meade (Mrs. L. T.). DRIFT.

Miller (Esther). LIVING LIES.

Mitford (Bertram). THE SIGN OF THE SPIDER.
Montresor (F. F.). THE ALIEN.

Morrison (Arthur). THE HOLE IN THE WALL.

Nesbit (E.) THE RED HOUSE.

Norris (W. E.). HIS GRACE.

GILES INGILBY.

THE CREDIT OF THE COUNTY.

LORD LEONARD THE LUCKLESS.

MATTHEW AUSTIN.

CLARISSA FURIOSA.

Oliphant (Mrs.). THE LADY'S WALK.

SIR ROBERT'S FORTUNE.

THE PRODIGALS.

THE TWO MARYS.

Oppenheim (E, P.). MASTER OF MEN.

Parker (Gilbert). THE POMP OF THE LAVILETTES

IVHEN VALMONDCAME TO PONTIAC. THE TRAIL OF THE SWORD.

Pemberton (Max). THE FOOTSTEPS OF A THRONE.

I CROWN THEE KING.

Phillpotts (Eden). THE HUMAN BOY.

CHILDREN OF THE MIST.

THE POACHER'S WIFE.

THE RIVER.

' $Q$ ' (A. T. Quiller Couch). T H E WHITE Wol.

Ridge(W. Pett). A SON OF THE STATE.

LOST PROPERTY.

GEORGE and THE GENERAL.

ERB.

Russell (W. Clark). ABANDONED. A MARRIAGE AT SEA.

IY DANISH SWEETHEART.

HIS ISLAND PRINCESS.

Sergeant (Adeline). THE MASTER OF BEECHWOOD.

BARBARA'S MONEY.

THE YELLOW DIAMOND.

THE LOVE THAT OVERCAME.

Sldgwick (Mrs. Alfred). THE KINSMAN.

Surtees (R. S.). HANDLEY CROSS. MR. SPONGE'S SPORTING TOUR. ASK MAMMA.

Walford (Mrs. L. B.). MR. SMITH. COUSINS.

THE BABX'S GRANDMOTHER. TROUBLESOME DAUGHTERS.

Wallace (General Lew). BEN-HUR. THE FAIR GOD.

Watson (H. B. Marriott). THE ADVENTURERS.

Weekes (A. B.). PRISONERS OF WAR. Wells (H. G.). THE SEA LADY.

White (Percy). A PASSIONATE PILGRIM 




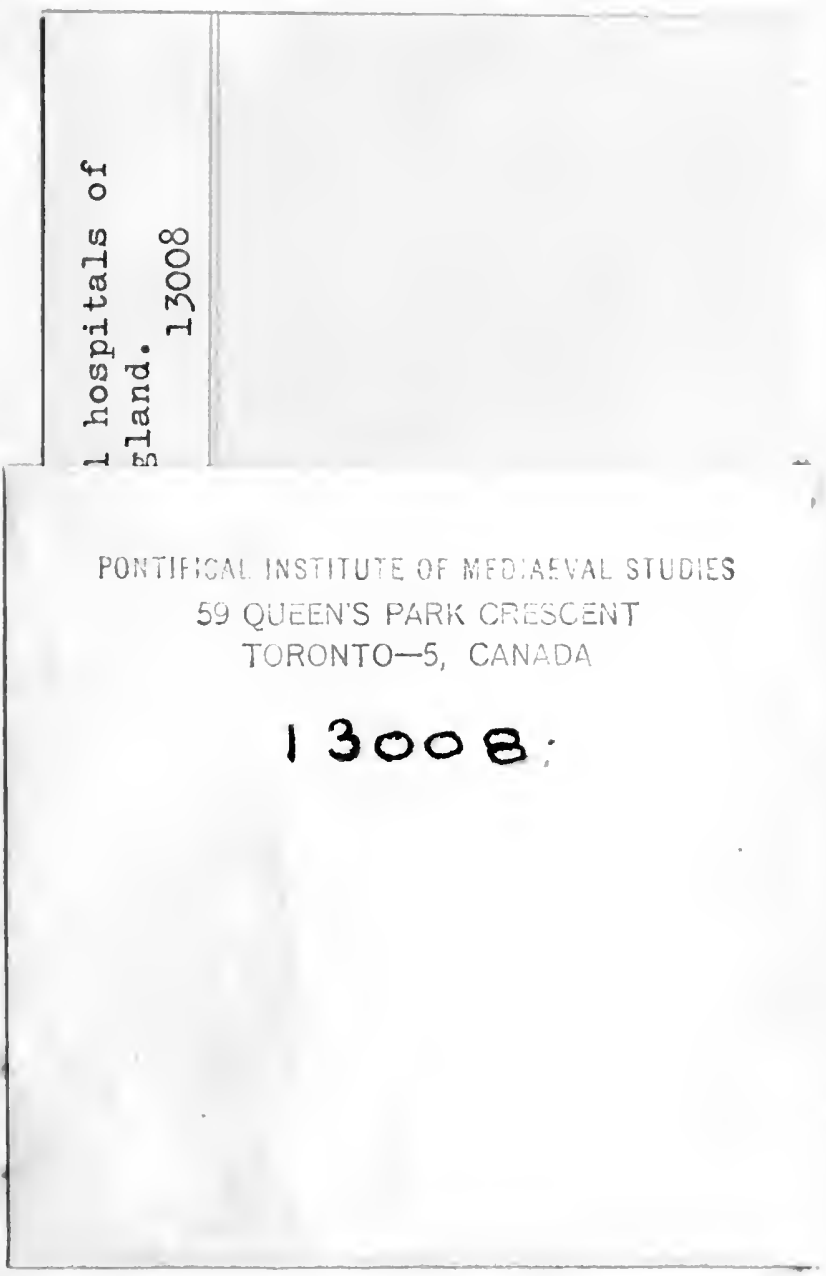


